\title{
HISTORICAL TANK CONTENT ESTIMATE FOR THE SOUTHEAST QUADRANT OF THE HANFORD 200 AREAS
}

\author{
WORK ORDER E11728
}

\author{
Prepared for \\ Westinghouse Hanford Company
}

June 1995

\begin{abstract}
DISCLAMER

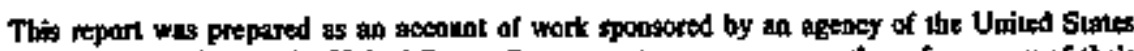

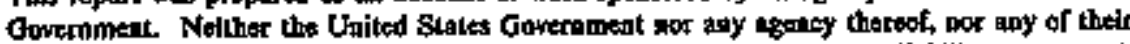

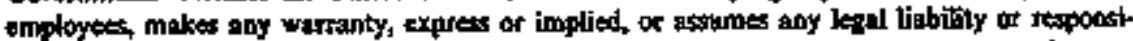
bility for the aceuracy, completenoss, oc usefulaess of any information, apparatus, prodoct, of

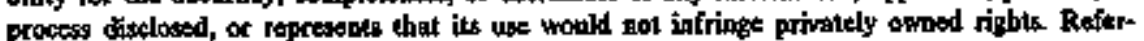
ence hetoin to any spectíic eommertial produet, process, or sesvice by trade nomes, tradement. manafactuter, or otherwise does not pecessarily coestivite or imply its endorsement, recommendation, of favoriag by the United States Groverament or any agency thereof. Tbe viows and opinions of suthors expressed herein do not necossariby state of repect those of the Unalied Stales Gowernment or any agency thersor.
\end{abstract}

\section{Prepared by}

ICF Kaiser Fanford Company Richland, Washington

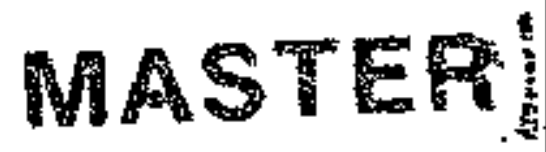

\section{ICF Kaiser Hanford Company}

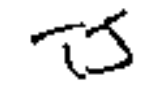




\section{DISCLAJMER}

Portions of this document may be illegible in electronic image products. Images are produced from the best available original document. 


\section{DISTRIBUTION SHEET}

\begin{tabular}{|c|c|c|c|c|c|}
\hline \multirow{2}{*}{ Do } & \multirow{2}{*}{\multicolumn{3}{|c|}{$\begin{array}{l}\text { From } \\
\text { C. H. Brevick } 53-10\end{array}$}} & \multicolumn{2}{|l|}{ Page 1 of 5} \\
\hline & & & & \multicolumn{2}{|c|}{ Date June 22, 1995} \\
\hline \multicolumn{4}{|l|}{ Project Title/Work Order } & \multicolumn{2}{|c|}{ EDT No. 607290} \\
\hline \multicolumn{4}{|c|}{$\begin{array}{l}\text { Historical Tank Content Estimate for the Southeast Quadrant of } \\
\text { the Hanford } 200 \text { East Areas / ER } 4945 / E 11728\end{array}$} & \multicolumn{2}{|l|}{ ECN No. } \\
\hline Name & MSIN & $\begin{array}{c}\text { Text } \\
\text { With All } \\
\text { Attach. }\end{array}$ & Text Only & $\begin{array}{l}\text { Attach./ } \\
\text { Appendix } \\
\text { Only }\end{array}$ & $\begin{array}{l}\text { EDT/ECN } \\
\text { Only }\end{array}$ \\
\hline
\end{tabular}

Westinghouse Hanford Company

H. Babad

D. A. Barnes

A. L. Boldt

D. R. Bratzel

T. M. Brown

T. H. Bushaw

If. P. Campbel1

R. J. Cash

5. C. Chalcraft

I. L. Cowley

H. L. Deffenbaugh

R. A. Dodd

G. L. Dunford

R. A. Dutton

S. J. Eberlein

C. S. Ehrbardt

D. B. Enge1man

K. O. Fein

G. D. Forehand

G. T. Frater

J. S. Garfield

P. W. Gibbons

K. D. Gibson

C. E. Golberg

J. M. Grigsby

R. D. Gustavson

D. B. Hagmann

D. L. Herting

B. A. Higley

R. H. Hisaw

E. 1. Husa

G. Jansen

G. D. Johnson

T. J. Keiley

ง. H. Kirch

J. G. Kristofzski

N. J. Kupfer

R. M. Marusich

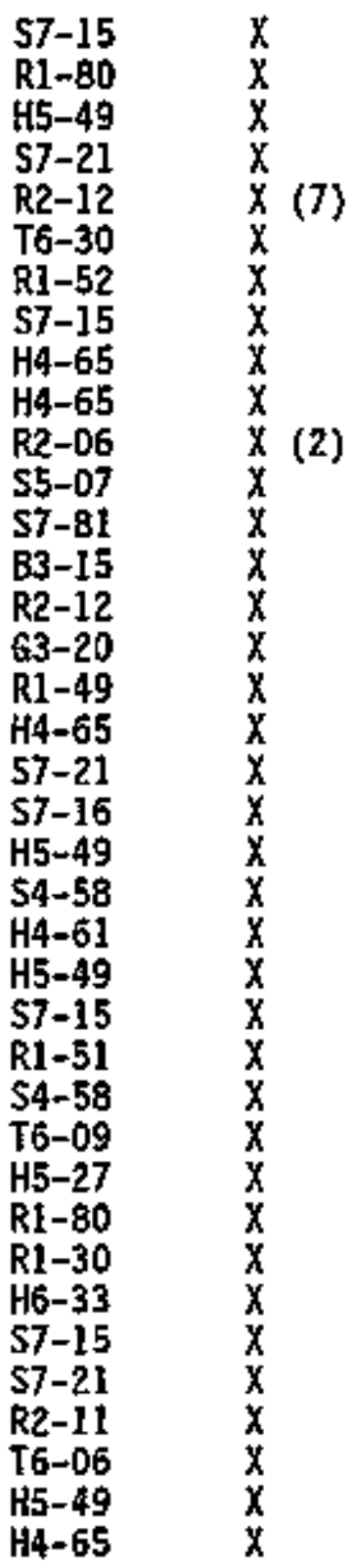


R. W. Mattichak

D. J. McCain

T. B. Mccall

G. A. Meyer

N. C. Hiller

C. T. Narquis

R. H. Palmer

M. A. Payne

D. E. Place

R. S. Popielarczyk

R. E. Raymond

E. F, Riedel

S. H. Rifaey

D. A. Reynolds

F. A. Schmittroth

J. S. Schofield

K. V. Scott.

N. J. Scott-Proctor

P. Segall

B. C. Simpson

G. L. Smith

H. J. Sutey

J. D. Thomson

G. L. Troyer

D. J. Washenfelder

M. S. Waters

TCRC (Tank Characterization

Records Center)

TFIC (Tank Farm Information Center)

Centră Fijes

OSTI

\begin{tabular}{ll} 
B4-08 & $X$ \\
$R 2-12$ & $X$ \\
$H 0-33$ & $X$ \\
$54-54$ & $X$ \\
$R 1-30$ & $X$ \\
T6-16 & $X$ \\
$R 2-58$ & $X$ \\
$57-84$ & $X$ \\
$H 5-27$ & $X$ \\
$R 1-30$ & $X$ \\
$R 2-54$ & $X$ \\
$\$ 33-90$ & $X$ \\
T4-07 & $X$ \\
$R 2-11$ & $X$ \\
$H 0-35$ & $X$ \\
$\$ 7-12$ & $X$ \\
$H 5-52$ & $X$ \\
$R 1-80$ & $X$ \\
$B 2-22$ & $X$ \\
$R 2-12$ & $X$ \\
$H 4-62$ & $X$ \\
T4-07 & $X$ \\
$R 2-76$ & $X$ \\
$T 6-50$ & $X$ \\
$H 5-27$ & $X$ \\
$\$ 6-30$ & $X$ \\
$R 2-12$ & $X(2)$ \\
$R 1-20$ & $X$ \\
$L 8-04$ & $X(2)$ \\
$A 3-36$ & $X$ \\
\hline
\end{tabular}

ICF-Kaiser Hanford Company
C. H. Brevick

\$3-10

$\$ 3-09$

$\$ 3-09$

$\$ 7-40$

$\$ 3-10$

$\$ 3-09$

R2-80

$\mathrm{B} 3-85$

$\$ 7-01$

E6-63

$53-10$

$x(5)$

$x$

$x$

$x$

$x$

$\hat{x}$

$x$

$x$

$\mathrm{O}$

ICF-KH Doc Control

Pacific Northwest Laboratory
W. J. Apley
R. M. Bean
S. F. Bobrowski
N. G. Colton
P. G. Eller
E. J. Eschbach
5. S. Goheen

$\begin{array}{ll}p 7-75 & X \\ K 9-76 & X \\ K 7-28 & X \\ K 3-75 & X \\ \$ 7-53 & X \\ K 1-24 & X \\ P 8-08 & X\end{array}$



J. G. Hill
K7-94
K7-97
G. H. Holter
$\mathrm{Kg}-73$
L. K. Holton
K7-22
M. Hoza
P7-19
L. K. Jagoda
k8-34
B. M. Johnson
P7-25
G. J. Lumetta
K6-84
B. D. McVeety
K7-22
I. C. McVeety
P. J. Mell inger
K9-76
K. E. Noffsinger
K5-20
A. F. Noonan
K9-81
G. K. Pate110
P7-18
L. R. Pederson
$\mathrm{K} 2-44$
K. M. Remund
K5-12
K7-94
$\mathrm{H} 2-53$
P8-44
P7-14
$\mathrm{K} 5-12$
K4-15
T. L. Traub
J. D. Vienna
K. D. Wiemers
P. D. Whitney

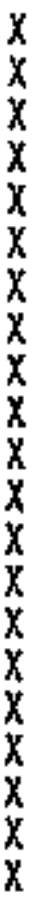

Department of Energy - Richland Operations
l. Erickson
R. E. Gerton
R. A. GiJbert
K. K. Kawabata
J. F. Thompson

$\$ 7-53$

$\$ 7-54$

$57-53$

$57-55$

$\$ 7-54$

$\mathbf{X}$
$\mathbf{X}$
$\mathbf{X}$
$\mathbf{X}$
$\mathbf{X}$

OFFSITE

Los Al amos National Laboratory

S. F. Agnew

Los Al amos National Laboratory

$X(6)$

CST-14, MS-J586

P. 0. Box 1663

Los A1 antos, NN 87545

Los Alamos TechnicaT Associates

A. T. DiCenso

$X$

Los Alamos Technical Associates

750 Swfft, suite 4

Richland, WA 99352

Oaden Environmental

R. J. Anema

Ogden Environmental

lole Wellsian Way

Richland, WA 99352 
CHzM Hill

Mel issa McAgee

$x$

CH2M HilT

P. 0. Box 91500

Bellevue, HA 98009-2050

Iank Advisory Panel

D. D. Campbell

$x$

102 Windham Road

Dak Ridge, TN 37830

D. Powers

$x$

Sandia Nationa] Laboratory

P. 0. Box 5800

MS-0744, Dept. 6404

Albuquerque, NM 87815

J. L. Kovach

Nuclear Consulting Services Inc.

$x$

P. 0. Box 29151

Col umbus, OH 43229-0151

B. C. Hudson

Chemical Reaction Sub-TAP

$x$

202 Northridge Court

Lindsborg, KS 67456

Tank Characterization Advisory Panel

J. Arvizu

Sr. Technical Consultant.

$x$

Contech

6301 Indian School Road NE, Ste 614

Albuquerque, NH 87110

Department of Energe - Headouarters

K. T. Lang

J. A. Poppitti

U. S. Bepartment of Energy

Office of Environmentai Restoration

and Waste Management (EM-563)

12800 Middlebrook Road

Germantown, MN 20874

H. Sutter

$x$

SAIC

2030 Centry B1yd.

Sulte 200B

Germant town, MD 20874 


\section{Colunbia Basin college}

Ron Weed

Columbia Basin College

2600 H. 20th Avenue

Pasco, HA 99301

Wastren. Inc.

E. E. Oscarson

$x$

Wastren, Inc.

$1050 \mathrm{Gi}$ more Ave, Sulte C

Richland, WA 99352

Rust Geotech. Inc.

J. R. Brodeur

$x$

Rust Geotech, Inc.

$x$

$x$

5215 W. Clearwater

Suite 112

Kennewick, WA 99352

Washington State Department of Ecology

A. B. Stone

Washington State Department of Ecology,

B5-18

$x$

1315 W. 4th

Kennewick, WA 99336 
2. Titlo

Historical Tank Content Estimate for the Southeast Quadrant of the Hanford 200 Areas.

5. Key Worda

Southeast Quadrant, Historica] Tank Content Estimate, Historical characterization, Tank Farms, Tank Waste Level, Tank Aerial Photos, In-Tank Photo, Tank Layer Model. Estialated Composite Inventories, Riser Locations, Tank Layering Model. Supernatant Mixing Model.
3. Nunber

WHC-SD-WIM-ER-350

4. Res Ho.

0

6. Aether

Hawe: CHBrevick/LAGaddis/WWP ickett

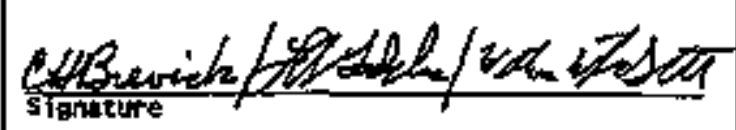

orginization/charge code 5A400/E11728

Facilities and Technical Support

\section{Abstract}

Histor1cal Tank Content Est1gate of the Southeast Quadrant provides historical evaluations on a tank by task basis of the radioactive mixed wastes stored in the underground double-she]] tanks of the Hanford 200 East and West Areas. This report summarizes historical inforgation such as waste history, temperature profiles, psychrometric data, tank integrity, inventory estimates and tank ievel history on a tank by tank bas1s. Tank Farm aerla1 photos and in-tank photos of each tank are provided. A brief description of instrumentation methods used for waste tank surveitTance are inciuded. Components of the data management effort, such as Waste Status and Transaction Record Summary, Tank Layering Model, Supernatant Mixing Model, Oefined Waste Types, and Inventory Estimates which generate these tank content estimates, are also given in thts report. 


\section{RELEASE AUTHORIZATION}

Doctument Number: WHC-SO-MN-ER-350, REV 0

Document Tite: Historical Tank Content Estimate for the Southeast Quadrant of the Hanford 200 Areas

Release Date: $\quad 6 / 28 / 95$

\section{This document was reviewed following the procedures described in WHC-CM-3-4 and is:}

\section{APPROVED FOR PUBLIC RELEASE}

\section{WHC Information Release Administration Specialist:}

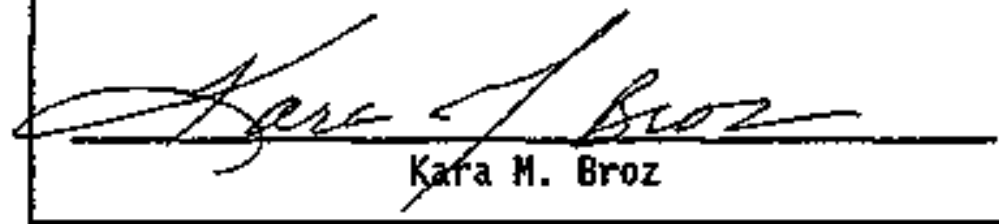

June 28, 1995

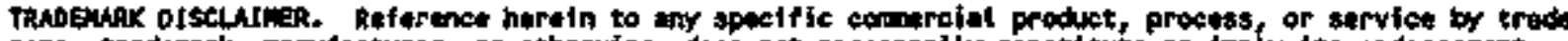

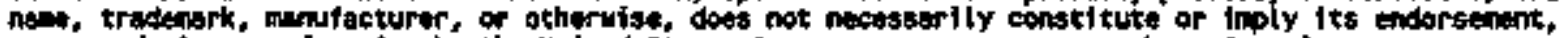

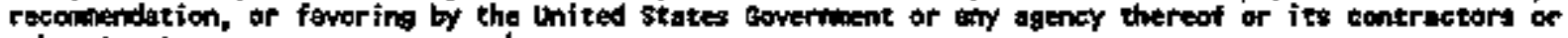
subcontractorg.

This roport has been reprodteed from the bots available copy. Avejleble in paper copy and microfiche. printed in the United states of Antrica. Avallable to the b.s. Deportent of Emargy and its contractors fron:

U.S. Department of Energy

Oftice of Scientific and Technional Intormation (0ST1)

P.0. Box 6z

Dak RIdpe, TH 37031

Tolephones (615) $576-8401$

Avetiable to the public fron;

U.S. Gepartment of comerce.

Hationsl technioul Inforation service (HTIs)

Stas Port Royel Roud

spritnot jetd, yh 22161

Telephone: (703) 487-4850 


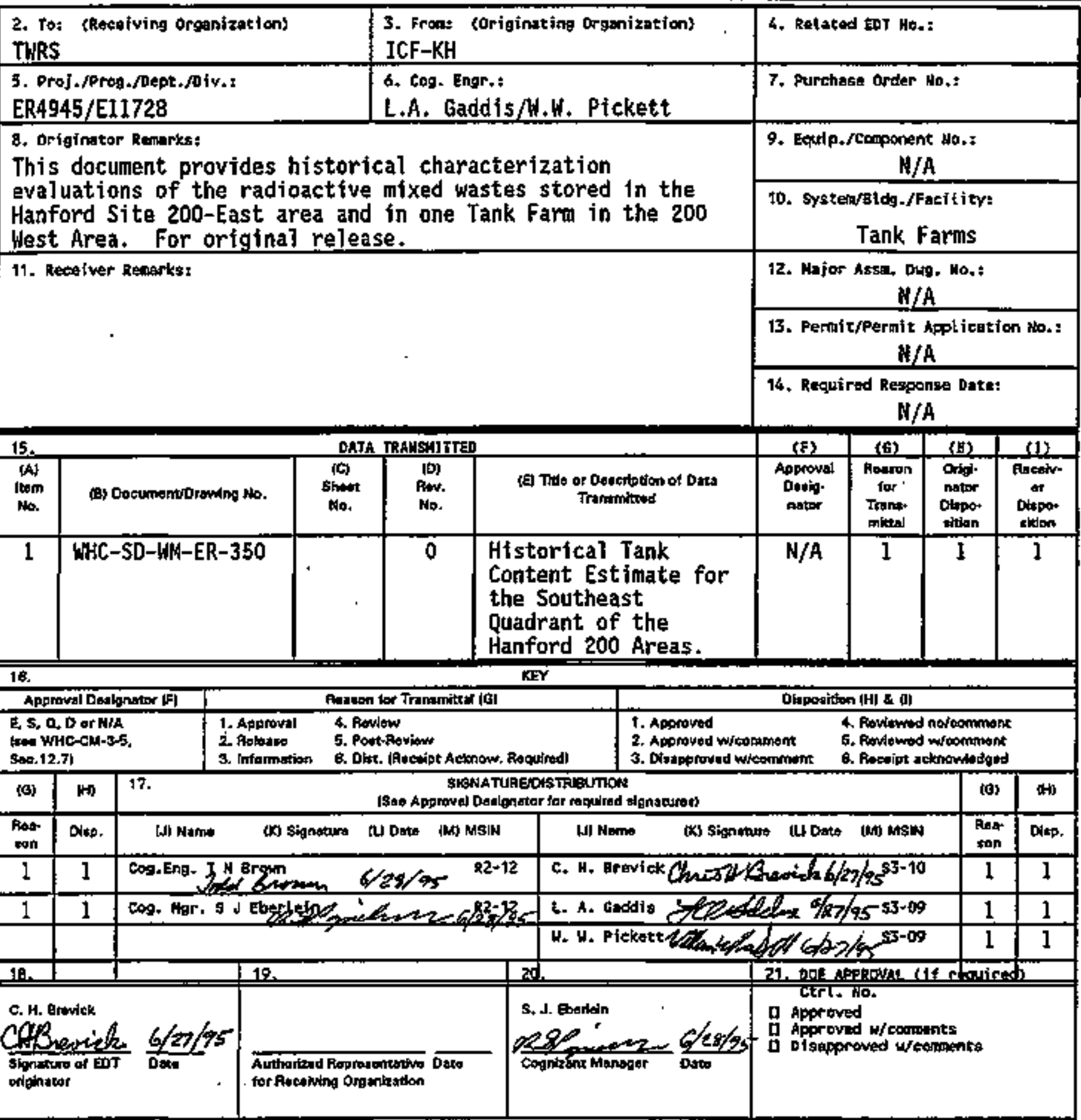




\title{
HISTORICAL TANK CONTENT ESTIMATE \\ FOR THE SOUTHEAST QUADRANT OF THE HANFORD 200 AREAS
}

\author{
WORK ORDER E11728
}

\author{
Prepared for \\ Westinghouse Hanford Company \\ Jone 1995
}

Prepared by

ICF Kaiser Hanford Company

Richland, Washington 


\title{
HISTORICAL TANK CONTENT ESTIMATE FOR THE SOUTHEAST QUADRANT OF THE HANFORD 200 AREAS
}

\author{
WORK ORDER E11728
}

\author{
Prepared by \\ ICF Kaiser Hanford Company \\ Richland, Washington
}

for

Westinghouse Hanford Company

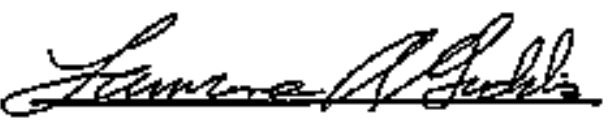

Principal Lead Engineer

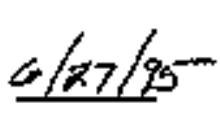

Date

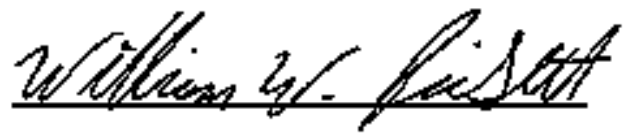

Technical Author

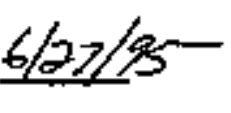

Date
Chnot Brevick

Project Manager
$6 / 27 / 95$

Date
Sinamisayless

Technical Doctuments
$6 / 27 / 95$

Date

Westinghouse Hanford Company

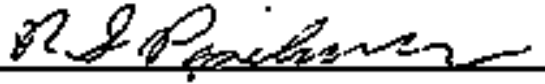

TWRS Technical Baseline Integration
$6 / 28 / 05$

Date 
MHC-SD-WH-ER-350, Rev. O

\section{ACKNOWLEDGIENT}

A project of the this magnitude would not be possible without the help of a significant number of persons and organizations.

ICF Kaiser fanford Cormany would like to acknowledge the contributions made by our LAML counterparts in this effort: Stephen F. Agnew, Kern Jurgensen, Rob Corbin, Tome Duran, and Bonnie Young. Also, Todd Brown and Brett Sirnpson of WhC are recognized for their contributions to this effort. 


\section{INFORMATION FEEDBACK CARD}

\section{HISTORICAL TANK CONTENT ESTIMATE FOR THE SOUTHEAST QUADRENT OF THE HANFORD 200 AREAS \\ E11728}

\section{COMMENTS AND CONTRIBUTIONS}

The reader is requested to utilize this card to comment on this working document, report any discrepancies, or contribute new information to improve the accuracy and content of the report. elease use the space provided below, add additional pages if necessary, and return to the addressee listed below.

Send comments to: MS. S. J. Eberlein

Manager, ThRs Technical Baseline intergration

P.O. Box 1970 HSIN R2-12

Richland, wA 99352 
1. Introduction . . . . . . . . . . . . . . . . . 1

1.1 Purpose .................... 1

1.2 Scope .................... 1

1.3 Approach

1.3.1 Surveillance Techniques for the Hanford

Radiotctive and Mixed Waste storage Tanks . . . 4

- 1.3.2 Approach and Development of Supporting Information Contained in the Historical Tank Content estimate

1.3.3 Approach and Development of the Erocess-Based Historical Tank Content Estimate ...... 10

1.3 .4 Assumptions ............... 12

1.4 Historical Information Quality . . . . . . . . 14

1.5 Background SE Quadrant . . . . . . . . . . . 16

1.5.1 Waste Generating Plants and Processes . . . . 17

1.5.2 Waste Management Operations ........ 19

1.5.3 Miscellaneous Waste Sources and Equipment . . 21

1.5.4 Timeline . . . . . . . . . . . . . . . 22

1.6 Safety Issues .............. 29

1.6.1 Watch Iist Safety Issues ........ 29

1.7 Occurrences List Safety Issues . . . . . . . . 30

2 AN Tank Farm +. . . . . . . . . . . . . . . . . . 32

2.0.1 AN Tenk Farm History ............ 32

2.0.1.1 AN Tank Farm Waste History ...... 34

2.0.1.2 AN Tank Farm Temperature History . . . 34

2.0 .1 .3 AN Tank Farm Occurrences ....... 34

2.0.1.4 AN Tank Farm Ventilation ....... 34

2.0.2 Current Status of AN Tank Farm . . . . . . . 35

2.1 Tank 241-AN-101 . . . . . . . . . . . . . 35

2.1 .1 241-AN-101 Tank History . . . . 35

2.1.1.1 Waste History of Tark 241-AN-101 ... 35

2.1.1.2 Teaperature History of Tank 241-AN-101 . 35

2.1.1.3-Occurrences of Tank 241-AN-101 ..: : 35

2.1.1.4 Psychrometries of Tank 241-AN-101 . . . 36

2.1.2 Current Status of Tank 241-AN-101 . . . . . 36

2.1.2.1 Inventory Estimate of Terk 241-AN-101:36

2.1.2.2 In-Tark Photograph of Tank 241-AN-101; 36

2.1.3 Synopsis of Tank 241-AN-101 - . + . . . . 36

2.2 Tank 241-AN-102 . . . . . . . . . 40

2.2 .1 241-AN-102 Tark History . . . . . . 40

2.2.1.1 Waste History of Tank 241-AN-102, . 40

2.2.1.2 Temperature History of Tank 241-AN-102:40

2.2.1.3 Oecurrences of Tank 241-AN $-102 \ldots . . .40$

2.2.1.4 Psychrometrics of Tank 241-AN-102 . . . 40

2.2.2 Current Status of Tank 241-AN-102 . . . . . . 41

2.2.2.1 Inventory Estimate of Tank 241-AN-102 * 41

2.2.2.2 In-Tank Photograph of Tank 241-AN-102:41

2.2.3 Symopsis of Tank 241-AN-102 . . . . . . . . . 41

2.3 Tank 241-AN-103 . . . . . . . . . . . 45 
2.3.1 241-AN-103 Tank History . . . . . . . . . . . 45

2.3.1.1 Waste Histary of Tank 241-AN-103 . . . . 45

2.3.1.2 Temperature tistory of Tank 241-AN-103, 45

2.3.1.3 Occurrences of Tank 241-AN-103 . . . . . 45

2.3.1.4 Psychrometrics of Tank 241-AN-203 . . . 46

2.3 .2 Current Status of Tank 241-AN-103 + . . . . . $\mathbf{4 6}$

2.3.2.1 Inventory Estimate of Tank 241-AN-103 . 46

2.3.2.2 In-Tank Photograph of Tank 241-AN-103 . 46

2.3 .3 Symopsis of Tank 241-AN-103 . . . . . . . . . 47

2.4 Tank 241 AN-104 . . . . . . . . . . . . . . . . 52

2.4.1 241-AN-104 Tank History . . . . . . . . . . . 52

2.4.1.1 Waste History of Tank 241-AN-104 - . . . 52

2.4 .1 .2 Temperature History of Tank 241-AN-104 * 52

2.4.1.3 Occurrences of Tank 241-AN-104 . . . . . 52

2.4.1.4 Psychrometries of Tenk 241-AN-104 . . . 52

2.4 .2 Current Status of Tank 241-AN-104 . . . . . . 53

2.4.2.1 Inventory Estimate of Tank 241-AN-104 . 53

2.4.2.2 In-Tank Photograph of Tank 241-AN-104 . 53

2.4.3 Symopsis of Tank 241-AN-104 . . . . . . . . . 53

2.5 Tank 241-AN-105 . . . . . . . . . . . . . . . . 58

$2.5 .1241-\mathrm{AN}-105$ Tank History . . . . . . . . . . 58

2.5.1.1 Waste History of mank 241-AN-105 . . . 58

2.5 .1 .2 Temgerature tilstory of Tank 241-AN-105 . 58

2.5 .1 .3 Decurrences of Tarik 241-AN-105 . . . . . 58

2.5.1.4 Esychrometrics of Tank 241-AN-105 . . . 58

2.5 .2 Current Statug of Tank 241-AN-105 . . . . . . 59

2.5.2.1 Inventory Estimate of rank 241-AN-105 . 59

2.5.2.2 In-Tank Photograph of Tank 241-AN-105 . 59

2.5.3 Synopsis Tank of Tank 241-AN-105 . . . . . . 59

2.6 Tank 241-2k-106 . . . . . . . . . . . . . . . 64

2.6 .1 241-AN-106 Tank History . . . . . . . . . . 64

2.6.1.1 Waste History of Tank 241-AN-106 . . . . 64

2.6.1.2 Temperature History of Tank 241-AN-106. 64

2.6.1.3 Occurrences of Tank 241-AN-106 ...... . 64

2.6.1.4 Esychrometrics of Tank 241-AN-106 . . . 64

2.6 .2 Current Status of Tank 241-AN-106 . . . . . . 65

2.6.2.1 Inventory Estimate of Tank 241-AN-106 * 65

2.6.2.2 In-Tank Photograph of Tank 241-AN-106 . 65

2.6 .3 symopsis of Tank 241-AN-106........... . 65

2.7 Tank 241-AN-107 . . . . . . . . . . . . . . . . 69

2.7 .1 241-AN-107 Tank History . . . . . . . . . 69

2.7.1.1 Waste History of Tank 241-AN-107 . . . . 69

2.7.1.2 Temperature History of Tank 241-AN-107. 69

2.7 .1 .3 OccuIrences of Tank 241-AN-107 . . . . . 69

2.7.1.4 Psychrometrics of Tank 243-AN-107 . . . 69

2.7 .2 Current status of Tank 241-AN-107 . . . . . . 70

2.7.2.1 Inventory Estimate of Tank 241-AN-107. 70

2.7 .2 .2 In-Tank Photograph of Tank 241-AN-107. 70

2.7 .3 Synopsis of Tank 241-AN-107......... . 70

3 AP Tank Farm . . . . . . . . . . . . . . . . . . . . . 75

3.0.1 AP Tank Farm History . . . . . . . . . . . . 75

3.0.1.1 AP Tank Farm waste History . . . . . . . 77

3.0.1.2 AP Tank Farm Temperature History . . . . 77 
WHC-SD-FM-ER-350, Rev. 0

3.0.1.3 AP Tank Farm Occurrences . . . . . . . 77

3.0.1.4 AP Tank Farm Ventilation . . . . . . . . 77

3.0.2 Current Status of AP Tank Farm . . . + . . . 78

3.1 Tank 241-AP-101 . . . . . . . . . . . . . . . . 78

3.1 .1 241-AP-101 Tank History . . . . . . . . . 78

3.1 .1 .1 Waste History of Tank 241-AP-101 ... . 78

3.1.1.2 Temperature History of Tank 241-AF-101. 78

3.1 .1 .3 Occurrences of Tark 241-AP-101 . . . . .78

3.1.1.4 Psychrometrics of Tank 241-AP-101 . - . 78

3.1.2 Current Status of Tank 241-AP-101 . . . . . . 79

3.1.2.1 Inventory Estimate of Tank 241-AP-101. 79

3.1.2.2 In-Tank Photograph of Tank 241-AP-101. 79

3.1.3 Synopsis of Tank 241-AP-101 . . . . . . . . . 79

3.2 Tank 241-AP-102 . - - . . . . . . . . . . . . . 83

3.2.1 241-AP-102 Tank History . . . . . . . . . . . 83

3.2.1.1 Waste History of Tank 241-AF-102 . . . - 83

3.2.1.2 Temperature History of Tank 241-AP-102 , 83

3.2 .1 .3 Occurrences of Tank 241-AP-102 . . . . . 83

3.2 .1 .4 Psychrometrics of Tank 241-AP-102 . . . . 83

3.2.2 Current Status of Tank 241-AP-102 . . . . . . 84

3.2.2.1 Inventory Estimate of Tank 241-AP-102 . 84

3.2.2.2 In-Tank Photograph of Tank 241-AP-102 * 84

3.2 .3 Symopsis of Tank 24I-AP-102 . . . . . . . . . 84

3.3 Tank 241-AP-103 . - . . . . . . . . . . . . . 88

3.3 .1 241-AP-103 Tank History + . . . . . . . . . 88

3.3 .1 .1 Waste History of Tank 241-AP-103 . . . . 88

3.3.1.2 Temperature History of Tank 241-AP-103 . 88

3.3 .1 .3 Occurrences of Tank 241-AP-103 . . . . 88

3.3.1.4 Isychrometrics of Tank 241-AP-103 . . . 88

3.3 .2 Current Status of Tank 241-AP-103 . . . . . . 89

3.3.2.1 Tnventory Rstimate of Tank 241-AP-103 . 89

3.3.2.2 In-Tank Photograph of Tank 241-AP-103 . 89

3.3.3 Synopsis of Tank 241-AP-103 . . . . . . . . . 89

3.4 Tank 241-AP-104 . . . . . . . . . . . .... 93

$3.4 .1241-\mathrm{AP}-104$ Tank History ........... 93

3.4.1.1 Waste History of Tank 241-AP-104 . . . . 93

3.4.1.2 Temperature History of Tank 241-AP-104. 93

3.4 .1 .3 Occurrences of Tank 241-AP-104 . . . . . 93

3.4 .1 .4 Esychrometrics of Tank 241-AP-104 * * . 93

3.4 .2 Curzent Status of Tank 241-AP-104 . . . . . 94

3.4.2.1 Inventory Estimate of Tank 241-AP-104 . 94

3.4.2.2 In-Tank Photograph of Tank 241-AP-104 . 94

3.4 .3 Symogsis of Tank 241-AP-104 . . . . . . . . . 94

3.5 Tank 241-AP-105 . . . . . - . . . . . . . . . . 98

3.5 .1 241-AP-105 Tank History . . . . . . . . . . 98

3.5.1.1 Waste History of Tank 241-AP-105 . . . . 98

3.5.1.2 Temperature History of Tank 241-AP-105 . 98

3.5.1.3 Occurrences of Tank 241-AF-105 . . . . . 98

3.5.1.4 Fsychrometries of Tark 241-AP-105 . . . 98

3.5 .2 Current status of rank 241-Ap-1.05 . . . . . . 98

3.5.2.1 Inventory Estimate of Tank 241-AP-105. 99

3.5.2.2 In-Tark Dhotograph of Tank 241-Ap-105 . 99

3.5.3 Synopsis of Tank 241-2.p-105 . . . . . . . . . 99

3.6 Tank 241-AP-106 . . . . . . . . . . . . . . . . 103 
3.6.1 241-AP-106 Tank History . . . . . . . . . 103

3.6.1.1 Waste History of Tank 241-AP-106 . . . . 103

3.6.1.2 Temperature History of Tank 241-AP-106. 103

3.6.1.3 Occurrences of Tank 241-AP-106.... 103

3.6.1.4 Psychrometrics of Tank 241-AP-106 *. . 103

3.6.2 Current Status of Tank 241-AP-106 . . . . . . 104

3.6.2.1 Inventory Estimate of Tank 241-AP-106. 104

3.6.2.2 In-Tank Photograph of Tank 241-AP-106. 104

3.6.3 Synopsis of Tank 241-AP-106 ......... 104

3.7 Tank 241-AP-107 . . . . . . . . . . . 108

3.7.1 241-AP-107 Tank History . . . . . . . 108

3.7.1.1 Waste History of Tank 241-AP-107... . 108

3.7.1.2 Temperature History of Tank 241-AP-107 * 108

3.7.1.3 Occurrences of Tank 241-AP-107 . . . . . 108

3.7.1.4 Psychrometrics of Tank 241-AP-107 *. . 108

3.7.2 Current Status of Tank 241-AP-107..... 109

3.7.2.1 Inventory Estimate of Tank 241-AP-107 * 109

3.7.2.2 In-Tank Photograph of Tank 241-AP-107: 109

3.7.3 Syriopsis of Tank 241-AP-107 . . . . . . . . + 109

3.8 Tank 241-AP-108 . . . . . . . . . . . . . . . . 113

3.8.1 241-AP-108 Tank History . . . . . . . . . . . 113

3.8.1.1 Waste History of Tark 241-AP-108 ... . 113

3.8.1.2 Temperature History of Tank 241-AP-108, 113

3.8.1.3 Occurrences of Tank 241-AP-108 . . . . . 113

3.8.1.4 Psychrometrics of Tank 241-AP-108 -. . 113

3.8.2 Current Status of Tank 241-AP-108 - - - - . . 114

3.8.2.1 Inventory Estimate of Tank 241-AP-108 - 114

3.8.2.2 In-Tank Photograph of Tank 241-AP-108 . 114

3.8 .3 Synopsis of Tank 241-AP-108 . . . . . . . 114

AN Tank Farm . . . . . . . . . . . . . . . . . . . 118

4.0.1 AW Tank Farm History ............ 118

4.0.1.1 AW Tank Farm Waste History...... . . 120

4.0.1.2 AN Tank Farth Tenperature History ... . 120

4.0.1.3 AN Tank Farm Occurrences . . . . . . . . 120

4.0.1.4 AN Tank Fanta Ventilation . . . . . . . 120

4.0.2 Current Status of AW Tank Farm . . . . . . . 121

4.1 Tank 241-AW-101 . . . . . . . . . . . . . . . . 121

4.1 .1 241-AW-101 Tank History . . . . . . . . 121

4.1.1.1 Waste History of Tank 241-AW-101... . 121

4.1 .1 .2 Temperature History of Tank 241-AN-101, 121

4.1.1.3 Occurrences of Tank 241-AW-101 . . . . 122

4.1.1.4 Psychrometrics of Tank 241-AW-101 * . 122

4.1.2 Current Status of Tank 241-AW-101 . . . . . 122

4.1.2.1 Inventory Estimate of Tank 241-AW-101, 122

4.1.2.2 In-Fank Photograph of Tank 241-AW-101, 123

4.1.3 Synopsis of Tank 241-AW-101 . . . . . . . . . 123

4.2 Tank 241-AW-102 . . . . . . . . . . . . . 128

4.2 .1 241-AW-102 Tank History . . . . . 128

4.2.1.1 Waste History of Tank 241-AW-102, , , 128

4.2.1.2 Temperature History of Tank 241-AW-102, 128

4.2 .1 .3 occurrences of Tank 241-AW-102 . . . . 128

4.2.1.4 Psychrometrics of Tank 241-AW-102 * . 128

4.2.2 Current Status of Tank 241-AW-102 . . . . . 129 
4.2.2.1 Inventory Estimate of Tank 241-AW-102 ' 129

4.2.2.2 In-Tank Photograph of Tank 241-AW-102 . 129

4.2.3 Synopsis of Tanik 241-AN-102 . . . . . . . . . 129

4.3 Tank 241-AW-103 ................... 133

4.3.1 241-AK-103 Tank History . . . . . . . . . 133

4.3.1.1 Haste History of Tark 241-iw-103, . . . 133

4.3.1.2 Temperature History of Tank 241-AW-103 . 133

4.3.1.3 Occurrences of Tank 241-AW-103 ..... . 133

4.3.1.4 Psychrometrics of Tank 241-AN-103 . . . 133

4.3.2 Current status of Tank 241-Aw-103 . . . . . . 134

4.3.2.1 Inventory Estimate of Tank 24i-AW-103 . 134

4.3.2.2 In-Tank Fhotograph of Tank 241-AW-103 . 134

4.3.3 Synopsis Tank of 241-AM-103 . . . . . . . . . 134

4.4 Tank 241-AW-104 . . . . . . . . . . . . . . . 138

4.4.1 241-AW-104 Tank History . . . . . . . . . . . 138

4.4.1.1 Waste History of Tank 241-AW-104 . . . . 138

4.4.1.2 Temperature History of Tank 241-AW-104 - 338

4.4.1.3 Occurrences of Tank 241-AW-104 - . . . . 138

4.4.1.4 Psychrometrics of Tank 241-AW-104 . . . 139

4.4.2 Current Status of Tank 241-Aw-104 . . . . . . 139

4.4.2.1 Inventory Estimate of Tank 241-AW-104. 139

4.4.2.2 In-Tank Photograph for Tank 241-4\$-104. 139

4.4.3 Symopsis of Tank 241-AW-104 . . . . . . . . . 140

4.5 Tank 24I-AW-105 . . . . . . . . . . . . . 145

4.5.1 241-AW-105 Tank History . . . . . . . . . 145

4.5.1.1 Waste History of Tank 241-AW-105 . . . . 145

4.5.1.2 Tenmerature History of Tank 241-AW-105 . 145

4.5.1.3 Occturrences of Tank 241-Ak-105 . . . . . 145

4.5.1.4 Rsychrometrics of Tank 241-AW-105 . . . 145

4.5.2 Current Status of Tank 24l-AW-105 . . . . . . 146

4.5.2.1 Inventory Estimate of Tank 241-AW-105 . 146

4.5.2.2 In-Tank Photograph of Tank 241-AW-105. 146

4.5 .3 Synopsis of Tank 241-AW-105 . . . . . . . . . 146

4.6 Tank 241-4W-106 . . . . . . . . . . . . . . 150

4.6.1 241-AW-106 Tank History . . . . . . . . . 150

4.6.1.1 Waste History of Tank 241-AN-106 . . . . 150

4.6 .1 .2 Temperature History of Tank 241-AN-106. 150

4.6 .1 .3 occurrences of Tank 241-AW-106... . . 150

4.6.1.4 Psychrometrics of Tank 241-AW-106. . . 150

4.6.2 Current Status of Tank 241-AW-106 . . . . . . 151

4.6.2.1 Inventory Estimate of Tank 241-Ai-106 * 151

4.6.2.2 In-Tank Photograph of Tank 241-AW-106 , 151

4.6.3 Symopsis of Tank 241-AW-106 . . . . . . . . . 151

5 AY Tank Farm . . . . . . . . . . . . . . . . . . . . 156

5.0.1 AY Tank Farm History . . . . . . . . . . 156

5.0.1.1 AY Tank Farm Waste History . . . . . . . 158

5.0.1.2 AY Tank Farm Teaperature History . . . . 158

5.0.1.3 AY Tank Farm Occurrences . . . . . . . 158

5.0.1.4 AY Tank Farm Veritilation . . . . . . . 158

5.0.2 Current Status of AX Tank Farm . . . . . . . 159

5.1 Tank 241-AY-101 . . . . . . . . . . . . . . . . 159

5.1.1 241-AY-101 Tank History . . . . . . 159

S.1.1.1 Waste History of Tank 241-AY-101 . . . 159 
5.1.1.2 Termperature History of Tank 241-AY-101 + 159

5.1.1.3 Occurrences of Tank 261-AY-101 . . . . . 160

5.1 .1 .4 Psyehrometrles of Tank 241-AY-101 . . . 160

5.1 .2 Current Status of Tank 241-AY-101 . . . . . . 160

5.1.2.1 Inventory Estimate of Tank 241-AY-101. 160

5.1 .2 .2 In-Tank Photograph of Tank 241-AY-101 - 161

5.1.3 Symopsis of Tank 241-AY-101. . . . . . . . . 161

5.2 Tank 241-AY-102 . . . . . . . . . . . . . . . . 166

5.2.1 241-AY-102 Tank History . . . . . . . . . . . 166

5.2.1.1 Waste History of Tank 241-AY-102 . . . . 166

5.2.1.2 Temperature History of Tank 241-AY-102 , 166

5.2.1.3 Occurrences of Tank 241-AY-102 . . . . . 166

5.2.1.4 Psychrometries of Tank 241-AY-102 . . . 166

5.2.2 Current Status of Tank 241-дY-102 . . . . . . 167

5.2.2.1 Inventory Estimate of Tank 241-AY-102 . 167

5.2 .2 .2 In-Tark Photograph of Tank 241-AY-102 . 167

5.2 .3 Synopsis of Tark 241-AY-102 . . . . . . . . . 167

AZ Tank Farm . . . . . . . . . . . . . . . . . . . . . 172

6.0.1 AZ Tank Farm History . . . . . . . . . . . . 172

6.0.1.1 AZ Tank Farm Waste History . . . . . . . 174

6.0.1.2 AZ Tank Farm Temperature History . . . . 174

6.0.1.3 AZ Tank Farm Occurrences . . . . . . . . 174

6.0.1.4 Az Tank Farm Ventilation . . . . . . . . 174

6.0 .2 Current Status of AZ Tank Farm . . . . . . . 175

6.1 Tank 241-AZ-101 ................... 175

6.2.1 241-AZ-101 Tank History . - . . . . . . . . . 175

6.1.1.1 Waste History of Tank 241-Az-101 . . . . 175

6.1.1.2 Temperature History of Tank 241-Az-101 . 175

6.1 .1 .3 Occurrences of Tank 241-Az-101 . . . . . 176

6.1.1.4 Psychrometrics of Tank 241-AZ-101 . . . 176

6.1.2 Current Status of Tank 241-Az-101 . . . . . . 176

6.1.2.1 Inventory Estimate of Trank 241-AZ-101 . 176

6.1.2.2 In-Tank Photograph of Tank 241-Az-101 . 176

6.1 .3 Synopsis of Tank 241-Az-101 . . . . . . . . . 177

6.2 Tank 241-Az-102 . . . . . . . . . . . . . . . . 182

6.2 .1 241-Az-102 Tank History - . . . . . . . . . . 182

6.2 .1 .1 Waste History of Tank 241-Az-102 . . . . 182

6.2 .1 .2 Temperature Fistory of Tank 241-AZ-102 . 182

6.2 .1 .3 occurrences of Tark 241-AZ-102 . . . 182

6.2.1.4 Psychrometrics of Tank 241-Az-102 . . . 182

6.2 .2 Current Status of Tank 241-Az-102 . . . . . . 183

6.2.2.1 Inventory Estimate of Tank 241-Az-102 * 183

6.2 .2 .2 In-Tank Photograph of Tank 241-Az-102 . 183

6.2 .3 Synopsis of Tank 241-Az-102 . . . . . . . . . 184

7 SY Tank Farm . . . . . . . . . . . . . . . . . . 189

7.0 .1 SY Tank Farm History . . . . . . . . . 189

7.0.1.1 SY Tank Farm Waste History . . . . + . + 191

7.0.1.2 SY Tank Farm Temperature History . . . . 191

7.0.1.3 SY Tank Farm Occurrences . . . . . . . 191

7.0.1.4 sY Tank Farm Ventilation . . . . . . . . 191

7.0 .2 Current Status of SY Tank Farm . . . . . . . 192

7.1 Tank 241-SY-101 . . . . . . . . . . . . . . . . 192 
7.1.1 241-SY-101 Tank Histozy . . . . . . . . . 192

7.1.1.1 Waste Fistory of Tank 241-5Y-101 . . . . 192

7.1.1.2 Temperature History of Tank 241-5Y-101 : 192

7.1.1.3 Occurrences of Tank 241-SY-101 . . . . . 193

7.1.1.4 Psychrometrics of Tank 241-SY-101 . . . 193

7.1.2 Current Statis of Tank 241-SY-101 . . . . . 194

7.1.2.1 Inventory Estimate of Tank 241-\$Y-101 . 194

7.1.2.2 In-Tank photograph of Tank 241-SY-101: 194

7.1 .3 Synopsis of Tank 241-\$Y-101 . . . . . . . 196

7.2 Tank 241-SY-102 . . . . . . . . . . . . . . . 199

7.2.1 241-SY-102 Tank History . . . . . . . . . . 199

7.2.1.1 Waste History of Tank 241-SY-102, . . 199

7.2.1.2 Temperature History of Tank 241-SY-102 : 199

7.2 .1 .3 Occurrences of Tank 241-SY-102 . . . . . 199

7.2.1.4 Psychrometrics of Tank 241-SY-102 . . . 200

7.2.2 Current Status of Tank 241-SY-102 . *.. . 200

7.2.2.1 Inventory Estimate of Tank 241-SY-102: 200

7.2 .2 .2 In-Tank Photograph of Tank 241-5Y-102 * 200

7.2 .3 Synopsis of Tank 241-SY-102 . . . . . . . . 200

7.3 Tank 241-5Y-103 . . . . . . . . . . . . . . . 205

7.3.1 241-5Y-103 Tank History . . . 205

7.3.1.1 Waste Histozy of Tank 241-SY-103 . . . . 205

7.3.1.2 Temperature History of Tank 241-SY-103 . 205

7.3.1.3 Occurrences of Tank 241-5Y-103 . . . . . 205

7.3.1.4 Psychrometrics of Tank 241-5Y-103 * . . 206

7.3 .2 Current Status of Tank 241-5Y-103 . . . . . . 206

7.3.2.1 Inventory Estimate of Tank 241-5Y-103. 206

7.3.2.2 In-Tank Photograph of Tank 241-SY-103 : 206

7.3 .3 Synopsis of Tank 241-5Y-103 . . . . . . . 207

8 Glossary . . . . . . . . . . . . . . . . 212

8.1 Waste Abbreviations . . . . . . . . . 235

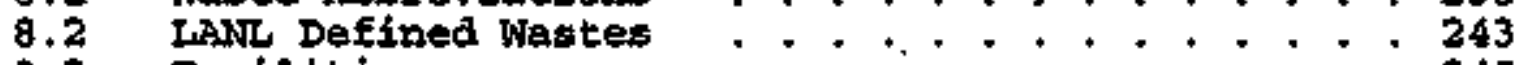

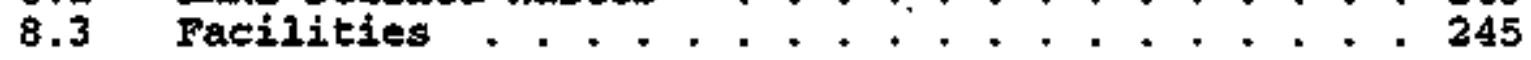

9 References . . . . . . . . . . . . . . 246 


\subsection{Furpose}

This docunent provides historical evaluations of the Iadioactive and mixed waste stored in the fanford site underground double-shell tanks (DSTs). A Historical Tank Content Estimate has been developed by reviewing the process histories, waste transfer data, and available physical and chemical characterization data from various Department of Energy (DOE) and Department of Deferse (DOD) contractors.

The historical data will supplement information that is currently being gathered from core sampling the wastes in the tanks. Review of a tank history accompanled by current characterization data will create an inventoxy estimate that is more complete and reliable then core sampling alone. A historical review of the tanks may reveal anomalies or unusual contents that are critical to characterization and post characterization activities.

Complete and accurate tank waste characterizations are critical first steps for the DOE and Westinghouse Hanford Coupany safety programs, waste pretreatment, and waste retrieval activities.

\subsection{Scope}

The scope of this document is limited to the DSTs in the Hanford 200 Area. The SY Itank Farm was added to the southeast quadrant because of its similarities with the other tanks and it is the only DST farm in the 200-West Area. The northeast and southeast quadrants represent an approximate goographical division of the 200-East Area tank farms. The division was made as follows:

NE Quadrant: A, AX, B, BX, BY, C

- SE Quadrant: AN, AE, AN, AY, AZ, SY

The maps on the following pages detail the 200-East and 200-West Arats.

\subsection{Approach}

This report is a compilation of work performed by ICF Kaiser Hanford Company, Los Alamos National Laboratory, and Westinghouse Hanford Company.

ICF Kaiser Hanford Company reviewed the history of the tanks in each of the four guadrants and incoxporated the inventory estimates and moclels of tank layers being developed by Los Alamos National Laboratory into the report. Historical waste transfer and level data, tank physical information, temperatur data, and sampling data have been compiled for this report and supporting documents for the Southeast quadrant Historical Tark Content Estimate (Breviek, 1995). 
WHC-SD-WH-ER-350, Rov. 0
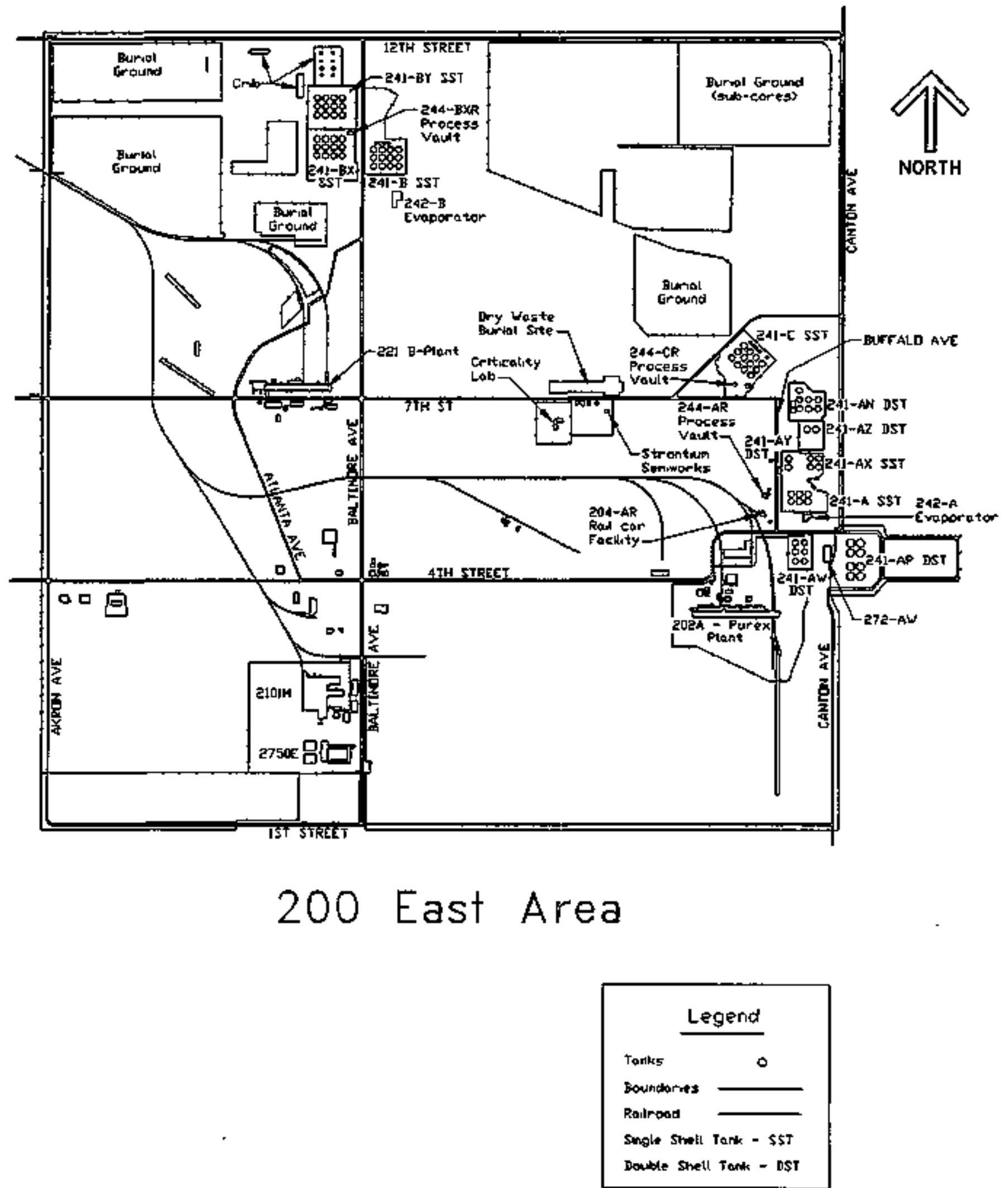
WHC-SD-WW-ER-350. Rav. O

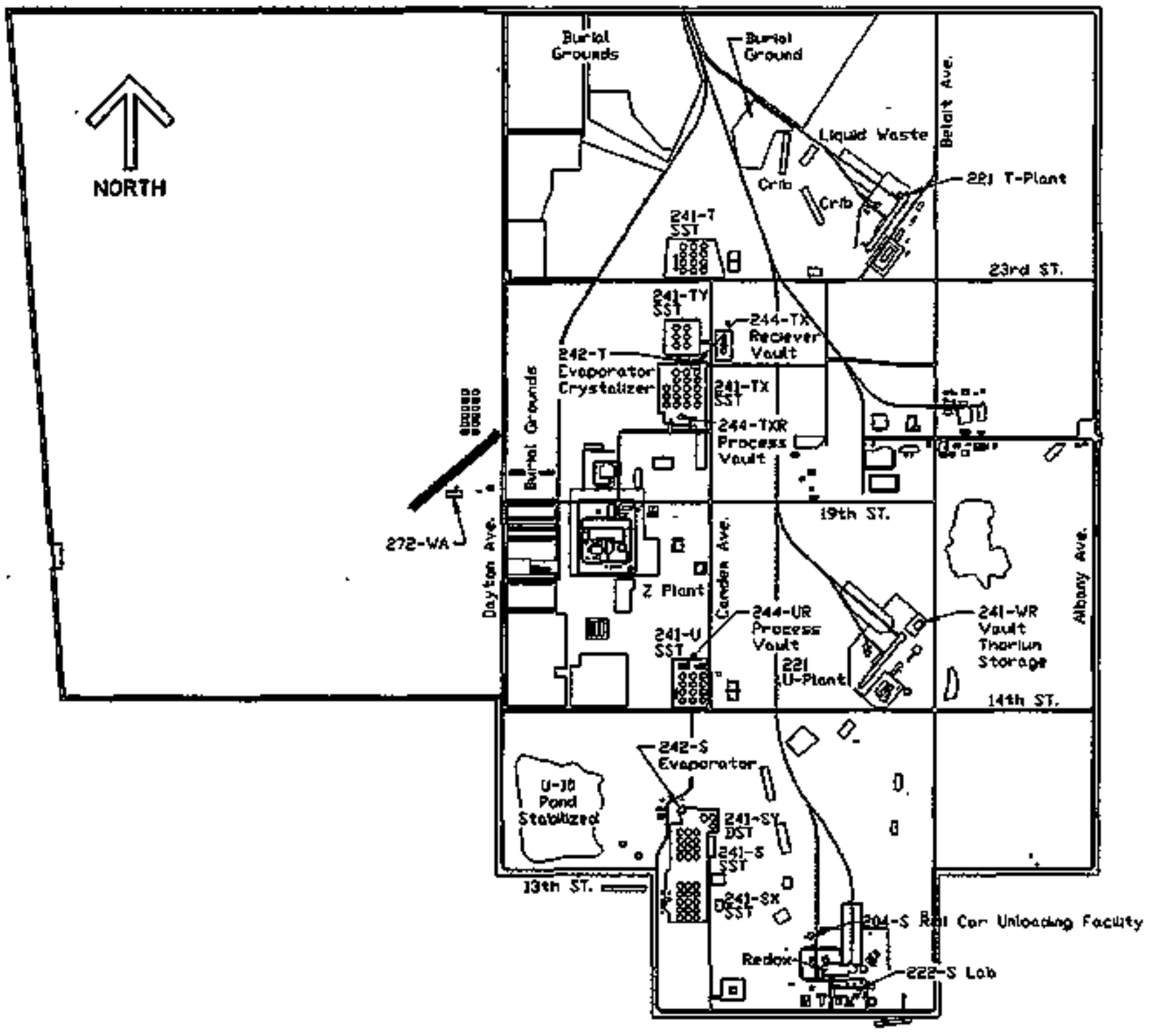

200 West Area.

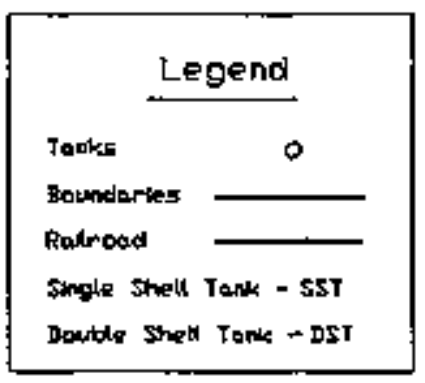




$$
\text { WHC-SD-WM-ER-350, ReV. } 0
$$

1.3.1 Survei11 ance Technigues for the Hanford Radioactive and Mixed Waste storage Tanks

Surveillance information is used to determine the condition of the tanks and the characteristics of the waste. Tank integrity $\{i . e .$, sound, assumed leaker, assumed re-leaker) is investigated by monitoring waste levels and the leak detection pits. Waste temperatures can be used to correlate the inventories of heat-generating radionuclides such as cesium $137\left({ }^{137} \mathrm{Cs}\right)$ and strontium $91\left({ }^{91} \mathrm{Sr}\right)$. The instrumentation and methods used for tank surveillance are described in the following sections.

In-Tank Surface Isvels

Four liguid level devices are used to monitor and control liquid levels in the primary tank of a double-shell tank: a level indicating transmitter or Food Instrument Corporation gauge, a level indicator assembly or manual tape, $\mathrm{A}$ high level detector, and the BNkAF 854 Liquid Ievel Indicator/Transmitter. A level indicator assembly or manual tape is used to measure liguid levels in the amnulus.

The Food Instrument Corporation gauge is used as the primary liquid level monitoring device with the manual tape as a backup in the primary tank. The high level detector is used to detect intrusions within the primary tank. The Food Instrument Corporation gauge consists of an electrode and steel tape that detects liguid on contact. The measurements are scanred hourly on the computer automated surveillance system (CASS).

The manual tape flake boxes are used as access for measuring liquid levels manually if the automatic system fails or does not exist in the primary tank. A hand crank on the flake box is used to lower the tape probe untll liquid is contacted and a liguid level measurement can be obtained. The flake boxes located over the annulus are used to lower manual tapes into the annulas to monitor leaks from the primary tank.

The ENPAF 854 Liquid Level Indicator/Transmitter has been installed on several tanks and will eventually replece the old level megsurement. devices. Eevel detection in the ENRAF is based on the principle of buoyancy of a non-floating polyethylene displecer. The weight of the displacer is entered into the memory of the gauge. A second weight of about 10-15 grams less than the actual welght of the aisplacer is entered into a different location in the memory. The displacer will move up or down untill it weighs the same as the second (lighter) weight. The displacer remains in contact with the waste and sustains the programmed second weight. The measurements are entered into the Tank Monitoring and Control System (THACS).

Sludge levels are determined with a sludge measurement device which consists simply of a "doughnut" shaped weight attached to a steel tape. The sludge measurement device is lowered into the tank until it stops. Several risers are used to determine the contours of the sludge below the liquid waste. 
WHC-SD-WM-ER-350, Rev. 0

Interstitial Iiquid Level (Liquid observation Wells)

Food Industry corporation gauges and manual tapes are limited to surface level measurement. Therefore, wells to observe licuid have been installed in Tanks 241-SY-102 and 241-AW-103 to monitor the interstitial liquid levels. The interstitial liquid is the liquid trapped within and underneath the solid waste. Gamm, neutron, and acoustic probes may be lowered into the liquid observation wells to detemine the interstitial liquid levels within the tank. The two observation wells are used strictly for special surveiliance and are not monitored on a regular basis.

Tenperatures

The temperatures of the double-shell tanks are monitored with thermocouples. A typical double-shell tank contains approximately 100 thermocouples at a variety of locations including the structural concrete of the tank foundation, walls, and come; the tank knuckle region; the insulating concrete in the base; the primary steel liner; and the tank waste and vapor space. The aging waste tanks (AY and AZ Tank farms) have thermocouples in their air lift circulators. Thermocouples in the waste are typically attached to a thermocouple tree anchored to a tank riser. Several tree designs exist, but a tree generaliy consists of thermocouples and leacs housed in a pipe that provides a means of flxing the probes at different heights in the waste. A typical double-shell tank contains one tree, and a typical tree contains 18 thermocouples. In recent years, aulti-functional instrument trees (MIT) have been installed into a few of the watch list tarks (Tanks 241-5Y-101, 241-SY-103, and 241-As-101). These trees measure other properties, such as gas pressure and hydrogen concentration in the vapor space, in addition to the temperature. An MIT contains. 22 thermocouples. Details on the status of the thermocouples as of Apxil 1993 can be found in the Thermocouple status, Single shell and Double Shell Waste Tanks (Tran 1993).

The temperatures are recorded either manualiy on data sheets using a portable potentiometer or by one of several computer-automated systems. These systems include the computer automated surveillance system (CASs). the tank monitor and control system (TMACS), and the data accuisition and control system (DACs). These systems record other data besides temperatures. The surveillance analysis computer system (SACS) is tho primaxy database for storing tank temperature data. The CASS and Tuacs record temperatures on some single-shell tanks and double-shell tarks. The DaCs only records temperatures in Tank 241-SY-101. In the past, the cASS has recorded temperatures of all double-shell tanks, but it gresently records temperztures only for the AP Tenk farm. The CASS stores temperature data on magnetic tape, bitt the data will be transferrad to the sxcs in the future. The TTACs presently records temperatures fox the AN and SY Tank farms, but it is plarmed to be operating for all tark farms by September 1996. The Thacs transfers its daily temperature readings to the SACS. Operators manually record temperatures on data sheets for the AP, $A W, A Y$, and Az Tank Farms. For the AP and AW Tank Farms, these temperatures from data sheets are manually entered and stored in the SACS. The SACS does not presently store tenperature data for AY and Az farms. 


$$
\text { WHC-SD-FM-ER-350， Rev, } 0
$$

Annulus

The couble-shell tanks are designed so that if a leak develops in the primary tank shell, the leak can be detected in the annulus, the spaco between the steel liners. The arnulus monitoring equipment is used to detect the presence of liquids, level of radiation, increase in temperature, and differential pressure. Drain channels are installed in the basal concrete to collect any leakage and direct it to the anmulus. Photographs were taken inside the annulus for inspection purposes during tank constraction.

Leak Detection Pits

Ieak detections pits are located next to the tank. Three measurement: devices are used in the leak detection pits: a liquid level detector, a thermocouple, and a radiation monitor. The liquid level detector used in the leak detection pits is a specific gravity dip tube. Since the dip tubes need to be checked for accuracy periodically, 6-inch water level is maintained in the bottom of the 24-inch leak detection pit to provide continuous checking capabilities. A thermocouple is placed at the bottom of the pit to detect an increase in temperature from arry leak of heat generating radionuclides. A drywell next to the leak detection pit, contains radiation monitoring device to determine background radiation levels and detect leaks.

\section{- Ventilation}

The ventilation for the primary tank and the annulus is filtered through high-efficiency particulate air (HEPA) filters and monitored continuously for malfunctions. All the double-shell tanks are actively ventilated to prevent radioactive releases to the enviromment. Because the ventilation ereater negative pressure in the primary tank, the negative pressure is monitored in the primary tank to prevent bickling of the tank bottom. The annulus vacuum or negative pressure is also monitoxed for changes that indicate a tank leak or system problems.

Gince differential pressure is related to ais flow in the tank, differential pressure readings are taken at the exhaust fans, filters, and deentrainers. The vapor space and atmospheric pressures are monitored and compared. High differenticl pressures are caused by filter plugging or wet filters, while low differential pressure can be caused by filter seal problems or tank pressurization. Continuous monitoring exists for radiation levels in the ventilation room and at various locations along the ventilation system.

- Evaporation Rate (Psychrometrics)

Psychrometric data are collected on all the double-shell tanks and high-heat load single-shell tanks. The data are obtained from air moving through the inside of each tank and the annulus. The schedule for obtaining psychrometric data is determined by wic Process Engineering. Eresently, data are recorded about once a month.

The main reason for recording psychrometric data for the tank is an attempt to determine the rate of evaporation in the terks. The evaporation rates can be used to account for loss of liguid from the tanks. The 
WHC-SD-TH-ER-350, ReV. 0

psychrometric data collected in the arnulus are used to guantify the moisture content of the air in the annulus. The psychrometric data can also be used to estimate the instantaneous rate of heat transfer into the ventilation systems of the tank and the annulis.

In order to calculate the evaporation rates and heat exchange in the tank, five pieces of information are required. The first two pieces are the wet-bujb and dry-bulb temperatures of air entering the tank. The next two pieces are the wet-bulb and ary-bulb temperatures of air leaving the tank. The final piece is the volumetric flow rate of air moving through the tank.

Dry-bulb temperatures are obtained using a standard thermometer. Met-bulb temperatures are measured with a thermometer whose bulb is covered by a cotton wick saturated with water. When the wet wick is placed in the air stream, some of the water in the wick is evaporated. As a result, the temperature of the water decreases. After awhile, the heat loss from the water by evaporation ecuals the heat gain From the air, and the water tempexature stabilizes. This stabilized temperature is the wet-bulb temperature.

Once the wet-bulb and dry-bulb temperatures are known, one can determine the properties (enthalpy, relative humidity, specific volume, and humidity ratio) of air at the tank entrance and exit. By comparing the properties of air at these points, one can determine the amount of water added and heat transferred to or from the air stream.

The raw data have always been measured and recorded in the field. However, methods of calculating the evaporation rate and heat transfer rate have differed. Before 1989, evaporation rates and heat transfer rates were calculated using a program on a Hewlett Packard Calculator. From 1989 until the prsent, the raw data were entered into a computer spreadsheet (Microsoft Excel) and the evaporation rate and heat transfer rate were automaticaliy calculated. The program was modified to represent more accurately the calculations made by the American Society of Heating, Refrigerating and Air-Conditioning Engineers, Inc. The main difference is that the density of water is now fit to a curve as a function of temperature to match the latest standards. These calculations have been documented and checked (Wood, 1993).

\section{In-Tank Photography}

In-tank photography is another method to determine the volume of waste. Photographs are used to resolve momalous measurements inside the tanks and to assist in determining tank integrity. Fhotographs can also be used to determine sludge and liquid levels, provide a degree of corroboration with other waste management processes, and be a source of information about foreign objects contained in the tanks. The photographs can be compared to see if wastes in tanks with similar histories have similar characteristics. Currently, photographs are not used to determine waste levels in double-shell tanks because none are leaking. Photographs were taken in each anmulus during construction for inspection purposes. 


$$
\text { WHC-SD-WM-ER-350, Rev. } 0
$$

1.3.2 Approach and Development of Supporting Information Contained in the Historical Tark Content Estimate and supporting Docunents

Extensive historical information was gathered for each tank. The data are summarized in the Historical Tank Content Estimate Report (HTCE) including the tank level history, in-tank photos, the Tank Layer Model, the Supernatant Mixing Model, and the inventory estimate. For a more comprehensive data set on each tark, refer to the Supporting Documents for the Historical Tark Content Estimate Reports for each respective tank farm in the southeastern quadrant (Brevick, 1995).

\section{- Tank Level Histories}

The tank level histories are gxephical representations of waste levels over the lifetime of a tank. They include information such as waste types, in-tank photograph dates, transfer data, and physical data. Information was gathered from various documents and the resulting conments were added directly to each drawing.

The liguid and solids levels are shown on the tank level history graphs as volumes and tank elevations. The following conversion was used to relate the elevation to the respective volume for all tanks in the doubleshell tank farms:

FORIUUIA

$$
\frac{\text { Total Gallons }}{2750 \frac{\text { Gallons }}{\text { Inch }}}=\text { Total Inches }
$$

\section{Temperature Plots}

The source of the historical temperatures presented here are the computer automated surveillance system, surveiliance analysis computer system, and data sheets from manual recordings. The raw data from these three sources span from July 1981 to Harch 1995. The computer automated surveillance system stored daily tempereture readings for all DST farms on magnetic tapes. The computer automated surveillance system stores temperatures for most thermocouples in the tank (foundation, walls, primary liner, etc.); however, only in-tank themocomple data are presented in thits report. The surveillance analysis computer system database provided weekly temperature readings for all ferms but the $A Y$ and $A 2$ Tank Farms. The surveillance andlysis computer system stores temperature readings for a subset of the in-tark thermocouples in each dotible-shell tank. Data sheets provided daily tenperature readings for the Az Tank Faxm ciuring a brief period of time in late 1989 and early 1990. More data sheets may exist. but they have not been located. 


$$
\text { WHC-SD-WH-ER-350, Rev. } 0
$$

The raw data from the computer automated surveillance system, surveillance analysis computer system, and data sheets were imported into the computer spreadsheet software (Microsoft Excel). Within the Excel program, time history plots of each thermocouple revealed suspect data points that were subsequently removed from the data set. Statistical and linear regression analyses besed on this reduced data set of non-suspect temperatures are presented in the individual tank sections. Suspect data points satisfied one of the following criteria: 1) a large scatter in temperatures from one day to the next over a continuous period of time; 2) an individual temperature reading not following the trend of the other temperatures recorded in the same period of time; 3) disagreement between data recorded at the same time from the computer automated surveillance system and surveillance analysis computer system; or 4 ) the disagreement between an individual thermocouple reading with the reading of thermocouples located above and below it on the tree. The non-suspect data set spanned from July 1983 to Decenber 1993. Tabular listings and plots of the in-tank temperature data are available in the supporting Documents for the southeast quadrant historical Tank content Estimate (Brevick, 1995).

Surface Ievel Plots

The surface tevel data from 1991 to 1994 were obtained from the Westinghouse Hanford Compary ORACLE database through the surveillance analysis computer systen. The information was parsed in a spreadsheet (Excel) and graphed to show waste level versus tims. Current surface level information is available in the supporting aocuments (Brevick, 1995 ).

Tank Profiles and Other Drawings

The drawings in this report were compiled from several sources including as-built arawings and the Double-shell Waste storage Tanks Riser study (Anderson, 1992) . The risers and penetrattons through the tank dome serve several purposes incluaing points of access for mont toring equipment and sampling the waste.

Photographs

The latest tank interjor and tank farm aerfal photographs were obtained from Pacific Northwest Laboratory. The tank farm aerial photographs were labeled to indicate the relative position of oth tank in the farm. Iarger equipment was labeled in the photographs. Photographs of tank interiors have been arranged to show the contents of each tank. The auxiliary equipment within each photographic collage was identified, if possible; and labeled appropriately.

Historical Sample Analysis Data

The sampling data were obtained from the WHC Tank Waste and Retrieval group. Tables of analytical data were macie for samples taken prior to September 1989. The information was compiled in the Microsoft Excel computer program to present the data as similarly as postible. The tables include physical dat and chemical and radiological analysis data by analyte (i.e., exch item analyzed). Other data included with the sample references are summarized as text. Historical tank sample analysis data are available in the supporting documents (Brevick, 1995). 
WHC-SD-FM-ER-350, Rev. O

\section{Psychrometric Plots}

The psychrometric data were obtained from both the manual and electronic records of the WHC Tank Farm Surveillance group. In order to represent the data, all the data needed to be besed on the same equations. Consequently, all the data were entered into computer spreadsheets (Excel), and the latest program (wood, 1993) was used to calculate evaporation rates and heat transfer rates. These quantities have been plotted against time on separate graphs. Evaporation rate versus time is plotted in gallons per week. Evaporation in gallons per week is used to show the amount of water removed from the tank. Heat transfer rates were plotted in Btu/hr.

The heat generated in the tank waste is dispersed into the environment: through the ventilation systems of the tank and annulus, through the tank walls into the soil, and through other types of heat loss. The major portion of the heat exchanged with the environment occurs through the ventilation systems. By plotting the rate of heat exchange between the waste and the ventilation systems, and reviewing the respective trends in conjunction with the flow rates and ambient temperatures, trends were postulated for the heat generation rate of the waste.

1.3.3 Approach and Development of the Process-Based Historical Tank content Estimate

The estimates of tank contents using process-based historical data, presented in this report were developed by Los Alamos National Laboratory. The estimates are the primary sources of data to characterize tank contents until the tank waste characterization reports are completed. The characterization reports will incorporate the results of eurrent core sampling and analyses with the tank content estimates based on historical data to present the most current evaluation of waste constituents.

Gererating tank content estimates based on historical information involves managing and evaluating large quantities of data. The system of generating the estimates is composed of several parts which are described in the following sections.

Waste status and Transaction Record Summary

The Waste Status and Transaction Record Stmmary (WSTRS) is a database containing all known waste transfer records. Historically, when waste was punped from plant (process) to tank or tank to tank, a record was kept of the volume and type of waste that was pumped. The transaction sumary is the recorded levels of the solids and supernatant.

The WSTRS is partitioned into four separate sections (i.e., quadrants). The database for the southeast quacrant is available in Document No. WHC-SD-MM-TI-689, Rev. 1 (Agmew, 1995).

Tank Layer Hode1

The Tank Layer model is derived from the WSTRS database. The purpose of the Tank Layer Model is to predict the vaste types and volumes of solids in each tank. The model is generated by reconciling the xeported levels 
MHC-SD-MM-ER-350, Rev. O

of solids from each tank in the WSTRS with the volume percent of solids expected for the primary additions of waste (Agnew, 1995). The transaction sumary database contains records of the types of waste that entered each tank and the corresponding increase in the solids volume from each waste entry. Not all transactions that occurred were recorded in the WSTRS. However, the primary waste ddditions and medsurements of solids levels used in the Tank Layer Model are well represented. The results of the model are reported in this document. The model is presented graphically with the inventory estimate described below.

- Defined Waste Types

Early in the development of the historical tank content estimates, * need to compile the chemical campositions of all known waste types into one zeference document was recognized. The information was compiled by Los Alamos National Laboratories. The Hanford defined wastes dociment was developed independently of the WSTRS database and the Tank Iayer Model. However, the Hanford defined waste list will be used with the model to obtain the tank waste inventory estimates described below.

The Hanford defined wastes document contains the compositions and physical properties For all known Hanford waste types that went into the double-shell and single-shell tanks. For more details on the methods used to develop these waste types, refer to Hanford Defined hastes: Chemical and Radiortuclide Compositions (Agnew, 1995).

Supernatant Hixing Hodel

Los Alamos National Laboratory developed the Supernatant Mixing Model that describes a "supernatant" portion of each tank as a combination of Hanford defined waste supernatants that have been concentrated by some factor. The following assumptions were used for this model:

1) Ideal mixing of the total volume of each tank throughout its history (i.e., no excluded volume for remaining solids layers).

2) Transactions were added to the MSTRS to resolve unknown transactions for each guarter according to a set of rules. Therefore, an updated WSTRS was used that will be published later as Rev. 2 .

3) Not all of the saltwell liquid sources for 1978 through 1995 are known. All unnown saltwell liquid is now assigned to water for this estimate.

- Inventory Estimates

The and result of combining the information from the Tank Layer Model, the Supernatant Mixing Model, and the Hanford defined westes document is the tank inventory estimate. When the volumes and compositions of each waste type in a particular tank are known from the above sources of information, the total chemical inventory in the tank is calculated. The Tank Iayer Nodel predicts unmown layers for some tanks. When possible, these unknown layers are assigned to a best estimate defined waste type for the composite inventory estimates. Layers that have not been assigned a best estimate waste type are not included in the composite tank estimates. Diatomaceous earth and cement are also not included in the composite 


$$
\text { HHC-SD-WM-ER-350, Rev. } 0
$$

inventory estimates. The tank invertories use data through the December 1993 Tank Farm Surveillance and Waste Status summary Reports (Hanlon, 1993). The results for individual tanks are presented in tabular form with tanks that have unassigned waste layers indicated.

The inventory estimates developed by Los Alamos National Laboratory are checked against existing date from current sample analyses, thermal and physical models, and historical records. The checking constitutes a large portion of the time reguired to develop the estimates. When estimates are checked against existing data, the models used may be reevaluated. Thus, the process of generating estinates will be iterated and the associated exrors will be reduced over time as the historical knowledge of the tank waste operations increases.

\subsubsection{Assumptions}

The grality of the historical information available for the tanks often requires that assumptions and judgenents be made on the applicability and validity of the data. Some assumptions were used to interpret the data.

\section{- Tenperature Data}

The temperature readings from the computer automited surveillance system, sturveillance analysis computer system, and manualiy recorded data sheets are assumed to apply to the same set of thermocouples on the same thermocouple tree. Thermocouples are identified by tag name; for example, thermocouple 36 in Tank 241-AP-101 is named TE-101-AP-36. The Tran report (1993) identifies all the double-shell tark thermocouples using this naming convention. The computer automated surveiliance system and aata sheets use this naming convention to identify thermocouples; therefore, it was easy to match the data from these two sources for identical thermocouples. The surveillance analysis computer system database uses a different naming convention. The thermocouples are numbered sequentially from 1 to 18 on an 18-thermocouple tree, from number 1 at the bottom of the tret to number 18 at the top. The difference in naming conventions could introduce errors during date entry into the survejilance analysis computer system. It is assumed that no mistakes were made during temperature data entry into the surveillance analysis conputer system and therefore the thermocouple number (1 to 18) corresponds to the correct thermocouple.

The data accilisition system that allows temperatures to be manually recorded on data sheets is assumed to be calibrated the same as the system used by the computex automated surveillance system.

Sanpling Data

The data obtained from the historical analytical information are understood to vary widely in type, cpality, and scope. The data range from the process control analysis obtained from a grab sanple on a few selected analytes to a total characterization suite performed on a core sample. There are no spicific criteria for quantitative data quality for the information incorporated into the historical tank content estimate. The information sources are assessed qualitatively during construction of the 


$$
\text { HHC-SD-WH-ER-350, Rev. } 0
$$

historical tank content ostimate. The available data will be assessed for suitability and consistency in the study and each data source is weighted appropriately for its contribution to the overail estimates.

When the sampling data were compiled, a sample was considered to be a solids sample if it contained greater than 30 solids. Sludge and sluxry sanples were included.

\section{Psychrometric Plots}

Psychrometric data are collected once a month, but at random times. The data from air entering the tank would not always be collected at the same time as the data from air exiting the tank. Therefore, the calculated evaporation rate and heat transfer rate may not be a true representation of the monthly, weekly, or daily average. The data represent only one point per month. By combining all these points, a trend is assumed to exist for each tank. The liquid waste temperature is assumed to be the same temperature as the outlet ary-bulb temperature.

\section{- Inventory Estimates}

Formation of solids in the wastes vary by type and are determined individually by examination of the historical fill records. Further refinement and bounding of the solids formation are provided by conformation to physically attainable systems fe.g.. waste volumes contained in the tanks do not exceed the tank capacity and negative void fractions are not possible). Waste stream compositions were based on process flowsheet information and previous analytical data.

The solids were assumed to be evenly distributed throughout the slurry during their transfer. In the Tank Layer Model, the distribution of solids is chronological and volumetric, but does not attempt to predict the solids stratigraphy (configuration of iayers). Localized mounding and pocketing in various areas of the tank may have occutxed due to phenomena around the inlets and outlets (e.g., cascades and transfers through floating suction pumps removing or depositing sludge). These thenomena would have affected only a small fraction of the tank area and do not inpact the overall results of this study. However, spatial variability within the physical configuration and process history is acknowledged. No method currently exists that would adequately model this discrepancy. An effort is underway to develop this concept further and incorporate it into the tank characterization process, but it is incomplete at this time.

Solids from a specifically designated waste type are assumed to be homogeneous. Variation and layering of the sludge due to differences in component concentration between batches, precipitats particle size, and particle density were guite likely. The effect of thess factors on the distribution of analytes within the solids is unknown. However, the effect probably was small and not detectable with the present sample collection and analysis process.

It was assumed that solids were not compacted and compaction was not accounted for in the study. Although compaction probably occurred in the history of the tariks because additional layers of solids formed atop each 


$$
\text { WHC-SD-WM-ER-350, Rev, } 0
$$

other, the degree of compression is unknown and, therefore, was not. incorporated.

Density and ather physical characteristics of the solids were determined from individual waste type using available information or were based on approximate physical analogues.

The capacity of each tank was never exceeded during transfers. Tank capacity is dependent on fill status, fill order, tank location in a cascade, and tank type.

Tank transfers were normally free of particulates. Therefore, the majority of solids were confined to their initial receiver tanks and were not sent to cribs or transferred extensively between tanks. This assumption was besed on the fact that the punping equipment typically was not designed to transfer substantial guantities of solids (except when sluicing or specifically transferring solids). Monitors on the crib discharge lines should have indicated significant solids contamination, and the tank farm operating procedures would have prevented discharging solids to the ground.

\subsection{Historical Information Quality}

The quality of historical data compiled for this report vaxied greatly. Some data came from published documentation. other data were retrieved electronically from various westinghouse Hanford Conpany databases. The quality of data used in the estimates is described in the following section.

\section{Level Historias}

The level history narrative is designed to give a general description of the waste types contained in a specific tank from startus to the present. The history presents physical characteristics such as the latest maximim temperature of the waste. The current status is also presented. The history is not designed to be detilied summery of every waste type and trensaction for a tank. Tho waste types are general and are usually given only for large transactions $(i . e .$, if a waste is not of sufficient volum to significarity impact the total volume of the tank, then it was not repoxted in the narrative). For a more complete record of transactions and types of wastes involved, refer to the Waste status and Transaction Record Summary (Agnew, 1995).

The accuracy of the tank level histories relies on the completeness of the Westinghouse Hanford Company document i History of the 200 Area Tank Farms" (Anderson, 1990); the monthly Westinghouse Hanford Company, Atlantic Richfield Hanford Company, and Rockwell Hanford Operations waste sumary reports; and the Waste Status and Transaction Record Summary (Agnew, 1995).

Surface level readings may be affected by plumet error, flushing water accumblation, waste surface irregularities and gas generation. Crystalline wastes (i.e., saltcake) can build up on the end of the plurmet 


$$
\text { WHC-SD-WM-ER-350, Rev. } 0
$$

gradually and contact the waste which indicates a Ealse surface level increase. significant level discrepancies occur when the buildup breaks off or when the measuring instrument plummet is flushed to remove the saltcake buildups. Flushing the Food Industry Corporation gauge, annual tapes, or any other equipment may cause accumulated wash water to collect: under the plummet which indicates a false increase in the overall volume of waste within the tank. Surface level readings are often difficult to obtain from tanks with a relatively ary saltcake surface. Some tanks have crystelline buildup on in-tank equipment (i.e., pumps, thermocouples, and other protruding equigment). As the stpermatant j.s pumped from the tanks, the crystalline structure may remiin attached to the equipment and be suspended above the liquid. Therefore, an accurate surface level measurement would be difficult if the breakup of the crystalline structure was inconsistent and a nonuniform waste surface was created. steel tapes that are bent or warped from operation or those discarded on the waste surface are other sources of altered surface level readings.

\section{Temperature Readings}

The quality of raw data from the computer automated surveillance system, surveiliance analysis computer system, and manually recorded data sheets has not been verified. Engineering judgement formed the basis of removing suspect data from this raw data set to produce a set of nonsuspect data. The raw data sources should be reviewed before using the data for any design purposes or safety evaluations.

- Surface Level Data

The surveillance analysis computer system data were obtained electronically from the Westinghouse Hanford Cormany surveillance group and were plotted. The data are actual surface levels recorded from the surveillance echtipment. If the survejilance equipment in a particular tank riser was removed from service, the readings may show 1 level ebange when a new instrument and/or riser is used, especially if the waste surface shows tevere heterogeneity.

Agreement between the plots and the data obtained from the eurveillance group has been verified. However, errors in the data prior to the exchange of information could still exist. The surveillance analysis computer system data were understood to bo urverified prior to the exchange. Therefore, the data should be reviewed before being used for any design purposes or safety evaluations.

- Riser Configuration

The riser configuration was determined from the Double-Shell waste storage Tanks Riser Study (Andersor, 1992) - Arry changes mode after the revision to the study would not be included.

Fhotographs

The photograph collages were made Erom the latest available in-tank photographs. In some tanks, photographs have not been taken since the early 1970s. Some tanks had fogging problems in the vapor space which prevented use of the latest photographs. Sometimes, a review of the older photographs was useful to determine the waste changes. Collages made from 


$$
\text { WHC-SD-WM-ER-350, Re } 0
$$

older photographs may not be indicative of current tank contents, especially if the tank had been purmed since the last time a photograph was taken.

Psychrometric Datt

The psychrometric data obtained from Westinghouse Hanford Company cane from hard copies before 1989 and electronic copies after 1969. Agreement between the raw data obtained from Westinghouse Hanford company and the psychrometric plots has been verified. However, errors in the data prior to the exchange of information may still exist.

The raw data could contain errors. The infet (ambient) conditions could have been measured when the operators first entered the farm and not immediately before the outlet measurements of each tank were taken. The volumetric flow rate is measured using a pitot tube. As the flow rate decreases, the pitot tube measurements become less accurate. Minteer (1994) demonstrated a high degree of uncertainty in determining changes in noisture content as air passed through a primary tank and annulus. Even though Minteer (1994) discusses uncertainties with Tank 241-C-106 (a single-she1l tank), some of the same principles and errors wist in the data obtained from the dotule-shell tajks. Dodd (1994) suggested that psychrometric data collection cease for tank amuli until more rigorous examination deternined whether colleeting the date was worthwhile.

Other considerations, besides the fact that the calculated data represent only one recorded data point per month, should be made before drawing any conclusions. The heat transfer rate only expresses heat transferred to or from the air stream; it does not include other methods of heat transfer such as conduction through the soil or radiant heat transfer. Floating objects or a surface crust could exist in the tank which would change the surface area available for evaporation and possibly change the temperature of the liquia.

- Historical Sample Analysis Data

The historicel sample results refer only to sample and analysis information obtained before August 1989. The historical sample and analysis results have not been validated by the characterization program. When validation occurs, they will be reissued in a later revision of the Historical Tank Content Estimate report and supporting docunentation. The sampie data often were retrieved from menoranda indicating the results of the sample analysis. The analytical methods, holding times, and guality control information are uravailable. The location at which the sample was taken was not provided which leads to integration of some uncertainty into the sampling results. The analytical scope performed in many cases was guite narrow which linited the available data set. However, the data set is the only available historical information on chemical characterization.

\subsection{Background SE Quadrant}

The double-shell tanks located on the Hanford site near Richland, Washingtor were built between 1968 and 1986 to provide interim storage for high-level nuclear wastes. Processes such as plutonium sepaxation from 
GHC-SD-WM-ER-350, ReV。O

spent nuclear fuel and uranium metal recovery generated the millions of gallons of mixed (radioactive and hazardous) waste stored within these tanks.

Several waste tanjes are on watch lists which are defined in a succeeding section of this report.

The southeast quadrant is Located in the 200-East exclusion area and consists of 28 tanks grouped into six tank farms: the AN Tank Farm (seven 1, 140,000 galion tanks), the AP Tank Farm (eight 1, 140,000 gallon tanks), the AN Tank Farm (six 1,140,000 gallon tanks), the AY Tank Farm (two 980,000 gallon tanks), the Az Tank Fand (two 980,000 gallon tanks), and the sy Tank Fari (thxee 1,140,000 gallon tanks). Double-shell tanks are constructed of a primary carbon steel cylinder and base inside e secondary carbon steel liner. The secondary liner is encased in a reinforced concrete shell and both liners are covered by a reinforced concrete dome. Depending on the farm, the top of the tanks are buried between six and eight feet underground.

The most comon waste stored in the SE guadrant is dilute waste. However, many tanks in the quadrant currently store wastes from the Plutonium Finishing Plant and onsite separation processes. Nuch of the waste is awaiting concentration in the 242-A Evaporator.

\subsubsection{Waste Generating Plants and Processes}

Although not all of the processes listed below contributed waste directly to tanks in the SE quadrant, the waste they generated could have been transferred indirectly to the quadrant through tank-to-tank transfers. The plants and processes that generated waste now contained in the singleshell and double-shell tanks are presented in chronological order in this section. Typically, the name of the plant and the process are synonymous.

- T Plant

T Plant was the first full-scale separations plant at Hanford. It was constructed in 1944 and was used as a separation fecility for irradiated production reactor fuel until 1956. The bismuth phosphate separation process used at $T$ Plant was identical to the one used at B Plant. The 224 Building, adjacent to $T$ plant, was part of the bismuth phosphate process. Since 1957, $T$ Plant has been used as a facility for repair and decontamination of equipment. The facility was modified in 1978 for storage of pressurized water reactor (PWR) core II fuel assemblies. T Plant facilities have bean used for repairing, testing, shipping. decontaminating, decomuissioning, and burying contaminated tools and equipment from locations both onsite and offsite.

The following wastes were sent to interim storage: waste solution from equipment aecontamination efforts at $T$ Plant, decontamination waste (DW), metal waste (MW) from the bismuth phosphate process, first-cycle (1C) decontamination waste from the bisunth phosphate process, second-cycle (2c) decontamination waste from the bismuth phosphate process, and (224) waste. 
HHC-SD-WH-ER-350, Rev. 0

B Plant

B Plant was constructed between August 1943 and February 1945 and was used for the bismuth phosphate process until 1952. As one of the Eirst plants built along with T Plant, B Plant was designed to separate plutonium from uranium and the bulk of fission products in irradiated fuel through the bismuth phosphate separation process. The 224 Building, adjacent to B Plant, was part of the bismuth phosphate process. In 1968, B Plant became a waste fractionation plant and was retrofitted to remove ${ }^{137} \mathrm{Cs}$ and ${ }^{90}$ SI Erom PUREX acid waste, high-level supernatant liguids, and sludge from self-boiling liquid wastes.

The following B Plant waste streams were sent to interim storage: B Plant high-level waste (B), B Plant flush (BFSH), low-level waste from the waste fractionation plant (BL), complex concentrate (CC) or (CCPL), complexed waste (CPLX), fission products waste (FP), metal waste (MW), REDOX ion exchange waste processed at $B$ Plant (RIX), ion exchange (IX), strontium sludge (SRS), cell 5 tank 6 waste (5-6), Eirst-cycle waste (1C), second-cycle waste (2C), and (224) waste.

Bismuth Phosphate Process

$B$ Plant and $T$ plant used the bismuth phosphate extraction process to renove plutonium from uraniom fuel elements. The 224 Buildings were also part of the bismuth phosphate process. The extraction waste that resulted was a metal waste that still contained 908 of the fission products and $99 \%$ of the original uranium. The metal waste (MW) was sent to specific tark cascades in the 200-East and 200-West Areas. First-cycle decontamination waste (1C) containing approximately $10 \%$ of the fission produets, secondcycle waste (2C), and (224) waste were also stored in other underground waste tanks in the 200 Area.

Plutonium Finishing Plant

The Plutonium Finishing Plant (PFF) or $z$ Plant, previously called Plutonium Recovery and Finishiag Operations, began operating in late 1949 to process plutonium and prepare plutonium products. The pFr operations inclualed plutonium handling, plutonium reclamation, plutonium corversion, and decontamination and decontissioning.

Wastes from the Flutonium Reclamation Facility and the remote mechanical c line (Z) were sent to tanks.

Uranium Oxide Plant

The 224-U Building was completed in 1944 as part of the $U$ Plant cormplex. The builting was converted to a $\mathrm{vO}_{3}$ plant in 1951. The 224-UA Building was constructed in 1957 with six installed calciners. The UO, plant was capable of handling the uraryl nitrate hexahydrate (UNH) stream from REDOX, $U$ Plant, and FUREX. The UO, plant shut down in 1972 and restarted in 1984 with the feed lines from REDOX and the $U$ Plant canyon dinconnected. Since 1984, there have been 17 campaigns at the plant that everaged eight days each. The plant can calcine unt much faster then the FUREX plant can produce it. Final deactivation was ordered for the plants in 1992. In April 1993, the $\mathrm{VO}_{3}$ plant resumed operations to convert 200,000 gallons of remaining UNH to uranium oxide powder. A final 
THC-SD-WM-ER-350, Rev, 0

deactivation plan for the facility was prepared in the sumuner of 1993 and will be carried out in the next few years.

\section{REDOX}

The Reduction and Oxidation extraction (REDOX) plant was built between Hay 1950 and August 1951 and operated until July 1967. Uranium and plutonium were extracted from solid uranium metal slugs that were irradiated in the Hanford reactors or piles. Uranium and plutonium were extracted with methyl isobutyl ketone (hexone) solvent in a contimuous solvent extraction process. The RBDOX process was the first at Hanford to recover both plutonium and uranium.

The following wastes were sent to interim storage: REDox process waste resulting from the dissolution of aluminum and zircaloy fuel element cladding, REDOX coating waste (CWR), RRDOX high-level waste (R), the supernatant liquid portion of waste generated by the RBDox process, and REDOX supernatant (RSN). RSN is found above the sludge in the underground storage tanks that received waste from REDOX.

प Plant

U Plant (221-U) was built as one of three original bismuth phosphate process facilities, elthough it was not used for that puxpose. $U$ plant was modified extensively and used for the uranium recovery process. $v$ Plant operated from 1952 to 1958. The main canyon at U Plant currently stores failed equipment.

Uranium in waste from the BiPO, process initially was stored in the SSTs. Later, it was mined by sluicing, dissolved in nitric acid, and processed through a solvent extraction process. The uranium extrection process yielded approximately 1.4 gallons of UR waste for every gallon of metal waste originally stored. The increase in waste volume made developing technology to reduce the volume of stored waste a priority. This need resulted in the development and implementation of the ferrocyanide scavenging process.

The waste sont to interim storage from U Plant was czlled tributyl phosphate ('TBP) even though it contained very little TBP. Therefore, to eliminate confusion, the waste will be referred to as uranium recovery (UR) waste in this report.

Strontium Semi-Works

The strontium or Hot semi-Works processing facility (i,e., C Plant) was built in 1949 as a hot pilot plant for the REDOX process but was converted to a pilot plant for the PUREX process. In 1960, the plant was reactivated and used as a process demonstration for the conversion of B Plant to a waste fractionation facility. The plant was used to recover ${ }^{90} \mathrm{Sr}$, pxomethium $147\left({ }^{147} \mathrm{Pm}\right)$, and ${ }^{14} \mathrm{Cs}$ from PUREX waste. The building and the building site have been decontaminated and decommissioned.

waste from-the Strontium Semi-Works sent to interim storage was known as hot semi-works (HS), strontium semi-works (SSW), and fission products waste (FP). 
HHC-SD-FM-ER-350, Rev, 0

- EUREX

The Plutonium Uranium Extraction \{PUREX\} plant (i.e., A Plant) was an advanced solvent extraction process that used tributyl phosphate in $a$ paraffin hydrocarbon solvent to recover uranium and plutonium from nitric acid solutions of ixradiated uranium. The PUREX plant was built between April 1953 and April 1955, and it operated until 1972 when it was closed for 11 years. Two thorium campaigns were conducted in the pUREX plant between 1966 and 1971. The irradiated waste was similar to the PUREX waste, but it contained thoriun and uranium 233 rather than uranium and plutonium which was extracted from typical PUREX waste. It restarted in Novenber 1983 and was shut down in 1988 after a safety violation. The EUREX plant was shut down several times between 1988 and 1990 for various reasons. In Oetober 1990, the PUREX plant was put on standoy and was eventualy identified for closure in December 1992 by Secretary of Energy James Watkins.

The following PURRX waste streams were sent to interim storage: cladaing waste (CW) or (CWP), organic solvent wash waste (OWW), neutralized FURaX plant acid waste (P), low-level waste from PUREX (PL), PUREX sludge supernatant liquid (PSS), organic wash waste using sodium carbonate (CARB), cesium feed (CF), and concentrated neutralized high-level waste (1WW).

\subsubsection{Waste Management Operations}

This section describes the different waste concentrating methods used in the 200 Area. Evaporating, concentrating, and scavenging are all methods used to refuce liquid volumes or precipitate solids out of supernatant solutions. The operations aro presented in chronological order.

\section{2-T Evaporator}

The 242-T Evaporator was built in the early 1950 s to reclaim nonboiling waste storage capacity in exibting tanks. The evaporator was shut down in the summer of 1955 and modified for tributyl phosphate scavenging, although scavenging was never performed in this evaporator. The 242-T Evaporator restarted in 1965 and operated until 1976. Tank 241-TX-118 was the feed tank for this evaporator.

The following wastes were sent to tanks from the 242-T Evaporator: slurry prodict from the evaporator bottoms (EB), evaporator feed (EF), and terminal liquor (TL).

\section{2-B Evaporator}

The 242-B Evaporator was built south of the B Tank Farm and started operating in December 1951. It received feed waste until November 1954 and was shutdown in Septemier 1955. The evaporator was never reactivated. Tanks 241-B-106 and -105 were used as the feed tank and bottoms tenk respectively. The evaporator operated at atmospheric pressure.

Ferrofyanide seavenging

Ferrocyanide scavenging was developed to reduce waste volumes. The ferrocyanide flowsheet wes first tested in $\mathrm{U}$ Plant in october 1953, and in- 
farm scavenging was completed in warch 1956 and December 1957 for the 200-West and 200-East Areas, respectively. The ferrocyaride scavenging program was designed to remove Eission products stoh as ${ }^{137} \mathrm{Cs}$ (half life $=$ $28.6 \mathrm{yr}$ ) and ${ }^{90} \mathrm{Sr}$ (half life $=30.2 \mathrm{yr}$ ) from the uramium recovery and $1 \mathrm{C}$ wastes as a precipitate. After the ${ }^{137} \mathrm{Cs}$ and ${ }^{90} \mathrm{Sr}$ precipitates settled, the clarified supernatant was sanpled and disposed of in cribs.

- In-Tank Solidification

The primary function of the in-tank solidification systems was to concentrate the nonboiling waste directly inside of specilly designed tanks. The in-tark solidification tanks produced a saltcake slurfy. Each in-tank solidification system included a heat exchanger for water evaporation and a series of bottoras tanks. The first in-tank solidification unit (ITS $\$ 1$ ) opexated with an airlift circulator through Tank 241-BY-102, and the second in-tank solidificetion unit (ITS \#2) opereted with a similar circulator through Tank 241-BY-112. Pank 241-BY-112 also contained a 4,000 kW electric immersion heater. Tank 241-BY-101 contained an in-tank solidification prototype that wes used for demonstration purposes only. In-tank solidification units 1 and 2 began operating in 1965 and 1968 , respectively. In 1971, in-tank solidification unit 1 became the cooler for inmtank solidification unit 2 . Both units were shut down in 1974 .

\section{RFDOX Concentrator}

The REDOX concentrator was used for volume reduction of dilute 200-West Area tank farm wastes by removing water. The concentrator received tank farm wastes Erom July 28, 1967 until June 30, 1972 . Cell D in the REDOX process was the concentration and neutralization section of the plant.

\section{- 242-5 Evaporator-Crystallizer}

The 242-s Evaporator-Crystallizer began operating in November 1973 and was shut down in 1981. It was designed as a reduced pressure (i.e., partial vacuim) evaporator-crystallizer. Agueous salt wastes were converted in the evaporator to salt erystals for storage in underground tanks. in the 241-S and 241-Sx Tank Farms.

The following waste types were sent to interim storage Erom the 242-s Evaporator: noncomplexed waste concentrated until the solution was neerly saturated with sodium aluminate known as double-shell siurry feed (DSSF), slurry product from the evaporator bottoms (EB), evaporator feed (EF), Hanford defense residual liquor (hDRL), partially neutralized feed waste (PNF), and terminat liquor (TH).

\section{- 242-A Evaporator-Crystallizer}

Construction of the 242-A Evaporator-Crystallizer was completed in 1976. The evaporator began operation in March 1977 with a design life of 10 years. In 1987, design changes were developed to extend the operating Iife of the facility by 10 years. The eveporttor was shut down in Apri3 i989 because of regulatory issues. The evaporator was restarted in MaY 1994 after extensive modifications. 


$$
\text { MHC-SD-FM-ER-350, ReV. O }
$$

The following evaporated waste was sent to interim storage: evaporator bottoins from B Plant low-level waste feed (BLEB), noncomplexed waste concentrated in evaporators known as double-shell sluxzy feed (DSSF), evaporator feed (EF) or (EVAP), evaporator bottoms (EB), and terminal liguor (TL).

\subsubsection{Miscellameous Waste Sources and Equipment}

Wastes from various other sources on the Hanford site have been added to the tanks. Some wastes are from the 300 Area, 100 Area production reactors, various laboratories, and catch tanks. Unicue contents added to single-shell tanks included laboratory wastes; diatomaceous earth; Fortland cement; shroud tubes; ceramic balls; experimental fuel elements; and relatively small amounts of enziched urenium, plutonium, cobalt, and natural uranium.

The Eollowing wasten contributed to interim storage waste: diatomaceous earth (DE), Hanford defense residual liguor (HDRL), Hanford laboratory operations $(\mathrm{HLO})$, filtexed Hanford water ( $\mathrm{H}_{2} \mathrm{O}$ ), phosphate decontamination waste from N Reactor (N), and noncomplexed waste (NCPL).

\section{- Critical Mass Lab}

The critical mass lab was used to develop data on the factors necessary to make a criticality or self-sustained nuclear reaction occur. Because plutonium is the key radioactive element on the Hanford site, the research was based on plutonium criticality safety in various fuel cycles. The facility was located next to the strontium semiworks and ran from the early $1950 s$ to the early 1980s. The plutonium used in the lab was reprocessed in pUREx.

\section{4-AR, -BXR, and $-\mathrm{CR}$ Process Vaults}

There are three process vaults in the NE quadrant: the 244-AR vault, the 244-BXR Vault, and the 244-CR vault. These vaults were composed of several process vessels or tanks used to prepare the waste for treatment or storage. Specific wastes from tanks can be pumped temporarily to the vaults and the wastes can be sent directly to desired tanks or processing facilities later.

The AR Vault was designed and constructed between 1964 and 1968 and is located next to the $A$ and AX Tank Farms. The AR Vault has been on standby since 1978 .

The 244-BXR vault is located south of the 241-BX Tank Farm and was constructed between 1950 and 1951. The BXR Vault began operating in 1952 and became inactive in 1956. The waste in the vault was difficult to handle, so the vault was jetted with high-pressure steem in 1976 . The vault was interimly isolated after 1976 and interinly stabilized in March 1985. Tank EXR-004 was removed in 1963.

The CR Vault was constructed in 1952 and is located next to the C Tark Farm. Saltwell waste from the $C$ Tank Farm is interimly stored in the $C R$ vault. The 244-BXR and $C$ CR vaults were oxiginally constructed to aid in 


$$
\text { WHC-SD-WM-ER-350, ReV. } 0
$$

the recovery of uranium from bismuth phosphate metel paste. The CR Vault received waste from the strontium semiworks Plant en route to the 241-C Tank Faxin.

- 204-AR and 204-S Railroad Car Facilities

The 204-AR rail car unloading facility was built in 1981 and replaced the 204-s rail car unloading facility. The facilities were built for unloading tank cars containing radioactive liguid waste.

Liquids or slurries from the 1314-N Building in the 100 Area and the 340 Building in the 300 Area are unloaded at the 204-AR unloading facility.

\subsubsection{Timeline}

A timeline is presented on the following pages that represents the times and spans of different events that occurred during the lifetime- of major Hanford plants and tank Earms in the 200-East and 200-West Areas. The plants were the main contributors to the waste currently contained in the tanks. The following is a list of abbreviations used in the timeline and their corresponding meanings:

FUREX: Plutonium uranium extraction process

UO, : Uranium trioxide

PFP: Plutonium Finishing plant

RG-RB : Rubber glove - Iemote button line

RHA: Renote mechanical 'A" line

RSE: Recuplex solvent extraction

RMC: Remate mechanical "C" line

FRF: Plutonium Reclamation Facility

FCB : Polychlorinated biphenyls

WESF: Waste Encapsulation and storage Facility

ITS: In-tank solidification (units \#1 and \#2)

PWR: Pressurized water reactor

REDOX: Reduction oxidation process 


\section{PROCESSES PRODUCING WASTE CONTAI}

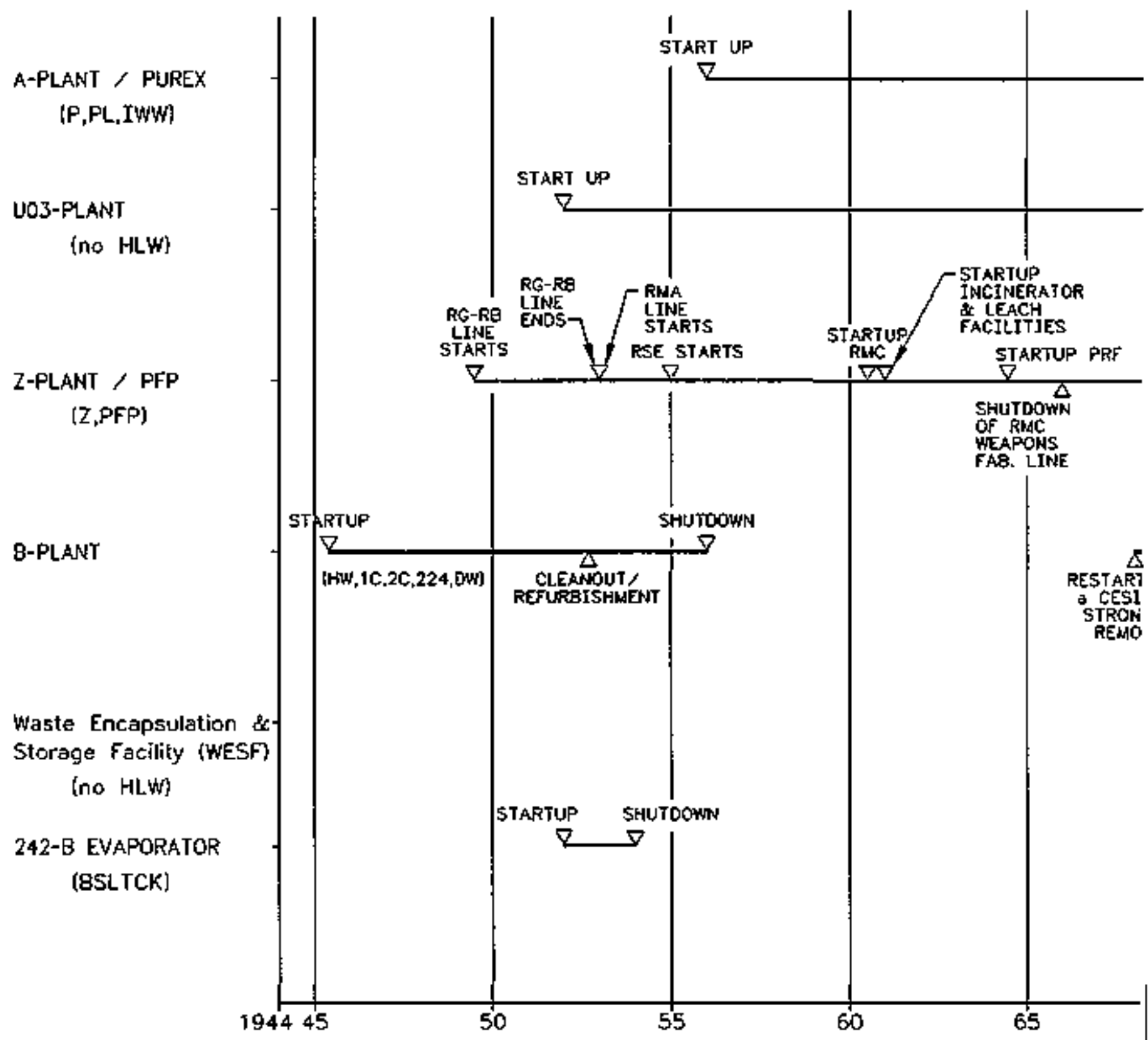


242-T EVAPORATOR

ITS UNIT \#1 (241-BY-102)

ITS UNIT \#2 (241-BY-112) (EYSLTCK)

242-S EVAPORATOR (S1SLTCK)

242-A EVAPORATOR [SWMA]

\section{T-PLANT}

U-PLANT

(UR, TBP, PFeCN1,PFeCN2, TFeCN, 1CFeCN]

S-PLANT , REDOX

( $R, C W R$ )

C-PLANT / HOT SEMIWORKS (HS)

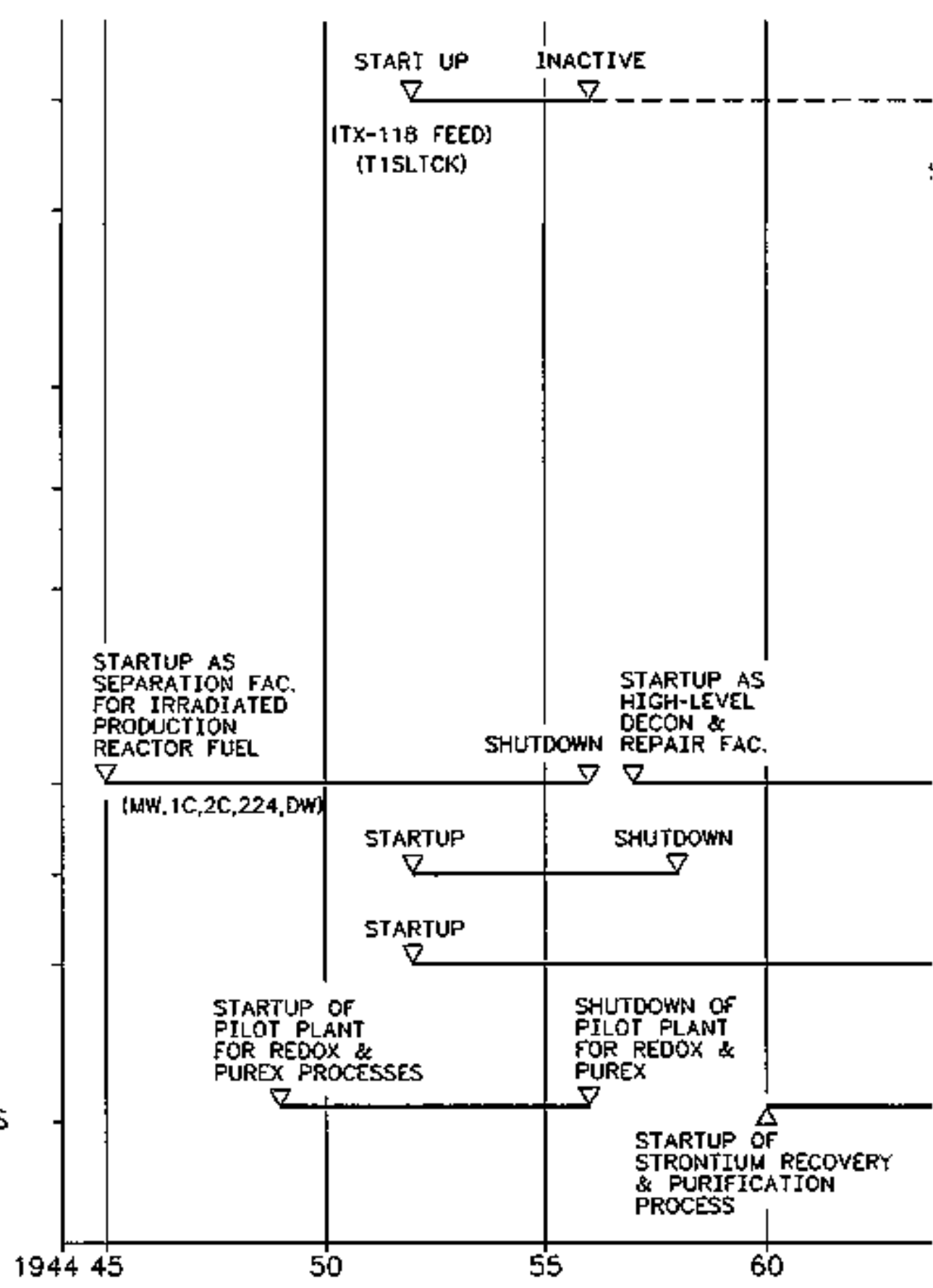


WHC-SD-WHS-ER-350. Rev. 0

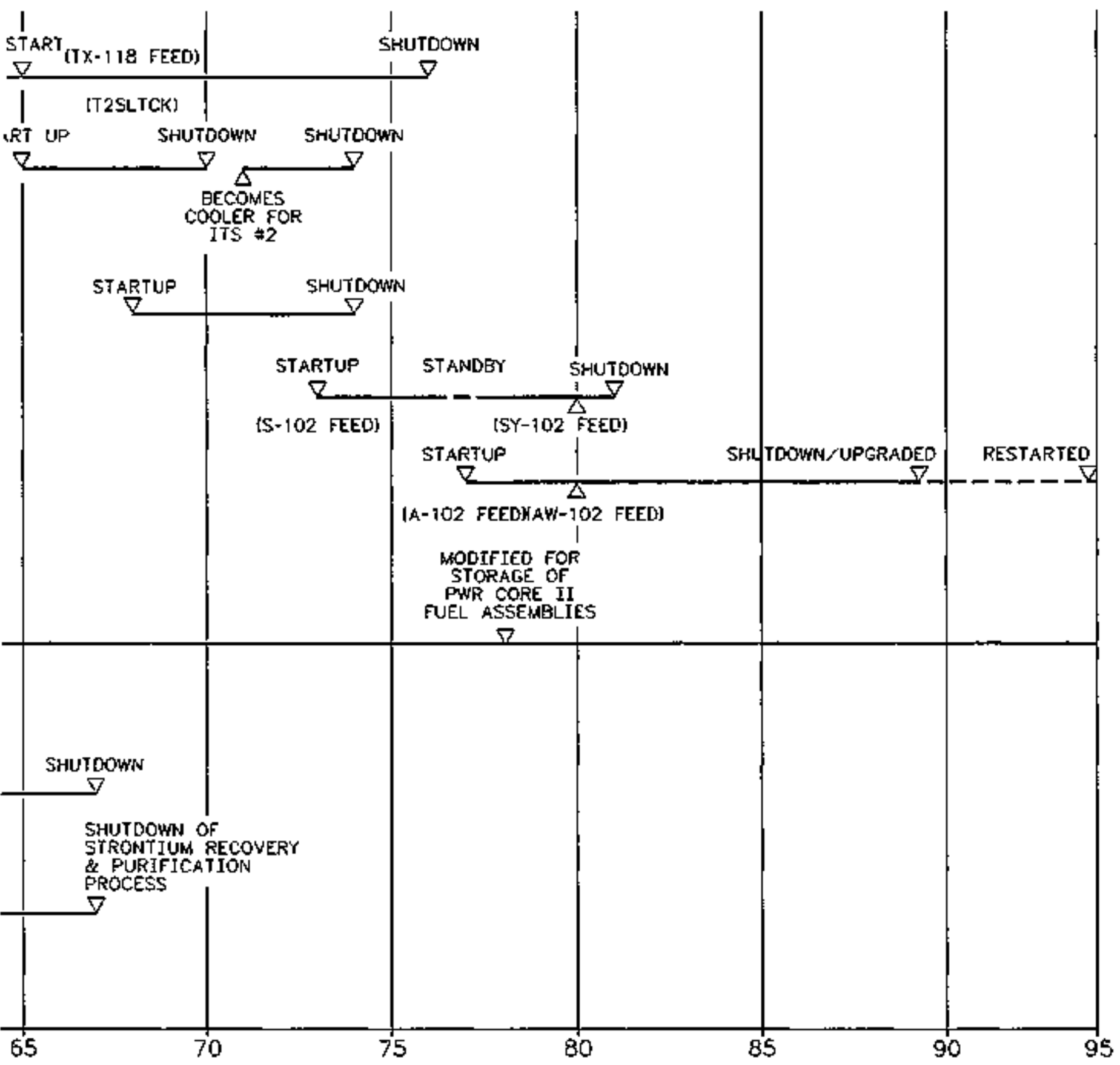




\section{NW/SW TA}

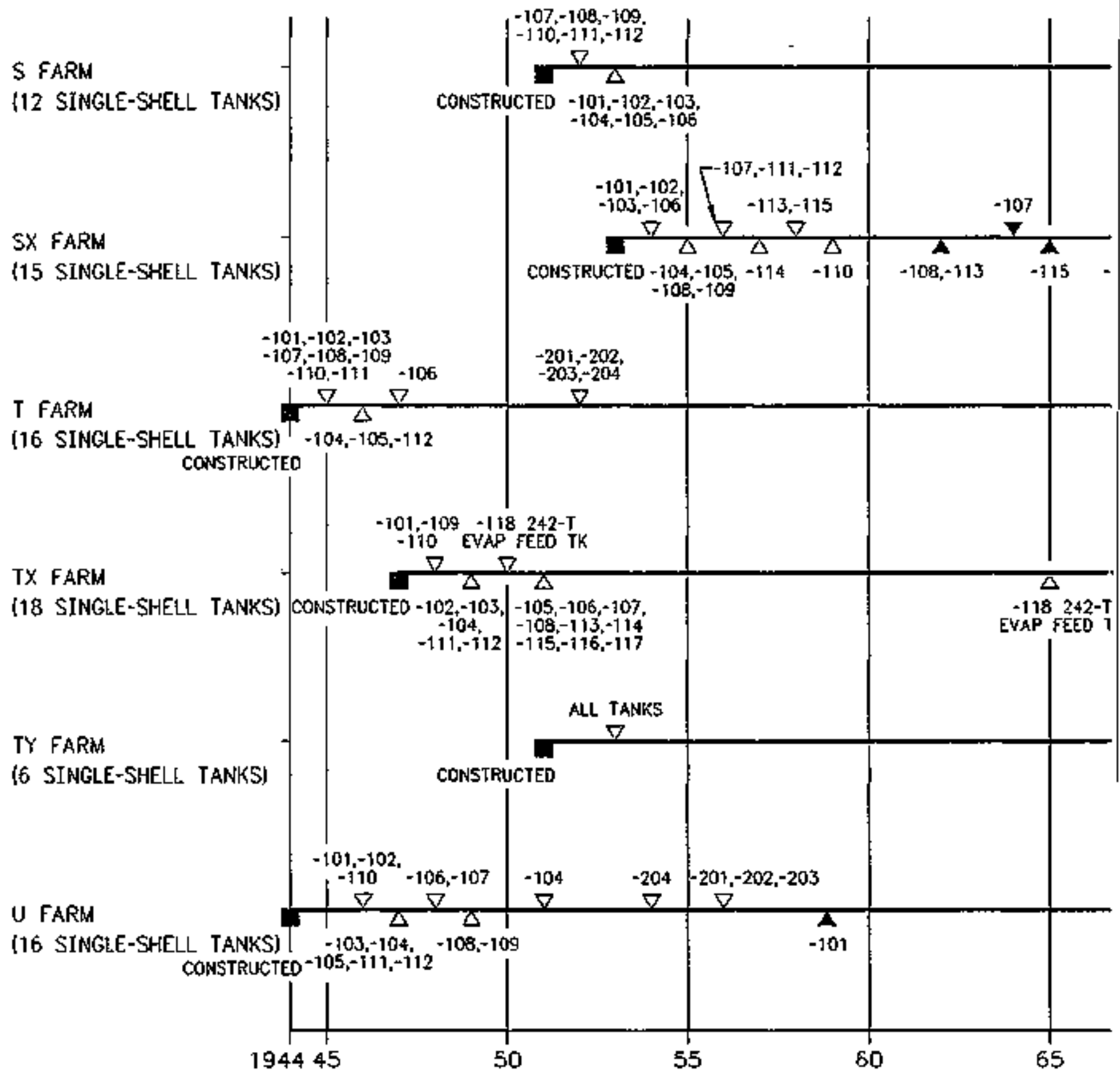




\section{LEGEND:}

\section{JK FARMS}

$\triangle$ INTO SERVICE

A REWOVED FROM SERVTCE

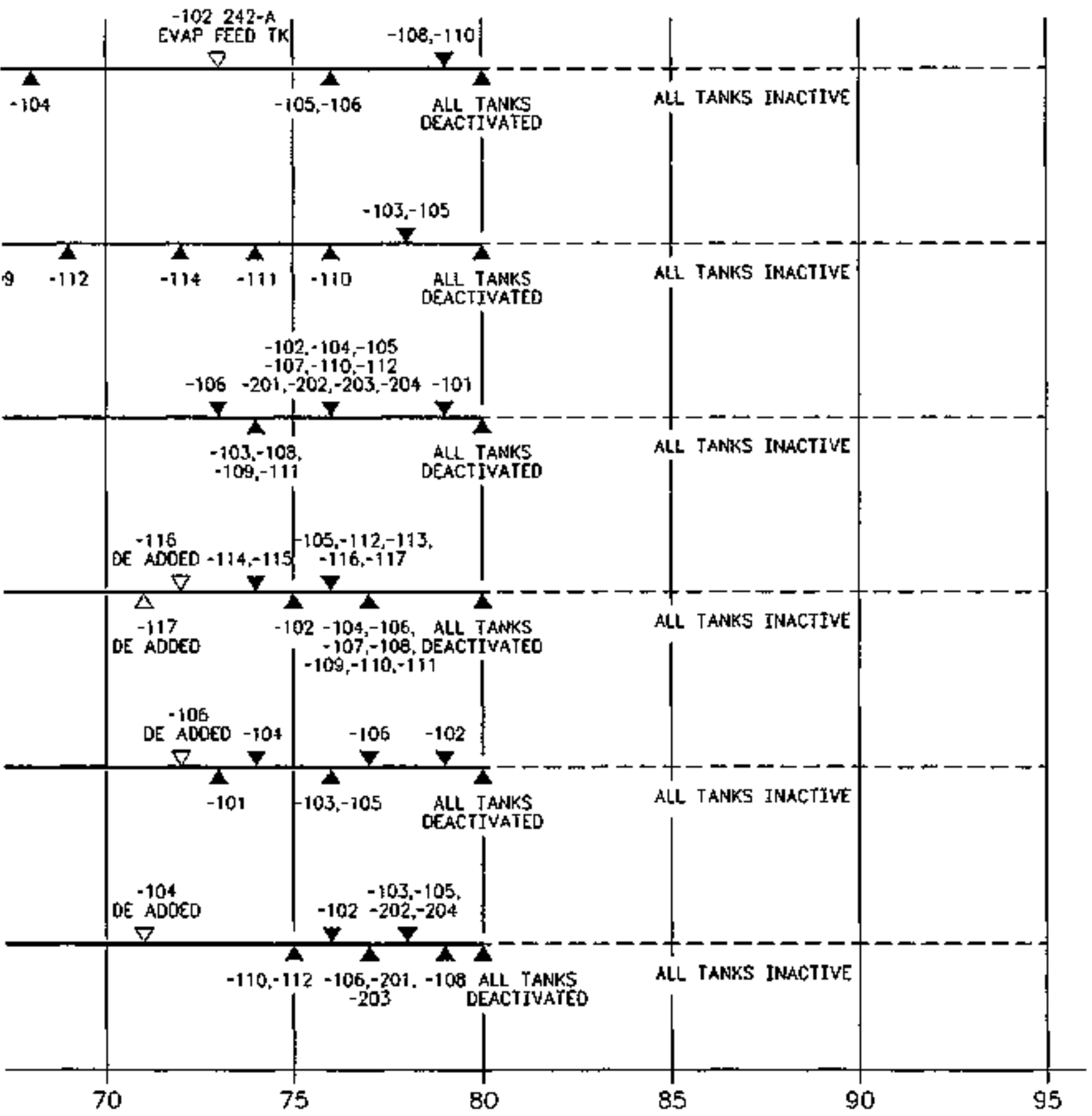


NE TANK

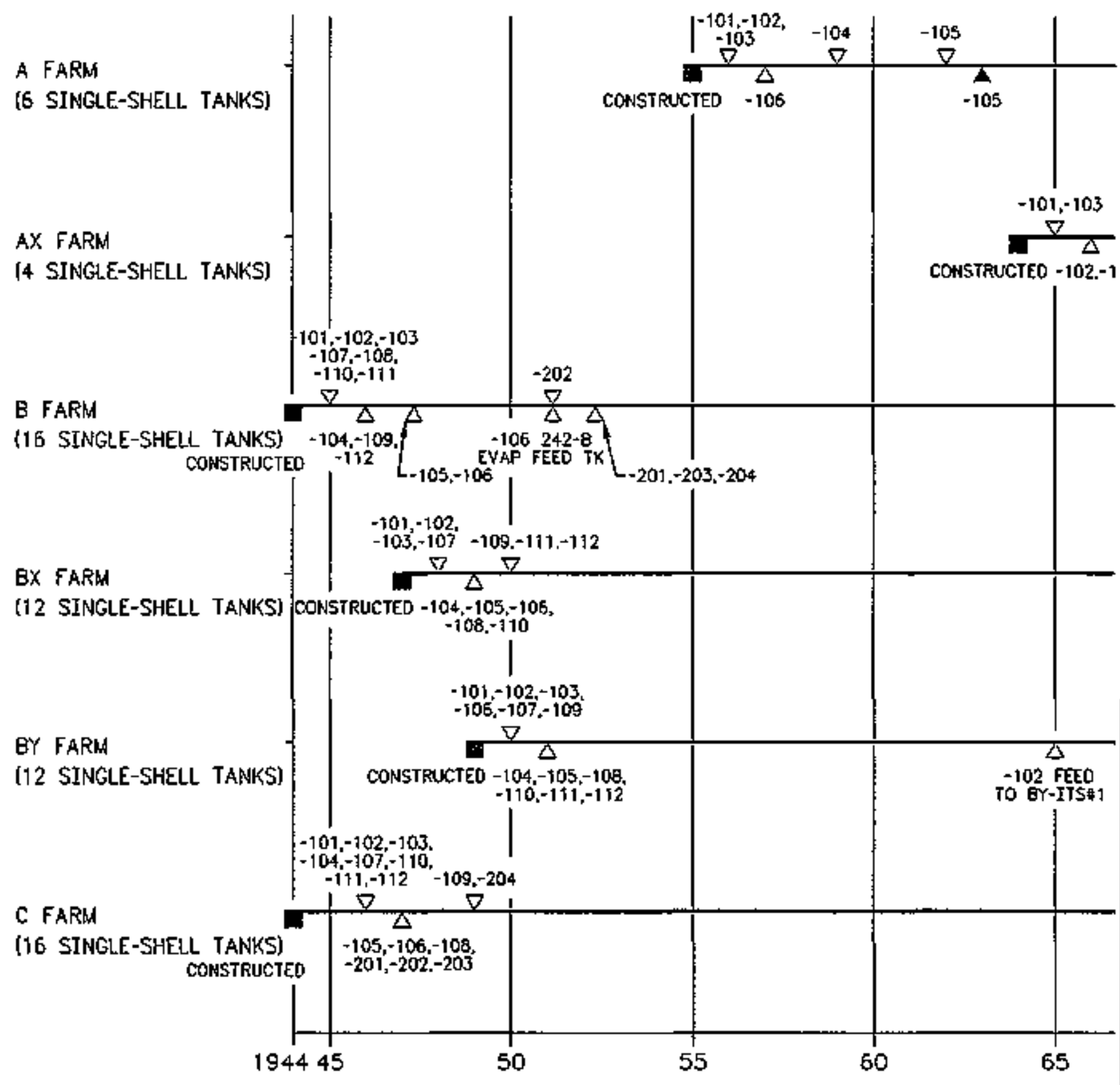




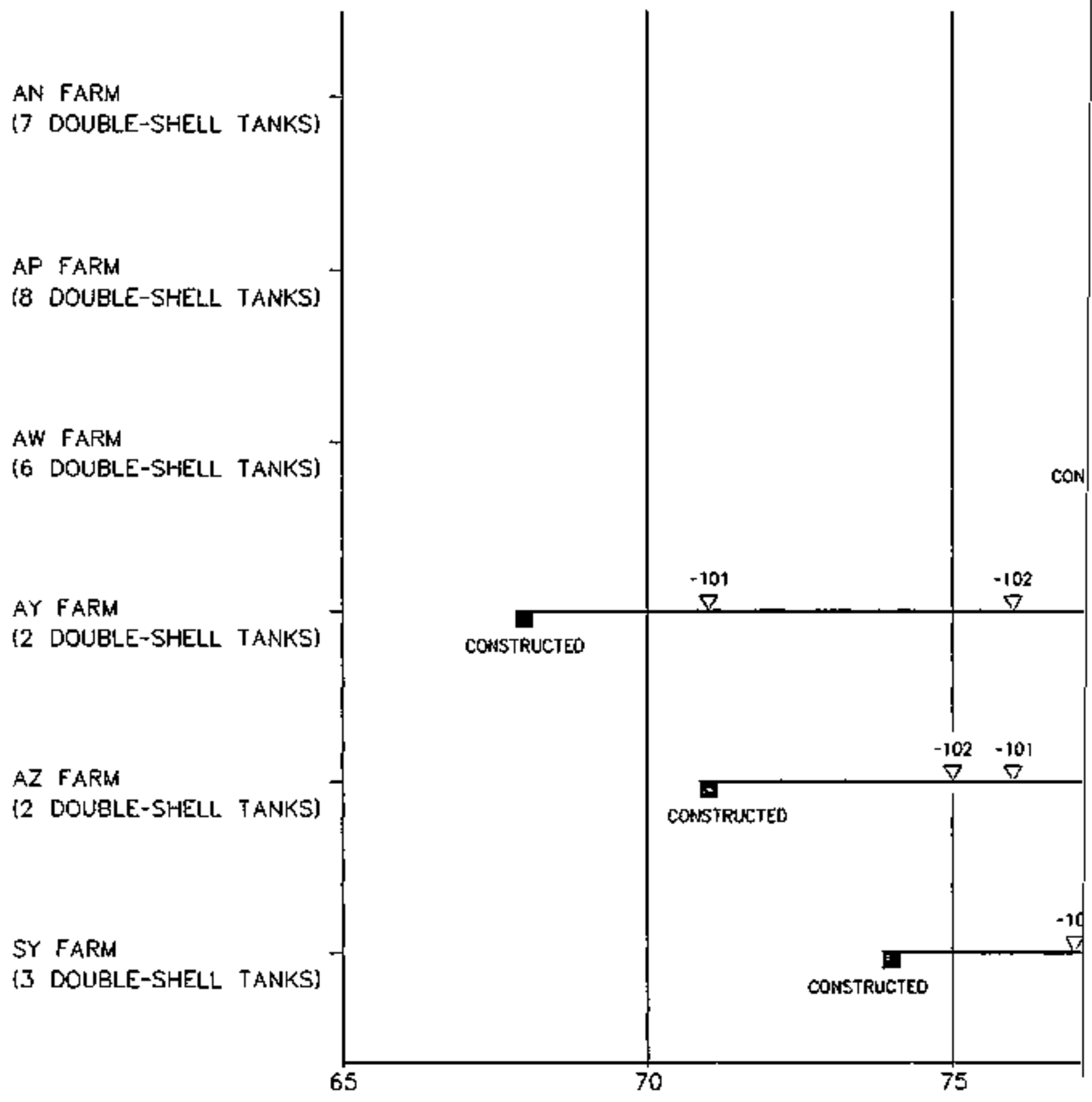


WHC-SO-WH-ER-35D, REV+ 0

SE TANK FARMS

LEGEND:

$\triangle$ INTO SERVICE

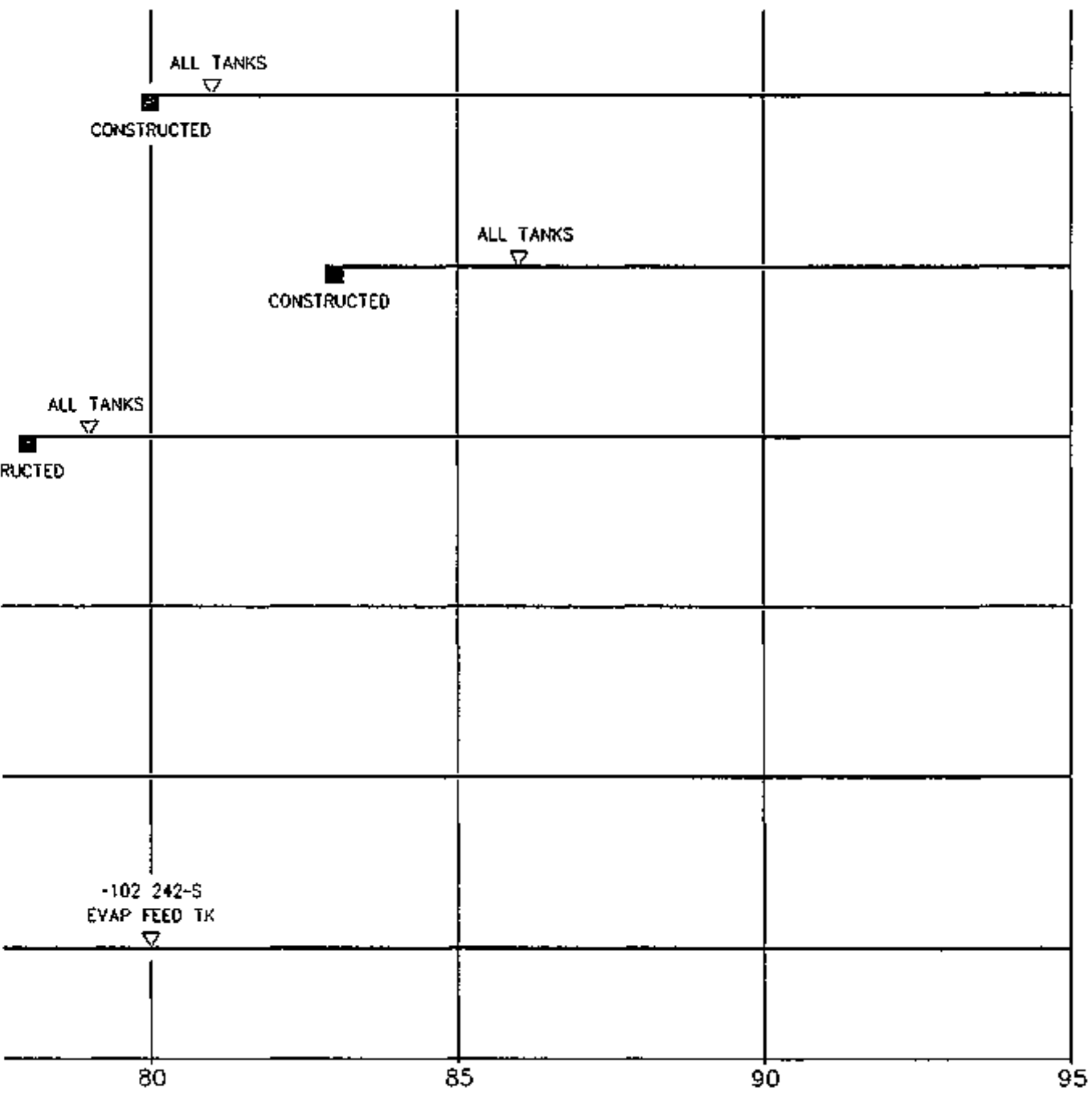




\subsection{Safety Issues}

The safety issues that affect the tanks can be aivided into two groups: watch list and nonwetch list. The watch lists are a Iisting of all tanks that are believed to pose potential safety hazards to the environment and the public. Non-watch list issues are of concern beckuse they may impact the environment.

\subsubsection{Match List Safety Issues}

Safety issues for these tanks were identified as "issues/situations that contain most necessary conditions that could lead to woxker (onsite) or offsite radiation exposure through an uncontrolled release of fission products" under Public Iaw 101-510, Section 3137, of the National Defense Authorization Act of Fiscal Year 1991 (i.e., the Wyden Amendment). As of November 1993, 45 SSTs and 6 DSTs are on a watch list. In the SE cruadrent, 6 of the 28 DSTs are on wateh 1ist. The four watch 1ist designations described in this report are fexrocyanide, hydrogen or other flammale gas, organic salts, and high-heat load. The following sections provide a general description and criteria of the different watch 1ists. For a more complete explanation, refex to the Hanford Site Tank Farm Facilities Interim Safety Basis (WHC, 1993).

\section{Ferrocyanide}

A tamk containing or believed to contain greater then 1,000 gram moles of ferrocyanide (dzy basis) is on the ferrocyanide watch list. Tanks containing ferrocyanide are potentially explosive if ferrocyanide and nitrates combine.

- Hyaragen or Other Flammable Gas

Tanks were placed on this watch list mostly hecause of the potential to contain flammble gases rather than the verified presence of hazardous concentrations. Tanks on the watch list for hydrogen or other flammable gases have been identified as an unreviewed safety question due to the concern that burning flammable gas could result in a radiological release.

Organic Salts

Tanks containing or believed to contain more than the equivalent of $10 \%$ by weight of sodium acetats or 3 wts total organic carbon (Toc) on a dry basis received a watch list designation as in the Tank Farm Surveillance and Waste Status Sunnary Report (Hanlon, 1993). Tanks containing organic salts could release waste if an uncontrolled increase in temperature or pressure results from oxidation by nitrates and nitrites.

- High-Heat Loads

Tanks with a heat load greater than $40,000 \mathrm{Btu} / \mathrm{hr}$ are designated as high-heat load tanks. Tank $241-c-106$ is the only high-heat load tank on the high-heat load watch list.

Any tank not appearing on the high-heat load tank list or the highheat load watch list, but with a heat load less than $40,000 \mathrm{Btu} / \mathrm{hr}$, is considered, by default, a low-heat load tank. 


$$
\text { WHC-SD-WM-ER-350, REV, } 0
$$

The following tabie Iists the tanks in the SE quadrant that appeared on a watch list as of November 1993. A ctrrent listing is published monthly in the Tank Farm Surveillance and Waste status Summary Report (Hanlon, 1993).

SE Quadrant DST Watch List Tanks

\begin{tabular}{|c|c|c|c|}
\hline 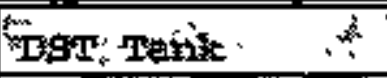 & 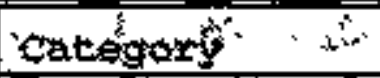 & 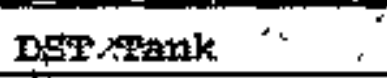 & categonys is \\
\hline 241-AN-103 & Hydroger & $241-A W-10 I$ & Fexrocyanicle \\
\hline $241-\mathrm{AN}-104$ & Hydrogen & 241-SY-101 & Hydrogen \\
\hline 241-AN-105 & Hydrogen & $241-5 Y-103$ & Hycirogen \\
\hline
\end{tabular}

\subsubsection{Non-watch List Safety Issues}

Tank leaks are a safety hazard because of the potential to release chemicals and radioactive liguids to the ground. Corrosion is the main cause of tank leaks. Three other safety issues that do not require a watch list and continual monitoring under the Wyden Amendment include criticality, tank bunps, and toxic vapor relezses.

\section{Corrosion}

Corrosion is believed to be caused by a localized ar general reduction in the thickness of the carbon steel liner. Localized reduction in the iner thickness is caused by three types of corrosion: pitting corrosion, stress corrosion cracking, and crevice cracking. Gerrexal reduction in Iner thickness may be caused by uniform corrosion.

Wone of the double-shell tanks are assumed or confirmed leaking.

Criticality

Criticality is an inadvertent, self-sustained, nuclear chain reaction. studies have concluded that a nuclear criticality accident in the tank farms is probably not an imminent risk. However, there is a lack of definitive knowledge on the inventory of fissile material and its distribution within the tanks. Therefore, eriticality remains a safety issue. The key radionuclide on the Eanford site that would be involved in a criticality accident is plutonium. To prevent a criticality, a maximum content of $125 \mathrm{~kg}$ of fissile material has been specified for the tanks. An unusual occurrence report involving nuclear criticality was filed in June 1991 for Tank 24I-C-104. Later, an inventory of $56 \mathrm{~kg}$ was calculated which indicated a low probability for criticality. Criticality is considered an unreviewed safety guestion, but is not affected by the Wyden Amendment according to the Hanford site Tank Farm Facilities Interim Safety Basis (WHC, 1993).

Tank Bumps

Tank bumps have been an issue at Hanford since 1953 with the last bump occurring in 1968. Tank bumps occur when heat fxom the hotter solid waste in the lower portion of the tank is suddenly transferred to near boiling 
supermatant. Mixing can be echieved by "roll over" or sudden restart of airlift circulators which results in rapid fluid vaporization and a sudden internal tank pressurization that causes a bump. The three acumented bumps that have occurred were due to airlift circulator failure followed by rapid startup of the airlift circulators which causes rapid mixing. Two key factors have been identified to control bumping: licuid and solid tempexatures must be maintained as far away from the local boiling point as possfble, and airlift circulators and ventilation systems just be operated as designed. A tank bums is extremely unlikely if eirlift circulators and vent flowrates are maintained at 500 to $1,000 \mathrm{ft}^{3} / \mathrm{min}^{\mathrm{per}}$ tank and $50 \mathrm{ft}^{3} / \mathrm{min}$ to the airlift circulators, according to the Hanford Site Tank Farm Facilities Interim Safety Basis (WHC, 1993).

\section{Toxic Vapor Releases}

Toxic vapor releases are a recently analyzed safety concern at Hanford. odors have been released from the $C$ Tank Farm in the NE cuadrant and from Tank 241-SY-101 in the SE guadrant. If toxic vapors are determined to exist in a tank, three safety recommendations should be followed: determine a release rate, determine offsite and onsite exposure concentrations, and determine if the release is a spray effect. The entire issue of toxic gas releases at the tank farms has just began to be understood, according to the Hanford site Tank Farm Facilities Interim Safety Basis (WHC, 1993).

\subsection{Occurremces}

Over the years, unusual events that occurred at the Hanford Site have been documented by various reporting methods. Some of these reports include Unusual oecurrences Reports (U.O.), off Nomal Reports (O.N.), Event Fact Sheets (E.F.S.) and occurrence Ieports. According to these reports, four unusual events apply to the southeastern quadrant as a whole. Occurrence reports RI-WHC-Tank Farm-1993-0072, RL--WHC-Tank Farm-1992-0028, RL--WHC-Tank Farm-1991-1031, and RL--WHC-Tank Farm-1991-1026 were written due to loss of power in the area. For more information on occurrences, refer to the supporting Document for the Southeast Quadrant HICE (Brevick, 1995). 


$$
\text { WHC-SD-WM-ER-350, ReV. } 0
$$

2 AN Tank Farm

\subsubsection{AN Tank Fazm History}

The AN Tank Farm is loceted north of 4 th Street and east of Buffalo Avenue in the 200-East Area. The AN Tank Farm contains seven, 100 series, 1,160,000 galion, 75-foot diameter double-shell tanks. The AN Tank Farm is the latest tank design with a reinforced concrete shell and dome, and an insulating concrete base. A heat-treated, stress-relieved, primaxy steel liner and a nonstress-relieved, outer steel liner are inside the concrete she11. These tanks were made to hold concentrated supernatant. The maximum design temperature for liquid storage is $350^{\circ} \mathrm{F}$. The tanks are at the same elevation and no cascade lines exist between the tanks.

A color aerial photograph taken in 1993 of the AN Tank Farm shows the orientation of the tanks, leak detection pits, annulus ventilation equipment, instrument house, and valve pits. 


\section{AN TANK̈ FARM \\ WHC-SD-WM-ER350, Rev. 0 .}

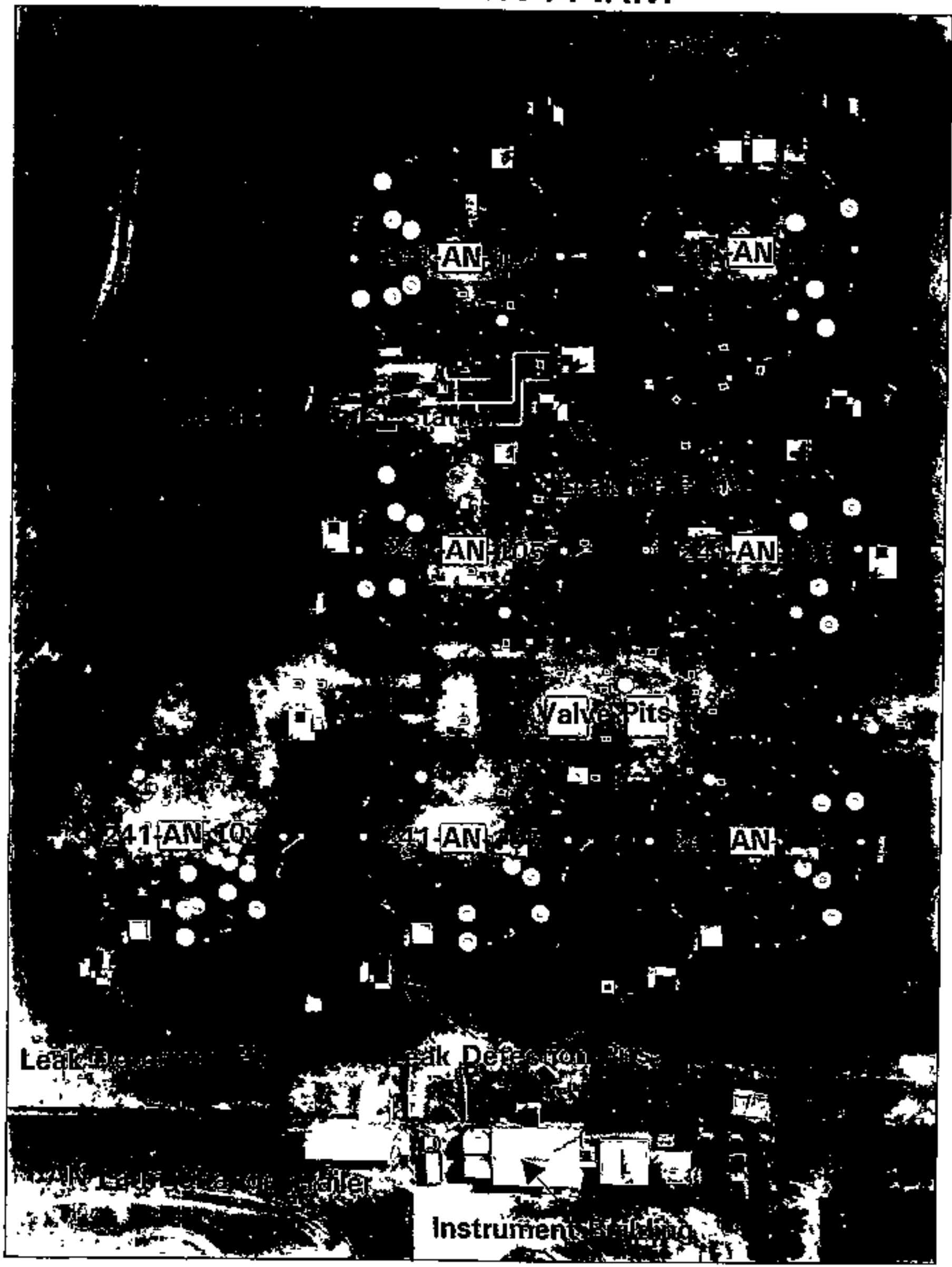


All tanks in the 241-Aw Tank Farm began receiving non-complexed waste in September 1981. Tank 241-AN-101 received waste from PUREX, Tanks 241-AN-102 and -103 received waste from Tank 241-SY-102, Tank 241-AN-104 received waste from Tank 241-AW-102, Tanks 241-AN-105 and -106 received waste from site sources, and Tank $24 \lambda-A N-107$ received waste from Tank 241-AN-102. The sources of waste have varied since then. Tanks 241-AW-102 and 241-AN-104 supplied dowble-shell slurry waste to tank 241-AN-105 from Decenber 1982 to the second quarter of 1985. Tanks 241-AN-101 and -103 received low-level waste Exom plant. Tanks 241-21N-102 and -104 received low-level waste from PURzx. Currently, all of the tanks, except 241-AN-101, are inactive.

\subsubsection{AN Tank Farm Temperature History}

The seven tanks within the AN Tank Farm contain at least one thermocouple tree with readings found for between $\sigma$ and 18 thermocouples per tree. Since 1991, Tanks 241-AN-103, 241-AN-104, and 241-AN-105 have been on the Hydrogen watch List. These watch list tanks are monitored weekly, at a minimum, with the remaining tanks required to have tempereture recorded semiannually. All of the tanks in the AN Tank Farm are monitored by the TMacs as of August 1994 .

\subsubsection{AN Tank Farm Occurrences}

Six umusual events affected AN Tank Farm as a whole. Occurrence reports RL--WHC-Tank Farm-1993-0070, RL-WHC-Tenk Farm-1993-0009, Rt--WHC-Sark Farm-1991-1077, and RL--WHC-Tank Farm-1991-1058 were written due to tanks pressurizing from equipment failures. Occurrence reports RL-WHC-Tank Farm-1990-0102 and RJ-WHC-Tank Farm-1991-1016 both concerned electricel problems. The problem described in RI--WHC-Tenk Ferm-1991-1016 caused a pressure inversion in every tank in the farm.

\subsubsection{AN Tanis Farm Ventilation}

Each tank is designed to have 85.7 standard cubic feet per minute of air travel through it and 800 cubic feet per minute of air travel through the annulus. Air enters the tarks by infiltration because there is no supply fan. After exiting each tank's system, the air ducts are joined to allow the service of one fan to send air into the primary exhaust system. Before the tank air is released to the atmosphere, the air is heated, forced through a prefilter, and then sent through two high-effiency particulate air (HEPA) Eilters. In the annulus system, eir enters a 358 prefilter and a HEPA filter before it enters the arrulus. Then the air enters an electric heater and two more HEPA filters before it is exhausted to the atmosphere. Both the tank and annulus systems have a prinary and a backug system. For more information, refer to drawing H-2-73935, sheets 1 and 2 .

The psychrometric date for tanks in the AN Tank Farm are recorded in two parts: the tank data and the amular data. For water and heat leaving 


$$
\text { WHC-SD-WM-ER-350, Rev. } 0
$$

the tank, the numbers are positive. Fsychrometric data have been recorded for 12 years from these tanks and annuli. For more information refer to the Supporting Document for the Soutbeast Quadrant HTCE for AN Tank Farm (Brevick, 1995).

\subsection{2 current status of Als Tank Farm}

Tanks 241-Aw-103, -104 , and -105 were officia2ly added to the Hydrogen Watch List in January 1991. The thres tanks have been identified as unreviewed safety questions due to the concern that burning flamuable gas could result in a radiological release. All tanks are actively vertilated and categorized as sound. The waste volune currently totals $6,564,000$ gallons. The estimated volumes (Agnew, January 1994) depicted in each tank cross-section total 6,024,000 gallons of waste. At the tiane of the estimate, thexe were 6,022,000 gallons of supernatant with $1,439,000$ galions of concentrated supernatant solids and 2,000 gallons of low-level waste from \& Plant.

\subsection{Tank 241-AN-101}

2.1.1 241-AN-101 Tank History

2.1 .1 .1 Waste History of Tank 241-AN-101

Tank 241-AN-10I began service by receiving non-complexed waste from PUREX in September 1981. Non-complexed waste was received and transferred through this tank until september 1990 when it began receiving dilute noncomplexed waste. During this time, the tank also received low-level waste from B Plant, decontamination waste from $N$ Reactor, and dilute noncomplexed waste fron the 200-East Area SSTs. As of March 1994, the tank was receiving only dilute non-complexed waste, currently, the tank is an active dilute receiver tank which receives non-complexed saltuell waste.

\section{1 .1 .2 Temperature History of Tank 241-AN 101}

Temperature data for Tank 241-AN-101 are recorded by 18 thermocouples at known elevations on one tree inside the tank located in riser $4 \mathrm{~A}$. Nonsuspect temperature data for all 18 thermocouples taken between July 1983 and May 1986 were available from the computer automated surveillance system. Non-suspect temperature data recorded between Jantiary 1990 and. September 1993 for six of the thermocouples were available fxom the suxveillance andlysis computer system. Within the time spans of each system, there were no significant breaks in the sequence of temperature data. The average temperature during these periods was $66.4^{\circ} \mathrm{F}$ with a minimum of $51^{\circ} \mathrm{F}$, a maximum of $82^{\circ} \mathrm{F}$, and a standard deviation of $6.2^{\circ} \mathrm{F}$. Linear regressions were performed on each thermocouple that had recorded temperature date beginning in January 1990. The slopes from these regressions were averaged with a resulting average slope of 0.00438 . Refer to the supporting document for a more thorough review of the temperatire data (Brovick, 1995). 


\subsubsection{Occurrences of Tank 241-AN-101}

Two unusual events occurred at Tank 241-AN-101. Off-Normal Feport 86-6 was issued in January 1986 due to an equipment problem. During a transtex of waste solution from Tank 241-AY-102 to Tank 241-AW-102, a valve leaked, sending solution into Tank 241-AN-101. Occurrence Report RL--WHC-Tank Farm-1993-0027 was issued in March 1993 because the waste level indicators failed.

\subsubsection{Psychrometries of Tank 241-AN-101}

The apparent trend of the ovaporation rate from the tank has decreased From 96.4 gallons per week in January 1983 to 59.6 gallons per week in Januery 1995. Over that same period, the trend in the rates of heat exchange through the primary tank and annular ventilation has apparently decreased. A review of the psychrometric data in Tank 241-AN-101 would suggest an overall decrease in the rate of heat generation by the waste.

\section{1 .2 Current Status of Tank 241-AN-101}

Tank 241-AN-101 entered into service in September 1981 and currently stores 859,000 gallons of waste. The following plan view and tank cross section depict the approximate waste volume of 700,000 gallons and risex configurations as of January 1994. At the time of the estimate, all 700,000 gallons were supernatant. The waste level in the tank is measured with the FIC gauge and the manual tape and has increased from about 128 inches in January 1991 to 312 inches in January 1995 . The 1ncrease was mostly the addition of dilute and non-complexed waste received from the 200-East Area single-shell tanks between June 1991 and February 1992 . The tank is active and receives non-complexed saltwell waste. The tank is actively ventilated and categorized as sound. Tank 241-AN-101 has 61 risers. One 12-inch riser (no.7B) is available for use.

\subsubsection{Inventory Estimate of Tank 241-AN-I01}

The tank layer model (a volume based approximation) that follows was derived from the Los Alamos National Laboratory Weste status and Trensaction Record Summary (Agnew, 1995) and Supernatant Mixing Model (Agnew, 1995). The estimeted inventories of total waste, solids, and supernatant in Tank 241-AN-101 are also presented.

2.1.2.2 In-Tank Photograph of Tank 241-AN-101

No in-tank photographs are available.

2.1.3 Synogsis of Tank 241-AN-101

(To be completed.) 


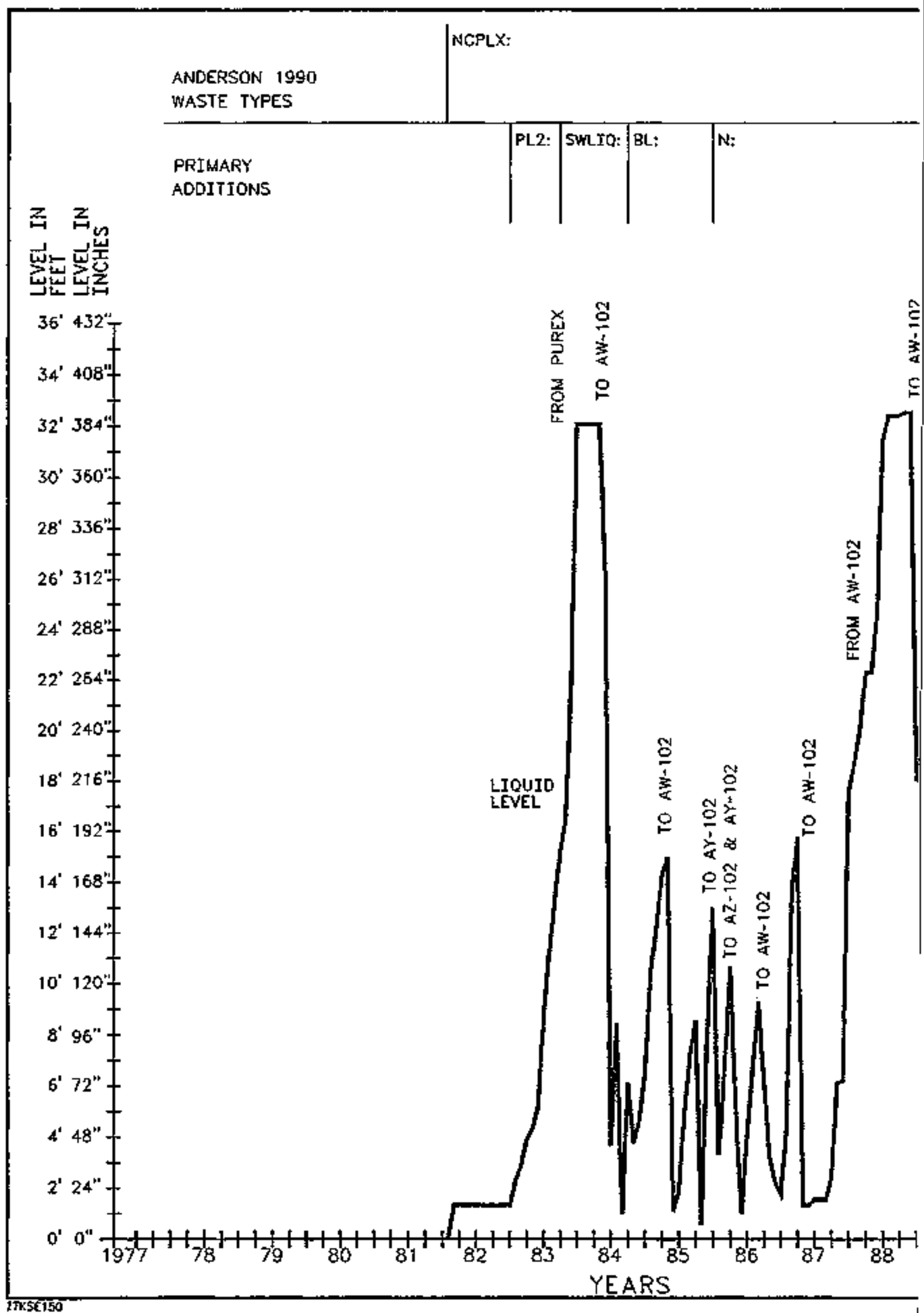




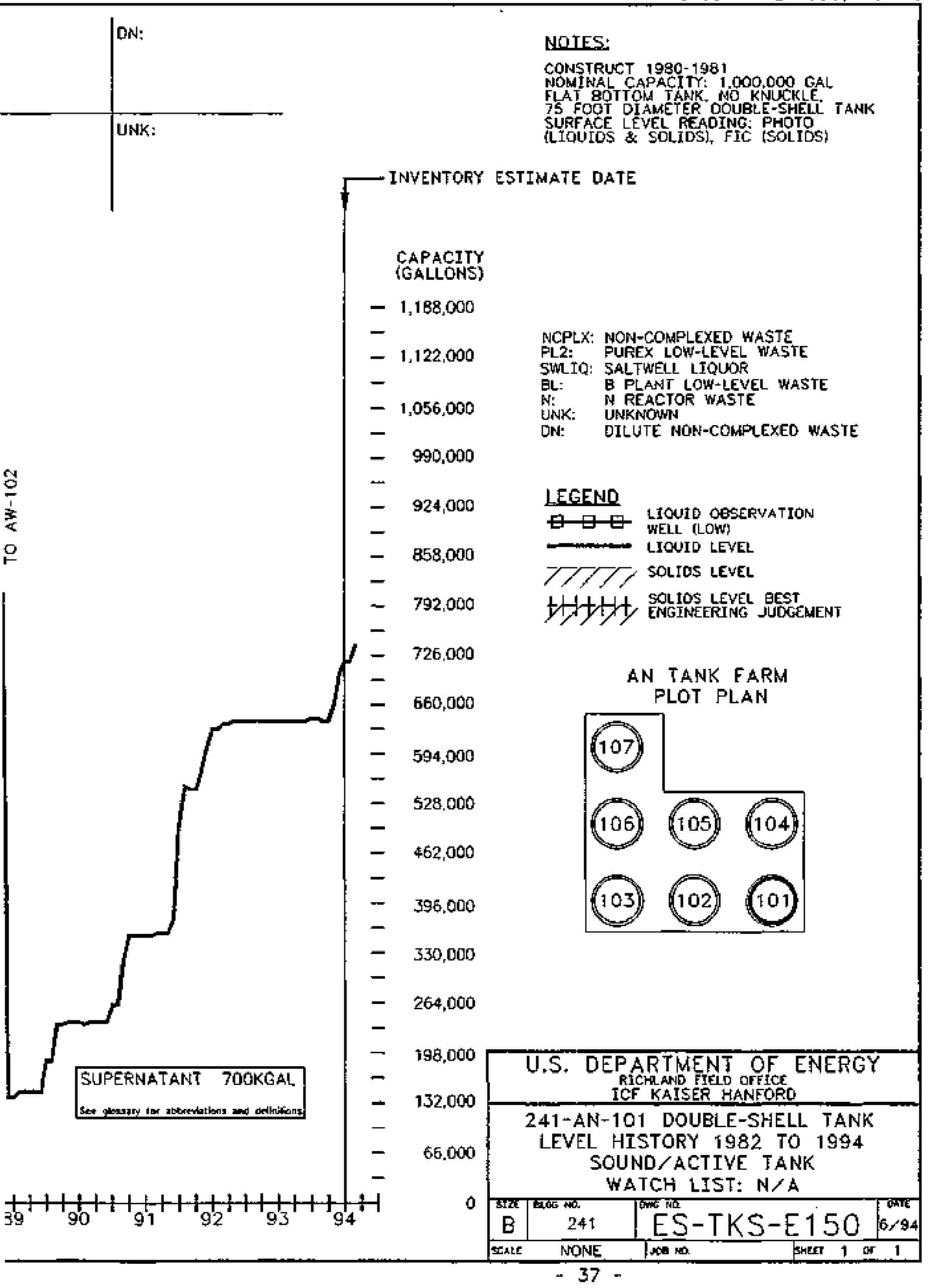


WHC-SD-WM-ER-350, ReV. O

\begin{tabular}{|c|c|c|c|}
\hline \multicolumn{4}{|c|}{ Dopble-Shell Tank 241-AN-10] } \\
\hline \multicolumn{4}{|c|}{ 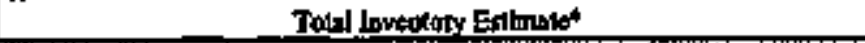 } \\
\hline \multicolumn{2}{|c|}{ 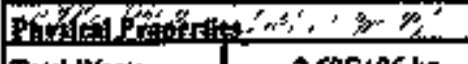 } & $x^{2}=3 x=3$ & 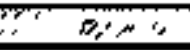 \\
\hline Tout Worte & $2.69 \mathrm{E}+06 \mathrm{~kg}$ & 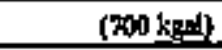 & \\
\hline Henilond & $0.102 \mathrm{~kW}$ & 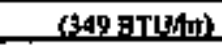 & \\
\hline elúk Densint & & $2,01(y)$ & \\
\hline wetet wets & & 97.6 & \\
\hline $\mathrm{TOC} \% \mathrm{C}$ (unt) & & 0.032 & \\
\hline \multicolumn{4}{|c|}{ 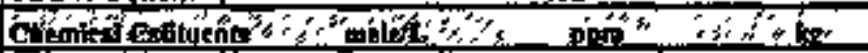 } \\
\hline Net+2 & 0.302 & $6,86 \mathrm{E}+13$ & $1.8 \mathrm{dE}+04$ \\
\hline$A^{*}$ & 3.2.98,-02 & 877 & 2.35E+03 \\
\hline 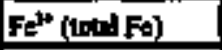 & $2.97 \mathrm{~T}-0.4$ & 16.4 & 44.0 \\
\hline Crit+ & [ 106E-0.5] & 42 & t.45 \\
\hline $\mathrm{BP}^{*}$ & $2.32 \mathrm{E}-0 \mathrm{~S}$ & 4.79 & 129 \\
\hline$\underline{\mu^{3}}$ & I.02E-OR & 1.39E:D? & $374 \mathrm{E}-12$ \\
\hline $\mathrm{H} \mathrm{s}^{\mathbf{3}^{4}}$ & $4.4[2-07]$ & 8,72E-02 & 0.294 \\
\hline 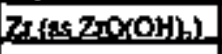 & 1,02E:04 & 2019 & 24.7 \\
\hline$P_{0}^{3+2}$ & $3,39 E-06$ & 0.692 & 1.86 \\
\hline 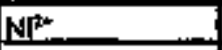 & 2.126 .004 & 12,3 & 32] \\
\hline $\mathrm{Si}^{*+}$ & $1,07 E-07$ & $9.28 E-03$ & $2,49 \mathrm{E}-02$ \\
\hline $\mathrm{Mn}^{*}$ & $4.14 E-04$ & 224 & 603 \\
\hline $\mathrm{Cr}^{*}$ & 2.0050 .03 & 82,3 & 221 \\
\hline $\mathbf{K}^{*}$ & 2315093 & 282 & 257 \\
\hline OSt' & 0.150 & $2.52 \mathrm{E}+0 \mathrm{0}]$ & $6.77 \mathrm{E}+05$ \\
\hline NG: & $0.13 \mathrm{t}$ & sourtetis & $2[60+10]$ \\
\hline №;:- & $3.960+02$ & $1.80 \mathrm{E}+0 \mathrm{3}$ & 4.638+09 \\
\hline $\mathrm{CO}_{4}^{2+}$ & 1.925:-102 & 1.1.14E:409 & $307+0+01$ \\
\hline $\mathrm{PQ}^{2}$ & $5.915-03$ & 55s & $1.49 \mathrm{~B}+0 \mathrm{OS}$ \\
\hline soz & $708 E_{-03}$ & 6il] & $100+09$ \\
\hline Silus sto, $\}$ & $1,472,03$ & $\Delta 0.8$ & 110 \\
\hline F & 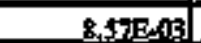 & 161 & 431 \\
\hline Cr & $5+17 E-05$ & 181 & 486 \\
\hline CH.OA. & 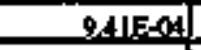 & 176 & 171) \\
\hline EDTA & 3.27E-0N & 93.0 & 2500 \\
\hline HenTA & 5,31F-A2 & 14 & 388 \\
\hline etreoleter: & $6.17 \mathrm{E}_{0} 09$ & 4592 & $\perp 273+0$ \\
\hline ecetinle & $3,555-04$ & 22.4 & 60.2 \\
\hline axakets. & 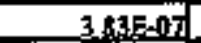 & $333 \mathrm{E}-02$ & 894600 \\
\hline DQP & $4,72 \mathrm{E}-04$ & 74.9 & 2001 \\
\hline thrisngi & $A 7 \mathrm{p}-04$ & 345 & 916 \\
\hline $\mathrm{NH}$ & 2.38E -02 & 398 & $1072+03$ \\
\hline \multicolumn{4}{|c|}{ Fe(CN)* } \\
\hline \multirow{2}{*}{\multicolumn{2}{|c|}{ 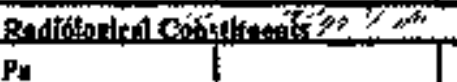 }} & 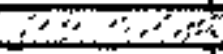 & $z x_{2}$ \\
\hline & & $222 \mathrm{E} 03(\mu \mathrm{Cj} / \mathrm{s})$ & $9,93 \mathrm{JE}-02(\mathrm{~kg})$ \\
\hline$\underline{U}$ & 2ASE-OA $(M)$ & 67.6 (ugs) & (8z) (L) \\
\hline C: & 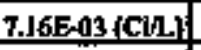 & $70,6\left(\mu \mathrm{C}_{3} \mathrm{~g}\right)$ & $1.90 \mathrm{E}+04(\mathrm{C})$ \\
\hline st & $7,43,5=04\{\mathrm{CHL}\}$ & $0.734\left(\mu C_{1} g\right)$ & 1.97g+09 (C) \\
\hline
\end{tabular}

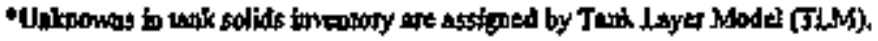

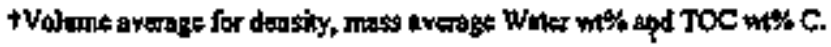

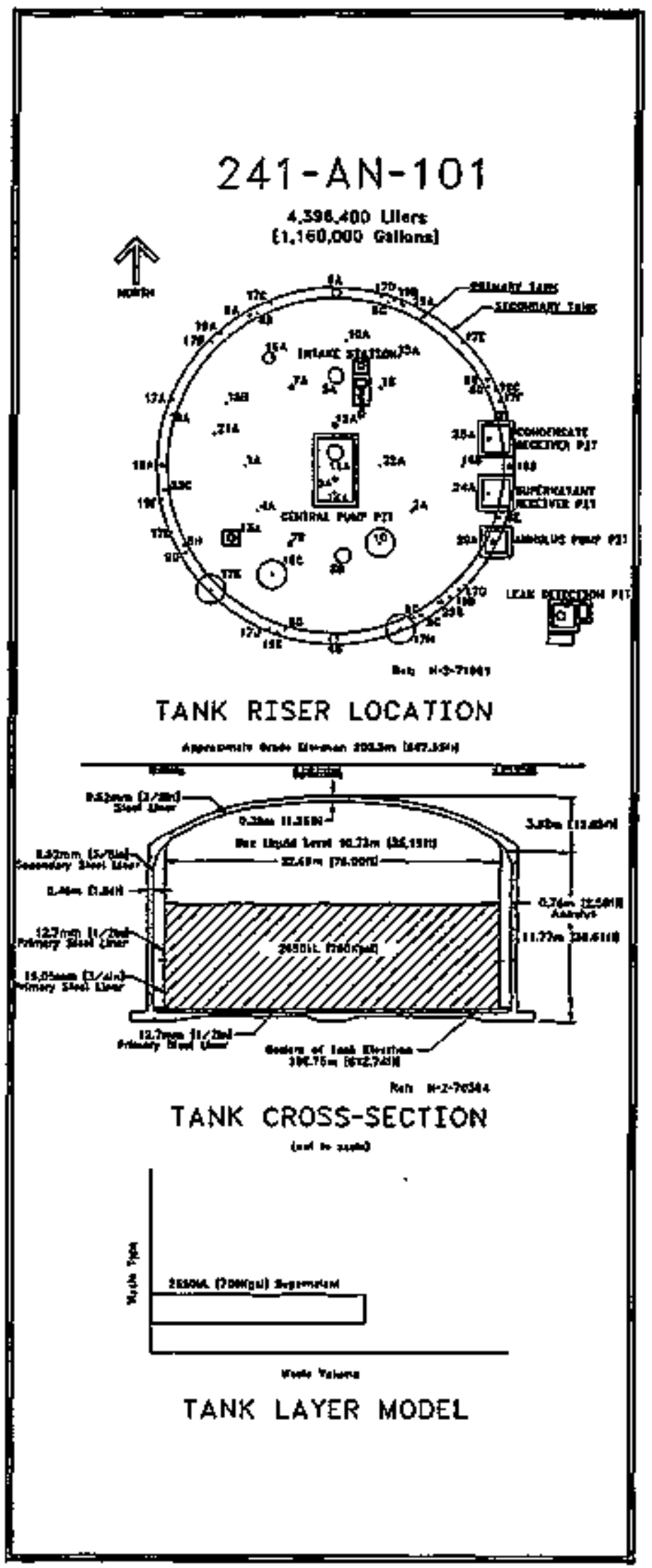

$6 / 95$ 


\begin{tabular}{|c|c|c|c|}
\hline \multicolumn{4}{|c|}{ Double-Sbell Tank 241-AN-101 } \\
\hline \multicolumn{4}{|c|}{ SMM Composile hy= maory Estrnnt: } \\
\hline 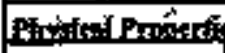 & 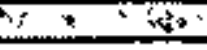 & $\therefore$ & 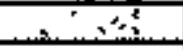 \\
\hline Tow Siperatara & $2.69 \mathrm{E}+06 \mathrm{~kg}$ & $(700 \mathrm{kgg})$ & \\
\hline सEallom & $0 / 02.12 \%$ & (AdS BTU/hr & \\
\hline Bgall: Densyits" & & 101 (1) & \\
\hline Water wast & & 97.6 & \\
\hline$T O C$ wt\% C (wet) & & 0.032 & \\
\hline \multicolumn{4}{|c|}{ 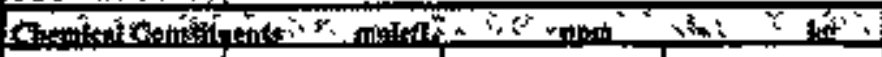 } \\
\hline $\mathbf{H}^{*}$ & 0,302 & $6.86 \mathrm{~g}+0 \mathrm{z}$ & $1.84 \mathrm{E}+04$ \\
\hline $\mathrm{Al}^{3+2}$ & 3 9xens & 87 & $2359+03$ \\
\hline $\mathrm{Fe}^{3 *}(\operatorname{cotal} \mathrm{Fe})$ & 2.97E-04 & 16.4 & 44.0 \\
\hline$c^{2 *}$ & 1.96E-03: & 화군 & 45 \\
\hline$B \mathrm{Bt}^{2}$ & 232E-05 & 4.79 & 12.9 \\
\hline $1 \%$ & 108:-017 & $1392=02$ & $3,24 E-02$ \\
\hline 부랄 & 4ASE-07) & $8.725-09$ & 0.234 \\
\hline 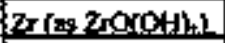 & $102 E=04$ & 919 & 247 \\
\hline $\mathrm{Fb}^{2 *}$ & $3.39 \mathrm{E}-\mathrm{al}$ & 0.692 & 1.86 \\
\hline $\mathrm{Mr}^{*}$ & $2.12 E=04$ & 12.3. & 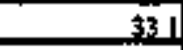 \\
\hline $5 r^{*}$ & $1.07 E-0, t$ & $928 \mathrm{E}-03$ & $2.49 E-02$ \\
\hline $\mathrm{sin}^{*}$ & $4(42-04)$ & 224 & 603 \\
\hline $\mathrm{Co}^{\mathrm{*}}$ & $2,0.03 \mathrm{E}-0 \mathrm{0}$ & 82.3 & 221 \\
\hline $\mathbf{K}^{-}$ & $73] \mathrm{B}, 0 \mathrm{x}$ & 282 & 757 \\
\hline 애 & 0.350 & $2,52=-0,3$ & $6,77 E+03$ \\
\hline $\mathrm{NO}$ & $0.13 \mathrm{Z}$ & 804E+0? & $2(6)+24$ \\
\hline $\mathrm{NO}_{-}$ & $3.96 \mathrm{E}-02$ & $1.20 \mathrm{E}+0.5$ & $4.83 \mathrm{E}+0,5$ \\
\hline $\cos$ & 192E-02 & $14 \mathrm{E}+03$ & 3070 +03 \\
\hline $\mathrm{PO}^{2}$ & 5.91E-19 & 359 & $\angle A 9 E+03$ \\
\hline 502 & TOSEAS? & 671 & $1: 00=03$ \\
\hline$S E\left(\Delta S S_{2}{ }^{2}\right)$ & $1.47 E-03$ & 40.8 & 110 \\
\hline $\mathrm{F}$ & $8.575=0.31$ & [a] & 431 \\
\hline $\mathrm{Cl}^{\circ}$ & $5.37 E-0.3$ & 181 & 486 \\
\hline c.tinos & 24IEE04I & ] & 471) \\
\hline EDTh* & $3.2 \pi E-04$ & 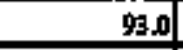 & 250 \\
\hline HEOTAL & S.36E-04: & $|4|$ & 386 \\
\hline fhxydes: & 6.17E-OB & 455 & L22EE+0: \\
\hline acestet & 3.85E-04 & 224 & 60.2 \\
\hline 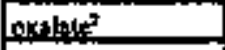 & $3835=-97$ & 333E-09 & B.91E:02 \\
\hline DEP & 4.72E-04 & 74.9 & 201 \\
\hline thetragl & 17PE=-04 & 34.5 & 92.6 \\
\hline $\mathrm{NH}$ & 23850.02 & 38 & $1.078+020$ \\
\hline $\mathrm{Feg}(\mathrm{CN})^{2}$ & $d$ & $d$ & \\
\hline \multicolumn{4}{|c|}{ 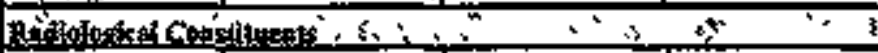 } \\
\hline$P_{\mathbf{u}}$ & 2.25 (14Cin] & & 9.91E-02 (Lg) \\
\hline$\underline{u}$ & 288 E.04: (hil & 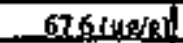 & $|8 z+(k \mathrm{~kg})|$ \\
\hline Cs & 316E-03 $\{\mathrm{C}$ il $)$ & 7.06 ( $\mu$ Cijs. & L.90E+04 (C) \\
\hline Sr & $2.43 \mathrm{E}-04\langle\mathrm{CH} i)$ & 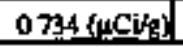 & $1.97 \mathrm{E}+03$ (C) \\
\hline
\end{tabular}

*Dencity is calculated based on $\mathrm{Ne}$, OHt, and $\mathrm{AlOz}$.

tWater wry derived thom the difference of dessity adod loted dissolved spectes.

\begin{tabular}{|c|c|c|c|}
\hline \multicolumn{4}{|c|}{ Double-Shell Tank 241-AN-101 } \\
\hline \multicolumn{4}{|c|}{ TLM Solids Composite torentory Estimate* } \\
\hline \multicolumn{4}{|c|}{ 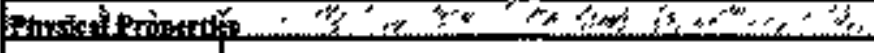 } \\
\hline Total Solid Wate & & (0 k kgl) & \\
\hline Heallowd & $0 \mathrm{~kW}$ & (ABTURri & \\
\hline Bulk pintsity. & & 0 (os & \\
\hline Water wris & & $\mathbf{0}$ & \\
\hline FOC $u+\% \mathrm{C}$ (wet) & & 0 & \\
\hline \multirow{2}{*}{\multicolumn{4}{|c|}{ 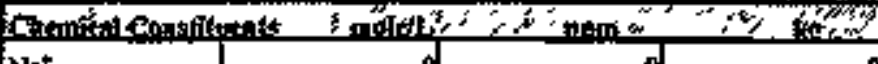 }} \\
\hline $\mathrm{Na}^{*}$ & & & 0 \\
\hline \multicolumn{4}{|l|}{$A P^{*}$} \\
\hline \multicolumn{4}{|l|}{$F^{3 *}$ (toral $\left.f_{0}\right)$} \\
\hline \multicolumn{4}{|l|}{$c^{*+}$} \\
\hline \multicolumn{4}{|l|}{ 吾 } \\
\hline \multicolumn{4}{|l|}{12} \\
\hline \multicolumn{4}{|l|}{$\mathrm{Hg}^{\mathrm{g}^{+}}$} \\
\hline \multicolumn{4}{|l|}{$2 x(15 z) 0(0)+3)$} \\
\hline \multicolumn{4}{|l|}{$\mathrm{Pb}^{*+}$} \\
\hline \multicolumn{4}{|l|}{$\mathrm{N}^{*}$} \\
\hline \multicolumn{4}{|l|}{$\mathrm{SH}^{4+}$} \\
\hline \multicolumn{4}{|l|}{$\mathrm{Mn}^{4}$} \\
\hline \multicolumn{4}{|l|}{$\mathrm{Ca}_{\mathrm{a}}{ }^{2}$} \\
\hline \multicolumn{4}{|l|}{$\mathbf{K}^{*}$} \\
\hline \multicolumn{4}{|l|}{ OH } \\
\hline \multicolumn{4}{|l|}{ No: } \\
\hline \multicolumn{4}{|l|}{ No: } \\
\hline \multicolumn{4}{|l|}{$\mathrm{Cos}^{2}$} \\
\hline \multicolumn{4}{|l|}{$\mathrm{PO}^{2}$} \\
\hline \multicolumn{4}{|l|}{ so: } \\
\hline \multicolumn{4}{|l|}{ Si(us $\left.5: 0^{7}\right)$} \\
\hline f & & (2) & 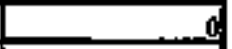 \\
\hline Cl. & c) & a] & 0 \\
\hline Cuthos. & & 0 & 0 \\
\hline EDTA* & 0. & of & 0 \\
\hline HEDTA & & 0 & $\Delta$ \\
\hline gheodate- & & a) & 0 \\
\hline acelaté & 아 & af & 0 \\
\hline 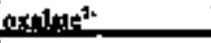 & & 0 & a \\
\hline DEP & 에 & d & t) \\
\hline Futand L & at & . & 0 \\
\hline $\mathrm{NH}_{2}$ & & a & to \\
\hline FerCN2 & d & d. & 0 \\
\hline 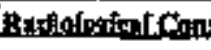 & Latents & 2y & 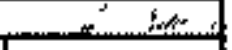 \\
\hline Py & & 0 & - \\
\hline it & & o & . \\
\hline$C_{5}$ & e. & & 0 \\
\hline Sr & 0] & 0 & a \\
\hline
\end{tabular}

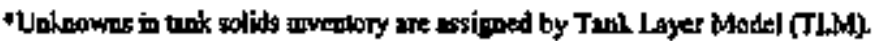


WHC-SD-WM-ER-350, Rev, 0

2.2 Tank 241-AN-102

2.2.1 241-AN-102 Tanik History.

2.2.1.1 Waste History of Tank 241-AN-102

Tank 241-AN-102 began service by receiving non-conplexed waste fxom Tank 241-SY-102 in September 1981. The tank received non-complexed waste until December 1982. The tank received complexant concentrate waste from Jaruary 1983 until october 1983. From November 1983 until June 1984, the tank again received non-complexed waste. During the first quarter of 1984 , the tank received low-level waste from PUREX. The tank received complexant concentrate waste from Tank 241-AW-101 from July 1984 until the fourth quarter of 1992 and has not received any waste since 1992. The tank is currently inactive and is considered a concentrated waste holding tank.

\subsubsection{Temperature Fistory of Tank 241-AN-102}

Tenperature date for Tank 241-AN-1.02 are recorded by 18 thermocouples at known elevations on one thermocouple tres inside the tank, located in risex 4A. Non-suspect termerature data taken between July 1983 and November 1990 for all 18 thermocouples were available from the computer automated surveillance system. However, the guality of the data varied between thermocouples. Therefore, tenperdure data for an individual thermocouple may not have encompassed this entire length of time. Nonsuspect temperature data taken between January 1990 and September 1993 for six thermocouples were available from the surveillance analysis computer system. - Within the time span for the computer autonated surveillance system, there were several small breaks in the sequence of the temperature data. Within the time span of the surveillance analysis computer system, there were no significant breaks in the sequence of temperature data. The average tempexature during these periods was $90.7^{\circ} \mathrm{F}$ with a minimum of $65^{\circ} \mathrm{F}$. a maximin of $104^{\circ} \mathrm{F}$, and a standard deviation of $9.0{ }^{\circ} \mathrm{F}$. Iinear regressions wer performed on each themocouple that recorded temperature date starting from January 1990. The slopes from these regressions were averaged with a resulting average stope of 0.00849 . Refer to the supporting document for a more thorough review of the temperature data (Brevick, 1995).

\section{2 .1 .3 Occurrences of Tank 241-AN-102}

One unusual event concerned Tank 241-AN-102. TFS \& O-EFS-89-046 was issued in July 1989. Samples taken indicated that the tark had a deficient amount of caustic. A second set of samples verified the problem.

\subsubsection{Psychrometrics of Tank 241-AN-102}

The apperent trend of the evaporation zate from the tank has increased from 97 gallons per week in August 1982 to 178.1 gallons per week in January 1995. Over that same period, the trend in the rates of heat exchange through the primary tank and annular ventilation has apparently increased. A review of the psychrometric data in Tank 241-AN-102 would suggest an overall increase in the rate of heat generation by the waste. 


\section{2 .2 Current Status of Tank 241-AN-102}

Tank 241-AN-102 entered service in September 1981 and currently stores $1,082,000$ gallons of waste. The following plan view and tark cross-section depict the approximate waste volume of $1,095,000$ gallons and riser configurations for January 1994. At the time of the estimate, there were 1,095,000 gallons of supernatant with 89,000 gallons of concentrated supernatant solids. The waste level in the tank is measured with the FIC gauge and has remained at about 400 inches over the last three years. The one increase was the addition of dilute and non-complexed waste from PUREX miscelianeots streams. This tank is inactive at the present time. The tank is actively ventilated and categorized as sound. Tank 241-AN-102 has 61 risers. One 4-inch riser (no.21A) and one 12-inch riser (no.7A) are available for use.

\subsubsection{Inventory Estimate of Tank 241-AN-102}

The tank layer model (a volume based approximation) that follows was derived from the Los Alamos National Iaboratory waste status and Transaction Record Sumary (Agnew, 1995) and Supernatant Mixing Model (Agnew, 1995). The estimated inventories of total waste, solids, and supernatant in Tank 241-AN-102 are also presented. Concentrated supernatant solids are considered as an integral part of the liguid for the purpose of estimating inventories, but are graphed as solids on the level histories. The actual substance, which was derived from double-shell slurry, appears as a solid if undisturbed, but the particles are resuspended in solution if heated or disturbed.

\subsubsection{In-Tank Photograph of Tank 241-AN-102}

No in-tank photograghs are available.

\subsubsection{Symopsis of Tank 241-AN-102}

(To be completed.) 


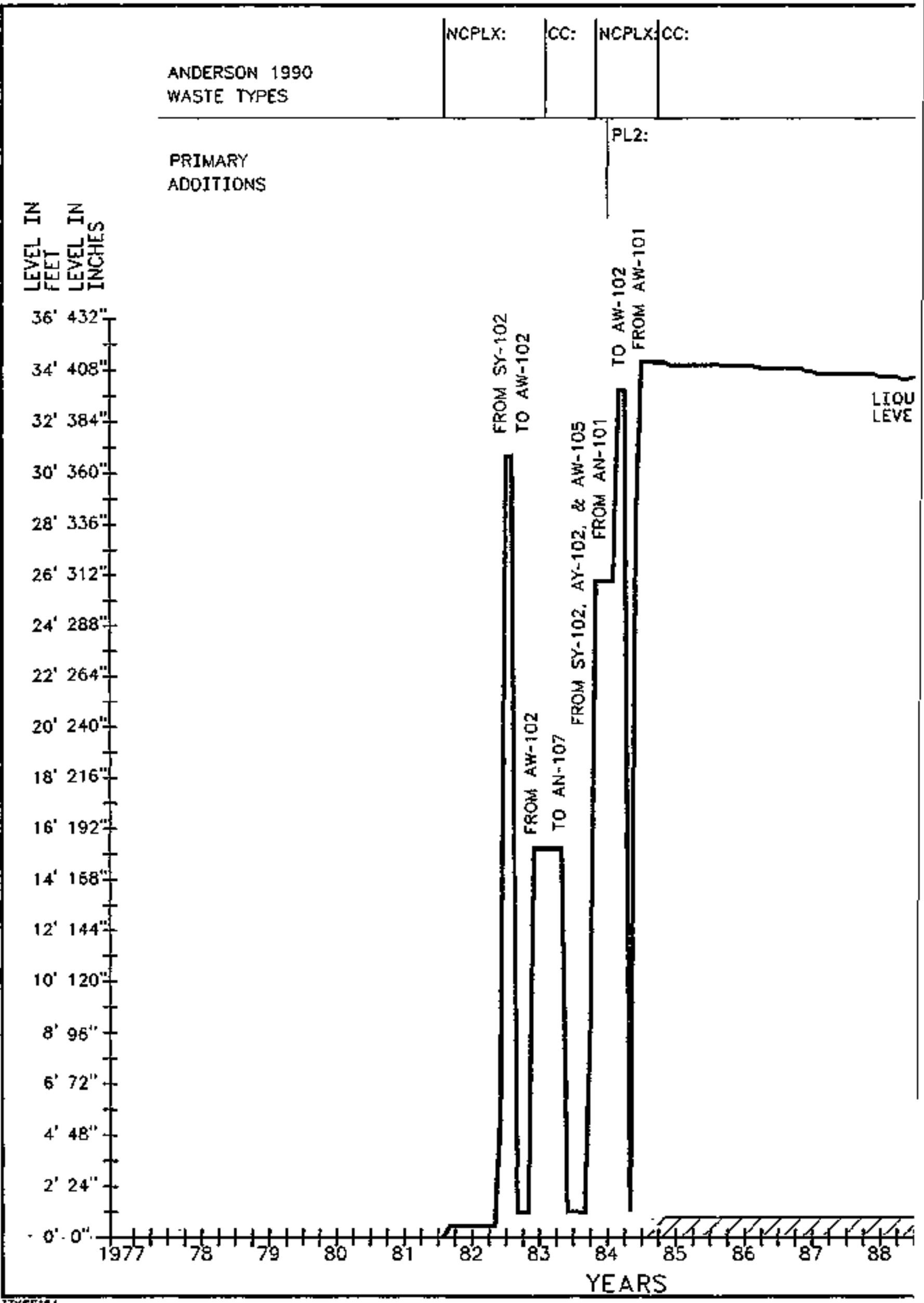




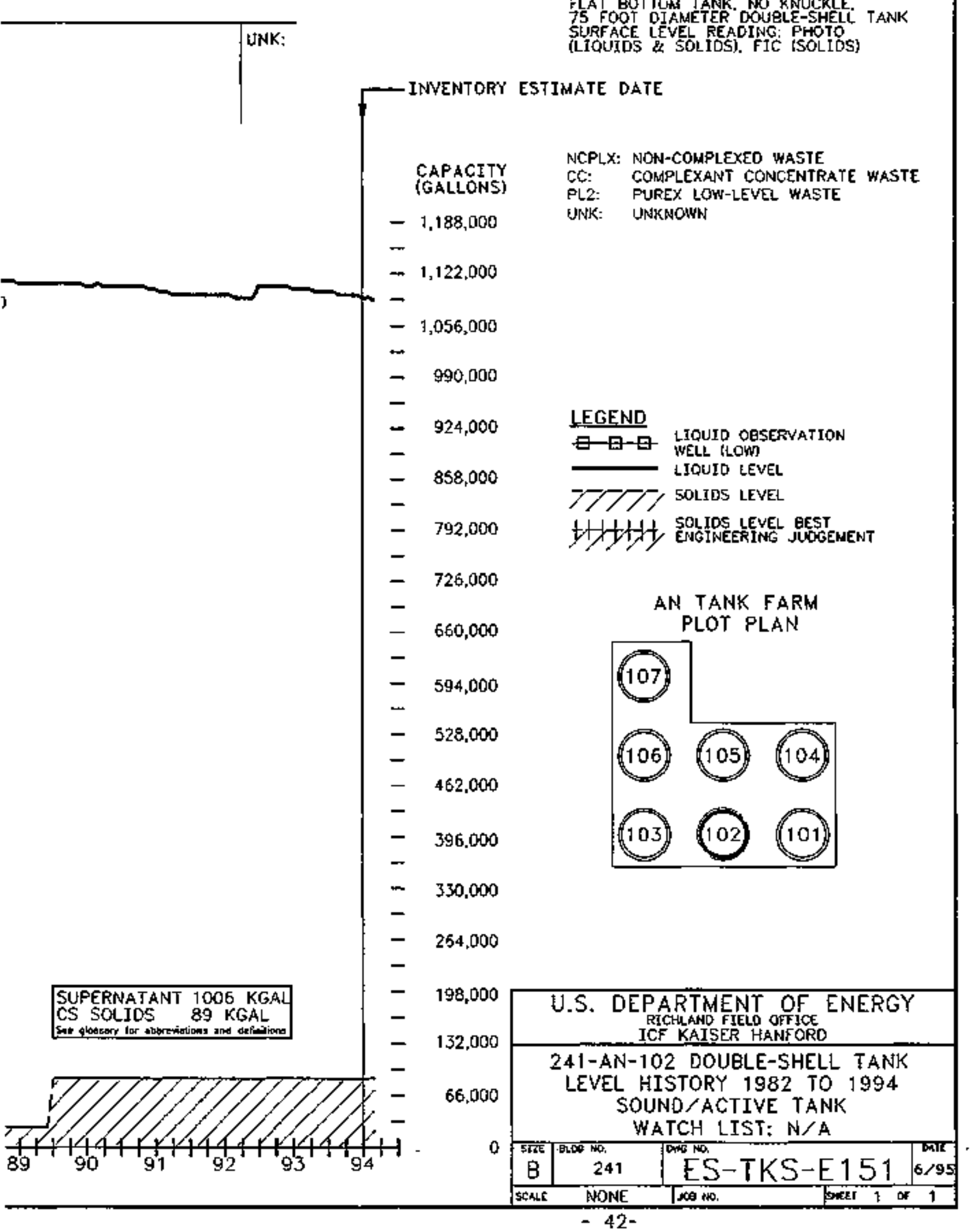

NOTES:

CONSTRLCT 1980-1981

NOWINAL CAPACITY: 1000000 GAL

FLAT BOTTOHA TAMK HO KNUCKLE.

75 FOOT DIAMETER DOUELE-SHELI TANK SURFACE LEVEL READING: PHOTO

CC: COMPLEXANT CONCENTRATE WASTE

PL2: PUREX LOW-LEVEL WASTE

$-1,188,000$

UNK: UNKNOWN

LEGEND

LIOUID OESERVATION

VELL HOW]

$77 \%$

$-\quad 792,000$

HH SOLIOS LEVEL EEST

$-\quad 726,000$

- 660,000

N TANK FARM

107

106

105

104

$-330,000$

$-\quad 254,000$

$-198,000$

$-\quad 132,000$ ICF KAISER HANFORO CS SOLIDS 89 KGAL 


\begin{tabular}{|c|c|c|c|}
\hline \multicolumn{4}{|c|}{ Double-Shell Tank 241-AN-102 } \\
\hline \multicolumn{4}{|c|}{ 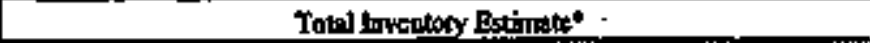 } \\
\hline 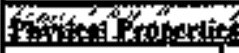 & mang & 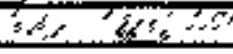 & 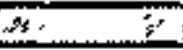 \\
\hline Tot: Waste & \multicolumn{3}{|c|}{$526 \mathrm{E}+06 \mathrm{~kg},(1.10 \mathrm{E}+03 \mathrm{k} \mathrm{k})$} \\
\hline Hettlond & \multicolumn{3}{|c|}{ 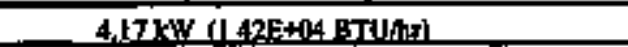 } \\
\hline Butk:Denstht & \multicolumn{3}{|c|}{$127(0 / 0)$} \\
\hline Wader wt\% & \multicolumn{3}{|c|}{62.8} \\
\hline To w w c (wefl & \multicolumn{3}{|c|}{0.736} \\
\hline \multicolumn{4}{|c|}{ 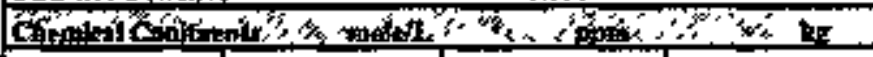 } \\
\hline 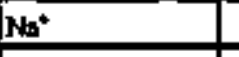 & 5.80 & 1.07te+05 & $5.625+09$ \\
\hline$\Delta]^{3 *}$ & 0.728 & $1.555+24$ & $8+4=404$ \\
\hline Fe't" (tolkel Fo) & $3.4[8-09]$ & 150 & 788 \\
\hline $\mathrm{Cs}^{*}$ & 219E-D? & :(6) & $4.5 \times 5+103$ \\
\hline 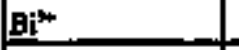 & 1320-04 & 1200] & 634 \\
\hline 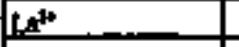 & 4.49E- -6 & Q48: & 259 \\
\hline He $\mathrm{e}^{\prime *}$ & $5.05 E-06$ & 0.797 & 420 \\
\hline $2 \mathrm{z} \times 2 \times \mathrm{OOOH}$ & 469E, 04 & 39.7 & 177 \\
\hline $\mathrm{Ph}^{3+2}$ & 6.18E-05 & 10.6 & 55.7. \\
\hline $\mathrm{NPF}^{*}$ & $297 \mathrm{E}-09$ & 137 & $m$ \\
\hline Srit. & $4.68 \mathrm{~B}-06$ & 0,923 & 1.70 \\
\hline $\mathrm{Min}^{*-}$ & T.LE-OA & 31 & $164 E+109$ \\
\hline $\mathrm{q}^{\mathrm{*}}$ & 2.38R-02 & 252 & $3.562+09$ \\
\hline $\mathrm{K}^{+}$ & $2.06 \leq=92$ & 639 & $34 \mathrm{E}+103$ \\
\hline 요 & 3.24 & 4.34E+04 & $2.28 \mathrm{E}+05$ \\
\hline No: & 207 & LO1E+0S & $533 E+05$ \\
\hline $\mathrm{NO}_{-}$ & 1.24 & $4.48 \mathrm{E}+04$ & $236 E+05$ \\
\hline$\infty 0^{2}$ & 0,302 & $14 \mathbb{E}+01$ & $7+5\} E+0$, \\
\hline PO: & $0.10 \mathrm{~s}$ & $8.08 \mathrm{E}+\mathrm{n}-19$ & 1.25E+04 \\
\hline 5027 & 0.162 & 1.23:840 & 6.ATE+A6 \\
\hline silas 510,2$)$ & $3.03 E-02$ & fat & $3,52 E+03$ \\
\hline $\mathrm{F}$ & $5060-02$ & 257 & 399E=03 \\
\hline $\mathrm{CF}$ & $9.98 \mathrm{~g}-02$ & $2.78 E+03$ & $147 E+04$ \\
\hline Cstron & $2355=-09$ & $349 E+03$ & 1.85s+04] \\
\hline EDT:A* & $1,12=0-0$ & $2.53 E+03$ & 1.33e +0.04 \\
\hline HEDTA. & $1,82 E=0$ & $3.93 E+03$ & $2078+24$ \\
\hline sthesintes: & $8960-02$ & $529 E=00^{3}$ & $278 \mathrm{E}+0 \mathrm{04}$ \\
\hline netentio & $133 E+02$ & $6 \mid 7$ & $3.23 \mathrm{E}+03$ \\
\hline 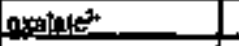 & 167205 & 116 & -6 to \\
\hline DAP & $1,25 \mathrm{E}-02$ & $1.58 E+00$ & $8.33 \mathrm{E}+02$ \\
\hline Lus:s,oll & $1.25 E_{A} d$ & 229 & $38 \mathrm{E}+0 \mathrm{x}$ \\
\hline $\mathbf{N}$ & 330E $40 \mathrm{OAd}$ & 442 & $222 E \div 03$ \\
\hline $\mathrm{F} Q \mathrm{CN})_{k}^{*}$ & & & \\
\hline Esidetions: & (1) & 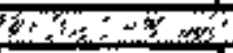 & $\because 2$ \\
\hline Pe & & 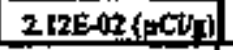 & $1.86(\mathrm{he})$ \\
\hline$\underline{u}$ & 4,02E-03 (M) & 33 (4).5n) & $3.96 \mathrm{E}+13, \mathrm{~kg})$ \\
\hline $\mathrm{CH}_{\mathrm{E}}$ & 0.201(CAL) & Ist (4Cits) & 6.33E+05 (C) \\
\hline $\mathrm{S}_{\mathrm{Y}}$ & 9.49E-03 (CiL) & $7.47(4 \mathrm{Ci})$ & $3.93 \mathrm{E}+04(\mathrm{Ci})$ \\
\hline
\end{tabular}

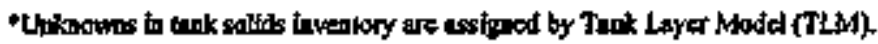

t Volume avergoge for dearity, mags Ivarage Watet wh\% sod TOC wTK C.

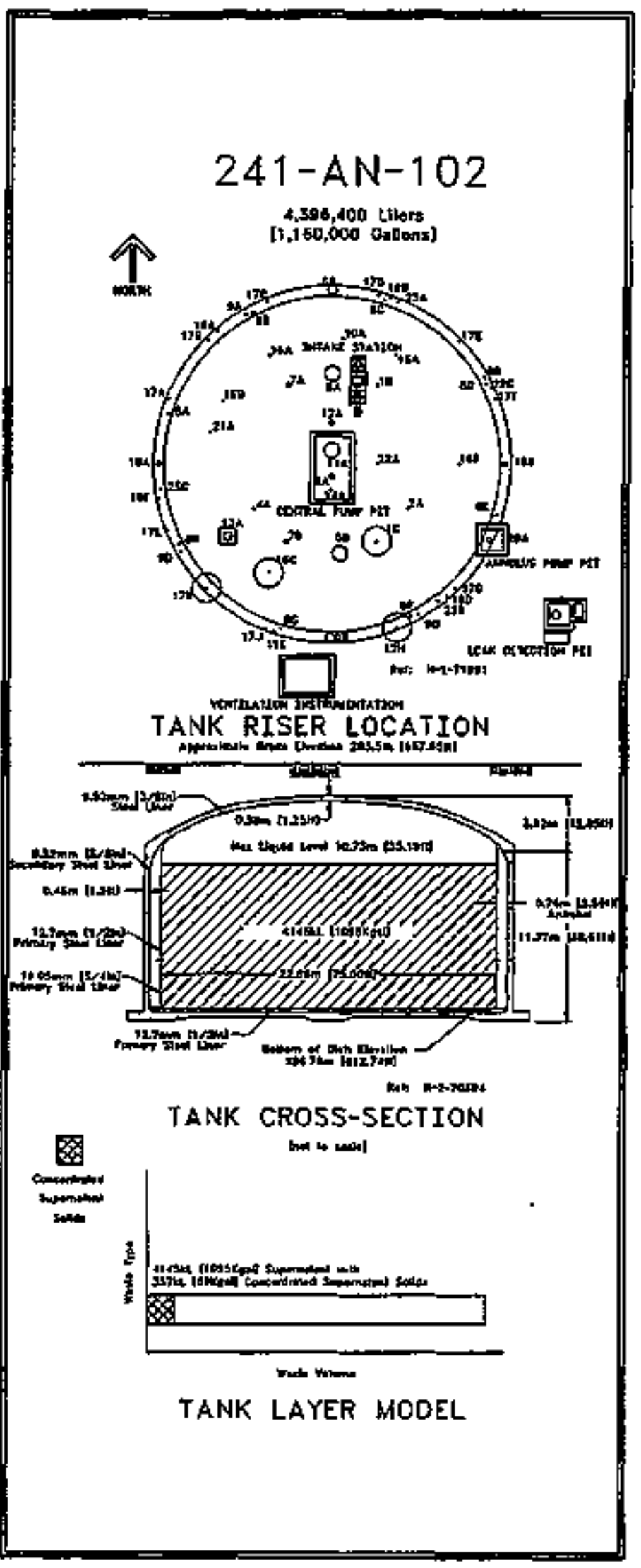




\begin{tabular}{|c|c|c|c|}
\hline \multicolumn{4}{|c|}{ Double-Shell Tank 241-AN-102 } \\
\hline \multicolumn{4}{|c|}{ 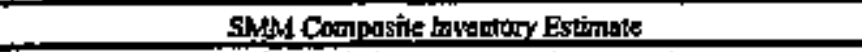 } \\
\hline 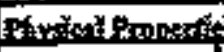 & $45,8 \div$ & 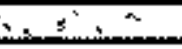 & $\therefore 2$ \\
\hline Totel Supertinatel & \multicolumn{3}{|c|}{$5.26 \mathrm{E}+06 \mathrm{~kg},(\mathrm{I} .10 \mathrm{k}+03 \mathrm{~kg}$} \\
\hline Heth Land & \multicolumn{3}{|c|}{ 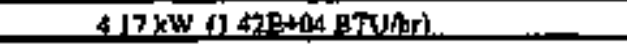 } \\
\hline Bul: Desogin" & \multicolumn{3}{|c|}{ 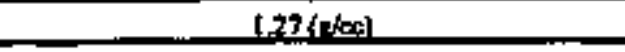 } \\
\hline Water wot & \multicolumn{3}{|c|}{62.5} \\
\hline$J 0 \mathrm{Cw} * \mathrm{C}(w-1)$ & \multicolumn{3}{|c|}{$\begin{array}{c}0.736 \\
\end{array}$} \\
\hline \multicolumn{4}{|c|}{ 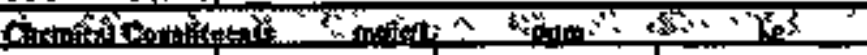 } \\
\hline Net & 5.90 & $1.07 \mathrm{Q}+0.05$ & $5.90+0.95$ \\
\hline $\mathbf{A l}^{\mathbf{b}}$ & 072 & I ssentos & 145404 \\
\hline Fot (10ted Fe) & $3,41 E(0)$ & 150 & $78 \mathrm{E}$ \\
\hline$c^{3+}$ & 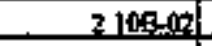 & A61 & 4.53E 409 \\
\hline BP & $3,32 \mathrm{e}, 0.4$ & 1200 & 634 \\
\hline La+* & 4498:05 & $048: 5$ & 2,55 \\
\hline$\underline{\underline{H}} \mathrm{~g}^{2 *}$ & S.05E-0.6 & 0.797 & 4.20 \\
\hline 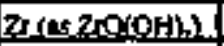 & $4,6950.04$. & 337 & 17 \\
\hline Ptrt* & 6.48E-05 & 10.6 & 557 \\
\hline $\mathrm{Nip}^{2}$ & $2978-03$ & 107 & 27 \\
\hline$s^{*}$ & $4.680+06$ & 0,323 & 1.70 \\
\hline $\mathrm{Nton}^{4 *}$ & $7 \pm 80_{0} 03$ & 311 & $164 \mathrm{E}+\mathrm{D} 3$ \\
\hline $\mathrm{Ca}^{2 *}$ & $2.38 E-02$ & 752 & $3.960+03$ \\
\hline$x^{*}$ & $20.6 \mathrm{E}-\mathrm{m}$ & 6.5.5. & $3345+013$ \\
\hline OH & 324 & 4.34E+04 & $228 E+05$ \\
\hline או: & 2 in & LOHF+15 & $5.33=105$ \\
\hline $\mathrm{NO}$ & 1.24 & 4ABE+ +04 & 2.36E +05 \\
\hline $\cos ^{2}$ & 0 șํㅛ & $14 \pi=40$ & 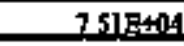 \\
\hline $\mathrm{PO}_{4}^{2}$ & 0.108 & g.DSE+0ㄹ & $4.256+04$ \\
\hline $\mathrm{SO})^{2}$ & 016 & $1273+04$ & $6,475+104$ \\
\hline Si $\left(\operatorname{ess} \mathrm{Si}^{3}\right)$ & $3,035,102$ & 630 & $3,32 E+03$ \\
\hline$F$ & S. DeEd) & 75 군 & $390+20$ \\
\hline c다. & 9,9.1E- 0 : & $2,78 \mathrm{E}+0 \mathrm{3}$ & $1,47 \mathrm{E}+04$ \\
\hline C.H:OLt & 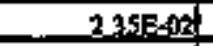 & $3495+09$ & $184 \sqrt{8}+04$ \\
\hline EOTA* & $1.12 \mathrm{E}-02$ & $2.53 E+63$ & 1. $33 \mathrm{~B}+04$ \\
\hline HEDTA $A^{2}$ & $1,2 \mathrm{E}-0$ & $393 E+13$ & $207 \mathrm{e}+0$ \\
\hline Pfybolate & s. & $5295+03$ & $278 \mathrm{E}+04$ \\
\hline necerise & 1.33E-02 & 6] & $3.25 E+05$ \\
\hline Oxalank". & 1 G1Eses & 116 & 810 \\
\hline DAP? & 125E- & $158 \mathrm{E}+03$ & $832+03$ \\
\hline buntand & $125 \mathrm{E} a \mathrm{q}$ & 721 & 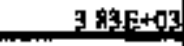 \\
\hline NH. & 3 302-002 & 442 & 233 =103 \\
\hline $\mathrm{Pe}(\mathrm{CN})^{4}$ & 国 & 0 & \\
\hline ERedlatodàlom & rin & & . \\
\hline Py & $26.9(\mu \mathrm{CH})$ & & $1.86(\mathrm{~kg})$ \\
\hline$\underline{U}$ & 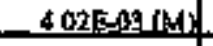 & 253 (u姲 & $396 E+03$ (x) \\
\hline Cs & 0201 (CVI) & 158 (uCug) & $833 \mathrm{E}+0.5 \mathrm{C}(\mathrm{Cl})$ \\
\hline$s$ & $9,49 \mathrm{E}-03(\mathrm{CH} / \mathrm{L})]$ & $1.47(\mu \mathrm{C}) \mathrm{y}$ & $393 \mathrm{E}+104$ (C) \\
\hline
\end{tabular}

-Dengity is calculated haged or Na, OH-, apd AlOO2.

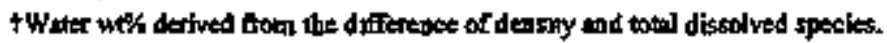

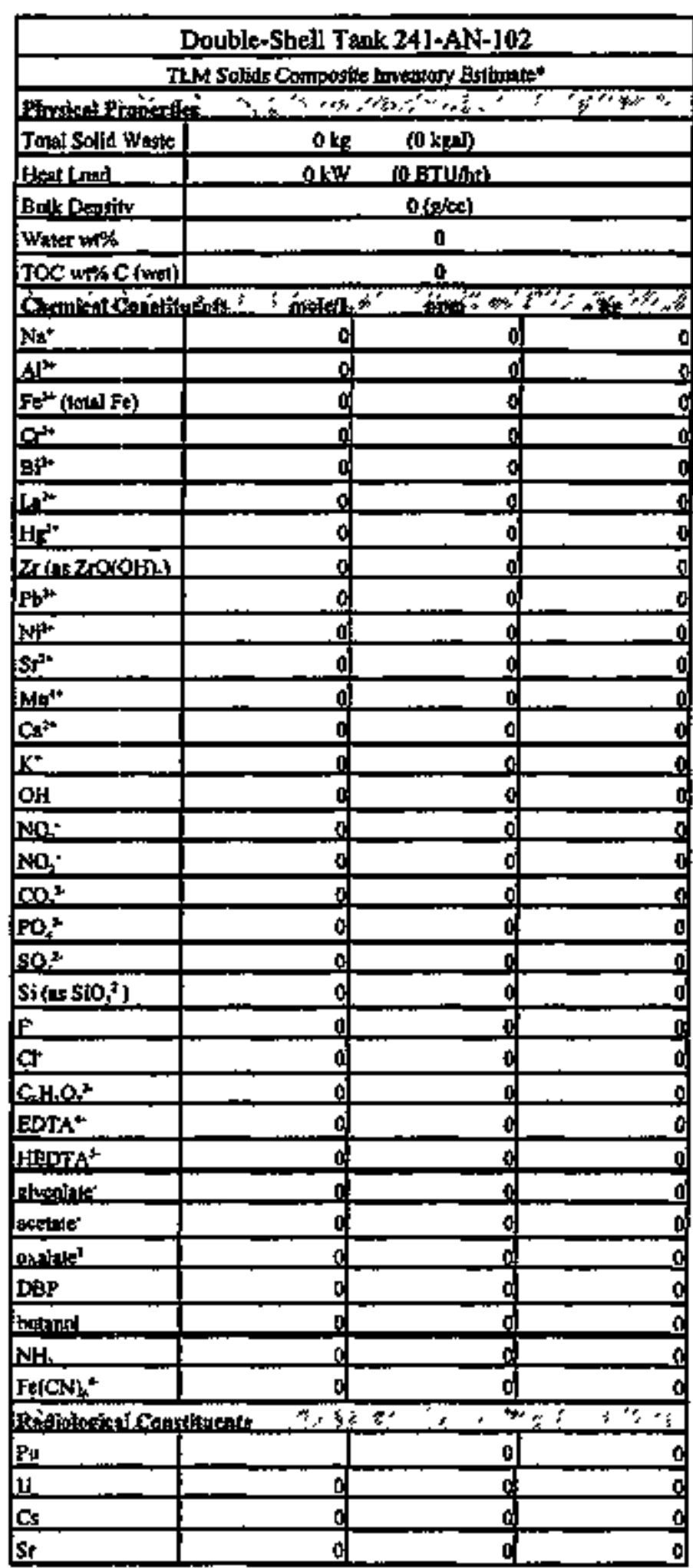

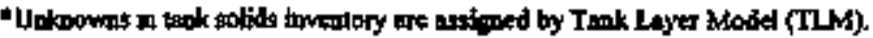


WHC-SD-WH-ER-350, Rev, O

2.3 Tank 241-AN-103

2.3.1 241-AN-103 Tank History

2.3.1.1 Waste History of Tank 241-AN-103

Tank 241-AN-103 began service by receiving non-complexed waste from Tank 241-5Y-102 in September 1981. The tark received non-complexed waste until February 1984. During 1983, the tank received Iow-level waste from B Plant and dilute non-complexed waste from the 200-East Area SSTs. The tank received double-shell slurry feed waste from March 1984 until April 1986. Since May 1986, the tank has contained double-shell slurry waste. The solid level readings in 1987 and 1988 seem to be in error. The reported solids level is higher than what can bo accounted for by the reported total volume of waste. The solids level may have risen during this time, but not to the values reported which exceeded the capacity of the tank. This exroneous data was rerooved. The slight level changes are attributed to slurry growth as a result of gas generation. The tank has not received any waste, other than wash water, since the first gavarter of 1986. The tank is currently inactive and is considered a concentrated waste holding tank.

\subsubsection{Tenperature History of Tank 241-AN-103}

Temperature data for rank 241-AN-103 are recorded by 18 thermocouples at known elevations on one tree inside the tank, located in riser 4A. Nonsuspect temperature data recorded between July 1983 and June 1991 for all 18 thermocouples were available from the computer automated surveiliance system. Non-suspect temperature data recorded between January 1990 and September 1993 for six thermocouples were available from the surveillance analyis conputer oystem. Within the tims span for the conputer automated surveillance system, there were several small breaks in the sequence of temperature data. Within the time span for the surveillance andysis computer system, there were no significant breaks in the seguence of temperature data. The average temperature during these periods was $103.7 \% \mathrm{~F}$ with a minimum of $62^{\circ} \mathrm{F}$, a maximum of $150^{\circ} \mathrm{F}$, and a standard deviation of $12.5^{\circ}$. Linear regressions were performed on each thermocouple that had temperature date starting from January 1990. The slopes from these regressions were averaged with a resulting average slope of 0,00235 . Refer to the supporting document for a more thorough review of the temperature data (Brevick 1995).

\section{3 .1 .3 Occurrences of Tank $241-\mathrm{AN}-103$}

Four unusual events occurred at Tank 241-AN-103. TFS \& O-EFS-88-0145 was issued in september 1988 due to surface level measurements exceeding procedural criteria. The charge was due to crystal growth and new surface level measuring equipment. TFs \& O-EFS-89-027 was issued in Merch 1989. The tark pxessurized to +0.3 inches water gauge when the primary exhauster did not start and when the secondary system was shut down. Occurrence Report RI--WHC-Tank Faxm-1991-1036 was issued in August 1991 due to personnel not recording tank level idta. Occurrence Report RL--WHC-Tank 
WHC-SD-WH-ER-350, Rev. 0

Farm-1991-1072 was issued in Decenber 1991 due to the 1iquid level in the leak detector pit exceeding safety limits.

\subsubsection{Psychrometrics of Tank 241-AN-103}

The apparent trend of the evaporation rate from the tank has decreased from 89.1 gallons per week in February $19 \mathrm{~B} 3$ to 79.6 gallons per week in January 1995. Over that same period, the trend in the rates of heat exchange through the primary tank and annular ventilation remained nearly constant. Any changes in the rate of heat exchange can be attributed to chenges in the average ventilation rates. A review of the psychrometric data in Tank 241-AN-103 would suggest a constant rate of heat generation by the waste.

\subsubsection{Current Status of Tank 241-AN-103}

Tank 241-AN-103 entered service in September 1981 and currently stores 951.000 gallons of waste. The following plan view and tank cross section depict the approximate waste volume of 953,000 gallons and Iiser configurations as of Jaruary 1994. At the time of the estinate, there were 951.000 gallons of supernatant with 935,000 gallons of concentrated supernatant solids and 2,000 galions of B Plant low-level waste (BL). The waste level in the tank is measured with the FIC gaugs and has rempined at about 345 inches over the last three years. This tank is on tho Hydrogen Watch List and, therefore, is prohibited from receiving waste. The tank is actively ventilated and categorized as sound. Tank 241-AN-103 has 61 risers. Two 4-inch risers (no.10A and no.21A) and ons 12-inch riser (no.7B) are available for use.

\subsubsection{Inventory Estimate of Tank 241-AN-103}

The tank layer model (a volume based approximation) that follows was derived from the Los Alamos National Laboratory Waste status and Trensaction Recozd Surmary (Agnew, 1995) and Supernatant Mixing Model (Agnew, 1995). The estimated inventaries of total waste, solids, and supernatant in Tank 241-AN-103 are also presented. Concentrated supernatant solids are considered as an integral part of the liquid for the purpose of estimating inventories, but are graphed as solids on the level histories. The actual substance, which was derived from double-shell. slurry, eppears as a solid if undisturbed, but the particles are resuspended in solution if heated or disturbed.

\subsubsection{In-Tank Photograph of Tank 241-AN-103}

The 1988 collage for Tank 241-AN-103 shows a waste surface which is typical for saltcake produced by the Hanford evaporators. The colors are off-white with areas of light yellow, and it is probably mostly composed of sodium nitrate. The tank walls and dome are rusted. Picture cuality is good and therefore the in-tank eguipment is clearly visible. This equipment has been identified and labeled for the reader. The tank contains 953,000 gallons of waste (Hanlon, 1994) which corresponds with a waste height of about 29 feet. 
WHC-SD-HK-ER-350, ReV, 0

2.3.3 Synopsis of Tank 24I-AN-103

(To be completed.) 


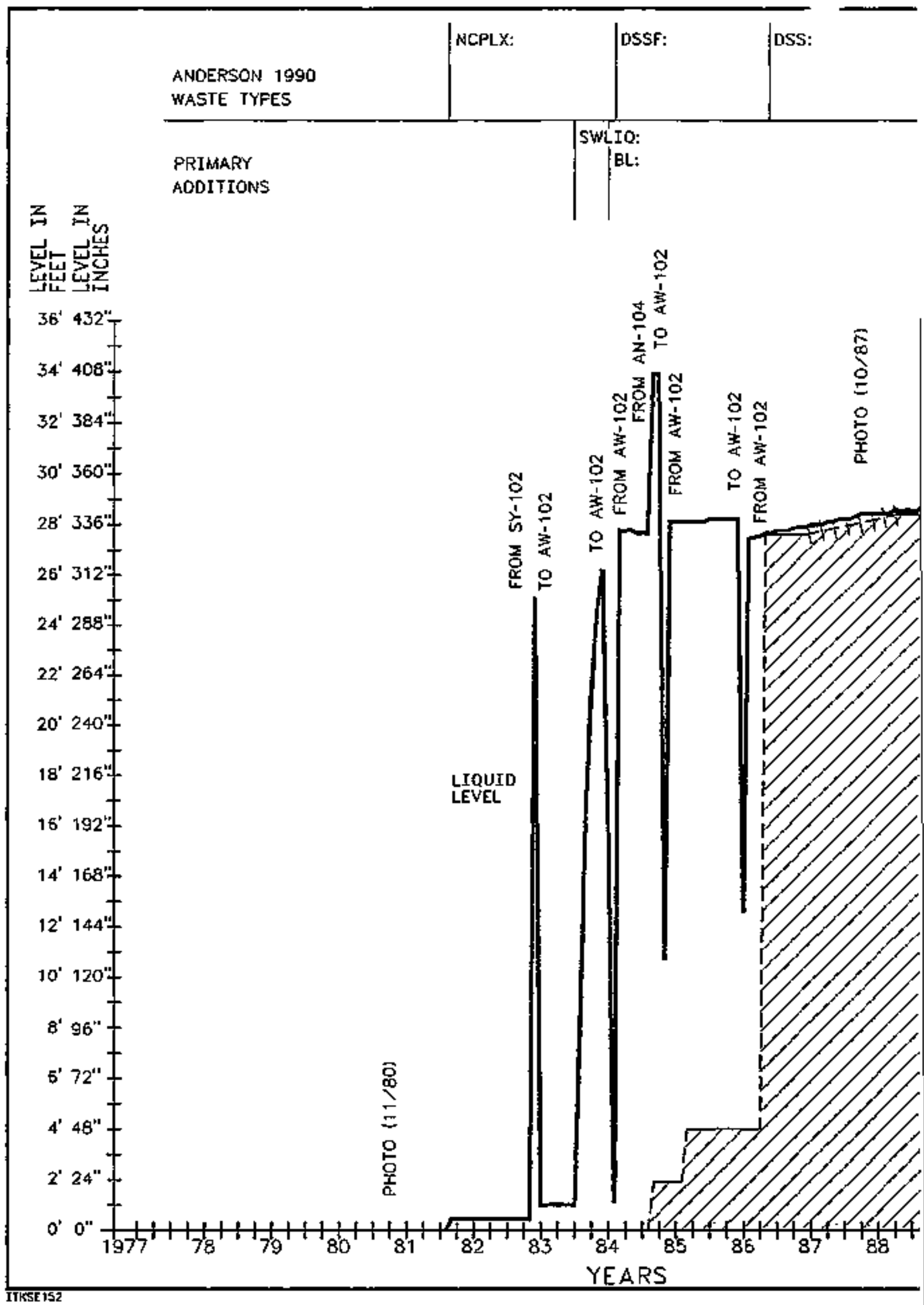


HHC-SD-WM-ER-350, Rev - 0

\begin{tabular}{|c|c|c|c|}
\hline \multicolumn{4}{|c|}{ Double-Sbell Tank 241-AN-103 } \\
\hline \multicolumn{4}{|c|}{ Tond levertory Estinasta" } \\
\hline \multicolumn{4}{|c|}{ 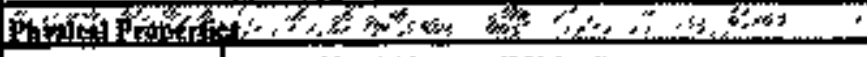 } \\
\hline & $5.66 \mathrm{E}+06 \mathrm{kp}$ & (959 keal) & \\
\hline Hesthond & \multicolumn{3}{|c|}{ 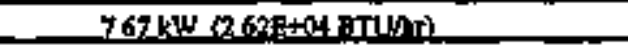 } \\
\hline Aulk Darkityt & \multicolumn{3}{|c|}{$157(0 / 00)$} \\
\hline Went wt\%t & \multicolumn{3}{|c|}{32.9} \\
\hline Tocwe C(ned) & \multicolumn{3}{|c|}{ L.45 } \\
\hline \multicolumn{4}{|c|}{ 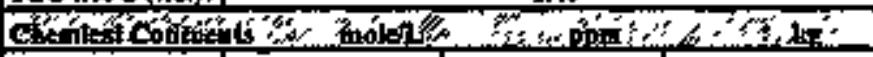 } \\
\hline $\mathrm{N}^{*}$ & $\begin{array}{r}-13,0 \\
\end{array}$ & 1.90Eस:05 & $1.08 \mathrm{E}+0.06$ \\
\hline$\Delta \mathbf{l}^{*}$ & 1.4 & 26 total & $1.500+2$ \\
\hline Fet (loded fe) & 1.34E-02: & $4 \pi$ & $2.70 \mathrm{E}+03$ \\
\hline$c_{r^{*}}$ & A.43E-102 & $147 \pm 090$. & $83+5+02$ \\
\hline Bj* & IASE-0I] & [92] & $1.09250 \mathrm{~g}$ \\
\hline $1 \mathbf{1}^{*}$ & $272 E 0.05$ & 0.72 & 452 \\
\hline 버: & 1.59E-asili & 2,04 & 11.5 \\
\hline 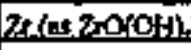 & 2.85E-49 & 171 & 970 \\
\hline $\mathrm{Pb}^{3 *}$ & $1,3450.04$ & 17.6 & 99.8 \\
\hline Nap: & 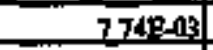 & 290 & $1648+08$ \\
\hline sti & 921E-06 & 0.519 & 29 \\
\hline $\mathrm{Mn}^{\prime \prime}$ & $1.5 ! 2-10$ & +2 & $2.98 \mathrm{e}+02$ \\
\hline$c_{a}^{2 n}$ & $6.600-02$ & $1.69 \mathrm{E}+0 \mathrm{9}$ & $9.55 \mathrm{E}+0 \mathrm{5}$ \\
\hline$K^{*}$ & 0.0 的 & 4 4. & 2690+od \\
\hline OH & 6.94 & 752E+0여 & 4,26E+0, \\
\hline Na: & sol & L29Eस & $12 \mathrm{E}+106$ \\
\hline Na: & 2.38 & $6.97 \pm+0.4$ & $3,94 E+05$ \\
\hline$\phi_{0}{ }^{2}$ & 0.701 & $2.68 \mathrm{E}+04$ & $1.52=+05$ \\
\hline po: & 0239 & $1,44 E+04$ & E. $12 \mathrm{E}+0.9$ \\
\hline SOL_ & 0.935 & $2058+04$ & $1.16 \mathrm{~F}+05$ \\
\hline 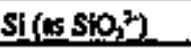 & $6.40 \mathrm{~B}-02$ & L.t.5P+03) & $6.49 \mathrm{E}+03$ \\
\hline$F$ & .0.261 & $3164+094$ & $1796+0$ \\
\hline C & 0.228 & $5,02 E+03$ & $284 E+104$ \\
\hline CH.t. & $455=0$ & $549 \mathrm{E}+0 \mathrm{n})$ & $31 \mathrm{HE} \times \mathrm{OA}$ \\
\hline EDTA & $2.000,00$ & $3.67 \mathrm{E}+09$ & 2.08E+04 \\
\hline$H A D A^{2}$ & $3,260,02$ & $569 \mathrm{E}=3$ & $322 \mathrm{~F}+\mathrm{x}$ \\
\hline elvenlete:- & 0215 & $1025=401$ & $5836+0.0$ \\
\hline acetank & 2.3aE-ODS & 895 & $\$ .06 \mathrm{E}+0 \mathrm{~g}$ \\
\hline gyanct & $3295-0,5$ & 1.5 & 104 \\
\hline $\mathrm{DBP}$ & 2.36E-02 & $2.49 E+03$ & $1,37 \mathrm{E}+0 \mathrm{~A}$ \\
\hline hutens: L L & $2.36=-091$ & {$[.12= \pm 0 ;]$} & $632=103$ \\
\hline $\mathrm{NH}+$ & 0.5921 & $5<10 \mathrm{R}+03$ & $3628+104$ \\
\hline $\mathrm{Fe}\left(\mathrm{CM}_{2}{ }^{+}\right.$ & 0 & of & \\
\hline \multicolumn{4}{|c|}{ 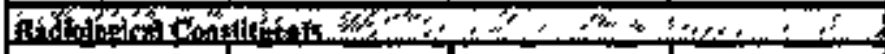 } \\
\hline Pu & & $5.1 \mathrm{BE}-02(\mu \mathrm{C})(\mathrm{r})$ & $4.84(\mathrm{~kg})$ \\
\hline$\underline{u}$ & $1.32 \mathrm{E}-02 \mathrm{M} 0$ & $200 \mathrm{E}+01$ (1) & 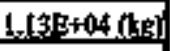 \\
\hline G. & 0.383 (Cla) & $244(\mathrm{pC}$ ) $\mathrm{s})$ & $1.38 \mathrm{E}+06(\mathrm{CD})$ \\
\hline sir & $\left.4.93 \mathrm{E}_{02}(\mathrm{CH}) \mathrm{L}\right)$ & 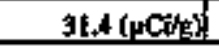 & $5.7 \mathrm{AE}+0.5(\mathrm{C})$ \\
\hline
\end{tabular}

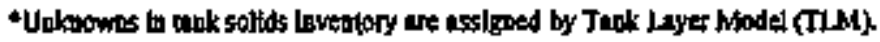

tVeluane average far tenshty, mass averige Wuter wt\% and TOC w\% C.

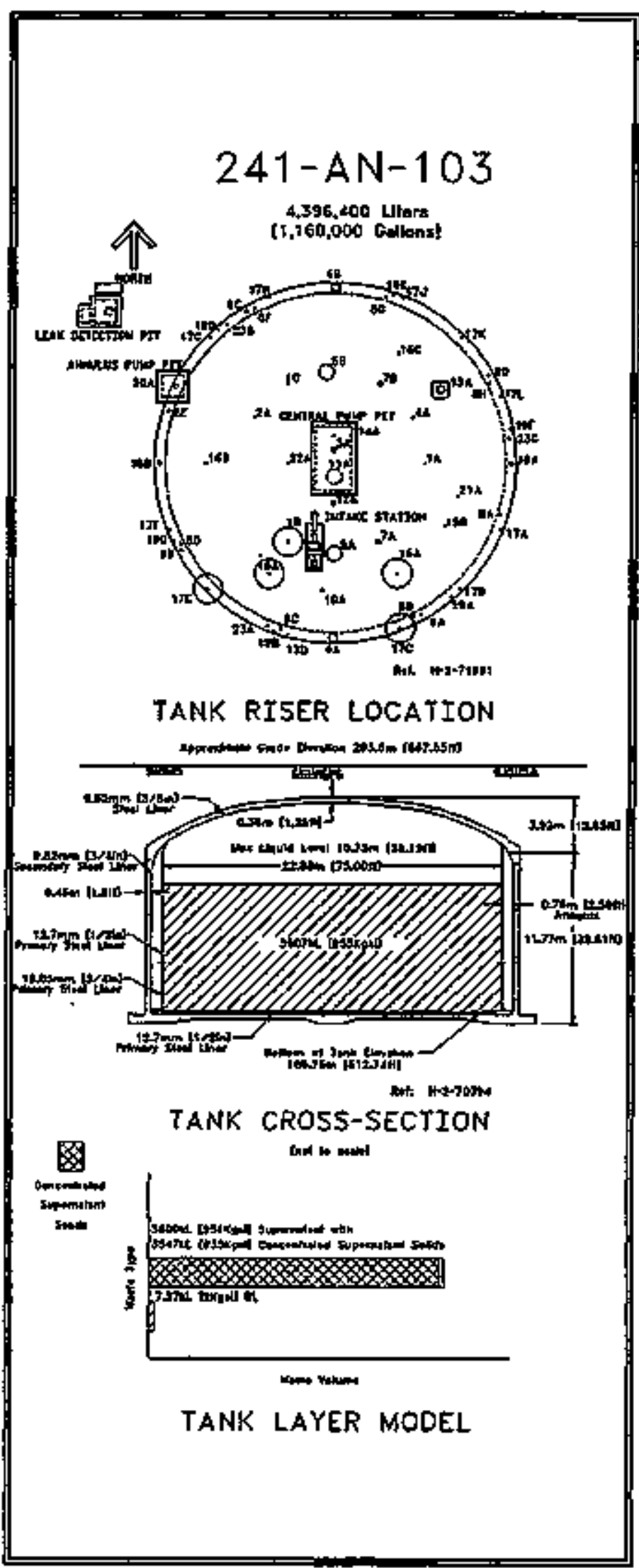




\begin{tabular}{|c|c|c|c|}
\hline \multicolumn{4}{|c|}{ Double-Shell Tank 241-AN-103 } \\
\hline \multicolumn{4}{|c|}{ 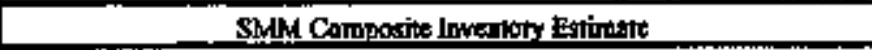 } \\
\hline 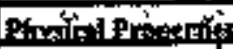 & 每 & 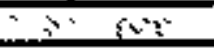 & 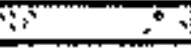 \\
\hline Toul Supernathit & $5.64 E+06 \mathrm{~kg}$ & (95I kgal) & \\
\hline Hextond & \multicolumn{3}{|c|}{706 KWY D.4IE+04 BTUAML } \\
\hline Bults Dinstry & \multicolumn{3}{|c|}{$1.57(\mathrm{r} / \mathrm{\alpha c})$} \\
\hline Wintef wot & \multicolumn{3}{|c|}{ 329 } \\
\hline TOC wrix C (w⿻1)] & \multicolumn{3}{|c|}{1.46} \\
\hline 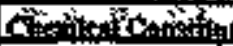 & mintentes & $n^{3} \sin x=$ & 15es \\
\hline $\mathrm{Ne}^{+}$ & 130 & $1.91 E+05$ & $1.00 \mathrm{E}+06$ \\
\hline$A I^{3+}$ & Lst & $2652+01$ & $1498+05$ \\
\hline$F^{3 *}\{$ tot:l $\mathrm{Fe}\}$ & $9.40 \mathrm{e}-0 \mathrm{z}$ & 353 & 1896409 \\
\hline C. & $44 \mathrm{E}-07$ & $\{47= \pm 03$ & 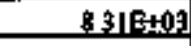 \\
\hline Bt+ & $1,44 \mathrm{E}-0 \mathrm{~J}$ & [92 & $1.002 E+03$ \\
\hline $\mathrm{LS}^{2+}$ & B 74EOG & 024 & 137 \\
\hline 뵤 $8^{2 *}$ & 1.60e-0s & 2.04 & 115 \\
\hline 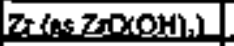 & $205 \mathrm{E}-13$ & 17 & 970 \\
\hline $\mathrm{PP}^{\mathbf{3 +}}$ & 1.34E-04 & 17.7 & 99.8 \\
\hline $\mathrm{N}^{2+2}$ & 7075-013 & 265 & $1498+08$ \\
\hline$s^{2}$ & 923E-06 & 0.516 & 2.9 \\
\hline $\sin ^{+}$ & L5ل테연 & 50 & 2. P8f +0X \\
\hline$C^{+*}$ & 65:5E-02 & $1.682+03$ & $9.49 \mathrm{~B}+03$ \\
\hline$x^{*}$ & 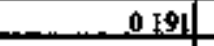 & 4765400 & $269 \mathrm{e}+46$ \\
\hline OH & 6.91 & 75eEtod & $4.23 E+05$ \\
\hline r & 50 & L98x+10s & L12E+106. \\
\hline $\mathrm{NO}_{i}$ & $23 \mathrm{~B}$ & $69 \mathrm{gE}+04$ & 3.94 E. 05 \\
\hline $\mathrm{CO}^{2-}$ & 0707 & 2605+14 & $1.54=105$ \\
\hline Po: & $0=33$ & $1,44 \mathrm{E}+04$ & s.12E+04 \\
\hline $\mathrm{SO}^{2}$ & $03 \pm 5$ & 20se+14 & 116地15 \\
\hline Si (at sio, $\left.{ }^{7}\right)$ & $6,27 \mathrm{x}-102$ & 1.129+103 & $6.34 \mathrm{E}+0 \mathrm{~s}$ \\
\hline 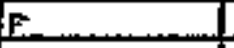 & 0261 & $3164+10$ & $179=4$ \\
\hline Cl & 0,223 & $5,03 E+0 \mathrm{~s}$ & $2.84 \mathrm{E}+04$ \\
\hline C.s.OS & $456 \mathrm{E}=12$ & 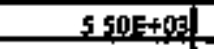 & Jlorfat \\
\hline EDTA* & $200 \mathrm{E}-0 \mathrm{~S}$ & $3.68 \mathrm{E}+0 \mathrm{~g}$ & $2085+04$ \\
\hline HEPTA ${ }^{3}$ & $326 \mathrm{E}-104$ & $571 F+09$ & $377 \sqrt{2}+0$ 션 \\
\hline slupointe" & 0.215: & Longent & $592 E+04$ \\
\hline asterte & $2.38 \mathrm{E}-0 \mathrm{2}$ & 898 & $5.965+03$ \\
\hline axhande- & 330505 & L\$5 & IAd \\
\hline DaP & $2.37 \mathrm{E}-0 \mathrm{2}$ & $243 E+03$ & 1.37E+0d \\
\hline burland & $2,37 \mathrm{P}-02$ & {$\left[: 2\left[\begin{array}{l}1 \\
1\end{array}\right]\right.$} & 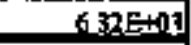 \\
\hline NH. & .0592 & 642E+10 & $36 \mathrm{~g}+\mathrm{E}+1 \mathrm{~d}$ \\
\hline Fe(CN) $)^{*}$ & a & 0 & \\
\hline 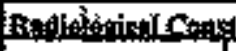 & noficis & $2: \therefore 68$ & E: $3,1,2$ \\
\hline $\mathrm{Pu}$ & $72.7(\mu \mathrm{Cil})$ & & 4.6. (kg) \\
\hline 11 & 104E-07(M) & $138 \mathrm{f}+03$ (unfar & $8932+05$ (1: \\
\hline Cr & (384) Cin) & $245(\mu \mathrm{Cu} / \mathrm{g})$ & 138E+16 (C) \\
\hline 5 & $242 \mathrm{E}-02$ (Cin) & $15.5(u \circ v)]$ & 8.73E+GA (Ci) \\
\hline
\end{tabular}

-Deasty is calculated besed on Nm, OH-, and Aloz-

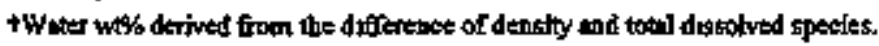

\begin{tabular}{|c|c|c|c|}
\hline \multicolumn{4}{|c|}{ Double-Shell Tenk 241-AN-103 } \\
\hline \multicolumn{4}{|c|}{ TLM Solids Compostle howewiory Estimak* } \\
\hline \multicolumn{4}{|c|}{ 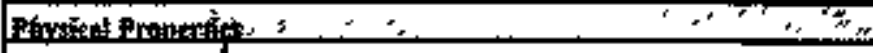 } \\
\hline Tots Solid Waste & $1,482+04 k y$ & (2k利) & \\
\hline Hentlow & \multicolumn{3}{|c|}{ 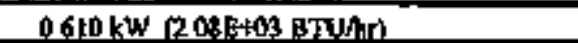 } \\
\hline Builk Bustity & \multicolumn{3}{|c|}{1.95 (p/oes) } \\
\hline Witer wf\% & \multicolumn{3}{|c|}{50.0} \\
\hline TOC wt\% & \multicolumn{3}{|c|}{0,251} \\
\hline \multicolumn{4}{|c|}{ 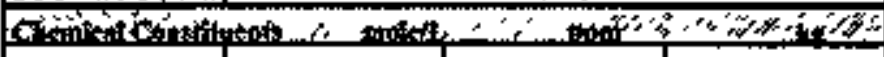 } \\
\hline $\mathrm{Na}^{*}$ & 422 & $4.975+104$ & $73:$ \\
\hline A & 200.1 & $2 \pi 0+04$ & 40 \\
\hline Fet (tolit Fe) & 1.92 & $5.496+00$ & 813 \\
\hline $\mathrm{C}_{\mathrm{s}}^{\mathrm{s}}$ & $167 E=07$ & 144E-03 & $6 \$ 58-05$ \\
\hline \multicolumn{4}{|l|}{ Be" } \\
\hline \multicolumn{4}{|l|}{ the } \\
\hline \multicolumn{4}{|l|}{ 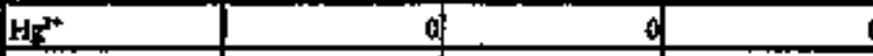 } \\
\hline \multicolumn{4}{|l|}{ 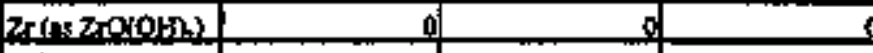 } \\
\hline \multicolumn{4}{|l|}{$\mathrm{Pb}^{*+}$} \\
\hline $\mathrm{NPH}^{*+2}$ & 0339 & $992 \mathrm{E}+0 \mathrm{3}$ & 547 \\
\hline \multicolumn{4}{|l|}{$\mathrm{s}^{*}$} \\
\hline \multicolumn{4}{|l|}{$\mathrm{Mn}^{* *}$} \\
\hline $\mathrm{Co}^{*}$ & 0.180 & $3,856+03$ & 36.9 \\
\hline \multicolumn{4}{|l|}{$\mathrm{K}^{*}$} \\
\hline OH & 20.9 & $1.02 \mathrm{E}+\mathrm{es}$ & $2.69 \mathrm{E}+03$ \\
\hline Mo: & 142 & $45 \mid 5+14$ & 667 \\
\hline NO; & 2.96E-02 & 461 & 6.82 \\
\hline $\cos ^{2}$ & 0398 & $122 \mathrm{E}+04$ & I: \\
\hline $\mathrm{PO}^{2}$ & 8.35E-03 & 405 & 6.00 \\
\hline so: & P186-02 & 45IE+02! & 66.9 \\
\hline st (as $\left.\mathrm{siO}_{1}{ }^{2}\right)$ & 0.67 & $9.70 \mathrm{E}+0 \mathrm{~S}$ & 144 \\
\hline \multicolumn{4}{|l|}{$\mathrm{F}$} \\
\hline cr & $5.37 E-02$ & $97 \mathrm{~S}$ & $\$ 4.4$ \\
\hline \multicolumn{4}{|c|}{ 125E-19 } \\
\hline \multicolumn{4}{|l|}{ EDTA } \\
\hline \multicolumn{4}{|l|}{ HADTA' } \\
\hline theoblak: & 0.67 & 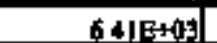 & 948 \\
\hline \multicolumn{4}{|l|}{ tectioce } \\
\hline \multicolumn{4}{|l|}{ oxaitat: } \\
\hline \multicolumn{4}{|l|}{ DeP } \\
\hline \multicolumn{4}{|l|}{ hid:데어. } \\
\hline $\mathrm{NH}_{1}$ & $370 \mathrm{E}-0$. & 3228E-12 & 176P-104 \\
\hline FacN: ${ }^{4}$ & id & 0 & \\
\hline 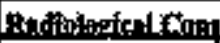 & 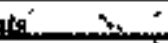 & ris & 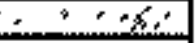 \\
\hline Eu & & $\left.\left.0.740\left(\mu C_{i}\right)_{2}\right)\right]$ & 0.183 (2) \\
\hline II & $-320 \mathrm{M}:$ & LStetos (netal & $239 \mathrm{E}+03$ (he) \\
\hline Cs & & & \\
\hline $\mathrm{Sr}$ & 120(Cill) & 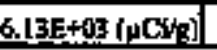 & $9.06 \mathrm{E}+04\left(C_{1}\right)$ \\
\hline
\end{tabular}

"Unknowns in taek galids imoutory aro essiged by Tank layer Model (TLM). 


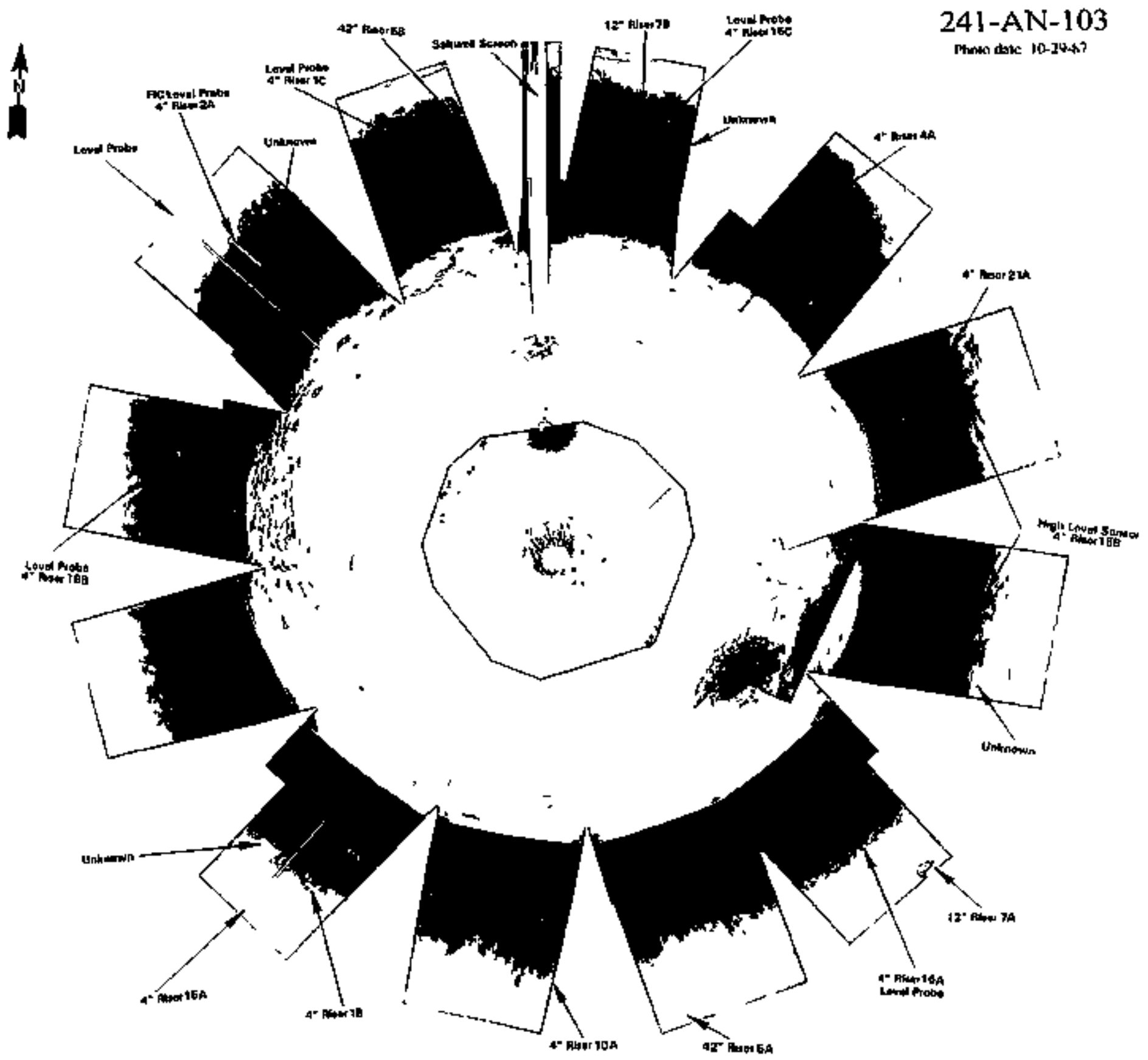


WHC-SD-WM-ER-350, Rev. 0

2.4 Tank 241-AN-104

2.4.1 241-ANN-104 Tank History

2.4.1.1 Waste History of Tank 241-AN-104

Tank 241-AN-104 began service by receiving non-complexed waste in September 1981. The majority of the waste was sent from Tank 241-AW-102 during the fourth guarter of 1982. The tank contimued to receive noncomplexed waste until November 1982. The tank has contained double-shell slury feed waste from December 1982 until the present. During the fourth cuarter of 1983, the tank also received low-level waste Erom PUREX. The tank has not received waste since the second quarter of 1985 . The slight level changes are attributed to slursy gxowth as a result of gas generation. The tank is currently inactive and is considered a concentrated waste holding tank.

\subsubsection{Temperature History of Tank 241-AN-104}

Temperature data for Tank 241-AN-107 are recorded by 18 thermocouples at known elevations on one tree inside the tank, located in riser 4A. Nonsuspect temperature data recorded between July 1983 and June 1991 for ell 18 thermocouples were available from the computer automated surveiliance system. Non-suspect temperature data taken between January 1990 and September 1993 for 12 thermocouples were available from the surveiliance analysis computer system. However, not all of the twelve thermocouples have data that enconpass the entire length of time. Within the time spans for both systems, there were several small breaks in the segueracs of temperature data. The average temperature during these periods was $91.8^{\circ} \mathrm{F}$ with a minimum of $72^{\circ} \mathrm{F}$, a maximum of $107^{\circ} \mathrm{F}$, and a standard deviation of $6.2 \%$. Iinear regressions were performed on each thermocouple that had temperature data starting from January 1990. The slopes from these regressions were averaged with a resulting average slope of 0.00483 . Refer to the supporting document for a more thorough review of the temperature date (Brevi.ck 1995).

\subsubsection{Occurrences of Tank 241-AN-104}

No unusual events are associated exclusively with Tank 241-AN-104.

\subsubsection{Psychrometrics of Tank 241-An-104}

The appazent trend of the evaporation rate from the tank has decreased from 111.4 gallons per week in December 1982 to 46.5 gallons per week in January 1995. Over that some period, the trend in the rates of heat exchange through the primary tank and annular ventilation has apparently decreased. A review of the psychrometric data in Tank 241-AN-104 would suggest an overall decrease in the rate of heat generation by the waste. 
HHC-SD-MM-ER-350, ReV. 0

2.4.2 Current Status of Tank 241-AN-104

Tank 241-AN-104 entered service in Septenter 1981 and currenty stores $1,061,000$ gallons of waste. The following plan view and tank crosssection depict the approximete waste volume of $1,058,000$ gallons and riser configurations in January 1994. At the time of the estimate, there were 1,058,000 gellons of supernatant with 264,000 gallons of concentreted supernatant solids. The waste level in the tank is measuxed with the FIC gauge and has remained at about 385 inches over the last three years. This tank is on the Hydrogen watch List and, therefore, is prohibited from receiving waste. The tank is actively ventilated and categorized as sound. Tank 241-AN-104 has 61 risers. Two 4-inch risers (no.10A and no.21A) are available for use.

\subsubsection{Inventory Estimate of Tank 241-AN-104}

The tank layer model (a volume based approximation) that follows was derived from the tos Alamos Nationel Leboratory Waste status and Transaction Record Sumary (Agrew, 1995) and Supernatant Mixing Model (Agnew, 1995). The estimated inventories of total waste, solids, and supernatant in Tank 241-AN-104 are also presented. Concentrated supernatant solids are considered as an integral part of the liquid for the purpose of estimating inventories, but are graphed as solids on the level histories. The actual substance, which was derived from double-shell slurry, appears as a solid if undisturbed, but the particles are resuspended in solution if heated or disturbed.

\subsubsection{In-Tank Photograph of Tank 241-AN-104}

The 1988 collage for this tank provides a clear picture of the tank interior. Waste surface color cennot be determined with certainty because the photographs were developed in such a way that some show the tank surface as light brown, some as grey, and some as off-white. Many tanks contein material with the off-white or light yellow color seen in some of these photographs and that appears to be the most likely color of this waste. The tark walls appear to be rusted heavily in some locations. Equipment is clearly visible. This tank contains 7 level probes, a saltwell screen, and a temperature probe which have been identified in the picture. This tank, which contains 1,057,000 gallons of waste (Hanlon, 1994), is almost filled to capacity. The waste height is about 32 feet.

\subsubsection{Synopsis of Tank 24I-AN-104}

(To be completed.) 


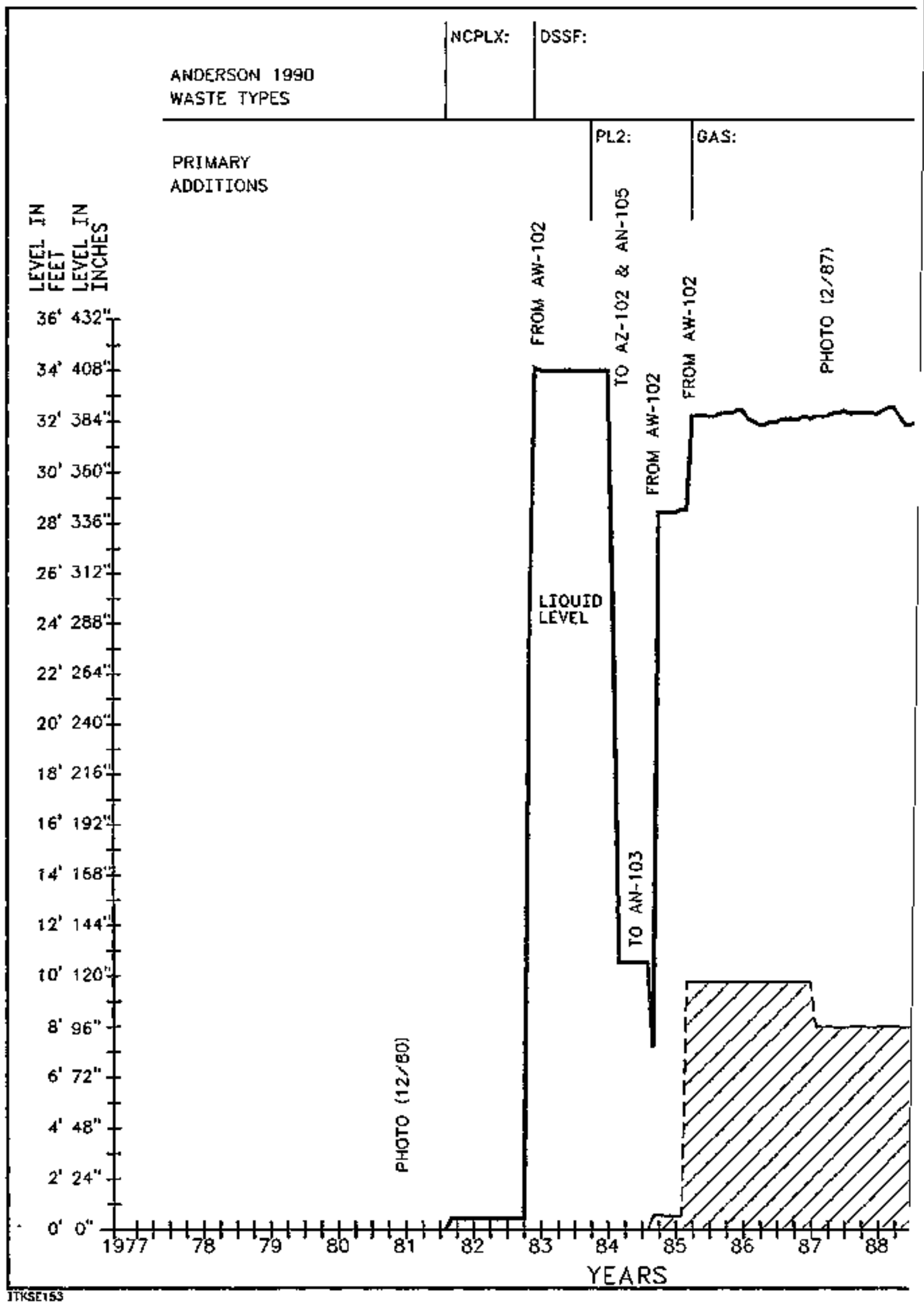




\begin{tabular}{|c|c|c|c|}
\hline \multicolumn{4}{|c|}{ Double-Shell Tank 241-AN-104 } \\
\hline \multicolumn{4}{|c|}{ 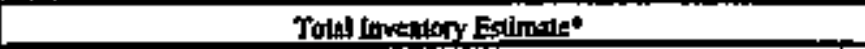 } \\
\hline \multicolumn{4}{|c|}{ 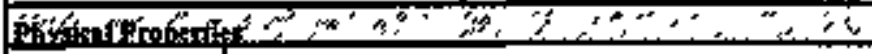 } \\
\hline Tolar Wats & \multicolumn{3}{|c|}{$5.4356406 \mathrm{~kg}_{8} \quad(1.06 \mathrm{E}+13 \mathrm{kga})$} \\
\hline Hatst Lat & \multicolumn{3}{|c|}{$516 \mathrm{fw}(1.26 \mathrm{E}+04 \mathrm{end} / \mathrm{dr}$} \\
\hline Br:lk Detralint & \multicolumn{3}{|c|}{$1.36 \mathrm{~m}$. } \\
\hline Waler unto & \multicolumn{3}{|c|}{53.9} \\
\hline Tocwoc & \multicolumn{3}{|c|}{0.919} \\
\hline \multicolumn{4}{|c|}{ 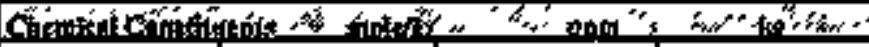 } \\
\hline sin & 7.78 & $1.32 E+05$ & $7.16 \mathrm{E}+25$ \\
\hline $\mathrm{Ap}^{\mathrm{p*}}$ & 0.965 & $1.22 E+04$ & Jofesto5 \\
\hline fet (hod fes) & 4.478-03 & 184 & $\$ 99$ \\
\hline 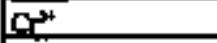 & 267 ․ㅔㄱㅛ & $1,022+03]$ & $5,55 \mathrm{E}+\mathrm{NQS}$ \\
\hline 早皮 & 2928,04 & |53]. & 830 \\
\hline L" & 6.100000 & 0,625 & 339 \\
\hline 4te & $8340-06$ & 1.23 & 6,70 \\
\hline 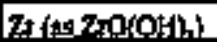 & 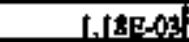 & 39,3 & 431 \\
\hline $\mathrm{Pb}^{2+}$ & $720 \mathrm{E}-0 \mathrm{~s}$ & {$[1,0$} & 59.7 \\
\hline $\mathrm{Ni}^{*}$ & 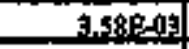 & lsts & 세 \\
\hline $\mathrm{sin}^{*+}$ & 6.45E- -6 & 0.417 & 2.26 \\
\hline Lit: & DOSE- & 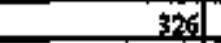 & $17 \pi+0 \%$ \\
\hline$a^{*}$ & 3.13E- -02 & 324 & $5.02 E+08$ \\
\hline$K^{*}$ & $6.51 E=02$ & $1.88+404$ & $100,+01$ \\
\hline 애 & 4,30 & $5,39 E+0,4$ & $2,99 E+0 S$ \\
\hline No: & 276 & $1.26 \mathrm{R}_{4} \mathrm{~s}$ & 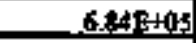 \\
\hline No: & 1.57 & $5.67 \mathrm{E}+104$ & $3,08 \mathrm{~B} 40,0 \mathrm{~s}$ \\
\hline $\mathrm{CO}^{2}$ & 0324 & $165 \mathrm{E}+2 \mathrm{QAd}$ & $8998+104$ \\
\hline $\mathrm{PO}_{i}^{*}$ & 0,136 & 9.51E+03 & $5.179+04$ \\
\hline 502 & 0212 & {$[30 \mathrm{E}+000$} & $168+01$ \\
\hline S3(as sio. & $3.800-02$ & 787 & 1.28E+03 \\
\hline Fm & ollt & $1,55 E+0,0$ & $842 \mathrm{~F}+0 \mathrm{~g}$ \\
\hline cl & 0.t3a] & $3.46 \mathrm{E}+03$ & $1.88 E+04$ \\
\hline C.HOL & 2.935 .02 & G.,08E \pm 03 & 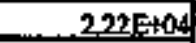 \\
\hline EDTÁ & L.435-02 & $3.04 E+03$ & $1.65 \mathrm{E}+\mathrm{0}, \mathrm{A}$ \\
\hline HRDTA. & 2,36EA & $4.77= \pm 173$ & $2596 \pm 01$ \\
\hline show & $0.1+4]$ & $6,3,3=039$ & 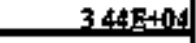 \\
\hline GeGtato & 1,60E-02 & 698 & $3.79 E-03$ \\
\hline mank12 & 7.300:-054 & 140 & 812 \\
\hline Dep & 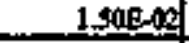 & L. $78 E+03$ & $9698+03$ \\
\hline burtand & 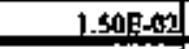 & 821 & $4469+03$ \\
\hline $\mathrm{NH}$ & Q.1F3 & $2300+00$ & $125=+0$ \\
\hline $\mathrm{Fe}(\mathrm{CN})^{4+}$ & 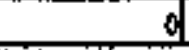 & 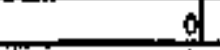 & \\
\hline 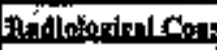 & maty 7,4 & & $5,-x, 29$ \\
\hline Ft & & $2.89 \mathrm{E}-02(\mu \mathrm{C} v \mathrm{~g})$ & $261(\mathrm{k} / 2)$ \\
\hline u & $553 E=03(M)$ & 97) (u⿰冫) & $5.285+03$ (knt) \\
\hline c. & 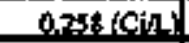 & 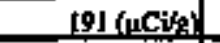 & $1.03 \mathrm{E}+06 \mathrm{CC}$ \\
\hline 5 & $1.15 E-02$ 〈CUL〉 & 8.50 ( $\mu$ C & 4.62 $\mathrm{E}+04(C \mathrm{C})$ \\
\hline
\end{tabular}

"Unknowns in tunk kalits Inverlocy we asslgead by Tank Layer Moded (TIM).

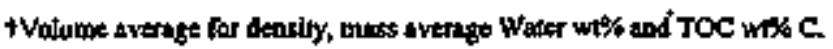

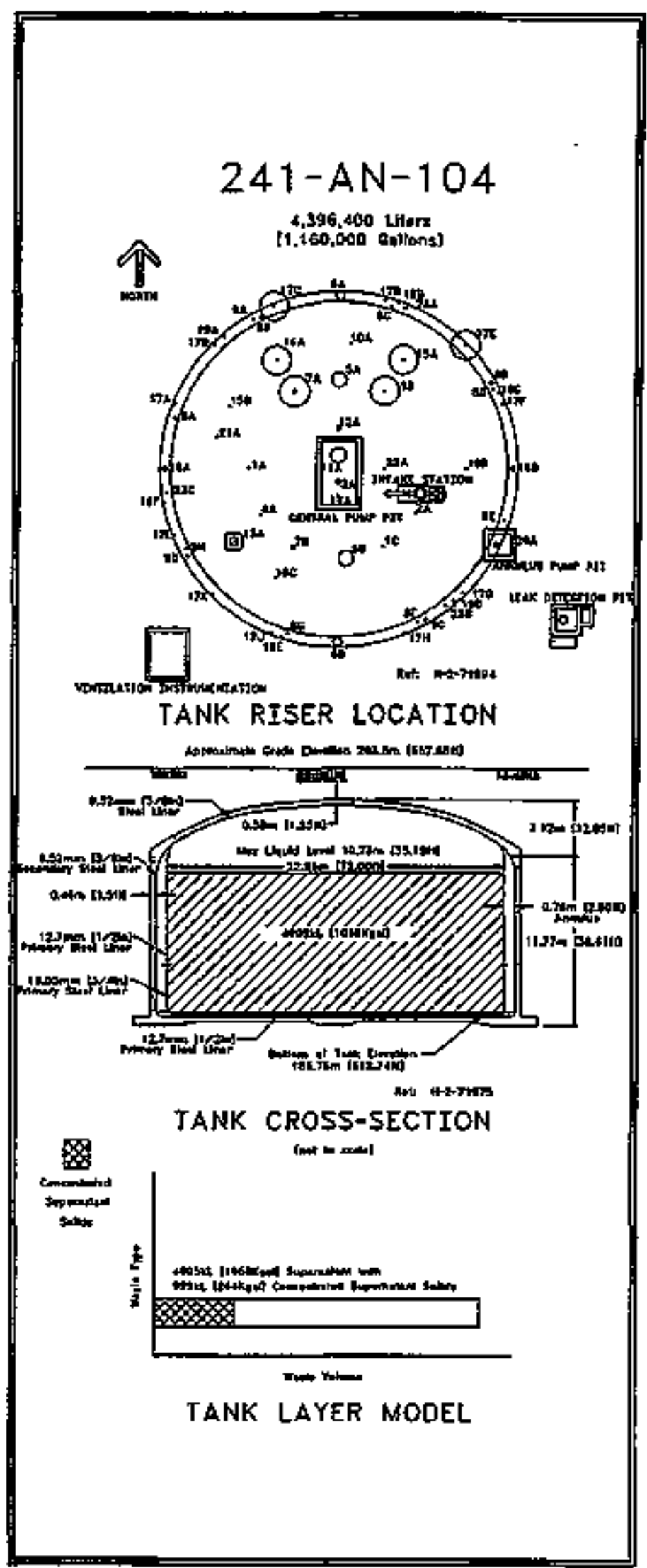




\begin{tabular}{|c|c|c|c|}
\hline \multicolumn{4}{|c|}{ Doub]e-Shell Tank 243-AN-104 } \\
\hline \multicolumn{4}{|c|}{ SMM Composive fordedory Extinate } \\
\hline 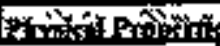 & 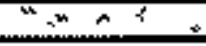 & 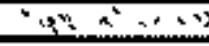 & $x^{\prime \prime}$, \\
\hline Touts Stremutant & \multicolumn{3}{|c|}{ 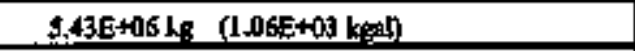 } \\
\hline Horlogad & \multicolumn{3}{|c|}{ 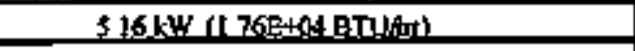 } \\
\hline Boll Desnsits & \multicolumn{3}{|c|}{ 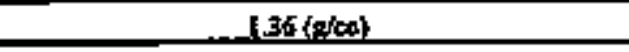 } \\
\hline Weter whot & \multicolumn{3}{|c|}{$-\$ 3.9$} \\
\hline TOC wis C (wd) & \multicolumn{3}{|c|}{0.919} \\
\hline \multicolumn{4}{|c|}{ 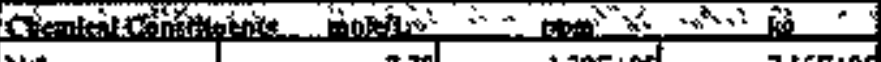 } \\
\hline 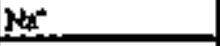 & 7.78 & $1,32 E+45$ & 7.16E+105 \\
\hline$\Delta !^{*}$ & 0965 & 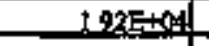 & LOAF+1) \\
\hline 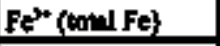 & 4.47E-6? & 184 & 998 \\
\hline C.5 & $267 \mathrm{P}-\mathrm{M}$ & [10?R+07] & $535+0 \mathrm{x}$ \\
\hline BH" & $9.92 \mathrm{~B}-0 \mathrm{~A}$ & Is: & $\mathbf{3 0}$ \\
\hline 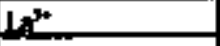 & 6 사뭉 & 0.625 & 339 \\
\hline $\mathrm{H}^{\mathrm{3}} \mathrm{S}^{3+}$ & 8345006 & $1, \mathbf{z}$ & 6.70 \\
\hline Zras $7: 0$ a) & L\&E: & 79 & 431 \\
\hline $\mathbf{P h}^{\mathbf{*}}$ & 2,20, $* 05$ & 11,0 & 59.7 \\
\hline $\mathbf{N}$ & $35 \% 5,0,3$ & 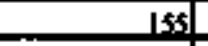 & 84 \\
\hline 5r" & 6.45E-00 & 0.417 & 2.26 \\
\hline $\sin ^{4}$ & 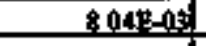 & 326 & $172 \times 403$ \\
\hline $\mathrm{Cs}^{*+}$ & 3.199-02: & .524 & $5.02 E+03$ \\
\hline$K^{*}$ & 6SIE-O2 & 1 18 & $102 \mathrm{~g}+\mathrm{ndd}$ \\
\hline OH: & $4.30^{\circ}$ & $539 \mathrm{BH}+4$ & $293 \mathrm{E}+0 \mathrm{~S}$ \\
\hline NQ: & 276 & $1268+05$ & 6워타영 \\
\hline $\mathrm{NO} ;$ & 1.67 & $5,672+0 \mathrm{~d}$ & 3.04e+00 \\
\hline $\mathrm{Co}^{2}$ & 1.374 & $1655+04$ & 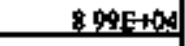 \\
\hline $\mathrm{PO}^{2}$ & 0.136 & $9 \leqslant 1 \pm 00$ & $5.17 \mathrm{E}+\mathrm{OAd}$ \\
\hline $\mathrm{SO}^{2}$ & 0212 & $1300+04$ & 816 Exy \\
\hline 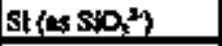 & 3.60E- 07 & 767 & $428 \theta+0 \mathrm{~g}$ \\
\hline$F$ & الليات & $155 \mathrm{~s}=09$ & 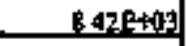 \\
\hline Cl' & 0.133 & $346 \mathrm{E}+\mathrm{ab}$ & $1.68 \mathrm{E}+0 \mathrm{4}$ \\
\hline C.sto. & $2935=00$ & $40.8 E+13$ & $222 \mathrm{~F}+0 \mathrm{a}$ \\
\hline EDTA ${ }^{*}$ & {$[.43 E, 02$} & $3.04 \mathrm{E}+03$ & 1.6SE+0d \\
\hline HẸTIA' & 7. $360=07$ & $477 E+0,5$ & 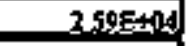 \\
\hline sluxinte: & ald & $6332+02$ & $344 \mathrm{E}+\mathrm{t}) \mathrm{d}$ \\
\hline iverile & $1,50 \mathrm{E}-0 \mathrm{2}$ & 69: & 3.79E+03 \\
\hline 0xalicted & 23010-005 & | $\mid d \varphi^{\prime}$ & 812 \\
\hline DEP & $150 \mathrm{E}-02$ & $1.78 E+03$ & $9.69 \mathrm{E}+0.5$ \\
\hline britencl & 150807 & sil & ddf $E+0 ?$ \\
\hline $\mathrm{NH}_{2}$ & (0): & $2306+009$ & 1245 \\
\hline $\mathrm{F} \in(\mathrm{C} N)_{3}{ }^{4}$ & 0 & 0 & \\
\hline 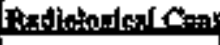 & $\tan :=z^{2}=4$ & $\sqrt{2}$ & 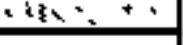 \\
\hline Pe & $39.2(\mu \mathrm{Ci} L)$ & & 261 (29) \\
\hline u & $55 \mathrm{FE}=03 \mathrm{MU}$ & 97l (uor). & $528=+0, A x=$ \\
\hline$c=$ & $0258 .(\mathrm{CH})$ & LQ] (tacjs) & 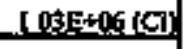 \\
\hline $\mathrm{Sr}$ & $1.15 \mathrm{E}-02$ (C) & 8.50 ( $\mu C U$ ) & $4.62 \mathrm{E}+04 \mathrm{Cii})$ \\
\hline
\end{tabular}

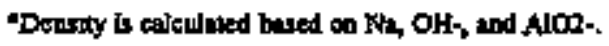

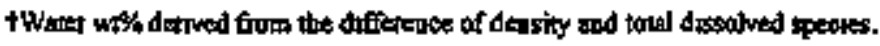

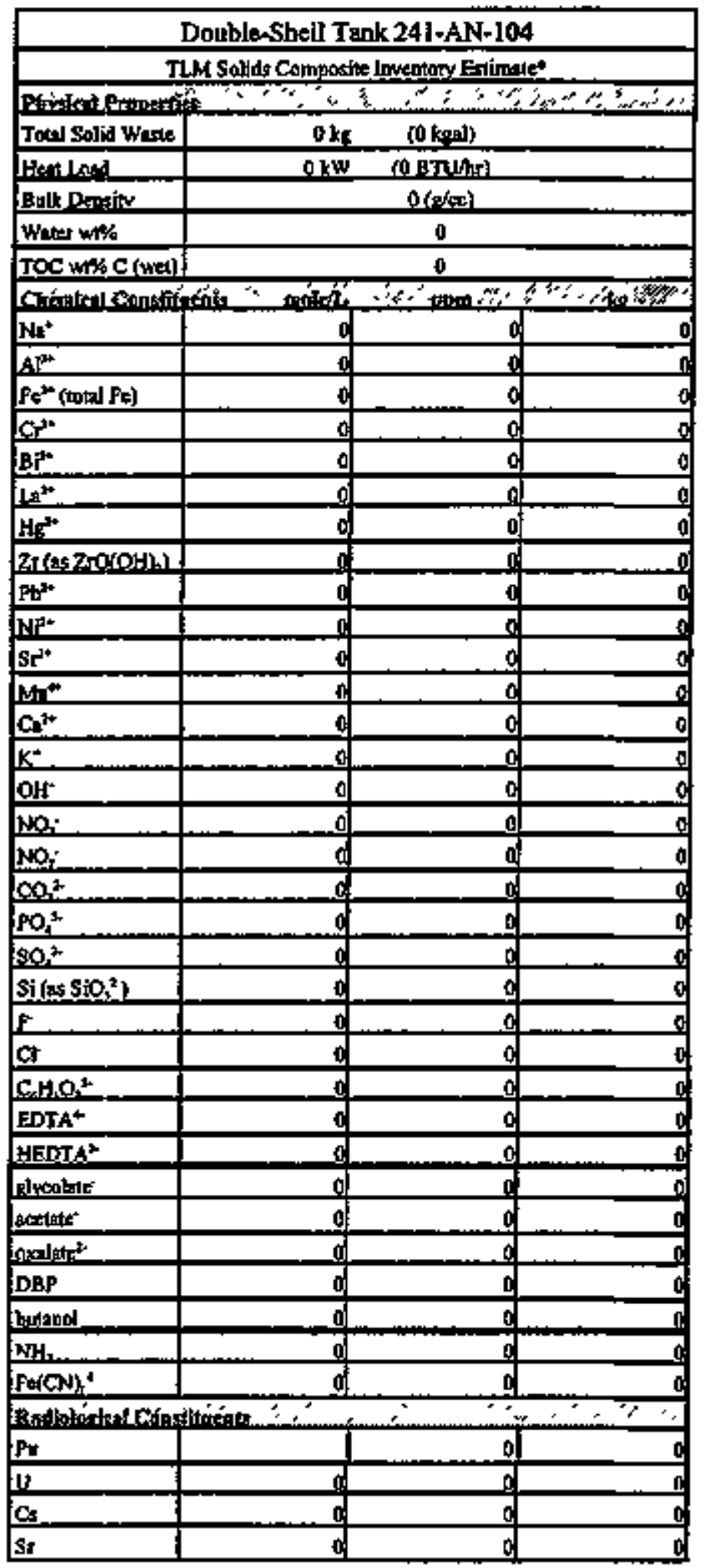

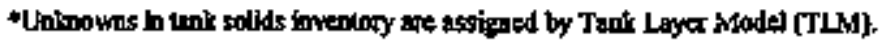

$$
\begin{array}{ll}
-56-6 / 95
\end{array}
$$




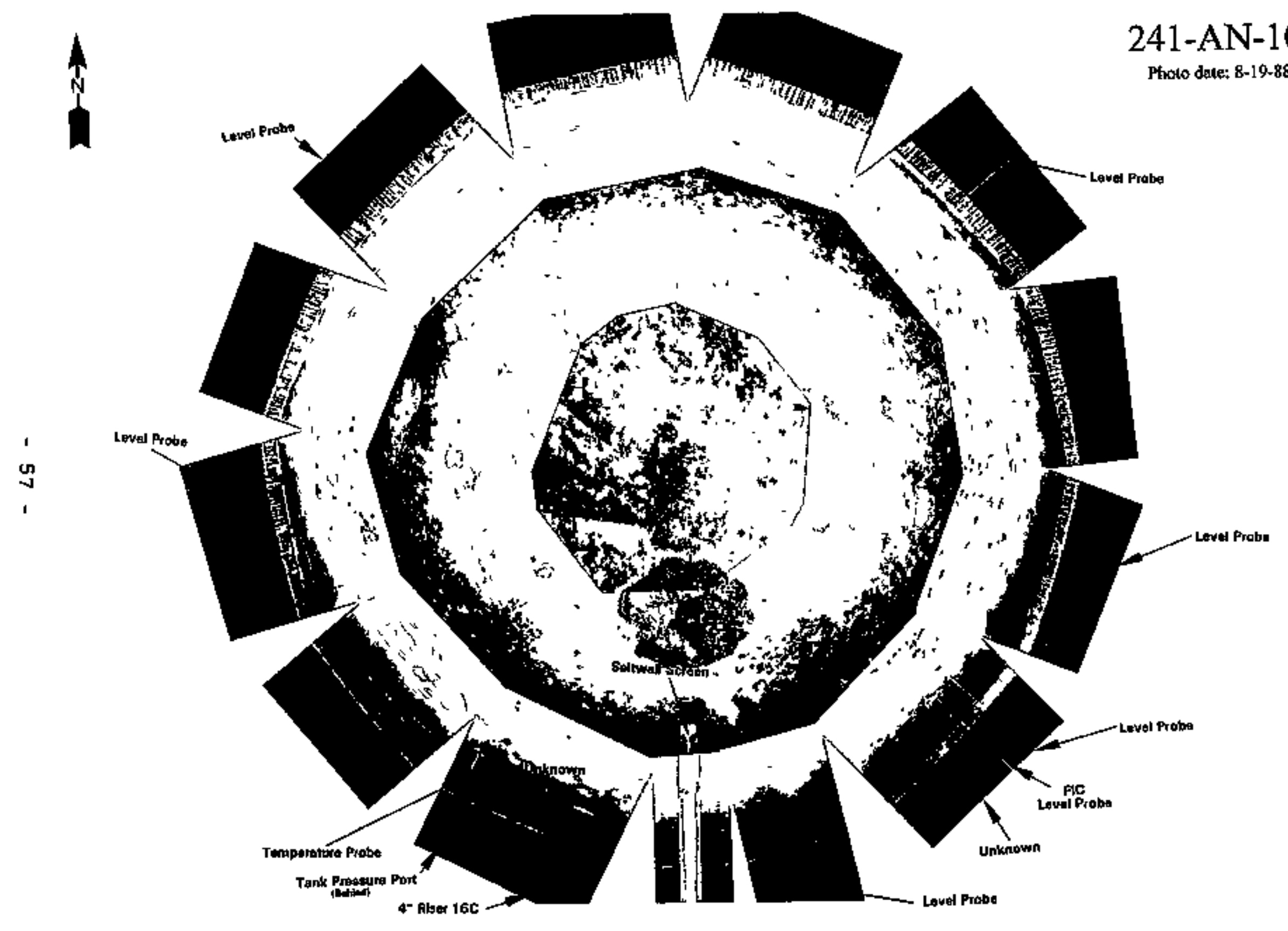

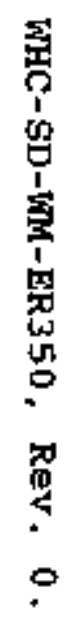




\subsection{Tank 241-AN-105}

2.5.1 241-2N-105 Tank History

2.5.1.1 Waste History of Tank 241-AN-105

Tank 241-AN-105 began service by receiving non-complexed waste in September 1981. The tank continued to receive non-complexed waste until November 1982. The tank received double-shell slurry feed waste from Tanks 241-AW-102 and 241-AN-104 from December 1982 until the second guarter of 1985, when waste reception ceased. The slight level changes are attributed to slurry growth as a result of gas generation. The tank is currently inactive and is considered a concentrated waste holding tank.

\subsubsection{Temperature History of Tank 241-AN-105}

Temperature data for Tank 241-AN-105 are recorded by 18 thermocouples at known elevations on one tree inside the tank, located in riser 4A. Nonsuspect temperature data recorded between July 1983 and June 1991 for all 18 thermocouples were available from the computer automated survetllance system. Non-suspect temperatuxe date from between January 1990 and September 1993 for six thexmocouples were avaitable from the surveillance analysis computer system. Within the time span of the computer automated surveillance system there are several small breaks in the seguence of temperature data. Within the time spen of the surveillance analysis computer system, there were no significant breaks in the sequence of temperature data. The avexage temperature duxing these periods was $96.0^{\circ} \mathrm{F}$ with a minimum of $67^{\circ} \mathrm{F}$, a maximum of $129^{\circ} \mathrm{F}$, and a standard deviation of $11.5^{\circ} \mathrm{F}$. Linear regressions were performed on each thermocouple that recorded temperature data starting from January 1990. The slopes from these regressions were averaged with a resulting average slope of 0.00097 . Refer to the supporting focument for a more thorough review of the temperature data (Brevick, 1995).

\subsubsection{Occursences of Tank 241-AN-105}

No unusual events are associated exclusively with Tank 241-AN-105.

\subsubsection{Psychrometxics of Tank 241-AN-105}

The apparent trend of the evaporation rate from the tank has decreased from 92.9 gallons per week in Eebruary 1983 to 28.9 gallons per week in January 1995. Over that same period, the trend in the rates of heat exchange through the primary tank ventilation has decreased. The annular ventilation heat exchange rate shows an increasing trend. The majority of the changes in the rate of heat exchange can be attributed to changes in the average ventilation rates. A review of the psychronetric data in Tank 241-AN-105 would suggest a constant rate of heat generation by the waste. 


$$
\text { WHC-SD-WM-ER-350, ReV. } 0
$$

\subsubsection{Current Status of Tank 241-AN-105}

Tank 241-AN-105 entered service in September 1981 and currently stores 1,131,000 gallons of waste. The following plen view and tank cross section depict the approximate waste volume of $1,131.000$ gallons and riser configurations as of Jenuary 1994. At the time of the estimate, all $1,131,000$ gallons were supernatant. The waste level in the tank is measured with the FIC and has remained at about 410 inches over the last three years. This tank is on the Hydrogen watch list and, therefore, is prohibited from receiving waste. The tank is actively ventilated and categorized as sound. Tank 241-AN-105 has 61 risers. Two 4-inch risers (no.10A and no.21A) and one 12-inch riser (no.7B) are available for use.

\subsubsection{Invertory Estimate of Tank 241-AN-105}

The tank layer model (a volume based approximation) that follows was derived from the Los Alamos National Laboratory Waste status and Transaction Record Summary (Agnew 1995) and Supernatant Mixing Model (Agnew 1995). The estimbted invertories of total waste, solids, and supernatant in Tank 241-AN-105 are also pxesented.

\subsubsection{In-Tank Photograph of Tank 24I-AN-105}

The 1988 collage for Tank 241-AN-105 shows a waste surface which its typical for saltcake produced by the Hanford evaporators. The colors are off-white with axeas of light yellow and it is probably mostly composed of sodium nitrate. The tank walls and dome are rusted. The picture quality is good and equipment is easily seen. The ecruipment has been identified and labeled for the reader. This tank, which contains 1, 131,000 gallons of waste (Hanlon 1994), is almost filled to capacity. The height of the waste is about 34 feet.

2.5 .3 Synopsis Tank of Tank 241-AN-105

(To be completed.) 


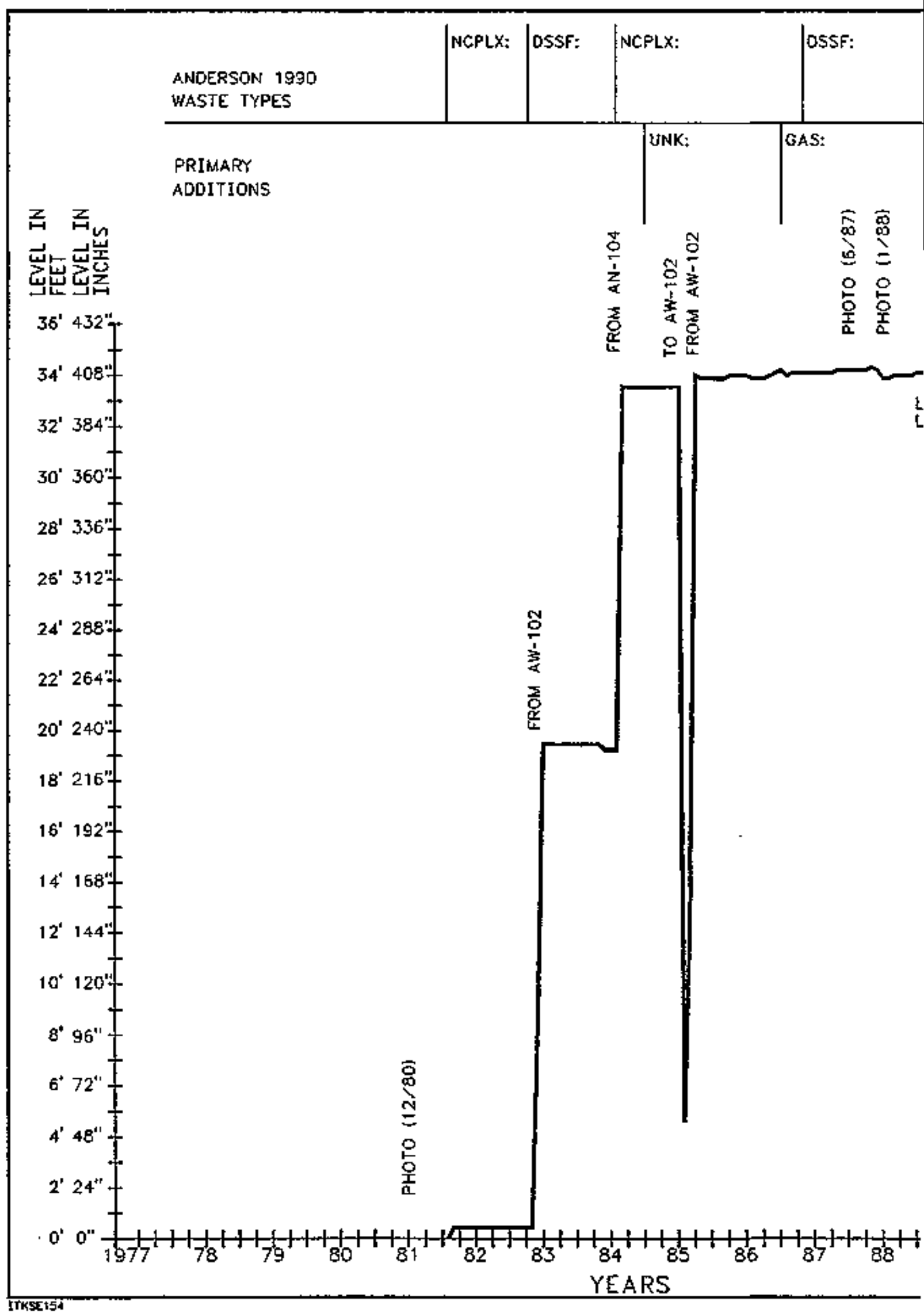


WHC-SD-WM-ER-350, Rev, 0

\begin{tabular}{|c|c|c|c|}
\hline \multicolumn{4}{|c|}{ Double-ShelI Tank 24l-AN-105 } \\
\hline \multicolumn{4}{|c|}{ 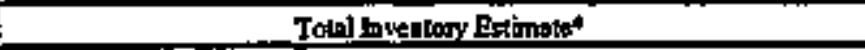 } \\
\hline \multicolumn{4}{|c|}{ 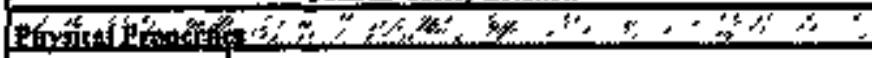 } \\
\hline Tomal Wistc & \multicolumn{3}{|c|}{$6.17 \mathrm{E}+0.6 \mathrm{~kg} \quad(1.13 \mathrm{E}+03 \mathrm{~kg}, \mathrm{~g})$} \\
\hline Higalines & \multicolumn{3}{|c|}{ 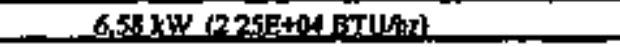 } \\
\hline Bull:Densint & \multicolumn{3}{|c|}{$1,44(0 / 50)$} \\
\hline Water wots. & \multicolumn{3}{|c|}{46.6} \\
\hline TOC wroc & \multicolumn{3}{|c|}{1.14} \\
\hline \multicolumn{4}{|c|}{$20 \sin 20$} \\
\hline & 9.57 & 1.53 E+0.5 & $9.42 \mathrm{E}+0.5$ \\
\hline$B I^{*}$ & 178 & 2298+0at & LAite+os \\
\hline Ft" (total Fe & 4.97E-0. & 193 & $1.19 E+03$ \\
\hline$C_{C}$ & 309502 & ILLE+103 & $658= \pm 03$ \\
\hline$\theta^{*+}$ & $1.275 \times 103$ & 184 & 1.13E+03 \\
\hline $1 x^{*}$ & $7498-06$ & (0)16 & $44 ?$ \\
\hline $\mathrm{Hg}^{3}$ & $8.68=0.06$ & 1.21 & 7.46 \\
\hline 2rins 20 orotll) & {$[0, E=-0 ;$} & 692 & 422 \\
\hline $\mathrm{Pb}^{3 *} \mathbf{2}$ & 928E-05 & 13.3. & 82.3 \\
\hline $\mathrm{NI}^{* *}$ & 4. $4 E-18$ & 669 & 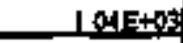 \\
\hline st" & 7.85E-46: & 0.477 & 2.98 \\
\hline $\mathrm{Mn}^{4+}$ & 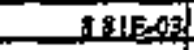 & 329 & $2.07 E+09$ \\
\hline $\mathrm{Cs}^{* *}$ & $3.485,-02$ & 968 & $5.97 \mathrm{E}+03$ \\
\hline $\mathbf{K}^{*}$ & $5,34 \mathrm{E}-0 \mathrm{0}$ & 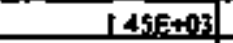 & \& $94 \mathrm{AE}+0 \mathrm{~F}$ \\
\hline $\mathrm{OH}$ & 5.42 & $6.39 B^{2}+04$ & $3.948+05$ \\
\hline $\mathrm{kH}=$ & 342 & $1478+05$ & $2058+105$ \\
\hline N: & $2,0.5$ & 6SAE+0N & $4,04 E+0,5$ \\
\hline $\cos ^{2}$ & 0,450 & $187 \mathrm{E} \pm 91$ & 1) $16 \mathrm{E}+05$ \\
\hline $\mathrm{FO}_{4}^{2}$ & 0,147 & $9.695+0.93$ & 5,906E+104 \\
\hline so. & 0265 & $176=+4$ & $209 \mathrm{~F}+1015$ \\
\hline Si (L Sig, & A.67E-02 & 910 & $5.61 \mathrm{E}+05$ \\
\hline$F$ & 0.112 & $1472+69$ & 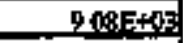 \\
\hline cr & 0,165 & 40:5e+03: & $2.52 \mathrm{E}+04$ \\
\hline CHAS & $3,68 E_{-0} 02$ & $485+0.03$ & $298=+00$ \\
\hline EDTA & 1.74E-0.9 & $3,472+03$ & $2.14 E+04$ \\
\hline HEDTA ${ }^{2}$ & $2759-002$ & $5270 \div 23$ & $325=200$ \\
\hline dueshates & olet & $763^{2}+00^{3}$ & $470=404$ \\
\hline 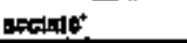 & $22 \leqslant 5-62$ & 922 & $5.695+03$ \\
\hline malantex & $2 \mathrm{~g} 0=0 \mathrm{~s}$ & 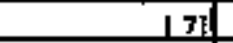 & 106 \\
\hline ses & $1.919-02$ & $2.13 c+03$ & $1,32 E+04$ \\
\hline hylunal & $191 \mathrm{IE}-02$ & 9821 & $6068+03$ \\
\hline NH. & $0 \perp 34$ & $158=+031$ & $978 \mathrm{E}+10 \mathrm{j}$ \\
\hline $\mathrm{F} \alpha\left(\mathrm{C} N \mathrm{~N}_{\mathrm{H}}{ }^{4}\right.$ & & - & \\
\hline 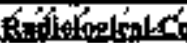 & 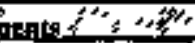 & 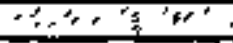 & \\
\hline Pa & & $3.26 \mathrm{E}-02<\mathrm{aCU} / \mathrm{g}$ & 3.15 (kst) \\
\hline u & 638E-03 OMV & 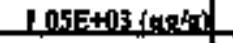 & $6508+030.10$ \\
\hline$C_{-}$ & 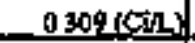 & 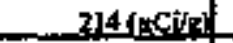 & $1328+06(C)$ \\
\hline$\underline{\text { s. }}$ & 1.34E-12 (C), & $9.26(\mu \mathrm{C} \mu \mathrm{g})$ & $5,72 \mathrm{E}+04(\mathrm{CO})$ \\
\hline
\end{tabular}

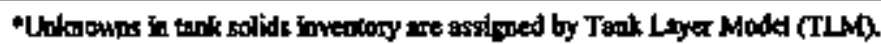

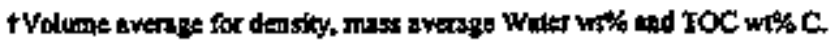

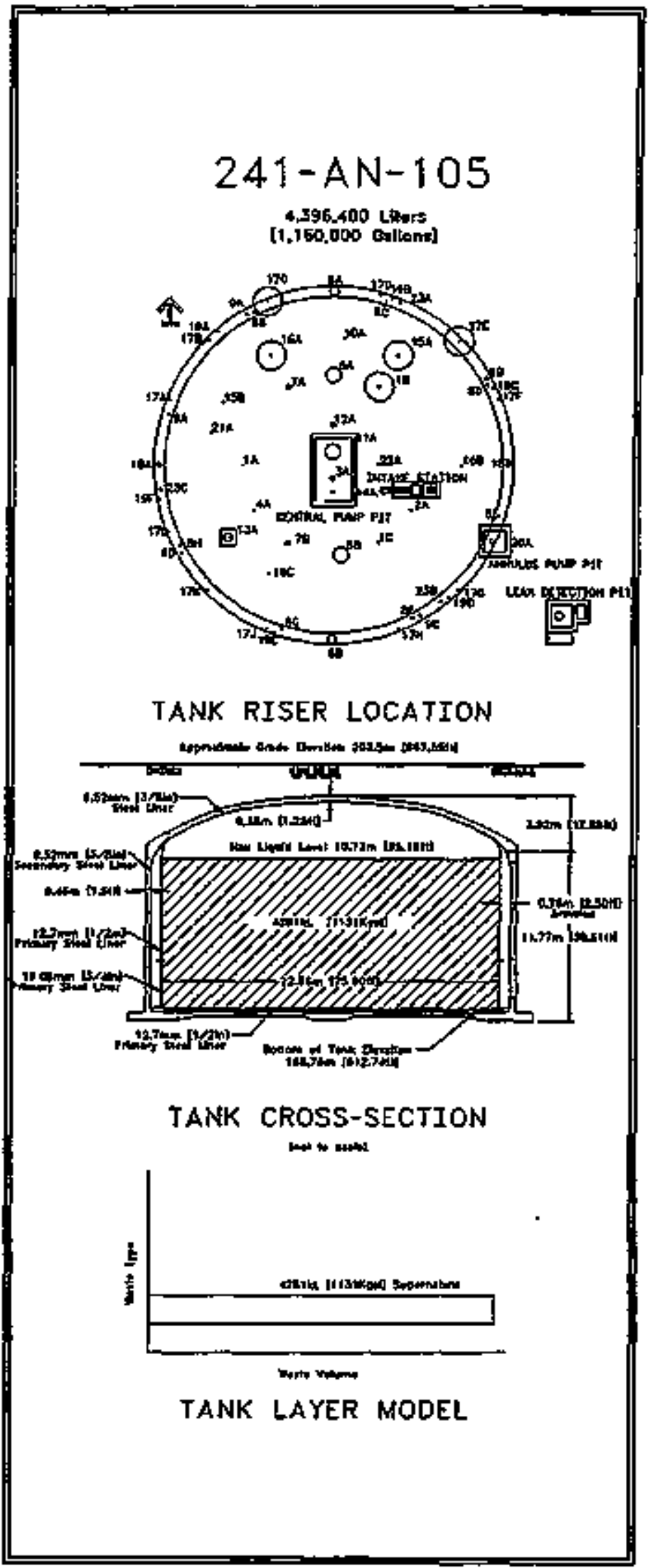




\begin{tabular}{|c|c|c|c|}
\hline \multicolumn{4}{|c|}{ Double-Sheil T2nk 241-AN+105 } \\
\hline \multicolumn{4}{|c|}{ 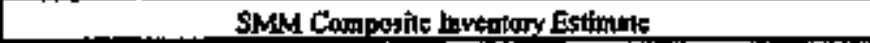 } \\
\hline \multicolumn{4}{|c|}{ 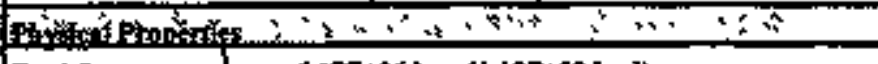 } \\
\hline Iotal Superritan & \multicolumn{3}{|c|}{$6 \mathrm{~J} 7 \mathrm{E}+\mathrm{06}(\mathrm{Lg} \quad(1.13 \mathrm{E}+03 \mathrm{xg} \mathrm{e})$} \\
\hline Hetlong & \multicolumn{3}{|c|}{ 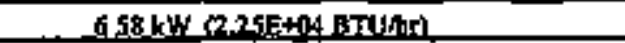 } \\
\hline Bill. Denstr. & \multicolumn{3}{|c|}{ J $44(g / g)$} \\
\hline W/ate wrot & \multicolumn{3}{|c|}{46,6} \\
\hline TOC wt: $C$ (w: & \multicolumn{3}{|c|}{214} \\
\hline 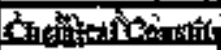 & Asiondson & in $x$ gnments & Wis ing \\
\hline $\mathbf{N a}^{*}$ & 9.57 & $1.55 \mathrm{E}+0 \mathrm{~s}$ & $9,42 \mathrm{E}+0.5$ \\
\hline Al & 12 & $279=+04$ & L4IF+09 \\
\hline Fe" (totel Fe) & 4.97E-05: & 193] & $1.19 \mathrm{E}+0 \mathrm{O}$ \\
\hline $\mathrm{C}^{2}$ & 3095019 & L2E+103 & 6.BSE 409 \\
\hline BP" & 127E-05: & 184 & $1,13 E+133$ \\
\hline Lent & $7429=0$ & 076 & 142 \\
\hline H: & $8.68 E-06$ & 1.21 & 7,46 \\
\hline 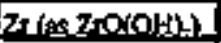 & LOSEAng & 69.21 & sh \\
\hline $\mathrm{Pb}^{\mathrm{m}}$ & 92:E-05: & 13.3 & 82.3 \\
\hline $\mathrm{NP}^{*}$ & 4]4E-AB & 1691 & $104 E+0 ;$ \\
\hline$S^{*+2}$ & 7.85E-06 & 0.47 & 2.95 \\
\hline $\mathrm{Mts}^{* *}$ & 8.JE-0. & 3.36 & $2070+09$ \\
\hline $\mathrm{Cr}^{2}$ & 3.48E-02 & 968 & $5.97 \mathrm{E}+09$ \\
\hline $\mathbf{K}^{*}$ & $534 E_{2}=2$ & $14 S E=693$ & 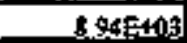 \\
\hline 아: & 5.42 & $6.39 E+04$ & 3.94E+0S \\
\hline No: & 342 & $\mid 477= \pm 0.5$ & Q00BE+05 \\
\hline $\mathrm{NO}$ & 2.05 & $6.54 E+04$ & $4.04 \mathrm{E}+05$ \\
\hline C오, & 0.450 & $1878+04$ & $\overline{116 \mathrm{E}+05}$ \\
\hline $\mathrm{PO}_{1}^{2}$ & 0.147 & $9692+03$ & $3.98 \mathrm{~B}+04$ \\
\hline SOs & 026 & $176+04$ & $109 \mathrm{E}+0.5$ \\
\hline$S \div\left(\Delta S^{2} O^{2}\right)$ & 4.670 .02 & 910 & $5.6 \mathrm{IE}+103$ \\
\hline$F$ & 017 & $147+2+0$ & $2083+0$ \\
\hline a & 0.166 & $4.08 \mathrm{~g} 5+03$ & $252 \mathrm{E}+04$ \\
\hline $\mathrm{CH}_{\mathrm{H}} \mathrm{O}^{2}$ & 36fe-0? & $48 \mathrm{~A} E+0 \mathrm{~A}$ & 2985+04 \\
\hline EDTHA & $1.74 \mathrm{E}-02$ & $3.4 \sqrt{2}+09$ & 2.14E+64 \\
\hline HEDTA & $277=001$ & $527 E+07]$ & $3255+04$ \\
\hline 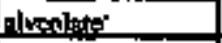 & 0.44 & $762 \mathrm{E}+019$ & 4 4 \\
\hline Acetuk: & 225E-02 & 9 & $5.69 E+03$ \\
\hline bexalonts" & 2 , 0 DE- & 1기 & los \\
\hline$D B P$ & 1.StE-02 & $2.13 E+03$ & $1.32=04$ \\
\hline bented & $191=01$ & 889 & $606 \mathrm{E}+13$ \\
\hline $\mathrm{NH}$ & 0130 & 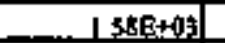 & $\Rightarrow 78$ \\
\hline $\mathrm{FoCON}{ }^{+}$ & a] & 0 & \\
\hline 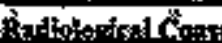 & $\because \because$ & 80 & soint \\
\hline$P_{u}$ & 469 ( & & $3,35(\mathrm{~kg})$ \\
\hline 11 & $638 \mathrm{E}-03 \mathrm{MN}$ & $105=03$ (unde) & $650 \mathrm{E}+103(1,0)$ \\
\hline$c_{s}$ & $0.3096 C_{1} / 2$ & 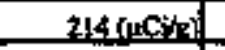 & $1378+06<C_{3}$ \\
\hline sr & 1.34E-02 (CIN) & $926(\mu \mathrm{C}) \mathrm{N}(\mathrm{O})$ & $5.72=04(C)$ \\
\hline
\end{tabular}

-Density bo calculuted based on Na, OH-, atod $\mathrm{AVO}$.

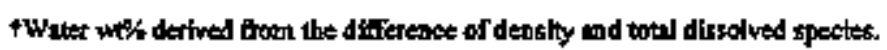

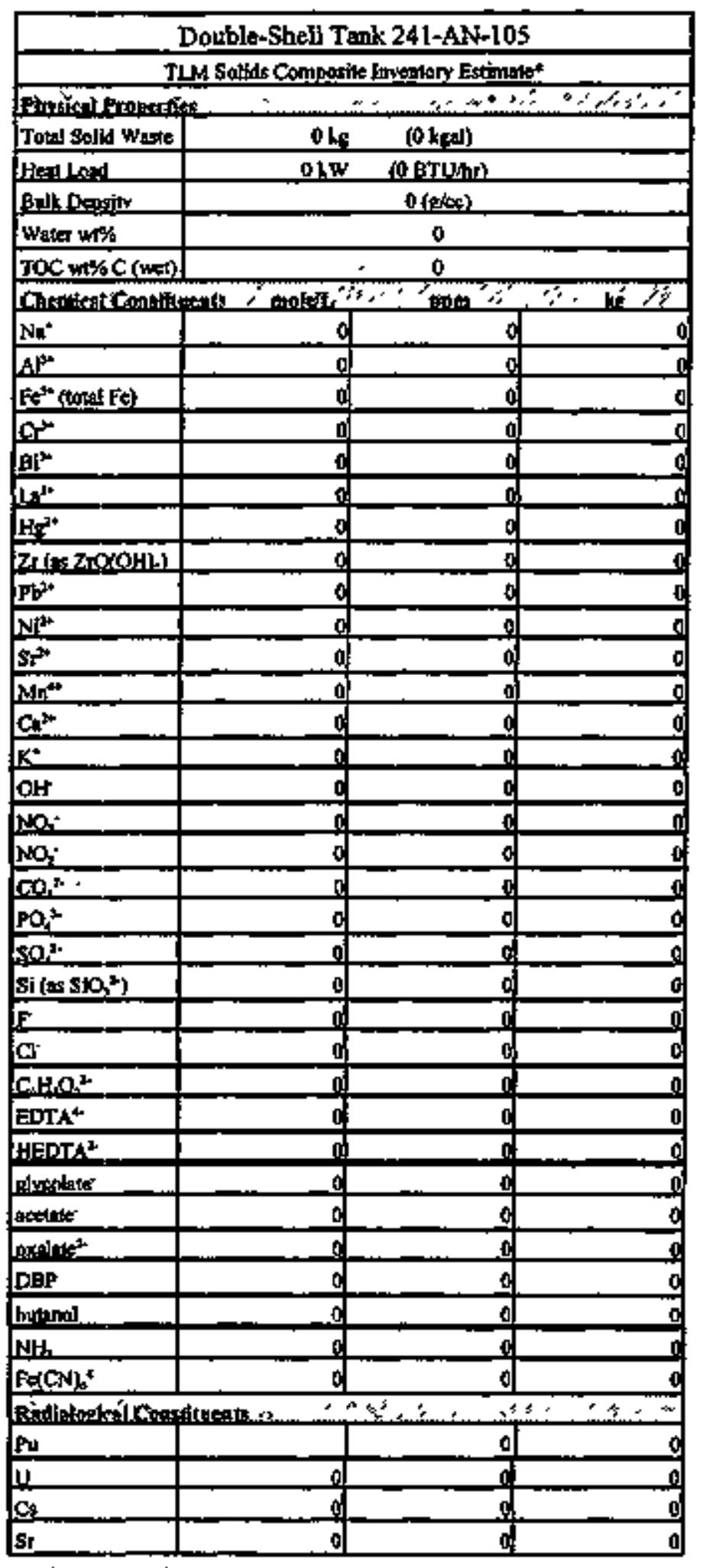

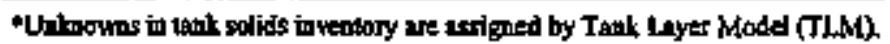




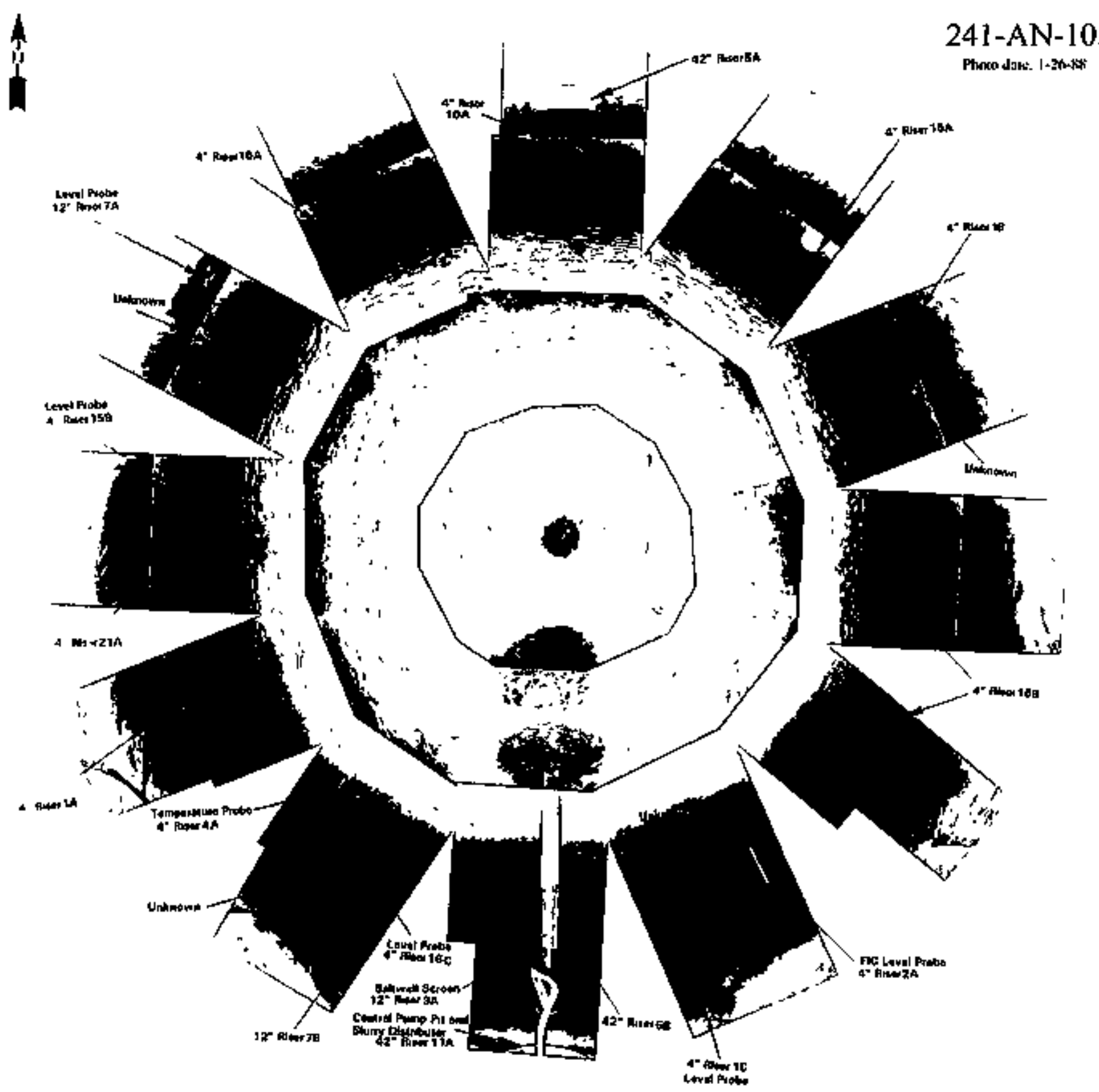


2.6 Tank 241-AN-106

2.6.1 241-AN-106 Tank History

2.6.1.1 Waste History of Tank 241-AN-106

Tank 241-AN-106 began service by receiving non-complexed waste in September 1981. The tank continued to receive non-complexed waste until Januazy 1983. From February 1983 until February 1984, the tank roceived concentrated custorner waste. The tank contained Hanford facility waste from Harch 1984 until May 1990. From June 1990 until the present, the waste contained in the tank has been designated as phosphate waste. The tank has not received any waste, other than wash water, since the third guarter of 1984. The supernatant was pumped to pank 241-AP-102 chring the second and third quarters of 1992. The tank is currently inactive and is considered a concentrated waste holding tank.

\subsubsection{Tenqerature History of Tank 241-AN-106}

Temperature data for Tank 241-AN-106 are recorded by 18 thermocouples at known elevations on one thermocouple tree inside the tank, located in riser 4A. Non-suspect tempertwre dets taken between July 1983 and June 1991 for all 18 thermocouples were available from the computer automated surveillance system. However, fot all of the 18 thermocouples have data that encompass the entire length of time. Non-suspect temperature data from between January 1990 and September 1993 for 12 thermocouples were available from the surveiliance analysis computer systen. Not all of the 12 theraocouples have data that encompass the entire length of time. Within the time spans for both systens, there were several small breaks in the sequence of temperature data. The average temperature during these pexiods wes $72.4^{\circ} \mathrm{F}$ with a minimum of $60^{\circ} \mathrm{F}$, a maximum of $113^{\circ} \mathrm{F}$, and a standard teviation of $5.5^{\circ} \mathrm{g}$. Linear regressiors were performed on each thermocouple that had temperature data starting from Jaruary 1990. The slopes from these regressions were averaged with a resulting average slope of 0.00041 . Refer to the supporting document for a more thorough review of the temperature date (Brevick, 1995).

2.6.1.3 Occurrences of Tank 241-AN-106

No unusual events are associated exclusively with Tank 241-AN-106.

\subsubsection{Psychrometrics of Tank 241-AN-106}

The apparent trend of the evaporation rate from the tank has decreased from 110.7 gallons per week in .February 1983 to 103.8 gallons per week in January 1995. Over that same period, the trend in the rates of heat exchange through the primary tank ventilation has remained nearly constant. The rates of heat exchange in the annular ventilation show a decreasing trend. The majority of the changes in the rates of heat exchange can be attributed to changes in the average ventilation rates. A review of the psychrometric data in Tank 241-AN-106 would suggest a decrease in the rate of heat generation by the waste. 
WHC-SD-WM-ER-350, Rev. 0

\section{6 .2 Current Status of Tank 241- XN-106}

Tank 241-AN-106 entered service in September 1981 and currently stores 420,000 gallons of waste. The following plan view and tank cross-section depict the approximate waste volume of 21,000 gallons and riser configurations in January 1994. At the time of the estimate, there were 21,000 gallons of supermatant with 17,000 gallons of concentrated supernatant solids. The weste level in the tank is measured with the FIC and has decreased from about 370 inches in January 1991 to 10 inches in Jenuary 3994, and then increased to 153 inches in september 1994. The cecrease was mostly from waste sent to Tank 241-Ap-102 between November 1992 and December 1992. The increase was due to a transfer Erom Tank 241-AW-106 in September 1994. This tank is inactive at the present time. The tank is actively ventilated and categorized as sound. Tank 241-AN-106 has 61 risers. Two 4-inch risers (no.10A and no.21A) and one 12-inch riser (no.7A) are available for use.

\subsubsection{Inventory Estimate of Tark 241-AN̈-106}

The tank layer model (a volume based approximation) that follows was derived from the Los Alamos National Laboratory Waste status and Transaction Record summary (Agnew 1995) and Supernatant Mixing Model (Agnew 1995). The estimated inventories of total waste, solids, and supernatant in Tank 24I-AN-106 are also presented. Concentrated stzpernatant solids are considered as an integral part of the liquid for the purpose of estinating inventories, but are graphed as solids on the level bistories. The actual substance, which was derived from double-shell slurry, appears as a solid if undisturbed, but the particles are resuspended in solution if heated or aisturbed.

\subsubsection{In-Tank Photograph of Tank 241-AN-106}

No in-tank photographs are available.

2.6.3 Synopsis of Tank 241-AN-106

(To be completed.) 


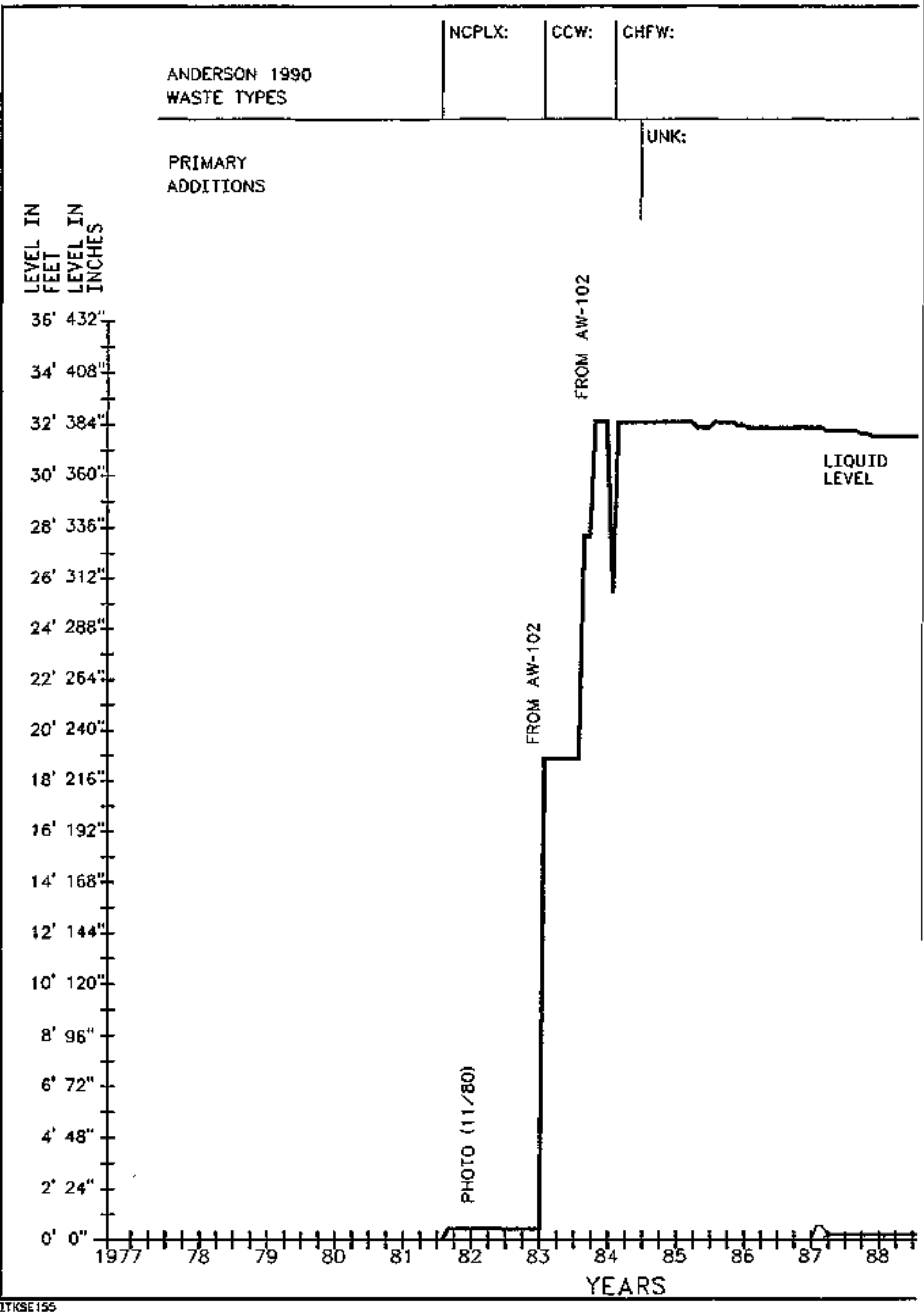


NOTES:

CONSTRUCT 1980-1981

NOMINAL CAPACITY: $1,000,000 \mathrm{GAL}$ FAT BOTTOM TANK, NÓ KNUCKLE. 75 FOOT DIAMETER DOUBLE-SHELE TANK SURFACE LEVEL REAOING: FHOTO

(LIOUIOS \& SOLIOS). FIC (SOLIOS)

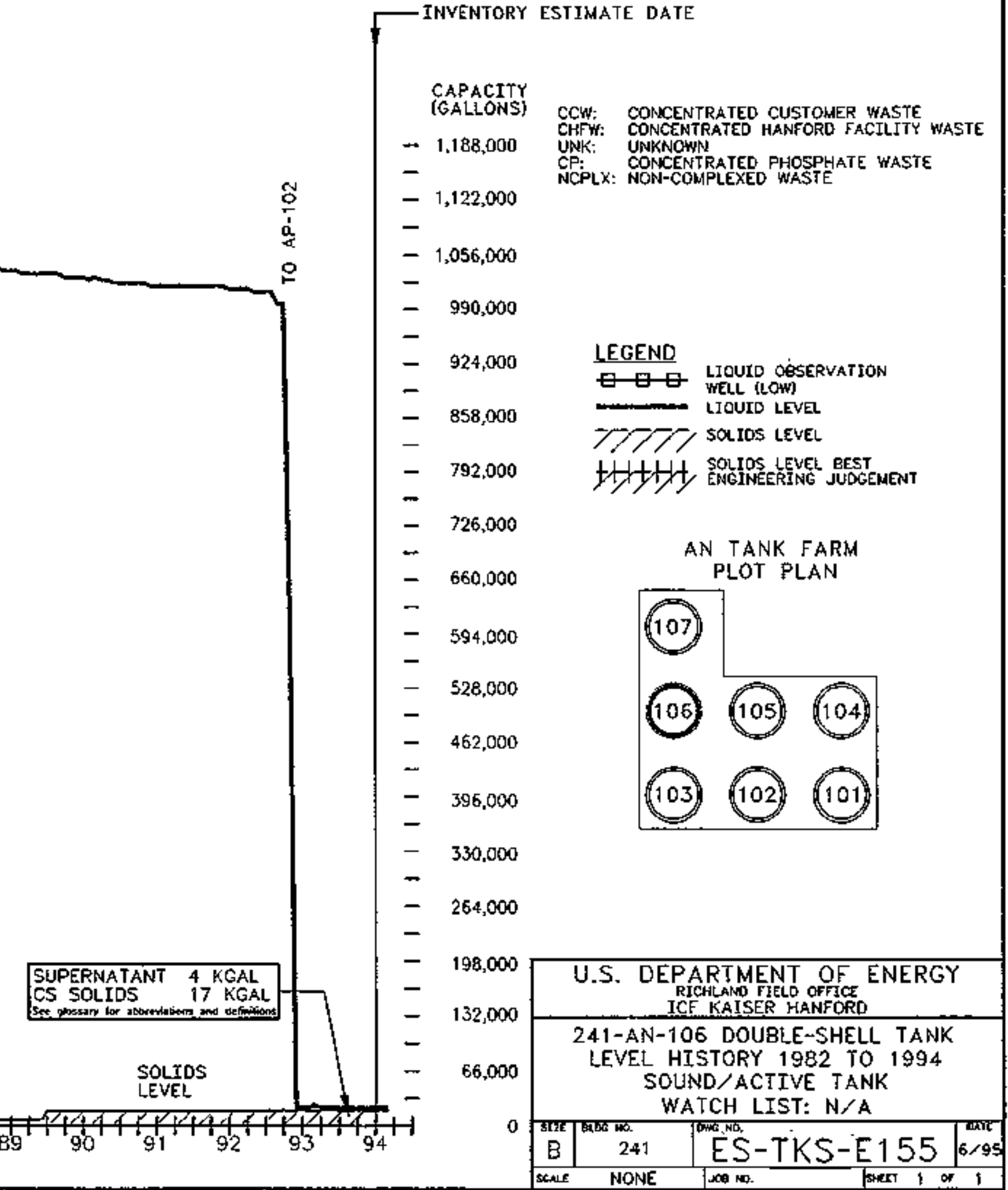

$-65=$ 
WHC-SD-WM-ER-350, Rev, 0

\begin{tabular}{|c|c|c|c|}
\hline \multicolumn{4}{|c|}{ Double-Sheld Tank 241-AN-106 } \\
\hline \multicolumn{4}{|c|}{ 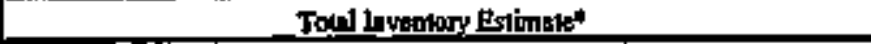 } \\
\hline \multicolumn{4}{|c|}{ 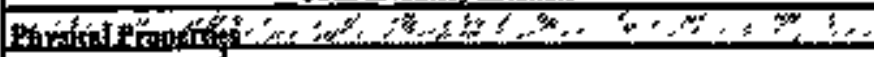 } \\
\hline Tond Wogle & $1.17 \mathrm{E}+0 \mathrm{~g} \mathrm{~kg}$ & (2! k咆) & \\
\hline Hearlond & 0.535.kw & $400 \mathrm{BT} \mathrm{U}$ hI & \\
\hline Bultepsingtivt & & $1.47(s)$ & \\
\hline Wher wet & & 44.2 & \\
\hline TOC whe & & 1.17 & \\
\hline \multicolumn{4}{|c|}{ 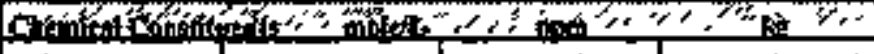 } \\
\hline $\mathrm{N}_{2}{ }^{+}$ & [n] 3$]$ & 1.GNE+0S & $1.88 \mathrm{E}+04$ \\
\hline Alt & $1.3:$ & $239= \pm 04$ & 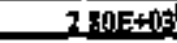 \\
\hline Fe" (tatd Fo) & 5.2.8E:03 & 2000 & 23.4 \\
\hline$\phi^{+2}$ & 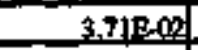 & $13+5 \pm 09$ & 159 \\
\hline Bà & LAIE-OB & 200 & 23.4 \\
\hline 10 & 10250 - & 0251 & 0.112 \\
\hline $\mathrm{He}$ & $8.54 E_{0} 0 \mathrm{~S}$ & 1.16 & 0.136 \\
\hline 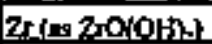 & 8459004 & 52 . 3 & 6.1. \\
\hline $\mathrm{Pb}^{2+}$ & 7,080005 & $11+1$ & 130 \\
\hline $\mathrm{Ni}^{3 *}$ & 461203 & 18 & 215 \\
\hline$S^{*}$ & 2.07e-05 & 0.639 & $248 \mathrm{E}-02$ \\
\hline $\mathrm{sin}^{*}$ & $7.25 \mathrm{se}-03$ & 270 & 317 \\
\hline$c^{*}$ & $3.70 \mathrm{E}-02$ & 1.01E+ot & $14 t^{3}$ \\
\hline $\mathbb{K}^{*}$ & $282 \mathrm{E}-01$ & 74 & 878 \\
\hline OH & $5,8 \mathrm{H}$ & $6.70 \mathrm{E}+0 \mathrm{~A}$ & $2.85 E+0.03$ \\
\hline No: & 3.59 & $L A 9 E+0 s$ & 17dE+04 \\
\hline $\mathrm{NQ}$ & 2.40 & 7.4xE+04 & $8.76+03$ \\
\hline$\omega^{2}:$ & Q4172 & $168 \mathrm{~B}+0.4$ & $197+013$ \\
\hline$P Q_{1}^{2}$ & 0.196 & $1262+94$ & $1.48 \mathrm{E}+03$ \\
\hline 150. & 0.2794 & $1,87 \pm+404$ & $2,13=103$ \\
\hline Si(a SOO & $4,505,012$ & 8s: & 100 \\
\hline$E$ & 2278-0.2 & 0.190209 & $140]$ \\
\hline a. & $0.17 \%$ & $4,30 E+09$ & sod \\
\hline C.H.O. & $3,75 \mathrm{E}-003$ & A81E409 & 도연 \\
\hline EDTA ${ }^{+}$ & 2.0SE.0. & 4,000 $+0,03$ & $46^{\circ}$ \\
\hline HEDTA2 & 3,36E-ga! & $6.25 E+03$ & 73 \\
\hline 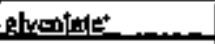 & - $0.2 \pm$ & $616 \mathrm{~B} ; 00$ & 745 \\
\hline | sectine" & 2.35E-02 & 942 & $110^{\circ}$ \\
\hline axal:art: & $3,84=-09$ & 2,29 & 0268 \\
\hline DBP & $1.946-02$ & $2.12 E \div-03$ & 248 \\
\hline trengt & 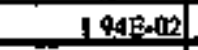 & 974 & 110 \\
\hline $\mathrm{NH}$ & $510=-197$ & 5883 & 689 \\
\hline \multicolumn{4}{|c|}{\begin{tabular}{l|l}
$\mathrm{FuN}_{4}{ }^{*}$ & 0 \\
\end{tabular}} \\
\hline \multirow{2}{*}{\multicolumn{4}{|c|}{ 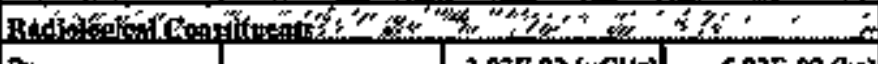 }} \\
\hline Pu & & & $5.92=02$ (k: \\
\hline if & 5.5IF-03a(M) & $958 \mathrm{ing} / \mathrm{t}$ & $120 \mathrm{fks}$ \\
\hline Cs & 0.347 cestid & 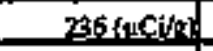 & 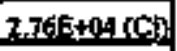 \\
\hline St & 1.01E02(C) ( ) & $6.88(14 \mathrm{c} / \mathrm{g}) \mathrm{t}$ & $805(\mathrm{Cl})$ \\
\hline
\end{tabular}

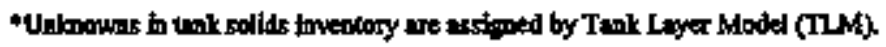

+Volume everage fint dengity, mass merage Wuer wrte and TOC wr\% C.

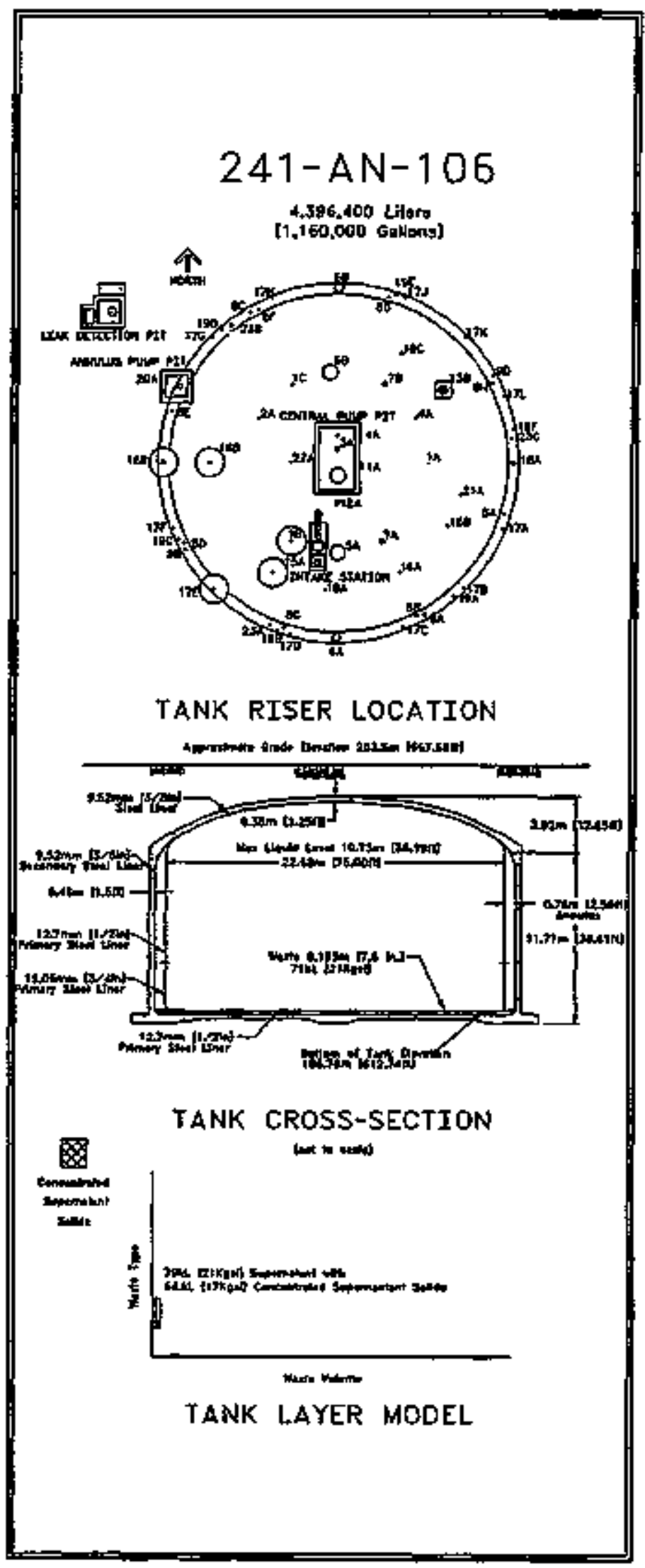


WHC-SD-WM-ER-350， Rev, O

\begin{tabular}{|c|c|c|c|}
\hline \multicolumn{4}{|c|}{ Double-Shell Tank 241-AN-106 } \\
\hline \multicolumn{4}{|c|}{ 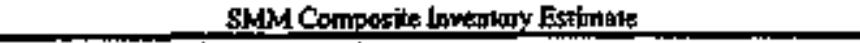 } \\
\hline 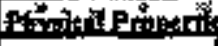 & man & 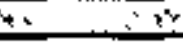 & $z$ \\
\hline Tolet Superamint & $1.17 \mathrm{E}+0.5 \mathrm{~kg}$ & (zl kgal) & \\
\hline Herat lood & Q & LG0 BFTlathl & \\
\hline Bulk nsaritu: & & $1, A 2(2, k x)$ & \\
\hline Woer wtot & & 44.2 & \\
\hline $\operatorname{ToC} w \% c(w a)$ & & 1.17 & \\
\hline \multicolumn{4}{|c|}{ 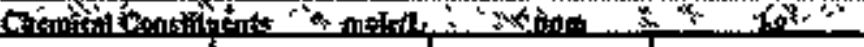 } \\
\hline$N$ & 10.3 & 1.6 Cef $+0 \mathrm{~S}$ & $1.88 \mathrm{E}+04$ \\
\hline$A^{\mathbf{H}^{*}}$ & إل31 & $2.392 \pm+04$ & $280 E+03$ \\
\hline$F=F^{\prime *}(t+1)$ & $5.28 \mathrm{E}-\mathrm{N} 0 \mathrm{3}$ & 200 & 23.4 \\
\hline 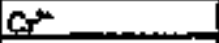 & $371 E=012$ & $\perp 3] \mathrm{E}+0.5$ & 153 \\
\hline Bp* & 1.ALE-03] & 200 & 23.4 \\
\hline It: & 1025-05 & 09 & a 112 \\
\hline H5: & $8.545-06$ & 1.16 & 0.136 \\
\hline $21 \mathrm{mog} 2 \mathrm{OH}$ & $845=-04$ & 523 & 613 \\
\hline $\mathrm{Pb}^{* *}$ & 7.88E.05: & II. & 1,30 \\
\hline $\mathrm{Nit}^{*}$ & A61E- $-93^{\prime}$ & -184 & 21.5 \\
\hline $\mathbf{s}^{*+}$ & 1.07E-095 & 0.639 & 7.48E-02 \\
\hline $\mathrm{Mr}_{\mathrm{I}^{*+}}$ & 725E- 03 F & $2 \pi$ & $3 \mathrm{ln}$ \\
\hline $\mathrm{Cu}^{*}$ & $3,700,002$ & L.01E+03 & 118 \\
\hline $\mathbf{k}^{*}$ & $282 \mathrm{E}-09$ & 24 & s2노 \\
\hline OH & 5.II & $6.70 \mathrm{E}+0.04$ & 7.SSE+493 \\
\hline No: & 3.55) & LA9E+15S & $174=04$ \\
\hline $\mathrm{No}$ & 2.40 & $7,48 E+04$ & 8.76E+0: \\
\hline$\infty 0^{2}$ & 0412 & $\perp 68 E+04$ & 10784103 \\
\hline $\mathrm{FO}^{2}$ & 0.196 & $1.26 \mathrm{E}+04$ & $1.48 E+13$ \\
\hline $502^{2}$ & 0279 & $183 E+94$ & 2132409 \\
\hline $\mathrm{Sil}\left(\mathrm{s} \mathrm{SO}_{2}^{2} \mathrm{~h}\right.$ & 450E-02 & 857 & 100 \\
\hline$F$ & 927Es:92 & U⿴囗十 +103 & 140 \\
\hline a & 0.179 & $430 \mathrm{E}+02$ & 504 \\
\hline $\mathrm{C}+\mathrm{H}_{\alpha} \mathrm{O}^{3}$ & $3.73 E=-02$ & $481 \mathrm{E}+0,3$ & 562 \\
\hline EDTA & $2.050-02$ & $4.000+03$ & 46: \\
\hline HEDTA $A^{x}$ & $396 \mathrm{~B}=07$ & $629 \mathrm{~g}+09$ & 722 \\
\hline Alvowlyly & 0.125 & $636 \mathrm{eng}$ & 755 \\
\hline 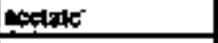 & 2.35E-02 & 942 & 110 \\
\hline oxalasta & 384E- $0^{5}$ & 222 & 10268 \\
\hline Desp & 1.94E- 92 & $2.12 \mathrm{E}+0 \mathrm{~s}$ & 248 \\
\hline botangl & 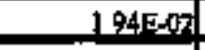 & 974 & $\mathrm{IL}$ \\
\hline NH_- & 510EAD & 588 & 69.0 \\
\hline $\mathrm{Fe}\left(\mathrm{C} N \mathrm{~N}_{k}{ }^{*}\right.$ & a) & 0] & 0 \\
\hline ReAlotorat Con & 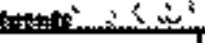 & 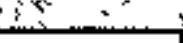 & $\theta: x^{2}$ \\
\hline Pu & $44.7(\mu C$; & & $5 ., 52+020$ \\
\hline L & $\$$ \$E_OB_(M) & 948 (408) & $100 \mathrm{ftan}$ \\
\hline Cs & $0.347\langle\mathrm{C} i 2)$ & $236\left(\mu \mathrm{C} y_{3}\right)$ & 2.76E + od (Cin) \\
\hline SI & 1.01E- 02 ( $\left.C_{12}, 2\right)$ & 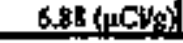 & Bos (Cij] \\
\hline
\end{tabular}

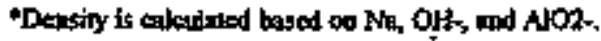

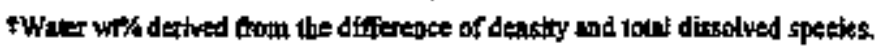

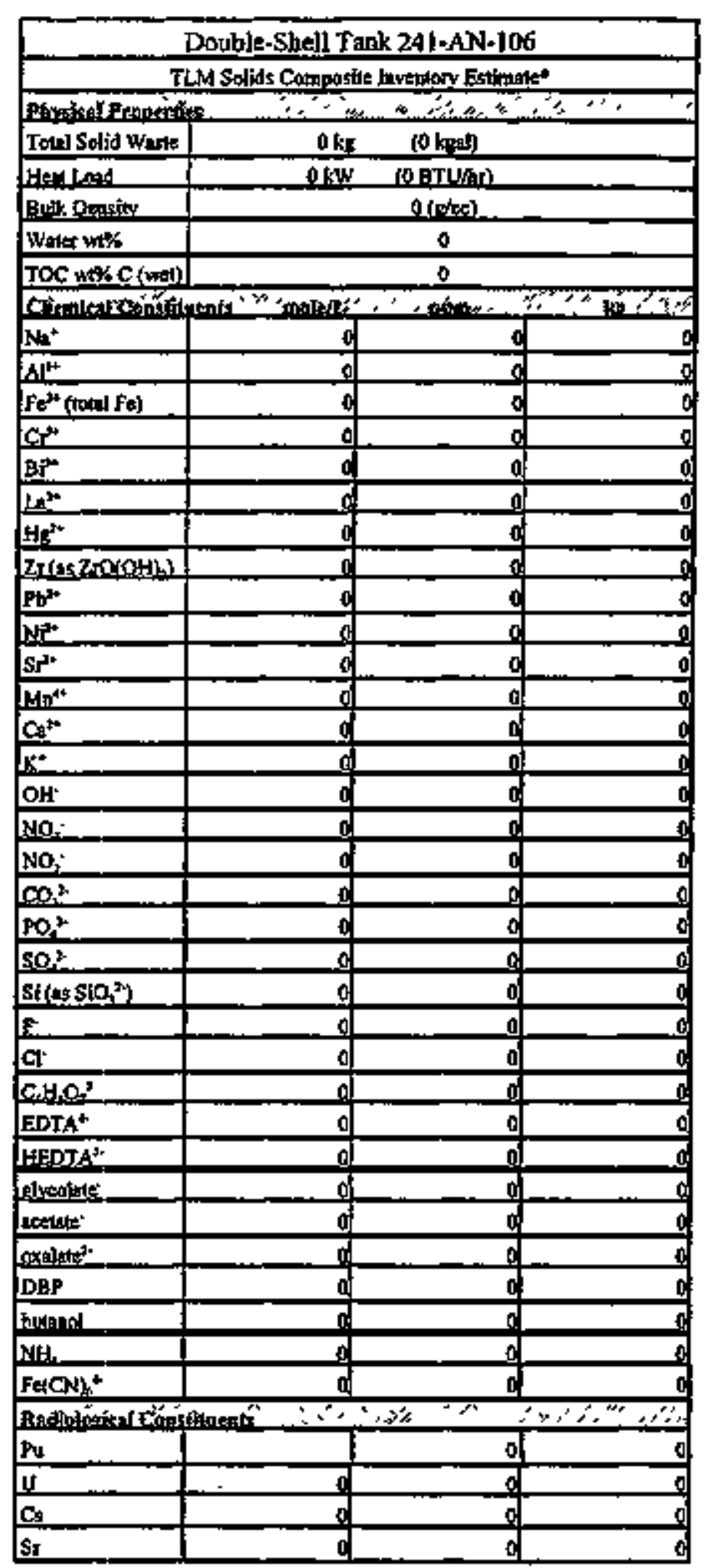

Undoowos is tank golids tomfelory are assigned by Tank Lsyer Model (TIM). 
WHC-SD-WM-ER-350, Rev, 0

2.7 Tank 241-AN-107

$2.7 .1 \quad 241-\mathrm{AN}-107$ Tank History

2.7 .1 .1 Waste History of Tenk $241-\mathrm{AN}-1,07$

Tank 241-AN-107 began service by receiving non-contlexed waste in September 1981 from Tank 241-AN-102. The tank continued to receive noncomplexed waste until June 19B3. Fron July 1983 until the present, the tank has conteined complexant concentrate waste, most of which was received from Tank 241-AZ-102 during the fourth guarter of 1983. The tank has not received any waste since the third quarter of 1986 . The tank is currently inactive and is considered concentrated waste holding tank.

\subsubsection{Temperature History of Tank 241-AN-107}

Temperature data for Tank 241-AN-107 are recorded by 18 thermocouples at Jnown elevations on one tree inside the tank, located in riser $4 \mathrm{~A}$. Nonsuspect tenperature data taken between July 1983 and June 1991 for a11 18 thermocouples were available from the computer automated surveillance system. Non-suspect temperature data recorded between January 1990 and September 1993 for 12 thermocouples were available from the surveillance anelysis computer system. However, not all of the 12 thermocouples have ata that encompass the entire length of time. Within the time spans for both systems, there were several smell breaks in the sequence of temperature data. The average temperature chring these periods was 91.80 with a minimum of $72^{\circ} \mathrm{F}$, a maximum of $107^{\circ} \mathrm{F}$, and a standard deviation of $6.2 \circ$. Iinear regressions vere performed on each thermocouple that hed temperature data stexting from January 1990. The slopes from these regressions were averaged with a resulting average slope of 0.00483 . Refer to the supporting aocument for a more thorough review of the temperature data (Brevick 1995).

\subsubsection{Occurrences of Tank 241-ART-107}

Two unusual events occurred at Tank 241-AN-107. TFS 0-BFS-89-046 was issued in July 1989 because samples indicated that the tank was deficient in caustic. A second set of samples verified the deficiency. Occurrence Report RI--WHC-Tank Farm-1992-0090 was issued in Decembez 1992 due to alarms for high levels of radon within the tank annulus.

\subsubsection{Psychrometrics of Tank 241-Ait 107}

The apparent trend of the evaporation rate from the tank has increased from 132.8 gallons per week in February 1983 to 164.1 gallons per week in January 1995. Over that same period, the trend in the rates of heat exehange through the primary tank and annular ventilation has apparently increased. A review of the psychrometric data in Tank 241-AN-107 would suggest an overall increase in the rate of heat generation by the waste. 


$$
\text { HHC-SD-MM-ER-350, ReV. O }
$$

\section{7 .2 Current Status of Tank 24I-AN-107}

Tank 241-AF-107 entered service in September 1981 and currently stares $1,060,000$ gallons of waste. The following plan view and tank cross section depict the approximate waste volume of $1,066,000$ galions and riser configurations as of Januery 1994. At the time of the estimate, there were $1,066,000$ gallons of supernatant with 134,000 gallons of concentrated supernatant solids. The waste level in the tank is measured with the FIC gauge and the manual tape and has remained at about 385 inches over the last three years. This tank is inactive at the present time. The tonk is actively ventilated and categorized as sound. Tank 241-AN-107 has 61 risers. Two 4-inch risers (no.10A and no.21A) and one 12-inch riser (no.7B) are available for use.

\subsubsection{Inventory Estimate of Tank 241-AN-107}

The tank layer model (a volume based appxoximation) that follows was derived from the Ios Alamos National Laboratory Whste status and Transaction Record Summary (Agnew 1995) and Supernatant Mixing Model (Agnew 1995). The estimated inventories of total waste, solids, and supernatant in Tank 241-AN-107 are also presented. Concentrated supernatant solids are considered as an integral part of the liquid for the purpose of estimating inventories, but are graphed as solids on the level histories. The actual substance, which was derived from double-shell slurry, appears as a solja if undisturbed, but the particles are resuspended in solution if heated or disturbed.

\subsubsection{In-Tank Photograph of Tank 241-AN-107}

The 1988 collage for Tank 241-aN-107 bhows a waste surface which is too dark and too hazy to determine the weste color or characteristics with much certainty. A dark bxown 2iquid appears to be on the surface, but, this could be due to the lighting ox the underlying solid material. Tank walls and equipment show up with excellent clarity in the picture. The walls appear to be in good condition and the equipment has all been identified and labeled. This tank, which contains $1,062,000$ gallons of waste (Hanlon 1994), is almost filled to capacity. The height of the waste is about 32 Eeet.

$2.7 .3 \quad$ Synopsis of Tank 241-AN-107

(To be completed.) 


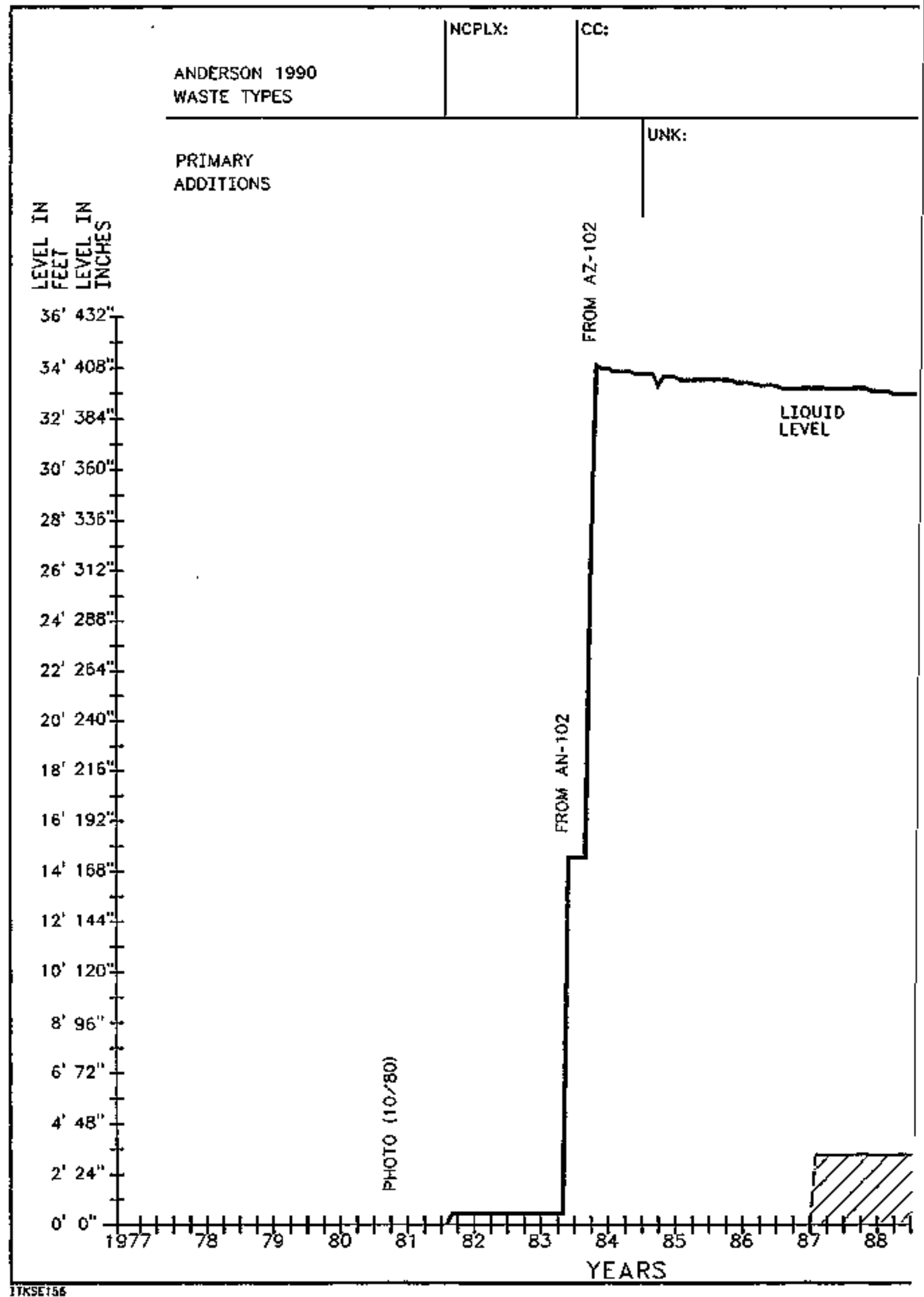


WHC-SD-WM-ER-350, Rev, 0

\begin{tabular}{|c|c|c|c|}
\hline \multicolumn{4}{|c|}{ Double-Shell Tank 24l-AN*107 } \\
\hline \multicolumn{4}{|c|}{ 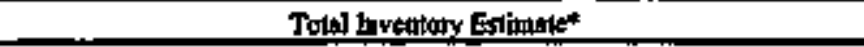 } \\
\hline \multicolumn{4}{|c|}{ 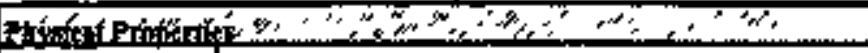 } \\
\hline Total Vilste & \multicolumn{3}{|c|}{$5.76 \mathrm{E}+06 \mathrm{~kg},(1.07 \mathrm{C}+03 \mathrm{~kg} a \mathrm{l})$} \\
\hline 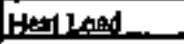 & \multicolumn{3}{|c|}{ 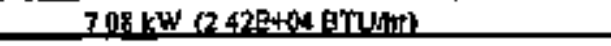 } \\
\hline Bulle Densilint & \multicolumn{3}{|c|}{ isis } \\
\hline Wellet witht & \multicolumn{3}{|c|}{17.8} \\
\hline TOC wt\%C & \multicolumn{3}{|c|}{1.46} \\
\hline 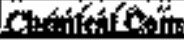 & 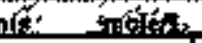 & $80_{0}, \ldots$ & $2 x_{i}, \mathrm{~N}_{\mathrm{N}} \mathrm{m}$ \\
\hline $\mathrm{Nas}^{*}$ & 9.27 & $1,495+08$ & $8.60 \mathrm{E}+0 \mathrm{~S}$ \\
\hline$\Delta^{*}$ & 1200 & $2.268+04$ & 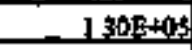 \\
\hline $\mathrm{Fo} *(\cot =\mathrm{Fol}$ & $3.95 E-03$ & - & $\mathbf{s 8 9}$ \\
\hline$G_{1}^{*+2}$ & 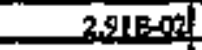 & I068+03 & $6120+403$ \\
\hline $\mathrm{BH}^{\mathrm{H}}$ & 127E-09: & 1.136 & $1.078+03$ \\
\hline istit & $796=-66$ & 077 & 446 \\
\hline Hل & 8.00E-06 & 1..2. & 6.48 \\
\hline $20(0,700(0+1)$ & 2145EA & 45.6 & 265 \\
\hline $\mathbf{P b}^{\mathbf{*}}$ & $1.07 E-04$ & 15.5 & 89.3 \\
\hline Ner & $333 \mathrm{~B}_{0} 0.0$ & 137 & 7 \\
\hline$s r^{*}$ & 8.42E-06 & 0.516 & 2.98 \\
\hline $\mathrm{Mnt}^{*}$ & $7095=03$ & 273 & LSTE+03 \\
\hline $\mathrm{Cs}^{2+}$ & $2.76 \mathrm{~B}-0.9$ & 775 & $4,47 E+103$ \\
\hline $\mathbf{K}^{*}$ & 2.84E-024 & 73 & $4 \leq 49 E+103$ \\
\hline oft & 5.32 & $6.34 \mathrm{E}+0 \mathrm{a}$ & $3.65 \mathrm{E}+0 \mathrm{~S}$ \\
\hline No. & 306 & 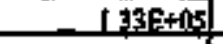 & $707 f+08$ \\
\hline Noi & 2.17 & 7.00: & $4.03 \mathrm{E}+0 \mathrm{~S}$ \\
\hline Cos: & 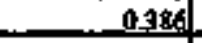 & $-1625+04$ & $035 \mathrm{~F}+\mathrm{ix}$ \\
\hline $\mathrm{BO}^{3}$ & 0.125 & 8견+03 & $4.79 \mathrm{E}+04$ \\
\hline $\operatorname{sot} 2$ & - 0232 & 1 B $89 F+04$ & $1060+0$ \\
\hline $\left.\sin (\sin )^{2}\right)$ & $4,79 \mathrm{E} .02$ & 942 & $5.43 E+03$ \\
\hline$F$ & ASEAOS & 114F:03 & $65 s+403$ \\
\hline$\sigma$ & 0.160 & $3.96 \mathrm{E}+\mathrm{O} 9$ & 2.38500 \\
\hline S, $\mathrm{H}_{2}$ & $\triangle F(0)=02\}$ & $529= \pm 03$ & $305 \mathrm{E}+0 \mathrm{~d}$ \\
\hline EDTA* & 2.74E-12f & $5.53 \mathrm{E}+0.3$ & 3.19E+04 \\
\hline HEDTA'. & $4,48 \mathrm{E}-12$ & $8.61 E+03$ & 496Etos \\
\hline Shcolate: & 0130 & $682 E+09$ & $393 \mathrm{E}+0 \mathrm{~d}$ \\
\hline wetinto & $3,200,02$ & $1.32 E+03$ & $2,61 E+03$ \\
\hline oxilyses: & $3015=05$ & -185 & 107 \\
\hline DBP & 2.25E-02 & $2.536+039$ & $1.46 \mathrm{E}+04$ \\
\hline Int!ngt & $2.25 \mathrm{E}-02$ & $17 \mathrm{E}+0 \mathrm{~d}]$ & $6 \pi \mathrm{E}+1 \mathrm{~A}$ \\
\hline $\mathrm{NH}_{2}$ & $4,16 \mathrm{E}=020$ & 496. & $286 \mathrm{E}+0$ 月 \\
\hline 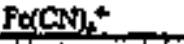 & $\mathbf{0}$ & 0 & \\
\hline 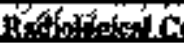 & 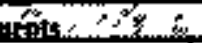 & axim $2 \%$ & $\because \cdots$ \\
\hline Pu & & 3.13E-42 (4 COU/) & 3.01 (ked) \\
\hline 1 & S $86 \mathrm{E}-03(\mathrm{M})$ & 976 (1: $/ 9)$ & 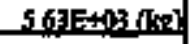 \\
\hline Cs & $0.359(6) 2)$ & 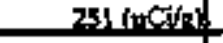 & $1.457+06(\mathrm{Ci})$ \\
\hline st & 1.10E-02 (CUL) & 7.70 (uchis) & $4.44 E+04\left(C_{i}\right)$ \\
\hline
\end{tabular}

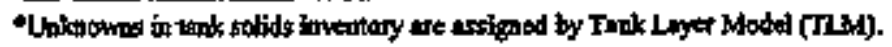

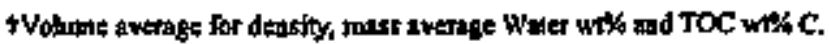

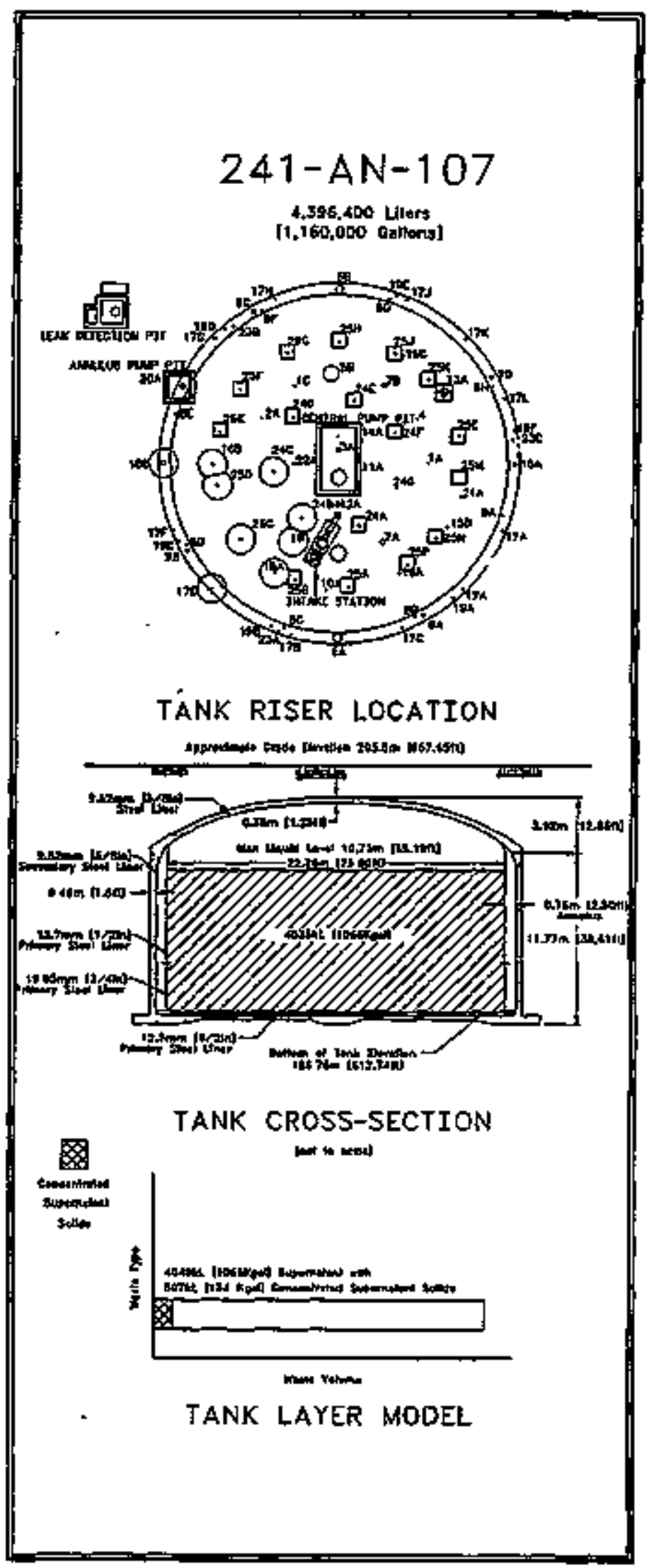


WHC-SD-WM-ER-350, Rev. O

\begin{tabular}{|c|c|c|c|}
\hline \multicolumn{4}{|c|}{ Double-Shell Tank 241-AN-107 } \\
\hline \multicolumn{4}{|c|}{ 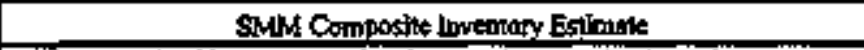 } \\
\hline 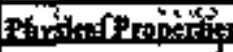 & m. & $\because \div \div$ & 3 \\
\hline Toul Superdotist & \multicolumn{3}{|c|}{$5.76 \mathrm{E}+06 \mathrm{~kg} \quad(1.072+0 \mathrm{~g} \mathrm{~kg}$ a $)$} \\
\hline $\mathrm{H}=\mathrm{k}$ losd & \multicolumn{3}{|c|}{ 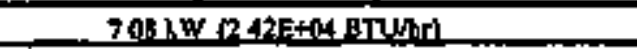 } \\
\hline Bulk Bestity & \multicolumn{3}{|c|}{ 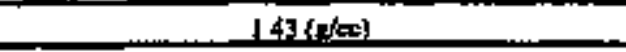 } \\
\hline Wusterst & \multicolumn{3}{|c|}{4.8} \\
\hline Tocktoc(wt) & \multicolumn{3}{|c|}{1.46} \\
\hline \multicolumn{4}{|c|}{ 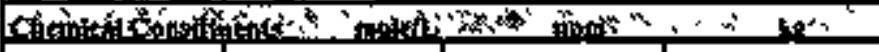 } \\
\hline \begin{tabular}{|l|l}
$\mathbf{N E}^{*}$ & \\
\end{tabular} & 9.27 & $1.49 \mathrm{E}+05$ & S.GDE+05 \\
\hline$A^{*+}$ & 120 & $2,26+2+04$ & $1+3 c_{r}=405$ \\
\hline$F^{\prime \prime}+(\ln (1) F e)$ & $3.95 E-03$ & 154 & \multirow{2}{*}{$\frac{859}{612 \mathrm{E}+109}$} \\
\hline (2) & $295 \mathrm{~g}=02$ & $1062+00$ & \\
\hline$B 3^{2}$ & $123 \mathrm{~B}+03$ & 186: & $1.072 \div 03$ \\
\hline مئي & 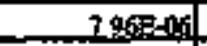 & 0776 & 446 \\
\hline $\mathrm{H}^{2} \mathrm{~s}^{+}$ & $8.002-06$ & 1.12 & 6.48 \\
\hline 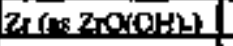 & T늘영 & 496 & \multirow{2}{*}{$\begin{array}{l}79.8 \\
89.3\end{array}$} \\
\hline $\mathrm{Pb}_{0}{ }^{2}$ & $1.07 E-04$ & 15.5 & \\
\hline $\mathrm{Ni}^{*}$ & 3390 (13) & 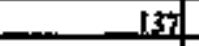 & 78 \\
\hline $5+4$ & 8.42Bac: & 0.516 & 2,98 \\
\hline $\mathrm{Mid}_{2}=$ & 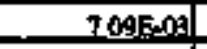 & 273 & $1572+40$ \\
\hline $\mathrm{Ca}^{2+}$ & 2.76E-MOA & 775 & $4.476+09$ \\
\hline $\mathrm{K}^{*}$ & 24809 & $\pi$ & $\triangle \angle Q E+10$ \\
\hline OH & 5.32 & $6.34 \mathrm{E}+04$ & $3.65=015$ \\
\hline $\mathrm{NO}$ & 3.06 & $13340 \mathrm{x}$ & $7675+05$ \\
\hline $\mathrm{NO}$ & $\begin{array}{r}2.17 \\
\end{array}$ & $7.006+04$ & 4.055E+05 \\
\hline $\mathrm{CO}^{2}$ & 0.38 & 16 th+口에 & $9355+04$ \\
\hline $\mathrm{PO}_{4}^{2}$ & 0.125 & $8316+0$ & 4.79E+104 \\
\hline 501. & 077 & 1 aㅏㄷㄴㅇㅔ & 10.68405 \\
\hline $\sin \left(a \sin { }^{2}\right)$ & $4.7 \% 5-02$ & 940 & $5.43 E+13$ \\
\hline $\mathrm{F}$ & 8S4테이 & 1.4로열 & $6 \leqslant 5 \mathrm{R}+13$ \\
\hline$Q$ & $0.16 \mu$ & 396E+0日 & $228 \mathrm{E}+04$ \\
\hline C.HAL & $40,0=0$ & $5290 \times 103$ & 30sEtos \\
\hline EDTA ${ }^{4}$ & 2.74E-02 & $553 \mathrm{E}+03$ & $3,19 \mathrm{E}+04$ \\
\hline HEDTA ${ }^{2}$ & 448E-OA & $86 \mathrm{~F}+0.5$ & A G6RAd \\
\hline stusool te: & 0130 : & $6885+10$ & $39 \mathrm{Ar}+0$ \\
\hline coetrate & $3.20 \mathrm{E}-02$ & 1.32E+05 & $7.61 \mathrm{E}+0 \mathrm{9}$ \\
\hline oxpintes- & 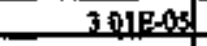 & 185 & 197 \\
\hline DgP & 225타-02 & $2.53 \mathrm{E}+0.03$ & $1.458+04$ \\
\hline hurteno1 & 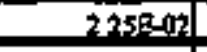 & $175+05$ & 67PF+13: \\
\hline NH. & 4.65091 & 496 & $2865+92$ \\
\hline$F(C O N)^{+}$ & & 0 & \\
\hline 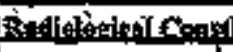 & 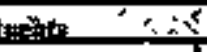 & $84 x^{2}$ & 0 \\
\hline p & 44.7 ( $\mu \mathrm{Cil})$ & & $3.01(\mathrm{ks})$ \\
\hline$\underline{u}$ & SR6E-03, (W1) & $976(\mathrm{~m} 2 / 2)$ & 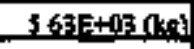 \\
\hline Cs & 0.359(Cin) & $2 \$ 1$ (1) & $1458+06$ (C) \\
\hline S & L. $10 \mathrm{E}-02(\mathrm{C}, 1)$ & $7.70\left(\mathrm{p}_{\mathrm{C}} \mathrm{C}_{\mathrm{g}} \mathrm{u}^{3}\right.$ & 4.41E+04,(C) \\
\hline
\end{tabular}

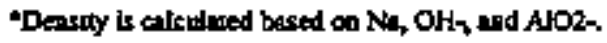

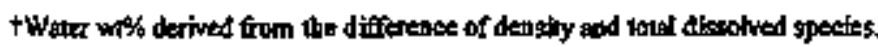

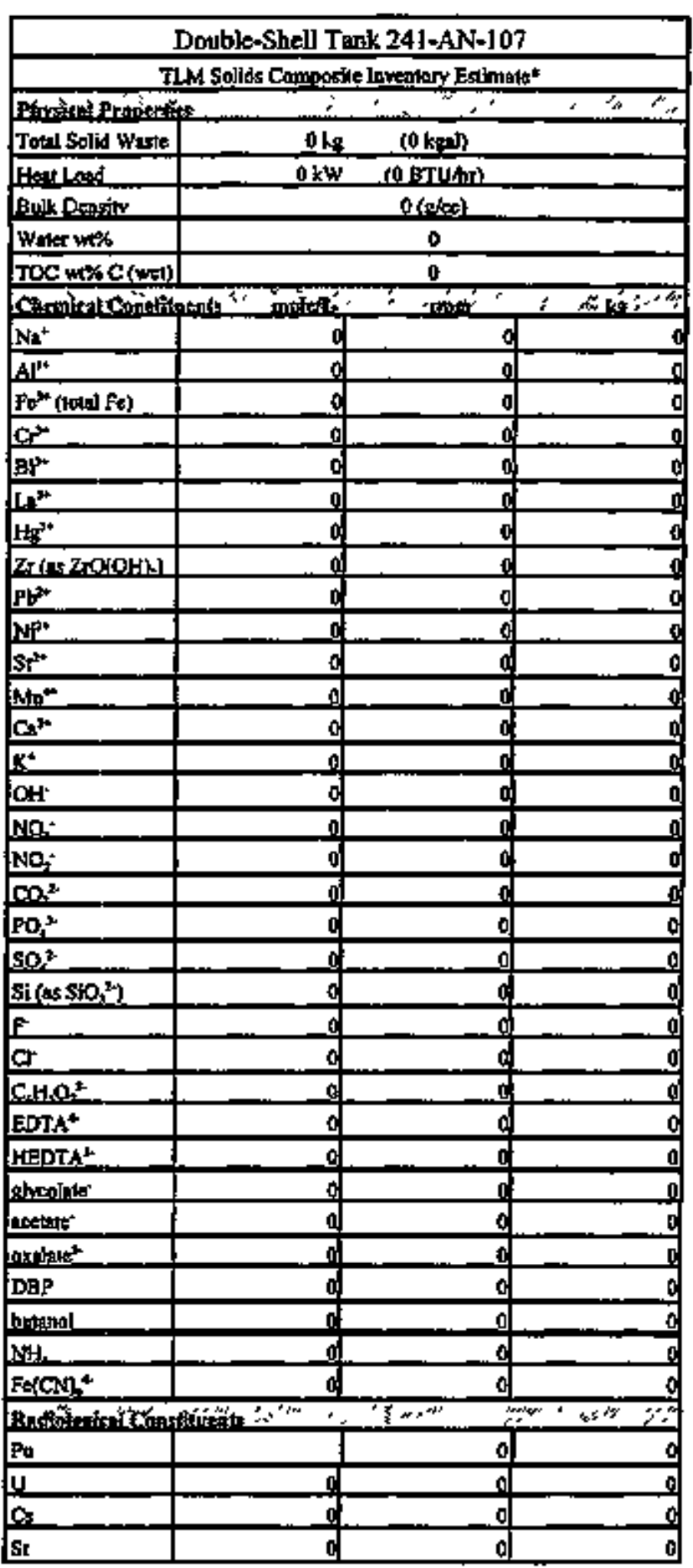

"Unknowas th tank solde tovenlocy are ossigped by Tank 1sya Madel (TLM).

$$
-73-\quad 6 / 95
$$




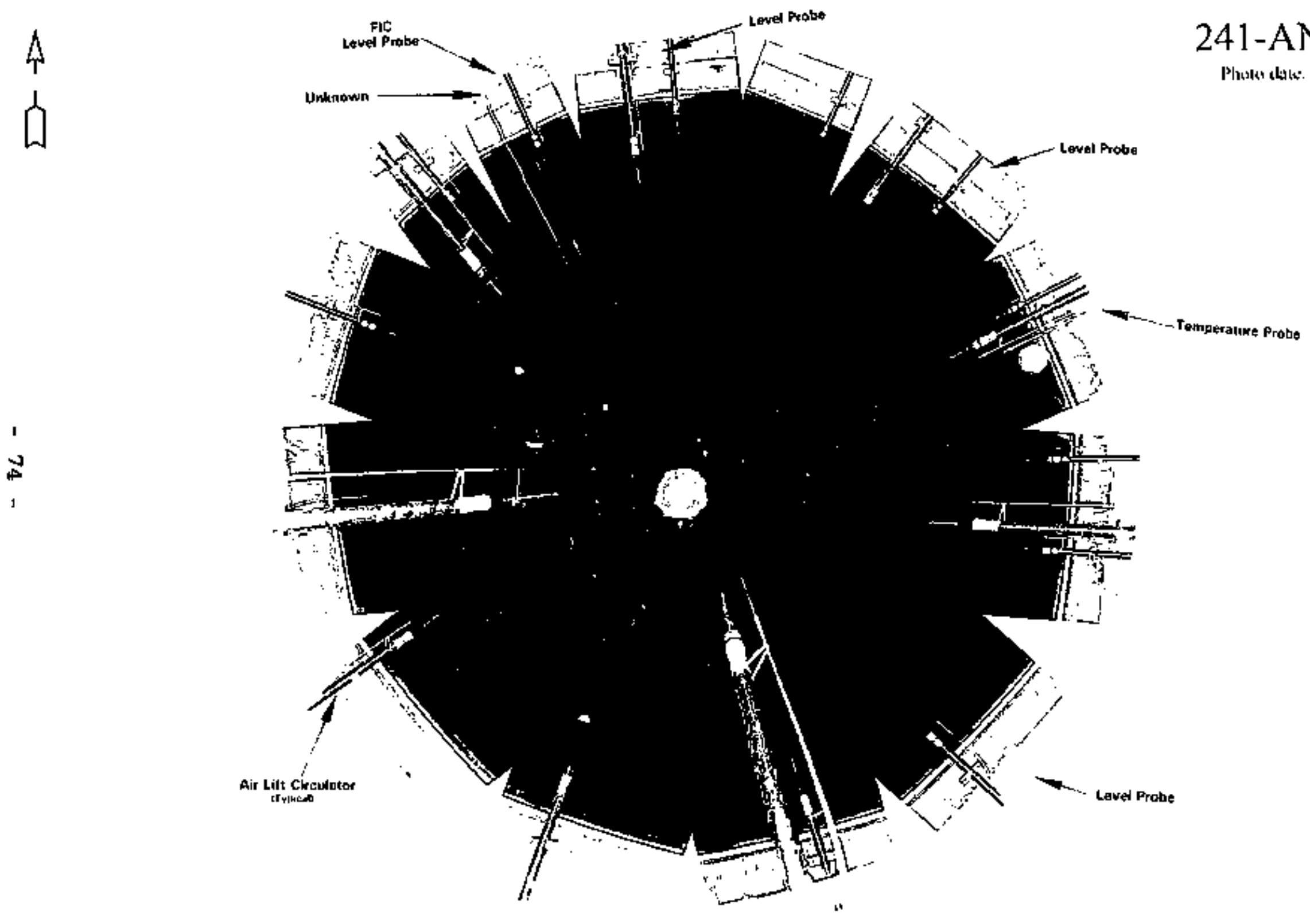




\subsubsection{AP Tank Farm History}

The AP Tank Farm is located south of 4 th Street and east of Canton Avenue in the 200-East Area. The AP Tank Farm contains eight, 100 series, 1,160,000-gallon, 75-foot diameter double-shell tanks. The AP Tank Farm is the most recent tank design, with a reinforced concrete shell and done and an insulating concrete base. A heat-treated, stress-relieved, primary steel liner and a non-stress-relieved, outer steel liner are inside the concrete shell. These tanks were made to hold concentrated supernatant. The maximum design temperature for 1 iquid storage is $300^{\circ} \mathrm{F}$. The tanks are all at the same elevation and no cascade lines exist between the tanks.

A color aerial photograph taken in 1993 of the AP Tank Farm shows the orientation of the 100 series tanks, leak detection pits, annulus exhaust equipment, air intake stations, and a valve pit. 
WHC-SD-PM-ER350, ReV. 0 .

\section{AP TANK FARM}

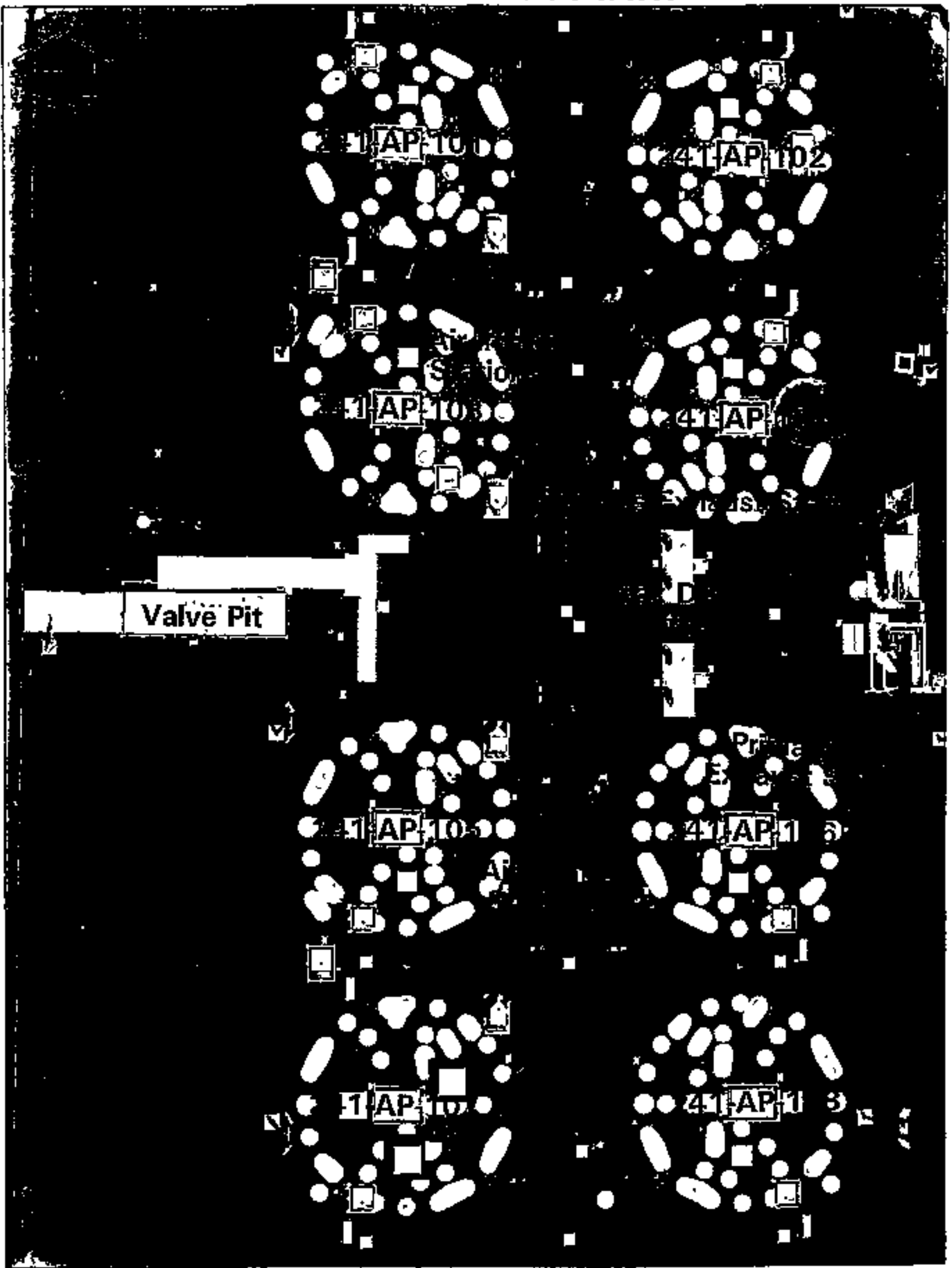


WHC-SD-WM-ER-350， Rev. 0

\subsubsection{AP Tank Farm Waste History}

The AP Tank Farm began receiving waste in July 1986. The first wastes consisted of of non-complexed waste, Hanford site facilites waste, and double-shell slurry waste. Low-ievel waste from EUREX was sent to Tanks 241-AP-101, -102, -103, -107, and -100 from 1987 to 1992. Tank 241-AP-104 received N Reactor decontamination waste in 1987. Tanks 241-AN-102 and -104 were feed tanks for the grout facility. Eresently, only Tanks 241-AN-101, -107, and -108 are active, and they are dilute process feed tanks to the 242-A Evaporator.

\subsubsection{AF Tank Farm Temperature History}

The eight tanks within the AP Tank Earm contain one thermocouple tree each, with 18 thermocouples per tree at known elevations. All of the AP tanks have a requirement for temperatures to be recorded semiannually and all are connected to cAss.

\subsubsection{AP Tank Farm Occurrences}

Five unusual events concerned AP Tank Farm as a whole according to the reports. Occurrence reports RI--WHC-Tank Farm-1993-0049, RL--WHC-Tank Farm-1992-0055, RL- WHC-Tank Farm-1992-0019, and RI--WHC-Fank Farm-1991-0226 were writter because equipment failures caused the tanks to reach atmospheric pressure. According to off-Normal Report 86-55 issued in December 1986, tanks were pressurlzed from a power failure causing loss of ventilation. For more information, refer to the Supporting Document for the Southeast quadrant HTCE for AP Tank Farm (Brevick, 1995).

\subsubsection{AP Tank Farm Ventikation}

Each tank is designed to have 146.25 SCFM of air travel through it and 1,075 SCFM of air travel through the annulus. Air enters the tanks by infiltration because there is no supply fan. After exiting each tank, the air ducts are foined to allow the service of one fan to send air into the primary exhaust system. Before the tank air is released to the atmosphere, the air is heated, routed through a prefilter, then sent through two hEPA filters. Each tank annulus recelves supplied air. Each source of supplied air serves two tank annuli after entering through a heater, prefilter, and HEPA filter. After air leaves each annulus, it is sent through joined ducts to a heater and two HEEA filters before it is released to the atmosphere. Both the tank and annulus systems have a primary and a backup system. For more information, refer to drawing H-2-90514, sheets 1 and 2 .

The psychrometxic data are recorded in two parts, the tank data and the annulus data. For water and heat leaving the tank, the numbers are positive. For more information, refer to the supporting Document for the Southeast Quadrant HTCE for AP Tank Farm (Brevick, 1995). 
WHC-SD-WM-ER-350, Rev. 0

3.0.2 Current Status of AP Tank Farm

Tanks 241-AP-101, -107, and -108 are active with the 242-A Evaporator. All tanks are actively ventilated and categorized as sound. The total waste volume is 4,201,000 gallons. The estimated volumes depicted in each tank cross-section total 7,269,000 gallons of waste (Agnew, January 1994). At the time of the estimate, there were 7,269,000 gallons of supernatant.

3.1 Tank 241-AP-101

3.1.1 241-AP-101 Tank History

3.1.1.1 Waste Hstory of Tank 241-AP-101

Tank 241-Ap-101 began service by recelving non-complexed waste in July 1986. During 1987, 1988, and 1989, the tank received waste from EUREX. The tank received non-complexed waste until May 1990. From June 1990 until the present, the tank has contained dilute non-complexed waste. The tank has not recelved any waste since the fourth guarter of 1989. The tank is currently an active dilute receiver tank containing waste that is being concentrated by the 242-A Evaporator.

\subsubsection{Temperature History of Tank 241-AP-101}

Temperature data for Tank 241-AP-101 are recorded by 18 thermocouples at known elevations on one themocouple tree inside the tank, located in riser 4. Non-suspect temperature data recorded between March 1986 and November 1993 for all 1B thermocouples were available from the computer automated surveillance system. Non-suspect temperature data taken between July 1989 and August 1993 for 12 of the themocouples were available from the surveillance analysis computer system. However, not all of the 12 thermocouples have data that encompass the entire length of time. Within the time spans of each system, there were small breaks in the sequence of temperature data. The average temperature during these periods was $60^{\circ} \mathrm{F}$ with a minimum of $49^{\circ} \mathrm{F}$, a maximum of $81^{\circ} \mathrm{F}$, and a standard deviation of 4. $3^{\circ} \mathrm{F}$. Ijnear regressions were performed on each thermocouple that had temperature data between January 1990 and January 1994. The slopes from these regressions were averaged with a resulting average slope of $-0: 0028$. Refer to the supporting document for a more thorough review of the temperature data (Brevick 1995).

\subsubsection{Occurrences of Tank 24I-AP-101}

No unusual events are associated exclustvely with Tank 241-AP-102.

\subsubsection{Psychrometrics of Tank 241-AP-101}

Psychrometric data have been recorded from this tank for 12 years and from the annulus for six years. The apparent trend of the evaporation rate

$$
-78-\quad 6 / 95
$$




$$
\text { WHC-SD-WM-ER-350, Rev. } 0
$$

from the tank has decreased from 76.7 gallons per week in May 1988 to 48.3 gallons per week in January 1995. Over that same period, the trend in the rates of heat exchange through the primary tank and annular ventilation has apparently decreased. A review of the psychrometric data in Tank 241-AP-101 would suggest an overall decrease in the rate of heat generation by the waste.

\section{1 .2 Current status of Tank 241-AP-101}

Tank 241-AP-101 was placed into service in october 1986 and currently stores 1,060,000 gallons of waste. The following plan view and tank crosssection depict the approximate waste volume of 1,060,000 gallons and configuration of risers in January 1994. At the time of the estimate, all 1,060,000 galions were supernatant. The waste level in the tank is measured with the FIC gauge and the manual tape and has increased and decreased between 385 inches and 54 snches. The increases were additions of waste from Tank 241-AP-108 occurring in october 1994 and January 1995. The decreases came from transferring waste to Tank 24i-AW-102 in October 1994. This tank is active and the waste is currently being concentrated by the 242-A Evaporator. The tank is actively ventilated and categorized as sound. Tank 241-AP-101 has 71 risers. Eight 4-inch risers (no.15, no.21, no.24, no.26, three no.27s, and no.28), three 12-inch risers (no.7 and two no.10s), and two 42 -inch risers (two no.5s) are available for use.

\subsubsection{Enventory Estimate of Tank 241-AP-101}

The tank layer model (a volume based approximation) that follows was derived from the uos Alamos National Laboratory vaste status and Transaction Record Summary (Agnew 1995) and Supernatant Mixing Model (Agnew 1995). The estimeted inventories of total waste, solids, and supernatant in Tank 241-AP-101 are also presented.

3.1.2.2 In-Tank Photograph of Tank 241-AP-101

No in-tank photographs are available.

3.1.3 Synopsis of Tank 24I-AP-101

(To be completed.) 


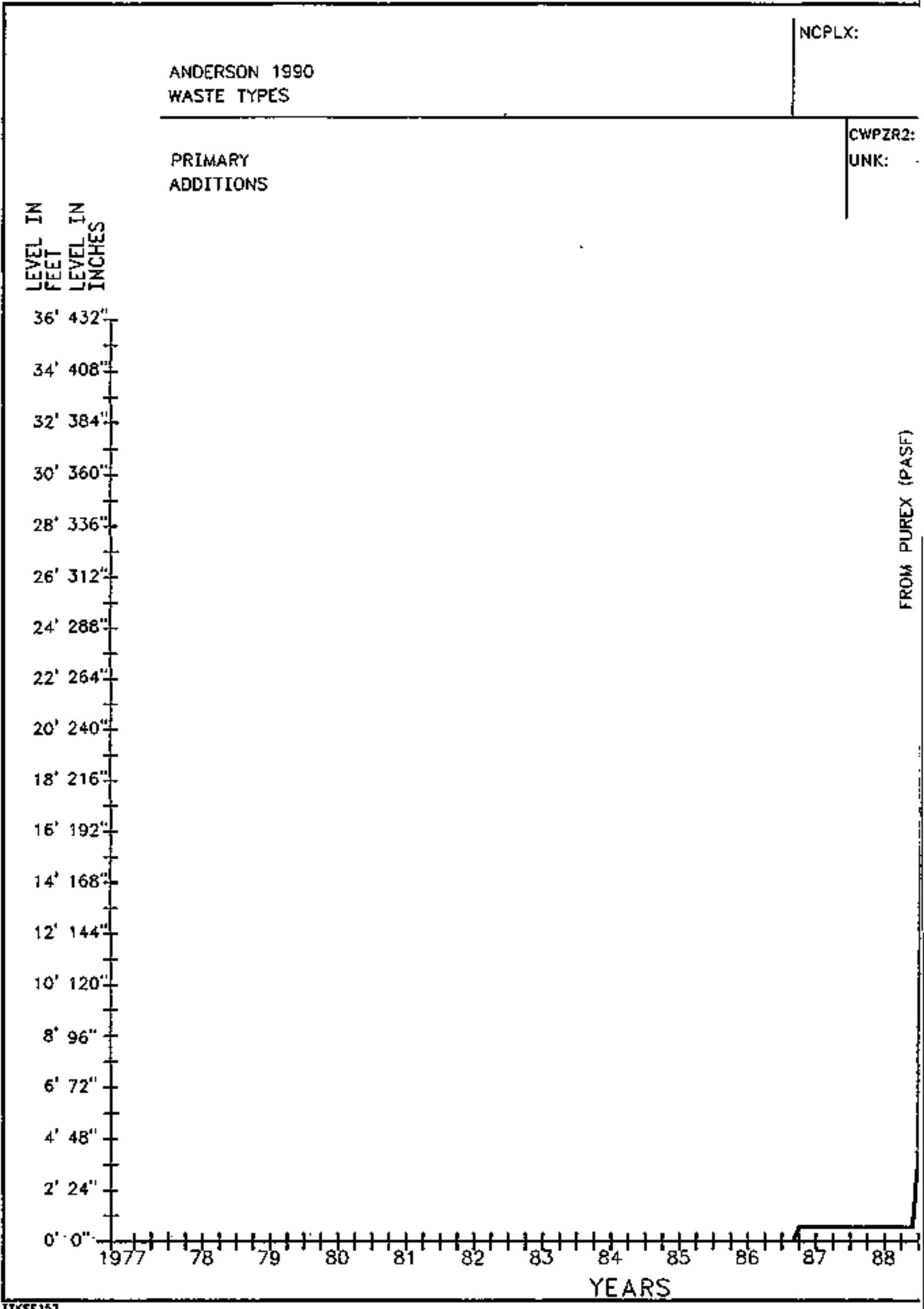


HHC-SD-HM-ER-350, Rev, 0

\begin{tabular}{|c|c|c|c|}
\hline \multicolumn{4}{|c|}{ Double-Shell Tank 241-AP-101 } \\
\hline \multicolumn{4}{|c|}{ 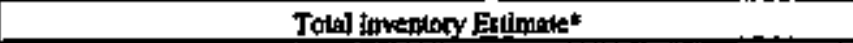 } \\
\hline \multicolumn{4}{|c|}{ 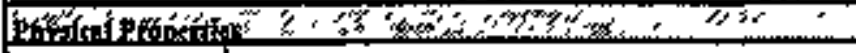 } \\
\hline Torol Whate & \multicolumn{3}{|c|}{ 4,16E+05 kg (10,06E+03 kga $\}$} \\
\hline Healland & \multicolumn{3}{|c|}{ 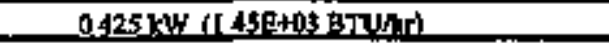 } \\
\hline Bull Dystigyt & \multicolumn{3}{|c|}{10 od $(y / x)$} \\
\hline Water wt:kt & \multicolumn{3}{|c|}{93.2} \\
\hline TOC whe & \multicolumn{3}{|c|}{0.086} \\
\hline \multicolumn{4}{|c|}{ 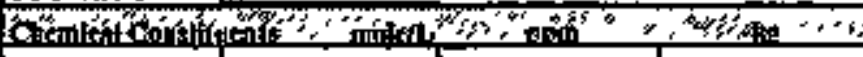 } \\
\hline $\mathrm{Na}^{*}$ & 0.349 & $1.87 \mathrm{E}+0.09$ & $7.79 \mathrm{~B}+0$ \\
\hline Al* & $879 \mathrm{EA} 2$ & $2,79 F+03$ & ES1P \\
\hline$F_{0}{ }^{3}(\operatorname{ton} a \mid f e)$ & 2.59E-0.5 & 139 & \\
\hline $\mathrm{C}^{\mathrm{p}+}$ & $257 \mathrm{E}=09$ & 129 & \\
\hline Bt" & 5.17E-0.s & 10.4 & \\
\hline $1 x^{*}$ & $360 \mathrm{E}-07$ & $482 \mathrm{E}, 02$ & \\
\hline $\mathrm{Hr}$ & $1.115+06$ & 0.216 & \\
\hline 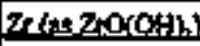 & 268E:-4.4 & 296 & \\
\hline $\mathrm{Fb}^{2+}$ & 8.83E-0.6 & 1.76 & \\
\hline $\mathrm{Min}^{2+4}$ & $5779-04$ & 324 & \\
\hline $5 t^{4+2}$ & $3.800-07$ & 321E-02 & 0.1 \\
\hline $\mathrm{Mn}^{4 *}$ & $\triangle 12 E-0 ;$ & 59.5 & \\
\hline$C^{* 2}$ & [.8IE-102 & 699 & 2.91E \\
\hline$x^{*}$ & |95E-0? & 734 & 3065 \\
\hline 욥 & 0.414 & $6.78 \mathrm{~B}+03$ & $2.82 \mathrm{E}$ \\
\hline NOA & 0409 & $2 \triangle 9 R \div 01$ & $\pm .01 \mathrm{E}_{1}$ \\
\hline No: & $9,06 E_{-02}$ & $4.02 E+0.9$ & 1.67E \\
\hline$c \alpha_{2}^{2}$ & $586 \mathrm{E}-02$ & 33904013 & LAlE \\
\hline $\mathrm{PO}_{4}^{+2}$ & 1.57E-02 & 1,44 포영 & S.97E \\
\hline sol. & |,902_02 & $176 \mathrm{E} 40 \mathrm{~g}$ & 732E \\
\hline$\$\left(A S O S^{2}\right)$ & 4,235-0.03 & 114 & \\
\hline$F$ & 2.23E:02: & 409 & LtoEto \\
\hline c도 & L.33E.02 & 454 & $1.59 \mathrm{E}+0$ \\
\hline chos. & 2A8E-0:3 & 453 & 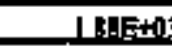 \\
\hline EOTA ${ }^{4}$ & $7.29 \mathrm{E}-04$ & 202 & 84 \\
\hline HEDT $\Delta^{2}$ & $121 E=03$ & 219 & $133 E+6$ \\
\hline 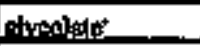 & 194E:02 & LAOEL & S.82840 \\
\hline ceelinté & B,A3EN-04 & 45.7 & \\
\hline onlutest. & $136 E_{-0} 04$ & 0.114 & 048 \\
\hline DBP & 1.13E-09 & 376 & \\
\hline hotitiol & $1,132-03$ & 200 & \\
\hline $\mathrm{NH}_{3}$ & Q & $177+00$ & $737 \sqrt{40}$ \\
\hline $\mathrm{F} \alpha \mathrm{CON} \mathrm{N}^{2}$ & & 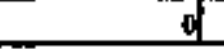 & \\
\hline \multicolumn{4}{|c|}{ 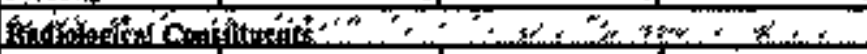 } \\
\hline Pu & & 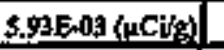 & 0,41! as \\
\hline $\mathbf{y}$ & $809 \mathrm{~B}_{\mathrm{B}}(\mathrm{ld} \alpha \mathrm{AM})$ & 186 fues: & $m_{2} s_{S B}$ \\
\hline $\mathbf{c s}$ & L.96E-02(C)t:) & $18, g(u C)$ & 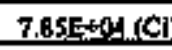 \\
\hline St & 213E-03 (Cin) & $2.06\langle 4 \mathrm{CVg}$ & $8.56 \mathrm{E}+0 \mathrm{0}(\mathrm{C}$ \\
\hline
\end{tabular}

-Uhipowos to rank solids hentory are arsigoed by Tant Layer Moded (TLM).

tVoltume average for deasty, mass averige Wake wth and IOC wro C.

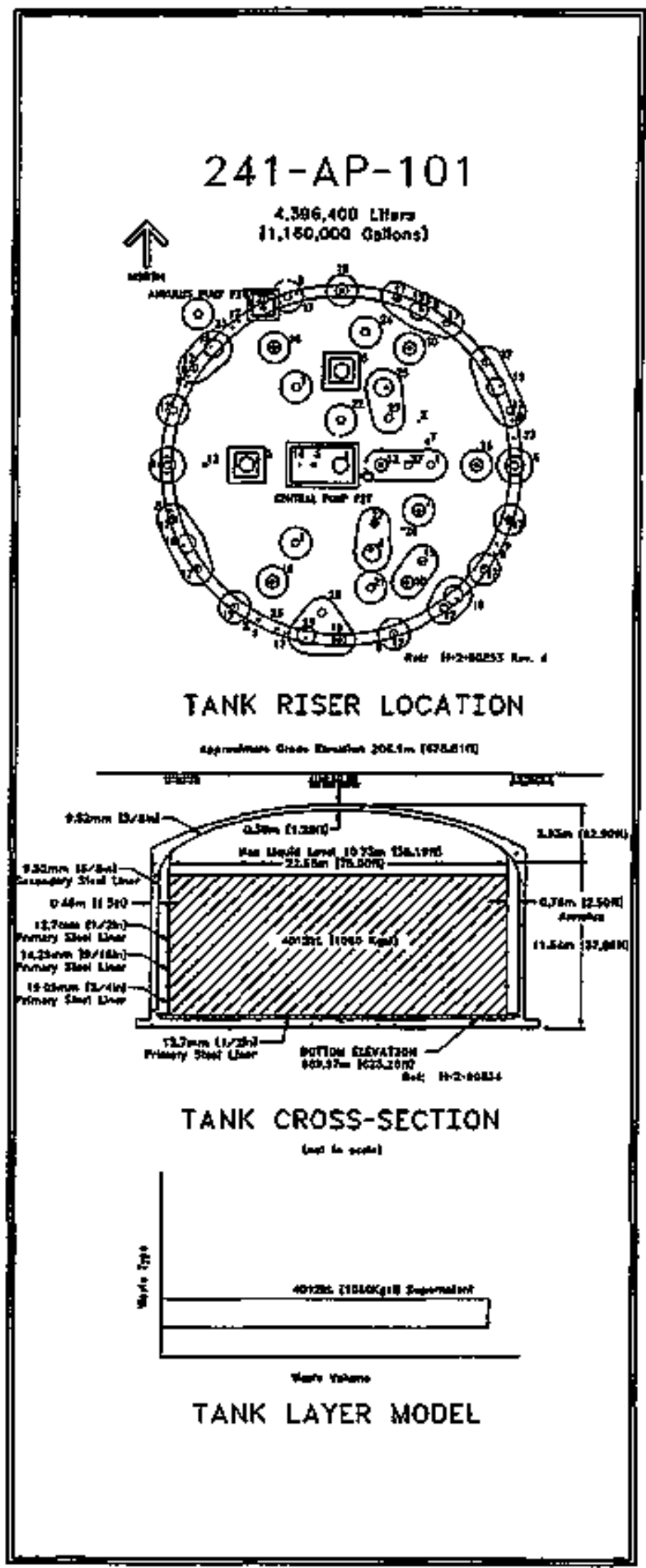




\begin{tabular}{|c|c|c|c|}
\hline \multicolumn{4}{|c|}{ Double-Shell Tank 241-AP-10] } \\
\hline \multicolumn{4}{|c|}{ 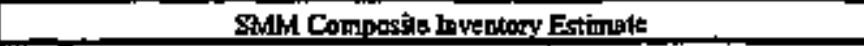 } \\
\hline \multicolumn{4}{|c|}{ 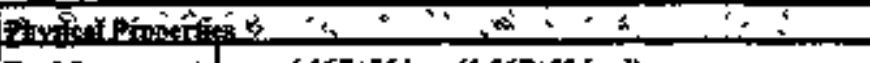 } \\
\hline 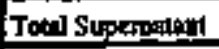 & \multicolumn{3}{|c|}{$4.16 \mathrm{E}+6.6 \mathrm{~kg}$ (1.06E+03 kgal) } \\
\hline 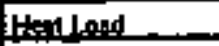 & \multicolumn{3}{|c|}{$0425 \mathrm{~kW}(145 \mathrm{E}+03 \mathrm{BTH} / \mathrm{hr}$} \\
\hline Bull. Denthe & \multicolumn{3}{|c|}{$1.04(\pi / 2 x)$} \\
\hline Wader wotkt & \multicolumn{3}{|c|}{932} \\
\hline $70 \mathrm{C}$ wet/ C (wel) & \multicolumn{3}{|c|}{0.0086} \\
\hline \multirow{2}{*}{\multicolumn{4}{|c|}{ 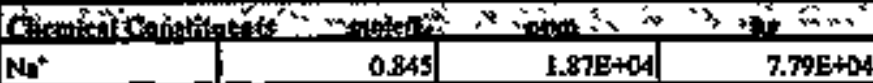 }} \\
\hline & & & \\
\hline $\mathbf{A l}^{*}$ & $879 \mathrm{E}-09$ & $2.295 \div+0 \mathrm{~g}$ & Q.51F+13 \\
\hline $\mathrm{F}=\mathrm{V}^{+}$(101al Fo) & 2.59E-0 & 139 & $\$ 79$ \\
\hline$C_{1}^{*}$ & 2,57E-0 & 129 & 57 \\
\hline $\mathrm{Bi}^{*}$ & 5.17E-0\$ & 10.4 & 43.4 \\
\hline Let & 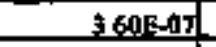 & $48>$ sing & 02 in \\
\hline Het. & 1.J1E,06 & 0.216 & 0.897 \\
\hline 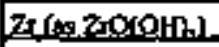 & 2688. 04 & 256 & 981 \\
\hline $\mathrm{Pb}^{1+}$ & 8.83E-06 & {$[.76$} & 7.34 \\
\hline $\mathrm{Ne}^{*+}$ & STENA4 & 32.4 & 130 \\
\hline $\mathbf{s i n}^{*+}$ & $3.800-07$ & $321 \mathrm{E}-02$ & 0.134 \\
\hline $\mathrm{MB}$ & 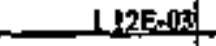 & 595 & 247 \\
\hline $\mathrm{Ce}^{\mathrm{T}}$ & $18 \mathrm{IE}-02$ & 699 & $2.91 \mathrm{E}+0 \mathrm{~s}$ \\
\hline $\mathbf{K}^{*}$ & 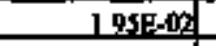 & 794 & 3 OSE +0 S \\
\hline 암 & $0,4 \mid 4$ & $6,78 \mathrm{E}+03$ & $2825+04$ \\
\hline $\mathrm{NO}_{+}^{+}$ & 0.407 & 2437401 & 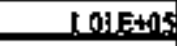 \\
\hline No: & 9.06E-02 & $4.02 E+03$ & L.67E+0.4 \\
\hline $\cos 2^{2}$ & SE6E_C? & $335=03$ & LAfE+14: \\
\hline $\mathrm{PO}^{2}$ & $1.57 \mathrm{E}-0 \mathrm{~d}$ & 1.44E+09 & $5.97 \mathrm{E}+09$ \\
\hline $\mathrm{SO}^{2 .}$ & 1 - $20=-0$ 에 & 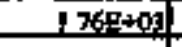 & $7325+19$ \\
\hline $\mathrm{Si}\left(\mathrm{as} \mathrm{SSO}_{2}^{2}\right)$ & 423E-109 & 114 & 476 \\
\hline $\mathrm{F}$ & 233E명 & 409 & L $70 \mathrm{~F}+403$ \\
\hline $\mathrm{Cr}$ & [ $33 E-02]$ & 454 & $1.89 \mathrm{E}+03$ \\
\hline $\mathrm{C}_{\mathrm{AH}} \mathrm{H}^{3}$ & 248됴영 & 453 & $18+85+03$ \\
\hline EDrA & $729 \mathrm{E}-04$ & 202 & 84 \\
\hline HETYA ${ }^{2}$ & 1.21 $\leq-03$ & 319 & {$\left[33 s_{4}+03\right.$} \\
\hline rivesulte: & $1,94 E=07$ & ل & 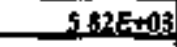 \\
\hline apdais" & $8.03 E-04$ & 45.7 & 190 \\
\hline arahtit. & L36E-06 & 0.115 & 0400 \\
\hline DBP & $1.13 \mathrm{E}-0 \mathrm{~s}$ & 176 & 73 \\
\hline bringl & 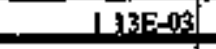 & 80 & 337 \\
\hline N & - 01098 & $1.72 \pm 03$ & 7375403 \\
\hline $\mathrm{Fe}(\mathrm{ON}) \mathrm{u}^{4}$ & 0 & & \\
\hline 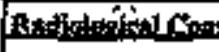 & 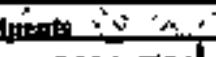 & 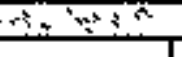 & $\therefore$ \\
\hline Pu & 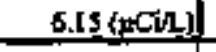 & & 0.45 (k) \\
\hline 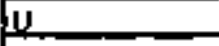 & $809 \mathrm{E}-\mathrm{OS}$ (M) & - I & 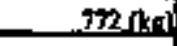 \\
\hline$c_{s}$ & 1.96E 02 (CAL) & $18.9(\mathrm{pC} / \mathrm{s})$ & $7.85 \mathrm{E}+04$ (C) \\
\hline st & 2.13E- 03 ( $\mathrm{CN}$ L) & $2.06(\mu \mathrm{C}+1 / \mathrm{g})]$ & $856 \mathrm{E}+03$ (C) \\
\hline
\end{tabular}

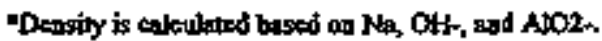

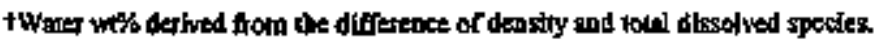

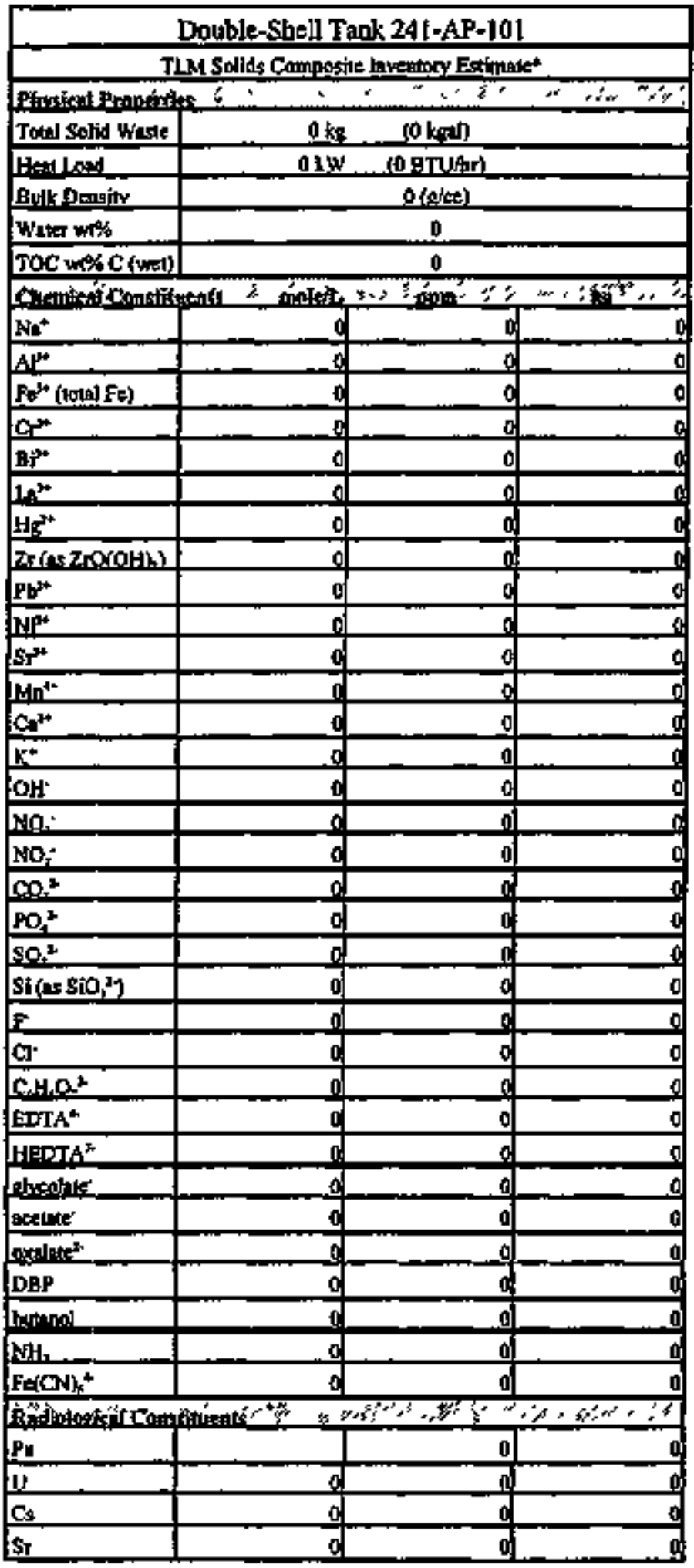

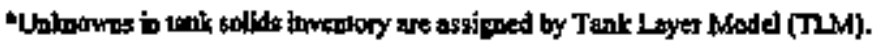


3.2 .1 241-AF-102 Tank History

3.2.1.1 Waste History of Tank 241-AP-102

Tank 241-AP-102 began service by receiving tanford facility waste in July 1986. The tank received Hanford facility waste until May 1990. During 1988 and 1989, waste was transferred from the tank to the grout vaults. The tank received waste from PURPX during the third and fourth quarters of 1989. The tank has contained dilute non-complexed waste since June 1990. The tank has not received any waste since the fourth guarter of 1992. The tank is currently an inactive, grout feed tank containing excess water from the grout facility.

\subsubsection{Temperature History of Tark 241-AF-102}

Temperature datz far Tank 241-AP-102 are recorded by 18 thermocouples at known elevations on one thermocouple tree inside the tank, located in ristr 4. Non-suspect temperature data recorded between Mazoh 1986 and Novenber 1993 for 17 thermocouples were available from the computer automated surveillance systen. Non-suspect temperature data from between July 1989 and August 1993 for 12 of the thermocouples were available from the surveiliance analysis computer system. However, not all of the 12 thermocouples have data that encompass the entire length of time. Within the time spans of each system, there were small breaks in the secuence of temperature data. The average temperature during these periods was $66^{\circ} \mathrm{F}$ with a minimum of $50^{\circ} \mathrm{F}$, a maximum of $86^{\circ} \mathrm{F}$, and a standard deviation of $8.5 \%$. I inear regressions were performed on each thermocouple that had temperature data between January 1990 and January 1994. The slopes from these xegressions were averaged with a resulting average slope of 0.017 . Refer to the supporting doctwent for a more thorough zeview of the temperature data (Brevick 1995).

\subsubsection{Occurrences of Tank 241-AP-102}

No unusual events concerned this tank since it went into service.

\subsubsection{Psychrometrics of Tank 241-AP-102}

Psychrometric data have been recorded from this tank and annulus for six years. The apparent trend of the evaporation rate from the tank has decreased from 63.4 gallons per week in May 1988 to 49.3 gallons per week in January 1995. Ovex that same period, the trend in the rates of heat exchange through the primary tank ventilation hes decreased. The rates of heat exchange through the annular ventilation show an increasing trend. The majority of the changes in the xate of heat exchange can be attributed to changes in the average ventilation rates. A review of the psychrometric data in Tank 241-AP-102 would suggest an increase in rate of heat generation by the waste. 


$$
\text { WHC-SD-WM-ER-350, ReV. O }
$$

3.2.2 Current status of Tan's 241-AP-102

Tark 241-AP-102 was placed into service in October 1986 and currently stores 1,104,000 gallons of waste. The following plan view and tank crosssection depict the approximate waste volume of $1,104,000$ gallons and configuration of risers in January 1994. At the time of the estimate, all 1.104,000 gallons were supernatant. The waste level in the tank is measured with the FIC gaugs and the manual tape and has increased from about 50 inches in January 1991 to 400 inches in Jantiary 1994 . The increase was mostiy waste received from Tank 241-AN-106 between November 1992 and January 1993. This tark is inactive at the present time. The tank is actively ventilated and categorized as sound. Tenk 241-AP-102 has 71 risers. Six 4-inch risers (no.15, no.21, three no.27s, and no.28), two 12-inch risers (no.7 and no.10), and two 42-inch risers (two no.5t) are availeble for use.

3.2.2.1 Inventory Estiante of Tank 241-Ap-102

The tank layer model (a volume based approximation) that follows was derived from the Los Alamos National Laboratory Waste status and Transaction Record summary (Agnew 1995) and Supernatant Mixing Model (Agnew 1995). The estimated inventories of total waste, solids, and supernatant in Tank 241-AP-102 are also presented.

3.2.2.2 In-Tank Photograph of Tenk 241-AP-102

No in-tark photographs are available.

$3.2 .3 \quad$ Symopsis of Tank 241-AF-102

(To be completed.) 
ANDERSON 1990

WASTE TYPES

즌

PRIMARY

AODITIONS

본넌

岂出

$36^{\circ} 432^{\prime \prime}$

34 408'牛

32 '384"-

$30^{\prime} 360^{\prime \prime}$

28' 336"-

26' 312"

$24^{\prime} 288^{\prime \prime}-$

$22^{\prime} 264^{4}+$

$20^{\prime} 240^{\circ}-$

18. $216 "$

16' $192^{\prime \prime}$

14. 168'

12' $144^{4}$

$10^{\prime} 120^{\prime \prime}$

8' 96.

6' $72^{\prime \prime}$

4. 48 "

LIQUID

LEVEL

2' $24^{\prime \prime}$

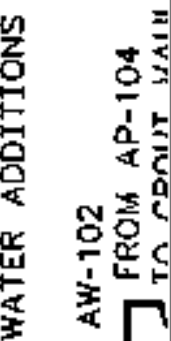

品 9

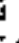




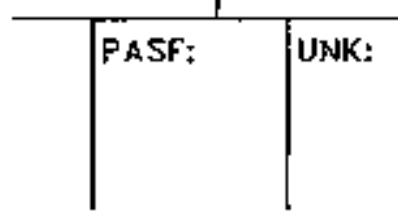

ON:

NOTES:

CONSTRUCT 1980-1981

NOMIHAL CAPACITY: $1,000,000$ GAL

75 FOOT OI AWTETER DOU KNUCKLEL' TANK

SURRACE LEVEL READING: FHOTO

(LIOUIOS \& SOLIDS), FIC (SOLIOS)

\section{INVENTORY ESTIHATE DATE}

CAPACITY

(GALLONS)

HFW: HANGORO FACILITY WASTE

DW: DILUTE NON-COMPLEXEO WASTE

$-1,188,000$

PASF: PUREX AMWONIA SCRUBEER FEEO WASTE

-

UNK: LNNKNOWN

$-1,122,000$

$-$

$-1,056,000$

-

$n$
5
3
5
5
0
0

$-990,000$

$-$

- 924,000

LEGEND

- 858,000

DE LIOUIO OESERVATION

— LIQUFO LEVEL

- 792,000

$777 /$ SOLIOS LEVEL

- 792,000

HH H H SOLIDS LEVEL OEST

-

$-726,000$

$-$

$-\quad 660,000$

$-$

$-\quad 594,000$

$-$

$-\quad 528,000$

-

- 462,000

$-$

- 396,000

$-$

- 330,000

$-$

- 264,000

YYYYY ENGINEERING JUDGEMENT

$-$

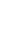

$-\quad 198,000$

$-$

$-\quad 132,000$

-

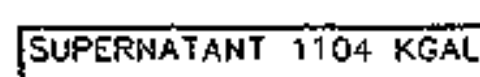

- 66,000

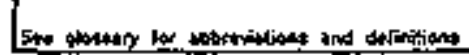

$-$

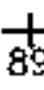

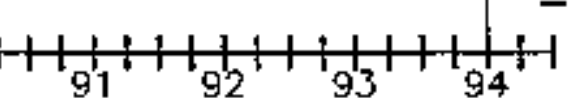

AP TANK FARM

PLOT PLAN

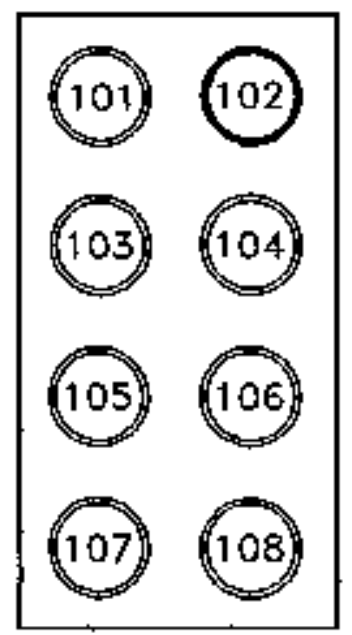

U.S. DEPA

PARTMENT OF ENERGY ICF KAISER HANFORD

241-AP-102 DOUBLE-SHELI TANK

LEVEL HISTORY 1986 TO 1994 SOUND/ACTIVE TANK WATCH LIST: $N / A$

0

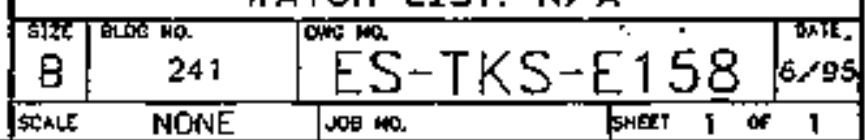


WHC-SD-WM-ER-350, Rev. O

\begin{tabular}{|c|c|c|c|}
\hline \multicolumn{4}{|c|}{ Double-Shell Tank 241-AF-102 } \\
\hline \multicolumn{4}{|c|}{ 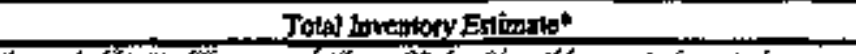 } \\
\hline \multicolumn{4}{|c|}{ 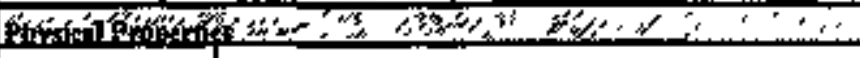 } \\
\hline Toul Waste & \multicolumn{3}{|c|}{$5.19 \mathrm{E}+06 \mathrm{~kg} \quad(1.10 \mathrm{~g}+03 \mathrm{kp}$} \\
\hline Hevertoot & \multicolumn{3}{|c|}{ 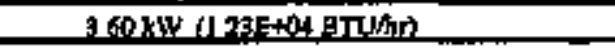 } \\
\hline Bulk Denimt & \multicolumn{3}{|c|}{$124(0 / k)$} \\
\hline Wascer wtht & \multicolumn{3}{|c|}{66.1} \\
\hline$T 0 C \sim \% \mathrm{C}$ & \multicolumn{3}{|c|}{0.58} \\
\hline \multicolumn{4}{|c|}{ 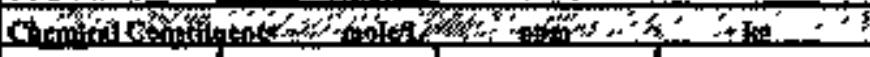 } \\
\hline $\mathrm{Ne}^{+}$ & 527 & $9.762+04$ & $5.07 \mathrm{E}+0 \mathrm{~S}$ \\
\hline Alit & 065 & $144 \operatorname{sen} 4$ & $750 \mathrm{E}+09$ \\
\hline 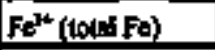 & 2.33E-093 & 127 & 659 \\
\hline$C^{3}+$ & 1SIEAP & 8III & $421 \mathrm{E}+0 \mathrm{~g}$ \\
\hline BH' & 7.18E-04 & 121] & 627 \\
\hline "اته & $4.916=96]$ & 0.549 & 2.55 \\
\hline Her & 4.3AE-16 & 0.701 & 3.64 \\
\hline $7 \mathrm{x}(\mathrm{x} \mathrm{xOH})$ & $4,30, E=0,04$ & 316 & 164 \\
\hline $\mathrm{Pb}^{7 *}$ & 4,00E-OS & 6.67 & 34.6 \\
\hline $\mathrm{N}^{*+}$ & 24760033 & $11: 7$ & EOS \\
\hline$s^{2 *}$ & S.49E-06 & 0.366 & 190 \\
\hline Mnsto & 3698:03 & $16 !$ & 84 \\
\hline $\mathrm{Ca}^{7+}$ & $1.98 \mathrm{E}=02$ & 698 & $3,31 \mathrm{E}+103$ \\
\hline $\mathbf{k}^{*}$ & JAME-02] & 4; & $234 \mathrm{E}+00^{3}$ \\
\hline 애 & 2.96 & 4.05E+0A & $2.10 E+0$ S \\
\hline $\mathrm{NO}:$ & 181 & gDope+os & $469 \mathrm{E}+0.8$ \\
\hline $\mathrm{NO}:$ & 1.22 & $4528+04$ & $2.35 \mathrm{E}+0 \mathrm{~B}$ \\
\hline $\mathrm{CO}_{2}^{2}$ & azlo & $1020+04$ & $5285=+04$ \\
\hline $\mathrm{PO}_{4}^{2}$ & 0.100 & $8378+03$ & $4.34+209$ \\
\hline$S 0^{2}$ & 01142 & t.lofe+of & $5 \pi=40$ \\
\hline st $\operatorname{cas} 5[0,2]$ & $2.29 \mathrm{E}-\mathrm{0O2}$ & \$12 & $2.69 \mathrm{E}+0.3$ \\
\hline$F$ & $421 \mathrm{E}$ QR? & 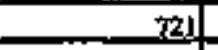 & $324 \mathrm{E}+03$ \\
\hline$a$ & 9.13E-02] & $260 \mathrm{E}+03$ & $1.35 \mathrm{E}+04$ \\
\hline $\mathrm{C}_{\mathrm{H}} \mathrm{H} \mathrm{O}^{2}$ & 13TE-0? & 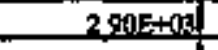 & $1515+29$ \\
\hline 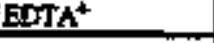 & $1.04 \mathrm{H}_{\mathrm{E}}, 02 \mathrm{a}$ & $2,42 E+03$ & 1.26E+04 \\
\hline BEUTA & $17 F=02$ & $378 . \pm 2 !$ & L96E+10 \\
\hline shupolitic: & S36E- 02 & $3,84 E+1 ; 3$ & $2005+20 y$ \\
\hline actesto" & t.196-02 & 557] & $294 E+03$ \\
\hline sanestat. & 1835E-05 & 131 & 688 \\
\hline Dap & $9.86 \mathrm{E}, 03$ & $\mid 2: E E+013$ & $6.635+03$ \\
\hline butus.d & 980.03 & s通 & $3005+03$ \\
\hline $\mathrm{NH}_{2}$ & $261 E-42]$ & 3597 & $185 \mathrm{E}+0 \mathrm{03}$ \\
\hline$F \in(C N)$ & & 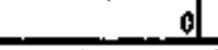 & \\
\hline \multicolumn{4}{|c|}{ 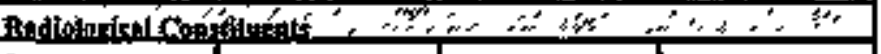 } \\
\hline By & & 1.BOE-02 (uCL:) & $1.58\langle\mathbf{k g}$ \\
\hline ㄴ․ & $2955-05 \mathrm{MI}$ & 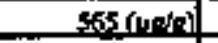 & $293 \mathrm{E}+0 \mathrm{0}$ (ks) \\
\hline $\mathrm{Cs}_{\mathbf{s}}$ & ontcind & 112(ucilg) & T38E+05(C) \\
\hline sri & 5. $16 \mathrm{E}-03$ (C) 2 ) & 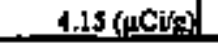 & 2.15E $=01$ (C) \\
\hline
\end{tabular}

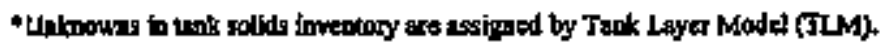

t Yolume evenge for desefity, mass everage Water wits and TOC w\%C.

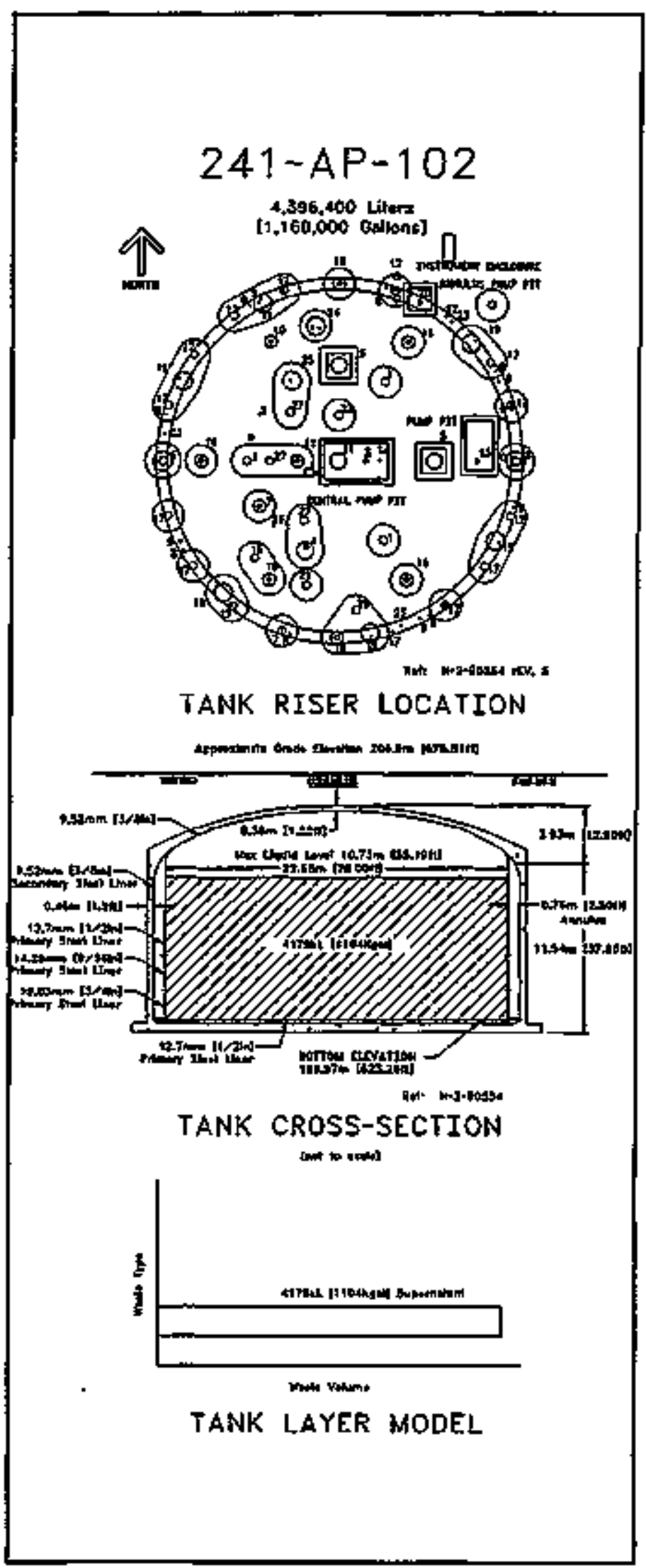




\begin{tabular}{|c|c|c|c|}
\hline \multicolumn{4}{|c|}{ Double-Sbell Tank 241-AP-102 } \\
\hline \multicolumn{4}{|c|}{ 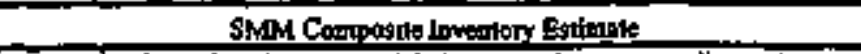 } \\
\hline \multicolumn{4}{|c|}{ 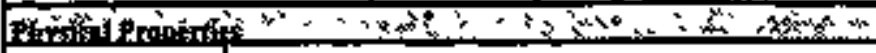 } \\
\hline Tond Suptemeinin & \multicolumn{3}{|c|}{ 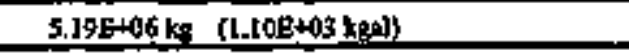 } \\
\hline Hexthend & \multicolumn{3}{|c|}{ 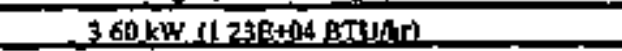 } \\
\hline Aylk Darisise & \multicolumn{3}{|c|}{$124(200)$} \\
\hline Wher netst & \multicolumn{3}{|c|}{66.1} \\
\hline$T O C$ wit $C$ (wa) & \multicolumn{3}{|c|}{0.596} \\
\hline \multicolumn{4}{|c|}{ 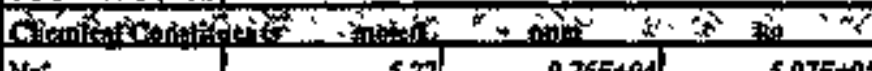 } \\
\hline & $5,2]$ & $9.76 E+(0)$ & \\
\hline $\mathrm{A}^{2 *}$ & 0.665 & 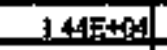 & $750=$ \\
\hline $\mathrm{Fe}^{*}(\mathrm{tgt}, \mathrm{Pa})$. & $2.83 \mathrm{E}_{-03}$ & 127 & \\
\hline 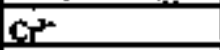 & 194:-00 & 811. & 4231E \\
\hline$B P^{*}$ & $7.18 \mathrm{E}-04$ & 121 & \\
\hline Le* & $491 E_{-106}$ & 0349 & \\
\hline $\mathrm{HO}^{3+}$ & $434 \varepsilon-06$ & $0.70]$ & \\
\hline $\mathrm{Zr}\left(\mathrm{w} \mathrm{K}_{\mathrm{L}} \mathrm{COOH}\right)$ & $430 \mathrm{CE}-04$ & 3) 6 & \\
\hline $\mathbf{P t}^{*+2}$ & 4.005 .05 & 6,67 & \\
\hline NFt & 247E-03 & {$[1,7$} & \\
\hline sin & $\left.5,19 E_{0} 00\right)$ & 0.366 & \\
\hline $\mathrm{Mn}^{*}$ & $21695,0,9$ & -163. & \\
\hline $\mathrm{Ca}^{*+}$ & L.98E-02 & 638 & $3.3[E+0$ \\
\hline$K^{+}$ & 1435-O? & 451 & $234=$ \\
\hline $\mathrm{OH}$ & 296 & $4.098+04$ & $2.108+0$ \\
\hline $\mathrm{NO}$ & {$[181$} & $9078+0$ & $4695+19$ \\
\hline No: & 1,22 & $4.528+0,00$ & $2.358+4$ \\
\hline $\mathrm{Ca}^{2}$ & 2210 & $102 E+04$ & $5218+4$ \\
\hline $\mathrm{gO}^{2}$ & 0.109 & $8378+0,0$ & $4,34 \mathrm{E}+4$ \\
\hline $\operatorname{sos}^{2}$ & 0.43 & 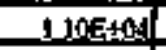 & $372 \mathrm{E}_{4}$ \\
\hline St $\left\{\right.$ as $S x_{1}^{29}$ & 2.29E-02 & s1 t & $2.695+0$ \\
\hline $\mathrm{F}$ & 471E-0.2 & zil & $324 \mathrm{E}$ \\
\hline $\mathrm{c}^{\circ}$ & 9.13E-02. & $2.60= \pm 03$ & $1,35=10$ \\
\hline Cstoin & $1915=02$ & $290= \pm 13$ & $151 \mathrm{Et}$ \\
\hline EDTA & 1.04E-02 & $2.42 \mathrm{E}+103$ & t. $26 \mathrm{E}+0$ \\
\hline HEDTA2 & $171 \mathrm{E}=012$ & $378 E+03$ & 1 96E $* 0$ \\
\hline ghrolates & 호 36름여 & $384 E+03$ & $2004+0$ \\
\hline atance & $1.196-108$ & 567 & $2.94 \mathrm{E}+0$ \\
\hline oxsalates & 185E-0S & -131 & \\
\hline DBP & 9.86E, 05 & 1.26E+03 & $6.63 E+03$ \\
\hline Anthol & $\left.986 E_{-2} n\right]$ & $58 \mathrm{~B}$ & $30.5 \mathrm{E}+103$ \\
\hline $\mathrm{NH}$ & 3.61E-02 & 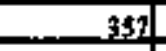 & $1858+0$ \\
\hline $\mathrm{F} \alpha \mathrm{CN})^{{ }^{4}}$ & 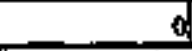 & & \\
\hline \multicolumn{4}{|c|}{ 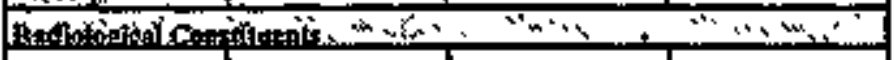 } \\
\hline Pu & $227(\mu \mathrm{C}) \mathrm{A})$ & & L.SB (kge \\
\hline ميل & 295E-05:401. & S65 (netros) & 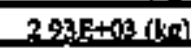 \\
\hline C: & $0.177(\mathrm{C} 2 \mathrm{~s})$ & 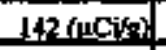 & 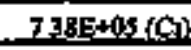 \\
\hline S* & $5.16 \mathrm{E}-03$ (C)L & $4.15\left(1, \mathrm{CH}_{\mathrm{g}} \mathrm{x}\right)$ & \\
\hline
\end{tabular}

*Densiby is cakulued besed an- $\mathrm{N}_{3}, \mathrm{OH}$, and $\mathrm{AlO2}$.

tWater wh\% derved from the difference of teasity and total dissalved sperios.

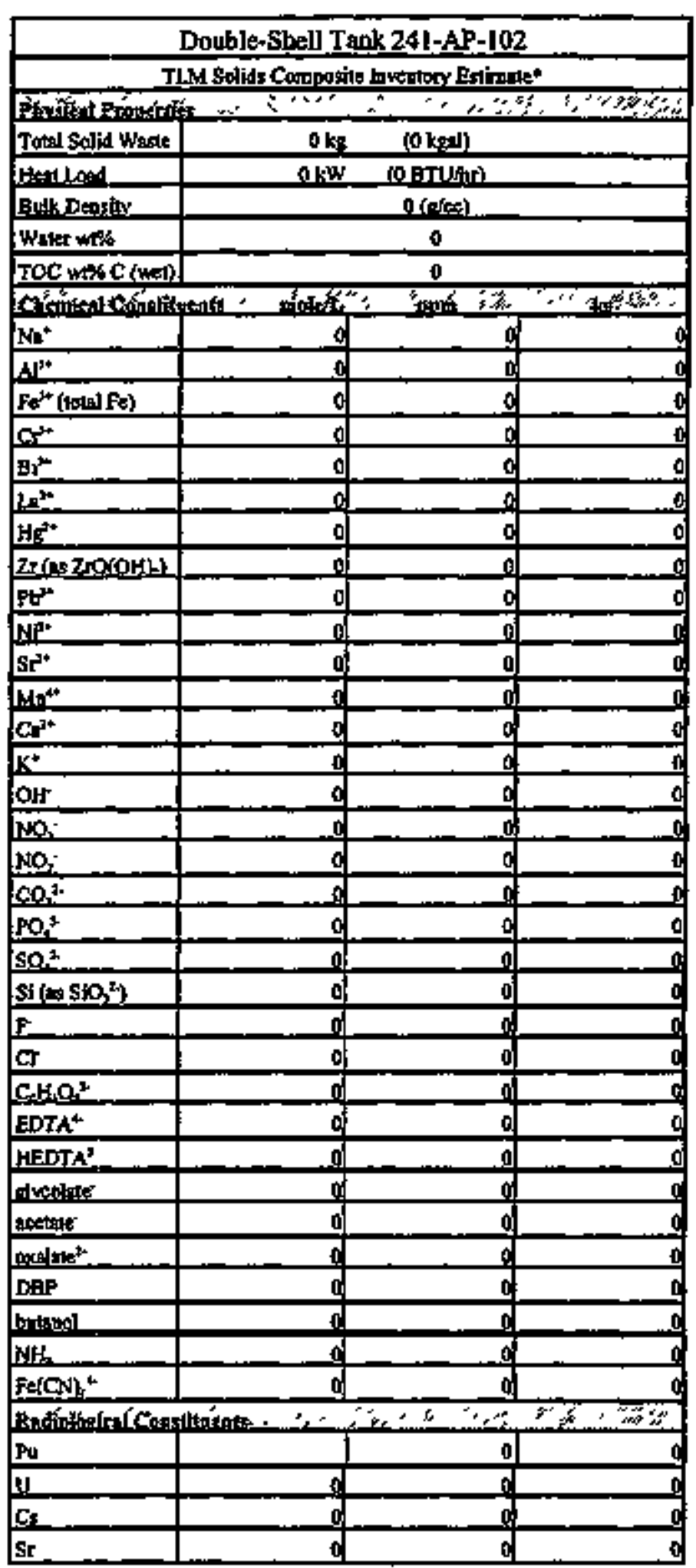

"Unknowas in tank solids invecuory are assigoed by Tank Loyer Moded (TMM). 
WHC-SD-WH-ER-350, Rev. 0

3.3 Tank 241-A.P-103

3.3.1 241-AP-103 Tank History

3.3.1.1 Waste History of Tank 241-AP-103

Tank 241-AP-103 began service by feceiving non-complexed waste in July 1986. The tank received non-complexed waste until May 1990. The tank received waste from PUREX during the first, second, and third quarters of 1988. From June 1990 until the present, the tank has contained dilute noncomplexed waste. The tank has not received waste since the second guarter of 1991. The tarik is currently an inactive dilute receiver tank.

\subsubsection{Temperature History of Tank 241-AP-103}

Temperature data for Tank 241-AP-103 are recorded by 18 thernocouples at known elevations on one thermocouple tree inside the tank, located in riser 4. Non-suspect tenperature data from between March 1986 and November 1993 for all 18 thermocouples were available from the computer automated surveillance system. Non-suspect temperature data taken between July 1989 and August 1993 for 12 of the thermocouples were available from the surveillance analysis computer system. However, not all of the 12 themocouples have data that encompass the entire length of time. Within the time spans of each system, there were small breaks in the sequence of temperature data. The average temperature during these periods was $63^{\circ} \mathrm{F}$ with a minimum of $52^{\circ} \mathrm{F}$, a maximum of $75^{\circ} \mathrm{F}$, and a standard deviation of $4.6^{\circ} \mathrm{F}$. Linear regressions were performed on each thermocouple that had temperatire date between January 1990 and January 1994. The slopes from these regressions were averaged with a resulting average slope of -0.0045 . Refer to the supporting document for a more thorough review of the temperature data (Brevick 1995).

\subsubsection{Occurrences of Tank 241-AP-103}

No unusual events exclusively concerned Tank 241-AP-103.

3.3.1.4 Psychrometrics of Tank 241-AP-103

Psychrometric data have been recorded for six years from this tank and annulus. The apparent trend of the evaporation rate from the tank has increased from 60.7 gallons per week in February 1988 to 79.9 gallons per week in January 1995. Over that same period, the trend in the rates of heat exchange through the primary tank ventilation has increased. The rates of heat exchange in the annular ventilation show decreasing trend. The majority of the changes in the rates of heat exchange can be attributed to changes in the average ventilation rates.. A review of the psychroinetric data in Tank 241-AP-103 would suggest a decrease in the rate of heat generation by the waste. 
3.3 .2 Current Status of Tank 241-AP-103

Tank 241-AP-103 was placed in se2vice in Detober 1986 and currently stores 27,000 gallons of waste. The following plan view and tank crosssection depict the approximate weste volume of 1,131,000 gallons and configuration of risers in January 1994. At the time of the estimate, all $1,131,000$ gallons were supernatant. Whe large decrease in volume was due to transferring waste to Tank 241-Aw-102. This tank is active and the waste is currentiy being concentrated by the 242-A Evaporator. The tank is actively ventilated and categorized as sound. Tank 241-AP-103 has 71 risers. Seven 4-inoh risers (no.15, no.21, no.24, three no.27s, and no.28), three 12-inch risers (no.7 and two no.10s), and two 42-inch risers (two no.5) are available for use.

\subsubsection{Inventory Estimate of Tank 241-AP-103}

The tank layer model (a volume based approximetion) that follows was derived from the fos Alamos National iaboxatory Waste Status and Transaction Record Summary (Agnew 1995) and Supennatant Wixing Model (Agnew 1995). The estimated inventories of total waste, solids, and supmrnatant in Tank 241-AP-103 are also presented.

3.3.2.2 In-Tank Photograpis of Tank 241-AP-103

No in-tank photographs are available.

3.3 .3 Symopsis of Tank 241-AP-103

(To be completed.) 


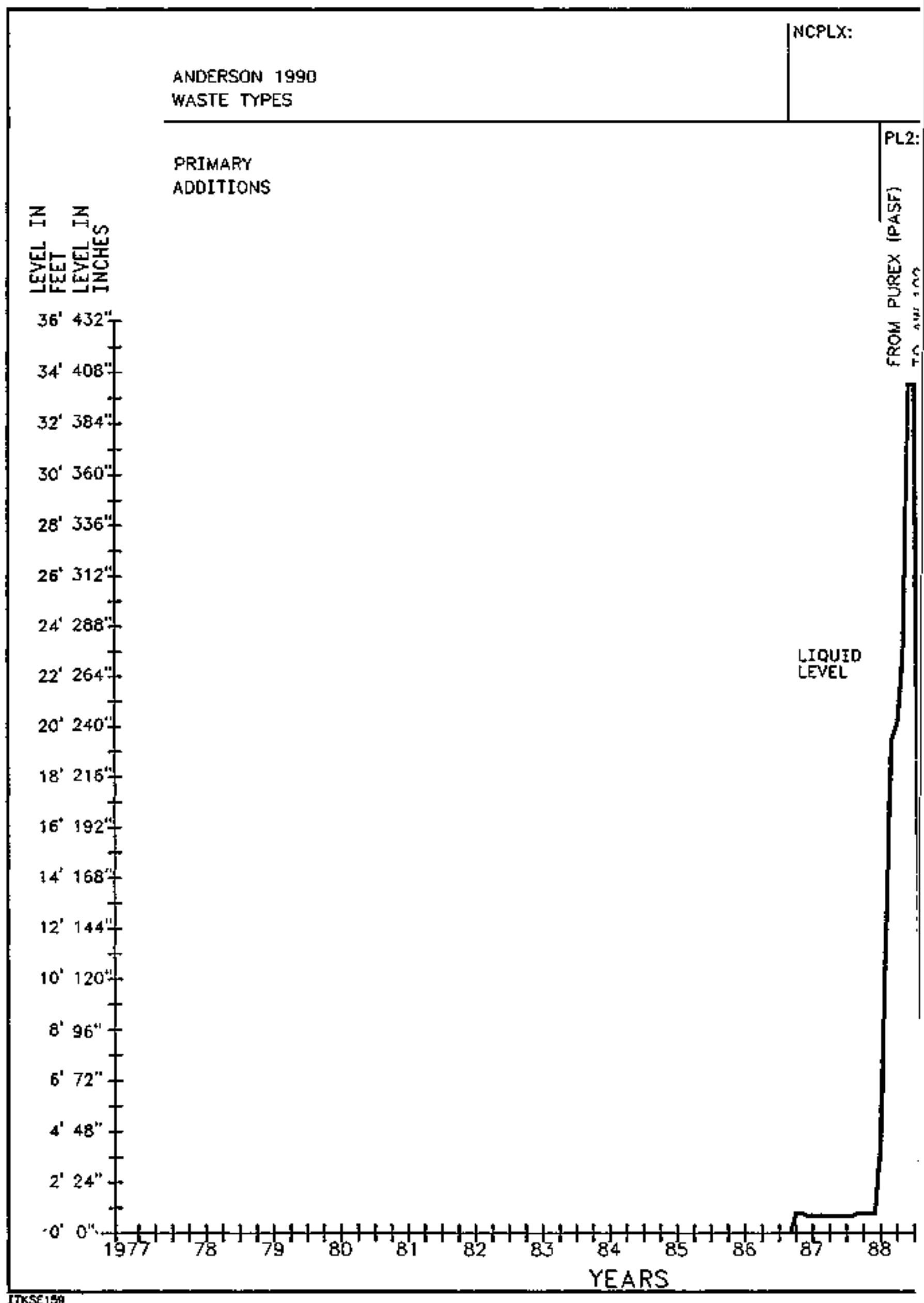


ON:

NOTES.

CONSTRUCT 1980-1981

NOWINAL CAPACITY: $1,000,000$ GAL

FAT BOTTON TANK, NO KNUCKLE.

75 FOOT DIAMETER DOUBLE-SHEWL TANK

SURFACE LEVEL READING: PHOTO

(LIOUIOS \& SOLIOS), FIC (SOLIDS)

INVENTORY ESTIMATE OATE

CAPACITY

(GALLONS)

$-1,188,000$

$-$

$-1,122,000$

-

$-1,056,000$

- 990,000

- 924,000

$-\quad 858,000$

$\sim$

$-\quad 792,000$

$-726,000$

$-$

- $\quad 660,000$

$-$

- $\quad 594,000$

$-$

- $\quad 528,000$

-

$-\quad 452,000$

$-$

- 396,000

-

- 330,000

$-$

$-\quad 264,000$

$-$

$-\quad 198,000$

$-$

$-\quad 132,000$

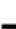

- 66,000
NCPLX: NON-COMPLEXED WASTE

ON: DILUTE NON-COMPLEXEO WASTE

PE2; PUREX LOW-LEVEL WASTE
LEGEND WELL (LOH) LIQUID LEVEL

7777, SOLIDS LEVEL

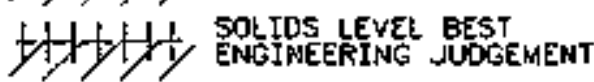

AP TANK FARM

PLOT PLAN

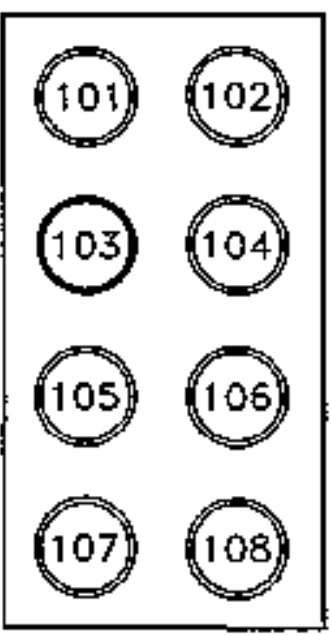

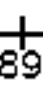

$\frac{1}{89}$

0

\begin{tabular}{|c|c|c|c|}
\hline \multicolumn{4}{|c|}{$\begin{array}{l}\text { U.S. DEPARTMENT OF ENERGY } \\
\text { RCCALAND FIELO OFFICE } \\
\text { ICF KAISER HANFORD }\end{array}$} \\
\hline \multicolumn{4}{|c|}{$\begin{array}{c}\text { 241-AP-103 DOUBLE-SHELL TANK } \\
\text { LEVEL HISTORY } 1986 \text { TO } 1994 \\
\text { SOUND/ACTIVE TANK } \\
\text { WATCH LIST: N/A }\end{array}$} \\
\hline $\begin{array}{l}\text { size } \\
\text { B }\end{array}$ & 241 & ES-TKS-E159 & \\
\hline Fulf & NONE & Nos to. The 1 & \\
\hline
\end{tabular}


WHC-SD-WM-ER-350, Rev, 0

\begin{tabular}{|c|c|c|c|}
\hline \multicolumn{4}{|c|}{ Double-Shell Tank 241-AP.103 } \\
\hline \multicolumn{4}{|c|}{ 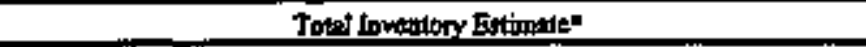 } \\
\hline \multicolumn{4}{|c|}{ 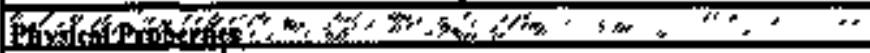 } \\
\hline Tutal Woste & \multicolumn{3}{|c|}{$4.71 \mathrm{E}+06 \mathrm{~kg},(1 \mathrm{~d} 3 \mathrm{E}+03 \mathrm{kgk})$} \\
\hline Hoil land & \multicolumn{3}{|c|}{ 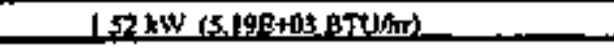 } \\
\hline Bun Densitut & \multicolumn{3}{|c|}{1.10 (abes) } \\
\hline Water west & \multicolumn{3}{|c|}{85.7} \\
\hline TOC WKC & \multicolumn{3}{|c|}{ - 0243} \\
\hline \multicolumn{4}{|c|}{ 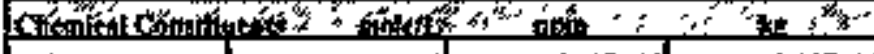 } \\
\hline $\mathrm{Na}^{*}$ & 2.19 & $4.58 \mathrm{E}+04$ & $2.155+05$ \\
\hline$A 1^{2 *}$ & 01267 & $6.54 \mathrm{R}+0 \mathrm{n})$ & $3008+04$ \\
\hline$F z^{2 *}$ (bold Fo) & 2.16E-0.3 & 310 & 516 \\
\hline C.t. & $4.88=03$ & 2311 & Logf +03 \\
\hline Bir* & 6.A6E-05 & 12.3. & 57.8 \\
\hline Lis* & $4125=07$ & $5200-02$ & 0,245 \\
\hline Hel: & 1395.006 & 0.243 & L.t.5 \\
\hline 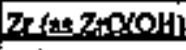 & 3.19E_ 04 & 26,3 & 124 \\
\hline $\mathrm{Pb}^{*+}$ & 1,09E-05 & 2.06 & 9.71 \\
\hline $\mathbf{H e}^{\mathbf{*}}$ & 156E:0? & 83.2 & 392 \\
\hline 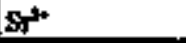 & 4,35E-0ri & 3.47E-002 & 0.163 \\
\hline $\mathbf{S h}^{4 *}$ & $1395=09$ & 693 & .376 \\
\hline . & 1.51 - -02 & ;ئ난 & $2.59=+09$ \\
\hline K. & $230 \mathrm{E} 02 \mathrm{~A}$ & 8194 & 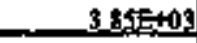 \\
\hline 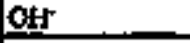 & 1.2. & $1.87 E+04$ & S.SIE+04 \\
\hline No: & .06 & $598 g_{+4}+4$ & 2.5]E+05 \\
\hline HO; & 0.139 & $\$ . \$ 18403$ & $2.55 \mathrm{E}+04$ \\
\hline$\omega_{0}^{2}$ & $0.0,150$ & $821 \mathrm{~B}+103$ & 3.875640 \\
\hline Fo: & 2.2IE-A2] & $1.916+0.3$ & $8.90 \mathrm{E}+03$ \\
\hline so: & $560.5-102$ & $489 \mathrm{E}+03$ & $230 \mathrm{E}+0 \mathrm{a}$ \\
\hline $\sin (\operatorname{sio})^{3}$ & 1.48E-02 & $\mathbf{3 7 9}$ & 1.78E+03 \\
\hline$F$ & 26:5E-07 & 463 & $218 \times+40$ \\
\hline Cl & 4.07ㄹ-02 & 1.31E+0: & $6.17 \mathrm{E}+0.3$ \\
\hline Cofing: & $7 \mid 72-0,4$ & $123 E+04$ & $500=103$ \\
\hline EDT:A & 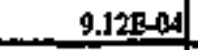 & 2390 & $1.12+03$ \\
\hline Hevor $A^{4}$ & $1 \leq 1 E=02$ & 376 & $1,77=01$ \\
\hline stueslmo: & 7BAE=0? & 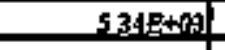 & $252 \mathrm{E}+04$ \\
\hline mentes & $1.01 E-03$ & 54.3 & 256 \\
\hline axame. & 2.55E-0.6 & 0.124 & 0.985 \\
\hline DBP & $2.4 \mid \mathrm{E}-0 \mathrm{0}$ & 206 & 972 \\
\hline botangl & $|4| \mathrm{E}-0 \mathrm{~B} \mid$ & 950 & 44 \\
\hline NH, & 8 :09E-D2? & $124 E+103$ & $5.84 \sqrt{2+012}$ \\
\hline $\mathrm{F} \in(\mathrm{CN}){ }^{*}$ & 0] & ol & 0 \\
\hline ffrotolós & 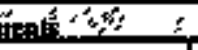 & 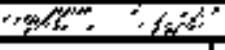 & 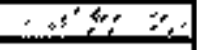 \\
\hline Pu & & 1.46E-02 $(\mu \mathrm{C} ; \mathrm{f}, \mathrm{s})$ & 1.140: \\
\hline u & $2 . \overline{1 F-03}(\mathrm{M})$ & 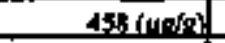 & $215 \mathrm{~F}=03$ (n) \\
\hline $\mathrm{Cs}$ & 6.921E $=02$ (C) & 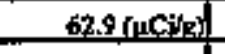 & 2.96e+05 (G) \\
\hline S & 4.59E-0 ( $\left.\mathrm{ClL}_{\mathrm{L}}\right)$ & 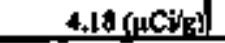 & $1,978+04(C)$ \\
\hline
\end{tabular}

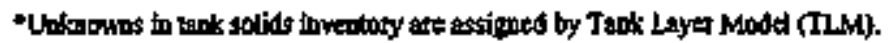

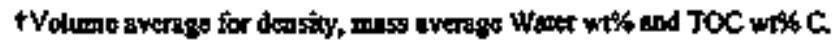

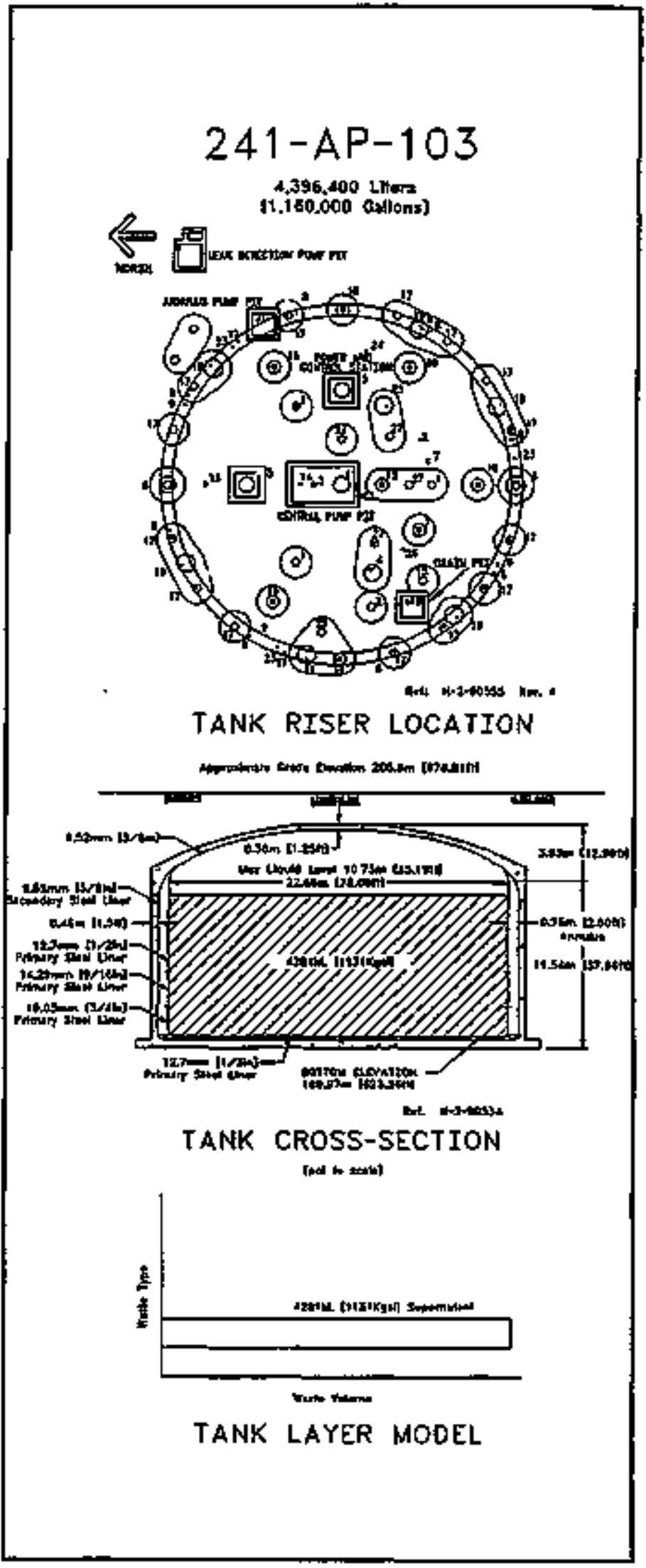




\begin{tabular}{|c|c|c|c|}
\hline \multicolumn{4}{|c|}{ Double-Shell Tank 241-AP-103 } \\
\hline \multicolumn{4}{|c|}{ 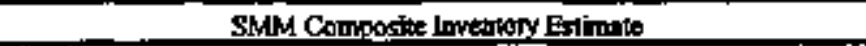 } \\
\hline \multicolumn{4}{|c|}{ 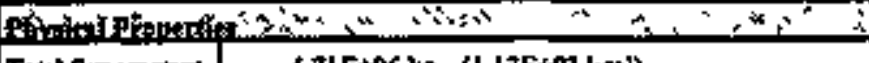 } \\
\hline & \\
\hline 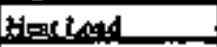 & \multicolumn{3}{|c|}{ 1.52 1) } \\
\hline Eumbonstix & \multicolumn{3}{|c|}{$1,10,(y) x)$} \\
\hline Weter wot/t & \multicolumn{3}{|c|}{83.7} \\
\hline TOC wts C (wet) & \multicolumn{3}{|c|}{0.243} \\
\hline \multicolumn{4}{|c|}{ 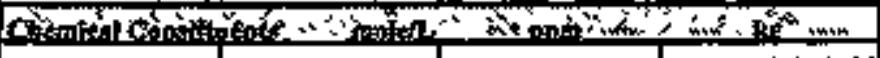 } \\
\hline $\mathrm{Na}$ & 219 & 45[E+04 & 2.15E+09 \\
\hline$A^{3+}$ & 0267 & 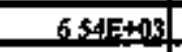 & $30 \mathrm{~g} 5+0 \mathrm{~d}$ \\
\hline Fe" (lotal Fe) & $2.165-0.5$ & 130 & $\$ 16$ \\
\hline$a^{*}$ & 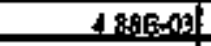 & 23] & $109+103$ \\
\hline $\mathrm{BP}^{*}$ & 6.46E-05 & 123 & 57.6 \\
\hline L2. & 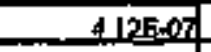 & $5200=02$ & $0 \geq 45$ \\
\hline He+ & 1.33E-06 & $0 \geq 243$ & 5,25 \\
\hline 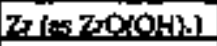 & $318 E-04$ & 263 & 124 \\
\hline $\mathrm{Pt}^{+*}$ & $1.09 \mathrm{~B}-0 \mathrm{~S}$ & 2.00 & 9.7] \\
\hline $\mathrm{Ni}^{2 *}$ & Lئ16:03 & 837 & $39 ?$ \\
\hline$s \mathrm{~s}^{3 / 2}$ & 4.35E-07 & $3,47 \mathrm{E}-0 \mathrm{2}$ & 0.153 \\
\hline$M n^{* *}$ & 139료료 & 693 & 326 \\
\hline$C^{2 *}$ & $\$ .51 \mathrm{E}, \mathrm{M}$ & 5s.1. & $2-596+05$ \\
\hline $\mathbf{K}^{+}$ & 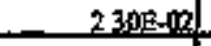 & 819 & $2856+03$ \\
\hline 요 & $1.2]$ & $1.87 E+04$ & 8.8IE+04 \\
\hline $\mathrm{NO}^{-}$ & 10.1] & 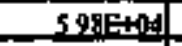 & T RIE+0.5 \\
\hline $\mathrm{NG}_{i}^{-}$ & 0.129 & $5.4 \mathbb{E}+03$ & $2.55 \mathrm{E}+(\mathrm{x}$ \\
\hline $\cos ^{2}$ & 0.150 & 82JEم:3 & 3 P7E $+0 \mathrm{~d}$ \\
\hline $\mathrm{PO}^{2}$ & 2.21E-02 & $1.9 \mathrm{IE}+0 \mathrm{~B}$ & $8.995+09$ \\
\hline $802^{2}$ & $560=-0$ & 4895+01 & $230 \mathrm{~F}+\mathrm{d}$ \\
\hline Sis $\left(\mathrm{siO},{ }^{1}\right)$ & 1.4. & 379 & $1.7 \mathrm{BE}+0 \mathrm{~g}$ \\
\hline $\mathrm{f}$ & 2 $6 \mathrm{ge}-1)$ & 46a & $218 \sqrt{2}+6 t$ \\
\hline a & $\$ 07 \mathrm{~B}-0 \mathrm{O}$ & $1315+03$ & $6.178+09$ \\
\hline C.t. $0^{2}$ & $717 \mathrm{~B}-0 \mathrm{O}$ & 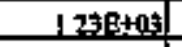 & 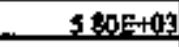 \\
\hline EDTA ${ }^{+}$ & $9.12 \mathrm{~B}-0 \mathrm{~s}$ & 239 & $1.12 \mathrm{E}+0 \mathrm{03}$ \\
\hline HEIDTA & ] & 376 & $1 \pi= \pm 01$ \\
\hline Iropleste: & $7 \times 3 \mathrm{~B}_{102}$ & $534 E+n$ S & 2525404 \\
\hline mentes" & 1.01E-03 & 34,3 & 256 \\
\hline gxylute: & 1 15SEA 016 & 0124 & 0.58 \\
\hline DBP & 1,4 $15-03$ & 206 & 972 \\
\hline brt 1,0$)$ & I 4 IE_0연 & 45 & 47 \\
\hline $\mathrm{NH}_{1}$ & $803 \mathrm{Fan}$ & $124 E+04$ & $584 \times+19$ \\
\hline $\mathrm{Fe}(\mathrm{CN})_{*}^{*}$ & & & \\
\hline 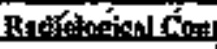 & سm & תس' ל' & "y \\
\hline Pu & 160 ( $\mathrm{gC}$ & & $1.14(t) g_{1}^{\prime}$ \\
\hline U & 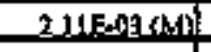 & $458 \mathrm{matgh}$ & 2.15E+03 (1) \\
\hline$\alpha$ & 6292E-02_(CWL) & $629(4, C), 2)$ & $296 \mathrm{E}+05(\mathrm{C})$ \\
\hline $\mathbf{s r}$ & A.\$9E-03 (CLL) & $4.18\left(\mu \mathrm{Cu}^{\prime} \mathrm{d}\right)$ & $1.97 \mathrm{E}+04$ (C) \\
\hline
\end{tabular}

"Densty is calculaded beazed on NB, OH-, and $\mathrm{NOO2}$.

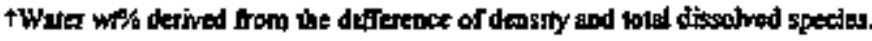

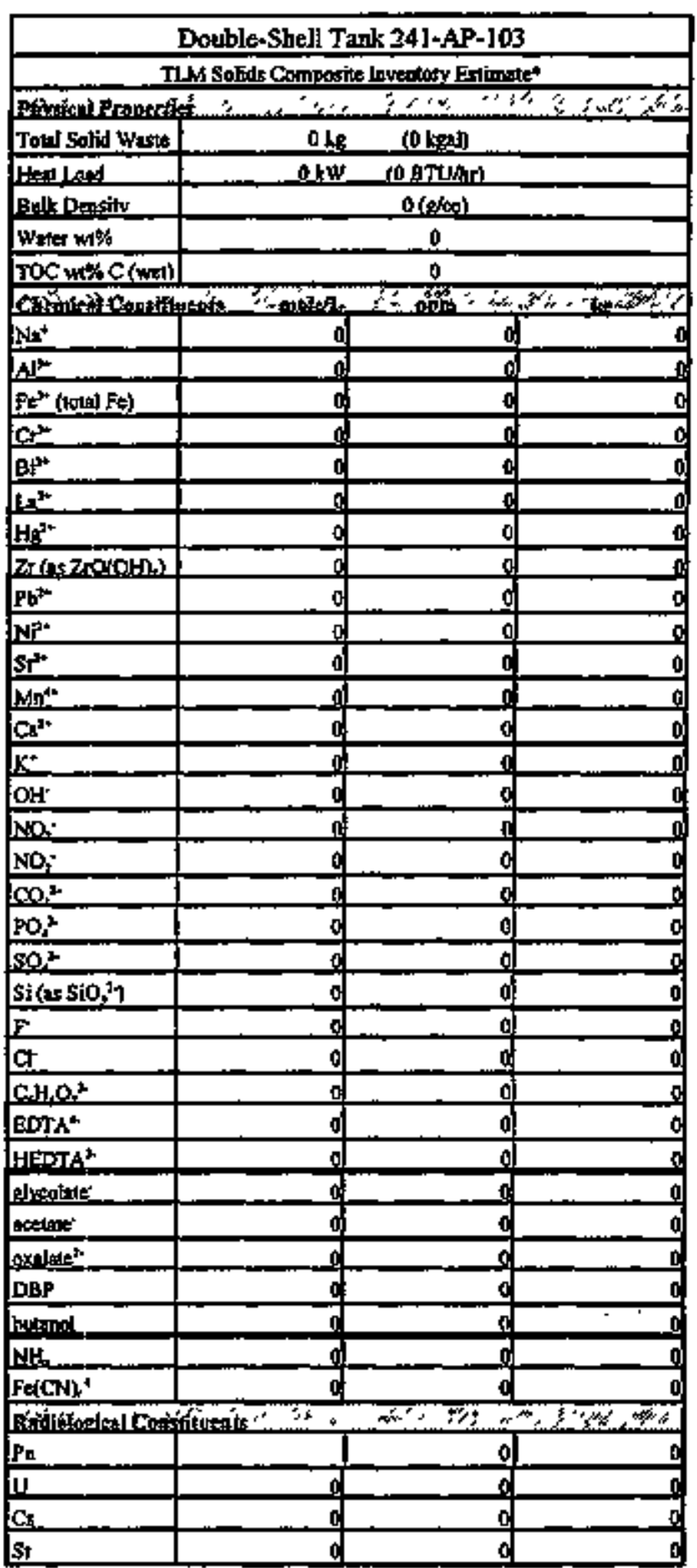

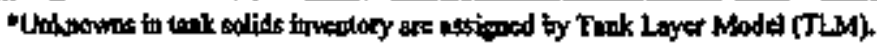


WHC-SD-WH-ER-350，Rev, O

3.4 Tank 241-AP-104

3.4.1 241-AP-104 Tank History

3.4.1.1 Waste History of Tank 241-AP-104

Tank 241-AP-104 began service by receiving Hanford facility waste in July 1986 and continued receiving this waste until May 1990 . The tank received decontamination waste from N Reactor from the first cuarter until the third quarter of 1987. From June 1990 until the present, the tank contained dilute non-complexed waste. The tank has not received waste since the third quarter of 1987. Currently, the tank is an inactive grout feed tank.

\subsubsection{Temperature History of Tank 241-AP-104}

Temperature data for Tank 241-AP-104 are recorded by 18 thermocouples at known elevations on one thermocouple tree instide the tank, located in riser 4. Non-suspect temperature data recorded between March 1986 and November 1993 for all 18 thermocouples were available from the computer automated surveillance system. Non-suspect temperature data taken between July 1989 and August 1993 for 12 of the thermocouples were available from the surveillance andysis computer system. However, not all of the 12 thermocouples have data that encompass the entire length of time. Within the time spans of each system, there were small breaks in the secuence of temperature data. The average temperature during these periods was $61^{\circ} \mathrm{F}$ with a minimum of $46^{\circ} \mathrm{F}$, a maximum of $72^{\circ} \mathrm{F}$, and a standard deviation of $6.0^{\circ} \mathrm{F}$. Linear regressions were performed on each thermocouple that had temperature data between January 1990 and January 1994 . The slopes from these regressions were averaged with a resulting average slope of -0.00049 . Refer to the supporting document for a more thorough review of the temperature data (Brevick, 1995).

\subsubsection{Occurcences of Tank 241-AP-104}

One unusual event occurred at Tank 241-AP-104. Occurrence Report RI--hHC-Tenk Farm-1991-0085 was issued in January 1991 because a loose wire to the alarm panel that monitors Tank 241-AP-104 caused a loss of power.

\subsubsection{Psychrometrics of Tank 241-AP-104}

Psychrometric data have been recorded for seven years from this tank ard annulus. The apparent trend of the evaporation rate from the tank has decreased from 71.1 gallons per week in April 1987 to 38.3 gallons per week in January 1995. Over that same period, the trend in the rates of heat exchange through the primary tank ventilation has decreased. The heat exchange rates in the annular ventilation show an increasing trend. The majority of the changes in the rate of heat exchange can be attributed to changes in the average ventilation rates. A review of the psychrometric data in rark 241-AF-104 would suggest an increase in the rate of heat generation by the waste. 
3.4 .2 Current Status of Tank 241-AF-104

Tank 241-AP-104 was placed into service in Octobex 1986 and currently stores 18,000 gallons of waste. The following plan view and tank crosssection depict the approximate waste volume of 18,000 gallons and configuration of risers as of January 1994. A12 18,000 gellons were supernatant at the time of the estimete. This tank is inactive at the present time. The tank is actively ventilated and categorized as sound. Tank 241-AP-104 has 71 risers. Six 4-inch risers ino.15, no.21, three no.27g, and no.28), two 12-inch risers (no.7 and no.10), and two 42-inch risers (two no.5s) are avilable for use.

\subsubsection{Inveptory Estimate of Tank 241-AP-104}

The tank layer model (a volume based approximation) that follows was derived from the Los Alamos National Laboratory waste status and Transaction Record Summary (Agnew 1995) and Supernatant Mixing Model (Agnew 1995). The estimated inventories of total waste, solids, and supernatant in Tank 241-AF-104 are elso presented.

3.4.2.2 In-Tank Photograph of Tark 241-AP-104

so in-tank photographs are available.

3.4.3 Synopsis of Tank 241-AP-104

(To be completed.) 


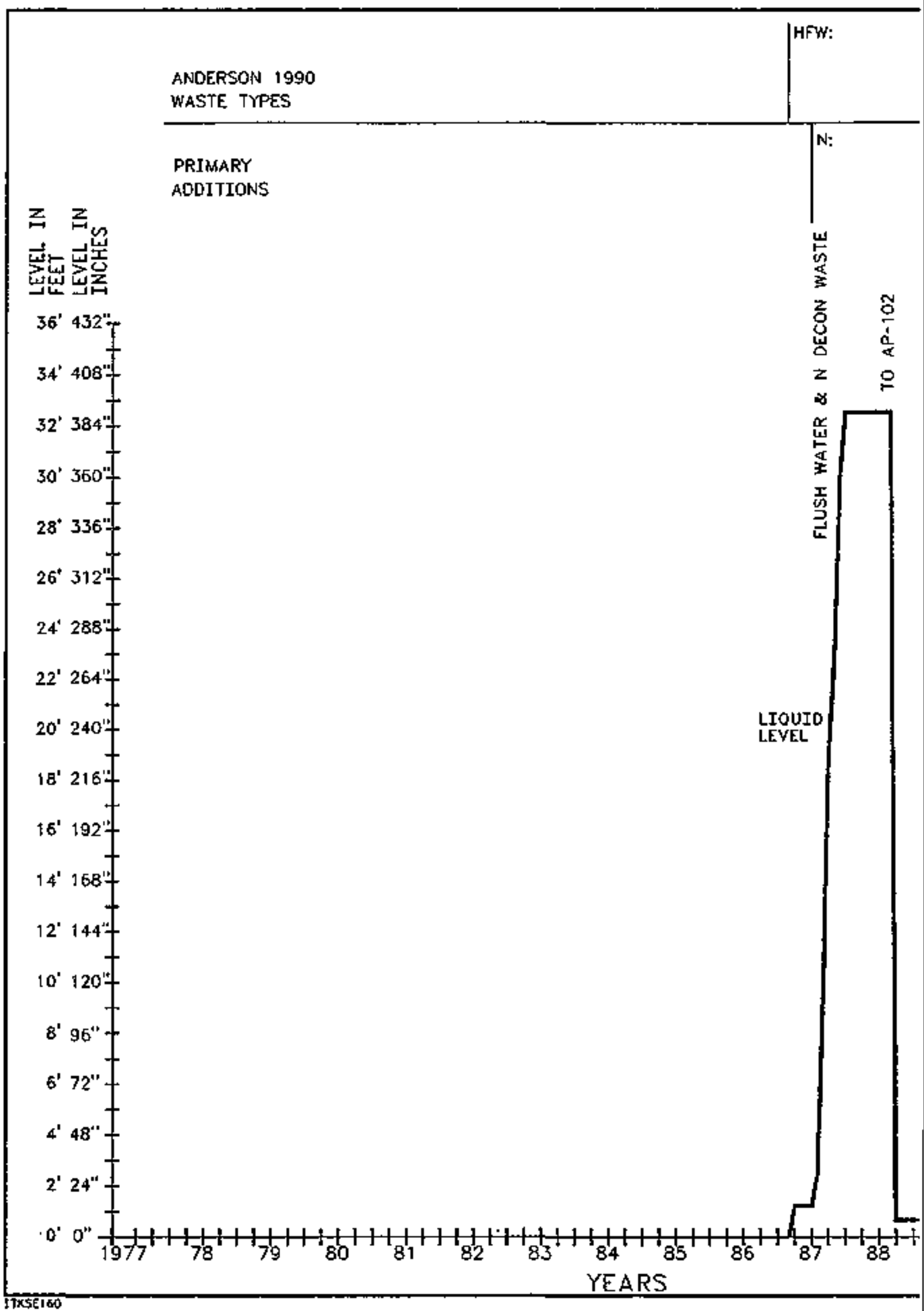


DN:

UNK:

NOIES:

CONSTRUCT 1980-198I

NOWINAL CAPACITY $1,000,000 \mathrm{GAL}$

FLAT BOTTOM TANK, NOO KNUCKEE,

75 FOOT DIAMETER' DOUBLE-SHELL' TANAK

SURFACE LEVEL READING: PHOTO

(LIOUIDS \& SOLIDS), FIC (SOLIDS)

INVENTORY ESTIHATE OATE

CAPACITY

(GALLONS)

HFW: HANFORO FACILITY WASTE

$-1.188,000$

N: N REACTOR WASTE

$-$

DN: DILUTE NON-COMPLEXED WASTE

UNK: UNKNOWN

$-1,122,000$

$-$

$-1,056,000$

-

- 990,000

$-$

$-\quad 924,000$

- $\quad 858,000$

LEGEND

LIOUIO OESERVATION

$-$

ament llown

- LIOUID LEVEL

$-792,000$

$77 / 7$ solios LeVEL

HHHA SOLIOS LEVEL GEST

$-$

HEYH H, ENGINEERING JUDGENENT

- 726,000

$-$

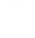

AP TANK FARM

PLOT PLAN

$-\quad 660,000$

$-$

- 594,000

101 102

- 528,000

-

- 462,000

$-$

- 396,000

$-$

- 330,000

-

$-\quad 264,000$

103

(104)

105

105

-

107

108

- 198,000 U.S. DEPARTMENT OF ENERGY

$-132.000$

RICALAND FIELD OFFICE ICF KAISER HANFORO

$-$

SUPERNATANT $18 \mathrm{KGAL}$

$-66,000$ WATCH LIST: N/A

\begin{tabular}{|c|c|c|}
\hline 8 & $\begin{array}{r}\text { GLDC NQQ } \\
241 \\
241\end{array}$ & $E S-T K S-E 160$ \\
\hline SCALE & NONE & EAtET i of \\
\hline
\end{tabular}


WHC-SD-WM-ER-350, Rev. 0

\begin{tabular}{|c|c|c|c|}
\hline \multicolumn{4}{|c|}{ Double-Shell Tank 241-AP-104 } \\
\hline \multicolumn{4}{|c|}{ Tolul hystany Estionmest } \\
\hline \multicolumn{4}{|c|}{ 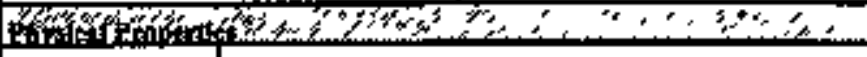 } \\
\hline Toul Worle & 6.91E+0A kg & $(18 \mathrm{~kg} \mathrm{~g})$ & \\
\hline Hettlond & olkw & (1) $\mathrm{RT}$ W/mrt & \\
\hline Ayenteptityt & 1.01 (ofos) & & \\
\hline Wolker watst & 97.4 & & \\
\hline TOC WH:C & 0 & & \\
\hline \multicolumn{4}{|c|}{ 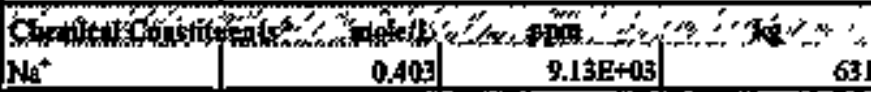 } \\
\hline \multicolumn{4}{|c|}{\begin{tabular}{|l|l|l|l|l}
$A^{*}$ & 0 & 0 \\
\end{tabular}} \\
\hline $\mathrm{Fe}^{*}(\operatorname{tos} 1 \mathrm{fe})$ & $1,27 E-03$ & 69.8 & 4.82 \\
\hline C: & 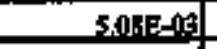 & 2604 & 180 \\
\hline \multicolumn{4}{|l|}{ Bi" } \\
\hline \multicolumn{4}{|l|}{$1 e^{2+}$} \\
\hline \multicolumn{4}{|c|}{$\mathrm{HF}^{\mathrm{*}}$} \\
\hline \multicolumn{4}{|c|}{ 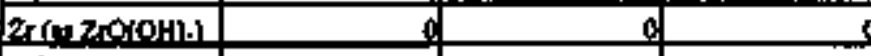 } \\
\hline \multicolumn{4}{|c|}{$\mathrm{pr}^{2+}$} \\
\hline $\mathrm{Ni}$ & 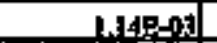 & 60 & 4.56 \\
\hline \multicolumn{4}{|l|}{$8 x^{2+}$} \\
\hline \multicolumn{4}{|l|}{$\mathrm{Mn}^{* *}$} \\
\hline $\mathrm{Ca}^{3 *}$ & \$.87E-103 & 35: & 24.2 \\
\hline \multicolumn{4}{|l|}{$\mathbf{K}^{*}$} \\
\hline он: & 3.28E-02 & 549 & 38.0. \\
\hline No. & $9918-07$ & 6,065:409) & 419 \\
\hline NO: & $8,89 \mathrm{E}-0 \mathrm{0}$ & 103 & 27.9 \\
\hline$\infty 0^{3}$ & $\triangle 42 E=0 ;$ & 261 & 1.1 \\
\hline $\mathrm{PO}_{1}^{2+}$ & 9.51E-02] & $8.90 \mathrm{E}+0 \mathrm{3}$ & 615 \\
\hline so: & $2,54 E=0.07$ & 341 & 166 \\
\hline \multicolumn{4}{|l|}{ Siceston } \\
\hline \multicolumn{4}{|l|}{$F$} \\
\hline Cl: & 2.02E-05 & 70.4 ! & 4.17 \\
\hline \multicolumn{4}{|l|}{$\mathrm{CH}_{\mathrm{H}} \mathrm{O}^{2}$} \\
\hline \multicolumn{4}{|l|}{$\operatorname{ECTTA^{4}}$} \\
\hline \multicolumn{4}{|l|}{ HEOTA } \\
\hline \multicolumn{4}{|l|}{ Alveobete:- } \\
\hline \multicolumn{4}{|l|}{ cedoute } \\
\hline \multicolumn{4}{|l|}{ sxilaged. } \\
\hline \multicolumn{4}{|l|}{ DEP } \\
\hline \multicolumn{4}{|l|}{ hent } \\
\hline \multicolumn{4}{|l|}{$\mathrm{NH}$} \\
\hline $\mathrm{F}\left(\mathrm{Q}(\mathrm{CN})_{1}^{4}\right.$ & 0 & 0 & L \\
\hline 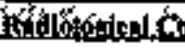 & Lotats & $4 y_{x}=$ & 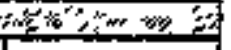 \\
\hline Pu & & 0 & 0 \\
\hline u & & 0. & 0 \\
\hline $\mathrm{cs}$ & & of & n \\
\hline$\underline{S}$ & 으 & of & 0 \\
\hline
\end{tabular}

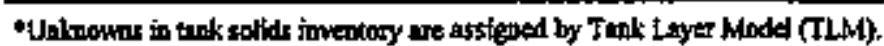

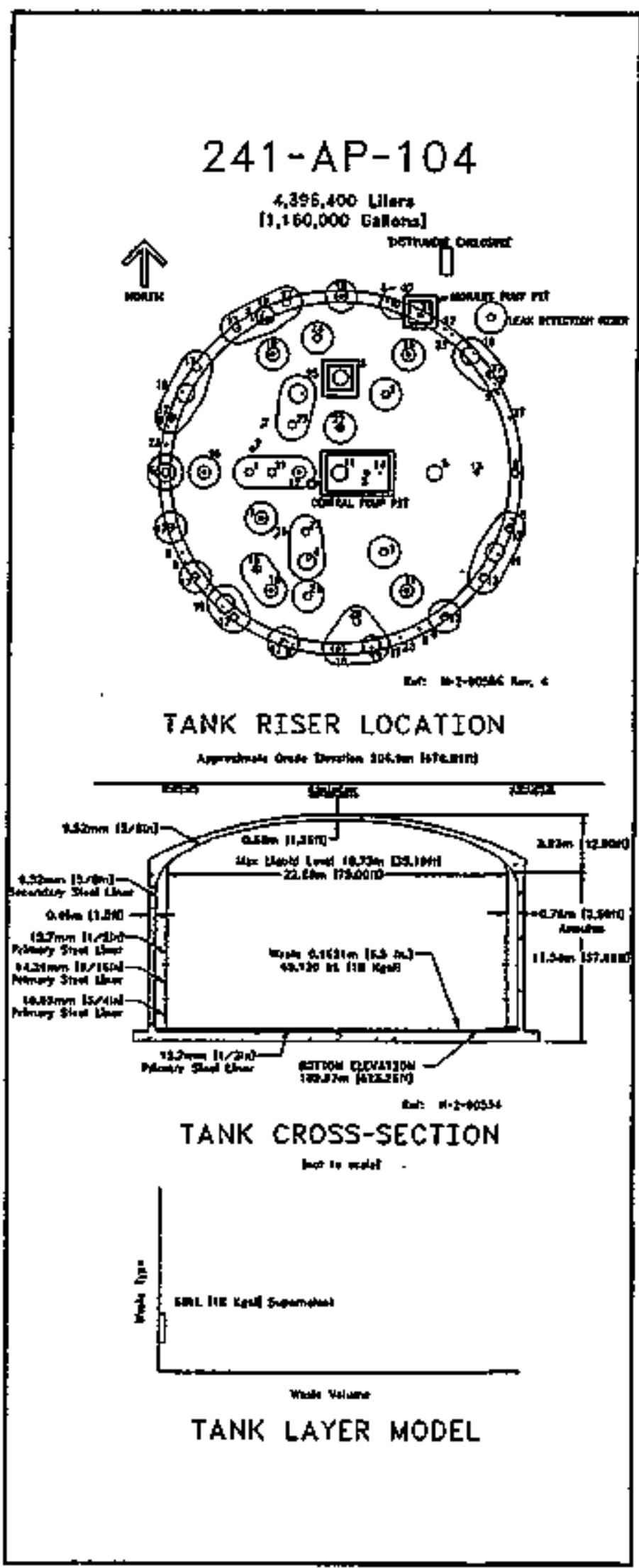

tWalume average for density, mass avernge Water wt\% abd TCC wt\$C. 
WHC-SD-WH-ER-350, REv, 0

\begin{tabular}{|c|c|c|c|}
\hline \multicolumn{4}{|c|}{ Double-Shell Tank 241-AP.104 } \\
\hline \multicolumn{4}{|c|}{ SWM Composine Imetrony Estimate } \\
\hline \multicolumn{4}{|c|}{ 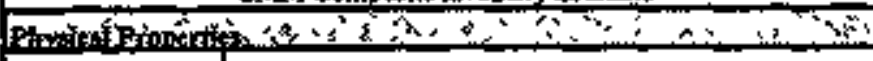 } \\
\hline Total Superostant & $6.91 \mathrm{E}+04 \mathrm{~kg}$ & (18 k:d) & \\
\hline Herilind & ok난 & gaTulor & \\
\hline Balk Denstby & & 1.01 ( $v /=$ = & \\
\hline Wher wot & & 97.4 & \\
\hline $\mathrm{TQC}$ w\% $\mathrm{C}$ (wet) & & 0 & \\
\hline \multicolumn{4}{|c|}{ 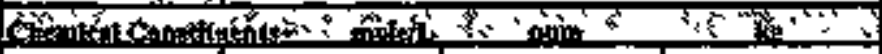 } \\
\hline $\mathbf{h a}^{+}$ & 0.403 & $9.13 \mathrm{E}+03$ & 631 \\
\hline \multicolumn{4}{|l|}{ (1) } \\
\hline 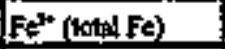 & $12 \pi=03$ & 69.8 & 4,82 \\
\hline $\mathrm{O}^{*}$ & $50 \mathrm{~g}=\mathrm{AB}$ & 2604 & 180 \\
\hline \multicolumn{4}{|l|}{ Bip } \\
\hline \multicolumn{4}{|l|}{$1 x^{3+2}$} \\
\hline \multicolumn{4}{|l|}{ 岳草 } \\
\hline \multicolumn{4}{|l|}{$7,(15,700(0) 4)$} \\
\hline \multicolumn{4}{|l|}{$P^{2}$} \\
\hline $\mathbf{N}^{P^{*}+}$ & L4F-0; & 600 & $4,56$. \\
\hline \multicolumn{4}{|l|}{ Stro } \\
\hline \multicolumn{4}{|l|}{$M:=$} \\
\hline $\mathrm{CP}^{*+}$ & $8.87 E_{0} 03$ & 350 & 24.2 \\
\hline \multicolumn{4}{|l|}{ K*+ } \\
\hline $\mathrm{or}$ & $328 \mathrm{E}-102$ & $\$ 49$ & 30.0 \\
\hline No: & 99915d & $606+0$ & 419 \\
\hline $\mathrm{No}:$ & $8.898-0 \mathrm{~B}$ & 4005 & 27.5 \\
\hline $0,{ }^{2}$ & 4 42FAA] & 261 & 18, \\
\hline $\mathrm{PO}^{2}$ & $9510-02$ & B. $90 \mathrm{E}+03$ & 615 \\
\hline $\mathrm{sO}^{2}$ & 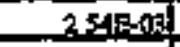 & 201 & 16.6 \\
\hline \multicolumn{4}{|l|}{$\sin (\sin 2)$} \\
\hline \multicolumn{4}{|l|}{$\mathbf{F}$} \\
\hline c & $2.02 \mathrm{E}-0 \mathrm{~g}$ & $m .4$ & 4.87 \\
\hline \multicolumn{4}{|l|}{$\mathrm{C} \mathrm{H}_{\mathrm{C}} \mathrm{O}^{+}$} \\
\hline \multicolumn{4}{|l|}{ EDT $A^{4}$} \\
\hline \multicolumn{4}{|l|}{ HEDTA ${ }^{2}$} \\
\hline \multicolumn{4}{|l|}{ Istrom } \\
\hline \multicolumn{4}{|l|}{ patale: } \\
\hline \multicolumn{4}{|l|}{ spolacki. } \\
\hline \multicolumn{4}{|l|}{ DBP } \\
\hline \multicolumn{4}{|l|}{ 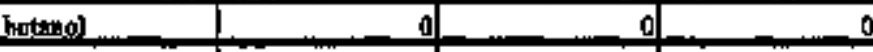 } \\
\hline \multicolumn{4}{|l|}{$\mathrm{NH}$} \\
\hline FuCON & a & d. & 0 \\
\hline 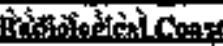 & si, & $\vdots$ & n's \\
\hline Pu & a & & 0 \\
\hline u. & & & 0. \\
\hline Cs & & d & 0 \\
\hline Sit & 0 & e] & 0 \\
\hline
\end{tabular}

"Dentity is calculwed bused on Na, OH-, and AlO2-.

tWate we\% derived from the difforente of density ad total dissolved species.

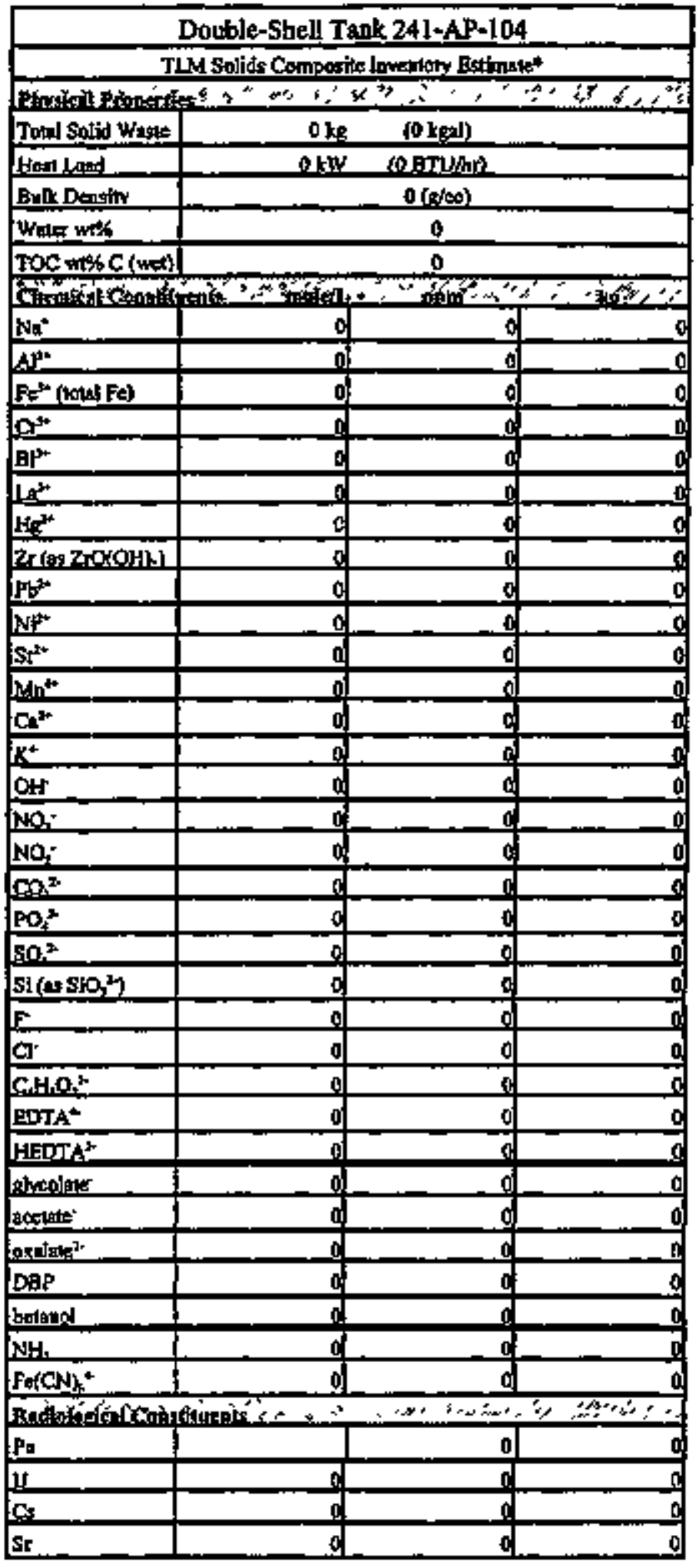

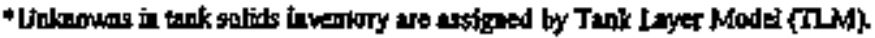




$$
\text { WHC-SD-TMS-ER-350, Rev. } 0
$$

3.5 Tank 241-AP-105

3.5.1 241-AP-105 Tank History

3.5.1.1 Waste History of Tank 241-AP-105

Tank 241-AP-105 begar service by receiving non-complexed waste in July 1986. The tank received non-couplexed waste until June 1989. From July 1989 until the present, the tank has contained double-shell slurry feed waste. The tank has not received waste since the third guarter of 1989 . The tanis is currently an inactive concentrated waste holding tank.

\subsubsection{Tenperature History of Tank 241-AP-105}

Temperature data for Tank 241-AP-105 are recorded by 18 thermocouples at known elevations on one thermocouple tree inside the tank, located in Iiser 4. Non-suspect tenperature data from between March 1986 and December 1992 for all 18 thermocouples were available from the computer automated surveillance system. Non-suspect temperature data recorded between July 1989 and August 1993 for 12 of the thermocouples were available from the surveillance analysis conputer system. However, not all of the 12 thexmocouples have deta that encompass the entire length of time. Within the time spans of each system, there were small breaks in the sequence of temperature data. The average temperature during these periods was $69^{\circ} \mathrm{F}$ with mirimum of $53^{\circ} \mathrm{F}$, a maximum of $88^{\circ} \mathrm{F}$, and a standard deviation of $6.2 \circ \mathrm{F}$. Iinear regressions were performed on each thermocouple that had tempexature data between January 1990 and January 1994. The slopes from these regressions were averaged with a resulting average slope of 0.0016 . Refex to the supporting documert for a more thozough review of the tenperature data (Brevick, 1995 ).

\subsubsection{3 occuxrences of Tank 241-AP-105}

No unusual events exclusively concerned rank 241-AP-105 since it went into service.

\subsubsection{Psychrometrics of Tank 241-AP-105}

Psychrometric data have been recorded for six years from this tank and annulus. The apparent trend of the evaporation rate from the tank has increased from 80 gallons per week in February 1988 to 95.5 gallons per week in January 1995. Over that same period, the trend in the rates of heat exchange through the primary tank and annular ventilation has apparently increased. A review of the psychrometric data in Tank 241-AP-105 would suggest an overall increase in the rate of heat generation by the waste.

\subsubsection{Current status of Tank 241-AP-105}

Tank 241-AP-10S entered service in October 1986 and currently stores 821,000 gallons of waste. The following plan view and tank cross-section depict the approximate waste volume of 821,000 gallons and configuration 
of risers in January 1994. At the time of the estimate, al1 821,000 gallons were supermatant. This tank is inactive at the present time. The tank is actively ventilated and categorized as sound. Tank 24I-AP-105 has 71 risers. Six 4-inch risers (no.15, no.21, no.24, three no.27s, and no.28), three 12-inch risers (no.7 and two no.10s), and two 42-inch risers (two no.5s) are available for use.

\subsubsection{Inventory Estimate of Tank 241-AP-105}

The tank layer model (a volume based approximation) that follows was derived from the Los Alamos National uaboratory Waste status and Transaction Record Summary (Agmew 1995) and Supernatant Hixing Model (Agnew 1995). The estimeted inventories of total waste, solids, and supermatant in Tank 241-AP-105 are also presented.

3.5.2.2 In-Tank Photograph of Tank 241-AP-105

No in-tank photographs are available.

3.5 .3 Symopsis of Tark 241-AP-105

(To be completed.) 


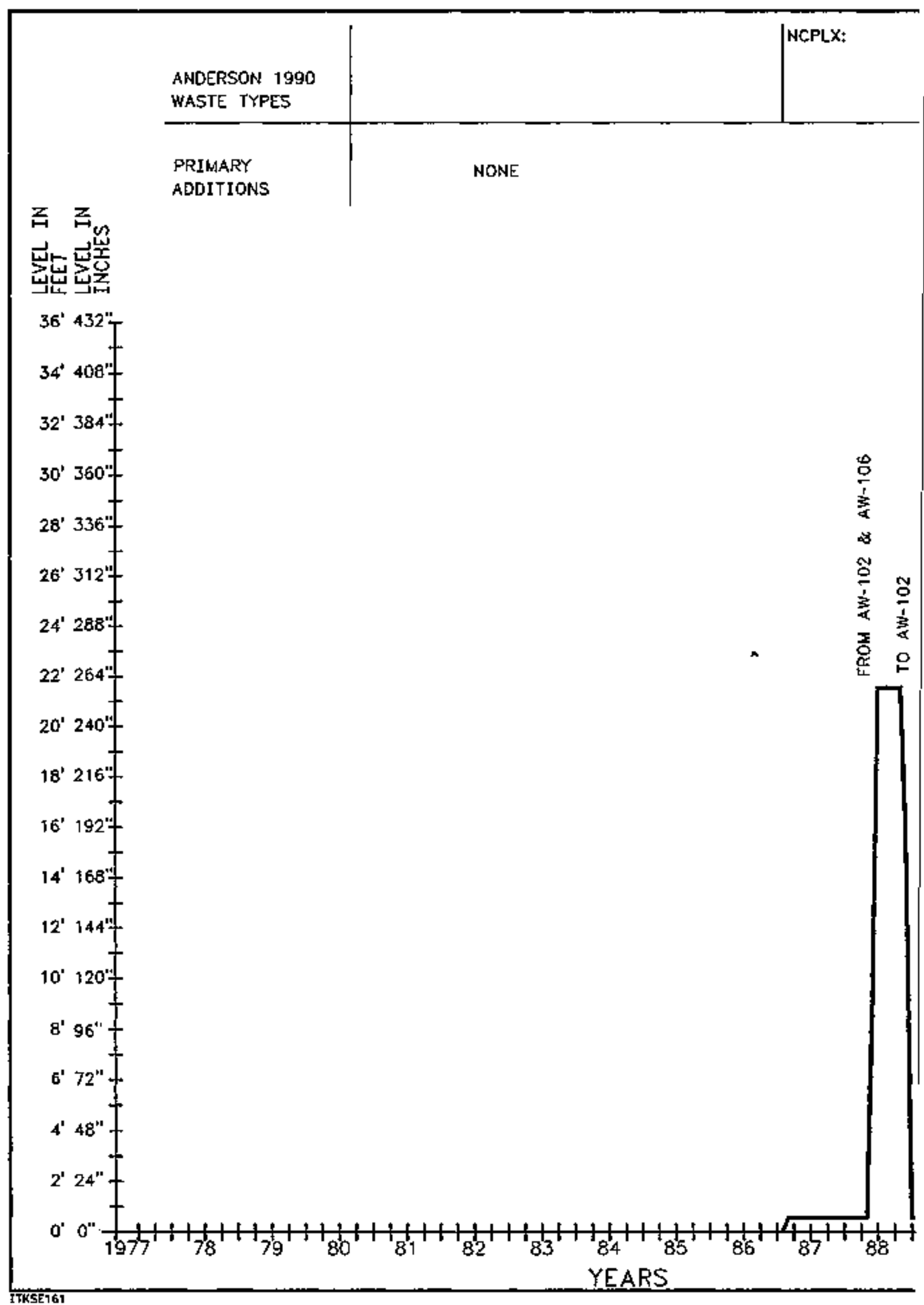


DSSF:

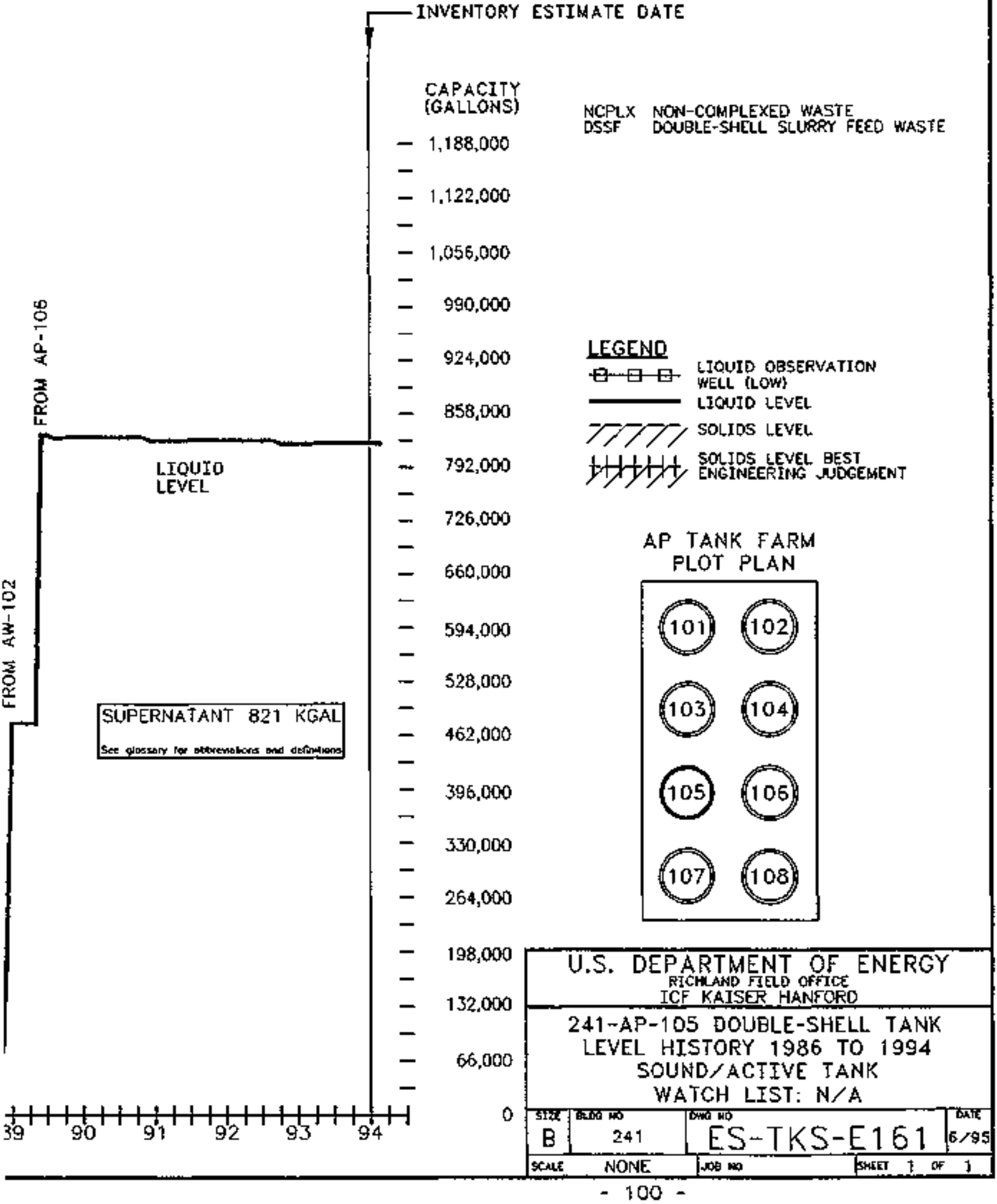

NOTES:

CONSTRUCT 1980-1981

NOMINAL CAPACITY $1000000 \mathrm{GAL}$

TH

75 FOOT OIAMETER DGUBLE-SHELL TANK

SURFACE LEVEL REAOING PHOTO

ILIOUIDS \& SOLIOS). FIC (SOLIDS)

NCPLX NON-COMPLEXED WASTE
DSSF DOUBLE-SHELL SLURRY FEEO WASTE

LEGEND

777 SOLIDS LEVEL

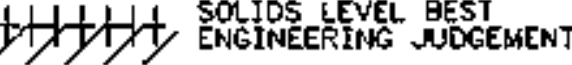

AP TANK FARM

101

102

04) 
WHC-SD-WM-ER-350, Rev, 0

\begin{tabular}{|c|c|c|c|}
\hline \multicolumn{4}{|c|}{ Dopble-Shell Tank 241-AP-105 } \\
\hline \multicolumn{4}{|c|}{ Total Inventory Eqliganct } \\
\hline \multicolumn{4}{|c|}{ S f w } \\
\hline Totol Worte & $4.14 \mathrm{E}+06 . \mathrm{kg}$ & (b2t kgi) & \\
\hline Herilsed & \multicolumn{3}{|c|}{ 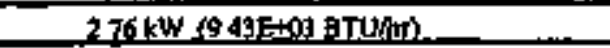 } \\
\hline Bull Densint & \multicolumn{3}{|c|}{$1.33($ p p $/(x)$} \\
\hline Waler with & \multicolumn{3}{|c|}{542} \\
\hline Tod wt $\% \mathrm{C}$ & \multicolumn{3}{|c|}{0.801} \\
\hline \multicolumn{4}{|c|}{ 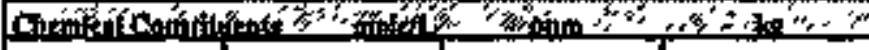 } \\
\hline $\mathrm{Na}^{*}$ & $\mathbf{3 , 4 4}$ & $1282+05$ & $5.32 \mathrm{E}+0.5$ \\
\hline A) & $0.80 .5]$ & 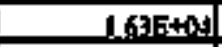 & $675 \mathrm{E}+04$ \\
\hline$f=0$ (fotal $F(4)$ & 2,24E-03 & 367 & L.60E+05 \\
\hline$C^{*}$ & $240,-02$ & 9.69) & A $001 \mathrm{~B}+03$ \\
\hline $\mid \mathbf{B}^{2 *}$ & $4.57 \mathrm{E}-04$ & 71.7 & 293 \\
\hline $1.3^{* *}$ & 2.085-06 & 6.311 & 120 \\
\hline Her" & 1.07E-0s & L俉 & 6.70 \\
\hline 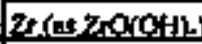 & 264E-199 & 1891 & 748 \\
\hline $\mathrm{Pb}^{\mathbf{*}}$ & $9.028 \times 05$ & {$[4,0]$} & $\$ 0.1$ \\
\hline $\mathrm{NI}^{3^{2}}$ & $5692+03$ & 248 & $103 \mathrm{E}+103$ \\
\hline$s^{2}$ & $3.150-0.6$ & 0.200 & 0.859 \\
\hline $\mathrm{Sr}^{4}$ & $1.160-02$ & 47 & $198 \mathrm{E}+03$ \\
\hline Costo & $647 E-02$ & $19.98+0.3$ & 2.05E+03 \\
\hline $\mathbf{K}^{\mathbf{*}}$ & 0.124 & $5695+07$ & 2358+0 \\
\hline oft & 3.67 & $4.68 E+04$ & $1.945+05$ \\
\hline 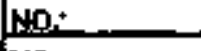 & 331 & LSAEA0 & $63 \pi 1+0$ \\
\hline No: & 0,804 & $278 \mathrm{E}+04$ & 1.ISE+0.5 \\
\hline $\cos 2^{2}$ & $0.580:$ & $239= \pm 24$ & 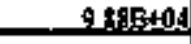 \\
\hline $\mathrm{FO}_{1}^{2}$ & 0,159 & $1.13 \mathrm{E}+\mathrm{N}$ & 4.6.5E+09 \\
\hline $50 \%$ & 0.125 & $126 \mathrm{E}=04$ & $5325+02$ \\
\hline $5(10,50,5)$ & $3.92 E-02$ & 825 & $3.42 E+05$ \\
\hline $\mathbf{F}$ & 0218 & $3.12 E+0]$ & I2AEEHAS \\
\hline$c$ & 0.122 & $325 E+03\}$ & $2.34 E+04$ \\
\hline Catsos & $228=-42$ ! & $3245+103$ & {$[34 E+\infty$} \\
\hline EDTA ${ }^{4}$ & 6,4SE,AB & $139 E+0\}$ & $\$, 77 \mathrm{E}+09$ \\
\hline HEDTA* & 1072.02 & $2 \geq 20 E+03$ & $400+0 ;$ \\
\hline piluesolete: & $0 \pm 83$ & $1038+04$ & $126 \mathrm{E}+101$ \\
\hline 等 & t.L2R:03 & ats & L.3IE \\
\hline 0 & $1 \mathrm{BE}, 0 \mathrm{~S}$ & 0244 & -308 \\
\hline DBP & 1.09E-02 & $1.32 \mathrm{E}+0.03$ & $5.45 E+03$ \\
\hline hestrol_ & LQ98:-07 & - 60.5 & $251 E+013$ \\
\hline NH. & $0 \in 665$ & $843 \times+09$ & $351 \mathrm{E}+\mathrm{t}$ \\
\hline $\mathrm{FeCCN \textrm {N } ^ { + }}$ & o & of & \\
\hline 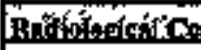 & sents. & 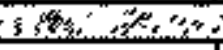 & 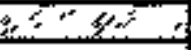 \\
\hline $\mathrm{Bu}_{\mathrm{u}}$ & & $4,36 \mathrm{E}-02(1+\mathrm{C} / \mathrm{g})]$ & $3.01\left(\mathrm{x}^{3} \mathrm{y}\right]$ \\
\hline $\mathrm{u}$ & $775 \mathrm{E}=0 \mathrm{as}$ (M) & 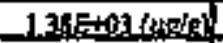 & $573 \mathrm{E}+020.9+3$ \\
\hline$C_{4}$ & $0.159(\mathrm{C}) \mathrm{L})$ & 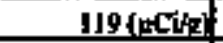 & $4.94 E+05$ (C) \\
\hline$s$ & 2.1SE-02 (CUA) & 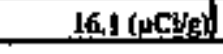 & $6.67 E+0)(C)$ \\
\hline
\end{tabular}

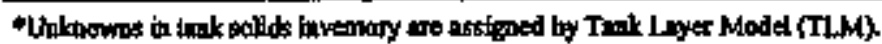

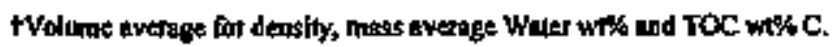

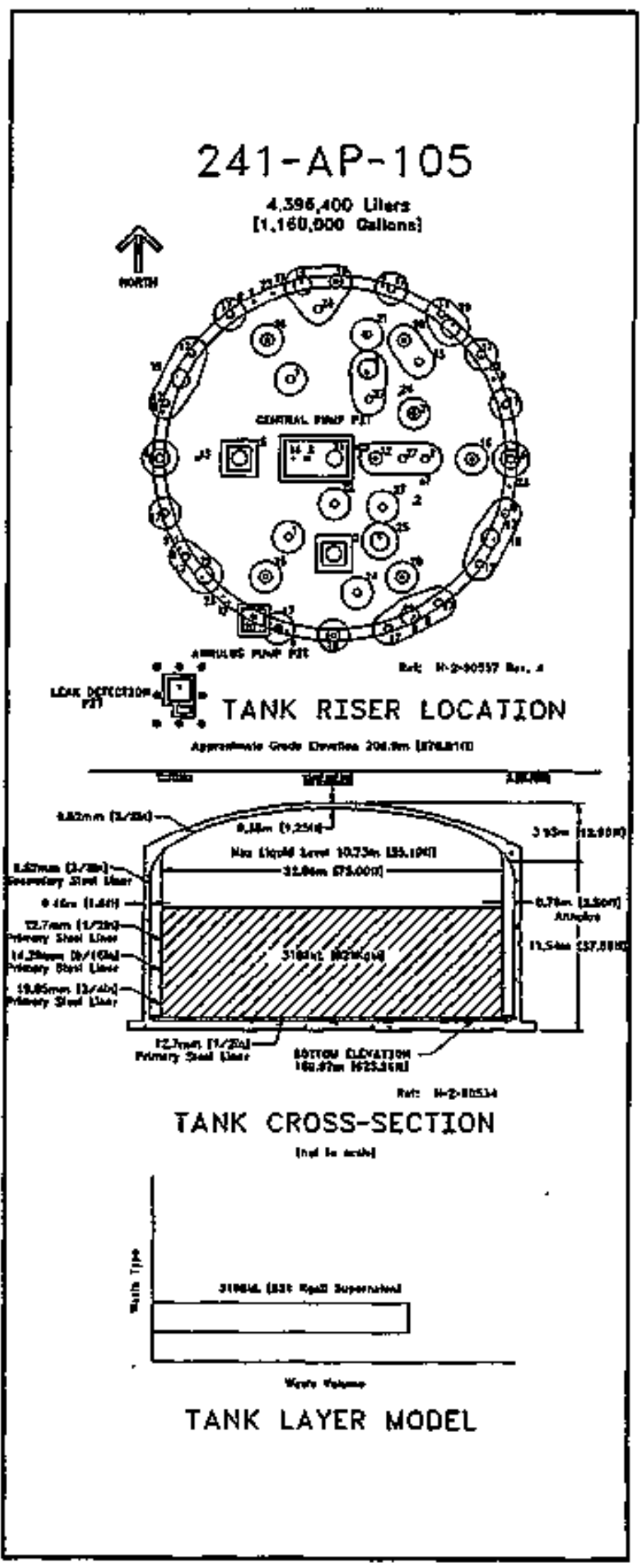




\begin{tabular}{|c|c|c|c|}
\hline \multicolumn{4}{|c|}{ Double-Shell Tank 241-AP-105 } \\
\hline \multicolumn{4}{|c|}{ SHA Cormposite Imentory Estimate } \\
\hline 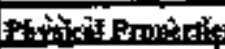 & 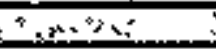 & 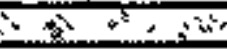 & 2, tami \\
\hline Total Stperpint & $4.14 \mathrm{E}+0 \mathrm{6} \mathrm{kg}$ & (821 kpal) & \\
\hline 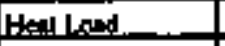 & $276 \times 14$ & Q A3E+13 BTWhn & \\
\hline Auk Denstate & & 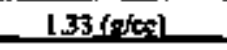 & \\
\hline Want wrotst & & 342 & \\
\hline TOC we $C$ (we-1)] & & 0.801 & \\
\hline \multicolumn{4}{|c|}{ 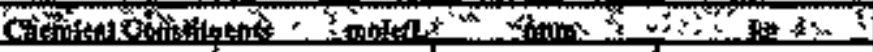 } \\
\hline $\mathrm{Ne}^{*}$ & 7.44 & $1289+45$ & $5332 \mathrm{E}+05$ \\
\hline $\mathrm{Al}^{*}$ & 0805. & 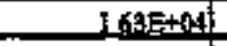 & 67SFA404 \\
\hline$F=$ (tortal Fel & 5245-03 & 367 & $1.60\left[\begin{array}{c}03 \\
0\end{array}\right.$ \\
\hline $\mathrm{c}^{4}$ & 248E-M & 269 & $4011 \times+010$ \\
\hline Bro & 4.57E-A & 7,3 & 297 \\
\hline Lيt & $2985=06$ & 03ل & 129 \\
\hline 보" & $1.07 \mathrm{E}-0 \mathrm{~S}$ & 1 & 5.70 \\
\hline $2 \mathrm{xis} 7 \mathrm{OSOHL}$ & 2645005 & (8) & 740 \\
\hline $\mathrm{Pr}_{0}{ }^{*+}$ & $9.02 \mathrm{E}, 05$ & 14.0 & 58.2 \\
\hline $\mathrm{NF}^{2}$ & $563 E_{0} 0 R_{2}$ & 248 & $10 A F+D$ \\
\hline $\mathrm{Sr}^{*}$ & 3.15E-00 & 0.207 & 0.859 \\
\hline Mr.4 & $1 / 09=02$ & 47료 & $1985+09$ \\
\hline $\mathrm{CA}^{2 *}$ & $6.47 \mathrm{E}-0,2$ & 1.94E+103 & $8.05 \mathrm{E}+013$ \\
\hline$K^{+}$ & 0.184 & 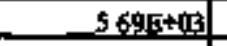 & 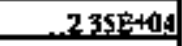 \\
\hline 압 & 3.67 & $4.68 E+0.4$ & $1.94 \mathrm{E}+4.5$ \\
\hline $\mathrm{NO}=$ & 315 & L545+05 & $6375-05$ \\
\hline NO: & 0.804 & $2.78 \mathrm{E}+04$ & 1.15E+05 \\
\hline $\mathrm{cos}^{2}$ & $0 \mathrm{skn}$ & $239= \pm 01$ & 98:E+8ds \\
\hline $\mathrm{FO}_{1}^{-2}$ & 0.159 & 1.13E+04 & $4.685+04$ \\
\hline 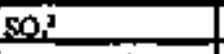 & 0178 & $126 \mathrm{E}+04$ & s2asento4 \\
\hline $\operatorname{si}\left(\mathrm{s}=\mathrm{sio}^{2}\right)$ & $3.925-02$ & 823 & $3.425+05$ \\
\hline $\mathrm{F}^{2}$ & 0218 & $\neq 17 f+0$, & 1,29E+ \\
\hline ct & 0.122 & $325 \mathrm{E}+0 \mathrm{~s}$ & {$[.34 \mathrm{E}+0 \mathrm{~d}$} \\
\hline C.HOS & $228 \mathrm{E}=0 \mathrm{0} 2$ & $324=40 \mathrm{a}$ & 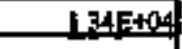 \\
\hline EDJA $^{4+}$ & 6.45E-0.5 & $1,39 \mathrm{E}+0$. & $3.7 \mathrm{E}+0 \mathrm{O}$ \\
\hline HEDTA & $107=-02$ & $220 x+002$ & $9096+0$ 조 \\
\hline Aveolete & 0.183 & $10 \times 3+04$ & $426, F+16$ \\
\hline Exatsie & 7.t2E-05: & 315 & $1.31 E+03$ \\
\hline ouspistex- & LAESOS & 0.74 & 300 \\
\hline DBP & $1.09 \mathrm{E}-02$ & $1.32 \mathrm{E}+0 \mathrm{3}$ & $5.45 E+03$ \\
\hline burtingl & $10 \mathrm{ge}-12$ & 606 & $2515+[1]$ \\
\hline NH. & Q665 & BA8E+03 & 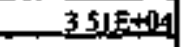 \\
\hline $\mathrm{F}(\mathrm{CN})_{k}{ }^{+}$ & 0 & - 0 & \\
\hline 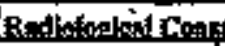 & tinitis: 2 & 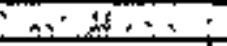 & $\therefore$ \\
\hline Pr & $\$ \$, 1$ (ncin) & & 3,01 (k跑) \\
\hline$\underline{u}$ & 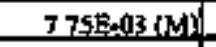 & $1388+03$ (4) & $573 F+93$ (h) \\
\hline $\mathrm{Cs}$ & 0.159 (Cin) & $119(\mu \mathrm{C} / \mathrm{s} / \mathrm{s})$ & $494 E+05$ (C) \\
\hline S & 2.15E-12 (C,LL) & 16. ( 1 C C & $667 \mathrm{E}+04(\mathrm{Cl})$ \\
\hline
\end{tabular}

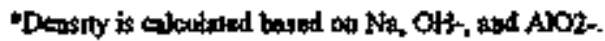

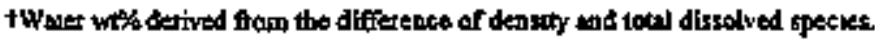

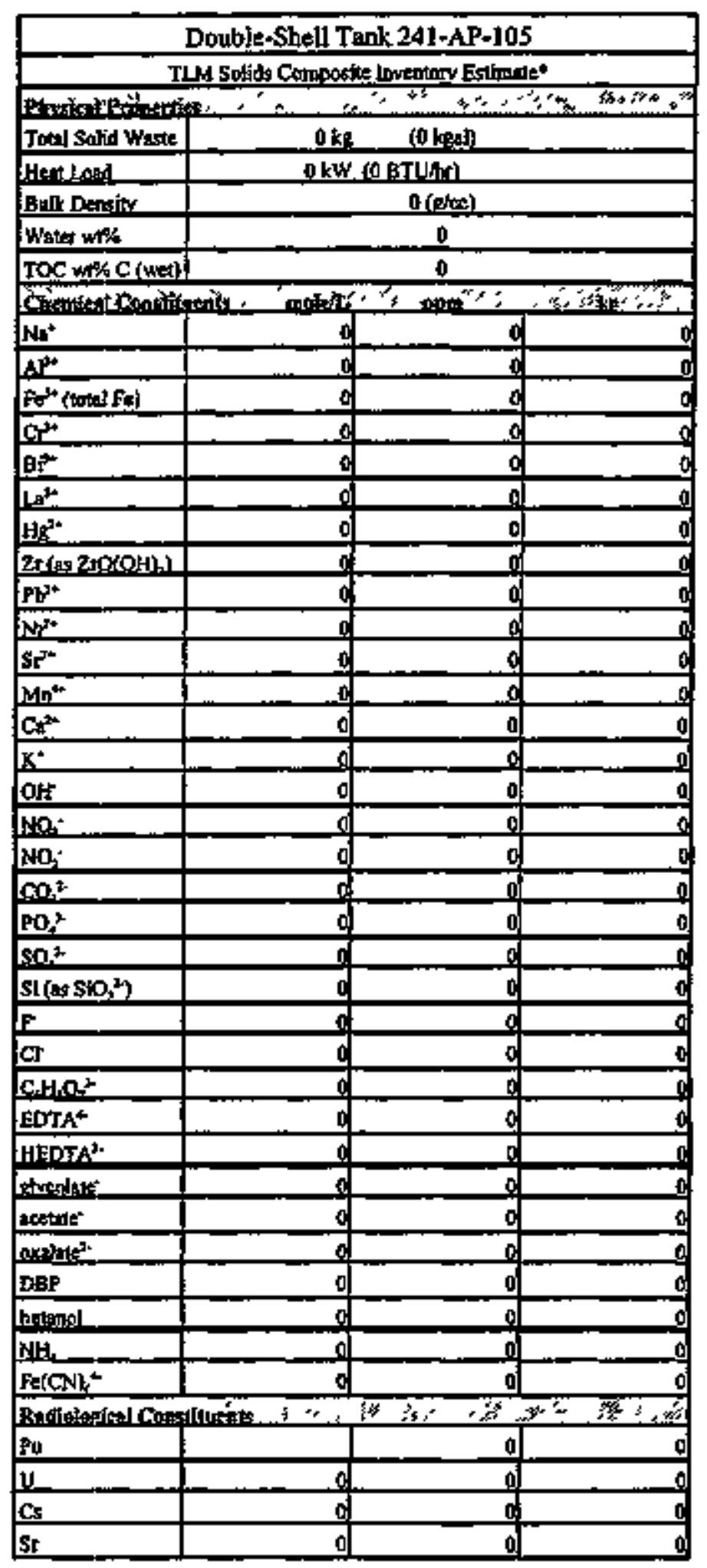

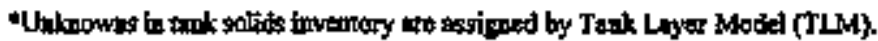




$$
\text { WHC-SD-WM-ER-350, ReV, } 0
$$

3.6 Tank 241-AP-106

3.6.1 241-AP-106 Tank history

3.6.1.1 Waste History of Tenk 241-AP-106

Tank 241-AP-106 began service by receiving Henford facility waste in July 1986. The tank continued to receive Hanford facility waste until Septenber 1986. From October 1986 until May 1990, the tank received noncomplexed waste. From June 1990 until the present, the tank has contained dilute non-complexed waste. The tank has not received waste since the fourth quarter of 1989 . The tank is currently an inactive dilute receiver tank.

\subsubsection{Temperature History of Tank 241-AP-106}

Temperature data for Tank 241-AP-106 are recoraed by 18 thermocouples at known elevations on one thexmocouple tree inside the tank, located in riser 4. Non-suspect tenperature data recorded between March 1986 and December 1992 for all 18 thermocouples were available from the computer automated surveillance system. Non-suspect temperature data recorded between July 1989 and August 1993 for 12 of the thermocouples were available from the surveillance analysis computer system. However, not al1 of the 12 thezmocouples have cata that encompass the entire length of time. Within the time spans of each system, there were small breaks in the sequence of termerature data. The average temperature curing these periods was $66^{\circ} \mathrm{F}$ with a minimum of $54^{\circ} \mathrm{F}$, a maximum of $107^{\circ} \mathrm{F}$, and a standard deviation of $7.2^{\circ} \mathrm{F}$. Linear regressions were performed on each thermocouple that had temperature data between Janwary 1990 and January 1994. The slopes from these regressions were averaged with a resulting average slope of -0.0020 . Refer to the supporting document for a more thorough review of the temperature date (Breviek, 1995).

\subsubsection{Occurrences of Tank 241-AP-106}

No unusual events exclusiveIy concerned this tank since it went into service.

\subsubsection{Psychrometrics of Tank 241-AP-106}

Psychrometric dat have been recorded for six years from this tank and annulus. The apparent trend of the evaporation rate from the tank has decreased from 94.7 gallons per week in May 1988, to 57 gallons per week in January 1995. Over that same period, the trend in the rates of heat exchange through the primary tank ventilation has decreased. The rates of heat exchange through the annular ventilation show an increasing trend. The majority of the changes in the rate of heat exchange can be attributed to changes in the average ventilation rates. A review of the psychrometric data in Tank 241-AP-106 would suggest an increase in the rate of heat generation by the waste. 
3.6 .2 Curfent status of Tark 241-AP-106

Tank 241-AP-106 was placed in service in october 1986 and currently stores $1,128,000$ gallons of waste. The following plan view and tark crosssection depict the approximate waste volume of $1,128,000$ gallons and configuration of risers as of January 1994. At the time of the estimate, all 1,128,000 gailons were supernatant. This tank is inactive at the present time. The tank is actively ventilated and categorized as sound. Tank 241-AP-106 has 71 risers. Eight 4-inch risers (no.15, no.21, no.24, no.26, three no.27g, and no.28), three 12-inch risers (no.7 and two no.10s), and two 42 -inch risers (two no.5s) are available for use.

3.6.2.1 Inventory Estimate of Tank 241-AP-106

The tank layer model. (e volume based approximation) that follows was derived from the tos Alamos Netional Laboratory Waste status and Transaction Record Summary (Agnew 1995) and Supernatant Mixing Model (Agnew 1995). The estimated inventories of total waste, solids, and supernatant in Tank 241-AP-106 are also presented.

3.6.2.2 In-Tank Photograph of Tank 241-AP-106

No in-tank photographs are available.

3.6 .3 Synopsis of Tank 241-AP-106

(To be completed.) 
ON:

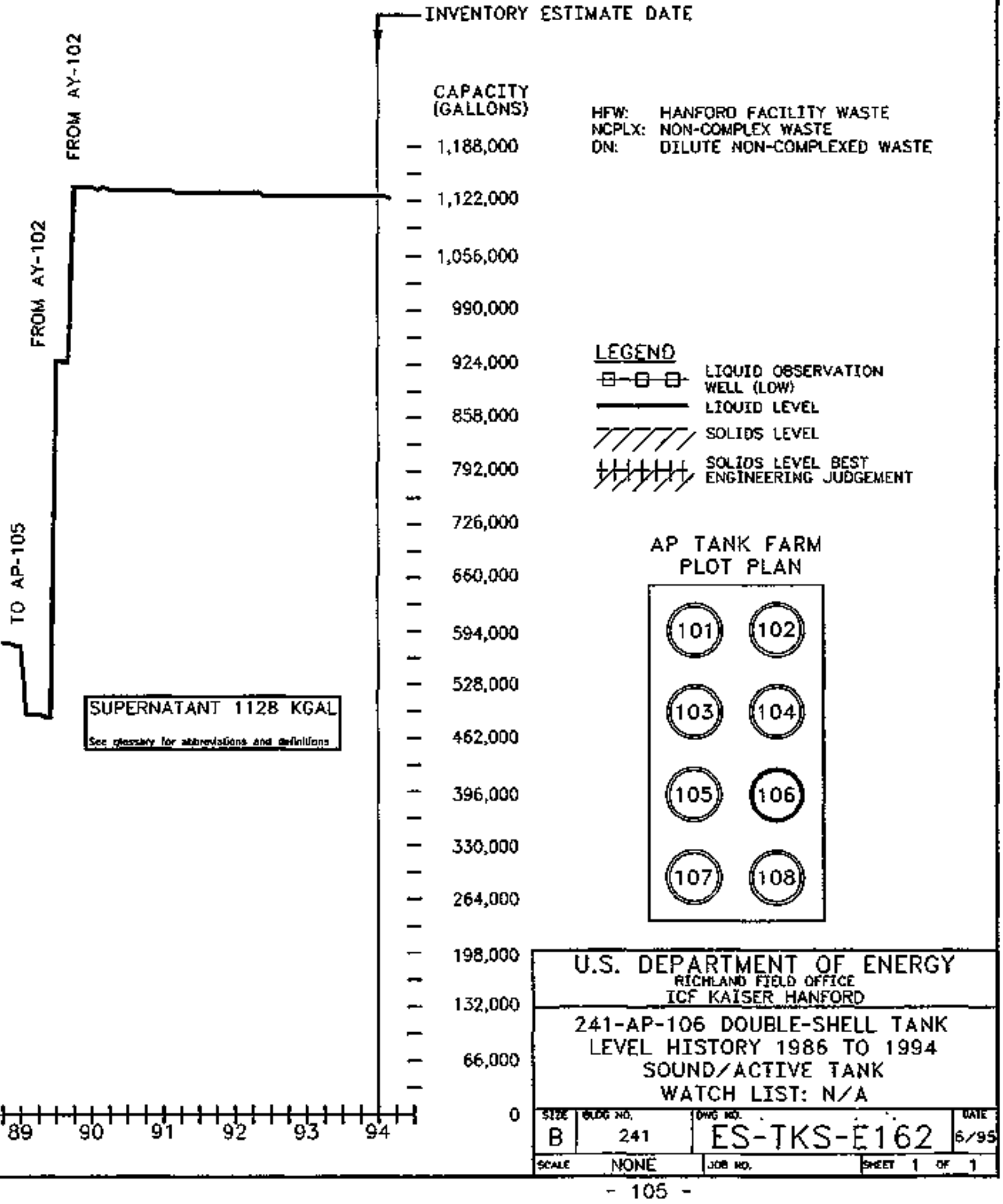




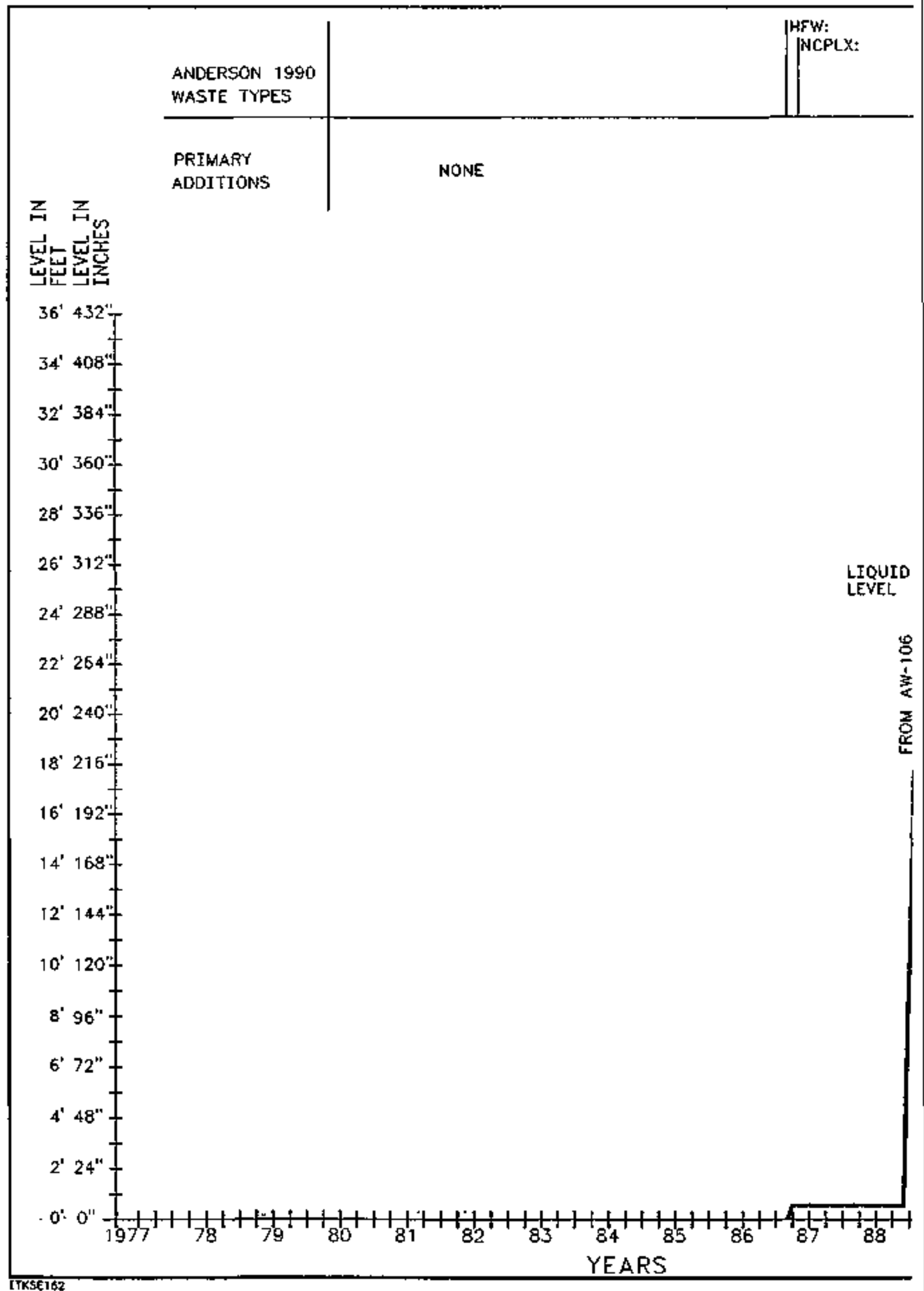


WHC-SD-FM-ER-350, ReV, 0

\begin{tabular}{|c|c|c|c|}
\hline \multicolumn{4}{|c|}{ Double-Shell Tank 241-AP.106 } \\
\hline \multicolumn{4}{|c|}{ Total javertocy Estimate } \\
\hline \multicolumn{4}{|c|}{ 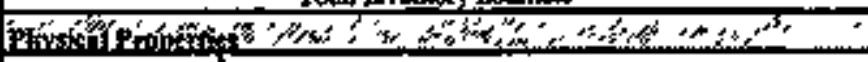 } \\
\hline Tolat Waste & $5.26 \mathrm{E}+0.5 \mathrm{~kg}$ & $(1.13 \mathrm{E}+03 \mathrm{kghal})$ & \\
\hline Heallond & $212 \mathrm{~kW}$ & (7238+03 ETLAIII & \\
\hline BulkDensiyt & & 12t $10 k$ & \\
\hline Water wotot & & 68.5 & \\
\hline TOC w1 $_{1} \% \mathrm{C}$ & & 0,511 & \\
\hline \multicolumn{4}{|c|}{ 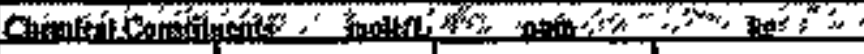 } \\
\hline $\mathrm{N}^{*}$ & 4.64 & $\quad 8.53 \mathrm{E}+04$ & 4.56E+0s \\
\hline$A]^{20}$ & 052 견 & WTE: & 604F+4 \\
\hline Red"(1019 Fet & $5,32 E-02$ & 240 & $1.27 \mathrm{E}+03$ \\
\hline ب. & $1392=09$ & S9: & $108+09$ \\
\hline$B \mathrm{Bi}^{4}$ & 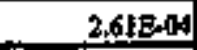 & 45.1 & 23 \\
\hline $1 x^{*}$ & $1,73 \mathrm{~g}_{0} 06$ & Q198: & 102 \\
\hline 볼 & $5.76 \mathrm{E}-0.69$ & 0.956 & 4.93 \\
\hline 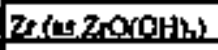 & 1396-09 & 105] & $\mathbf{s} 3 \mathbf{3}$ \\
\hline $\mathrm{Pb}^{2+}$ & 4.71E-0.5 & 8.02 & 41.6 \\
\hline $\mathrm{Ni}^{\mathbf{1 *}}$ & 39SEA0! & -163 & 240 \\
\hline 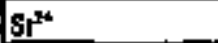 & $1.82 E-06$ & 0.132 & 0.682 \\
\hline $\mathrm{Hur}^{4 *}$ & 6096009 & 279 & $141 E+09$ \\
\hline C." & $3.13 \mathrm{E}-02$ & 1.24E+08 & $6.38 \mathrm{E}+03$ \\
\hline$K^{*}$ & 0.02 & 3290009 & 工 ToE 204 \\
\hline CH' & 2.37 & 334E+04 & $1.72 \mathrm{E}+05$ \\
\hline No: & $2 \cdot 10$ & $10 \pi 2+054$ & 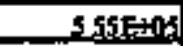 \\
\hline No; & 0.462 & $1.76 \mathrm{E}+04$ & $9.0 T E+04$ \\
\hline $\mathrm{cos}^{\mathrm{F}}$ & 0374 & $1610_{004}$ & S3IF+104 \\
\hline Po: & $8.460-02$ & $6.65 \mathrm{E}+03$ & $3,43 E+04$ \\
\hline $50^{2}$ & 0.112 & $8945+05$ & $46]+2+4$ \\
\hline stcos $\left.\operatorname{sio}_{1}^{21}\right)$ & 263e-09: & $6 \mathrm{t11}$ & 3.15E+03 \\
\hline$F$ & 0.II: & $|92 E \pm 03|$ & $2 \leq 38 \pm 03$ \\
\hline ct & 7.85E-02: & $2.30 E+03$ & L19E+04 \\
\hline c.4t:Ost & 1498:-09 & 23atedgat & L19:E:04 \\
\hline EDTA & $3.68:=03$ & 87 & $4.53 \mathrm{E}+0 \mathrm{~B}$ \\
\hline 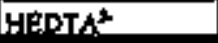 & 6.10E=01 & $138= \pm 03$ & 7LIAEAD \\
\hline efrealetse & 0.122 & 292E+00 & $4009+0$ \\
\hline actiak: & 4. A6E ANA? & 198 & $1.02 E+103$ \\
\hline maxtlat:s. & 6S1Ean & 0.424 & 245 \\
\hline DBP & 5.90E-03 & 785 & $4.055+03$ \\
\hline hyranol & $590=00$ & 369 & $18 D=09]$ \\
\hline $\mathrm{NH}$ & 0.349 & $4915+01$ & $2.53 \mathrm{E}+2 \mathrm{a}$ \\
\hline $\mathrm{Pe}(\mathrm{CN}\}^{4}$ & D & a & 0 \\
\hline 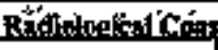 & 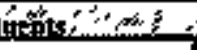 & 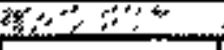 & 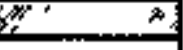 \\
\hline $\mathrm{Pu}$ & & $2.99 \mathrm{E}-02(\mu \mathrm{C} / \mathrm{S})$ & $2.57(\mathrm{~kg})$ \\
\hline$\underline{y}$ & $473 \mathrm{E}-\mathrm{M} \mathrm{MI}$ & 931 (u & $480 \mathrm{E}+150$ (1.r) \\
\hline C9 & 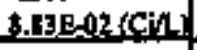 & $73,0(\mu \mathrm{C} / 2)]$ & $3.77 \mathrm{E}+05$ (C) \\
\hline st. & 1,22E-02 (Cin) & 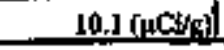 & $5,22 \mathrm{E}+04$ (C) \\
\hline
\end{tabular}

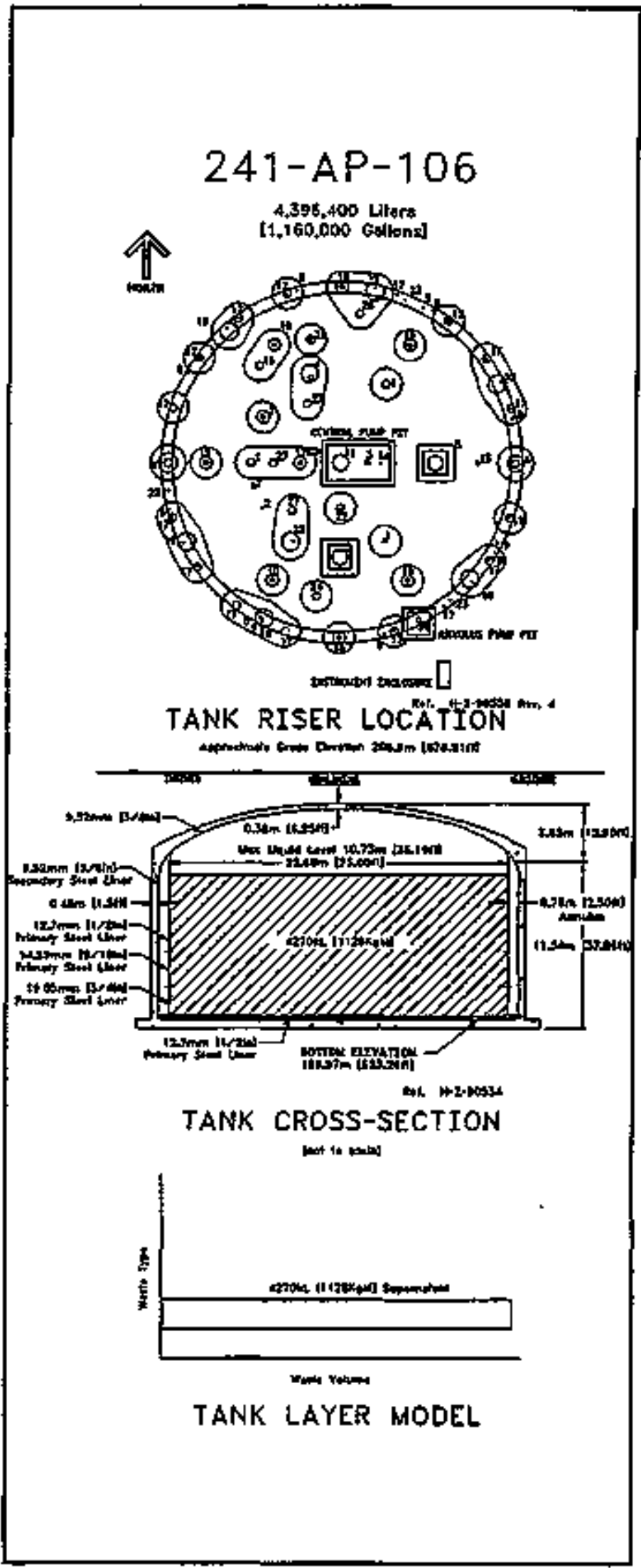




\begin{tabular}{|c|c|c|c|}
\hline \multicolumn{4}{|c|}{ Double-Sbell Tark 24t-AP.106 } \\
\hline \multicolumn{4}{|c|}{ SwM Composite Invectory Estimalts } \\
\hline \multicolumn{4}{|c|}{ 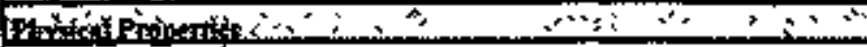 } \\
\hline Total Supernatux & \multicolumn{3}{|c|}{$5.16 \mathrm{E}+061 \mathrm{~g}(1.13 \mathrm{E}+03 \mathrm{kgal})$} \\
\hline tttettLend & \multicolumn{3}{|c|}{ 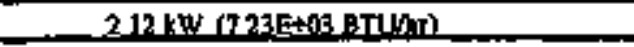 } \\
\hline Butk Dentitye & \multicolumn{3}{|c|}{$121(n / x)$} \\
\hline Water wekt & \multicolumn{3}{|c|}{68.5} \\
\hline$n 0 \mathrm{c} w \mathrm{t} \% \mathrm{C}$ (wot) & \multicolumn{3}{|c|}{0.511} \\
\hline \multicolumn{4}{|c|}{ 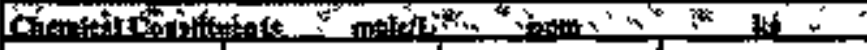 } \\
\hline hat & 4.64 & $8.835+04$ & $4.56 E+05$ \\
\hline$\Delta \mathrm{A}^{\mathbf{*}}$ & 0.524 & $1.17=+04$ & $604=+104$ \\
\hline$F_{0}{ }^{2 *}$ (tetd Fet & $5.32 E-13$ & 246 & $1.27 \mathrm{E}+09$ \\
\hline$a^{*}$ & L_39E-OR & 598 & 30085403 \\
\hline BP* & 2.61E-CA & 45.1 & 233 \\
\hline L." & 1,73 E-O6 & 0198 & 102 \\
\hline$H \mathrm{H}^{*+}$ & S.76E- -06 & 0.9565 & 4.93 \\
\hline $2+(\mathrm{m}=\mathrm{Z} \times \mathrm{O}(\mathrm{OH}) \mathrm{H}$ & $1395=-193$ & 105 & 343 \\
\hline $\mathrm{Pb}^{\mathbf{*}}$ & 4.71E-05 & 8.07 & 41.6 \\
\hline $\mathrm{NF}^{*}$ & 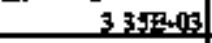 & 169 & \$4⿻ \\
\hline $\mathrm{Si}^{*}$ & J.t2E-06 & 0.1302 & 0.682 \\
\hline $\sin ^{*}$ & 60te.00 & 273 & 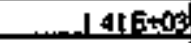 \\
\hline $\mathrm{CQ}^{\mathbf{2}^{2}}$ & 3.1PE-DO & $1.24 E+05$ & $6.38 \mathrm{E}+03$ \\
\hline$\underline{K}^{*}$ & 이에 & $129 E \div 09$ & $130 \mathrm{x}+94$ \\
\hline $\mathrm{OH}$ & 2,37 & $3.34 \mathrm{E}+04$ & $1.72 E+0 s$ \\
\hline No: & 2104 & DTE +05 & $555=+05$ \\
\hline $\mathrm{NO}$ & 0.46 & $1.76 \mathrm{E}+04$ & $9.07 E+04$ \\
\hline$\infty 0^{1}$ & 0324 & 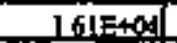 & $831 E+04$ \\
\hline $\mathrm{PO}^{2}$ & AGE-02 & $6.63 \mathrm{E}+03$ & $3.43 E+04$ \\
\hline so. & 0.12 & B 94E+0? & 461540: \\
\hline Si (us $\mathrm{SiO}^{\mathrm{d}} \mathrm{y}$ & 2.63E-02 & 6It & 3.1.5E+03 \\
\hline$F$ & 016 & 182E+03] & 228 $8+103$ \\
\hline ct & $7.85 \mathrm{E}-0.02$ & $230 \mathrm{E}+03$ & 1.19E+04 \\
\hline Catsos. & $488=0$ & 23JE=203 & $-1.99= \pm 24$ \\
\hline EOTA & $3.68 \mathrm{E}-0.03$ & 87 & $4.53 \mathrm{E}+03$ \\
\hline HEDTA & 6. $x \mathrm{E}_{-2} \mathrm{~N}$ & $\{18= \pm 03$ & $746+0$ ? \\
\hline elventent: & $0[2 B]$ & $72 \mathrm{EE}+13$ & $409 E+04$ \\
\hline $\sec x=1 \theta^{\circ}$ & $4.06 \mathrm{E}-03$ & 198 & $1.02 E+03$ \\
\hline oxaln $t^{2}$ & $655=-061$ & 0474 & 245 \\
\hline DAP & $5.900-03$ & $7: 5$ & 4.05E +05 \\
\hline bontand & SQn: $=095$ & 362 & $187 \mathrm{E}+13$ \\
\hline $\mathrm{NH}_{2}$ & 0,349 & 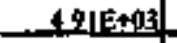 & . 5 고타에 \\
\hline $\mathrm{Fe}(\mathrm{CN}) \mathrm{k}^{+}$ & of & of & \\
\hline \multicolumn{4}{|c|}{ 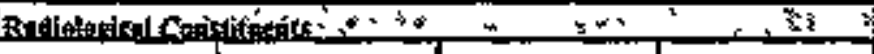 } \\
\hline Pu & 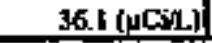 & & $2.57(\mathrm{~kg})$ \\
\hline ii & $4735-03$ iMil & palinos & $4 B 0=+03(\mathrm{kgl})$ \\
\hline G. & $8,835=02(\operatorname{Cin})$ & 73 A (4) & 3,77200 (C) \\
\hline$S_{r}$ & L.22EEN? (Cit)l] & 10.1 (acis) & $532 \mathrm{E}+04(\mathrm{CF})$ \\
\hline
\end{tabular}

- Density is calloulated based oo Na, OH, and AOO2-

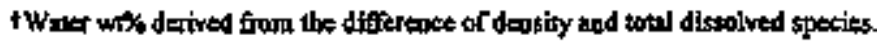

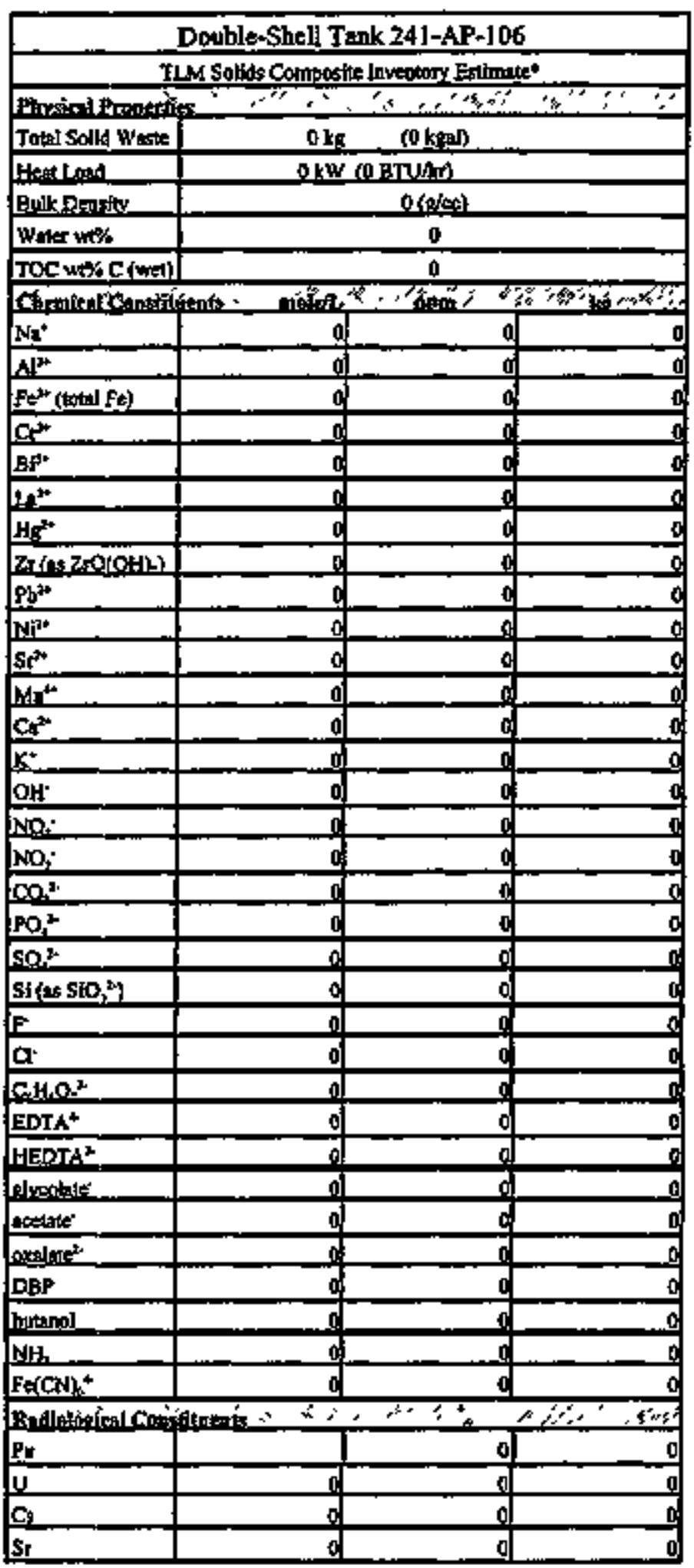

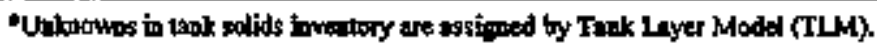


3.7 Tank 241-AP-107

3.7.1 241-AP-107 Tank History

3.7.1.1 Waste zistory of Tank 241-AP-107

Tank 24I-AP-107 begen service by receiving doublemshell slurry feed waste in July 1986. The tank received double-shell slurry feed waste until September 1986. From October 1986 until May 1990, the tank received noncomplexed waste. The tank received waste from puREX during the first guarter of 1990. The tank has contained dilute non-complexed waste from June 1990 until the present. The tank has not received waste since the first quarter of 1990. The tank is currently an active dilute recejver tarik conteining waste that is being concentrated by the 242-A Evaporator.

\subsubsection{Tempereture History of Tank 241-AP-107}

Temperature data for Tank 241-AP-107 are recorded by 18 themocouples at known elevations on ons thermocouple tree inside the tank located in riser 4. Three of the 18 thermocouples gave data that consistently did not match the trend of the rest and, subsequently, were not considered in the statistical values. Non-suspect tentperature data taken between March 1986 and December 1992 for all 18 thermocouples were available from the computex automated surveillance system. Non-suspect tempexature data recorded between July 1989 and August 1993 for 12 of the thermocouples were available from the surveillance analysis computer system. However, not all of the 12 thermocouples have data that encompass the entire length of time. within the time spans of each system, there were small breaks in the securence of temperature data. The average temperature during these periods was $61^{\circ} \mathrm{F}$ with a minimum of $45^{\circ} \mathrm{F}$, a meximum of $71^{\circ} \mathrm{F}$, and a standard deviation of $4.8^{\circ} \mathrm{F}$. Iinear regressions were performed on each thermocouple that had temperature data between January 1990 and January 1994 . The slopes from these regressions were averaged with a resulting average slope of -0.0056 . Refer to the supporting document for a more thorough review of the temperature data (Brevick, 1995).

\section{7 .1 .3 Occurzences of Tank 241-AP-107}

No unusual events concerned the tank since it wont into sexvice.

\subsubsection{Psychrometrics of Tank 241-AP-107}

Psychrometric data have been recorded from this tank for Eive years and from the anmulus for six years. The apparent trend of the ovaporation rate Erom the tank has increased from 122.3 gallons per week in December 1989 to 184.6 gallons per week in Jenuary 1995. Over that same period, the trond in the rates of heat exchange through the primary tank and annular ventilation has apparently increased. A review of the psychrometric data in Tank 241-AP-107 would suggest an overall increase in the rate of heat generation by the waste. 
3.7 .2 Current Status of Tank 241-AP-107

Tank 24l-AP-107 was placed in service in October 1986 and currently stores 161,000 gallons of waste. The following plan view and tank crosssection depict the approximate waste volume of $1,108,000$ gallons and configuration of risers as of January 1994. At the time of the estimate, all 1,108,000 gallons were supernatant. The waste level in the tank is measured with the FIC gauge and the manual tape, and has decreased from 405 inches to 59 inches. The decrease was due to transferring waste to Tank 241-AW-102 on October 1994. This tank is active and the waste is currently being concentrated by the 242-A Evaporator. The tank is actively ventilated and categorized as sound. Terk 241-AP-107 has 71 risers. Seven 4-inch risers (no.15, no.21, no.24, three no.27s, and no.28), three 12-inch risers (no.7 and two no.10s), and two 42-inch risers (two no.5s) are evailable for use.

\subsubsection{Invertory Estimate of Tank 241-AP-107}

The taak 1ayer model (a volume based approximation) that follows was derived Erom the Los Alamos National taboratory Maste status and Transaction Record Summary (Agnew I995) and Stpernatant Mixing Model (Agnew 1995). The estimated inventories of total waste, solids, and supernatant in Tank 241-AP-107 are also gresented.

3.7 .2 .2 In-Tank Photograph of Tank 241-AP-107

No in-tank photographs are available.

3.7.3 Synopsis of Tank 241-AP-107

(To be completed.) 


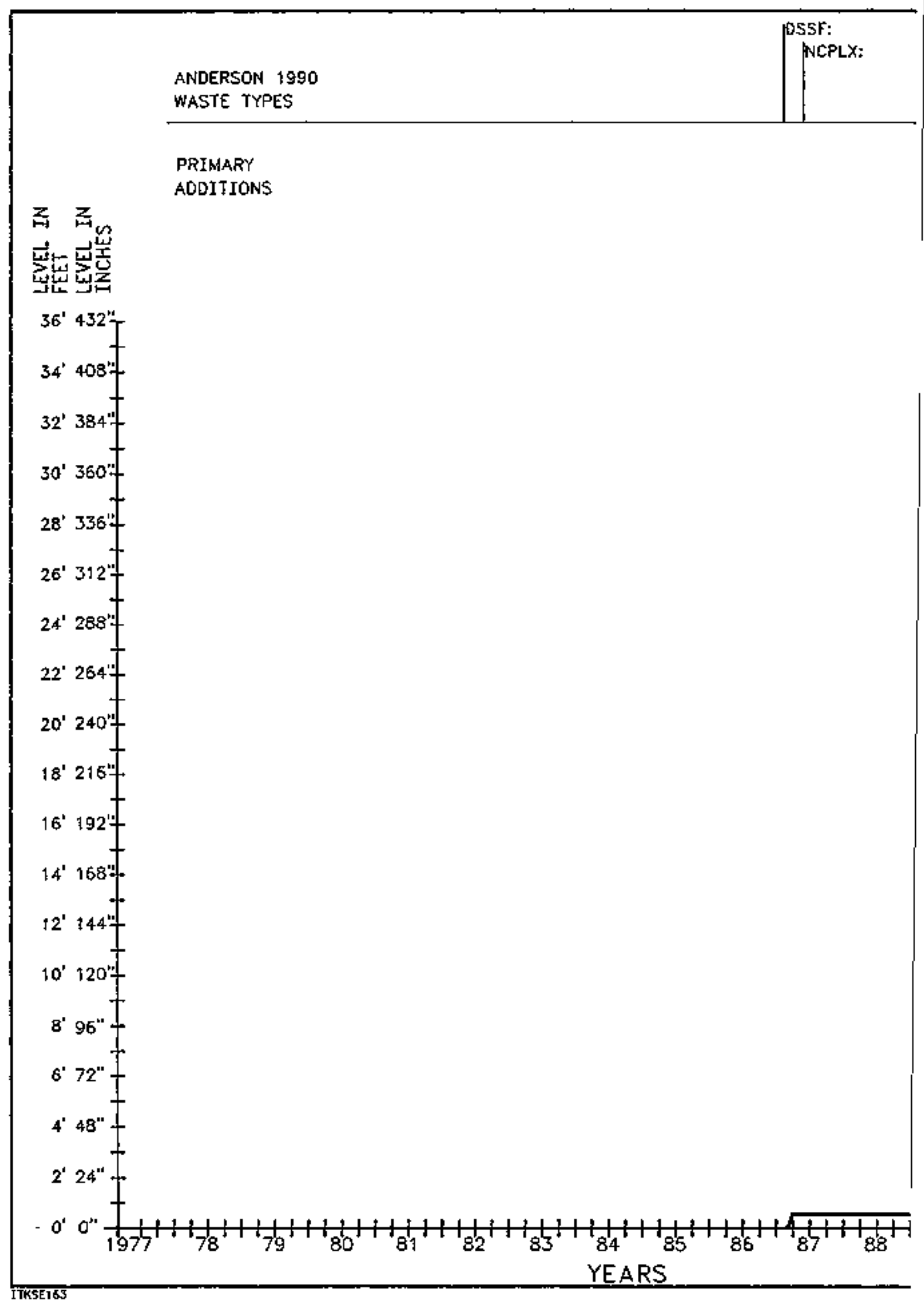




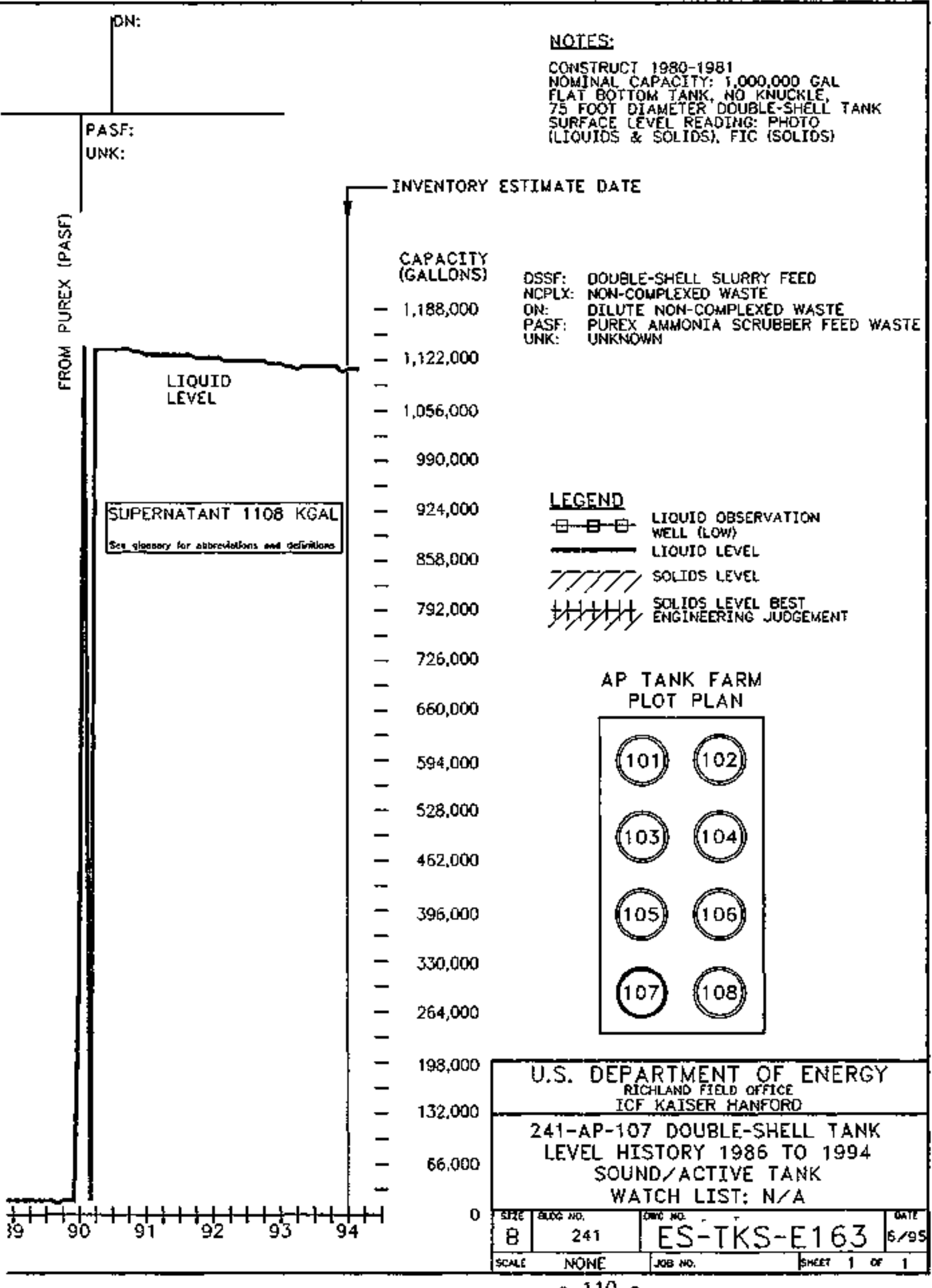


WHC-SD-WH-ER-350, Rev. 0

\begin{tabular}{|c|c|c|c|}
\hline \multicolumn{4}{|c|}{ Doutble-Shell Tank 241-AP-107 } \\
\hline \multicolumn{4}{|c|}{ 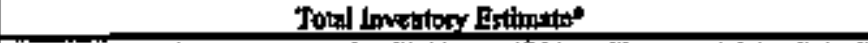 } \\
\hline \multicolumn{4}{|c|}{ 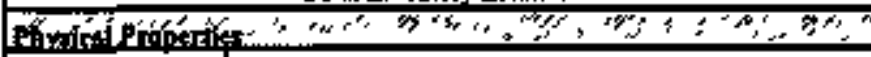 } \\
\hline Todin Whast & \multicolumn{3}{|c|}{ 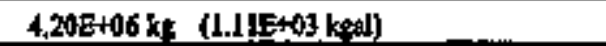 } \\
\hline Hea1 Load & \multicolumn{3}{|c|}{ okw of BTHAl } \\
\hline Byill Dengtivt & \multicolumn{3}{|c|}{1.00 fapect } \\
\hline Worer wrot & \multicolumn{3}{|c|}{923} \\
\hline $\mathrm{TOC}$ unte & \multicolumn{3}{|c|}{0} \\
\hline \multicolumn{4}{|c|}{ 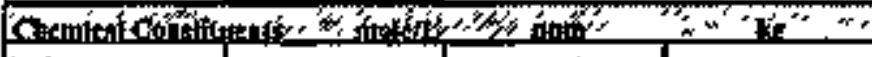 } \\
\hline Nit & $5.73 \mathrm{~B}-02$ & $132 \div+03$ & $5.53 \pm+63$ \\
\hline \multicolumn{4}{|l|}{$\Delta^{2+2}$} \\
\hline$F e^{2 *}(t+0,1 F t)$ & L.99E-0.03 & 110 & 46:3 \\
\hline \multicolumn{4}{|l|}{ 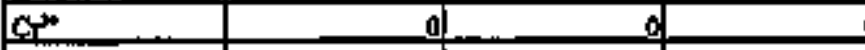 } \\
\hline \multicolumn{4}{|l|}{ B: } \\
\hline \multicolumn{4}{|l|}{$\mathrm{He}^{\mathrm{g}^{\mathrm{t}}}$} \\
\hline \multicolumn{4}{|l|}{ H安 } \\
\hline \multicolumn{4}{|c|}{ 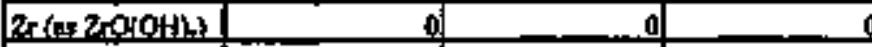 } \\
\hline \multicolumn{4}{|c|}{$\mathrm{Pb}^{*}$} \\
\hline \multicolumn{4}{|l|}{$N^{2 *}$} \\
\hline \multicolumn{4}{|l|}{$s^{s}$} \\
\hline \multicolumn{4}{|l|}{$\mathrm{Mnn}^{4+}$} \\
\hline $\mathrm{Ca}^{*+}$ & $\pm .38 \mathrm{E}-02$ & 553 & $232 E+03$ \\
\hline \multicolumn{4}{|l|}{$k^{*}$} \\
\hline art & 1.58E-02: & 268 & $1,13 E+405$ \\
\hline No: & $6.52 \mathrm{E}-0.2$ & $404 E_{-103}^{3}$ & $170 \mathrm{e}+04$ \\
\hline \multicolumn{4}{|l|}{ No: } \\
\hline Co: & $4932-02$ & 295 & I2AE +0.0 \\
\hline \multicolumn{4}{|l|}{ PO?: } \\
\hline \multicolumn{4}{|l|}{50,2} \\
\hline \multicolumn{4}{|l|}{ Silot Sto.11) } \\
\hline $\mathbf{F}$ & d & . & D \\
\hline $\mathrm{Cr}$ & 0 & c: & 0 \\
\hline EH. & 贯 & at & G \\
\hline EOTA+ & G & 0 & 0 \\
\hline HEVTA ${ }^{2}$ & a & 讨 & 0 \\
\hline resepalate: & & & \\
\hline acotation & of & 0 & 0 \\
\hline axtatenta & d) & a] & 0 \\
\hline DAP & 0] & a & 0 \\
\hline hytemal & of & . & 0 \\
\hline $\mathrm{NH}_{\mathrm{N}}$ & 4 2965-074 & Bs? & $3875+02$ \\
\hline Fo(C) & 0 & 0 & 0 \\
\hline A & & sis & 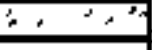 \\
\hline Pu & & 0 & 0 \\
\hline $\mathbf{u}$ & 0 & of & a \\
\hline cs & 0 & c & 0 \\
\hline St & a & of & 0 \\
\hline
\end{tabular}

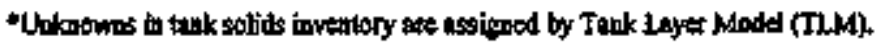

f Volume everape for dexrily, whass avenge Wuter wr\% and TOC wr\% C.

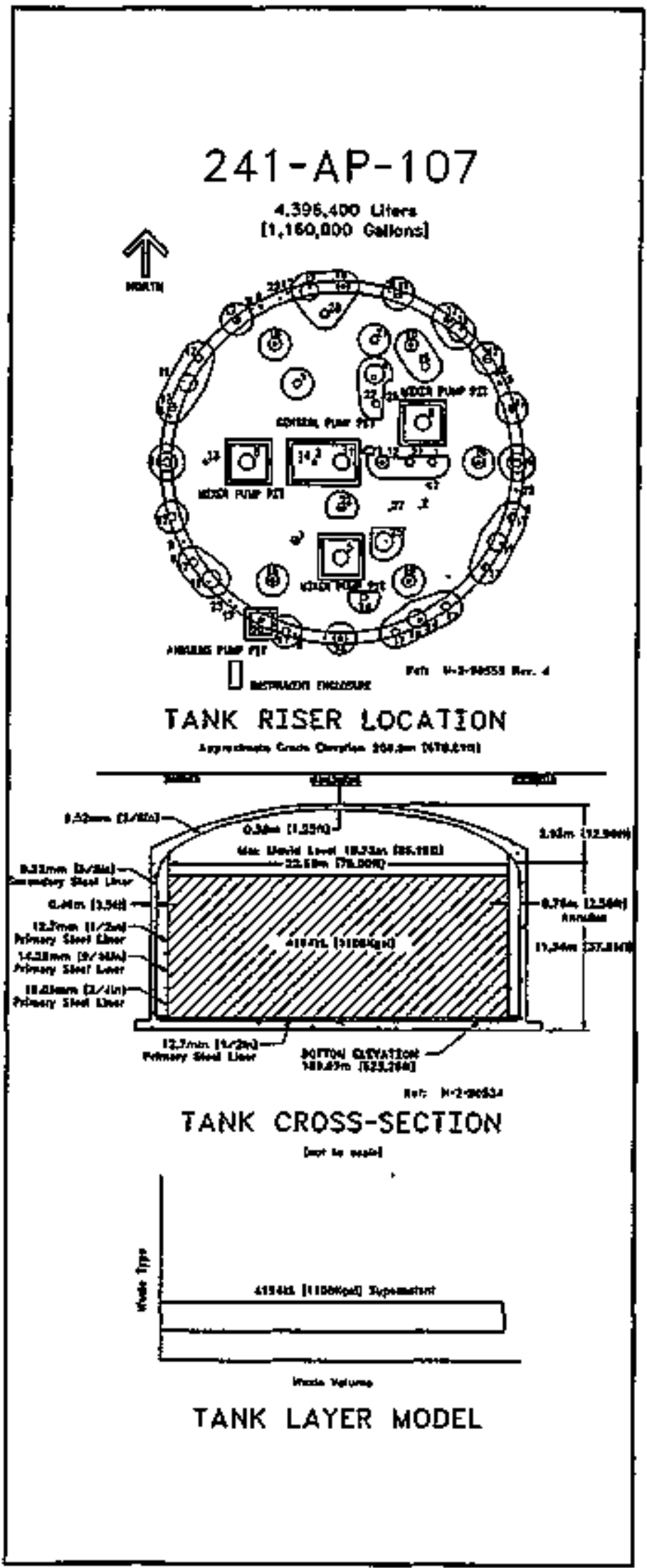


WHC-SD-WM-ER-350, Rev, 0

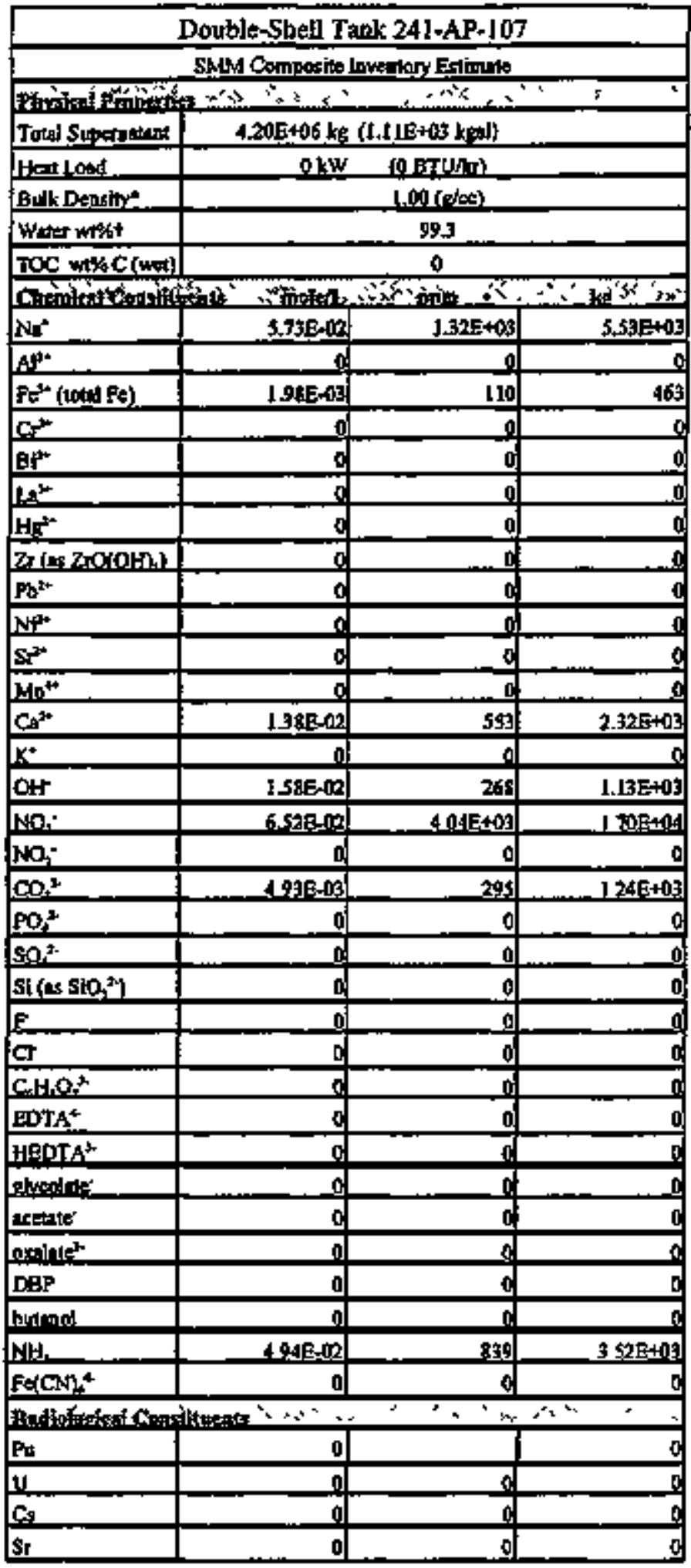

- Dabsity is cakuloked besed on Nk, OH-, and AYOZ.

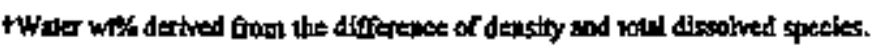

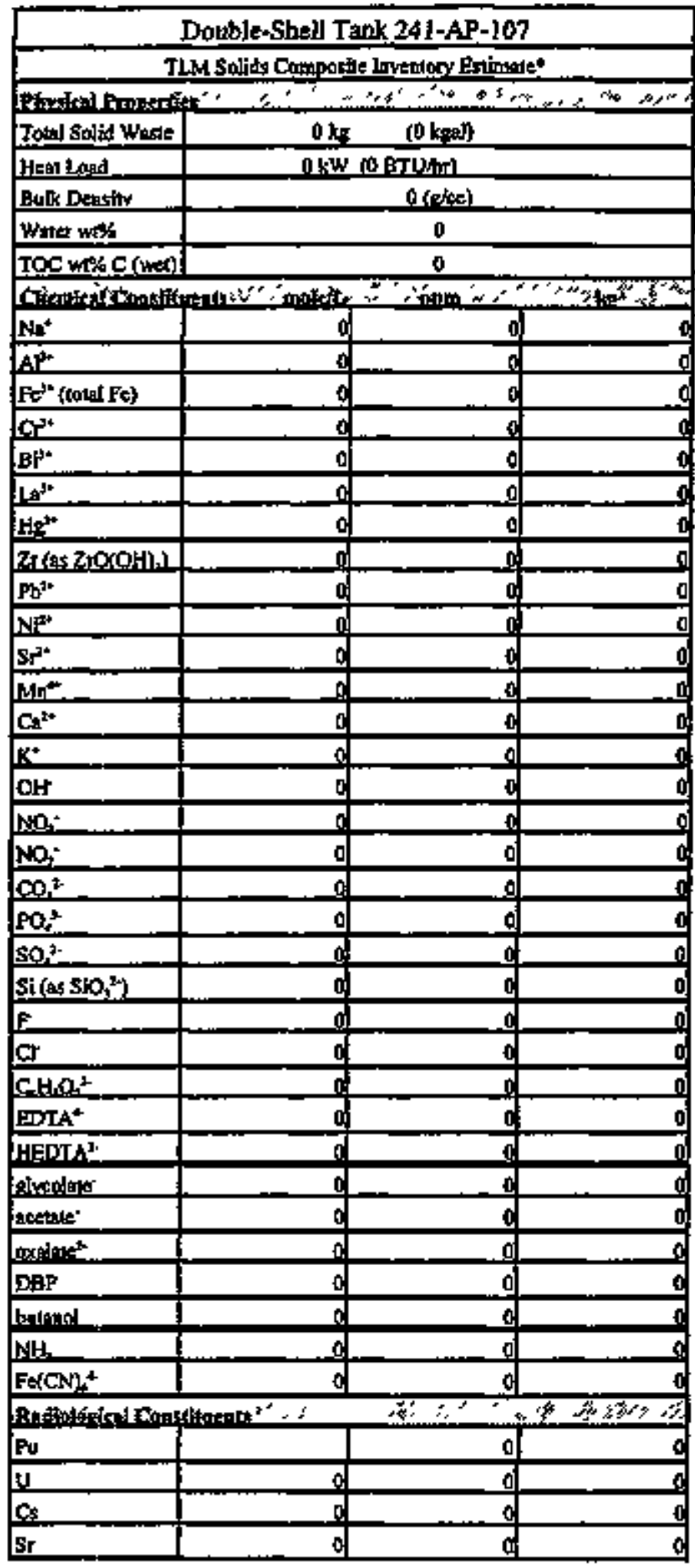

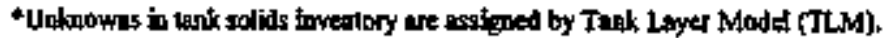


HHC-SD-WM-ER-350, ReV. 0

3.8 Tank 241-AP-108

3.8.1 241-AP-108 Tank History

3.8.1.1 Waste History of Tank 241-AP-108

Tank 241-AP-108 began servics by receiving double-shel1 slurry feed waste in July 1986, and continued to receive this waste until September 1986. From October 1986 until May 1990, the tank received non-complexed waste. From the firet quarter of 1990 until the second guarter of 1992 , the tank received waste from PUREX. The tank has contained dilute noncomplexed waste from June 1990 until the present. The tank is currently an active dilute receiver tank with waste that is being concentrated by the 242-1 Evaporator.

\subsubsection{Temperature History of Tank 241-AP-108}

Temperature data for Tank 241-AP-108 are recorded by 18 thermocouples at known elevations on one thermocouple tree inside the tank located in risex 4. Non-suspect temperature data recorded between March 1986 and December 1992 for all 18 thermocouples were available fzom the computer automated surveillance system. Non-suspect temperature data taken botween July 1989 and August 1993 for 12 of the thermocouples were available from the surveillance analysis computer system. However, not all of the 12 thermocouples have data that encompass the entire length of time. Within the time spans of each system, there were small breaks in the seguence of temperature data. The average temperature during these periods was $63^{\circ} \mathrm{F}$ with a minimum of 50\%, a maximum of $74^{\circ} \mathrm{F}$, and a standara deviation of 5.1\% F. Iinear regressions were performed on each thermocouple that had temperature data between Jamuary 1990 and January 1994. The slopes from these regressions were averaged with a resulting average slope of 0.0057 . Refer to the supporting document for a more thorough review of the temperature data (Brevick, 1995).

\section{8 .1 .3 Oceurrences of Tank 241-AP-108}

No untsplal events concexned the tank since it went into service.

\subsubsection{Psychrometrics of Tank 241-AP-108}

Fsychrometric data have been recorded from this tank for five years and from the annulus for six years. The apparent trend of the evaporation zate from the tank has increased from 42.3 gallons per week in December 1989 to 125.9 gallons per week in January 1995. Over that same period, the trend in the rates of heat exchange through the primary tank and annular ventilation has apparently increased. A review of the psychrometric data in Tank 241-AP-108 would suggest an overall increase in the rate of heat generation by the waste. 
3.8.2 Current status of Tank 241-AP-108

Tark 241-AP-108 entered service in October 1986 and currently stores 793,000 gallons of waste. The following plan view and tank cxoss-section depict the approximate waste volume of 899,000 gadlons and configuration of risers as of January 1994. At the time of the estimate, all 899,000 gallons were supernatant. The waste level in the tank is measured with the FIC gauge and the memual tape and has increased from about 50 inches in January 1991 to 325 inches in January 1994, then decreased to 288 inches in January 1995. The increase was caused mostly by waste received from Tank 241-AY-102 in November 1991. The decrease was because waste was transferred to Tanks 241-AP-101 and 241-AW-102 in October 1994. This tank is active and the waste is currently being concentrated by the 242-A Evaporator. The tank is actively ventilated and categorized as sound. Tank 241-Ap-108 has 71 risers. Eight 4-inch risers (no.15, no.21, no.24, no.26, three no.27s, and no.28), three 12-inch risers (no.7 and two no.10s), and two 42 -inch risers (two no.5s) are available for use.

3.8.2.1 Inventory Estimate of Tank 241-AP-108

The tank layer model (a volume based approximation) that follows was derived from the Los Alamos National Laboratory Waste Status and Transaction Record Summary (Agnew 1995) and Supernatant Mixing Model (Agnew 1995). The estimated inventories of total waste, solids, and supernatant in Tank 241-AP-108 are lso gresented.

3.8 .2 .2 In-Tank Photograph of Tank 241-AP-108

No in-tank photographs are available.

3.8.3 Synopsis of Tank 241-AP-108

(To be completed.) 


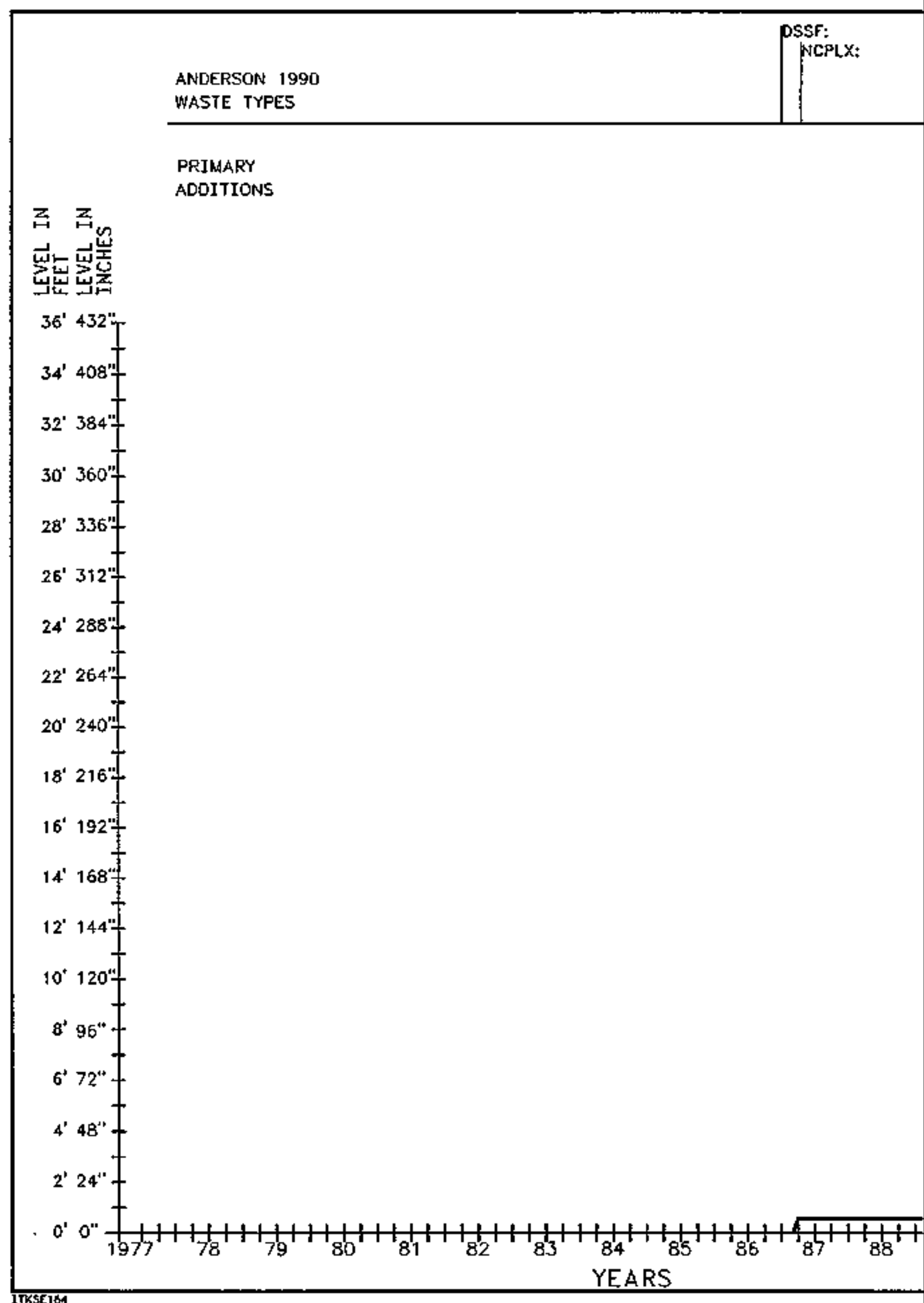




\begin{tabular}{|c|c|c|c|}
\hline \multicolumn{4}{|c|}{ Double-Shell Tark 241-AP-108 } \\
\hline \multicolumn{4}{|c|}{ Tolal loweriory Extimutest } \\
\hline \multicolumn{4}{|c|}{ 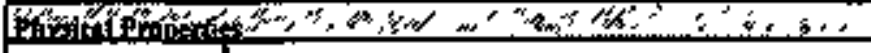 } \\
\hline Tmel Waste & $3.70 \mathrm{E}+06 \mathrm{~kg}$ & (899 $\mathrm{kgan}$ & \\
\hline thend.nes & \multicolumn{3}{|c|}{ 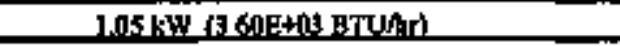 } \\
\hline Bull Denntitut, & \multicolumn{3}{|c|}{ 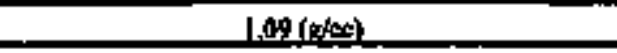 } \\
\hline Wwer watst & \multicolumn{3}{|c|}{$\mathbf{5 . 6}$} \\
\hline TOC whec & \multicolumn{3}{|c|}{0238} \\
\hline \multicolumn{4}{|c|}{ 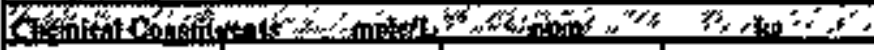 } \\
\hline $\mathrm{Na}^{*}$ & $\ldots$ & $4.036+04$ & 1,492405 \\
\hline 신 & 0246 & $610 \mathrm{E}+03$ & $226=04$ \\
\hline 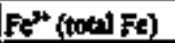 & 1. gSE-03] & 99.9 & 370 \\
\hline$c_{0}^{*}$ & 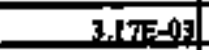 & $|\leq 1|$ & 560 \\
\hline Bi & 3,45E-05 & 6,62 & 24.5 \\
\hline מה. & 2.31E-07 & 2958002 & 0109 \\
\hline Hg" & $7560-07$ & 0.1399 & 0.516 \\
\hline $2 \operatorname{san} 7 \mathrm{rog}$ & $1.83 E-04$ & $15,7]$ & 567 \\
\hline $\mathrm{Pb}^{\mathbf{*}}$ & 1.07e-0s & 2.05 & 7.57 \\
\hline $\mathbf{N u}^{\mathbf{3}}$ & J.33E-0. & 7IA & 266 \\
\hline 5 & 2.44E-07) & 1.97g-02 & 7.28E-02 \\
\hline $\mathrm{Min}^{4 *}$ & 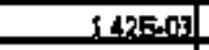 & 716 & 265 \\
\hline $\mathrm{Ca}^{*}$ & $1,36 \mathrm{E}, 02$ & 502 & $1.86 \mathrm{E}+03$ \\
\hline $\mathbf{K}^{*}$ & LAOE=M & 502 & $186 \mathrm{E} 403$ \\
\hline Ott & I. $10^{0}$ & $1.72 E+04$ & $6.36 \mathrm{E}+04$ \\
\hline NO: & 0.89: & $5.12 E+04$ & I \\
\hline NO: & 1.72E-102 & $3.26 \mathrm{E}+0.9$ & $1 .+19+04$ \\
\hline $\mathrm{Cos}^{2}$ & $0,14.5$ & $7092+09]$ & $2.968+04$ \\
\hline PO: & 2.17E- -0 & $1.892+03$ & $7.05 \mathrm{E}+03$ \\
\hline 503 & 5.34E-M? & $4715+03$ & $174 \mathrm{P}+\mathrm{ag}$ \\
\hline$S 1(a, s i 0,2)$ & $1.50 \mathrm{E}-02$ & $3 B 8$ & L.A4E+0. \\
\hline P & L55E=0? & 27 & $100 \mathrm{E}+40$ \\
\hline$c+$ & $3.34 \mathrm{E}-02$ & $1.09 \mathrm{E}+0 \mathrm{03}$ & $4.03 E+03$ \\
\hline chost & 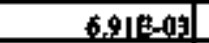 & $2+200003$ & $448 \mathrm{~F}+103$ \\
\hline EDTA+ & 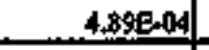 & 129 & 479 \\
\hline HEDTA H. $^{2}$ & $810 \mathrm{E} .000$ & 204 & 75s \\
\hline streolain: & $872 \mathrm{E}-02$ & 5710403 & $2,12 \mathrm{E}+04$ \\
\hline axpes & $5.398-0.94$ & 29.2 & 105 \\
\hline axalotet. & $8725-107$ & 2.065 .02 & 026 \\
\hline DAP & L.1IE- 03 & 164 & 607 \\
\hline bulamal_ & ILIE_A3 & $75:$ & 279 \\
\hline Nh_ & $5 \perp 9 E_{-102}^{-02}$ & s.1 & $3000-28\}$ \\
\hline $\mathrm{F}=(\mathrm{CN})^{4}$ & & 0 & \\
\hline Aly & $9: 4$ & 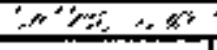 & \#" \\
\hline P) & & E.42E-02 (p $C \mathrm{C}+\mathrm{H})$ & $0 \cos 3(k x)$ \\
\hline$\underline{\underline{u}}$ & 203E-015 OM: & $444(y-1)]$ & 164800 $0 \mathrm{kn}$ \\
\hline Cs & 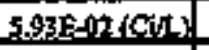 & SAss(uCify) & $202 \mathrm{E}+0 \mathrm{~s}_{1} \mathrm{CO}$ \\
\hline Sir & 4,72E-03 (CtL) & 434 (ncis) & t.61E+a4 (Ci): \\
\hline
\end{tabular}

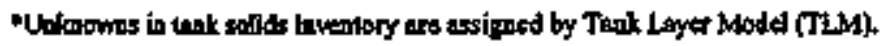

t Volume average for dencity, mus averags What int and IOC wro $C$.

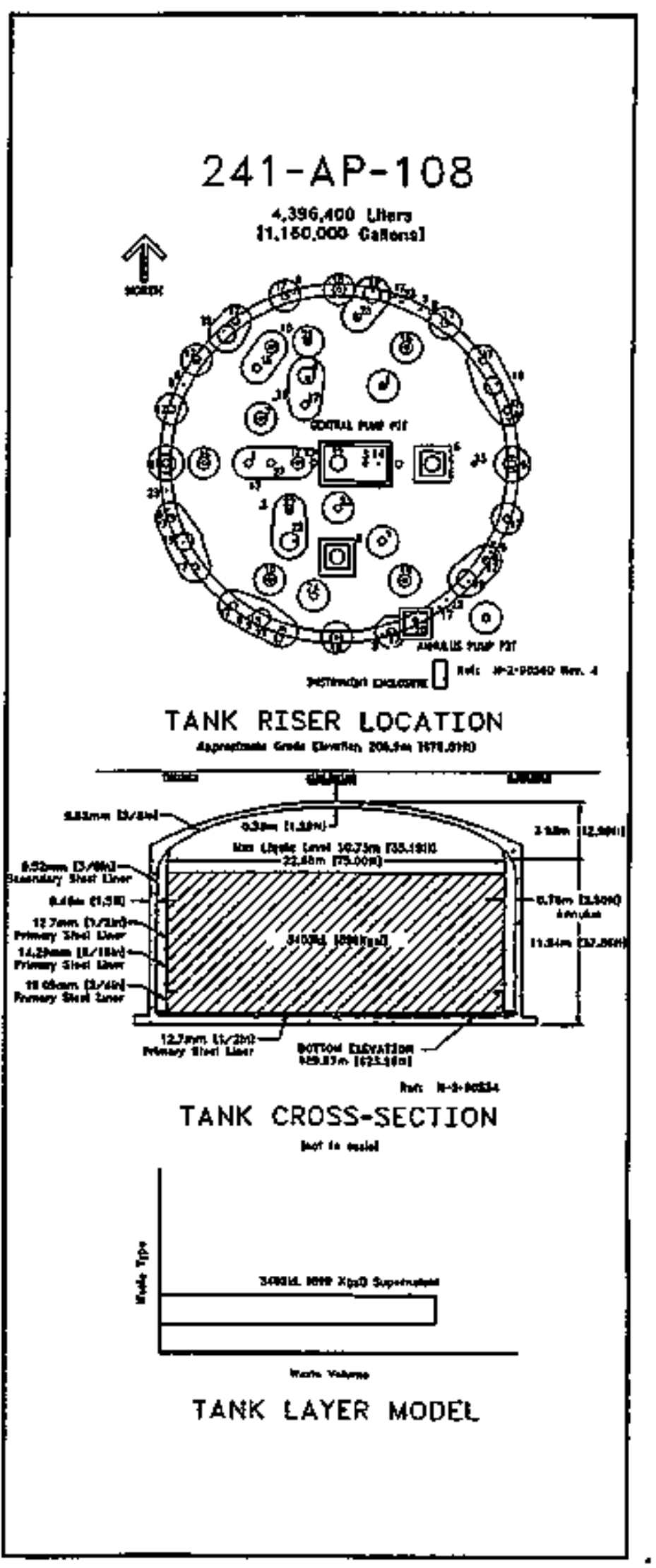

$6 / 95$ 
THC-SD-WM-ER-350, ReV * 0

\begin{tabular}{|c|c|c|c|}
\hline \multicolumn{4}{|c|}{ Double-Shedl Tank 241-AP-108 } \\
\hline & \multicolumn{3}{|c|}{ 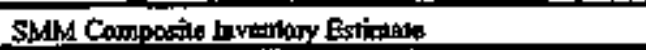 } \\
\hline 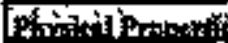 & 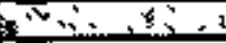 & $\therefore \quad \therefore=4$ & $\because 3$ \\
\hline Fotel Supetoratend & $3,70 \mathrm{E}+06 \mathrm{~kg}$ & (B99 kgal) & \\
\hline Hortagd & \multicolumn{2}{|c|}{$\frac{3.70 \mathrm{E}+06 \mathrm{~kg} \quad(\mathrm{Bg9} \mathrm{kgz})}{105 \mathrm{~kW}(3.60 \mathrm{E} 403 \mathrm{BT} \text { ) }}$} & \\
\hline Bulk Pegring & \multicolumn{3}{|c|}{$1.09(9.000)$} \\
\hline Werer wetht & \multicolumn{3}{|c|}{85.6} \\
\hline$T O C$ wts $\mathrm{C}$ (wel) & \multicolumn{3}{|c|}{0.238} \\
\hline \multicolumn{4}{|c|}{ 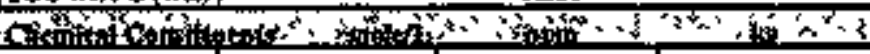 } \\
\hline $\mathrm{Nat}^{*}$ & 191 & 4.03E+0. & 1.49E+0S \\
\hline$|A|^{*}$ & 0246 & $6108+03$ & $2265+109$ \\
\hline 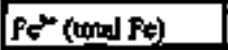 & 1.95E-0: & $\$ 9.9$ & 370 \\
\hline a & $3] \overline{75-03}$ & 131 & 360 \\
\hline Gip+ & 3.45s-0s & 6.62 & 245 \\
\hline $2 t^{2 *}$ & $23 \mathrm{IE}-1 \mathrm{~N}$ & 2056013 & $g[0$ \\
\hline $\mathrm{Hg}$ & $7.56 e_{-0.07}$ & 0.139 & 0.516 \\
\hline 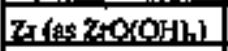 & 18380 a! ! & 153 & 56 \\
\hline$P \mathbf{b}^{20}$ & $1.07 E-05$ & 2.05 & 7.57 \\
\hline $\mathrm{NF}^{2 *}$ & $\perp 33 E_{-02}$ & 교요 & 266 \\
\hline $\mathrm{sr}$ & 2,44E-0nt & $1970-02$ & $728 \mathrm{~s}=02$ \\
\hline $\mathrm{Min}^{*}$ & 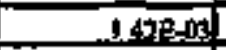 & II. & 76 \\
\hline $\mathrm{CF}^{7^{*}}$ & $136 \mathrm{E} \cdot 0 \mathrm{0}$ & 502 & $1.86 \mathrm{~B}+03$ \\
\hline$x^{*}$ & LAGESOS & 801 & $1860+09$ \\
\hline ot: & 1.10 & $1.72 \mathrm{E}+0 \mathrm{~d}$ & $636 \mathrm{E}+0 \mathrm{~N}$ \\
\hline NQ: & 089: & $512 \times+00$ & $189 \mathrm{E}+0.5$ \\
\hline No: & $7.72 E-02$ & $3.26 E+03$ & $1.21 \mathrm{E}+04$ \\
\hline $\cos ^{2}$ & 0.45 & $799 \mathrm{E}+103$ & $296 \mathrm{E}+104$ \\
\hline $\mathrm{PO}^{2}$ & $2.17 E-02$ & $1.89 \mathrm{E}+0.5$ & $7,01 \ldots+03$ \\
\hline $500^{2}$ & $534=-02$ & $471=40$ & $124 \mathrm{E}+104$ \\
\hline$S i\left(=\sin ^{2}\right)$ & $1.50 E-02$ & 38 & $1.44[+03$ \\
\hline$r$ & $1.55=-92$ & 27 & $10,0 \mathrm{E}+03$ \\
\hline$\omega$ & $3,348 \cdot 02$ & $1.02 E+03$ & $4.05 E+03$ \\
\hline c.tho.2 & $692 E_{0} 03$ & L $20 E+0 \mathrm{E}$ & $448 \mathrm{~B}+10 \mathrm{f}$ \\
\hline EDTA ${ }^{2}$ & $4.896-04$ & 120 & 479 \\
\hline HEPTA $A^{2}$ & 8105.04 & 204 & 75 \\
\hline duraldere & $8292-07$ & $5717+033$ & $212 \mathrm{E}+04$ \\
\hline Lefisic: & 5.3 ge $-0 \mathrm{~d}$ & 292 & 100 \\
\hline Doploret & 8 3720-07 & $706 \mathrm{E}-47$ & 025 \\
\hline Dep & L.|1E-03| & 164 & 607 \\
\hline hutanal & $|2| e_{0}-0 \mid$ & 795 & 279 \\
\hline $\mathrm{NH}_{2}$ & $5 \triangle \mathrm{E} E \mathrm{O}_{2}$ & 8닌 & $30018 \div 02$ \\
\hline $\mathrm{F} x\left(\mathrm{CN}_{k}\right)^{4}$ & & 0 & \\
\hline 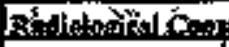 & 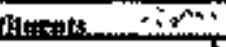 & & 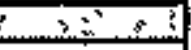 \\
\hline $\mathrm{Pu}$ & $15.4(\mathrm{ACH})$ & & $0.8730 \mathrm{gs}$ \\
\hline u & $203 E_{-0}$ (M) & 446 (u) & 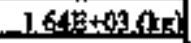 \\
\hline c: & 5.92E-A2 (CH) & 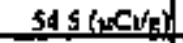 & $2.02 \mathrm{E}+05(\mathrm{C}) \mathrm{s}$ \\
\hline Sr & 4,22B-13 (C) & $4,34(1, C) / 4)$ & $161 \mathrm{E}+04(\mathrm{Ci})$ \\
\hline
\end{tabular}

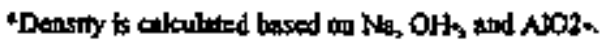

\begin{tabular}{|c|c|c|c|}
\hline \multicolumn{4}{|c|}{ Double-Shell Tank 241-AP-108 } \\
\hline \multicolumn{4}{|c|}{ 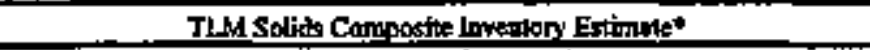 } \\
\hline \multicolumn{4}{|c|}{ 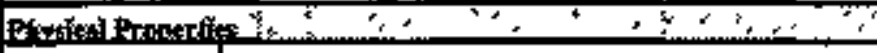 } \\
\hline Tow Sold Wagle & $0 \mathrm{~kg}$ & (0 kgl) & \\
\hline 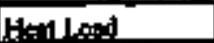 & \multicolumn{3}{|c|}{ onw $(0 . B T(\mu / 4)$} \\
\hline Bulk Defraty & \multicolumn{3}{|c|}{0 of $\cos 0$} \\
\hline Waler whe & \multicolumn{3}{|c|}{0} \\
\hline TOC wis C (una) & \multicolumn{3}{|c|}{0} \\
\hline \multicolumn{4}{|c|}{ 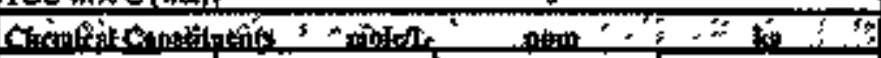 } \\
\hline \multicolumn{4}{|c|}{\begin{tabular}{|l|lll}
$\mathrm{Na}^{*}$ & 0 & 0 & 0
\end{tabular}} \\
\hline \multicolumn{4}{|l|}{$\mathrm{A}^{\mathrm{N}^{*}}$} \\
\hline \multicolumn{4}{|l|}{ 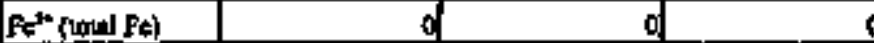 } \\
\hline \multicolumn{4}{|l|}{$c^{*}$} \\
\hline \multicolumn{4}{|l|}{$\operatorname{sit}^{2}$} \\
\hline \multicolumn{4}{|l|}{ L每 } \\
\hline \multicolumn{4}{|l|}{$\operatorname{Hin}$} \\
\hline \multicolumn{4}{|l|}{ Zu(s) ZroroHh) } \\
\hline \multicolumn{4}{|l|}{$\mathrm{Pb}^{\mathrm{*}}-\mathrm{O}$} \\
\hline \multicolumn{4}{|l|}{$\mathrm{Nit}^{*+}$} \\
\hline \multicolumn{4}{|l|}{ sts } \\
\hline \multicolumn{4}{|l|}{$\mathrm{Mp}^{*+}$} \\
\hline \multicolumn{4}{|l|}{$\mathrm{CP}^{2+}$} \\
\hline \multicolumn{4}{|l|}{ Ka } \\
\hline \multicolumn{4}{|l|}{$\mathrm{OH}$} \\
\hline \multicolumn{4}{|l|}{ No: } \\
\hline NO: & 0 & a) & 0 \\
\hline $\cos _{2}^{2}$ & & of & a \\
\hline Pots & o & 0 & 0 \\
\hline son. & & a & . \\
\hline $\sin \left(\cos \operatorname{sig}{ }^{2}\right)$ & & 0 & 0 \\
\hline$F$ & & d & 0 \\
\hline $\overrightarrow{C T}$ & 0 & 4 & 0 \\
\hline $\mathrm{CH} \mathrm{O}^{2}$ & & 1 & 0 \\
\hline Eorst & of & 4 & A \\
\hline HEDTA & d & $a$ & 0 \\
\hline elucohis: & & $a$ & n. \\
\hline acotoste & 0 & of & 0 \\
\hline $0 \times 10.1 t^{2}$ & & i) & (1) \\
\hline DEP & 0 & of & 0 \\
\hline butrual & & at & n \\
\hline Nㅓㄴ & & 0] & 0 \\
\hline $\mathrm{Fe}(\mathrm{CN}){ }^{*}$ & of & o- & 0 \\
\hline 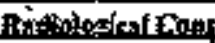 & siss & $y^{\prime}$ & 'x \\
\hline $\mathrm{Pa}$ & & 0 & 0 \\
\hline 4 & & of & 0 \\
\hline$c_{1}$ & & d] & 0 \\
\hline 8 & d) & o. & 0 \\
\hline
\end{tabular}

"Unkerwos in tuk solids incutory are assigaed by Tank Layer Moded (TLM).

tWate wes derived from the difference of densuly and kill disolved specises. 
$4 \quad$ AW Tank Farm

\subsubsection{AN Tank Fazm History}

The AW Tank Farm is located south of 4 th street and west of canton Avenue in the 200-East Area. The AW Tank Farm contains six, 100 series, 1,160,000 gallon, 75-foot diameter double-shell tanks. The AW Tank Farm is the latest tank design with a reinforced concrete shell and dome, and an insulating concrete base. A heat-treated, stress-relieved, primary steel liner and a non-stress-relieved, otter steel liner are inside the concrete shell. These tanks were ande to hold concentrated supernatant. The maximim design temperature for liquid storage is $350^{\circ} \mathrm{F}$. The tanks are at the same elevation and no cascade lines exist between the tanks.

A color aerial photogxaph taken in 1993 of the Aw Tank Farm shows the orientation of the 100 series tanks, leak detection bits, annulus ventilation equipment, instrument house, and valve pits. 
WHC-SD-WM-ER350, Rev, 0 .

\section{AW TANK FARM}
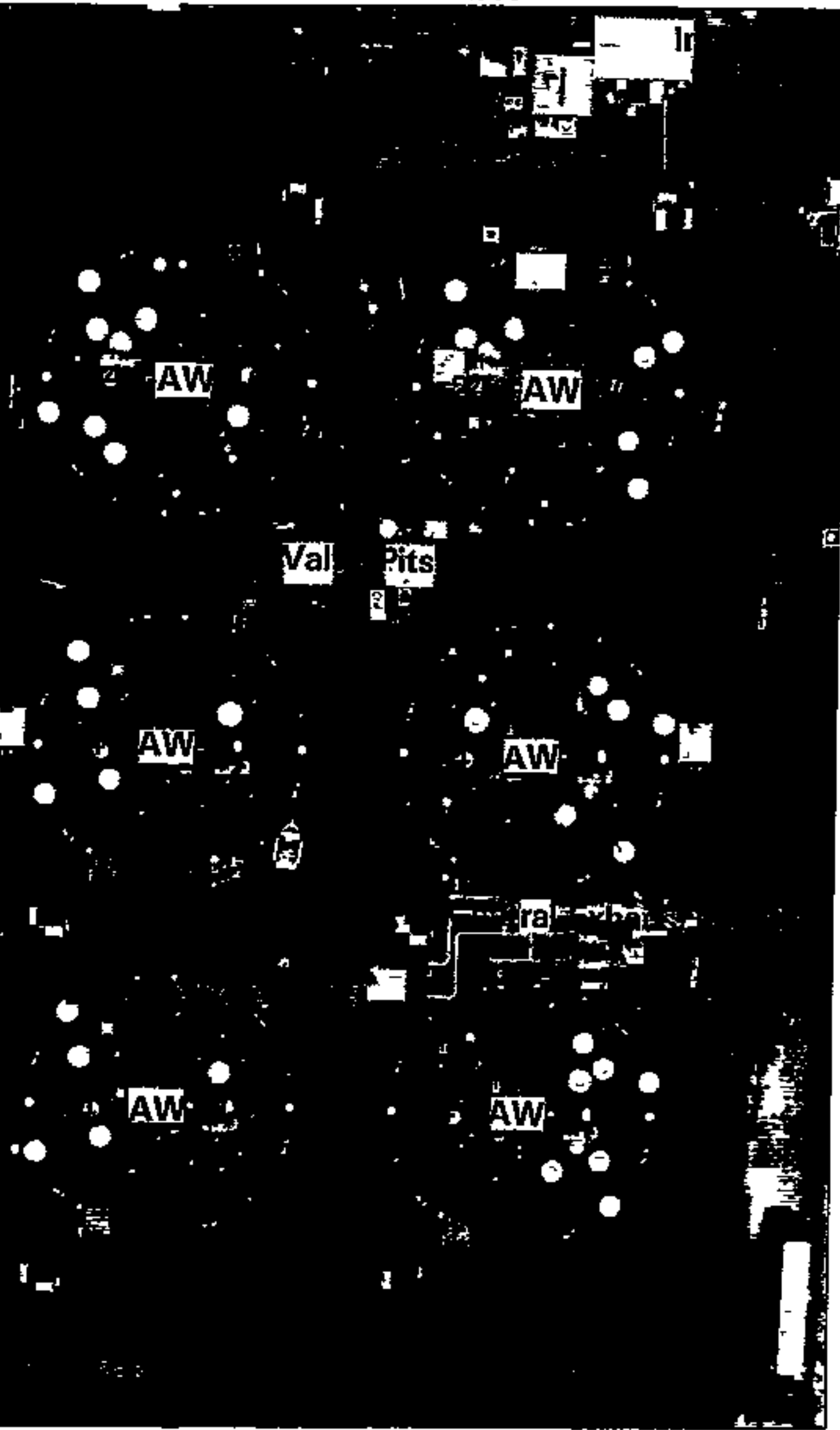


$$
\text { WHC-SD-WM-ER-350, Rev, } 0
$$

\subsubsection{AW Tank Farm Waste History}

Non-complexed waste was received by the An Tank Farm in July 1980, and was ditributed to all tanks except Tank 241-AW-106 which received complexant concentrate waste. Tanks 241-AW-101, -103, -105, and -106 received double-shell slurry waste from December 1981 to May 1990. Complexant concentrate waste was also sent to Tanks 241-AW-104 and -105, while Tank 241-AW-101 received complexed waste and dilute non-conglexed waste Irom the 200-Bast Area single-shell tanks. Iow-level PUREX waste has been added to Tanks 241-AW-101, -103, -104, and -105. Presently, Tanks 241-Ait-102 and -106 are the feed and slurry receiver tanks, respectively, for 242-A Evaporator.

\subsubsection{AW Tank Farm Temperature History}

Each of the six tariks within the Aw Tank Farm contains at least one thermocouple trae with readings indicating between 6 and 12 thormocouples per tree. Since 1993, Tank 241-AW-101 has been on the Hydrogen Watch List. This tank is monitored weskly, at a minimum, with reguirements that the temperatures of the remaining tanks are recorded semiannually. Temperature data are stored in the computer automated surveillance system and the surveillance analysis computer system. These two databases hold all the temperature data used in developing the statistical results for each tank.

\subsubsection{AW Tank Fam Oscuxrences}

Six unusual events concexned Af Tank Farm as a whole. Occurrence report RL-MHC-Tank Farm-1990-0346 and Off-Normal Reports 86-33, 86-27, 86-25, and 86-17 were written because failing ecuipment caused tanks to pressurize. O.N. Report 86-27 was issued in June 1986 when the back up ventilation system failed curing changing of the HERA filters. $0 . N$. Repoxt 86-25 was issued in April 1986 when the exhaust ventilation syotem shut down for 21 minutes. O.N. Report 86-17 was issued in February 1986 when the exhaust ventilation system shut down again. O.N. Report 83-19 was written because tanks pressurized during a waste transfer. For more information, refer to the supporting Document for the Southeast Quadrant HTCE for AW Tank Farm (Brevick, 1995).

\subsubsection{Aw Tark Farm Ventilation}

Each tank is designed to have 167 sCFM of air travel through it and $800 \mathrm{~cm}$ of dir travel through the amulus. Air enters the tanks by infiltration because there is no supply fan. After exiting each tank syatem, the aix ducts are joined to allow the service of one fan to send the aix into the primary exhaust system. Before the tank air is released to the atrosphere, the air is heated, run through a prefilter, and then run through two HBEA filters. In the annular system, air enters $a 35 \%$ preEilter and a HEPA filter before it enters the annulus. Then the air enters an electric heater and two more HEFA filters before it is exhausted to the atmosphere. Both the tank and annular systems have a primary and backup aystem. For more information, refer to drawings $4-2-70336$ and H-2-90905. 


$$
\text { WHC-SD-WM-ER-350, ReV. } 0
$$

The psychrometric data are recorded in two parts, the tank data and the annulus data. Por water and heat leaving the tank, the numbers are positive. For more information, refer to the Supporting Document for the Southeast Quadrant HTCE for Aw Tank Farm (Brevick, 1995).

\subsubsection{Current Statis of AW Tank Farm}

Tank 241-AW-101 was officially added to the Hydrogen watch List in Tune 1993. The tank is identified as an ureviewed safety question due to the concern that burning flammable gas could result in a radiological release. All tanks are actively ventilated and categorized as sound. currently, the total waste volume is 3,849,000 gallons. The estimated volumes (Agnew, January 1994) depicted in each tank cross-section total 6,000,000 gallons of waste. At the time of the estimate, there were $5,232,000$ gallons of supernatant with 549,000 gallons of concentrated supernatant solids; 1,000 gallons of low-level waste fxom B Plant; 184,000 gailons of low-level waste from PUREX; and 583,000 gallons of coating waste from $z$ Plant and REDOX.

\subsection{Tank 241-AW-101}

4.1.1 241-AW-101 Tank History

4.1.1.1 Waste History of Tank 241-AW-101

Tank 241-AW-101 began service by receiving non-complexed waste in July 1980. The tank continued to receive non-complexed waste until November 1981, and again from December 1982 until Harch 1983. From December 1981 until November 1982, the tank received dilute double-shell slurry feed waste. The tank received complexant concentrate waste from April 1983 until June 1984. From July 1984 until April 1986, the tank again received non-complexed waste. The tank received waste from PUREx and dilute noncomplexed waste from the 200-East Area SSTs from the third quarter of 1984 unti.t the first guarter of 1986. The tank contained double-shell slurry feed waste from May 1986 until the present. The slight changes in level moasurements are attributed to sluxry growth as a result of gas generation. The tank has not received waste since the thisd quartex of 1986 . The tank is currently an inactive concentrated waste holding tark.

\subsubsection{Temperature History of Tank 241-AW-101}

Temperature data for Tank 241-AW-101 are recorded by 18 thermocouples at known elevations on one thermocouple tree inside the tank, located in riser 4A. Non-suspect temperature data taken between July 1983 and April 1992 for all 18 thermocouples were available from the conputer automated surveillance system. However, not all of the 18 thermocouples have data that encompass the entire length of time. Non-suspect tenperature data recorded between July 1989 and September 1993 for 12 of the thermocouples were available from the survejl.lance analysis computer system. Not all of the twelve thermocouples have data that encompass the entire length of time. Within the time spans for both systems, there were several small breaks in the sequence of temperature data. The average temperature during 
WHC-SD-WM-ER-350, ReV. 0

these veriods was $98^{\circ} \mathrm{F}$ with a minimum of $75^{\circ} \mathrm{F}$, a maximum of $135^{\circ} \mathrm{F}$, and a standard deviation of $9.0^{\circ} \mathrm{F}$. Lindar regressions were performed on each thermocouple that had temperature data between January 1990 end January 1994. The slopes from these regressions were averaged with a resulting average slope of -0.0029 . Refer to the supporting document for a more thorough review of the temperature data (Brevick, 1995).

\subsubsection{Occurrences of Tank 241-AW-101}

Nine unusual events occurred at Tank 241-AW-101. Occurrence report RL--WHC-Fank Farm-1993-0103 was written due to an equipnent failure associated with waste level measurements. Occurrence report RL-- hitc-Tank Farm-1992-0083 was written because the tank burped. O.N. Reports 86-2, 85-24, and 84-33 each describes the tank pressurizing during a waste transfer. $0 . N$. Reports 85-48, 85-41, and 85-36 were written because of problems during a transfer of waste. $0 . N$. Report 85-25 describss inproper use of equipment causing the tank to pressurize.

\subsubsection{Psychrometrics of Tank 241-AW-101}

Psychrometric data have been recorded for 12 years from this tank and armulus. The apparent trend of the evaporation rate from the tank has decreased from 185 gallons per week in November 1981 to 42.4 gallons per week in January 1995. Over that same period, the trend in the rates of heat exchange through the primary tank ventilation has decreased. The rates of heat exchange through the annular ventilation show an increasing trend. The majority of the changes in the rate of heat exchange can be attributed to changes in the average ventilation rates. A review of the psychrometric date in Tank 241-AW-101 would suggest a decrease in the rate of heat generation by the waste.

\subsubsection{Current Status of Tank 241-AW-101}

Tank 241-Ak-101 entered service in August 1980 and currently stores $1,123,000$ gallons of wasts. The following plan view and tank cross-section depict the approximate waste volume of $1,138,000$ gallons and configuration of risers in January 1994. At the time of the estimate, there were $1,077,000$ gallons of supernatant with 23,000 gallons of concentrated supernatant solids and 61,000 gallons of PUREx low-level waste (PL2). The waste level in the tank is measured with the FIC gauge and the manual tape and has remined at about 410 inches over the last three years. This tank is on the Hydrogen watch List and, therefore, is prohibited from receiving waste. The tank is actively ventilated and categorized as sound. Tank 241-AW-101 has 64 risers. One 4-inch riser (no.13A), three 12-inch risers (no.7B, no.24A, and no.24B), two 20-inch risers (no.25A and no.25B), one 36 -inch riser (no.26A), and two 42-inch risers (no.5A and no.5B) are available for use.

\subsubsection{Inventory Estimate of Tank 241-AW-101}

The tank layer model (a volume based approximation) that follows was derived from the Los Alamos National Iaboratory haste status and 
Transaction Record Sumtary (Agnew 1995) and Supermatant Mixing Model (Agnew 1995). The estimated inventories of total waste, solids, and supernatant in rank 241-AW-101 are also presented. Concentrated supernatant solids are considered as an integral part of the liguid for the purpose of estimating inventories, but are graphed as solids on the level histories. The actual substance, which was derived from double-shell slurry, appears as a solid if undisturbed, but the particles are resuspended in solution if heated or disturbed.

\subsubsection{In-Tank Photograph of Tank 241-AW-101}

As of April 1994. Tank 241-AW-101 contained 1,124,000 gallons of double-shell slurry feed (Hanlon 1994) which corresponds with a waste height of about 34 feet. This collage should represent accurately the contents of the tank which were the same in 1988 when the photographs were taken (Thurman 1988). The picture guality is good which allows items in the tank to be easily identified. Items identified have been labeled including a temperature probe, three level probes, a supernatant pump, a high level sensor, and many risers in the dome.
4.1 .3
Synopsis of Tank 241-AW-101

(To be completed.) 


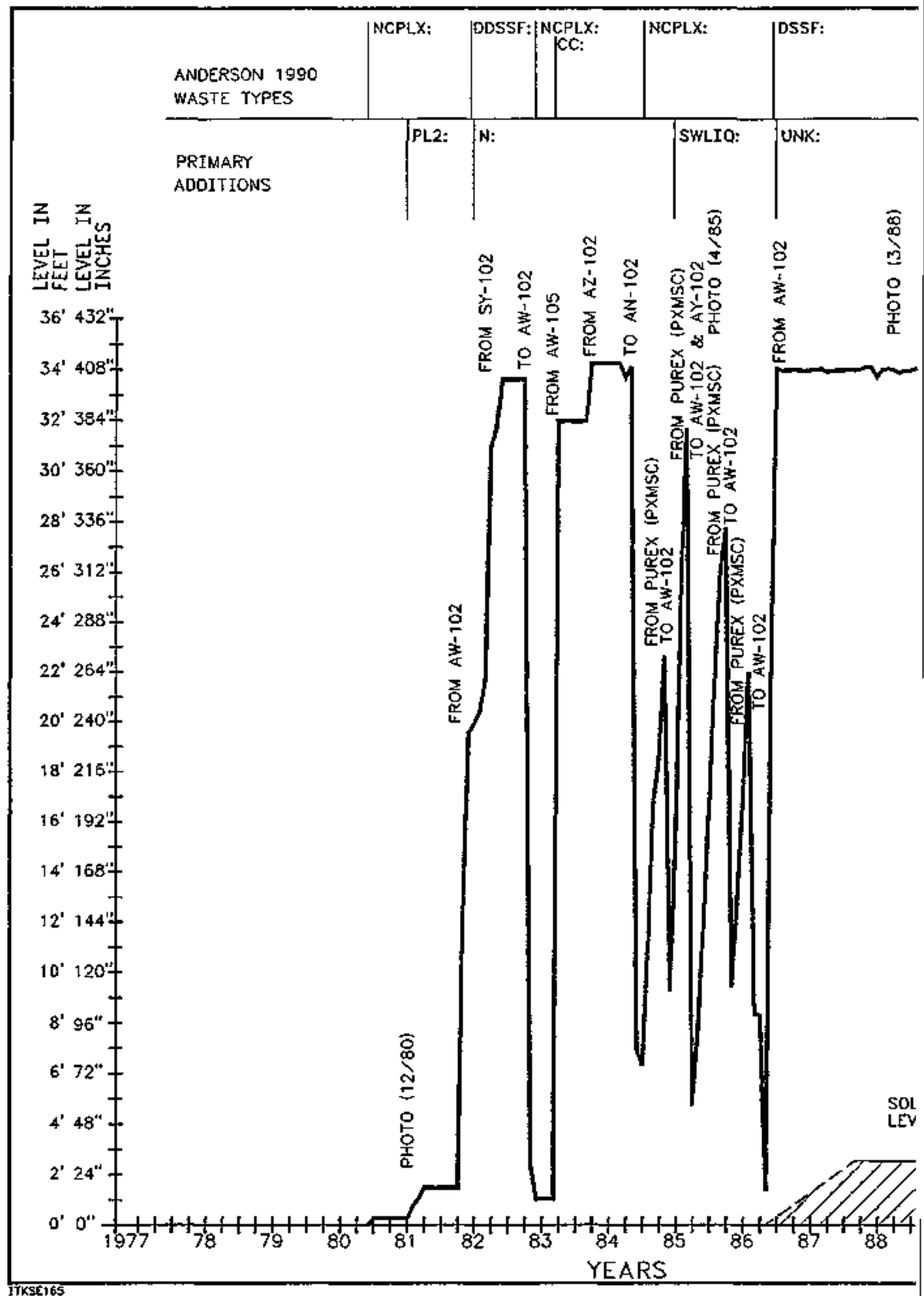


WHC-SD-WM-ER-350， ReV. 0

\begin{tabular}{|c|c|c|c|}
\hline \multicolumn{4}{|c|}{ Doutble-Shell Tank 241-AW-101 } \\
\hline \multicolumn{4}{|c|}{ Tolal Inveatoriy Estimant* } \\
\hline \multicolumn{4}{|c|}{ 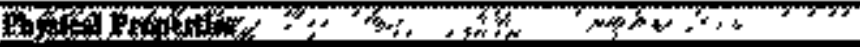 } \\
\hline Fotal Wete & $5.95 \mathrm{se}+06 \mathrm{~kg}$ & (1.14E+03 ks:4) & \\
\hline Han Lowd & \multicolumn{3}{|c|}{$6.82 \mathrm{~kW}(2.35 \mathrm{E}+04 \mathrm{ETU} / \mathrm{h})$} \\
\hline Bulk Detsikyt & \multicolumn{3}{|c|}{$1,38(1)(x)$} \\
\hline Woer wht & \multicolumn{3}{|c|}{51.1} \\
\hline TOC w* $* \mathrm{C}$ & \multicolumn{3}{|c|}{0.907} \\
\hline \multicolumn{4}{|c|}{ 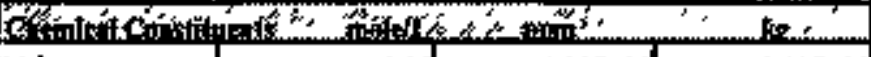 } \\
\hline $\mathrm{Na}$ & $\mathbf{8 . 2 6}$ & $1.38 \mathrm{~g}+0.05$ & $8.18 \mathrm{E}+05$ \\
\hline 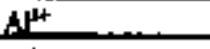 & 0.946 & $|85 E+04|$ & $1.10 \mathrm{E}+05$ \\
\hline 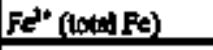 & 0.100 & 4.398+03 & $2.61 \mathrm{E}+0.4$ \\
\hline $\mathrm{Cs}^{*}$ & $2,972-02$ & $1.12+0.09$ & $6.659+03$ \\
\hline $99^{*}$ & $8.620-04$ & [31] & 76 \\
\hline 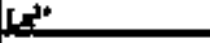 & 5.3458 .46 & 0.538 & 3.20 \\
\hline $\mathrm{H}^{8^{3+}}$ & 1.03E-0E & 1.49 & 8.84 \\
\hline $2 x$ (M:OOHh) & 1.958-8! & {$[301$} & $\pi R$ \\
\hline$P_{t}^{* t+}$ & 9.26E-10 & 13.9 & 2.6 \\
\hline $\mathrm{Nit}^{+2}$ & IOFE-OP! & 462 & $2.75 \mathrm{E}+0 \mathrm{a}$ \\
\hline$s r^{3 *}$ & 5.65E-05 & 0.358 & 2.13 \\
\hline $\mathrm{Mn}^{*}$ & LQBE-M? & 431 & $256 \mathrm{E} \pm 9$ \\
\hline $\mathrm{Ca}^{2 *}$ & 5.67E- -02 & $1.65 \mathrm{E}+0 \mathrm{03}$ & $9.79 \mathrm{E}+03$ \\
\hline$x^{*}$ & 0.131 & 3.71日:40) & 2.21E+04 \\
\hline oيtr & 4,50 & $5.658+04$ & 3.36E+09: \\
\hline No. & 3.26 & $1,47+R+09$ & B.TF+09 \\
\hline $\mathrm{NO}$ & 1.43 & $4.788+0$ 여 & 2.SAEt(1) \\
\hline $\mathrm{CO}:-$ & 0.481 & $2.092+04$ & $1.24 \mathrm{E}+105$ \\
\hline $\mathrm{PO}_{4}^{+}$ & 0,162 & $1.128+09$ & $6.6 \mathrm{ag}+0.4$ \\
\hline $\mathrm{SO}^{2}$ & 020.6 & $1.438 \div 09$ & 8.525100 \\
\hline 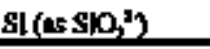 & $3.87 \mathrm{E}, 02$ & 7sa: & 4.6958+103 \\
\hline $\mathbf{F}$ & 0.177 & 2379449 & 141E404 \\
\hline Cr ${ }^{*}$ & 0.141 & $3.62 \mathrm{R}+03$ & 2.15A+04 \\
\hline C.tHo: & 2.74:-02 & 3.818403 & $2,278+04$ \\
\hline EDTA* & 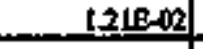 & $25 \mathrm{EE}+0 \mathrm{t}$ & $151 \mathrm{E}+04$ \\
\hline HegOr $A^{2}$ & 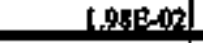 & 3.994E+03] & $2,34 P+00$ \\
\hline okxcoluts: & 0.0 .35 & 7.328+4094 & $4+35 f+0$ \\
\hline 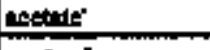 & 1A2E-O2: & 608 & $3,62 \mathrm{E}+103$ \\
\hline 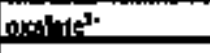 & 2.092_-0.5: & 1.29 & 764 \\
\hline Dief & $1.51 \mathrm{E}-02$ & L.73E+034 & $1.06 \mathrm{E}+0 \mathrm{~d}$ \\
\hline brimnol & |SIE_009 & 8:12 & 4.858+n: \\
\hline $\mathrm{NH}_{\text {_H }}$ & 0.409 & $5.00 \mathrm{~F}+0 \mathrm{0}=$ & $2.97 \mathrm{E}+0 \mathrm{OA}$ \\
\hline $\mathrm{Fe}(\mathrm{CN})_{t}^{+}$ & & & \\
\hline 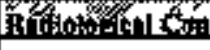 & & $83 \quad \therefore$ & 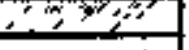 \\
\hline Pu & & $4302-02(\mu C V / g)$ & 4.26(t) \\
\hline II & 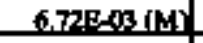 & -1.65to3 furdory & 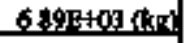 \\
\hline cs & $0240(\mathrm{C}) \mathrm{j}$ & 174 ( $\left.\mu_{1} \mathrm{C} ; \mathrm{s}\right)$ ) & t.03E+0.06(Cl) \\
\hline s. & 6.00E-02 (CL1) & $49.2\left(u \mathrm{C}^{2} \mathrm{~s}\right)$ & $2038+05$ (C) \\
\hline
\end{tabular}

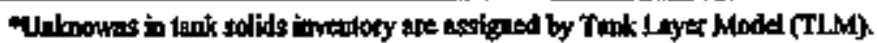

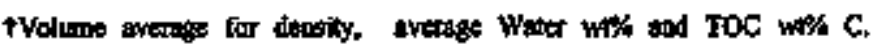

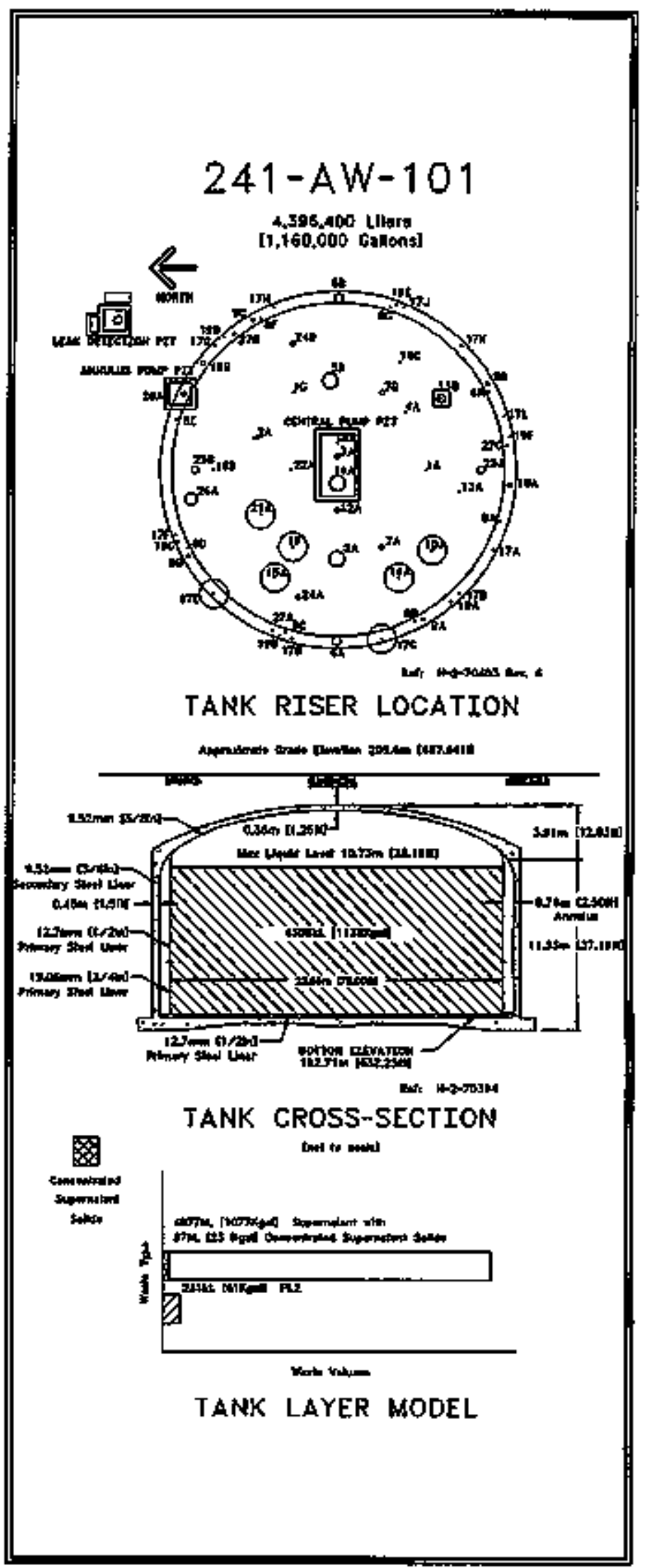


WHC-SD-WM-ER-350, Rev. 0

\begin{tabular}{|c|c|c|c|}
\hline \multicolumn{4}{|c|}{ Doubk-Shell Tank 241-AW-101 } \\
\hline \multicolumn{4}{|c|}{ SMM Compasto Inremory Estimile } \\
\hline \multicolumn{2}{|c|}{ 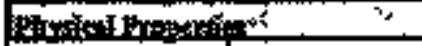 } & $y=3 x_{0}$ & 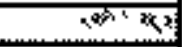 \\
\hline Totel Superitiont & $5.6 \mathrm{EE}+\infty \mathrm{k}_{\mathrm{Y}}$ & (1.08E+03 Lgen) & \\
\hline Hen Ln: & \multicolumn{2}{|c|}{$5,30 \mathrm{LW}$ (18) } & \\
\hline Bulk.Density* & \multicolumn{2}{|c|}{$139,\{9(x)$} & \\
\hline Wat ux" & \multicolumn{2}{|r|}{49.5} & \\
\hline TOC wt\% $\mathrm{C}$ (we) & \multirow{2}{*}{\multicolumn{2}{|c|}{$\frac{0.956}{2 t^{2}{ }^{24}}$}} & \\
\hline 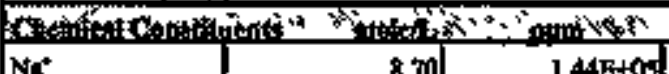 & & & 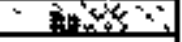 \\
\hline $\mathrm{Na}$ & 270 & 1.44E+0g & 2.15B+05 \\
\hline $\mathrm{Al}^{3 *}$ & 1.001 & $1.945 ; 0$ 어: & I.JOE 40 A \\
\hline$F e^{2+}($ totol Fe) & 6.83E- -03 & $27 \mathrm{~d}$ & $1.55 \mathrm{~B}+0.3$ \\
\hline Crt & $3.100=-02$ & $1.16=+09$ & 6.558*103 \\
\hline $\mathrm{Bi}^{*}$ & g.lLE-O4 & t3니 & 776 \\
\hline Let+ & 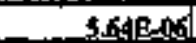 & 0,969 & 3.39 \\
\hline Heg $\mathrm{g}^{2}$ & 1.09E-0S & 1.56 & 8.8: \\
\hline 7.:as $\mathrm{ZaC}(\mathrm{OH}) \mathrm{L}$ & 2018-28 & 136 & $m$ \\
\hline $\mathrm{Pb}^{*}$ & $9.56 \mathrm{E}-05$ & $14: 2$ & 80.7 \\
\hline NFE" & $5.44 \mathrm{E}-0 ;$ & 316 & $1,296+03$ \\
\hline $\mathbf{s}^{*}$ & $5978-06$ & 0.373 & 2.19 \\
\hline$x_{0}^{*+}$ & $1+1 / x_{0}=0$ & 459 & $2,496+09$ \\
\hline $\mathbf{C}^{3+}$ & 4.7AE-OO & {$[.38 E+103$} & $7.81 \mathrm{E}+0 \mathrm{~g}$ \\
\hline$x^{4}$ & 0.139 & $3.83 \mathrm{E} \pm 03$ & $2,208+104$ \\
\hline OH & 451 & $5.50 \mathrm{E}+0.4$ & $3.12 \mathrm{E}+0.5$ \\
\hline (N) & 3.44 & $1.53 \mathrm{E}+10.5$ & $8,605+104$ \\
\hline No: & $1 \leq 1$ & $5.00 \mathrm{E}+0 \mathrm{nt}$ & $2.84 \mathrm{~B}+0.5$ \\
\hline $\mathrm{CO}^{2}$ & 0.49 & $2 \cdot 128+4$ & $5.20 \mathrm{E}+105$ \\
\hline $\mathrm{PO}_{4}{ }^{+}$ & 0.160 & 1.14E+04| & $6.49 E+0.0$ \\
\hline $\operatorname{sos}^{2}$ & 0.217 & $|.508 \pm 04|$ & $8,51 \mathrm{E}+0 \mathrm{~A}$ \\
\hline $\operatorname{Si}\left(\operatorname{sis} \operatorname{sig}^{2}\right)$ & 4.09E-O2 & 826 & $4.69 \mathrm{E}+03$ \\
\hline$f$ & 0.187 & $2.48 \mathrm{E}+103$ & $1,418+0$ \\
\hline ct & 0.49 & $3.78 \mathrm{E}+103 \mathrm{3}$ & 2.J3E+0. \\
\hline$C H O^{2}$ & $2,048-02$ & $399 \mathrm{~B}+102$ & $2.77+40$ \\
\hline EDTA $^{+}$ & $1.28 \mathrm{E}-\mathrm{B}$ & $265 \mathrm{E}+03$ & $1,51 E+0 e$ \\
\hline HEDTA & $2.10 \mathrm{~B}-02$ & $4,13 \theta+08$ & $234 \mathrm{E}+0$ \\
\hline shroelesto & 0.442 & $767 \mathrm{E}+01$ & $A 35 E \div 04$ \\
\hline wate & [SOE-02] & 697 & $3.62 \mathrm{E}+0 \mathrm{3}$ \\
\hline axalboted. & $2.13 \mathrm{E}-0.5$ & 1.73 & 764 \\
\hline DEP & $158 \mathrm{E}-00$ & $1.83 E+03$ & $1.04 \mathrm{E}+0.4$ \\
\hline tytarisol & 1580.002 & 841 & $478 E+0$ \\
\hline Nㅐ. & 0479 & $524 F+03]$ & $2978+0$. \\
\hline Fe(C) $)_{4}^{*}$ & $0^{0}$ & & \\
\hline \multicolumn{4}{|c|}{ 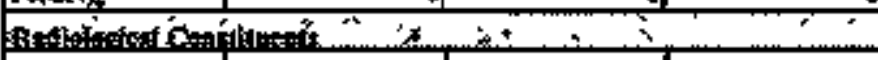 } \\
\hline Pu & $53.1(\mu \mathrm{C}$ (s) & & $3.61(\mathrm{atg})$ \\
\hline$\underline{H}$ & $7005000(M)$ & 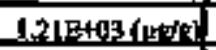 & 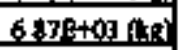 \\
\hline Cs & $0.2 \times 2$ (C) & 18: ( $(\mu \mathrm{CH}(\mathrm{g})$ & $1.03 \mathrm{E}+0.6 / \mathrm{Cr})$ \\
\hline $\mathbf{s}$ & $1,76 \mathrm{E}) 2(\mathrm{C}) \mathrm{L})$ & $12.6(\mu \mathrm{C} f / g)]$ & $3.178+04$ (C) \\
\hline
\end{tabular}

-Deasily to cakulated besed on Ne, OH-, ard AKO2.

tWater wto derived flom the difference of density and tot dissolved species.

\begin{tabular}{|c|c|c|c|}
\hline \multicolumn{4}{|c|}{ Doubtos Shat Tank 241*AW-10! } \\
\hline \multicolumn{4}{|c|}{ TLM Solids Composite Invintory Estimate* } \\
\hline \multicolumn{4}{|c|}{ 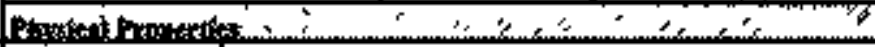 } \\
\hline Toul Solid Wots & $2.03 \mathrm{E}+05 \pm \mathrm{s}$ & (61) 副) & \\
\hline Healloid & $1.52 \mathrm{~kW}$ & $(5,[9 \mathrm{~F}+1) 3$ & \\
\hline Bulk Dessity & & $1.16(46 \mathrm{sec}$ & \\
\hline Void Fration & & 0918 & \\
\hline Wher whes & & 79.1 & \\
\hline TOC wto: (wret) & & 0.036 & \\
\hline \multicolumn{4}{|c|}{ 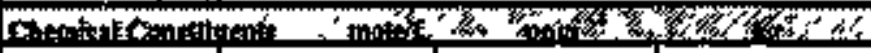 } \\
\hline $\mathrm{Na} \mathrm{a}^{*}$ & 0.589 & $1.17 E+04$ & $3.12 \mathrm{E}^{2}+0 \mathrm{~d}$ \\
\hline \multicolumn{4}{|l|}{ Al+ } \\
\hline $\mathrm{Fe}^{2 *}(\mathrm{cotal} \mathrm{F}$ ) & 1.90 & 9.15E+04 & $2.45 \mathrm{E}+04$ \\
\hline G & $7,358-0.03$ & 329 & $8.1,3$ \\
\hline \multicolumn{4}{|l|}{ B?+2 } \\
\hline \multicolumn{4}{|l|}{ 1...8 } \\
\hline \multicolumn{4}{|l|}{ 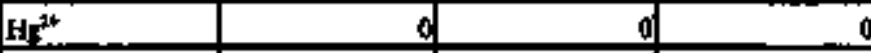 } \\
\hline \multicolumn{4}{|l|}{ 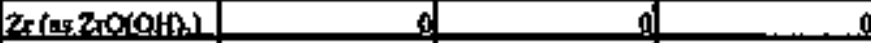 } \\
\hline $\mathrm{pb}^{2+}$ & 3.99E-05 & 7,13 & 1,91 \\
\hline $\mathrm{NI}^{*}$ & 0.12 & $566 \mathrm{E} \pm 09$ & $\sqrt{1.328+03}$ \\
\hline \multicolumn{4}{|l|}{8} \\
\hline $\mathrm{Mn}^{*}$ & 5.5180 .03 & 26 & $\pi, 0$ \\
\hline C.2* & 0.215 & $7,41 \mathrm{~B}+03$ & $1.99 \mathrm{E}+0 \mathrm{~g}$ \\
\hline $\mathbf{K}^{+}$ & $5.51 F-0,03$ & 180 & 49.8 \\
\hline $\mathrm{OH}^{-}$ & 5.94 & $8.69 \mathrm{~B}+0.4$ & $2.33 \mathrm{E}+04$ \\
\hline NO: & 0.232] & $1.2 A B+\infty$ & $3,32 \mathrm{R}+0 \mathrm{~s}$ \\
\hline NO; & 125:-02 & 510 & 137 \\
\hline$\infty 0^{2}$ & o.3ng & $1.592+04$ & $4,2774+47$ \\
\hline Po; & 639502 & $5.23 E+09$ & $1.403+00$ \\
\hline $\mathrm{so}^{2-}$ & 3.7P年0: & 308 & $k_{2}$ \\
\hline \multicolumn{4}{|l|}{$\operatorname{si}\left(\cos 50^{2}\right)$} \\
\hline \multicolumn{4}{|l|}{$\mathbf{F}$} \\
\hline cr & 3,59800 & 110 & $29 . A$ \\
\hline \multicolumn{4}{|l|}{ C.H. s. $^{3}$} \\
\hline \multicolumn{4}{|l|}{ EOTA } \\
\hline \multicolumn{4}{|l|}{ HEPTA } \\
\hline \multirow{2}{*}{\multicolumn{4}{|c|}{ finesplaté }} \\
\hline & & & \\
\hline \multicolumn{4}{|l|}{ prelldet } \\
\hline DeP & 289E-13 & 663 & 178 \\
\hline brimol & $289 \mathrm{E}-13$ & 185 & 49.5 \\
\hline $\mathrm{NH}_{1}$ & $4.86 \mathrm{E}-0.6$ & $7.28=02$ & $1.918-07$ \\
\hline $\mathrm{P}=(\mathrm{CN})_{*}^{*}$ & 0 & 0 & 0 \\
\hline \multicolumn{4}{|c|}{ 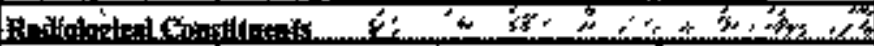 } \\
\hline Pu & & $0.147(\mu \mathrm{CH})$ & 0,656 (kg) \\
\hline 1) & 4.75E-04 OMn: & 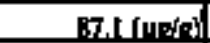 & $23,3 \mathrm{kga}$ \\
\hline o & $\left.2.76 \mathrm{E}-07 \mathrm{C}_{\mathrm{i}} \mathrm{i}\right) \mathrm{T}$ & 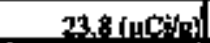 & $6.378+03(C)$ \\
\hline st & 0.957 (Cil) & $52\left(\mu \mathrm{Ci}_{\mathrm{s}}\right)$ & 2.21B+0S (Cl)] \\
\hline
\end{tabular}

"Unloowns in tank olids invatory are assipued by Tank Layer Model (TIM). 


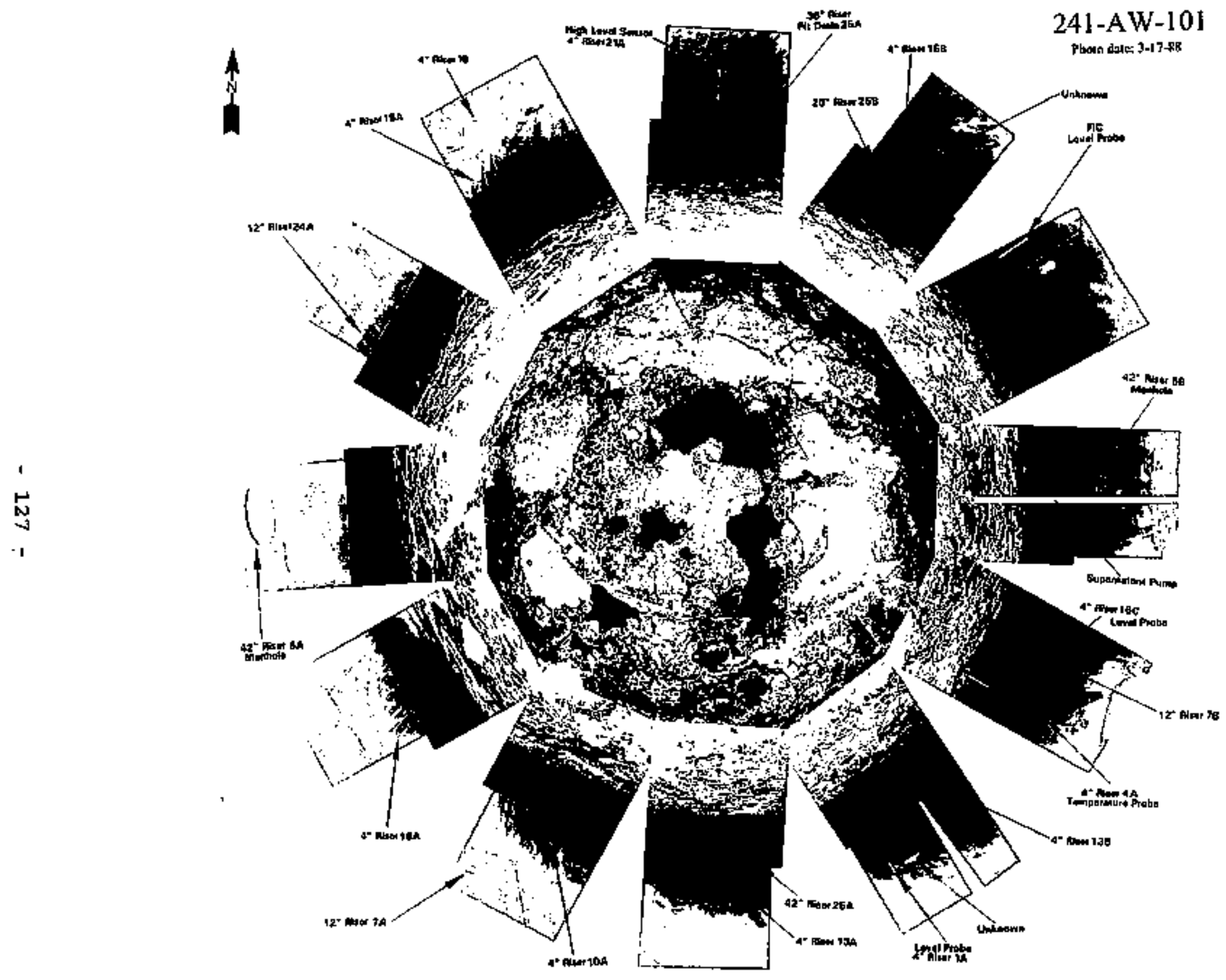

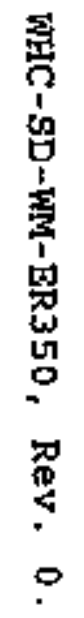


HHC-SD-TM-ER-350, Rev. 0

4.2 Tank $241-A W-102$

4.2.1 241-AW-102 Tank History

4.2.1.1 Waste History of Tank 241-AW-102

Tank 241-AW-102 began service by receiving non-complexed waste in July 1980. The tank received non-complexed woste until May 1983 . The tank received evaporator feed weste from June 1983 until December 1984 . During 1983 and 1984, the tank received ailute nor-complexed waste from the 200-East Area SSTs. Between January 1985 and April 1986, the tenk received Hanford facility waste. From May 1986 until May 1990, the tank received non-complexed waste from other DSTs. The tank has contained diInte noncomplexed waste from June 1990 until the present. The slight level changes are attributed to slurry growth resulting from gas generation. The tank is currently an active, evaporator feed tank for the 242-A Bvaporator.

\subsubsection{Tenperature History of Tank 241-AW-102}

Temperature data for Tank 241-AW-102 are recorded by 18 thermocouples at known elevations on one thermocouple tree inside the tank, located in riser 4A. Non-suspect tenperature data from between July 1983 and June 1991 for 18 thermocouples were available from the computer automated surveillance system. However, not gll of the 18 thermocouples have data that encompass the entire length of time. Non-suspect temperature data taken between July 1989 and September 1993 for 12 of the thermocouples were available from the surveillance andysis computer system. Not all of the 12 thermocouples have data that encompass the entire length of time. Within the time spans for both systems, there were several small breaks in the sequence of temperature data. The average temperature during these perlods was $79^{\circ} \mathrm{F}$ with a minimim of $53^{\circ} \mathrm{F}$, a maximum of $130^{\circ} \mathrm{F}$, and a standard deviation of $16^{\circ} \mathrm{F}$. Linear regressions were performed on each thermocouple that had temperature data between January 1990 and January 1994 . The slopes from these regressions were averaged with a resulting average slope of -0.0068 . Refer to the suppoxting document for more thorough review of the temperature data (Brevick, 1995).

\subsubsection{Occurrences of Tank 24.1-AW-102}

Six unusual events occurred at tank 241-AF-102. Occurrence reports RL--WHC-Tank Farm-1992-0072, RL--WHC-Tank Farm-1992-0025, RL--WHC-Tank Farm-1991-1066, and RL--WHC-Tank Farm-1991-1050, and off-Normal (0.N.) Report 82-01 concern unexpected waste transfers. O.N. Report 86-36 was written when a transfer of waste caused the tank to pressurize.

\subsubsection{Psychrometrics of Tank 241-AW-102.}

Psychrometric data hive been recorded for 12 years from this tank and annulus. The apparent trend of the evaporation rate from the tank has increased from 318.9 gallons per week in october 1981 to 364.4 gallons per week in January 1995. Over that same period, the trena in the rates of heat exchange through the primary tank and annular ventilation has 
WHC-SD-WM-ER-350, Rev, O

apparently decreased. A review of the psychronetric data in Tank 241-AW-102 would suggest an overall decrease in the rate of heat generation by the waste.

\subsubsection{Current Status of Tank 241-AW-102}

Tank 241-AM-102 entered service in August 1980 and currently stores 86,000 gallons of waste. The following plan view and tank cross-section depict the approximate waste volume of 966,000 gallons and configuration of risers in January 1994. At the time of the estimate, there were 966,000 gallons of supernatant with 1,000 gallons of concentrated supermetant solids. The waste level in the tank is measured with the FIC gauge and the manual tape and has decreased and increased from about 370 inches in January 1991 to 31 inches in January 1995. The decrease was mostly waste sent to Tank 241-AW-106 in September 1992 and various 242-A Evaporator campaigns. The increase was from the 242-A Evaporator between August 1992 and January 1994. Other increases were from waste transferred from Tank 241-AP-103 in May 1994, and Tanks 241-AP-101, -107, and -108 in October 1994. This tank is an active Eeed tank to the 242-A Evaporator. The tank is actively ventilated and categorized as sound. Tank 241-AW-102 has 64 risers. One 20-inch riser (no.25A) and two 42-inch risers (no.5A and no.5B) are available for use.

\subsubsection{Inventory Estimate of Tank 241-Aw-102}

The tank layer model (a volums based approximation) that follows was derived from the Los alamos National Lpboratory waste status and Transaction Record Summary (Agnew 1995) and Supernatant wixing Model (Agnew 1995). The estimeted inventories of total waste, solids, and supernatant in Tank 241-3W-102 are also presented. Concentrated supernatent solids are considered as an integral part of the liquid for the purpose of estimating inventories, but are graphed as solids on the level histories. The actual substance, which was derived from double-shell slurry, appears as a solid if undisturbed, but the particles are resuspended in solution if hezted or disturbed.

4.2.2.2 In-Tank Photograph of Tank 241-AW-1.02

No in-tank photographs are available.

4.2.3 Symopsis of Tank 241-AV-102

(To be completed.) 


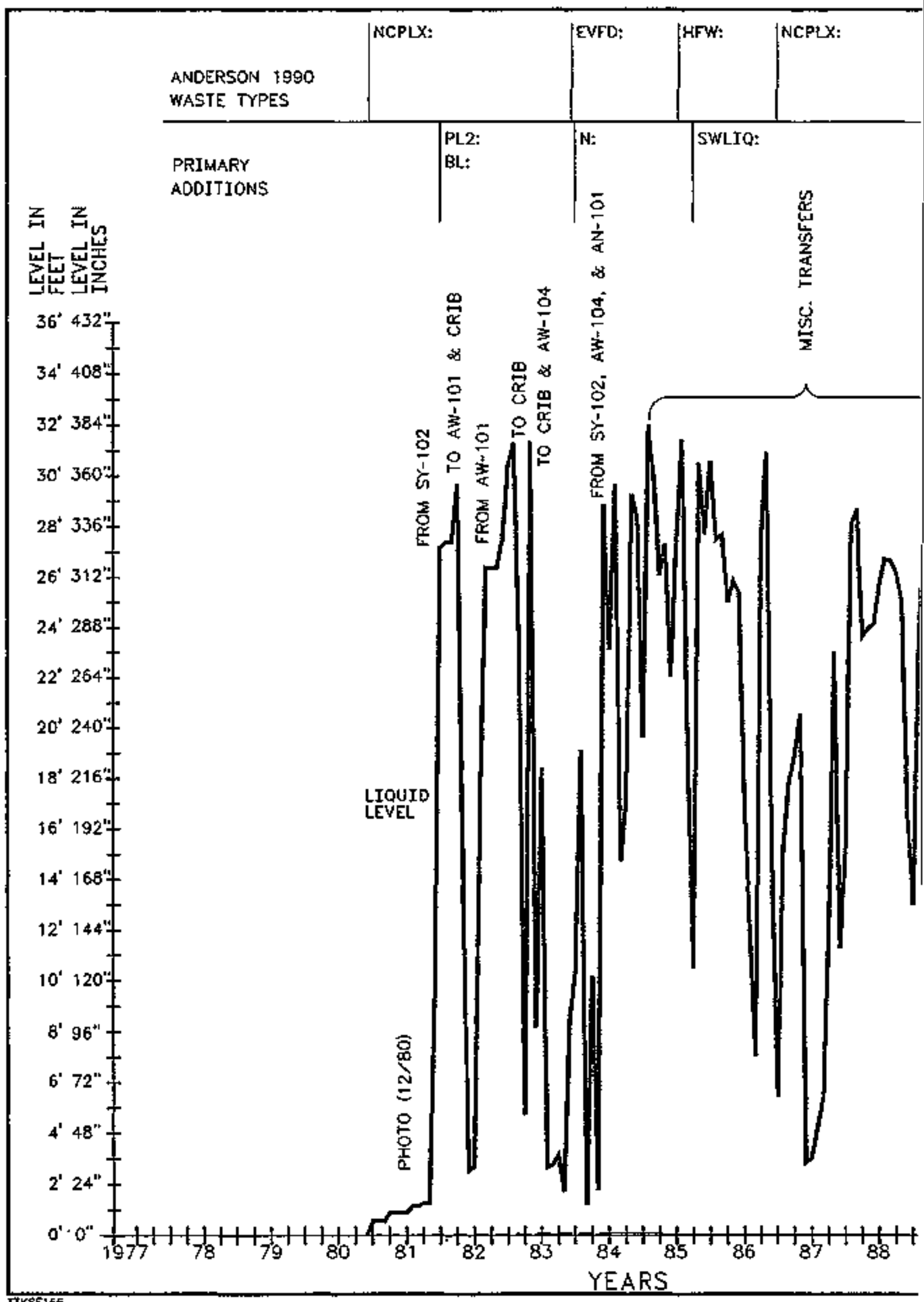


ION:

UNK:
NOTES:

CONSTRUCT 1978-1980

NOMINAL CAPACITY: $1,160,000$ GAL

FIT GOTTO TANK NO KNUCKIE

75 FOOT DIAWETER DOUELE-SHEEL TANK SURFACE LEVEL READING: PHOTO

[LIQUIOS \& SOLIDST, FIC [SOLIOS)

\section{INVENTORY ESTINATE DATE}

(GALLONS) NCPLX: NON-COMPLEXED WASTE

EVFD: EVAPORATOR FEED

HFW: MANFORD FACILITY WASTE

DN: DILUTE NON-COWPLEXED WASTE

PL2: PUREX LOW-LEVEL WASTE

BL: B PLANT LOW-LEVEL WASFE

$-1,122,000$

N REACTOR WASTE

-

SWLIO: SALTWELL LIQUOR

$-1,056,000$

UNK: UNIKNOWN

-

- 990,000

$-$

- 924,000

LEGEND

- 858,000

LIOULO OESERVATION

WELL (LOW)

— LIQUIO LEVEL,

- 792,000

$777 /$ SOLIOS LEVEL

$-$

tH $+H t$ SOLTOS LEVEL BEST

- 726,000

$-660.000$

AW TANK FARM

$-660000$

PLOT PLAN

SUPERNATANT 965 KGAL CS SOLIDS

-

- 594,000

(101)

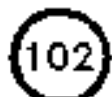

- $\quad 528.000$

$-$

- 462,000

$-$

- 395,000

$-$

- 330,000

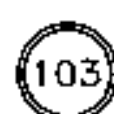

104
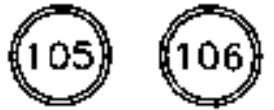

$-$

$-\quad 264,000$

$-$

- 198,000 U.S. DEPARTMENT OF ENERGY

- 132,000

- 66,000 ICF KAISER HANFORO

241-AW-102 DOUBLE-SHELL TANK LEVEL HISTORY 1986 TO 1994 SOUND/ACTIVVE TANK

WATCH LIST: $N / A$

0

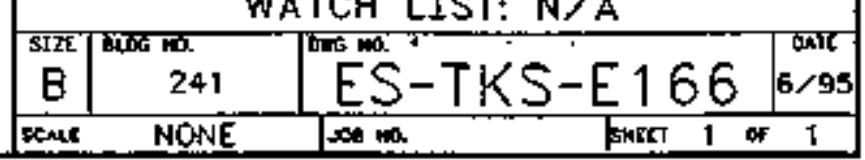


MHC-SD-PA-ER-350, Rev. 0

\begin{tabular}{|c|c|c|c|}
\hline \multicolumn{4}{|c|}{ Double-Sheil Tank 241-AW-102 } \\
\hline \multicolumn{4}{|c|}{ 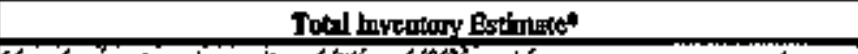 } \\
\hline \multicolumn{4}{|c|}{ 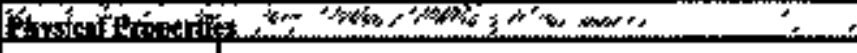 } \\
\hline Total Whete & $4.21 \mathrm{E}+06 \mathrm{~kg}$ & (966t时) & \\
\hline Hen1 1.002 & \multicolumn{3}{|c|}{$2,10 \mathrm{~kW}$ (7.198403 BTW/1ri } \\
\hline Bull:. Denstityt & \multicolumn{3}{|c|}{$1.15(\operatorname{sinc)}$} \\
\hline Wake wat & \multicolumn{3}{|c|}{75.9} \\
\hline Toc upe & \multicolumn{3}{|c|}{0.360} \\
\hline \multicolumn{4}{|c|}{ 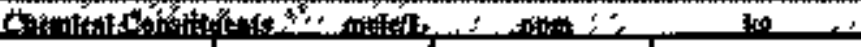 } \\
\hline $\mathbf{N k}^{\mathbf{4}}$ & 3.40 & $6.78 \mathrm{~B}+04$ & 2.85E+0.5 \\
\hline Alst & 0,369 & $8.620+00^{2}$ & 3.698504 \\
\hline $\mathrm{Fo}^{+}(\mathrm{tg}(\mathrm{N}) \mathrm{Fe})$ & 4.tge-03 & 2038 & 855 \\
\hline$c_{0} s^{*}$ & 1.1.13E-192 & 509 & $2.14 F+13$ \\
\hline $\mathrm{BP}^{*}$ & 207E-04 & 37.5 & 158 \\
\hline 1.5. & L.968.06 & 0.164 & 0.691 \\
\hline H马. & $4.74 \mathrm{E} \times 06 \mathrm{~d}$ & 0.825 & 3.47 \\
\hline 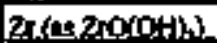 & 1.168090 & 9.6 & 3.56 \\
\hline $\mathrm{Pb}^{3+}$ & $3.96 \mathrm{E}-05$ & 7.12 & 390 \\
\hline $\mathbf{N P}^{\mathbf{*}}$ & 2950-13 & 100 & s47 \\
\hline sit & 1.44E-06 & 0.109 & 0,460 \\
\hline Mons & $5,08 \mathrm{E}-\mathrm{ng}$ & 242 & $102 \mathrm{E}+0 \mathrm{~g}$ \\
\hline $\mathrm{Cu}^{\mathrm{j}}$ & $2,93 \mathrm{E}-02$ & $1.02 \mathrm{E}+103$ & $4,30 \mathrm{E}+03$ \\
\hline$K^{*}$ & $8,42-09$ & 2.8040 .05 & j210404 \\
\hline 왕 & 1.60 & $2.498+04$ & I. $.05 \mathrm{E}+0.5$ \\
\hline HOL & 1.51 & SLlUE+04| & 3,$42 ; \mathrm{B} \pm 1 \mathrm{~K}$ \\
\hline No; & 0.369 & 1.47E+0.1 & $6200+04$ \\
\hline $\cos ^{2}$ & 0.248 & $1.24 \mathrm{E}+104$ & $5,7+2+10$ \\
\hline $\mathbf{P O}^{2}$ & 6,98E-02: & $5.758+09$ & $2,428+0,04$ \\
\hline $\operatorname{sot}^{2}$ & SOlE- -0 ? & $6.69 \mathrm{~s}+0 \mathrm{n}]$ & $2828+04$ \\
\hline Sin $\left( \pm 0, S_{0}^{2},{ }^{2}\right)$ & $1.80 \mathrm{E}-0.02$ & 438 & 1.65E+09 \\
\hline$F$ & 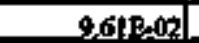 & $1998+09$ & 6668009 \\
\hline cl: & 5.6319-02 & $1.73 \mathrm{E}+0 \mathrm{ag}$ & $7.30 \mathrm{E}+03$ \\
\hline CHos & 1.038EA2 & $1699+19$ & $7.125+09$ \\
\hline EDTA & 2.92E-03 & 730 & $3.07 \mathrm{Tz}+0 \mathrm{~B}$ \\
\hline HEDTAX & 4.83E-0?] & I.15E+103 & $484 E_{+10}$ \\
\hline slyeselete- & 823609 & $5366+10$ & $236 \mathrm{E}+104$ \\
\hline comple & .1.22E-03: & 165 & 694 \\
\hline $0 \times 1 \cdot \ln ]^{3}$ & 5.15E-06f & 0,392 & 16 \\
\hline DEP & 4.8AdE-0as: & 676 & $2.858+103$ \\
\hline becr.ct & $484 \mathrm{E}_{0} 03$ & 311 & $1,31 \mathrm{E}+03$ \\
\hline $\mathrm{NH}_{4}$ & 02924 & $4,30 \mathrm{E}+103$ & $1.81 \mathrm{E}+0 \mathrm{~d}$ \\
\hline $\mathrm{Fe}\left(\mathrm{CN}_{3}{ }^{+}\right.$ & of & 0 & \\
\hline 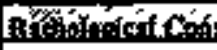 & 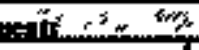 & 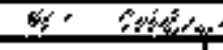 & \\
\hline Pu & & $2.31 \mathrm{E}-02\left(\mathrm{urCV}_{\mathrm{a}}\right)$ & $2.62(k, y)$ \\
\hline$\underline{t}$ & 3.48E- 03 GMW & 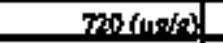 & 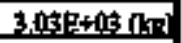 \\
\hline$c_{1}$ & $0.109(\mathrm{c}) \mathrm{L}) \mathrm{]}$ & 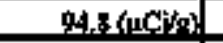 & $3.99 \mathrm{E}+1 \mathrm{0S}(\mathrm{C})$ ) \\
\hline st & 9.53E-03 (CL)) & 828 pacis. & $3,48 \mathrm{E}+(04)(C))$ \\
\hline
\end{tabular}

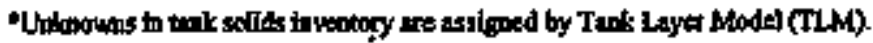

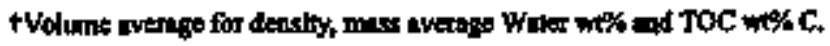

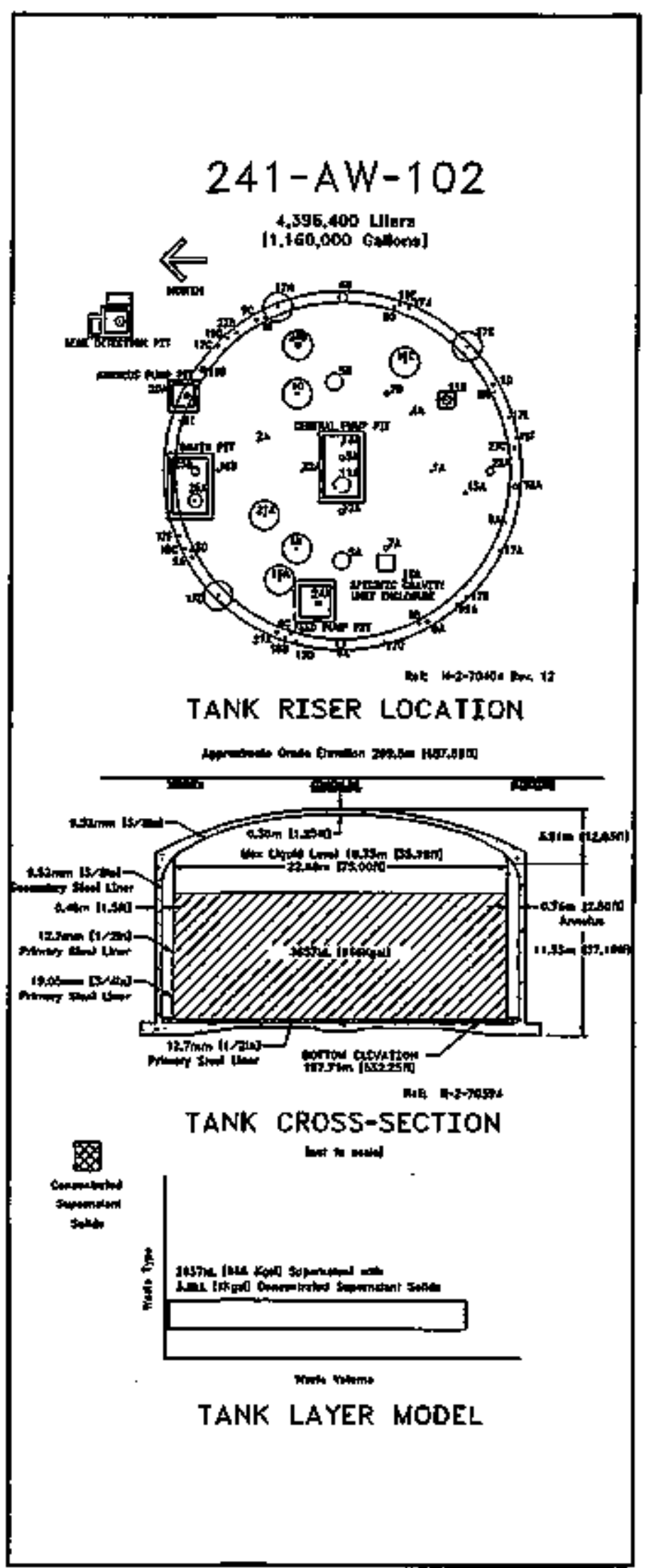




\begin{tabular}{|c|c|c|c|}
\hline \multicolumn{4}{|c|}{ Double-Shell Tank 241-AW-102 } \\
\hline \multicolumn{4}{|c|}{ ShM Composite Imveriorr Estirtale } \\
\hline \multicolumn{4}{|c|}{ 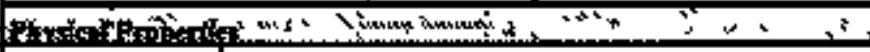 } \\
\hline Totol Sypangand & $4.21 \mathrm{E}+06 \mathrm{~kg}$ & (966 kmet) & \\
\hline 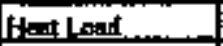 & \multicolumn{3}{|c|}{ 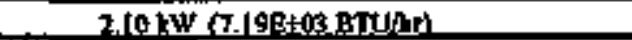 } \\
\hline Ball Deisity & \multicolumn{3}{|c|}{$1.15(0 / \infty)$} \\
\hline Wad at witst & \multicolumn{3}{|c|}{75.9} \\
\hline TOC wt:C (wet) & \multicolumn{3}{|c|}{0.360} \\
\hline \multicolumn{4}{|c|}{ 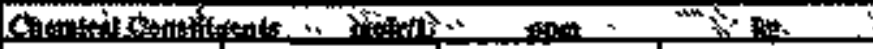 } \\
\hline $\mathrm{No}^{*}$ & 3.40 & $6.788+04$ & $285 E+0$ \\
\hline$\Delta]^{*}$ & 0,36 & 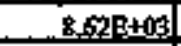 & 3.63840 \\
\hline$F^{\prime *}$ (toted Fe) & 4. $\operatorname{lgB}-0 \mathrm{~g}$ & 203 & 85 \\
\hline $\mathrm{Co}^{\mathrm{*}}$ & 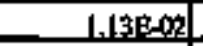 & ;09: & $2.14: 40$ \\
\hline $\mathbf{B P}^{*}$ & 2.07B-OA & 375 & [5 \\
\hline In & $1368 \mathrm{Bg}$ & P.16A & 060 \\
\hline $\mathrm{He}^{*+}$ & 4.74E-06 & o.tes & 3.4 \\
\hline 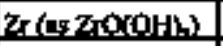 & |l6B-07] & 916 & 38 \\
\hline $\mathrm{Pb}^{2 *}$ & $3.96 \mathrm{E}-0 \mathrm{~s}$ & 7.12 & 30,0 \\
\hline$N^{*}$ & 2.55EA & $1 \geqslant 0$ & s4 \\
\hline $5 \mathrm{r}^{*}$ & $1.44 \mathrm{E}-06$ & 0.109 & 0.460 \\
\hline $\mathrm{Mn}^{4+}$ & 5 . & 240 & $100 x+09$ \\
\hline $\mathrm{Cr}^{2}$ & $2.936-102$ & $1.020+02$ & $4.30 \mathrm{E}+0 \mathrm{~B}$ \\
\hline $\mathbf{K}^{*}$ & 8478009 & $2889 \mathrm{E}+0 \mathrm{~A}$ & $1,2 \cdot P=1$ \\
\hline OH: & $\begin{array}{r}1.59 \\
\end{array}$ & $2,45+09$ & $1.05 \mathrm{E}+0 \mathrm{~g}$ \\
\hline $\mathrm{NOA}$ & 1.51 & 8.JE+tod & 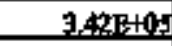 \\
\hline No: & 0360 & 1,4]+연 & $6.20 \mathrm{~F}+04$ \\
\hline $\mathrm{CO}^{2}$ & 0.2혀연 & l2선엉 & sخلي \\
\hline $99^{2}$ & 6.48- 02 & $5.79 \mathrm{E}+\mathrm{ca}$ & $242 \mathrm{~B}+0 \mathrm{4}$ \\
\hline $\mathrm{SO}^{2}$ & 8.01F $-0 \%$ & 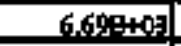 & 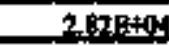 \\
\hline Si $\left(0, \sin _{2}^{2}\right)$ & $1.80 \mathrm{E}-02$ & 43. & $1.8 \mathrm{EE}+0 \mathrm{~g}$ \\
\hline F & 9.61F_of & 159:+0) & 6.6018407 \\
\hline Ct & $5.63 \mathrm{E}-0 \mathrm{2}$ & $1.73 \mathrm{E}+0 \mathrm{3}$ & $730 \mathrm{E}+03$ \\
\hline C.HO ${ }^{2}$ & 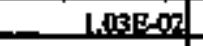 & 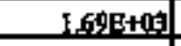 & $7.127+103$ \\
\hline RDT $\mathbf{A}^{+}$ & $2,928,00$ & 730 & $3.07 \mathrm{E}+03$ \\
\hline HEPTA2 & $4.83 \mathrm{~B} .09$ & 1.15E+09 & 48AE $\div$ (19) \\
\hline droughate- & $8,7 \mathrm{JP}-0 \mathrm{z}$ & 5.3601 & 2265ith \\
\hline ats & $3 \pm 28-00$ & เ65 & 694 \\
\hline popalnete & $5.130-0.6$ & 0322 & 169 \\
\hline DBP & $4.84 B-03$ & 676 & $2.858+103$ \\
\hline buttonal & 4.84E_03 & 311 & 1318+113 \\
\hline NH. & 029 & $4.30 \mathrm{P}+105$ & $18 \mathrm{JP}+1 \mathrm{~g}$ \\
\hline $\mathrm{Fe}(\mathrm{CN}) \mathrm{x}^{4}$ & 0 & O & \\
\hline Fing & 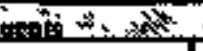 & & 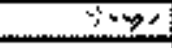 \\
\hline Po & 26.6 (12) & & 1,62(kํ) \\
\hline$\underline{\underline{u}}$ & $348 \mathrm{~g}=0 \mathrm{~B}(\mathrm{~m})$ & 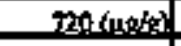 & 3,09Ft13 (kes) \\
\hline $\mathrm{C} s$ & 0.109 (CH) & 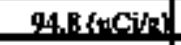 & $3.895+0,5$ (C) \\
\hline St & 9.53E-OB (CE) & 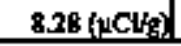 & $3.48 \mathrm{E}+04$ (C) \\
\hline
\end{tabular}

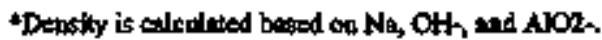

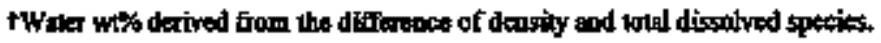

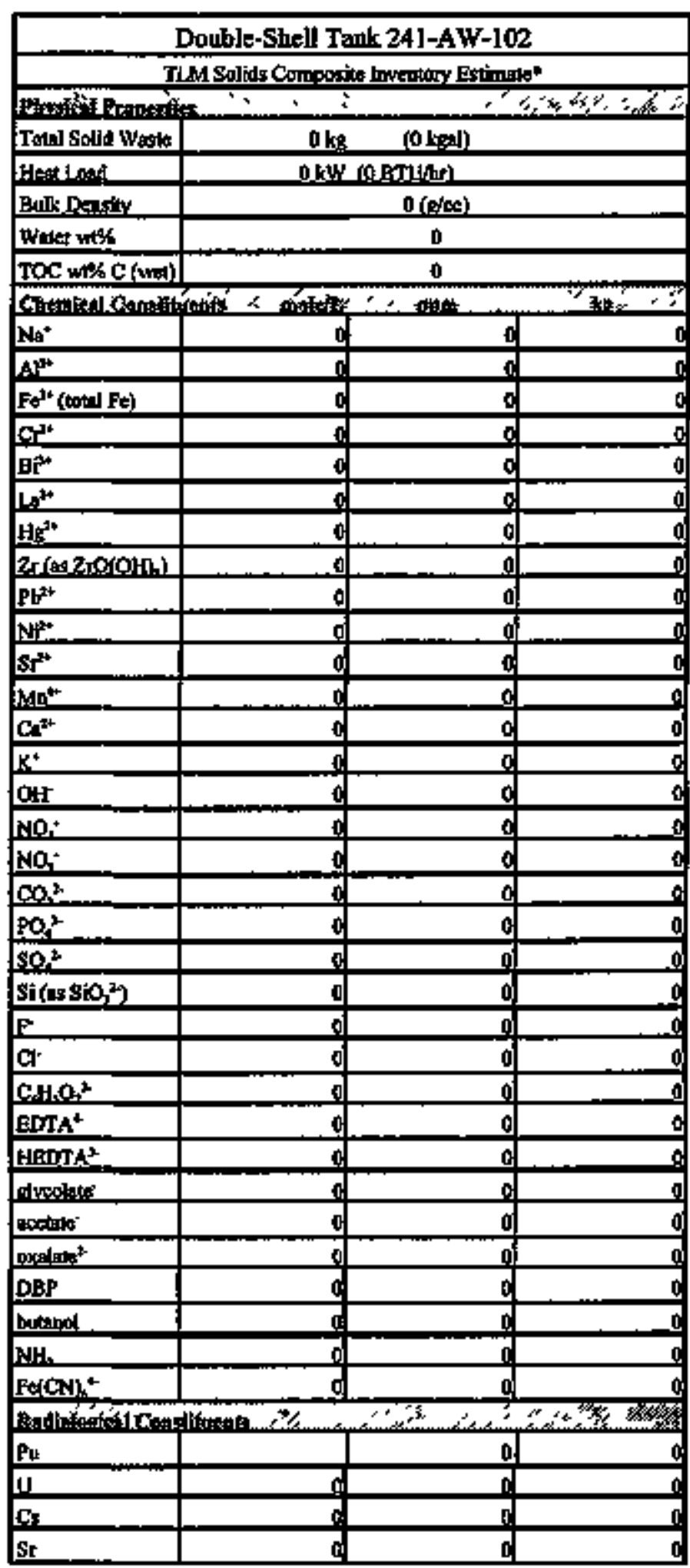

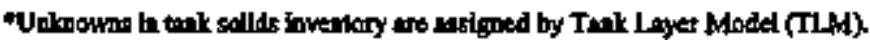


WHC-SD-MM-ER-350, Rev. 0

4.3 Tank 24I-AW-103

4.3.1 241-AW-103 Tank History

4.3.1.1 Waste History of Tank 241-AW-103

Tank 241-AW-103 began service by feceiving non-complexed waste in July 1980. From the following month until November 1981, the tank received double-shell slurry feed waste. The tank received pukax waste from the second quarter of 1983 until the fourth quarter of 1988. From December 1981 until Maxch 1983, the tank received dilute doubie-shell slurry feed waste. During April and May 1983, the tank received double-shell slurry feed waste. The tank received non-coaplexed waste from June 1983 until kay 1990. From June 1990 until the present, the tank has contained dilute noncomplexed and PUREX neutralized cladding removal waste. The tank has not received waste since the third quarter of 1992 . The tank is currently an inactive dilute receiver tank.

\subsubsection{Termerature History of Tank 241-AW-103}

Termperature data for Tank 241-AW-103 are recorded by 18 thermocouples at known elevations on one tree inside the tank, located in riser 4A. Nonsuspect temperature data taken between July 1983 and June 1993 for all 18 thermocouples were available from the coinjuter automated surveillance systern. Non-suspect termerature data recorded between July 1990 and September 1993 from 12 of the thermocouples were available from the surveillance analysis computer systen. However, not all of the 12 thermocouples have data that encompass the entire length of time. Within the time spans for both systems, there were several small breaks in the sequence of temperature data. The everage tenperature during these periods was $76^{\circ} \mathrm{F}$ with a minimum of $59^{\circ} \mathrm{F}$, a maximum of $100^{\circ} \mathrm{F}$, and a standard deviation of $8.8^{\circ} \mathrm{F}$. Linear regressions were performed on each thermocouple that had temperature data between January 1990 and January 1994. The slopes Erom these regressions were averaged with in resulting average slope of -0.0058 . Refer to the supporting document for a more thorough review of the temperature data (Brevick, 1995).

\subsubsection{Occurrences of Tank 241-AW-103}

Seven untusual events occured at tank 241-AW-103. TFS \& 0-EFS-88-0146 and off-Normal Reports 85-47, 85-15, 85-13, and 85-09 were witten when transfers of waste caused the tank to pressurize. TFS \& 0-EFS-88-007 concerns an unexpected waste transfer. Off-Normal Report 85-25 was written because improper use of equipment caused the tank to pressurize.

\subsubsection{Psychrometrics of Tank 241-Ain-103}

Psychrometric data have been recorded for 13 years from this tank and annulus. The apparent trend of the evaporation rate from the tark has decreased from 171.9 gallons ber week in November 1980 to 101.1 gallons per week in January 1995. Over that same period, the trend in the rates of heat exchange through the primary tank and annular ventilation has 
WHC-SD-TM-ER-350, Rev. O

epparently decreased. A review of the psychrometric data in Tank 241-AW-103 would suggest an overall decrease in the rate of heat generation by the waste.

\subsubsection{Current Status of Tank 241-AN-103}

Tank 241-Aw-103 entered service in August 1980 and currently stores 515, 000 gallons of waste. The following plan view and tank cross-section depict the approximate waste volume of 647,000 gallons and configuration of risers as of January 1994. At the time of the estimate, there were 284,000 gallons of supernatant and 363,000 gallons of coating waste from 2 Plant and REDOX (CW/ZR2). The waste ievel in the tank is measured with the FIC gauge and the manual tape and has decreased from 235 inches to 187 inches in 1995. The decrease is due to a waste transfer to Tank 241-AP-107 in October 1994. This tank is inactive at the present. The tank is actively ventilated and categorized as sound. Tank 241-Aw-103 has 59 risers. Two 4-inch risers (no.10A and no.15A), one 12-inch riser (no.7A), and two 42-inch risers (no.5A and no.5B) are available for use.

4.3.2.1 Inventory Estimate of Tank 241-Aw-103

The tank layer model (a volume based approximation) that follows was derived from the Los Alamos National Laboratory waste status and Transaction Record Summary (Agnew 1995) and Supernatant Mixing Model (Agnew 1995). The estimated inventories of total waste, solids, and supernatant in Tank 241-AW-103 are also presented.

4.3.2.2 In-Tank Photograph of Tank 241-AW-103

No in-tank photographs are available.

4.3.3 Synopsis Tank of 241-AW-103

(To be completed.) 


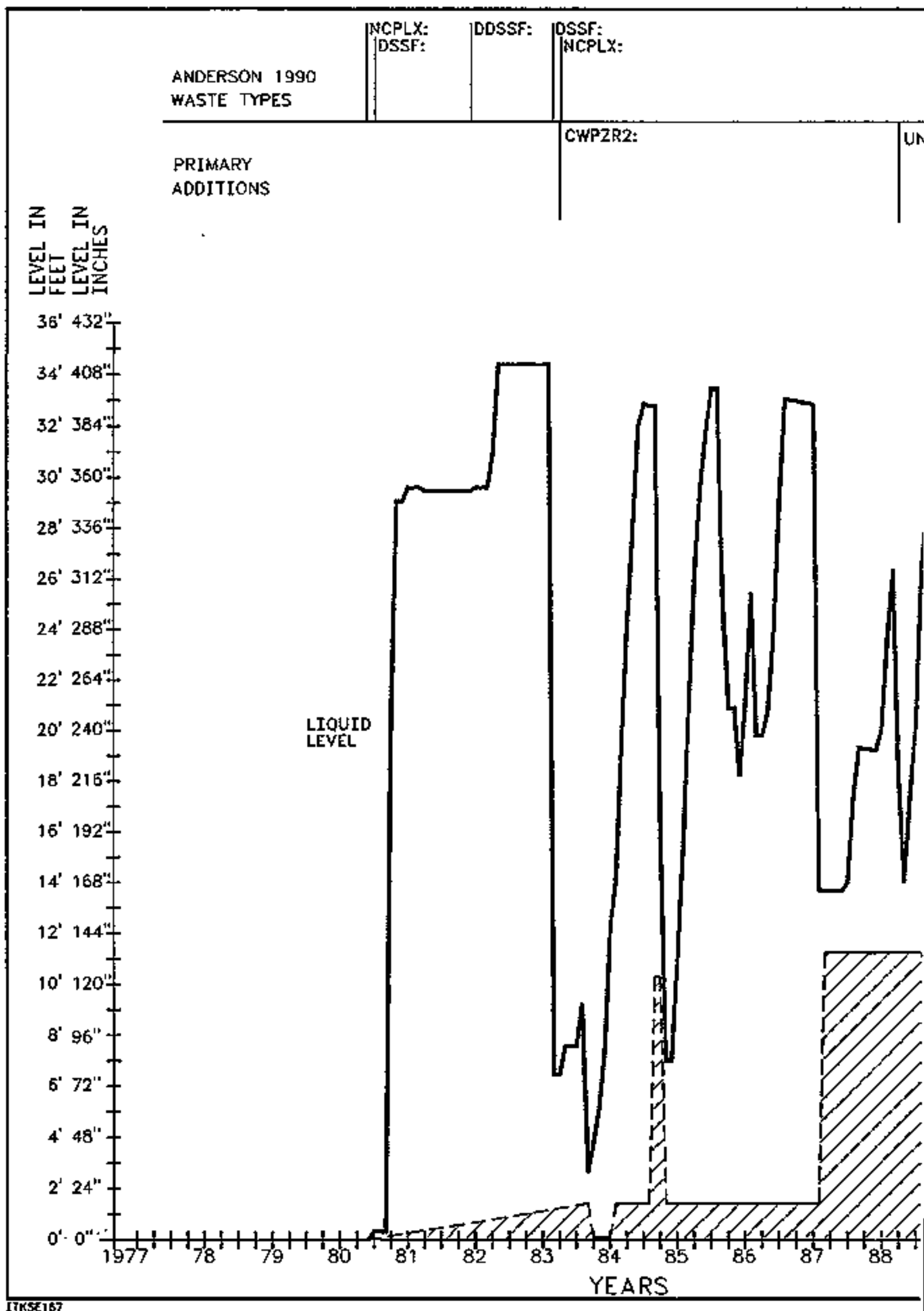


WHC-SD-WM-ER-350， Rev. 0

\begin{tabular}{|c|c|c|c|}
\hline \multicolumn{4}{|c|}{ Doubleskell Tank 241-AW-103 } \\
\hline \multicolumn{4}{|c|}{ 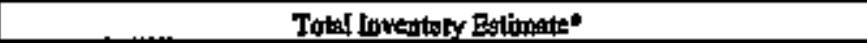 } \\
\hline \multicolumn{4}{|c|}{ 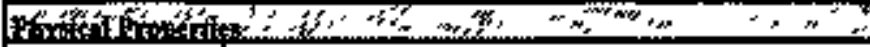 } \\
\hline Total Waste & $2.848+06 \mathrm{~kg}$ & (647 k & \\
\hline Atentulast & \multicolumn{2}{|c|}{$9.91202 \mathrm{~kW}(338$, ETUt⿱一兀) } & \\
\hline Bulk Demilyt & \multicolumn{3}{|c|}{$1.16(0 / \infty)$} \\
\hline Woter wtht & \multicolumn{3}{|c|}{80.1} \\
\hline Toc wt\%C & \multicolumn{3}{|c|}{0.009} \\
\hline \multicolumn{4}{|c|}{ 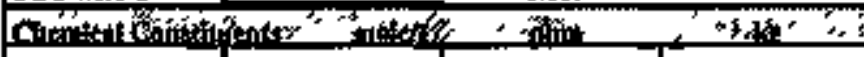 } \\
\hline $\mathbf{N a}^{*}$ & 3.2. & 6.49E+0A & 1.392405 \\
\hline \multicolumn{4}{|c|}{ 9.17?:-10 } \\
\hline Fut: (1)tal Fo) & 0.205 & $9.85 E+03$ & $260 E+04$ \\
\hline \multicolumn{4}{|c|}{$3,489-04$} \\
\hline \multicolumn{4}{|c|}{ 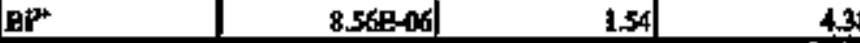 } \\
\hline \multicolumn{4}{|c|}{ 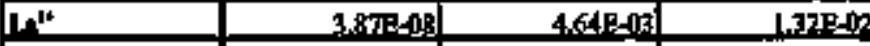 } \\
\hline \multicolumn{4}{|c|}{ 1,07R-03 } \\
\hline Zrins $2 \mathrm{r} \times \mathrm{COH}$ & $0,55]$ & $4.09 \mathrm{E}=0404$ & 2. $16 \mathrm{E}+\mathrm{t}+\mathrm{S}$ \\
\hline \multicolumn{4}{|c|}{$133 \mathrm{E}-06$} \\
\hline \multicolumn{4}{|c|}{ 6.158-0.9 } \\
\hline$S x^{2+}$ & $4,09 \mathrm{~B}-0 \mathrm{O}$ & $3,098-09$ & B.7AEAS \\
\hline $\mathbf{M n}^{\mathbf{4 *}}$ & $1.618-04$ & 7.5 & 21.6 \\
\hline \multicolumn{4}{|c|}{ 3.30e.02 } \\
\hline \multicolumn{4}{|c|}{$5,27= \pm 10 ;$} \\
\hline \multicolumn{4}{|c|}{ 4.10R+00 } \\
\hline \multicolumn{4}{|r|}{4,612404} \\
\hline \multicolumn{4}{|c|}{$1.9 \mathrm{gig}-\mathrm{an}$} \\
\hline \multicolumn{4}{|c|}{ 3.THE-0.9 } \\
\hline \multicolumn{4}{|c|}{2.1 驾 -03} \\
\hline \multicolumn{4}{|l|}{$\mathrm{SO}_{2}^{2}$} \\
\hline Si $\left(a s S_{0}{ }^{2}\right)$ & 3689004 & 8.92 & 25.3 \\
\hline F & 300 & $49 S E+10$ & $1.41 \mathrm{E}_{4}, 5$ \\
\hline $\mathbf{C r}$ & 45\%:03 & 140 & 397 \\
\hline$C_{1} H_{1} O^{2}$ & 2.698:-04 & 437 & 124 \\
\hline EOSA & 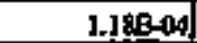 & 202 & 8. \\
\hline HEDTA & $191 \mathrm{~B}-04$ & 45.1 & 28 \\
\hline dived!nge- & LIIE-OA & 84 & $240:$ \\
\hline oxtale & 1.4AE-04 & 1,32 & 20.8 \\
\hline axalument & 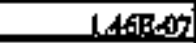 & 1.111E-0.2 & $3.15 E_{12}$ \\
\hline DEPP & 1.7ME-A4 & $26, t$ & 70.3 \\
\hline Indtancl & I.78E_언 & II & 324 \\
\hline $\mathrm{NH}$ & -0:47 & $802 \mathrm{E}+0 \mathrm{0}$ & $228 \mathrm{E} \pm \mathrm{an}$ \\
\hline$P=(C N)_{3}{ }^{4}$ & & & \\
\hline 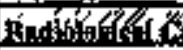 & tex & 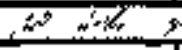 & \\
\hline Pu & & $0.454\left(\mu \mathrm{CH}^{2} \mathrm{~g}\right)$ & $21,5(\mathrm{kE})$ \\
\hline II & $2098-030 \mathrm{Ml}$ & aztiuesph & $1.21 \mathrm{~B}=0 \mathrm{ag}$ \\
\hline C & 4.96E-13 (CI) 1$)$ & $4.28\left(u C^{\prime}(p)\right.$ & $122 \mathrm{E}+04$ (C) \\
\hline $\mathbf{S r}$ & $256 \mathrm{E}-03(\mathrm{CiL})$ & $220(1, \mathrm{C}$ (1) & $6,26 \mathrm{Q}+03\left(\mathrm{Cl}_{3}\right)$ \\
\hline
\end{tabular}

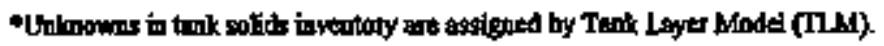

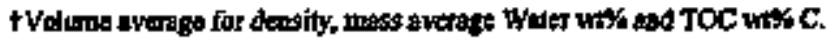

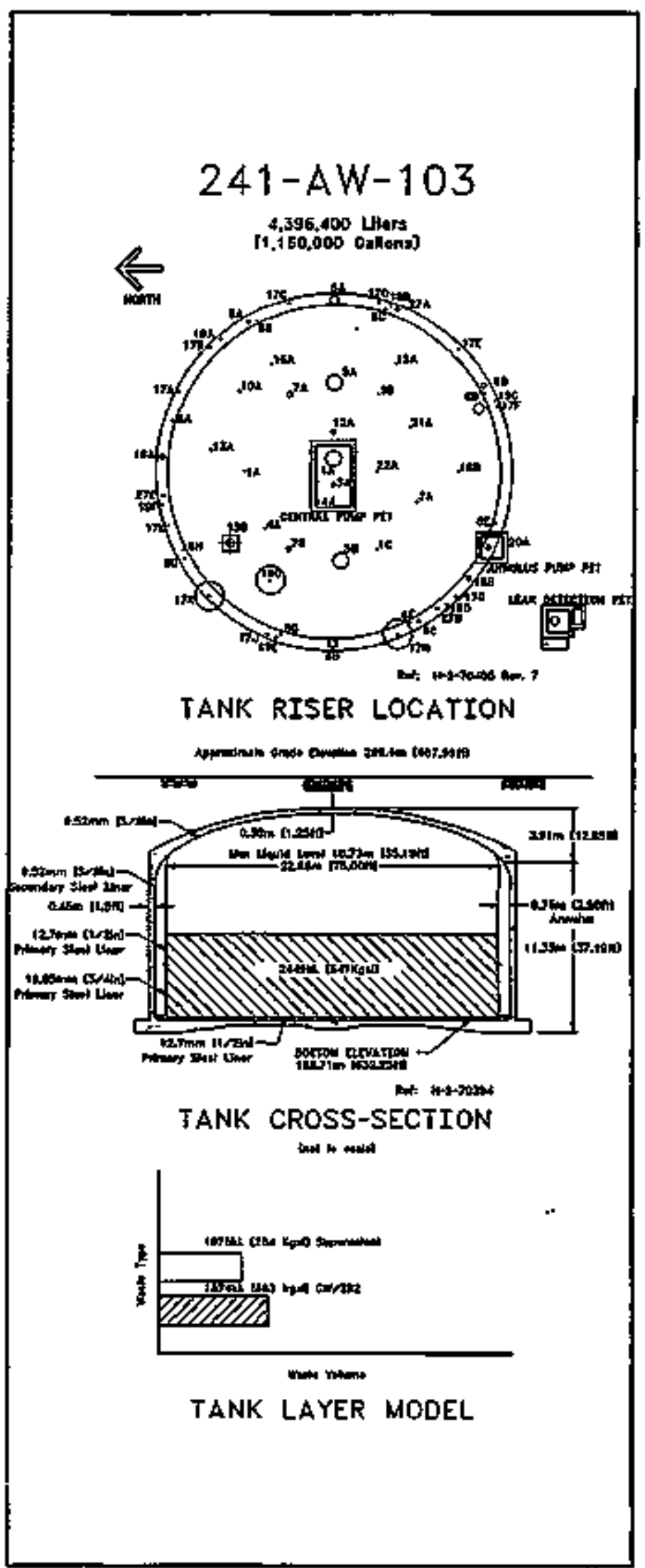


WHC-SD-WM-ER-350, Rev, 0

\begin{tabular}{|c|c|c|c|}
\hline \multicolumn{4}{|c|}{ Double-Shen Tank 241-AW-103 } \\
\hline \multicolumn{4}{|c|}{ 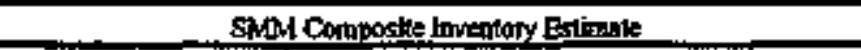 } \\
\hline fow & ג' & 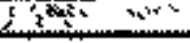 & 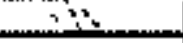 \\
\hline Toul Srpenintax & $1.09 \mathrm{E}+06 \mathrm{kx}$ & $(284$ kogn) & \\
\hline Henlead & $5.395 .02 . \mathrm{K}: \mathrm{H}$ & 84 BTHAm & \\
\hline Bulk Dersity* & & (.0) $(0,00)$ & \\
\hline Water wt\%t & & $\$ .9$ & \\
\hline TOC ma $\mathrm{C}($ wet $)$ & & 0.021 & \\
\hline \multicolumn{4}{|c|}{ 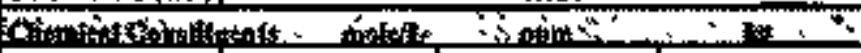 } \\
\hline $\mathrm{Na}^{+}$ & \begin{tabular}{|r|}
$0.43 \mathrm{~d}$ \\
\end{tabular} & $9.34 \mathrm{E}+19$ & $1.06 \mathrm{E}+0 \mathrm{~d}$ \\
\hline $\mathrm{AP}^{\mathrm{H}}$ & $200 \mathrm{E}=0 \mathrm{O}$ & 55 & 603 \\
\hline$\left.F_{0}^{*}(10+1) F e\right)$ & L.16E-03 & 63.5 & 69.4 \\
\hline$a^{n}$ & $7,92 \mathrm{~B}, 0 \mathrm{OA}$ & 40.5 & 443 \\
\hline $\mathrm{Bp}^{*}$ & L.95E-06 & 4.01 & 4.38 \\
\hline 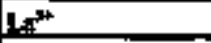 & $8.828-09$ & 12:?:-104 & $1.37 \mathrm{E}-\mathrm{AP}$ \\
\hline $\mathrm{HF}^{*+}$ & $5,11 E-0,0$ & 1.01 & $\mathrm{t} .10$ \\
\hline 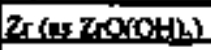 & 1.S1E-09 & 139 & 148 \\
\hline $\mathrm{Pb}^{2+}$ & $3.05 \mathrm{E}-0 \mathrm{0}$ & 0.618 & 0.675 \\
\hline $\mathrm{kE}^{+2}$ & 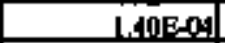 & 800 & 8.85 \\
\hline SH" & $9.32 \mathrm{E}, 0 \mathrm{O}$ & $8.036-03$ & $2.78 \mathrm{~B} 403$ \\
\hline $\mathrm{Mn}^{+\mathbf{+}}$ & $3.66 \mathrm{E}, 04 \mathrm{Al}$ & 10,8 & 21.6 \\
\hline $\mathrm{Ca}^{\mathrm{a}}$ & 8.09E-05 & 319 & 349 \\
\hline $\mathbf{K}^{*}$ & 0.121 & $4,31 E+013$ & 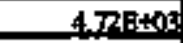 \\
\hline OH: & 0.145 & 2A3E+03 & $2.66 \mathrm{E}+0 \mathrm{~g}$ \\
\hline No: & 0.264 & $16\left[\begin{array}{lll}2+04 \\
\end{array}\right.$ & $1.76 \mathrm{E}+404$ \\
\hline NO: & $3,64 \mathrm{E}-0 \mathrm{x}$ & $1.65 \mathrm{E}+0 \mathrm{0}$ & $1.60 \mathrm{E}+0 \mathrm{~B}$ \\
\hline $\cos ^{2}$ & L94:-807 & $1.148+09$ & 2,25907 \\
\hline $\mathrm{PQ}_{1}^{2}$ & $4.992-03$ & 460 & 510 \\
\hline $\mathrm{SO}_{2}^{2}$ & $4670-191$ & 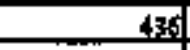 & 47 \\
\hline 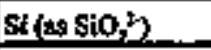 & $839 \mathrm{ean}$ & 29.2 & 25.3 \\
\hline $\mathrm{F}$ & 0.124 & $2.26 \mathrm{eq}$ & $2 \mathrm{AT}+4 \mathrm{ng}$ \\
\hline 도 & $5,31 B-0$, & Ltes & 202 \\
\hline CAHOL & 6.51:-041 & إلإل & 120 \\
\hline EDTA ${ }^{+}$ & 2,6AE-04 & 76.0 & 83.1 \\
\hline HeTtat & A 34E-0ㅇ & |] & 126 \\
\hline 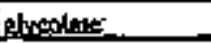 & 290003 & |219 & 240 \\
\hline cotintest & $3.25 \mathrm{E}-0 \mathrm{-1}$ & 19.0 & 20.0 \\
\hline $\log n \ln _{0} \mathrm{~s}^{2}$ & $333 \mathrm{E}-07$ & 2RBE-AD & 3.15E-02 \\
\hline DBP & 4.06iE-04 & 64.4 & 70.3 \\
\hline botsonol & $4060-0 \mathrm{~A}$ & 296 & 324 \\
\hline NHA. & 0.3921 & $6.54 E+103$ & 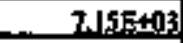 \\
\hline $\mathrm{Fe}(\mathrm{CON})^{4}$ & 0 & a & \\
\hline 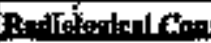 & fitp:=nts_ & $\therefore$ & $x^{2}$ \\
\hline Pn & $12.8(\mu \mathrm{Cil})$ & & $0230(\mathrm{~kg})$ \\
\hline U & $1.5 \pi=0130 \mathrm{Mn}$ & 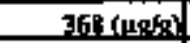 & $40 ? \mathrm{kn}$ \\
\hline 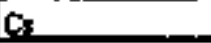 & $7.59 \mathrm{e}_{-03}(\mathrm{C}$ & 746 (1) C 48 & 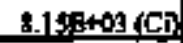 \\
\hline Sr & 2.16E-03 (C) & 2.13 (nCis) & $2.320+03$ (C) \\
\hline
\end{tabular}

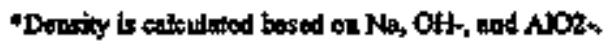

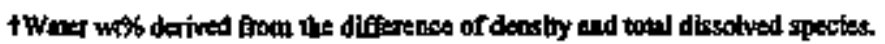

\begin{tabular}{|c|c|c|c|}
\hline \multicolumn{4}{|c|}{ Double-Shell Tank 241-AW-103 } \\
\hline \multicolumn{4}{|c|}{ 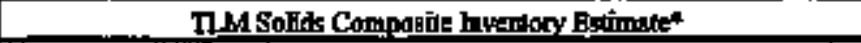 } \\
\hline \multicolumn{4}{|c|}{ 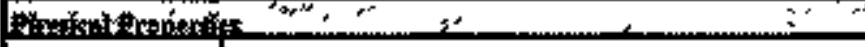 } \\
\hline Tomel Solit Wasla & $1.79 E+06 \mathrm{~kg}$ & 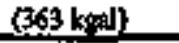 & \\
\hline Hexthent & \multicolumn{3}{|c|}{ 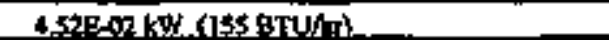 } \\
\hline Byllk Detesty & \multicolumn{3}{|c|}{$1.27(p / s)$} \\
\hline What wto & \multicolumn{3}{|c|}{67.5} \\
\hline TOC wis C (wet) & \multicolumn{3}{|c|}{0} \\
\hline \multicolumn{4}{|c|}{ 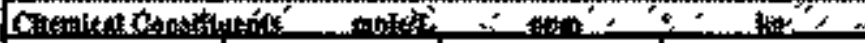 } \\
\hline $\mathrm{Ne}^{+}$ & 5.50 & 9,95E+04 & $1,74 \mathrm{E}+0 \mathrm{~S}$ \\
\hline \multicolumn{4}{|l|}{$\Delta \mathrm{P}^{*}$} \\
\hline$F 0^{\prime \prime}(\cot 1 \mathrm{Fo})$ & 0.364 & $1.60 \mathrm{E}+04$ & $2,79 \mathrm{E}+04$ \\
\hline \multicolumn{4}{|l|}{$\mathrm{Cr}^{2+}$} \\
\hline \multicolumn{4}{|l|}{$B P^{*}$} \\
\hline \multicolumn{4}{|l|}{$1 . a^{3}$} \\
\hline Hes"i" & $1.919-03$ & 301 & 526 \\
\hline 7. & 0.927 & $6.65 \mathrm{Sen}+4$ & $1.168+09$ \\
\hline \multicolumn{4}{|l|}{ Pto } \\
\hline \multicolumn{4}{|l|}{$\mathrm{Nin}^{2+}$} \\
\hline \multicolumn{4}{|l|}{$\mathrm{si}^{*}$} \\
\hline \multicolumn{4}{|l|}{$\mathrm{Mat}$} \\
\hline $\mathrm{C}_{2}^{2+}$ & 524E-12 & $1.65 \mathrm{E}+103$ & $2,89 \mathrm{E}+0 \mathrm{~g}$ \\
\hline $\mathrm{x}^{\mathbf{*}}$ & 0.19 & $5,89 E_{2+13}$ & $1.0 \mathrm{AE}+0 \mathrm{~A}$ \\
\hline OH' & 4.88 & $6.52 \mathrm{E}+04$ & $2.14 \mathrm{E}+0 \mathrm{~s}$ \\
\hline NO:- & $0,33.5$ & $1.635 \pm 0.09$ & $2.85 \mathrm{E}+04$ \\
\hline No: & 7.04E-03 & 25 : & 44 \\
\hline $\mathrm{cos}^{2}$ & $5,24 \mathrm{EAO}$ & $2.478+0 \pm 2$ & $4,32 \mathrm{~B}+\mathrm{n}) \mathrm{f}$ \\
\hline \multicolumn{4}{|l|}{ PO? ${ }^{2}$} \\
\hline \multicolumn{4}{|l|}{ sor } \\
\hline \multicolumn{4}{|l|}{$\sin \left(\operatorname{sisin}_{2}^{2}\right)$} \\
\hline $\mathrm{F}$ & 5.79 & $7,90=+04$ & 1.3880405 \\
\hline G. & $4.00 \mathrm{E}-0 \mathrm{3}$ & 111 & 19: \\
\hline \multicolumn{4}{|l|}{ 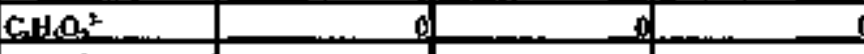 } \\
\hline \multicolumn{4}{|l|}{ BDTA4 } \\
\hline \multicolumn{4}{|l|}{ Henga. } \\
\hline \multicolumn{4}{|l|}{ 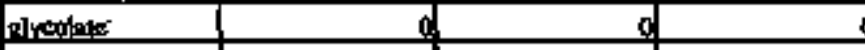 } \\
\hline \multicolumn{4}{|l|}{ entes } \\
\hline $\left.\operatorname{exc} 1 \ln ^{2}\right)^{2}$ & & a & 0 \\
\hline DBP & 0 & 0 & a \\
\hline Futt!ned & & of & o \\
\hline $\mathrm{NH}_{4}$ & 0.668 & $8,995+03$ & -1.56R+04 \\
\hline $\mathrm{Fe}(\mathrm{CN})\}^{4}$ & 0 & d & \\
\hline 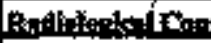 & tates & $\sin$ & $0 y^{\alpha} / s_{f}$ \\
\hline Pven_m & & $0.730(\mu \mathrm{C}) \mathrm{s})$ & $213(\mathrm{~kg})$ \\
\hline $\mathbf{u}$ & $248 E-03-14:$ & $4(4,(y) / \sigma)$ & $8) 1$ (4s): \\
\hline cs & 2.9IE-03 (CiL) & $2 x$ (ncyls) & 4.0\%+13(C): \\
\hline $\mathrm{si}_{\mathrm{r}}$ & $2.36-08\left(\mathrm{Cl}_{2}\right)$ & 2.25 ( $\mu$ C & $\left.3.94 \mathrm{E}_{4}+03, \mathrm{CO}\right)$ \\
\hline
\end{tabular}

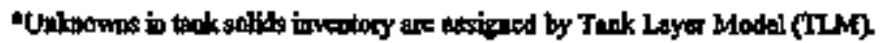


WHC-SD-WM-ER-350, Rev. 0

4.4 Tank 241-AW-104

4.4.1 24I-AW-104 Tank History

4.4.1.1 Waste History of Tank 241-AW-104

Tank 241-AW-104 began service by receiving non-complexed waste in July 1980. The tank received non-complexed waste until July 1981, and egain from October 1992 until Kay 1990. During August, September, and October 1981, the tank received complexant concentrate waste. From November 1981 to September 1982, the tank received complexed waste. The tant contained non-complexed waste from october 1982 until May 1990. The tank received waste from PUREX from the third quarter of 1986 until the second cuarter of 1991. From June 1990 until the present, the tank has contained ailute non-complexed waste. The tank has not received waste since the third quarter of 1992. Currently, the tank is an inactive dilute receiver tank.

\subsubsection{Temperature History of Tank 241-AW-104}

Temperature data for Tank 241-AW-104 are recorded by 18 thermocouples at known elevations on one thermocouple tree inside the tank, located in risex 4A. Non-suspect temperature data taken between July 1983 and June 1991 for all 18 thermocouples were available from the computer automated surveillance system. Non-suspect temperature data recorded between July 1989 and Septembex 1993 for 12 thermocouples were available from tho survelliance analysis computer system. However, not all of the 12 thermocouples have data that encoupass the entire length of time. Within the time spans for both systems, there were several smill breaks in the sequence of temperature data. The average temperature during these pertods was $90^{\circ} \mathrm{F}$ with a minimum of $62^{\circ} \mathrm{F}$, a maximim of $133^{\circ} \mathrm{F}$, and a standard deviation of $14^{\circ} \mathrm{F}$. Iinear regressions were performed on each themocouple that had temperature data between January 1990 end January 1994. The slopes from these regressions were everaged resulting in slope of -0.011 . Refer to the supporting document for a more thorough review of the temperature alta (Brevick, 1995).

\subsubsection{Occurrences of rank 241-AW-104}

Two unusual events occuraed at this tank since it went into service. off-Normal Report 83-14 was issued in December 1986 due to transferring solution from 242-A kvaporator to Tank 241-AN-102. The tank pressurized to +0.65 inches water gauge. Off Normal Report 86-55 was issued in December 1986 due to a test on the ventilation system at AN Tank Faxm. The tank maintained a negative pressurize of -0.05 inches water gauge, but exceeded the limits specified for ventilation. 
WHC-SD-WW-ER-350, Rev, 0

\subsubsection{Psychrometrics of Tank 241-AW-104}

Psychrometric data have been recorded for 12 years from this tank and annulus. The apparent trend of the evaporation rate from the tank has decreased from 175.4 gallons per week in Octobex 1981 to 124.6 gallons per week in January 1995. Over that same period, the trend in the rates of heat exchange through the primary tank ventilation has decreased. The rates of heat exchange through annular ventilation show an increasing trend. The majority of the changes in the rate of heat exchange can be attributed to changes in the average ventilation rates. A review of the psychrometric data in Tank 241-Av-104 would suggest a decrease in the rate of heat generation by the waste.

\subsubsection{Current Status of Tank 241-AN-104}

Tank 241-AW-104 entered service in August 1980 and currently stares 1,123,000 gallons of waste. The following plan view and tank crossmection depict the approximate waste volume of 1,123,000 gallons and configuration of risers as of January 1994. At the time of the estimate, there were $1,020,000$ gallons of supernatant with 187,000 gallons of concentrated supernatant solids; 98,000 gallons of pUREX low-level waste (PL2); and 5,000 gallons of coating waste from $z$ Plant and REDOX (CW/ZR2). The waste level in the tank is measured with the FIC gauge and the manual tape and has increesed from about 360 inches in Jantary 1991 to 410 inches in Jarnuary 1994. The increase was mostly dilute and non-conplexed waste from PUREX miscellaneous streams between Januazy 1991 and March 1991 . The tank is inactive at this time. The tank is actively ventilated and categoxized as sound. Tank 241-Ah-104 has 59 risers. Two 4-inch risers (no.15A and no.19C), one 12-inch riser (no.7B), and two 42-inch risers (no.5A and no.5B) are available for use.

\subsubsection{Inventory Estimate of Tank 241-AM-104}

The tank layer model (a volume based approximation) that follows was derived from the Los Alamos National baboratory Waste status and Transaction Record Sumbary (Agnew, 1995) and supernatant mixing Model (Agnew, 1995). The estimated invertories of total waste, solids, and supermatant in Tank 241-AN-104 are also presented. concentrated sipernatant solids are considered as an integral part of the liguid for the purpose of estimating inventories, but are graphed as solids on the level histories. The actuel substance, which was derived from dolble-shell slurxy, appears as a solid if undisturbed, but the particles are resuspended in solution if heated or disturbed.

\subsubsection{In-Tank Photograph for Tenk 241-AW-104}

As of April 1994, Tank 241-AW-104 contained 1,122,000 gallons of dilute non-complexed waste (Hanlon 1994) fron PUREX which corresponds with a waste height of about 34 feet. The collage for this tank was produced from 1983 photographs and shows liquid at 2 much lower level. In this picture, the licuid appears to be black with some very fine particles suspended on the surface and distributed in random patterns. The tank 
walls are only slightly rusted. The location of equipment in the tank should be unchanged from 1983. Equipment which are identified include a saltwell screen, an FIC level probe, a temperature probe, and a high-level sensor.

4.4.3 Synopsis of Tank 241-AW-104

(To be completed.) 


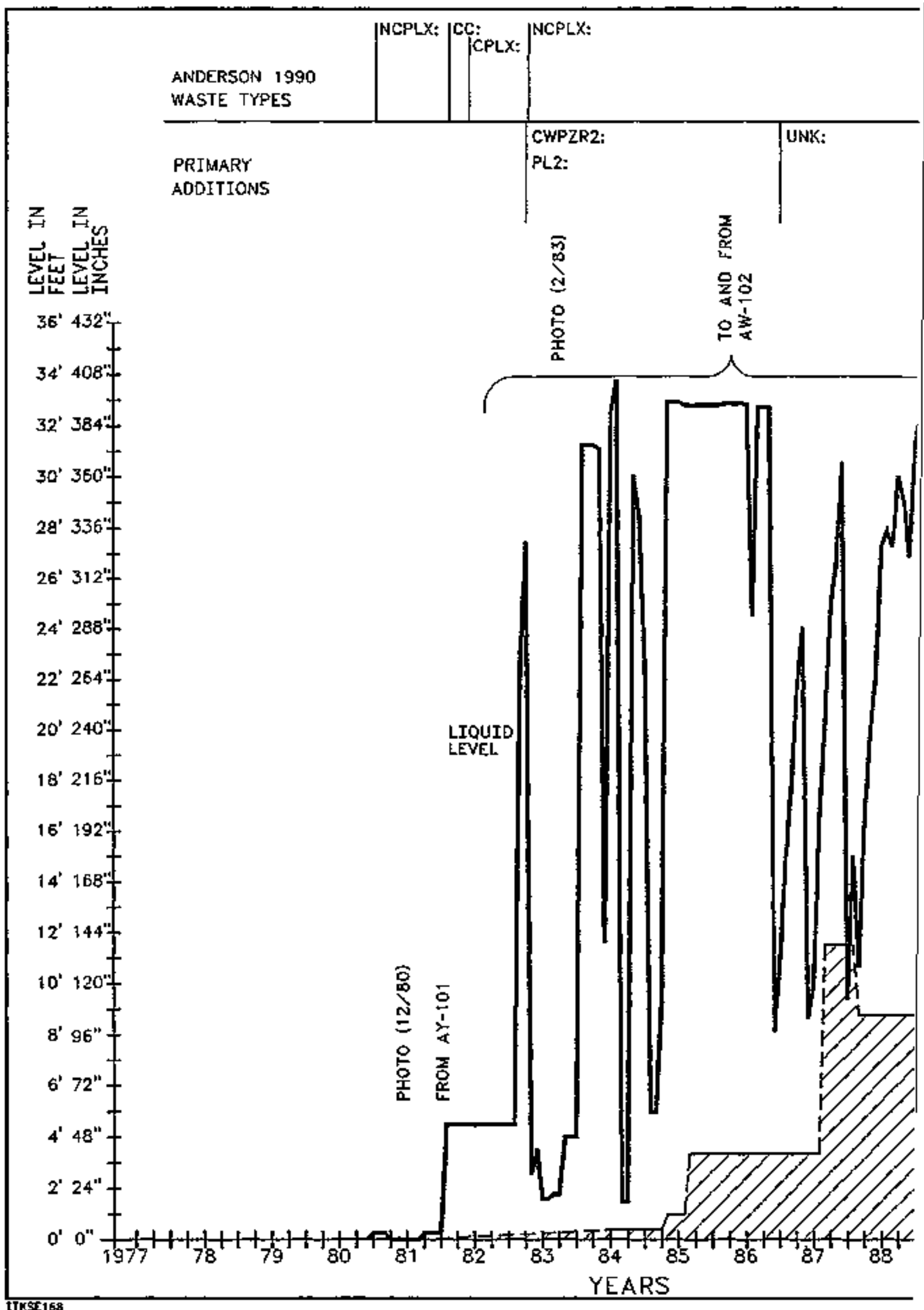




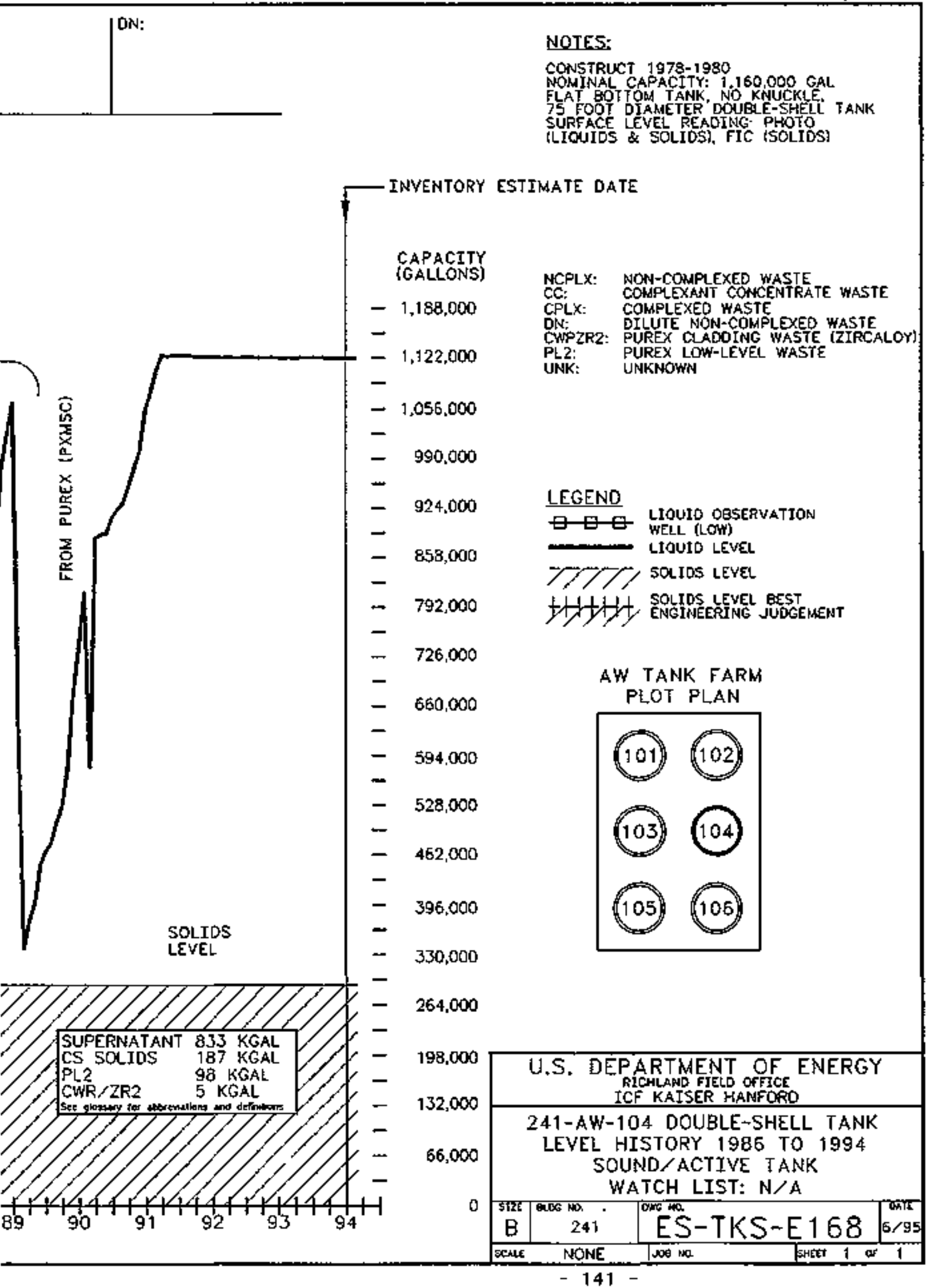


WHC-SD-FM-ER-350, Rev. 0

\begin{tabular}{|c|c|c|c|}
\hline \multicolumn{4}{|c|}{ Double-Shell Tank 241-AW.104 } \\
\hline \multicolumn{4}{|c|}{ 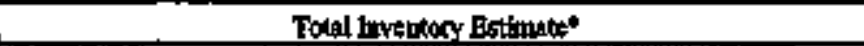 } \\
\hline \multicolumn{4}{|c|}{ Fof } \\
\hline Toral Waste & \multicolumn{3}{|c|}{$4.408+06 \mathrm{~kg}$ (1.128+03 kgals } \\
\hline Het/and & \multicolumn{3}{|c|}{$3.11 \mathrm{kw}$ (1068404 BTWhrl } \\
\hline 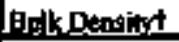 & \multicolumn{3}{|c|}{ Iof(o/cs) } \\
\hline Water whet & \multicolumn{3}{|c|}{94.1} \\
\hline ToCutsc & \multicolumn{3}{|c|}{0.041} \\
\hline \multicolumn{4}{|c|}{ 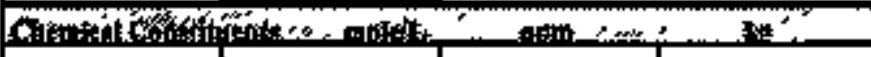 } \\
\hline $\mathbf{N a}^{*}$ & 0.618 & $13 \% \mathrm{E}+0 \mathrm{04}$ & $6.04 E+04$ \\
\hline$A !^{3 P}$ & 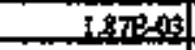 & 48. & 214 \\
\hline Fo" $(\operatorname{cotat} 1 \mathrm{Fo})$ & 0.169 & $9.13 \mathrm{E}+0.0$ & $4.02 \mathrm{E}+04$ \\
\hline cat & 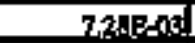 & 364 & $1,61 P+0 t$ \\
\hline $\mathrm{Bl}^{\mathbf{+}}$ & 1.84E-00] & 0.371 & 1.63 \\
\hline $1 \mathbf{A}^{3}$ & 8.45E:09: & 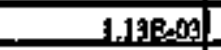 & $4.928-019$ \\
\hline $\mathrm{He}^{\mathrm{z}}$ & esogenad & 1.60 & 725 \\
\hline 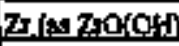 & $4,13 \mathrm{E}, 09$ & $36 \mathrm{As}$ & $1.602 \pm 09$ \\
\hline $\mathrm{Pb}^{\mathrm{z+}}$ & $3,94 \mathrm{dE}, 0 \mathrm{~S}$ & 7.89 & 34.7 \\
\hline Nit? & LIVE-OP? & 69 & $2.81 \mathrm{E}+4 \mathrm{9}$ \\
\hline $\mathbf{s i}^{+}$ & 1.938-09 & 35secol & $3.33 \mathrm{E}-03$ \\
\hline hat" & S.44E- -9 : & 27t:요 & $12+24+409$ \\
\hline $\mathrm{Co}^{\mathbf{2}}$ & $3.05 E-02$ & $1.18 E+0 \mathrm{~g}$ & $5.202+03$ \\
\hline $\mathbf{K}^{+}$ & 63te-193 & $\mathbf{2} \mathrm{s}$ & -10584013 \\
\hline ofr- & 0.561: & $9.22 \mathrm{E}+03$ & $4.06 \mathrm{E}+04$ \\
\hline NO: & 0.295 & $240 \mathrm{E}+\mathrm{AP}$ & 6.18E+Dd \\
\hline No: & $1 . \sec -02$ & 70.1 & $3.09 \mathrm{E}+03$ \\
\hline $\cos )^{2}$ & $0,123 !$ & $2,15 \mathrm{~B}+0.3$ & $3.15 \mathrm{R}+04$ \\
\hline $\mathrm{PO}^{2}$ & $6.31 \mathrm{E-02}$ & $5.7 \mathrm{aE}+03$ & $255 \mathrm{E}+04$ \\
\hline sot & 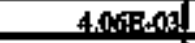 & 377 & 1.66840: \\
\hline Sis $(\mathbf{x}$ Sto & 7,47E-0S & 203 & s.92 \\
\hline$F$ & $23 \pi,-10$ & 434 & [.91E+0)] \\
\hline $\mathrm{C}$ & $3.81 E-03$ & 1300 & $5 \pi$ \\
\hline$C_{4}+O_{+}+$ & $3,640-0,5$ & \pm 0.3 & 45.3 \\
\hline EMTA $A^{*}$ & 2.69E-05: & 7.49 & 33.0 \\
\hline HEDTÁ & 448E-GA & 11.9 & 527 \\
\hline el & 2.35E-04 & 120. & 748 \\
\hline acelare" & 2.89E-0s & 1.69 & 725 \\
\hline mathotiot & 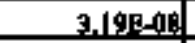 & 2.71E 02 & $1.198-0 ?$ \\
\hline DQP & $2,07 \mathrm{E}-09$ & 420 & 2.08E $=03$ \\
\hline hevtensl & 283ed & 206 & 2016 \\
\hline $\mathrm{NH}$ & 3.03P:-19: & 49.8 & 219 \\
\hline $\mathrm{Fe}(\mathrm{CN}))_{4}^{4}$ & & $d$ & 0 \\
\hline \multicolumn{4}{|c|}{ 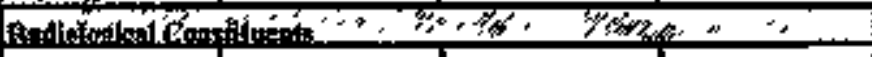 } \\
\hline Pu & & 1.91E-m $\left.\left(1 C_{1}\right)\right]$ & L40(kㅐ) \\
\hline II & $4.39 \mathrm{E}, 04 \mathrm{M}:$ & $10 \perp\{t a v d x$ & $44(\mathrm{~km})$ \\
\hline$C_{B}$ & $7.760 \mathrm{~A}\left(\mathrm{C}_{2} \mathrm{~s}\right)$ & $26,7\{\mathrm{uC} / \mathrm{s})$ & $1.17 \mathrm{E}+0 \mathrm{OS}(\mathrm{C})$ \\
\hline St & 8.97E-N2(CiL) & 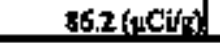 & $3.200+05(C)$ \\
\hline
\end{tabular}

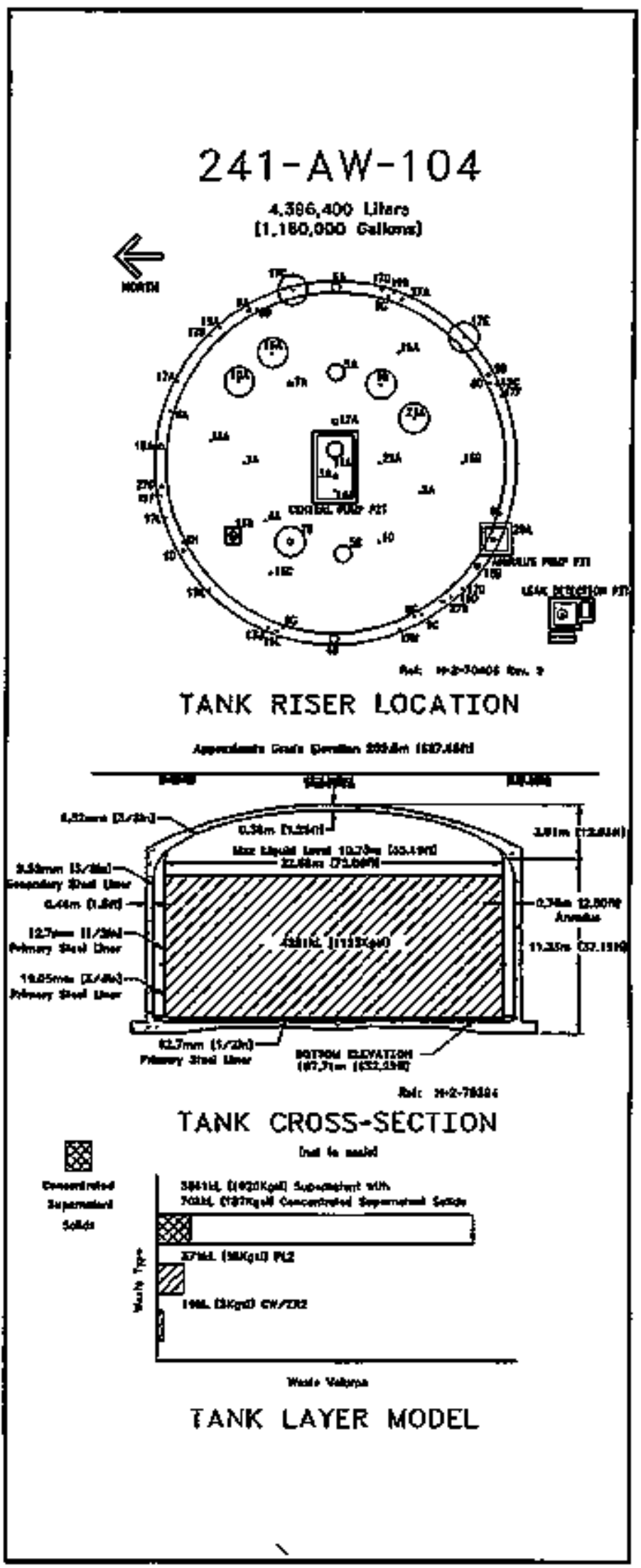




\begin{tabular}{|c|c|c|c|}
\hline \multicolumn{4}{|c|}{ Double-Shell Trak 241-A W-104 } \\
\hline \multicolumn{4}{|c|}{ SMdM Compasite hevemtory Eximsite } \\
\hline 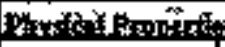 & 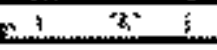 & ${ }^{x} n^{2} \quad n$ & $\therefore$ \\
\hline Total Sepentatat & \multicolumn{3}{|c|}{ 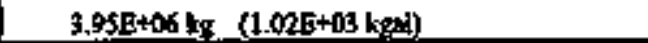 } \\
\hline Hentlond & \multicolumn{3}{|c|}{ 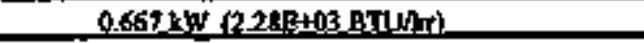 } \\
\hline 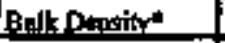 & \multicolumn{3}{|c|}{$1.02(1 / 0)$} \\
\hline Water wr\%t & \multicolumn{3}{|c|}{95.6} \\
\hline 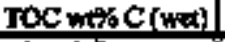 & \multicolumn{3}{|c|}{0.042} \\
\hline 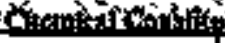 & 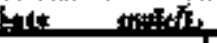 & 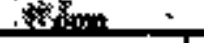 & $\mathrm{be}(1,2)$ \\
\hline $\mathrm{Na}^{+}$ & 0.597 & $134 \mathrm{E}+04$ & $5.306+04$ \\
\hline$A)^{3+}$ & $2058-03$ & 54 & 2/4 \\
\hline$F^{y^{*}}($ (kotal $f g)$ & $1.22 E-03$ & 99.4 & 3902 \\
\hline$\alpha^{*}$ & T.J1E-OA & 37 & $\pm .436+109$ \\
\hline $\mathrm{Bg}^{20}$ & 2.02806 & 0.4ts & L.6: \\
\hline $12^{*}$ & $9.30 \mathrm{e}, 0 \mathrm{9}$ & 1,26E-0 & 4,09803 \\
\hline $\mathrm{Hg}^{2+2}$ & $131 \mathrm{3E}-09$ & $2.5 \pi-0.35$ & 1.02E-02 \\
\hline $2 x(0200 \mathrm{OHL})$ & 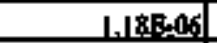 & 0,0 웅 & 0,45 \\
\hline $\mathrm{PD}^{2 *}$ & 3,95B-05 & s.ol. & $3 \mathrm{LL}$ \\
\hline $\mathbf{N H}^{*}$ & LGLIE_I3 & gase & 371 \\
\hline $5 \mathbf{S}^{*}$ & 9.53E-09] & 8.42E-0ㄱ. & 3.32E-0 \\
\hline $\mathrm{Mn}^{*+}$ & 5.46E- 03$]$ & 20月 & $1.62+10 \mathrm{~g}$ \\
\hline $\mathrm{C}^{*}$ & $12 \pi \in-n a d$ & 499 & $\perp 978+09$ \\
\hline $\mathbf{X}^{*}$ & $S .490,03\}$ & 210 & $87:$ \\
\hline or. & 239g-02 & $3 \% 8$ & $1.572+03$ \\
\hline 솔 & a.23 & $1,67+04$ & $5.61 \mathrm{~N}+14$ \\
\hline $\mathrm{NO} ;$ & $1610-02$ & 725 & $2,66 \mathrm{E}+0 \mathrm{03}$ \\
\hline $\boldsymbol{C O}^{2}$ & 0.106 & $6228 \pm+19$ & $246 \mathrm{a}+0$ \\
\hline $\mathrm{PO}_{4}^{2}$ & $6.39 B-02$ & $5.88 \mathrm{E}+0 \mathrm{a}$ & $2328+09$ \\
\hline $\mathrm{sO})^{2}$ & $4.12 p-10 !$ & 357 & $1.53 \mathrm{E}+0 \mathrm{03}]$ \\
\hline $\mathrm{si}\left(\mathrm{siO}, \mathrm{Si}^{\mathrm{i}}\right)$ & 8בSE-05 & 2.26 & 8.92 \\
\hline$E$ & 1778004 & 2,37 & 2.35 \\
\hline$\Phi$ & $3.89 \mathrm{E}, 0 \mathrm{~B}$ & 133 & 58 \\
\hline $\mathrm{Cs}_{\mathrm{H}} \mathrm{O}^{2}$ & 6 6718045 & إك.للف. & 45,3 \\
\hline EDTA ${ }^{4}$ & 2. 9 KE-A연 & B.3. 35 & 39.0 \\
\hline HEDTA2 & 4.93E- 0 S & 132 & 522 \\
\hline 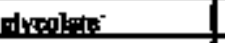 & 2.38p-04 & 18.9 & 74.8 \\
\hline cetalcicis & 3.1요,-05 & 1.84 & 725) \\
\hline 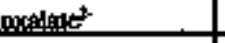 & 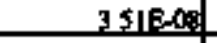 & $3020-03$ & $1.19 \mathrm{E}=02$ \\
\hline Desp & 2.89E-OOA & 456 & $1798+43$ \\
\hline burmanal & 2898.03 & 2009 & 826 \\
\hline $\mathrm{NH}_{2}$ & $5800-0.5$ & 0.265 & 3.81 \\
\hline $\mathrm{Fe}(\mathrm{CN}){ }^{*}$ & 0 & ol & 0 \\
\hline 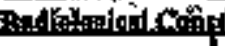 & 19: & & $\Delta$, \\
\hline $\mathrm{Pa}$ & $0.844(\mu \mathrm{Cl})$ & & $5.43 \mathrm{E}-12(\mathrm{~kg})$ \\
\hline$\underline{\underline{u}}$ & 430504010 & 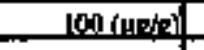 & $395(\mathrm{k} \times)$ \\
\hline$c_{8}$ & 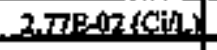 & 27.1 ( $\mu$ Cidgl & 1.07E+06 (C) \\
\hline Sr & $6.35 \mathrm{E}-03$ (c) & $621\left(4 C_{i n}\right)$ & $2,450+0 \mathrm{~A}$ (C) \\
\hline
\end{tabular}

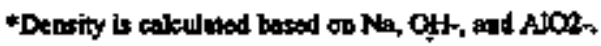

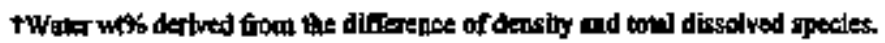

\begin{tabular}{|c|c|c|c|}
\hline \multicolumn{4}{|c|}{ Dopble-Shell Tank 241-AW-104 } \\
\hline \multicolumn{4}{|c|}{ ThM Soldids Composite Invostions Estimute" } \\
\hline \multicolumn{2}{|c|}{ 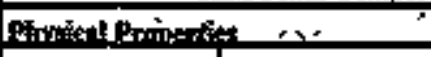 } & $\because, \infty$ & 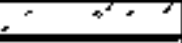 \\
\hline Totad Sold Waste & \multicolumn{3}{|c|}{ A.S5E+05 kg (103 liggl) } \\
\hline Heatlond & \multicolumn{3}{|c|}{ 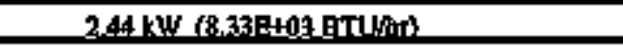 } \\
\hline Bus.j, Denstity & \multicolumn{3}{|c|}{$[.17(\mathrm{p} / \mathrm{kc})$} \\
\hline Water wots & \multicolumn{3}{|c|}{78.5} \\
\hline $100 \mathrm{w} \% \mathrm{C}(\mathrm{me})$ & \multicolumn{3}{|c|}{0.053} \\
\hline \multicolumn{4}{|c|}{ 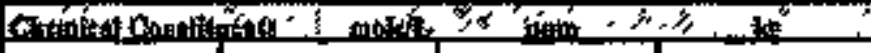 } \\
\hline $\mathrm{Nat}^{*}$ & 0.827 & $1.69 \mathrm{~B}+4 \mathrm{4}$ & $7,418+03$ \\
\hline \multicolumn{4}{|l|}{$A \mathrm{~B}^{* *}$} \\
\hline $\mathrm{PE}^{\prime \prime}$ (16tal fe) & L.B3 & $8.752+04$ & $9,98 \mathrm{E}+04$ \\
\hline$C^{n+}$ & 7000000 & 312 & -142 \\
\hline \multicolumn{4}{|l|}{$B a^{n}$} \\
\hline \multicolumn{4}{|l|}{$1 x^{3}$} \\
\hline $\mathrm{Hr}_{\mathrm{g}}^{\mathrm{*}}$ & 9.26E-05 & [5.9] & 7.24 \\
\hline 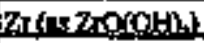 & 4 SODESOP & $3,5,5 \mathrm{E}+03$ & $16001+03$ \\
\hline$\left.P_{0}\right\}^{* x}$ & $3.80 \mathrm{E}-0 \mathrm{~g}$ & 6.79 & 3.07 \\
\hline $\mathrm{Ni}^{{ }^{2+}}$ & 0.106 & $5.76 \mathrm{E}+0 \mathrm{a}$ & $2.44 \mathrm{E}+103$ \\
\hline \multicolumn{4}{|l|}{$8 z^{*}$} \\
\hline $\mathrm{Mr}^{*+}$ & $5.75 \mathrm{E}-1 \mathrm{A3}$ & 247 & 112 \\
\hline $\mathrm{Ca}^{\mathbf{2}^{*}}$ & 0,200 & $7,118+03$ & $3.23 E+10$ \\
\hline $\mathbf{K}^{*}$ & $1458=02$ & 45 & 271 \\
\hline OH & 5.88 & 8.58E+0d & $3.90 \mathrm{E}+104$ \\
\hline No: & 0,27 & $1.268+04$ & $5,725+09$ \\
\hline No; & $1.26 \mathrm{~B}-02$ & 496 & 226 \\
\hline$\infty 0^{2}$ & 0290 & $1528+04$ & $6,99 \mathrm{E}+49]$ \\
\hline Po: & $6.085-002$ & $4.958+09$ & $2,258+03$ \\
\hline $50 x^{2}$ & $3.54 \mathrm{R}-0 \mathrm{~g}$ & 残 & 10 \\
\hline \multicolumn{4}{|l|}{ 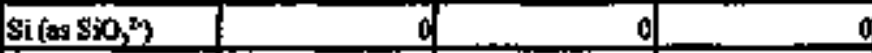 } \\
\hline $\mathbf{F}$ & 0,257 & $4.18 E_{40}$ & $1 \mathrm{gNE}+03$ \\
\hline CT & $3.61 \mathrm{E}_{0} \mathrm{03}$ & 110 & 49.9 \\
\hline \multicolumn{4}{|l|}{$\mathrm{C}, \mathrm{H}, \mathrm{O}^{*}$} \\
\hline \multicolumn{4}{|l|}{ BDTA4 } \\
\hline \multicolumn{4}{|l|}{ HEQT $\mathrm{h}^{2}$} \\
\hline \multicolumn{4}{|l|}{ shcollite; } \\
\hline \multicolumn{4}{|l|}{ acetstis } \\
\hline \multicolumn{4}{|l|}{ oxallats? } \\
\hline DBP & 2.758003 & $52 \mathrm{O}$ & 206 \\
\hline Butongl & $275 E-09$ & 175 & 79.6 \\
\hline $\mathrm{N}_{\mathrm{NH}_{2}}$ & $3.25 \mathrm{~F}-02$ & 474 & 215 \\
\hline $\mathrm{Fe}(\mathrm{ON})^{*}$ & 0 & $d$ & 0 \\
\hline \multicolumn{4}{|c|}{ 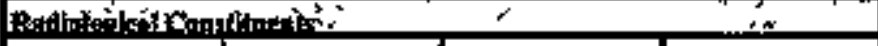 } \\
\hline Pu & & $0.178(\mu \mathrm{CV} / \mathrm{l})$ & $135(\mathrm{~kg})$ \\
\hline $\mathbf{u}$ & S.24E-0404: & lopiurfor & $40.7 \mathrm{kgs}$ \\
\hline $\mathrm{Cs}$ & 2.648 An (CiL) & $726(\mu \mathrm{C} y)$ & F.99F+at (C): \\
\hline st & $0,911(\mathrm{CH})$ & 781 (u) Cirl & $3.55 \mathrm{E}+0.5\left(\mathrm{CO}_{1}\right)$ \\
\hline
\end{tabular}

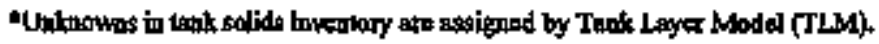




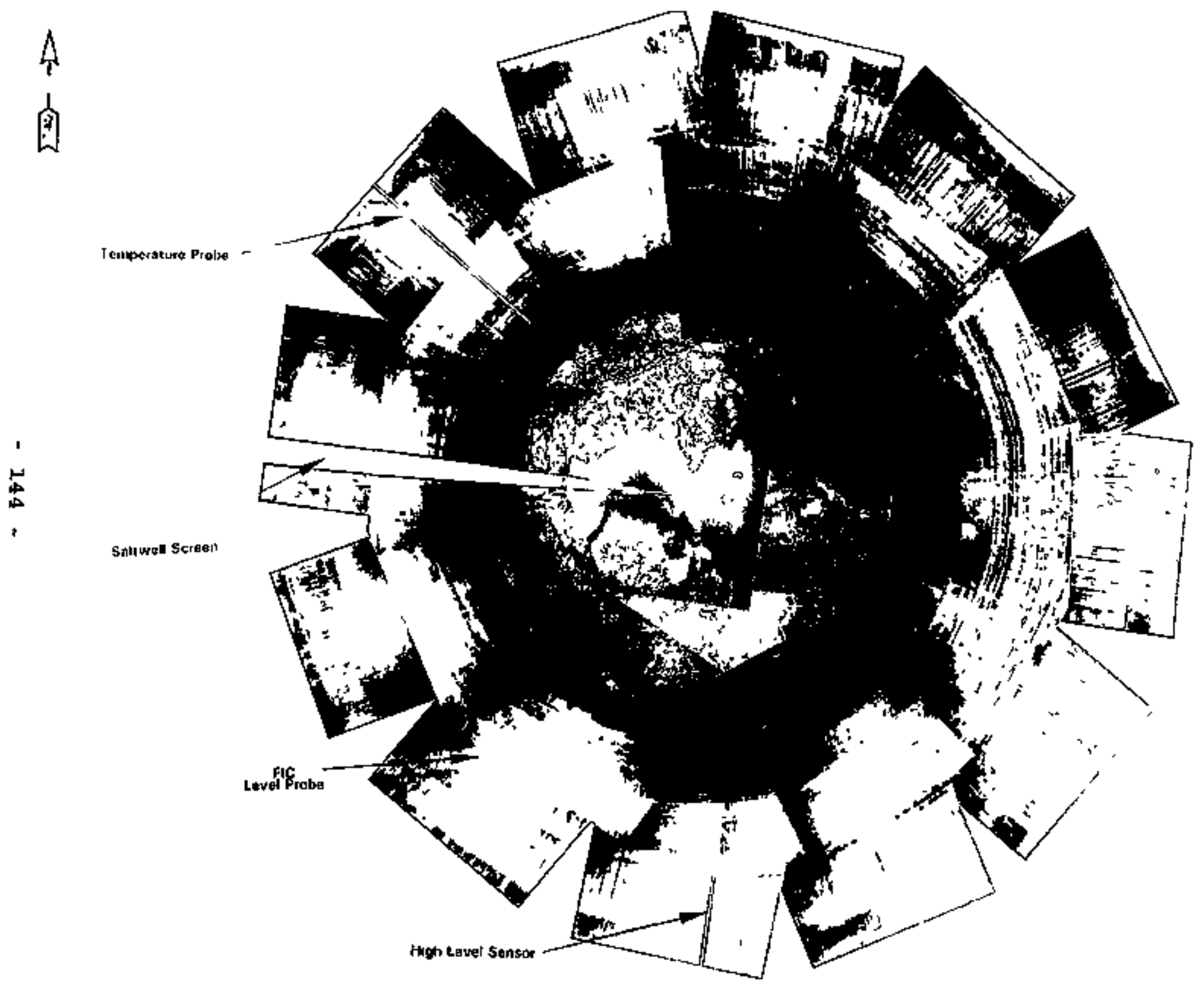

241-AW-I04

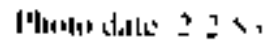


WHC-SD-WM-ER-350, Rev, 0

4.5 Tank 241-AW-105

4.5.1 241-AN-105 Tank History

4.5.1.1 Waste History of Tank 241-AW-105

Tank 241-AW-305 began service by receiving non-complexed waste in July 1980. The tank received complexant concentrate waste from August 1980 until Hay 1983. The tank received waste from EUREX from the second guarter of 1983 until the fourth quarter of 1988. From June 1983 until MaY 1990, the tark received non-complexed waste. During July 1986, the tank received double-shell slurxy feed waste. From June 1990 until the present, the tank has contained dilute non-complexed waste and PURBX neutralized cladaing removal waste. The tank is currently an active, dilute receiver tank receiving waste from puREx.

\subsubsection{Temperature History of Tank 241-AW-105}

Temperature data for Tank 241-AN-105 are recorded by 18 thermocouples at known elevations on one thremocouple tree inside the tank, located in riser 4A. Non-suspect temperature deta recorded between July 1983 and June 1991 for all 18 thermocouples were available from the computer automated surveillance system. Non-suspect temperature date taken between July 1989 and september 1993 for 12 thezmocouples were available from the surveiliance analysis computer system. However, not all of the 12 thermocouples have data that encompass the entire Iength of time. Within the time spans for both systens, there were several small breaks in the sequence of temperature data. The average temperature during these periods was $77^{\circ} \mathrm{F}$ with a minimum of $58^{\circ} \mathrm{F}$, a maximum of $110^{\circ} \mathrm{F}$, and a standard deviation of 110F. Linear regressions were performed on each thermocouple that had temperatuse data between January 1990 and Januaity 1994 . The elopes from these regressions were averaged with a resulting average slope of -0.0058 . Refer to the supporting document. For a more thorough review of the temperature data (Brevick, 1995).

\subsubsection{Occurrences of Tank 241-AW-105}

Three unusual events concerning Tank 241-AW-105 are described in TFS \& O-EFS-88-0125, TFS \& O-EFS-88-0123, and Off-Normal Report 86-21. Each report was written because transferring waste caused the tank to pressurize.

\subsubsection{Psychrometrics of Tank 241-AW-105}

Psychrometric data have been recorded for 13 years from this tank and annulus. The apparent trend of the evaporation rate from the tank has decrensed from 198.3 gallons per week in September 1980 to -23.1 gallons per week in January 1995. Over that same period, the trend in the rates of heat exchange through the primary tank and annular ventilation has apparently decreased. A review of the psychrometric date in Tank 241-AW-105 would suggest an overall decrease in the rate of heat generation by the waste. 
4.5.2 Current status of Tank 241-AW-105

Tank 241-AW-105 entered service in August 1980 and currently stores 342,000 gallons of waste. The following plan view and tank cross*section depict the approximate waste volume of 1,044,000 gallons and configuration of risers as of January 1994. At the time of the estimate, there were 804,000 gallons of supermatant with 43,000 gallons of concentrated supernatant solids; 215,000 gallons of coating waste from $z$ Plant and REDOX (CW/ZR2); and 25,000 gallons of PUTEX low-level (BL2). The waste 1evel in the tank is measured with the FIC gauge and the manual tape and has increased from about 330 inches in January 1991 to 380 inches in January 1994. The waste level decreased to 124 inches in Jaruary 1995 . The increase was mostly the addition of dilute and non-complexed waste from PUREX miscellaneous streams between July 1992 and January 1994 . The decrease was from a transfer to 241-AF-108 in December 1994. This tank is an active waste receiver of PUREx and is concentrated by the 242-A Evaporator. The tank is actively ventilated and categorized as sound. Tank 241-2W-105 has 59 risers. Two 4-inch riserg (no.10A and no.15A) and two 42-inch Iisers (no.5A and no.5B) are available for use.

\subsubsection{Inventory Estimate of Tank 241-AW-105}

The tank layer model (a volume based approximation) that follows was derived from the Los Alamos Nationel Laboratory Waste status and Transaction Record Summary (Agnew, 1995) and Supernatant Mixing Hodel (Agrew, 1995). The estimated inventories of total waste, solids, and supermatant in Tank 241-Aw-105 are also presented. Concentrated supernatant solids are considered as an integral part of the liquid for the purpose of estimating inventories, but are graphed as solids on the level histories. The actual substance, which was derived from double-shell slurry, appears as a solid if undisturbed, but the particles are resuspended in solution if heated or disturbed.

4.5.2.2 In-Tank Photograph of Tank 241-AW-105

No in-tank photographs are available.

4.5.3 Synopsis of Tank 241-AW-105

(To be completed.) 


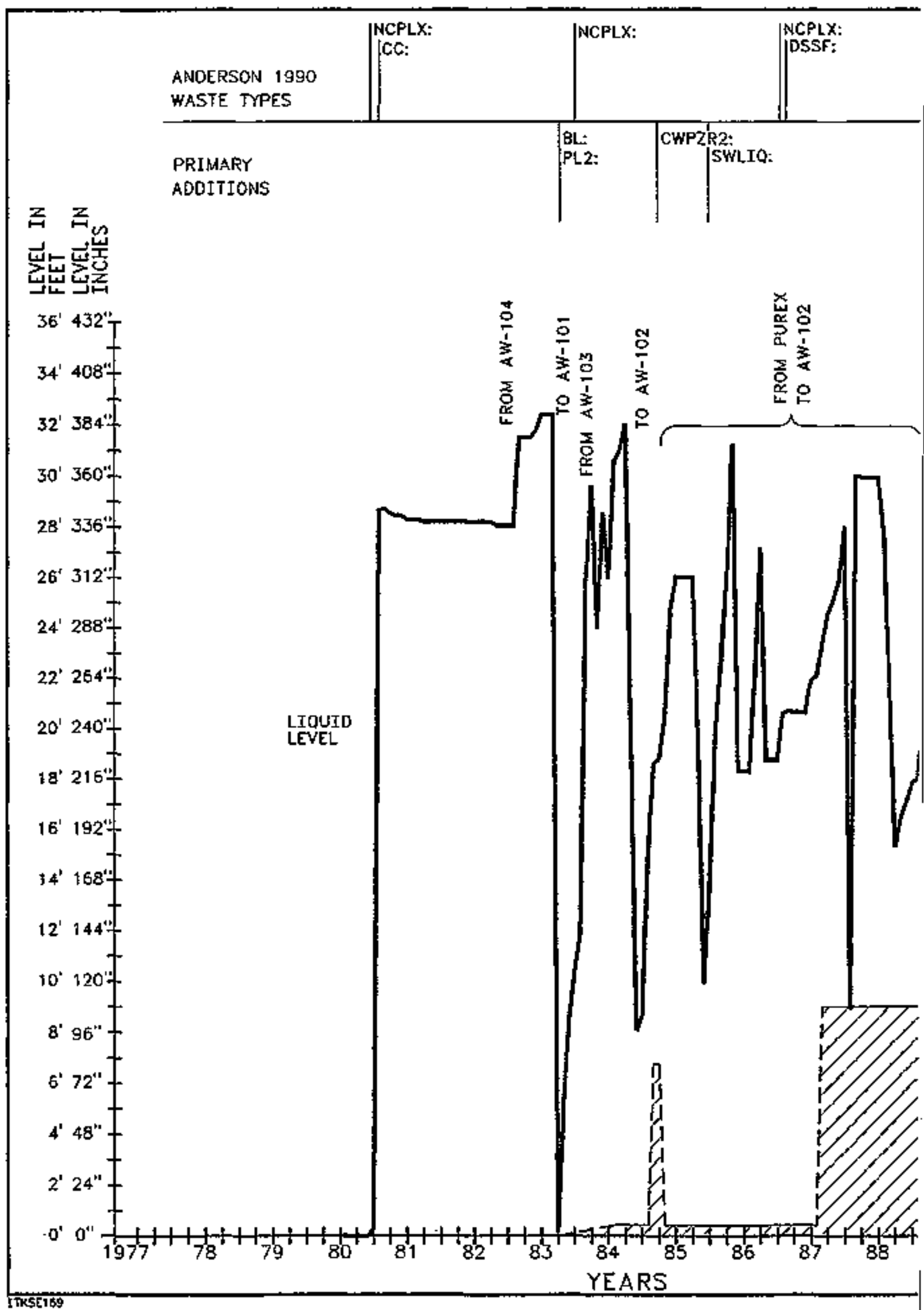


WHC-SD-WH-ER-350, ReV. 0

\begin{tabular}{|c|c|c|c|}
\hline \multicolumn{4}{|c|}{ Double-Shell Tank 241-AW-105 } \\
\hline \multicolumn{4}{|c|}{ Toal Inventory Estimace" } \\
\hline 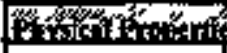 & 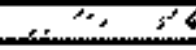 & " & \\
\hline Tolal Weste & \multicolumn{3}{|c|}{$4.65 \mathrm{~g}+06 \mathrm{~kg}$ (1.04E+03 kpgin) } \\
\hline Henllond & \multicolumn{3}{|c|}{$1.96 \mathrm{~kW}(6,6 \mathrm{E}+0.3 \mathrm{BOU} / \mathrm{hr}$} \\
\hline Bulk Densikt & \multicolumn{3}{|c|}{ L.18 (Bjoce) } \\
\hline Worer wat & \multicolumn{3}{|c|}{74.0} \\
\hline TOC wis $\mathrm{C}$ & \multicolumn{3}{|c|}{0.273} \\
\hline \multicolumn{4}{|c|}{ 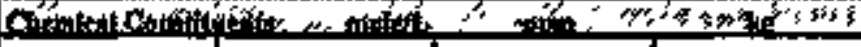 } \\
\hline $\mathbf{N a}^{*}$ & $\mathbf{3 . 7 8}$ & $7.398+04$ & $3.44 \mathrm{E}+0 \mathrm{~s}$ \\
\hline$A^{3 *}$ & 0.289.! & $6.42 \mathrm{~B}+109$ & 2.988+04 \\
\hline 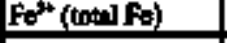 & $\mathbf{0 , 1 2 2}$ & $5.166 \mathrm{E}+4 \mathrm{n}]$ & $2.72 \mathrm{~B}+04$ \\
\hline 少 & 9.115:09) & 晹 & $1.7+4.03$ \\
\hline B̈" & 1.B9E-04 & 33.6 & 156] \\
\hline A & $121 \mathrm{~B}=06$ & 0,160 & 06603 \\
\hline Hest. & 3.98B-0ㅇ & 67.8 & 315 \\
\hline 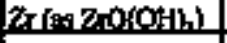 & a.192 & $1498+04$ & 6.935stid \\
\hline$p^{*}$ & $3.07 \mathrm{E}-0 \mathrm{9}$ & 5.40 & 每 \\
\hline $\mathrm{Ni}^{2+2}$ & $4.573,-193$ & 226 & $1.05 E+103$ \\
\hline $\mathrm{Sr}^{*}$ & 128E-06 & 9.50E-02 & 0.442 \\
\hline $\mathrm{uin}^{*}$ & $3,84 \geq 03$ & - & 833 \\
\hline $\mathrm{Cx}^{-3}$ & $3.6 \pi \mathbb{2}-0.2$ & [.25E+05 & $5.81 \mathrm{E}+0 \mathrm{G}$ \\
\hline$K^{*}$ & f.153 & $4,36 \mathrm{E}+n^{2} 5^{3}$ & $2003 \mathrm{~s}+\mathrm{x} \times \mathrm{y}$ \\
\hline $\mathrm{OH}^{*}$ & 2.44 & $3.898+04$ & $1.6+\mathrm{B}+05$ \\
\hline No: & $1.24 \mid$ & 7.3725+041 & $3,058+0 x$ \\
\hline No: & 0.328 & $1.45 \mathrm{E}+04$ & $5.97 \mathrm{P}+0 \mathrm{0}$ \\
\hline $0 \alpha^{2}$ & 0.19 .1$. & |N9:E+10| & 4.507401 \\
\hline $\mathrm{PO}_{1}^{2}$ & S37E-02 & $4.17 \mathrm{E}+4 \mathrm{E3}$ & $2.01 E+04$ \\
\hline sos & 605F-09 & $5.56 \%+0.7$ & 2,251704 \\
\hline $\sin \left(a S_{1}^{2}\right)$ & [2, & 343 & 1.42E+03 \\
\hline$F$ & 1.19 & 2.89R:04| & A.8. \\
\hline$G$ & $4.49 \mathrm{~g}-02$ & $1.528+03$ & $6.28+(0)$ \\
\hline$C_{0} H_{0} \alpha^{2}$ & $7.968 \times 09$ & $144=\div 09$ & $5.958+09$ \\
\hline BDTA+ & $2,67 E-0,03$ & 736. & $3.04 E+03$ \\
\hline HEDTA- & $439 \mathrm{E}-43$ & 1.15B+09 & $4,7 \in \mathbb{E}+03$ \\
\hline 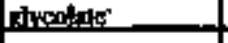 & 5.10102002 & 3.959tan & $1,638+0$. \\
\hline entestes & $3.040-13$ & In & 705 \\
\hline mancisti: & $4.369=06$ & 0.364 & $\begin{array}{l}1.59 \\
\end{array}$ \\
\hline DBP & 4.09E- 03 & 630 & $2.60 \mathrm{~B}+03$ \\
\hline butnot. & $4.058=03$ & 287 & L.19E +03 \\
\hline $\mathrm{NH}$ & 0.44 & $7.16 \mathrm{E}+105$ & $2.99 \mathrm{E}+0 \mathrm{~A}$ \\
\hline $\mathrm{Fe}(\mathrm{CN}))^{*}$ & ․ㅐ & 0 & \\
\hline 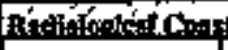 & kets & 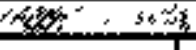 & 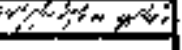 \\
\hline Pat & & $0.185(0, C i k)$ & $1430 \mathrm{kgt}$ \\
\hline t) & 3ADE-03 CLS & 687 (ustor) & $320 \mathrm{E}+\mathrm{CO} 0 \mathrm{ax}$ \\
\hline $\mathrm{Cs}_{\mathrm{s}}$ & $6.17 \mathrm{ESO}_{2}\left(\mathrm{C}_{2} \mathrm{~h}\right)$ & $524(1, c+2)$ & 2.44E:05 (C) \\
\hline$\underline{\mathbf{s}}$ & 3.05E-02 (CIL)! & $26.0\left(1, C_{10}\right)$ & $12(8+05(C):$ \\
\hline
\end{tabular}

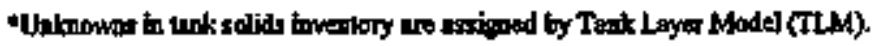

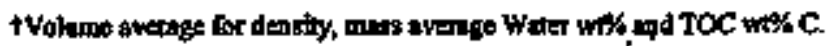

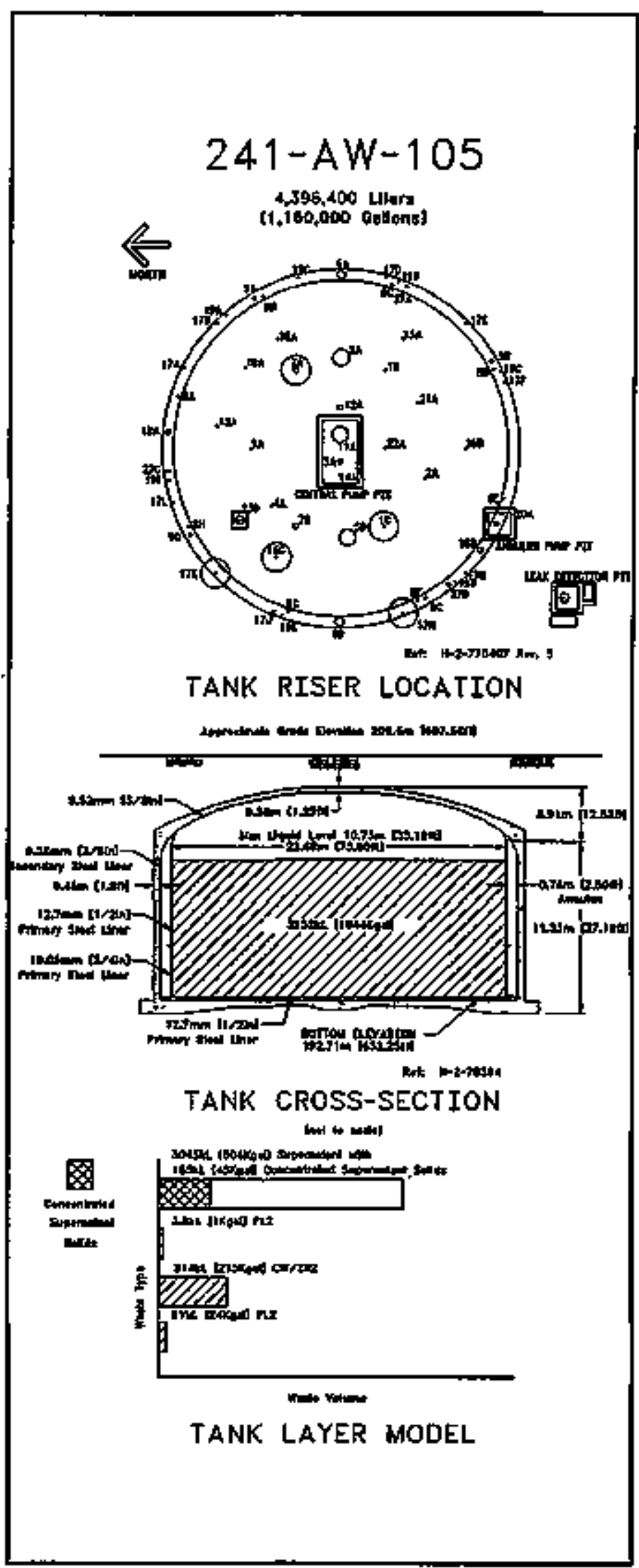




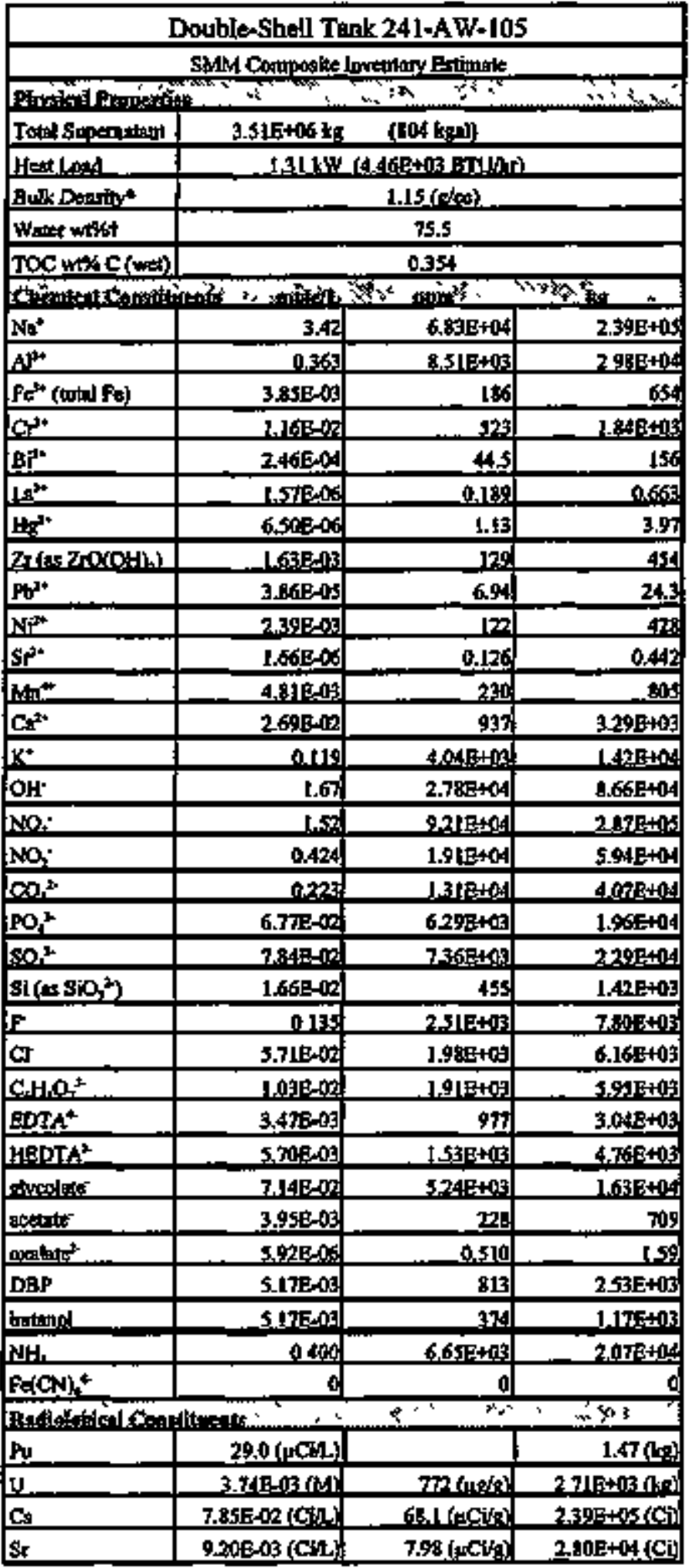

"Decosity is calculated bespod on No, Ott, and AlOz-

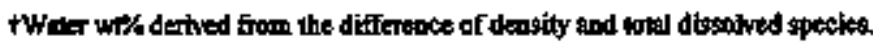

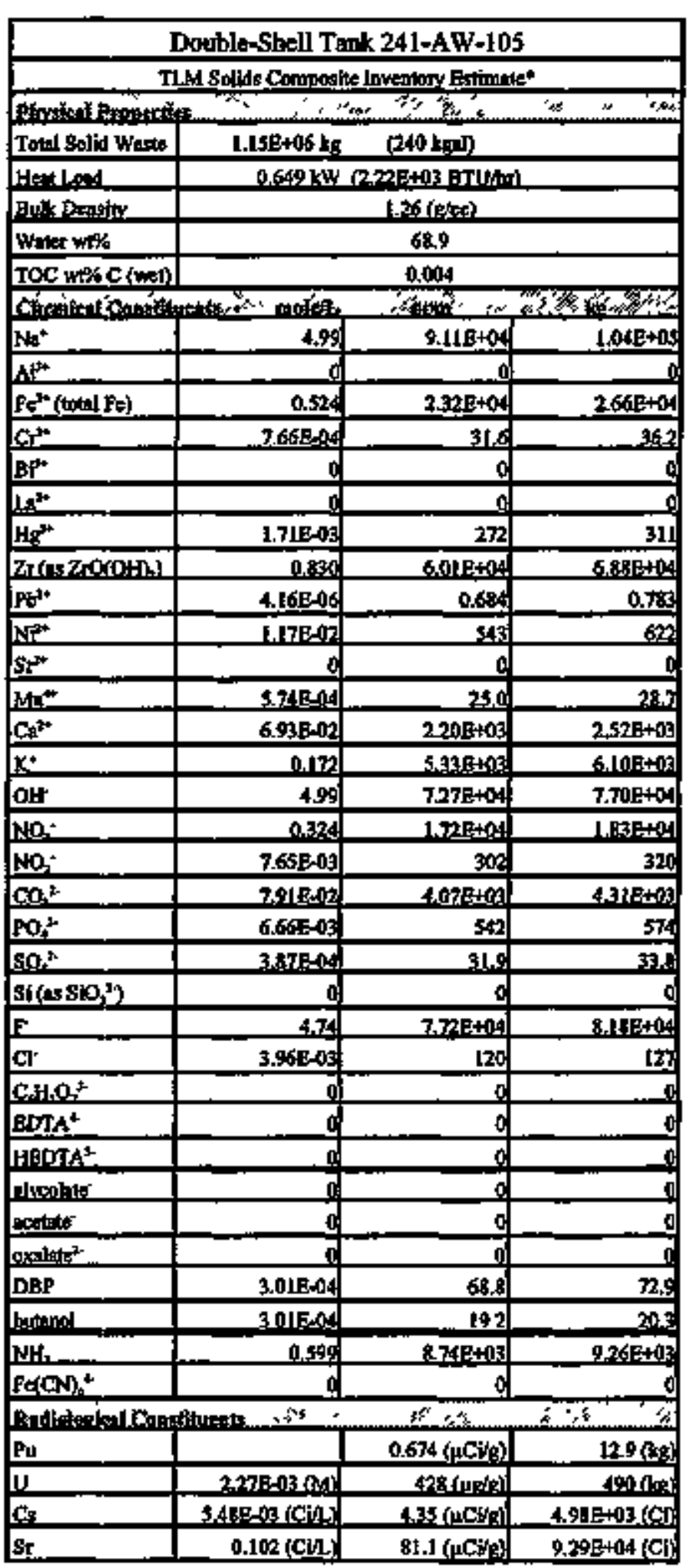

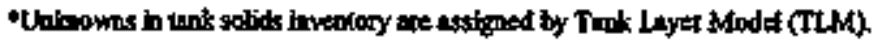


WHC-SD-WM-ER-350, Rev, 0

4.6 Tank 241-AW-106

4.6.1 241-ain-106 Tank History

4.6.1.1 Waste History of Tank 241-AW-106

Tank 241-AW-106 hegan service by receiving complexant concentrate waste in July 1980. The tark received complexed waste during August and September 1980. From October 1980 to February 1983, the tank received concentrated customer waste. The tank received double-shell sluxry feed waste from March 1983 until Hay 1990. During July 1986, the tank received non-complexed waste. Since June 1990, the tank has contained dilute noncomplexed waste. Currently, the tank is an active slurry receiver tank for the 242-A Evaporetor.

\subsubsection{Temperature History of Tank 241-AW-106}

Temperature data for Tank 241-AW-106 are recorded by 18 thermocouples at known elevations on one thermocouple tree inside the tank, located in riser 4A. Non-suspect temperature data taken between July 1983 and June 1991 for all 18 thermocouples were available from the computer automated surveillance system. However, not all of the 18 thermocougles have data that encompass the entire length of time. Non-suspect temperature data for 12 thermocouples recorded between July 1989 and September 1993 were available from the surveillance analysis computer system. Not all of the 12 thermocouples have data that encompass the entire length of time. Within the time spans for both systems, there were several small breaks in the sequence of temperature data. The everage temperature during these pexiods was $89^{\circ} \mathrm{F}$ with a minimum of $66^{\circ} \mathrm{F}$, a maximm of $123^{\circ} \mathrm{F}$, and a standard deviation of $13^{\circ} \mathrm{F}$. Linear Iegressions were performed on each thezmocouple that had temperature data between January 1990 and January 1994 . The slopes from these regressions were averaged with a resulting average slope of -0.0037 . Refer to the supporting document for a more thorough. review of the temperature data (Brevick, 1995).

\subsubsection{Occurrences of Tank 241-AW-106}

Four unusial events occurred at Tank 241-AW-106. Occurrence report RL--WHC-Tank Farm-1993-0020 and off-Nomal Report 84-42 were written because waste was transferred unexpectedly. Off-Normal Reports 86-20 and 85-19 involved the tank becoming pressurized during a transfer of waste.

\subsubsection{Dsychrometrics of Tank 241-AW-106}

Psychrometric data have been recorded for 13 yedrs from this tank and annulus. The apparent trend of the evaporation rate from the tank has increased from 127.1 gallons per week in September 1980 to 264.8 gallons per week in January 1995. over that same period, the trend in the rates of heat exchange through the primary tank and annular ventilation has apparently increased. A review of the psychrometric data would suggest an overall increase in the rate of heat generation by the waste. 
HHC-SD-WM-ER-350, Rev, 0

4.6.2 Current status of Tank 241-AW-106

Tank 241-AW-106 entered service in August 1980 and currently stores 660,000 gallons of waste. The following plan view and tank cross-section depict the abproximete waste volume of $1,082,000$ gallons and configuration of risers as of January 1994. At the time of the estimate, there were $1,081,000$ gallons of supernatant with 295,000 gallons of concentrated supernatant solids and 1,000 gallons of low-level waste from $B$ Plant. The waste level in the tank is measured with the FIC gauge and the manual tape and has increased from about 190 inches in January 1991 to 240 inches in January 1994. The increase was mostly waste received from Tank 241-AW-102 in August 1992 and with some waste from the 242-A Evaporator between August 1992 and January 1994. This tank is an active receiver for the 242-A Evaporator. The tank is actively ventilated and cytegorized as sound. Tank 241-A -106 has 59 risers. Two 4-inch risers (no.13A and no.19c) and two 42-inch risers (no.5A and no.5B) are available Eor use.

\subsubsection{Inventory Estimate of Tank 241-AW-106}

The tank layer model (a volume based approximation) that follows was derived from the Los Alamos National Laboratory Naste Status and Transaction Record Summary (Agnew, 1995) and Supernatant Mixing Model (Agnew, 1995). The estimated inventories of total waste, solids, and supernatant in Tank 241-Aw-106 are also presented. Concentrated superratant solids are considered as an integral part of the liquid for the purpose of estimnting inventories, but are graphed as solids on the level histories. The actual substance, which was dertved from double-shell slurry, appears as $\mathrm{z}$ solid if undisturbed, but the particles are resuspended in solution $1 f$ heated or disturbsd.

\subsubsection{In-Tank Photograph of Tank 241-AW-106}

As of April 1994, Tank 241-AW-106 contained 988,000 gallons of dilute non-complexed waste from PUREX (Hanlon, 1994). The collage for this tank was produced from 1983 photographs. Tank contents were lower then than now and probably different, so the collage will not be representative of current tank contents. The 1983 picture shows some green and white materials crystallizing on the surface of a dark 1fquid. The tank walls are rusted, but not badly. The location of equipment in the tank should be unchanged from 1983. Equipment which are identified include a supermatant pump, an FIC level probe, a temperature probe, and a high-level sensor. The height of the waste in the tank currently is about 30 fect.

4.6.3 Symopsis of Tank 241-AW-106

(To be completed.) 


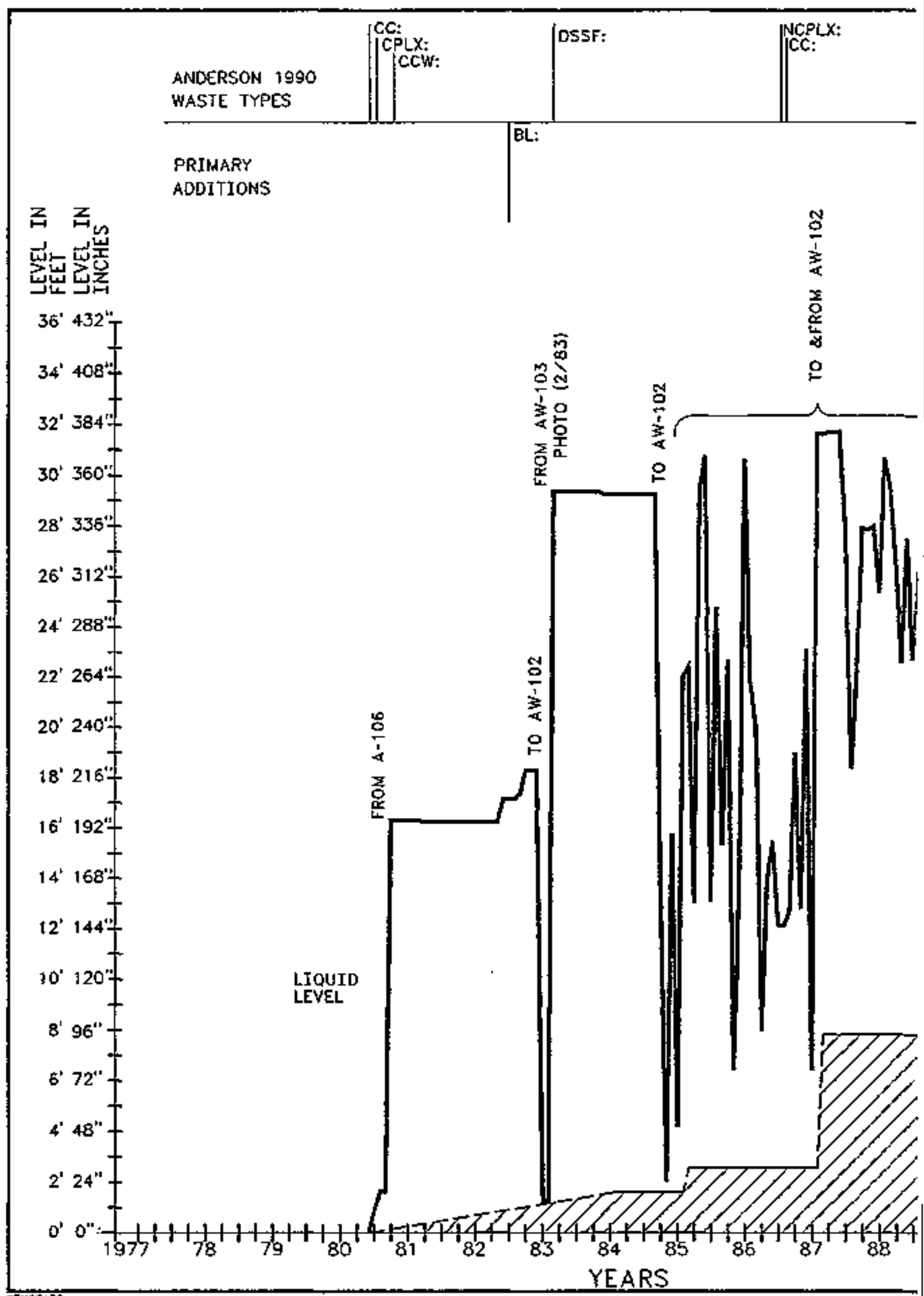




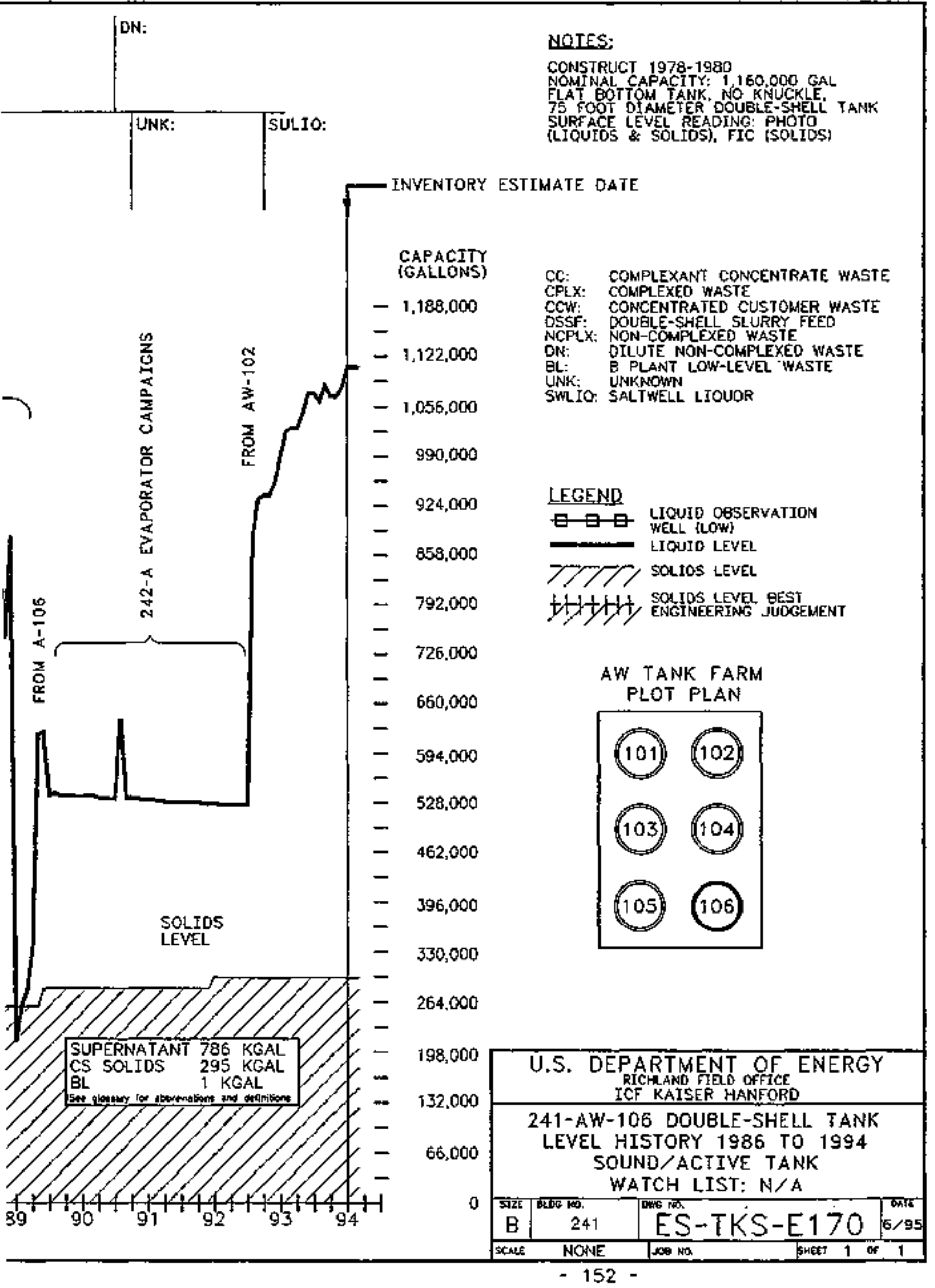


WHC-SD-FM-ER-350, Rev. 0

\begin{tabular}{|c|c|c|c|}
\hline \multicolumn{4}{|c|}{ Double-Shell Tank 241-AW-106 } \\
\hline \multicolumn{4}{|c|}{ Toul beventory Bestimate" } \\
\hline \multicolumn{4}{|c|}{ 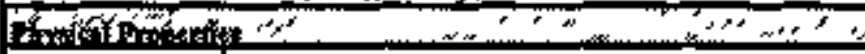 } \\
\hline Total Viaste & \multicolumn{3}{|c|}{$4.93 \mathrm{~B}+05 \mathrm{~kg},(1.0 \mathrm{sE}+03 \mathrm{~kg})$} \\
\hline Hathos. & \multicolumn{3}{|c|}{ 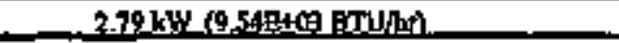 } \\
\hline Bdt:Dengitive & \multicolumn{3}{|c|}{ 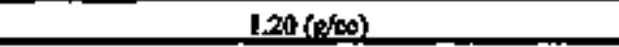 } \\
\hline Water wrot & \multicolumn{3}{|c|}{69.0} \\
\hline Toc w\% C & \multicolumn{3}{|c|}{0.488} \\
\hline \multicolumn{4}{|c|}{ 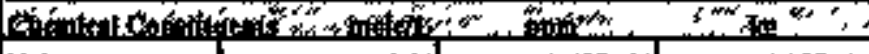 } \\
\hline $\mathrm{No}^{*}$ & 4.54 & $8.678+0.4$ & $4.278+05$ \\
\hline$A^{2+2}$ & n496 & 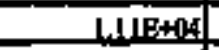 & $5,47 E_{+20}$ \\
\hline$F=0$ & 7.37E-033 & 342 & $1.69 \mathrm{E}+0 \mathrm{~s}$ \\
\hline G. & latgE=10? & 6! & $3.16 \mathrm{E}+12$ \\
\hline Bi* & 2,72E-OA & 472 & 233 \\
\hline s" & Done-06 & 0,207 & 1.0 \\
\hline 보 $\mathrm{p}^{72}$ & $6.37 \mathrm{E}-0.0$ & 1.06 & $52:$ \\
\hline $2,(15,2000)$ & L.FGESOR: & 118 & \\
\hline$P^{3+2}$ & S.33E-QS & 9.1日: & 45.5 \\
\hline $\mathrm{Ni}^{2+2}$ & M, 27EAOA & 181 & \\
\hline $\mathrm{sen}^{*+}$ & 1.90E-06 & $0,13 \mathrm{E}$ & 0,68 \\
\hline $\mathrm{Hin}^{*}$ & 6.89293 & 313 & $1,448+n f$ \\
\hline $\mathbf{C n}^{\mathrm{7*}}$ & $3,942,02$ & 1318+09 & $6.46 E+03$ \\
\hline$K^{*}$ & 0.115 & $3.738 \times 403$ & $1,84 \mathrm{E}+04$ \\
\hline or & 227] & $3,36+04$ & $1.5 \mathrm{sE}+0.5$ \\
\hline No: & 20.9 & $10928+054$ & S.13E+05 \\
\hline No: & 0.48 ] & $2.928+04$ & $9.06 \mathrm{E}+04$ \\
\hline $\mathrm{CO}^{2}$ & 0,323 & L.68setat & $7928+04$ \\
\hline PO: & 9.4LE-0ed & 7.75E+03 & $3.66 \mathrm{E}+04$ \\
\hline $\mathrm{sot}^{*}$ & .0.10\% & 8.94: +103 & $428 \mathrm{R} 404$ \\
\hline 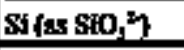 & 249E-102 & $6 \mathrm{~W}$ & $2,86 \mathrm{~B}+23$ \\
\hline$F$ & [1/30! & 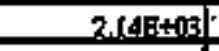 & L.01:E404 \\
\hline $\mathbf{c}$ & 7.48E-02 & $2.30 \mathrm{E}+0 \mathrm{3}$ & $1.09 \mathrm{E}+\mathrm{N}$ \\
\hline EAt: $2^{2}$ & $1,0 \mathrm{E}-0 \mathrm{P}$ & $2,29 \mathrm{E}+033$ & 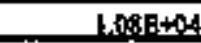 \\
\hline EOTA* & 3.85E- 0 at & gsd & 4.5E $\div 05$ \\
\hline Hetyot & $6.35:-03$ & $1.518+09$ & $7.128+107$ \\
\hline 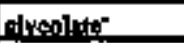 & 0.14 & $7 A 1 E+03 !$ & $3,49 \mathrm{~F}+\mathrm{Q1}$ \\
\hline nofisto & $4232-02$ & $\therefore \quad 217$ & $1.02 B+09$ \\
\hline pjatalatata & $6.78 \mathrm{~g}=06$ & assin & 2.4 \\
\hline DBP & 6,45E-0: & 901 & 4.26E 402 \\
\hline batsol & $645 \mathrm{~B}-0.03$ & $4 ! 5 !$ & $1,962=419$ \\
\hline $\mathrm{NH}$ & 0,799 & $5.48+0$ & $2.7 \mathbb{E A}+0$ \\
\hline $\mathrm{F}(\mathrm{CO})_{6}{ }^{*}$ & & 0 & \\
\hline X) & 4 & 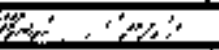 & Pon \\
\hline Pe & & $3.06 \mathrm{E}-12 \mathrm{f}(\mathrm{HCV})$ & $2.52(\mathrm{~kg})$ \\
\hline I & 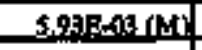 & 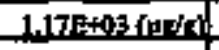 & $5.792+090 \mathrm{~kg}$ \\
\hline & 0.111 (CS2) & 92,3 (us & 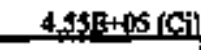 \\
\hline & $2,40 \mathrm{~B}-02(\mathrm{C} S \mathrm{~L}) \mathrm{l}$ & $12.9(\mathrm{p} C \mathrm{H} \mathrm{s})$ & $9.928+04(C)$ \\
\hline
\end{tabular}

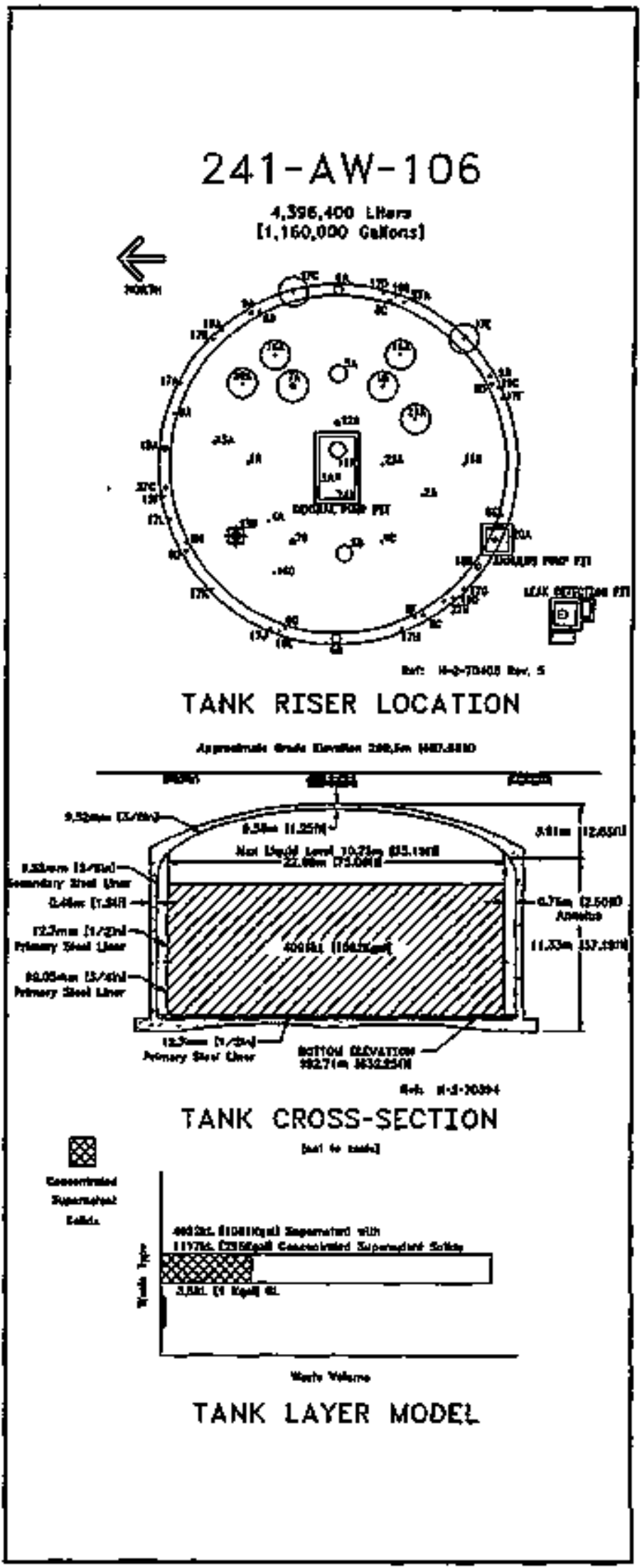




\begin{tabular}{|c|c|c|c|}
\hline \multicolumn{4}{|c|}{ Double-Shell Tank 241-AW-106 } \\
\hline \multicolumn{4}{|c|}{ SMM Canposite lmeptary Primote } \\
\hline \multicolumn{4}{|c|}{ 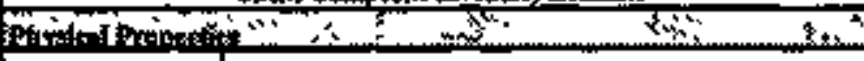 } \\
\hline Totul Superathint & \multicolumn{3}{|c|}{$4.927+06 \mathrm{~kg} \quad(\mathrm{~L} .0 \mathrm{gE}+03 \mathrm{~kg})$} \\
\hline HeaLood & \multicolumn{3}{|c|}{ 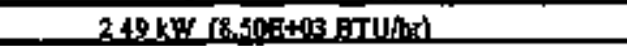 } \\
\hline Bullk Denstbe & \multicolumn{3}{|c|}{$120(n / c)$} \\
\hline Water wht & \multicolumn{3}{|c|}{68.1} \\
\hline $\operatorname{IOC}$ wes $C$ (rit) & \multicolumn{3}{|c|}{0489} \\
\hline \multicolumn{4}{|l|}{ (6) } \\
\hline & 4.54 & $8.673+04$ & $4.27 \mathrm{E}+0 \mathrm{~S}$ \\
\hline$A \mathbf{A}^{\mathrm{S}}$ & 0.494 & IلIF+n & $5,45 \mathrm{E}+04$ \\
\hline Ft" (tont Fo) & $5,600-03$ & 260 & $128 \mathrm{e}+63$ \\
\hline $\mathrm{Cs}^{*}$ & $148=-0 ?$ & 69!! & 3.16 的+43 \\
\hline Gire & 2,72004 & 47.3 & 233 \\
\hline $\mathrm{Len}^{3}$ & 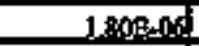 & 0.200. & 107 \\
\hline H. & 6.38g-0. & 1.06 & 323 \\
\hline 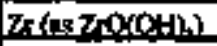 & $15680,0]$ & 10 & 584 \\
\hline $\mathrm{Pot}^{*+2}$ & $534 \mathrm{E}-0 \mathrm{~s}$ & 920 & 453 \\
\hline $\mathrm{N}^{+*}$ & $3,41 F[00$ & 160 & 818 \\
\hline$s^{*}$ & $1.900-0$ & 0,138 & 0.681 \\
\hline Mtete & 6.86터에 & 313 & $1.548+13$ \\
\hline $\mathrm{Cs}^{2+}$ & $3920-02$ & $\pm .318+03$ & $6.43 \mathrm{E}+03$ \\
\hline $\mathbf{K}$ & - & 3.798+03 & 1.t4fented \\
\hline OH & 225 & $3,33 \mathrm{~B}+04$ & L\$TEE+05 \\
\hline No: & 200 & 1.09E+105 & $5,13,8+05$ \\
\hline $\mathrm{No}$ & $0,4 \mathbf{1}$ & $1.92 \mathrm{E}+04$ & 9.06E+04 \\
\hline $\mathrm{CO}^{2}$ & 0.322 & 160.8+04 & $7.918+? 4$ \\
\hline PO: $=$ & 9.41E-0? & 7.T6E+105 & $3,66 \mathrm{E}+94$ \\
\hline $80^{2}$ & o.ten & $8.95 \mathrm{~B}+05$ & $4 x \in+9$ \\
\hline Si(ns $\left.\$ \alpha_{1}^{3}\right)$ & 245E-09. & 592 & 27.79E+03 \\
\hline $\mathrm{F}$ & 0,130 & $2.48 B+15$ & L.01E+4 \\
\hline$c$ & 7,A8B-0? & $230 \mathrm{E}+03$ & $1.0 \mathrm{BE}+0 \mathrm{~A}$ \\
\hline C.,H. $0^{2}$ & lADB:D? & $2798+19$ & 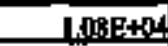 \\
\hline 토순 & $3.84 \mathrm{E}-0 \mathrm{a}$ & 959 & $4.52 \mathrm{E}+13$ \\
\hline Hedet & $635=0$ 13 & L5IP+0 & $7.12 \mathrm{~F}+0 \mathrm{~s}$ \\
\hline alucoslets: & 0.114 & $740 \mathrm{n}+10 \mathrm{~s}]$ & $3,49= \pm 04$ \\
\hline lestate & 424E-03 & 217 & $1.02 \mathrm{E}+0 \mathrm{3}$ \\
\hline $\log \mid y^{2}=$ & $6.78 \mathrm{~F}_{2} 0 \mathrm{GS}$ & 0.5189 & 24 \\
\hline DBP & $6.46 \mathrm{E}-03$ & 900 & $4.26 \mathrm{E}+103$ \\
\hline butingl & 6462003 & 416 & 1.968+08 \\
\hline NH. & 0.395 & $583 E+0,5$ & $2.75 \mathrm{E}+0$ \\
\hline $\mathrm{Fe}(\mathrm{CN})^{+}$ & 0 & (l) & \\
\hline 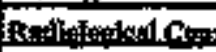 & (1) & & 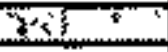 \\
\hline Pu & $35.6(\mu \mathrm{Cil})]$ & & 2.43 (k㫨) \\
\hline bs & $472 \mathrm{E} 0 \mathrm{~B}$ (W) & 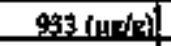 & 4.59R+03 (kR) \\
\hline$C_{5}$ & (4) & 9.4(uCits) & 45SE+4t5 (C) \\
\hline $\mathrm{gx}$ & $129 \mathrm{E}-02$ (C) & 10.7 ( & $5.29 \mathrm{E}+04(\mathrm{C})$ \\
\hline
\end{tabular}

"Dearity is calculated based on $\mathrm{No}$, OH: and $\mathrm{NO}_{2}$,

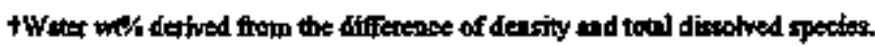

\begin{tabular}{|c|c|c|c|}
\hline \multicolumn{4}{|c|}{ Double-Shell Tank 241-AW-106 } \\
\hline \multicolumn{4}{|c|}{ 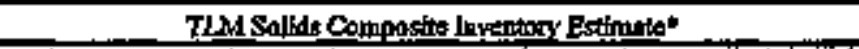 } \\
\hline \multicolumn{4}{|c|}{ 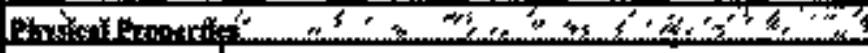 } \\
\hline Total Solid Worte & $7.408+03.5$ & (1 kesiln & \\
\hline Ho:m lo:ad & \multicolumn{3}{|c|}{ 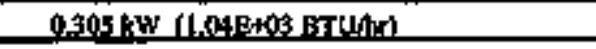 } \\
\hline 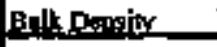 & \multicolumn{3}{|c|}{1.95 ( $(\mathrm{gkNC})$} \\
\hline Wuter w* & \multicolumn{3}{|c|}{$\mathbf{3 0 . 0}$} \\
\hline Toc wo Chet & \multicolumn{3}{|c|}{0.251} \\
\hline \multicolumn{4}{|c|}{ 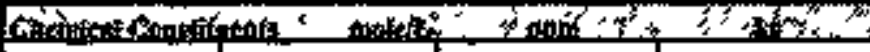 } \\
\hline $\mathrm{Nr}^{*}$ & 4.22 & 4.97E+OQ & 36 \\
\hline$A B^{+*}$ & 200 & $277 \mathrm{E}+04$ & 20 \\
\hline$F^{3+}($ watat $F \varphi)$ & 1.92 & $5,49 \mathrm{E}+0.4$ & 40.5 \\
\hline$C^{3+}$ & 1,6 至- 0 年 & 4.4.10 & 3.292005 \\
\hline \multicolumn{4}{|l|}{ ger } \\
\hline \multicolumn{4}{|l|}{$1 n^{3+}$} \\
\hline \multicolumn{4}{|l|}{$\mathrm{H}^{3 *}$} \\
\hline \multicolumn{4}{|l|}{ 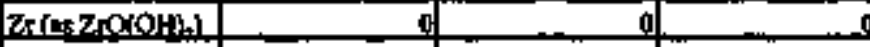 } \\
\hline \multicolumn{4}{|l|}{$\mathrm{Pb}^{2+}$} \\
\hline \multicolumn{4}{|c|}{$9 \times 10+03$} \\
\hline \multicolumn{4}{|l|}{ sti" } \\
\hline \multicolumn{4}{|l|}{$\mathrm{BP}^{\mathrm{T}}$} \\
\hline $\mathrm{Cot}^{2 *}$ & $0.18 \div$ & 3.tg $E+0 \mathrm{~g}$ & 285 \\
\hline \multicolumn{4}{|l|}{$\mathrm{K}^{*}$} \\
\hline 요 & 20.c다 & 2.52: $+0 \mathrm{~s}$ & $1.35 \mathrm{E}+0 \mathrm{~g}$ \\
\hline No: & let? & 6.998+0연 & 3ty \\
\hline $\mathrm{NO}:$ & $1.965-02$ & 714 & 3.4] \\
\hline Co.'- & 0.39: & 1908+od & no, ? \\
\hline $\mathrm{PO}^{2}$ & 8.35E-0 & 629 & 3.00 \\
\hline 80. & 9.108002 & 7.0.06401 & 354 \\
\hline$S 1\left(\operatorname{sis} 0^{2}\right)$ & 0.675 & $1.50=04$ & TI.t \\
\hline \multicolumn{4}{|l|}{$F$} \\
\hline cr. & $5.37 E-02$ & 1.51R+0 & 721 \\
\hline C.H. & $1,24 \mathrm{~B}-0 \mathrm{y}$ & $1889+19$ & B.92 \\
\hline \multicolumn{4}{|l|}{ EDTA* } \\
\hline \multicolumn{4}{|l|}{ HFDTA } \\
\hline \multicolumn{4}{|l|}{ 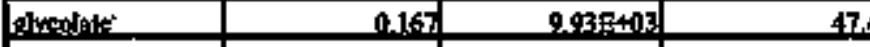 } \\
\hline \multicolumn{4}{|l|}{ Icentate" } \\
\hline \multicolumn{4}{|l|}{ lokntand } \\
\hline \multicolumn{4}{|l|}{ DEP } \\
\hline Hollig ol & & 0] & \\
\hline NH: & 3.708s01. & $4.998 .0 \%$ & 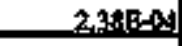 \\
\hline FeXNR* & & 0 & \\
\hline 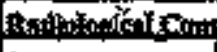 & & 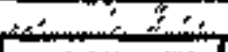 & 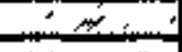 \\
\hline $\mathrm{Pn}$ & & $0.740(\mu C \mathrm{C} / \mathrm{g})$ & 9.13E-02 (k, \\
\hline u. & 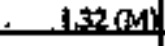 & $1697+05(4)=2)$ & I. \\
\hline $\mathrm{C}_{6}$ & & . & \\
\hline St & 12.0 (CAL). & 6.13E+03 (u, & $4512+04(\mathrm{Cl})$ \\
\hline
\end{tabular}

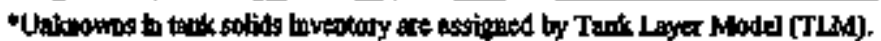




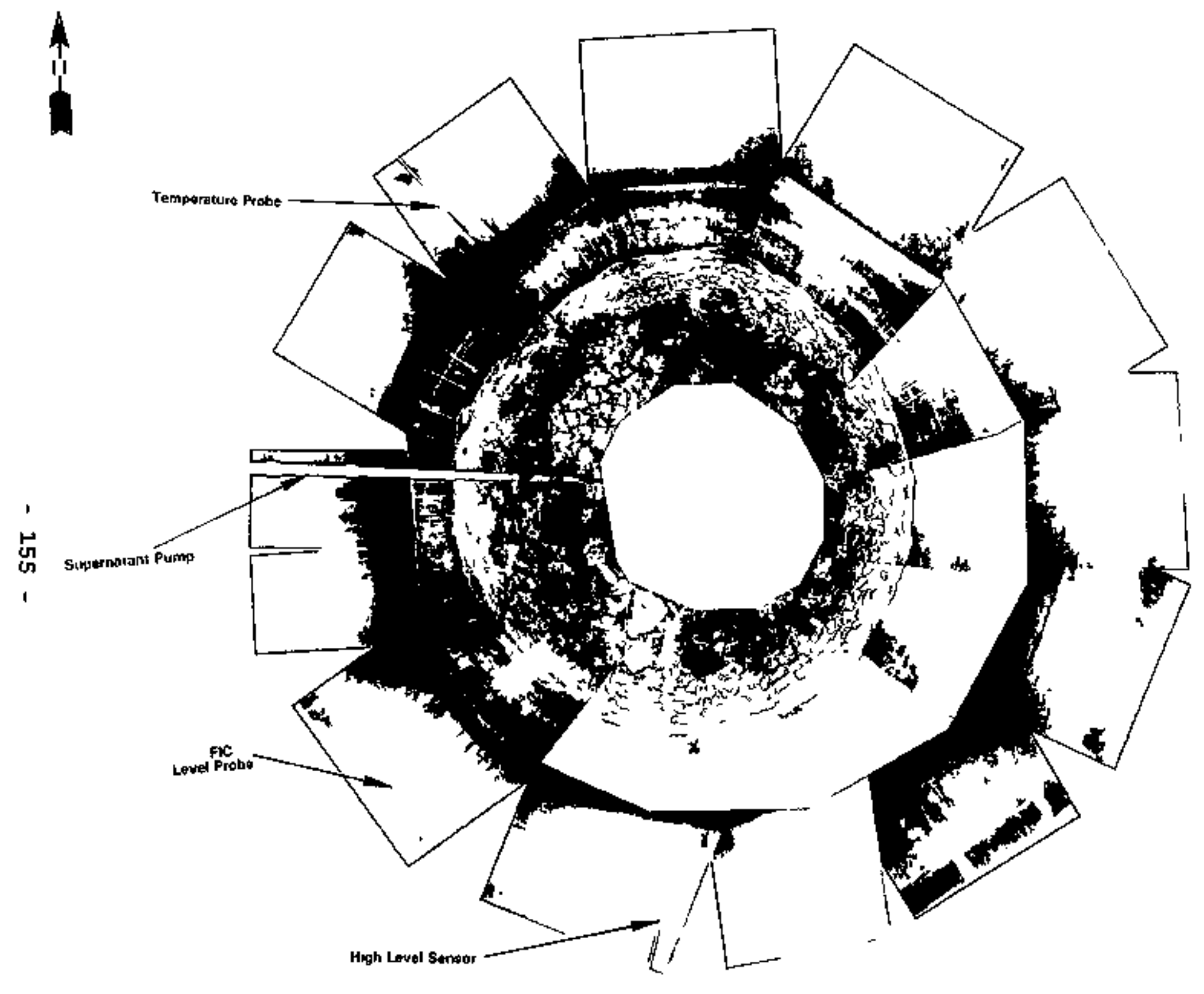


$5 \quad$ AY Tante Faxm

\subsubsection{AY Tank Farm History}

The AY Tank Farm is located east of Buffalo Avenue and west of canton Avenue in the 200-East Area. The AY Tank Farm contains two, 100 series, 1,000,000 gallon, 75-foot diameter double-shell tanks. The AY Tank Facm is the latest tank design with a reinforced concrete shell and dome and an insulating concrete base. A heat-treated, stress-relieved, primary steel liner and a ron-stress-relieved, outer steel liner are inside the concrete shell. These tanks were made to hold aging waste from PUREx and B Plant. The ventilation system is shared between the AY and AZ Tank Farms because they are both aging wate tanis fazms. Haximum desigr tenperatures in the tanks are: $350^{\circ} \mathrm{F}$ for sludge, $220^{\circ} \mathrm{F}$ for vapor, and $260^{\circ} \mathrm{F}$ for licqud. The tanks are at the same elevation and no cascade lines exist between tanks.

A color aerial photograph taken in 1993 of the AY Tank Farm shows the orientation of the 100 series tarks, leak detection pits, annulus ventilation equipment, and instrument house. The AY change trailer is used Eor entry into the $\mathrm{AX}, \mathrm{A}_{\mathrm{r}}$ and $\mathrm{Az}$ Tank Farms. 
WHC-SD-FM-ER350, Rev. 0 .

\section{AY TANK FARM}

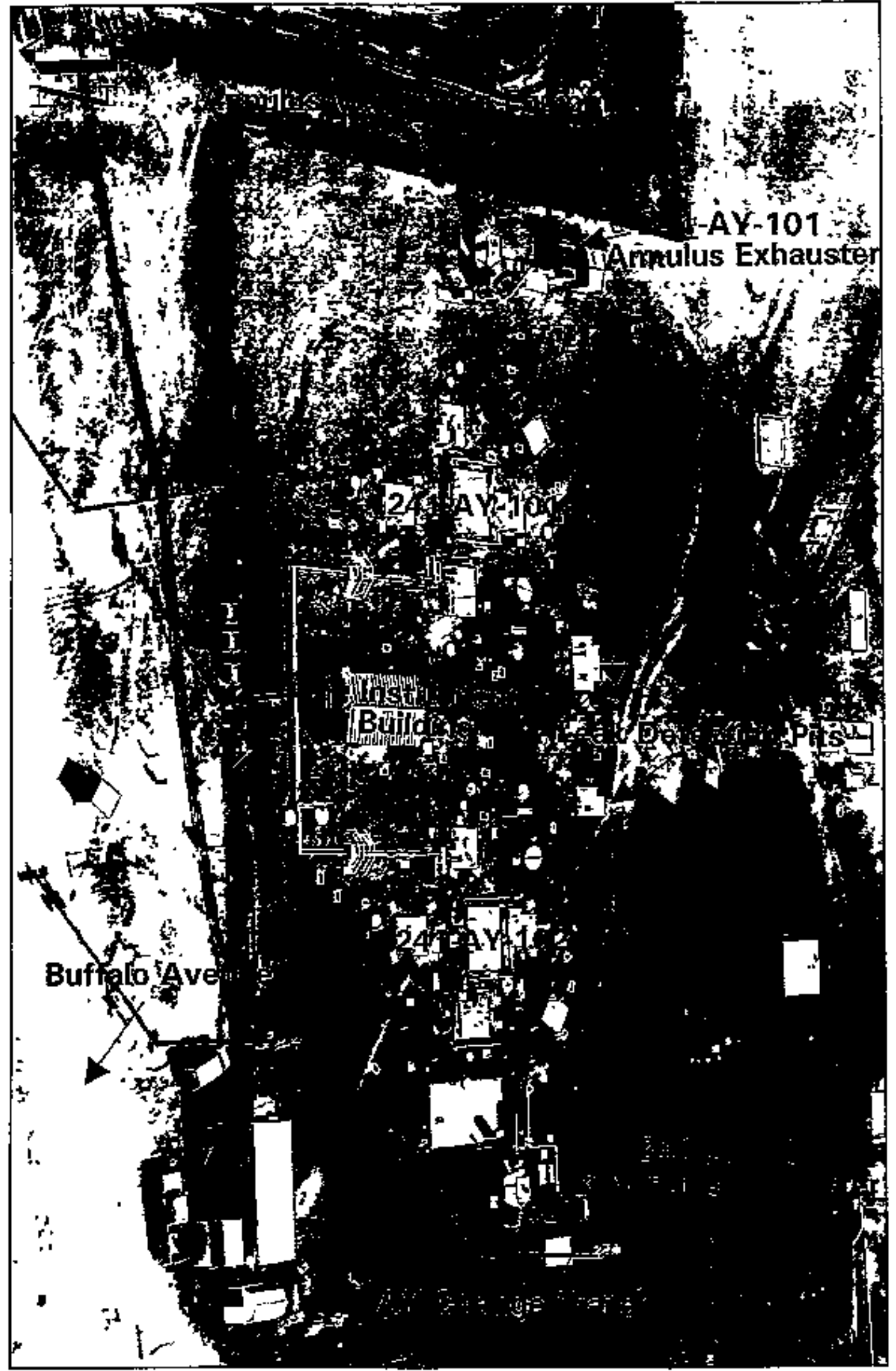




\subsubsection{AY Tank Farm waste History}

The AY Tank Farm is classified as an aging waste tank farm. It recefved aging tank waste in 1976 through 1978 . Tank 241-AY-101 also contains high-level B Plant waste, B Plant cesium feed waste, nonconplexed, concentrated complexed and cosium and strontium recovery waste. Presently, the tank receives only condensate from other aging waste tanks. rank 241-AZ-102 begen receiving evaporator waste before receiving aging waste followed by double-shell tank slurry, low-level waste from B Blant, and non-complexed waste. Tank 241-AZ-102 now receives only condensate from other aging waste tanks.

\subsubsection{AY Tank Farm Termerature History}

The AY Tank Farm has thermocouples on the air circulators and at various depths in the tank. Both tanks are required to have temperature readings recoxded semitnnually and both are connected to the computer automated surveillance system. The computer automated surveillance systern holds all the temperature data used to develop the statistical results for each tank.

\subsubsection{AY Tank Farm Occurrences}

Sixteen unusual events concerned AY Tank Fazm as a whole. Occurrence reports FL--WHC-Tank Farm-1993-0088 and RL--hHC-Tank Farm-1993-0031 were witten due to equipment failures. Occurrence reports RL-MtC-Tank Farm-1993-0083 and RI--WHC-Tank Farm-1992-0033 concern eqaipraent that was out of compliance with procedures. Occurrence reports RL--intic-Tank Farm-1993-0011, RL--WHC-Tank Farm-1991-1064, RL--WHC-Tank Farm-1991-1004, and RL-WHC-Tank Farm-1991-0043; Off-Normal Reports 86-53, 86-22, 86-13, 86-10, and 85-39; and Unusual Dccurrence Report 84-81 concern Eailing ecuipment causing tanks to pressurize. Occurrence report RT-WHC-Tank Farm-1991-1074 and Unusual occuryence Report 80-51 were written due to unexpected waste transters. For more information, refer to the supporting Document for the Southeast Quadrant HICE for AY Tank Farm (Brevick, 1995 ).

\subsubsection{AY Tank Farm Ventilation}

Each tank is desigried to have 2,000 CFu of air travel through the annulus. Air enters the tanks by infiltration because there is no supply fan. The tank air ducts are joined after leaving the tank and the exhaust air is sent to the 702-A primary ventilation system. In the annulus system, air enters radiant heaters, a prefilter, a HEPA filter, and a heater before it enters the annulus. Then the air enters an electric heater and two mors HEPA filters before it is exhausted to the atmosphere. The tank has a backup system. For more information, refer to drawings $\mathrm{H}-2-64461, \mathrm{H}-2-64462, \mathrm{H}-2-92066$, and $\mathrm{H}-2-35749$.

The psychrometric data are recorded in two parts, the tank data and the arnulus data. For water and heat leaving the tank, the numbers are positive. For more infozmation, refer to the Supporting Document for the Southeast Quadrant HTCE for AY Tank Farm (Brevick, 1995). 


$$
\text { WHC-SD-HM-ER-350, Rev. O }
$$

\subsubsection{Current Status of AY Tank Farm}

Tanks 241-AY-101 and -102 are both inactive. All tanks are actively ventilated and categorized sound. Currently, the total waste volume is 1,668,000 gallons. The estimated volumes (Agnew, January 1994) depieted in each tark cross section total 1,835,000 gallons of waste. At the time of the estimate, there were 1,770,000 gallons of supernatant witb 18,000 gallons of concentrated supernatant solids; 33,000 gallons of B Plant lowlevel waste (BI); 4,000 gallons of PUREX low-level waste; 8,000 gallons of waste sent to B Plant for strontium recovery (SRR); 7,000 gallons of waste sent to B Plant for cesium recovery (CSR); and 13,000 gallons of B Plant high-level waste (B).

\subsection{Tank 241-AY-101}

5.1.1 241-AY-101 Tank History

5.1.1.1 Waste History of Tank 241-AY-101

Tank 241-AY-101 began service by receiving B Plant high-level waste in the second quarter of 1971. The tank received high-level waste from B Plant until the second gracter of 1976. Aging waste was sent to the tank from the third quarter of 1976 until the fourth quarter of 1977. During the first quarter of 1978, the tank received active B plant cesium feed waste. The tank received non-complexed waste from the second quarter of 1978 until the fourth guarter of 1979. From January 1980 until October 1981, the tank received complexant concentrate waste. The tank received complexed waste from November 1981 until May 1990. Cesium and strontium recovery waste were sent to the tank from the first cuarter of 1983 until the third guarter of 1986. The tark has contained dilute complexed weste from June 1990 until the present. The tank is considered an aging waste tank, an inactive, dilute receiver tank that receives only condensate from other aging waste tanks.

\subsubsection{Temperature History of Tank 241 AY-101}

Termperature deta for Tank 241-AY-101 are recorded by fifteen thermocouples aftixed at known elevations to seven thermocouple trees inside the tank. The thermocouple trees are located in risers 13A, B, C. $D$ and $16 \mathrm{~A}, \mathrm{~B}, \mathrm{C}$. There are between one and three thermocouples on each tree. Non-suspect tenperature data recorded between July 1983 and Febriary 1990 for all fifteen thermocouples were availabie from the computer automated surveillance system. However, not all of the fifteen thermocouples have data that encompass the entire length of time. Within the time span of the computer automated surveillance system, there were several small breaks in the sequence of the temperature data. The average temperature during this period was $94^{\circ} \mathrm{F}$ with a minimum of $50^{\circ} \mathrm{F}$, a maximum of $247^{\circ} \mathrm{F}$, and a standard deviation of $21^{\circ} \mathrm{F}$. Linear regressions were performed on each thermocouple over the lite of the tank. The slopes from these regressions were averaged with a resulting average slope of 0.0011 . Refer to the supporting document for a more thorough review of the temperature data (Brevick, 1995). 


$$
\text { WHC-SD-WM-ER-350, Rev. } 0
$$

\section{1 .1 .3 Occurrences of Tank 241-AY-101}

Five unusual events occurred at Tank 241-AY-101. Occurrence report RL-- WHC-Tank Farm-1993-0008 concerns failing equipment during a waste transfer. Occurrence report RL--WHC-Tank Farm-1991-0074 was written due to equimment failure. Off-Normal Reports 84-01 and 83-10 were written due to unexpected waste transfers. Unusual occurrence Report 76-132 was written because radiation was detected in the onnulus ventilation system.

\subsubsection{Psychrometries of Tank 241-AY-101}

Psychrometric data have been recorded for 10 years from the tank annulus. Psychrometric data were not recorded for the tank. The rates of heat exchange through the annular ventilation show a decreasing trend from October 1980 to October 1991. The data would suggest a decrease in the rate of heat generation in Tank 241-AY-101, but no corroborating data from the tank ventilation exists.

\subsubsection{Current status of Tank 241-AY-101}

Tank 241-AY-101 entered service in April 1971 and currently stores 864,000 gallons of waste. The following plan view and tank cross section depict the zpproximate waste volume of 891,000 gallons and configuration of risers as of January 1994. At the time of the estimate, there were 858,000 gallons of supernatant with 18,000 gallons of concentrated supernatant solids; 8,000 gallons of waste sent to B Flant for strontium recovery (SRR); 7,000 gallons of waste sent to B Plant for cesium recovery (CSR); 5,000 gallons of B Plant low-level waste (BL); and 13,000 gallons of B Plant high-level waste (B). The waste level in the tank is measured with the manual tape and has increased and decreased around 325 inches from January 1991 until January 1994. The increase was mostly from the addition of complexed saltwell liguid waste from the 200-East Area between December 1991 and February 1992. The cause of the decreases in tank level is unknown. This tank is inactive and only receives condensate from aging waste tanks. The tank is actively ventilated and categorized as sound. Tank 241-AY-101 has 117 risers. One 4-inch riser (no.5B), eight 6-inch risers (no.15A, no.15G, no.15I, no.15K, no.15M, no.150, no.15Q, and no.15S), and one 42-inch riser (no.24A) are available for use.

\subsubsection{Inventory Estimate of Tank 241-AY-101}

The tank layer model (a volume based approximation) that follows was dexived from the Los Alamos National Laboratory Maste Status and Transaction Record Summary (Agnew, 1995) and Supernatant Mixing Model (Agnew, 1995). The estlmated inventories of total waste, solids, and supernatant in Tank 241-AY-101 are also presented. Concentrated supermatant solids are considered as an integral part of the liguid for the purpose of estimating inventories, but are graphed as solids on the level histoxies. The actual substance, which was derived from double-shell. sluxxy, appears as a solid if undisturbed, but the particles are Iesuspended in solution if heated or disturbed. 
5.1.2.2 In-Tank Photograph of Tank 241-AY-101

In April 1994, Tank 241-AY-101 contained 879,000 gallons of dilute complexed waste from PUREX (Hanlon, 1994) with a waste depth of about 27 feet. The most recent collage for this tank is 12 years old and was assembled from photographs taken in December 1982. At that time, the tank contained 180,000 gallons of complexed waste. The waste is the same type now as it was in 1982, so the waste may appear now as it does in this picture. The picture is hazy, but the waste is deep in the tank and appears to be a dark liquid. These photographs provide an accurate picture of the equipment in the tank. This is one of the four double-shell tanks containing aging waste and, therefore, it has more instruments compared to other waste storage tanks. Monitoring instruments which can be seen in this picture and have been identified include six tenperature probes, four level probes, and five drywells. In addition, the tank contains air lift circulators, heating coils, drains, risers, and nozzles.

5.1 .3 Synopsis of Tank 241-AY-101

(To be completed.) 


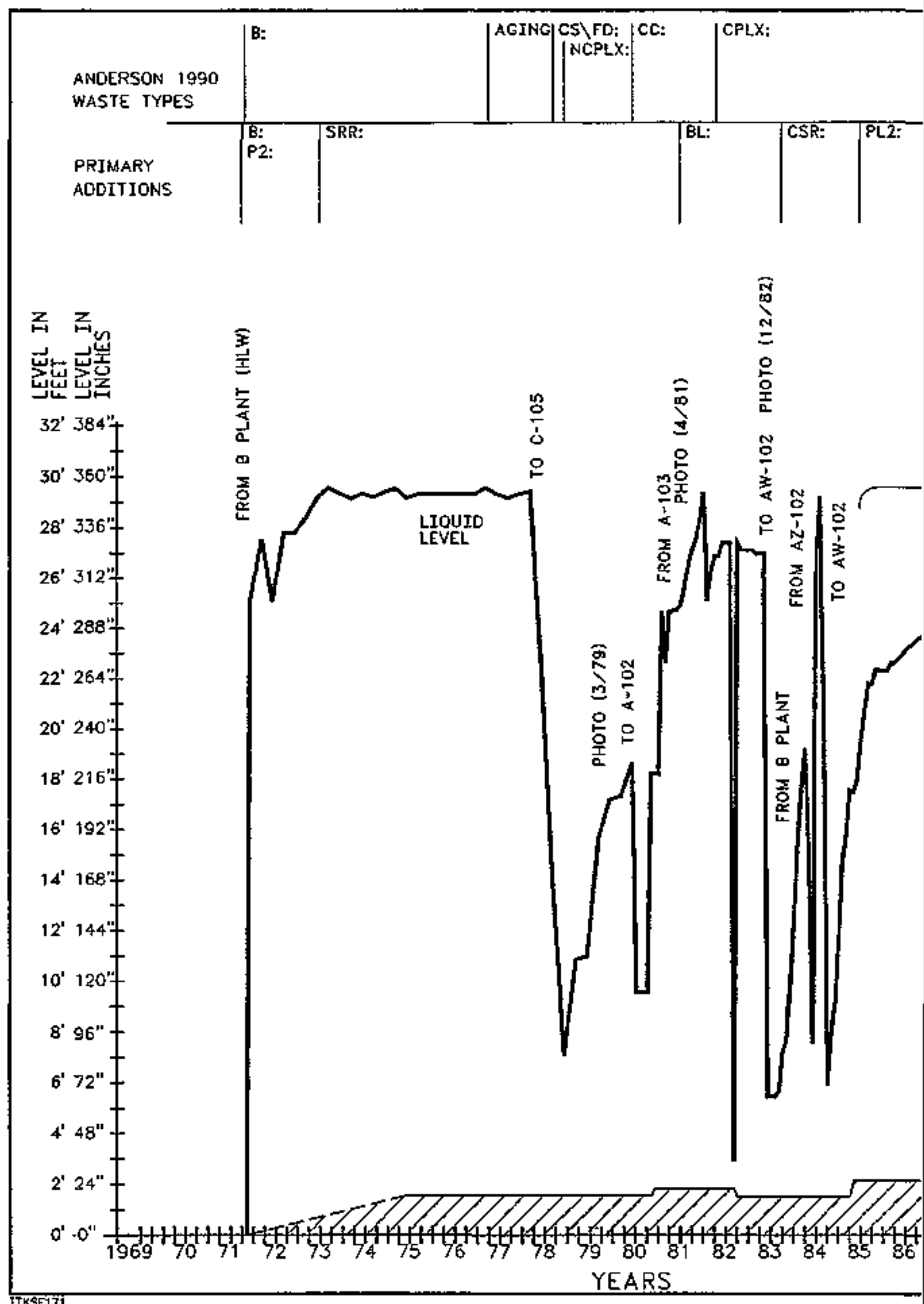


HHC-SD-WM-ER-350, ReV. 0

\begin{tabular}{|c|c|c|c|}
\hline \multicolumn{4}{|c|}{ Double-Shell Tank 241-AY-10] } \\
\hline \multicolumn{4}{|c|}{ 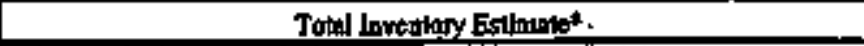 } \\
\hline \multicolumn{4}{|c|}{ 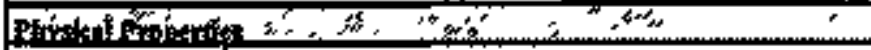 } \\
\hline Totel Wrate & $3.7 \mathrm{E}+06 \mathrm{~kg}$ & (891 leg: & \\
\hline Hert load & \multicolumn{3}{|c|}{ 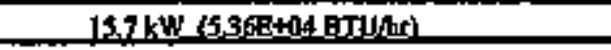 } \\
\hline Gunk:Daryitut & \multicolumn{3}{|c|}{$1, \pm 1(g / \infty)$} \\
\hline Water wo\%t & \multicolumn{3}{|c|}{$8 \mathbf{2 . 8}$} \\
\hline TOC whe & \multicolumn{3}{|c|}{1.08} \\
\hline \multicolumn{4}{|c|}{ 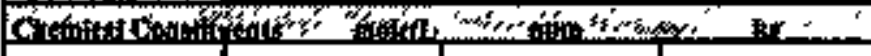 } \\
\hline $\mathrm{Nat}^{+}$ & 2.10 & $436 \mathrm{E}+0 \mathrm{0}$ & 1,69:045 \\
\hline Als' & 0.201065 & $5.02 \mathrm{E}+03$ & 1,470204 \\
\hline 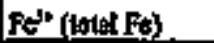 & 0.146 & $3.39 \mathrm{E}+0.3$ & $2.79 E+04$ \\
\hline$c^{*}$ & $8.045=0$ - & 378 & $1,41 \mathrm{E}+03$ \\
\hline $\mathrm{Bp}^{\mathrm{n}}$ & 1.55e-04 & 292 & 109 \\
\hline |l & 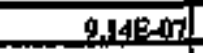 & 0.1.5. & 0.428 \\
\hline Hest & $3,23 E-06$ & 0.580 & 2.19 \\
\hline 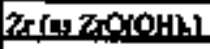 & $88835-0.5$ & 2.29 & 27.2 \\
\hline$p b^{* *}$ & 1,I4E-0s & 2.14 & 7.99 \\
\hline $\mathbf{N}^{\mathbf{H}}$ & $5,00 \mathrm{~B}, 03$ & 266 & ger \\
\hline $\mathrm{S}^{*}$ & 9.66B.07 & 7,6SE-OP & 0.285 \\
\hline $\mathrm{Mn+}$ & $6.50 \mathrm{E}=03$ & 33.3 & $1200+49$ \\
\hline$C_{s^{n+}}$ & $2.68 \mathrm{E}-02$ & 972 & $3.62 \mathrm{E}+09$ \\
\hline$K^{+}$ & 7.4A8E日 & 2,65 & 267 \\
\hline OHF & 1.4: & 2.2aE+0a & $3.50 E+04$ \\
\hline No: & 0.670 & $3.76 \mathrm{E}+104$ & 1.40E+AS \\
\hline No: & 0,297 & $1.24 E+104$ & $4.618+0.0$ \\
\hline $\mathrm{Con}^{2}$ & 0.135 & 2358+013 & $276 \mathrm{~B}+0$ \\
\hline FOA. & $1.57 \mathrm{e}, 02$ & $1.35 \mathrm{E}+03$ & $5,05 \mathrm{~B}+0 \mathrm{~g}$ \\
\hline $80^{2}$ & 5.04E-02 & $5,258+10 ?$ & 1.96Etols \\
\hline$\Delta\left(a \sin ^{2}\right)$ & $3.33 \mathrm{Ead}$ & 846 & $3.16 \mathrm{E}+03$ \\
\hline $\mathbf{E}$ & 9.76R-094 & 169 & 625 \\
\hline $\mathbf{r}$ & $3.57 \mathrm{~B}-02 \mathrm{~A}$ & $1.14 E+03$ & $4.26 \mathrm{E}+03$ \\
\hline $\mathrm{C}_{\mathrm{H}} \mathrm{O}^{\mathrm{2}}$ & $1.27 E_{2} 07$ & $\left.2.188+00^{2}\right)$ & 8.17\%+03] \\
\hline EDr $\mathrm{A}^{4}$ & 2.5LE-02 & $6.538+03$ & $2,442+04$ \\
\hline HEDTA & $4,91 E_{-10}$ & 1232401 & $4.5 d B_{10}$ \\
\hline 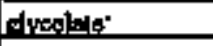 & 6 6. & 4.177409 & 156409 \\
\hline pectatef & $323 \mathrm{E}-0 \mathrm{~B}$ & 173 & 643 \\
\hline 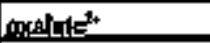 & 3ASEAC & $0,276 !$ & 102 \\
\hline DAP & 4.52E, $-1,5$ & 662 & $2.47 \mathrm{E}+03$ \\
\hline hrit:nol & 448E-103] & son. & $1.12 x+103$ \\
\hline $\mathrm{NH}_{2}$ & $6,30 \mathrm{~g}=0$ & 25.9: & 361 \\
\hline $\mathrm{Fe}\left(\mathbf{C} \mathrm{N}_{\mathrm{s}} \mathrm{s}^{4}\right.$ & 4 & 0 & 0 \\
\hline 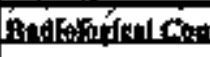 & $\mathrm{F}_{1}$ & 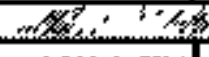 & 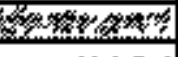 \\
\hline Pu & & $0,302\left({ }_{10 \mathrm{Cl} g}\right)$ & 18.0 (n?) \\
\hline $\mathrm{u}$ & l.t.tentm & 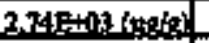 & $1027+040 \mathrm{kr}:$ \\
\hline $\mathrm{Cs}$ & A99E-02(Ch) & H.3. (acts) & $3.03 \mathrm{E}+0 \mathrm{~d}(\mathrm{CD})$ \\
\hline $\mathbf{s} \mathbf{r}$ & 0.620 (Ch) & $568(p+C l g)$ & $2.12 \mathrm{E}+06(\mathrm{Cl})$ \\
\hline
\end{tabular}

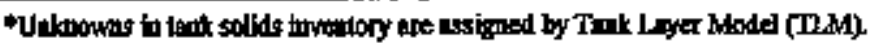

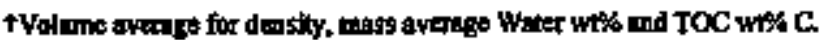

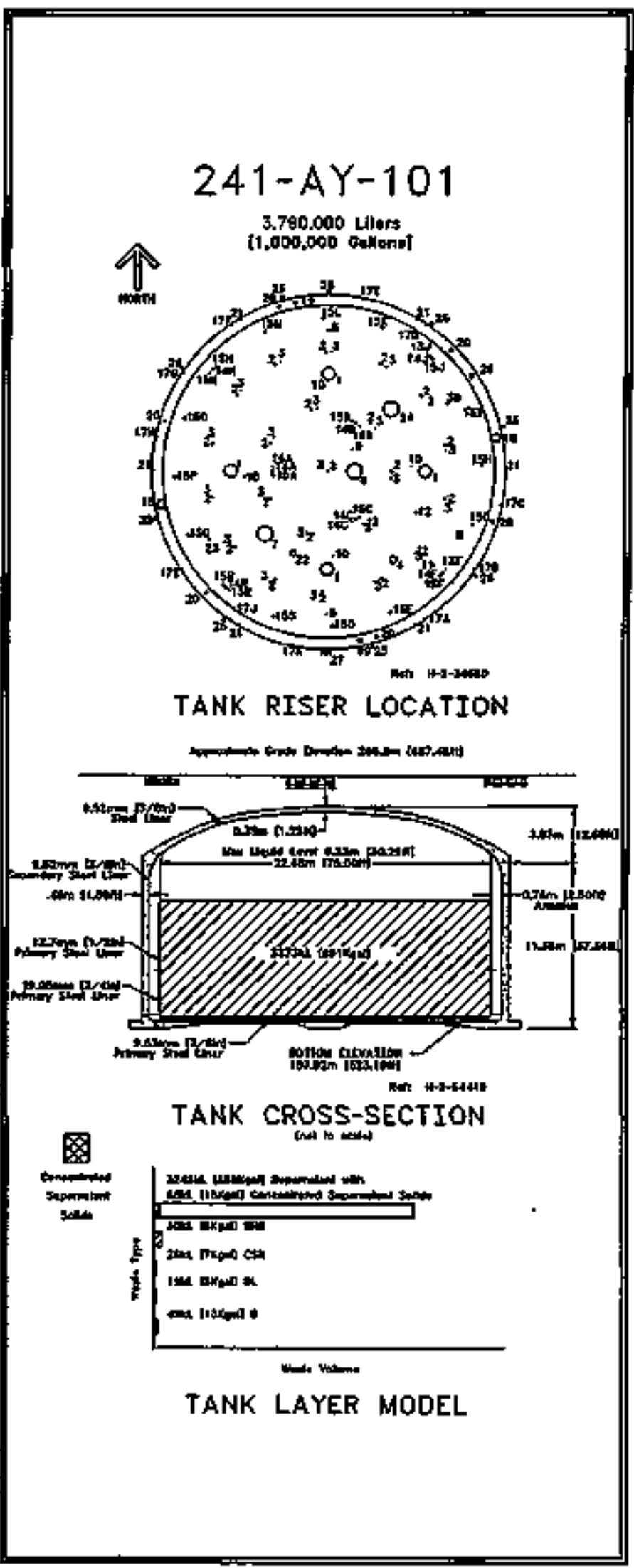




\begin{tabular}{|c|c|c|c|}
\hline \multicolumn{4}{|c|}{ Double-Shell Tauk 241-AY-101 } \\
\hline \multicolumn{4}{|c|}{ Shim Composite Fremtory Estimale } \\
\hline \multirow{2}{*}{ 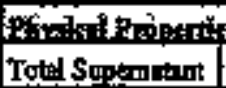 } & rom & 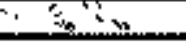 & 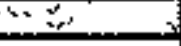 \\
\hline & \multicolumn{2}{|c|}{$3.54 \mathrm{E}+0.06 \mathrm{~kg} \quad(858 \mathrm{~kg}$} & \\
\hline 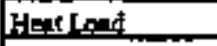 & \multicolumn{2}{|c|}{ 1.39. } & \\
\hline Qult Dentitu & \multicolumn{2}{|c|}{$1.09(t) / 0 x)$} & \\
\hline Woler wot $\%$ & \multicolumn{2}{|r|}{4.3} & \\
\hline TOC un $\mathrm{C}$ (wed) & \multicolumn{3}{|c|}{104} \\
\hline \multicolumn{2}{|c|}{ 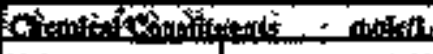 } & 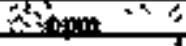 & - \\
\hline $\mathrm{Na}+2-2$ & 200 & 4.41E +04 & $1.56 \mathrm{~B}+0.5$ \\
\hline Alv' & . & $4348+019$ & t. S4EE+O4 \\
\hline Fot (toden Pa) & 1.40B-09.9. & 729 & 254 \\
\hline $\mathrm{c}^{*}$ & 8그료용 & 39 & ! $39 \mathrm{~F}+0 \mathrm{E}$ \\
\hline $\mathrm{Bl}^{*}$ & I.60E-0ㄱ & 30.7 & 109 \\
\hline$L^{2+4}$ & 949E_OH & O.la.|l & ospes: \\
\hline $4 \mathrm{H}^{*+}$ & 3.31E-06 & 0.610 & 2.16 \\
\hline 2t. & 9.16E_0 & 767 & 27.1 \\
\hline $\mathrm{Pu}^{* 4}$ & E.lges-0s & 200 & 7,98 \\
\hline $\mathbf{N F}^{2+}$ & 974B 0 A & 979 & 186 \\
\hline $\mathrm{Sr}^{+}$ & 1.00B-AG & s.07e-m & 0.253 \\
\hline $\mathrm{Str}^{4+}$ & AlmEena & 19n. & 67 \\
\hline$c^{*}$ & 9.S1B-03 & 361 & $1.28 E+07$ \\
\hline $\mathbf{K}^{+}$ & 7695-0여 & 276 & 971 \\
\hline olt & 0.877 & $1372+09$ & 4.84E+04 \\
\hline MO: & 067 & $3.857+40$ & 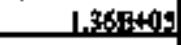 \\
\hline Mo: & 0,906 & 129두영 & $4.57 \mathrm{~F}+0 \mathrm{~d}$ \\
\hline $\log ^{2}$ & ] & $6.55940 \mathrm{~g}$ & $373 f+0$ \\
\hline $\mathrm{PO}^{2}$ & $1.62 \mathrm{~F} \cdot 02$ & $1,41 B+0 \mathrm{~A}$ & $5,00 \mathrm{EAOA}$ \\
\hline $\mathrm{sol}^{2}$ & 6.01E_on & s.328409 & 1 $80 \mathrm{R} 4 \mathrm{n}$ \\
\hline$S i\left(s, 50,{ }^{2}\right)$ & 2.162-00. & \$5t & $1.978+03$ \\
\hline$F$ & 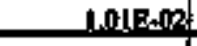 & t77 & 635 \\
\hline ct & $3.5 \%=-02$ & $1.173+03$ & $4.139+03$ \\
\hline C.Hos & $1.295=-19$ & $2.24 E+13$ & $299 \mathrm{~A}+10$ \\
\hline $\mathrm{et} \mathrm{TA}^{+}$ & $2.47 \mathrm{E}-0 \mathrm{R}$ & $654 E+03$ & 231E+04 \\
\hline HTEDTA & $481 \mathrm{E}=0 \mathrm{P}$ & 1PFENA & $4317+04$ \\
\hline stredtite: & 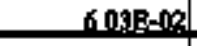 & $4,168+03$ & 1478H \\
\hline aratede & $3.36 \mathrm{E}-0 \mathrm{5}$ & ts: & $6+3$ \\
\hline ayntetes. & 3 s. 150 연 & 0.290 & 2.00 \\
\hline DAP & $4.65 \mathrm{E}-03$ & 688 & $2.43 E+05$ \\
\hline 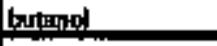 & 465E- 01 & 317 & $1.12=+009$ \\
\hline $\mathrm{N} \mathrm{H}_{1}$ & $5 \mathrm{SEO}$ & Ll举 & 3600 \\
\hline $\mathrm{Fe}\left(\mathrm{CN}_{1}{ }^{+}\right.$ & & 0 & 0 \\
\hline 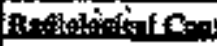 & 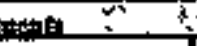 & 4 & ب. \\
\hline Pu & 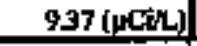 & & $0.507 \mathrm{~kg}]$ \\
\hline II & $201 \mathrm{E}-\mathrm{O}$ (N) & $40(u) / 2)$ & $1568+0 x$ (ks) \\
\hline Cs & $8.89 \mathrm{ABO}(\mathrm{C})$ & $81,1(\mu \mathrm{CH} k)^{\prime}$ & $287 \mathrm{E}+0 \mathrm{~S}(\mathrm{Cl})$ \\
\hline s & 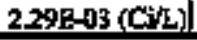 & $211(\mathrm{uCt} / \mathrm{s})$. & $7,45 \mathrm{E}+43(\mathrm{CH})$ \\
\hline
\end{tabular}

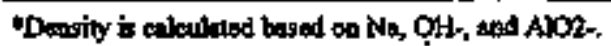

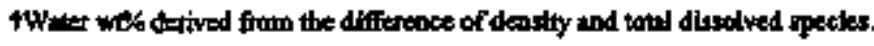

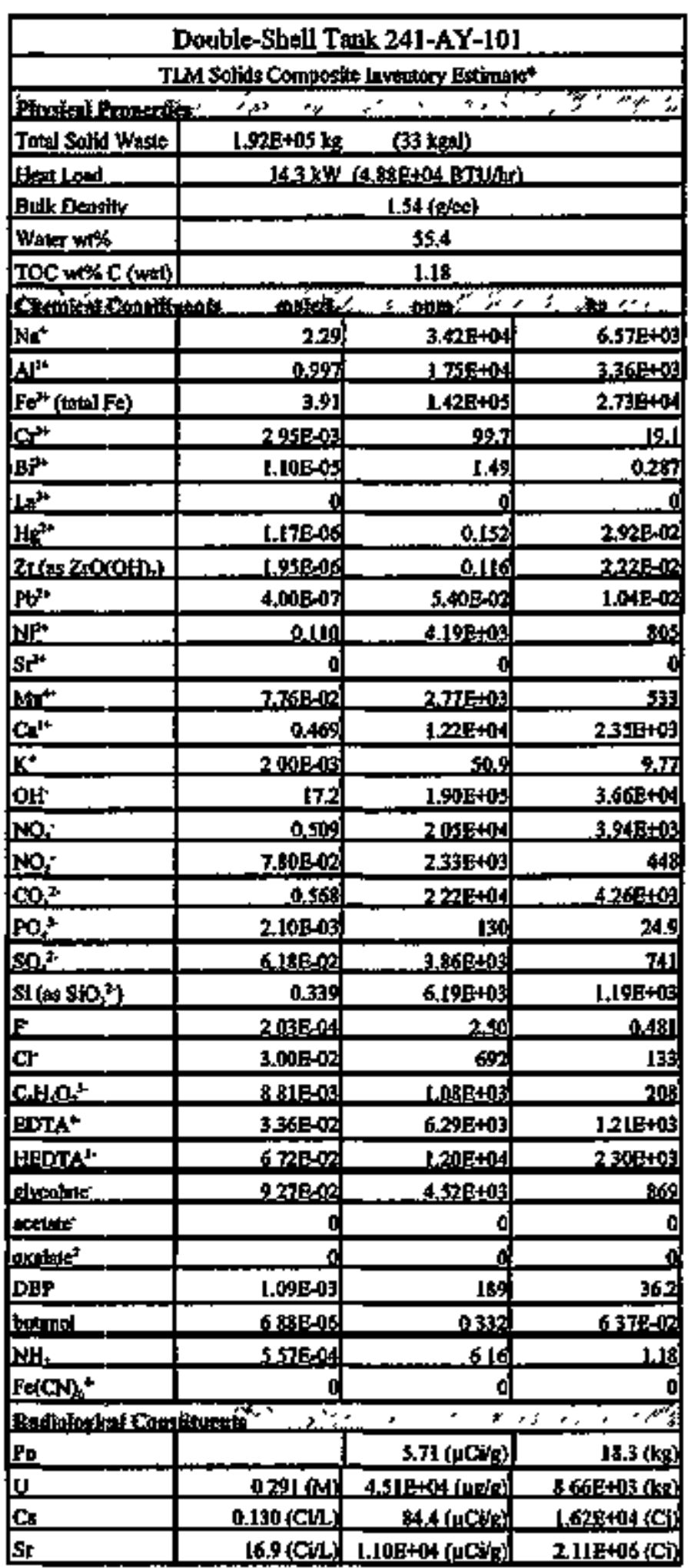

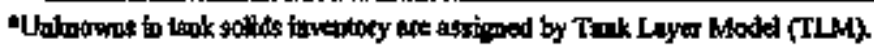




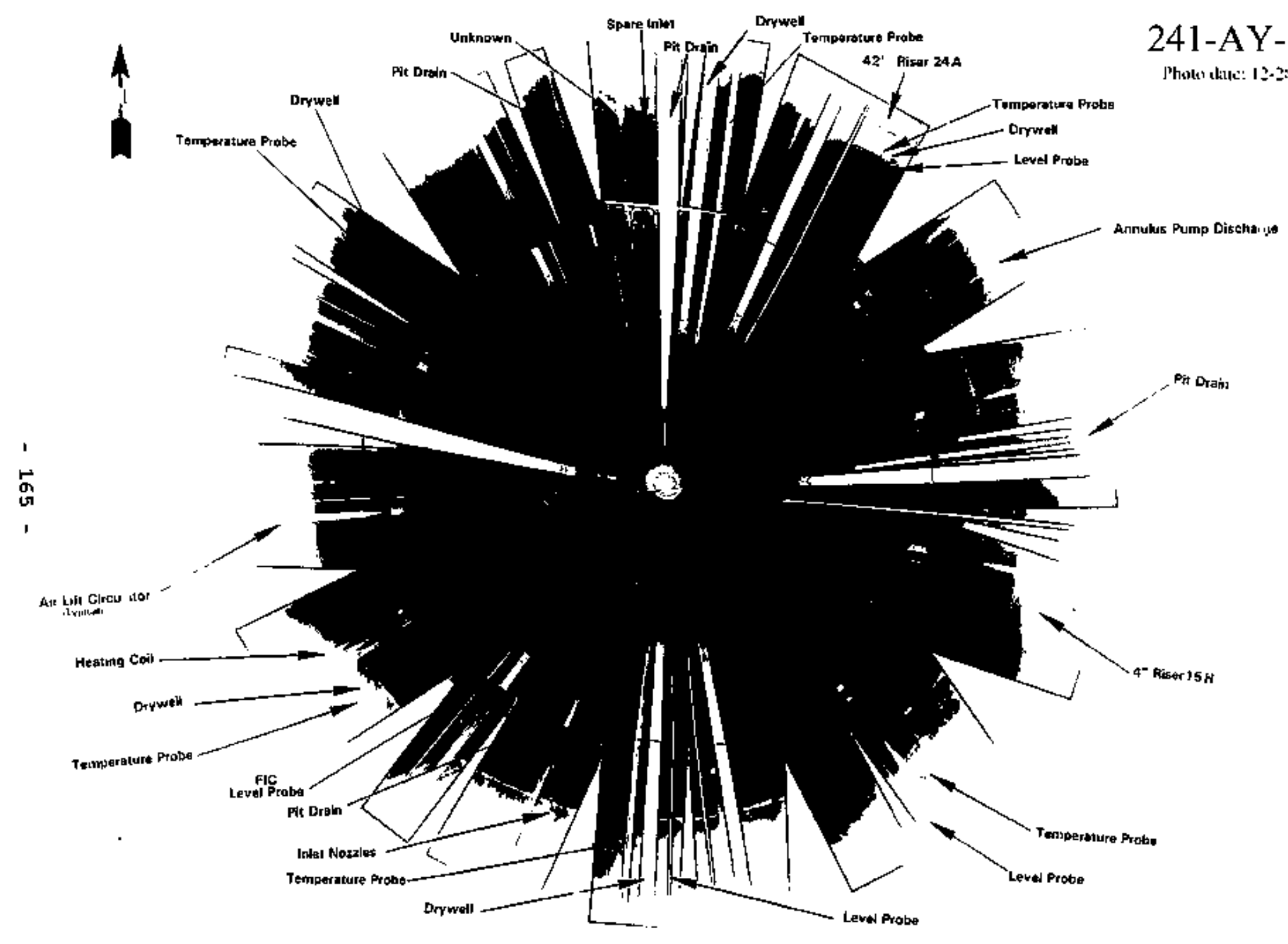


WHC-SD-WM-ER-350, ReV. 0

5.2 Tank 241-AY-102

5.2.1 241-AY-102 Tank History

5.2.1.1 Waste History of Tank 241-AY-102

Tank 241-AY-102 began service by receiving water in the second guarter of 1971 and was labeled as a spare tank. The tank received evaporator waste from the third guarter of 1976 mtil the first guarter of 1977 . From the second quarter of 1977 until the second guarter of 1978 , the tank received aging waste. The tank received double-shell slurry feed waste from the third cuartex of 1978 until the second guarter of 1980 . From the first quarter of 1980 until the fourth guarter of 1992, the tark received waste from B Plant. The tank received non-complexed waste from August 1980 until May 1990. The tank has contained dilute non-complexed waste from June 1990 until present. The tank is considered an aging waste tank, an inactive, dilute receiver tank that receives only condensate from other aging waste tanks.

\subsubsection{Temperature History of Tank 241-AY-102}

Tenperatire data for Tank 241-AY-102 are recorded by 15 thermocouples affixed at known elevations to seven thermocouple trees inside the tank. The thermocouple trees are located in risers 13A, B, C, D and $16 \mathrm{~A}, \mathrm{~B}, \mathrm{C}$. Between one and three thexnocouples are on each tres. Onit 10 of the 15 thermocouples had temperature data. Non-suspect temperature dath from the records takeri between July 1983 and June 1988 for the 10 thermocouples wert avallable from the conputer automated surveillince system. However, not all of the 10 thezmocouples have data that encompass the entire length of time. Within the time span of the couputer automated surveillance system, there were several small breaks in the sequence of the temperature data. The average temperature during this period was $77^{\circ} \mathrm{F}$ with a minimum of $54^{\circ} \mathrm{F}$, a maximum of $123 \% \mathrm{~F}$, and a standard deviation of $10^{\circ} \mathrm{F}$. Iinear regressions were performed on each thermocouple over the lite of the tank. The slopes from these regressions were averaged with a resulting average slope of 0.0028 . Refer to the suppoxting document for a more thoxough review of the temprature data (Breviek, 1995).

\subsubsection{Occurrences of Tank 241-AY-102}

Thelve umusual events occurred at Tank 241-AY-102. Occurrence repoxts RL--WHC-Tank Farm-1993-0014 and RL--WHC-Tank Farm-1991-1068; Off-Normal Reports 85-22 and 82-12; and Unusual Decurrence Reports 81-52, 80-88, 80-8, $76-148$, 76-138, and 75-127 were written due to unexpected waste transfers. U.O. Report 80-37 was written because failing equipment caused the tank to pressurize. U.0. Report 74-30 was witten because a procedural reguirement was not met.

5.2.1.4 Psychrometrics of Tank 241-AY-102

Psychrometric data have been recorded for ten years fron the tank enmulus. There are two psychrometric data points, recorded on the same 
HHC-SD-RM-ER-350, Rev, 0

day, in the tank. Due to the small amount of data for the tank, no plots were made to display the data graphically. The trend in the rates of heat exchange through the annular ventilation increased from october 1980 to February 1991. This would suggest an increase in the rate of heat generation in Tank 241-AY-102, but no corroborating cata from the tank veratilation exists.

\section{2 .2 Current status of Tank 241-AY-102}

Tank 241-AY-102 entered service in April 1971 and currently stores 804,000 gallons of waste. The following plan view and tank cross-section depict the approximate waste volume of 944,000 gallons and configuration of risers as of January 1994. At the time of the estimate, there were 912,000 gallons of supernatant, 28,000 gallons of B Plant low-level waste (BL), and 4,000 gallons of PUREx low-level waste (PL2). The waste level in the tank is measured with the FIC gauge and the manual tape and has increased and decreased between Jamuary 1991 and January 1994. The increases were mostly from additions of dilute and non-complexed waste from B-Plant cell drainege and flush water from miscellaneous sources between January 1991 and January 1994. The decreases were mostly from waste sent to Tanks 241-AP-103 and -108. This tank is inactive and only receives condansate Erom aging waste tanks. The tank is actively ventilated and categorized as sound. Tank 241-AY-102 has 117 risers. One 4-inch riser (no.5A), nine 6-inch risers (no.15A, no.15E, no.15G, no.15I, no.15K, no.15M, no.150, no.15Q, and no.155), and one 42-inch riser (no.24A) are available for use.

\subsubsection{Inventory Estimate of Tank 241-AY-102}

The tank layer model (a volume based approximation) that follows was derived from the Los Alamos National Ixboratory Waste status and Transpction Record Summary (Agnew, 1995) and Supernatent uixing Hodel (Agnew, 1995). The estimated inventories of total waste, solids, and supernatant in Tank 241-AY-102 are also presented.

\subsubsection{In-Tank Photograph of Tank 241-AY-102}

In April 1994, Tank 241-AY-102 contained 721,000 gallons of dilute non-complexed waste from PUREX (Hanlon, 1994) with a waste depth of about: 22 feet. The most recent collage for this tank is 13 years old and was assembled from photographs taken in Apri1 1981. At that tire, the tank contained 282,000 gallons of non-complexed waste (Mudd, 1981). Not much can be determined from this picture as it is hazy and incomplete. Ecripment which could be identified has been labeled.

\subsubsection{Synopsis of Tank 241-AY-102}

(To be cormleted.) 


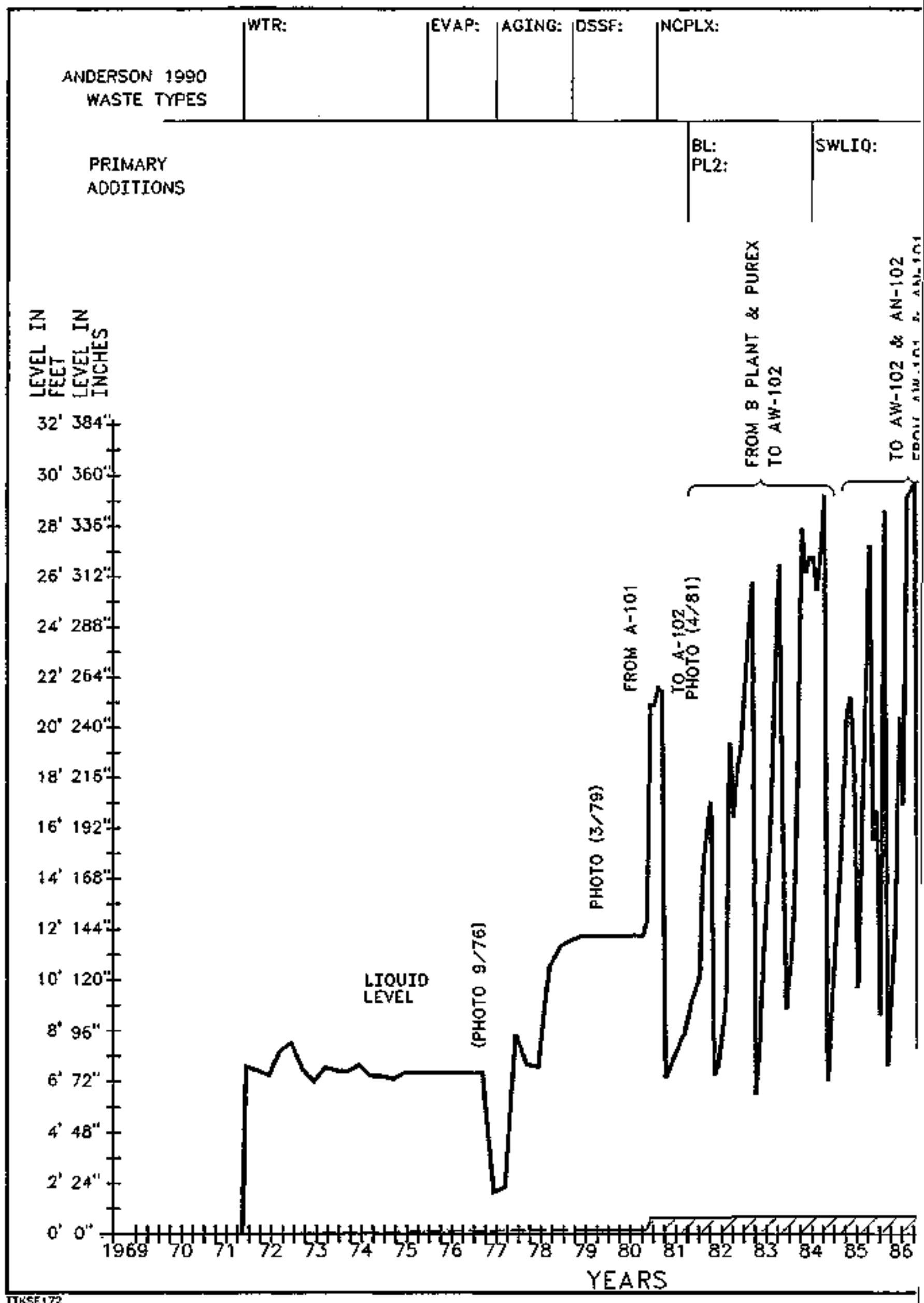


WHC-SD-WM-ER-350, Rev, 0

\begin{tabular}{|c|c|c|c|}
\hline \multicolumn{4}{|c|}{ Double-Shell Tank 241-AY-102 } \\
\hline \multicolumn{4}{|c|}{ 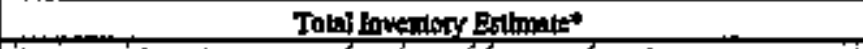 } \\
\hline \multicolumn{4}{|c|}{$6 x^{\prime \prime 2 y}$} \\
\hline Toxal Worle & 3.87E+0.6k? & (944 kgall ) & \\
\hline 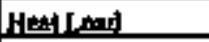 & \multicolumn{3}{|c|}{ Q15.5W (3.130404 ETL/hri } \\
\hline Aulik Pe:stityt & \multicolumn{3}{|c|}{ 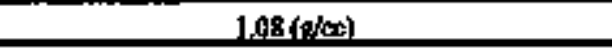 } \\
\hline Worer wtht & \multicolumn{3}{|c|}{88.6} \\
\hline TOCwac & \multicolumn{3}{|c|}{0.158} \\
\hline \multicolumn{4}{|c|}{ 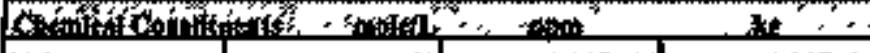 } \\
\hline $\mathrm{Me}^{*}$ & 1.27 & $270 \mathrm{~B}+0 \mathrm{~A}$ & $1.04 \mathrm{E}+0.5$ \\
\hline$\Delta 1^{2}$ & 0,215 & $5.37: 200$ & 2OBF+104 \\
\hline $\mathrm{Fe}^{\text {th }}$ (toted Fo) & $6.00 \mathrm{E}-\mathrm{m}$ & $3.412+03$ & $1322+04$ \\
\hline $\mathrm{cos}^{3+}$ & 1.4tFon & 30.6 & 273 \\
\hline $\mathrm{BP}^{\mu}$ & 1.67e-05 & 3.22 & 12.5 \\
\hline $18^{5+}$ & $79 \mathrm{~g}=0 \mathrm{~g}$ & $1078-02$ & 3.5nE-12? \\
\hline He & $3.6 \pi-07$ & $6.800-02$ & 0.263 \\
\hline 7. & $8.860-15$ & 247 & 28.9 \\
\hline Pb't: & 3.065-06] & 0.580 & 220 \\
\hline $\mathrm{Ni}^{P^{*}}$ & 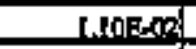 & 597 & $2318+03$ \\
\hline $5 \mathbf{s}^{* \prime}$ & 8.43E-06 & $6.835-03$ & $2.64 E-02$ \\
\hline $\mathrm{Nin}^{4}$ & 3.898_0여 & $\ln , 1]$ & 754 \\
\hline$c^{*}$ & 1.31E-02 & 4 4s: & 1. $18 \mathrm{E}=0 \mathrm{~g}$ \\
\hline$K^{*}$ & $647 E-0: 3$ & 234 & 903 \\
\hline OH & L.39 & $2.108+0.04$ & $8.128+04$ \\
\hline 누:- & 0,597 & $3,36 \mathrm{EE}+\mathrm{d} d$ & $1,3 n e+15$ \\
\hline NO: & $4.00 \mathrm{E}-1 \mathrm{P}$ & $1.700+03$ & $6.57 \mathrm{TE}+03$ \\
\hline $\mathrm{co}^{2}$ & $2,59=0 p$ & $5.31 \mathrm{E}+03$ & $2.05 \mathrm{E}+04$ \\
\hline $\mathrm{pO}^{2}$ & $8.078-09$ & 704 & $272 \mathrm{E}+0 \mathrm{~B}$ \\
\hline 502 & $3.6 \div 2=10$ & $322 \mathrm{E}+(0 \mathrm{0})$ & $1.258+0 d$ \\
\hline $\operatorname{sic}\left(\cos \sin ^{2}\right)$ & $2.972-102$ & mo & $298 \mathrm{E}+0 \mathrm{~g}$ \\
\hline F & 7.5.5endis & -137 & stif \\
\hline a & 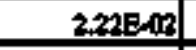 & 720 & $2.828+09$ \\
\hline$C, H O^{2}$ & $4.75 \mathrm{R}, 03$ & 834 & $3.238+09$ \\
\hline EDTA* & 2,3an-04 & 65,3 & 245 \\
\hline Heptat & 3.99E-OM! & 99.6 & 5.65 \\
\hline 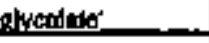 & S.922E-0? & 4. 10 EE+103 & $1.596+04$ \\
\hline acestate' & 26AB-04 & 14A & 55,7 \\
\hline axponte. & 301E-OA] & $2458-52$ & 9.47E-M \\
\hline DBP & 3.81E-0에 & 579 & 29 \\
\hline hortane & 3.818-01 & 26.1 & 101 \\
\hline $\mathbf{N} \mathrm{H}_{1}$ & $2,238 \leq 0$ & 3511 & $1.36 \mathrm{E}+0.7$ \\
\hline $\mathrm{Fe}(\mathrm{CN})_{5}{ }^{+}$ & 0 & & 0 \\
\hline 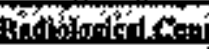 & 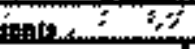 & $\therefore \neq 1 \%, 2,78$ & 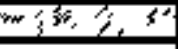 \\
\hline$p_{n}$ & & 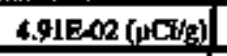 & $3.17(\mathrm{~kg})$ \\
\hline II & A.05E-APNA. & 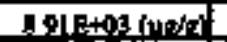 & $\left.3 A^{5}=404 \mathrm{~kg}\right)$ \\
\hline$a$ & 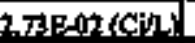 & $25.2(\mu C d)$ & $9.74 \mathrm{E}+04$ (C) \\
\hline$s$ & 0.361 (Cin) & $334(\mu \mathrm{CH} /)$ & 1 과연 \\
\hline
\end{tabular}

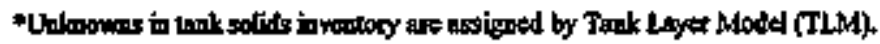

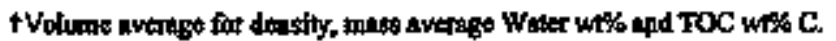

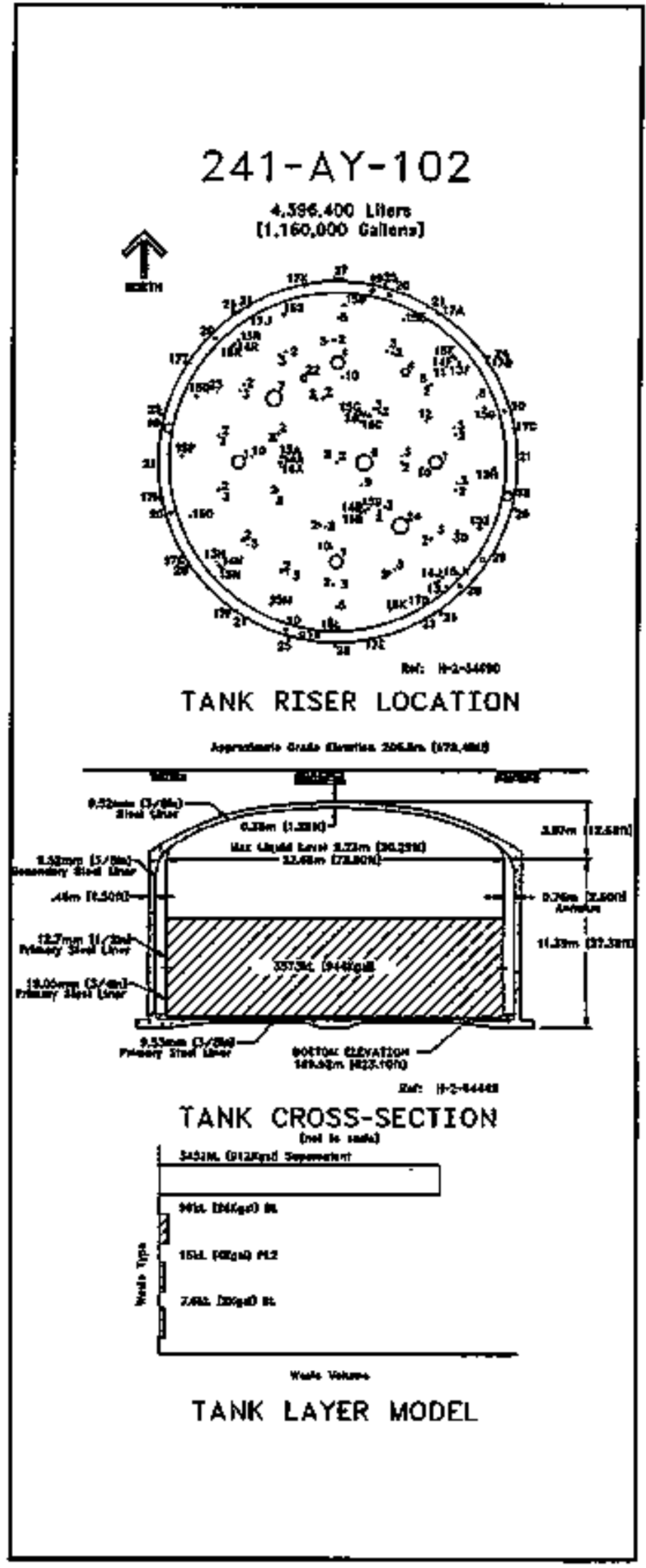




\begin{tabular}{|c|c|c|c|}
\hline \multicolumn{4}{|c|}{ Double-Sbell Taak 24l-AY-102 } \\
\hline \multicolumn{4}{|c|}{ 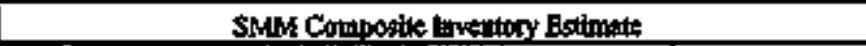 } \\
\hline 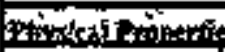 & $-1-1$ & $i_{x} x_{2}$ & \\
\hline Toto: Strpernutint & $3.64 \mathrm{E}+\mathrm{D} 6 \mathrm{Lg}$ & (912 kgal) & \\
\hline HertLo:d & n.512kW & 75E+03 ATUShl & \\
\hline Bull: Densite & & 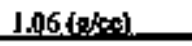 & \\
\hline Watur wtst & & 90.8 & \\
\hline$T O C$ we $\%$ (wet) & & 0.154 & \\
\hline \multicolumn{4}{|c|}{ 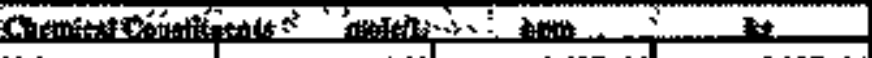 } \\
\hline Na* & 1.18 & 2\$8E+0N & $9.38 E+04$ \\
\hline$\Delta \mathbf{S}^{*}$ & $0, \mathrm{t} 61$ & $A \mid 1, F+1,0]$ & 1.50):+에 \\
\hline$F^{3+}\left(\operatorname{ton} 1 \mathrm{~F}^{3}\right)$ & $9.79 \mathrm{~B}-04$ & st.8 & 189 \\
\hline $\mathrm{Cr}^{3}$ & 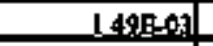 & $7,1,3]$ & 267 \\
\hline $\mathrm{Bi}^{*}$ & $1.73 \mathrm{E}-0 \mathrm{~s}$ & 3.42] & 12:3 \\
\hline $1 . \mathrm{s}^{2+}$ & B.,26E $-0 \mathrm{O}$ & 1.09g-0? & $3.968-072$ \\
\hline $\mathrm{H}=$ & $3.20 \mathrm{E}-07$ & $720-00$ & 0,263 \\
\hline 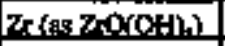 & F.17E-05 & 79 & 288 \\
\hline PQt" & $2.99 E-06$ & ansty & 2.14 \\
\hline Nit. & 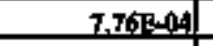 & \$3.2 & 157 \\
\hline $\mathrm{Sr}^{4}$ & 6.73E 0.0 .5 & 7.25E- -03 & 264E-02 \\
\hline $\mathbf{M n}^{*+1}$ & $3.76 \mathrm{E}-0 \mathrm{~A}$ & 18.7 & 71. \\
\hline $\mathrm{CO}^{3+}$ & $6.86 \mathrm{E}-0 \mathrm{~s}$ & 260 & 948 \\
\hline $\mathrm{Cl}^{*}$ & 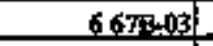 & 242 & 800 \\
\hline OH & 0.716 & 1.15E+0N & $4.20=04$ \\
\hline NO: & n.5.5:5 & 3.31F+40: & 1218405 \\
\hline No: & 4.07E-02 & $1.78 \mathrm{E}+0 \mathrm{0}$ & $6.47 \mathbb{Z}+03$ \\
\hline $\mathrm{CO}^{2}$ & 8.55:20?: & $486 \mathrm{R}+1 \mathrm{~B}$ & $17 \pi+404$ \\
\hline $\mathrm{PO}^{2}$ & $7.760-05$ & 699 & 2,54R+05 \\
\hline SO1. & $3,4 \pi=01 ?$ & $3.167+403$ & J.JFEH104 \\
\hline Si $\left(x, \mathrm{sin}^{2}\right)$ & $1.005-02$ & 266 & 968 \\
\hline $\mathbf{F}$ & 7.795 .0 .3 & 140 & 511 \\
\hline C. & $2.14 \mathrm{E}-02$ & 717 & $2.61 \mathrm{IP}+05$ \\
\hline C.rlos & $456 \mathrm{~F}-0 \mathrm{z}$ & 816 & $29 \pi+03$ \\
\hline EDTA & $2,46 \mathrm{E}-104$ & 672 & 245 \\
\hline HEDTA & $4078-1$ & 1065 & 385 \\
\hline shesolente & $5,61 ! E=0 ?$ & $3.997+113$ & $1,4,5=404$ \\
\hline actate & 2.73E- 04 & 153 & 55.7 \\
\hline gakl:gt? & 3.12E-07i & 2608_R? & D.47F-02 \\
\hline DBP & $3.82 \mathrm{E}-04$ & 382 & 212 \\
\hline butt:riol & 389004 & 26.8 & $97 \pi$ \\
\hline $\mathbf{N H}$ & 23.1日E-OQ & 378 & 1.36Rtent, \\
\hline $\mathrm{FE}(\mathrm{CN})^{+}$ & $d$ & 0 & 0 \\
\hline 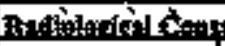 & 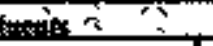 & " & سـس \\
\hline Pu & 9.83 (ucll) & & $0.567(\mathrm{k})$ \\
\hline $\mathbf{y}$ & $1.28 \mathrm{E}=03$ (M) & 289(tolg) & 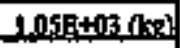 \\
\hline Cs & $2.815-02$ (COM) & 26.60 (1 & 9.2XEY 04 (C) \\
\hline $\mathbf{s t}$ & 2. $\left.49 \mathrm{E}_{0} 03(\mathrm{C}+\mathrm{H})\right]^{3}$ & 2,36 (1:CL). & E.59E+03 (C) \\
\hline
\end{tabular}

-Density is caboulered based on Ne, OH, ind AOO2-

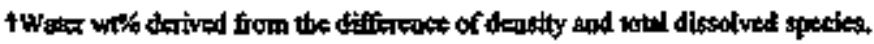

\begin{tabular}{|c|c|c|c|}
\hline \multicolumn{4}{|c|}{ Double-Shell Tank 24 1-AY-102 } \\
\hline \multicolumn{4}{|c|}{ 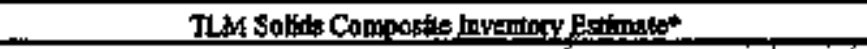 } \\
\hline \multicolumn{4}{|c|}{ 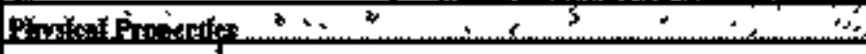 } \\
\hline Tơn Solid Wale & 225E+05 kg & (321. 国) & \\
\hline & \multicolumn{2}{|c|}{ 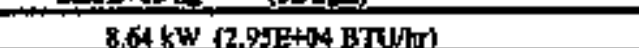 } & \\
\hline Bẹtk. Detșity & \multicolumn{3}{|c|}{ 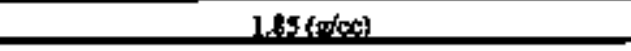 } \\
\hline Water wex & \multicolumn{3}{|c|}{$\mathbf{5 3 . 6}$} \\
\hline ToC who C (wet) & \multicolumn{3}{|c|}{0274} \\
\hline \multicolumn{4}{|c|}{ 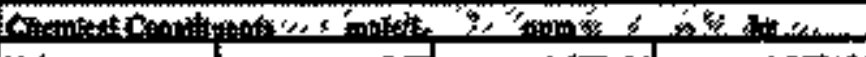 } \\
\hline $\mathrm{Ne}^{*}$ & & $4.6 \pi+0 \mathrm{~d}$ & $1.0 \mathrm{sin}+04$ \\
\hline $\mathbf{A l}^{\mathbf{H}}$ & 1.74 & 2.55: & 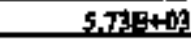 \\
\hline$F_{0}{ }^{\text {th }}$ (10t: $\left.\mathrm{F}_{0}\right)$ & 1.92 & $\$ .78 \mathrm{~B}+0.4$ & $1,34 \mathrm{EPOA}$ \\
\hline $\mathrm{CS}^{*+}$ & 9.19E-04 & 759 & 5.79 \\
\hline \multicolumn{4}{|l|}{ Es: } \\
\hline \multicolumn{4}{|l|}{ ln } \\
\hline \multicolumn{4}{|l|}{$\mathrm{H} \mathrm{g}^{2+}$} \\
\hline \multicolumn{4}{|l|}{ 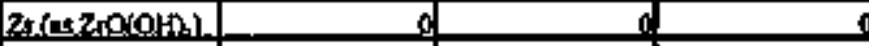 } \\
\hline $\mathbf{P t}^{*}$ & 4.99E-0. & 0.558. & 0.125 \\
\hline $\mathbf{N F}^{*}$ & 0.303 & 9.5tE+4at & $2.15 p+07$ \\
\hline \multicolumn{4}{|l|}{ Sart } \\
\hline $\mathrm{Sr}^{4}$ & 6 G9F-14 & 2in & 4.59 \\
\hline $\mathrm{CP}^{7 *}$ & 0.191 & $4+132+0$ & 927 \\
\hline $\mathrm{K}^{*}$ & 6.1980? & 14,5 & 3.26 \\
\hline 안 & I9.1 & $1.755+0 \mathrm{~s}$ & $3.52 \mathrm{~F}+0 \mathrm{4}$ \\
\hline $\mathrm{MO}$ & $1.7 \pi$ & $4.2515+16$ & e.56tath \\
\hline No: & 1,37200 & 469 & 10영 \\
\hline $50^{2}$ & 0.387 & $1,25 \mathrm{E}+1 \mathrm{1}$ & 2.818+09 \\
\hline $\mathrm{PO}^{-}$ & 1.55E-02 & 783 & 175 \\
\hline $\sin ^{2}$ & 8.01,5:B? & 4.18:E+15) & 040 \\
\hline$S i\left(a S_{1} O_{i}{ }^{2}\right)$ & 0.59 나 & C.94E+0s & $2.018+05$ \\
\hline \multicolumn{4}{|l|}{$F$} \\
\hline Cr & 4.75E-02 & $90 \mathrm{~A}$ & 204 \\
\hline \multicolumn{4}{|l|}{ C.Sk $0^{2}$} \\
\hline \multicolumn{4}{|l|}{ BSTA ${ }^{+}$} \\
\hline \multicolumn{4}{|l|}{ HatOT: } \\
\hline \multicolumn{4}{|l|}{ 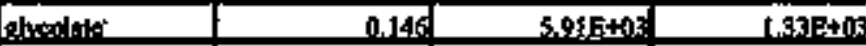 } \\
\hline \multicolumn{4}{|l|}{ acestate' } \\
\hline \multicolumn{4}{|l|}{ axtlate } \\
\hline DBP & 3.62E-04 & 51.9 & II. \\
\hline \multicolumn{4}{|c|}{$362 \mathrm{E}-1 \mathrm{4}$} \\
\hline $\mathrm{NH}$. & 3.8APAOA & 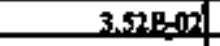 & T.918-013 \\
\hline \multicolumn{4}{|l|}{$\mathrm{Fe}\left(\mathrm{CWN}_{2}{ }^{+}\right.$} \\
\hline \multicolumn{4}{|c|}{ 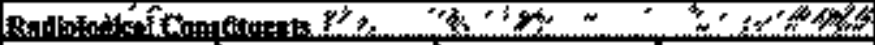 } \\
\hline Pu & & $0.694(\mu \mathrm{C}) \mathrm{g} g)$ & $2.60(\mathrm{~kg})$ \\
\hline 山 & 1.36.0.15: & $149+405[\mathrm{mg} / \mathrm{g}]$ & $3,348+040(12)$ \\
\hline 安 & 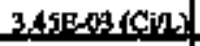 & 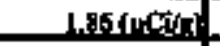 & 4IICT) \\
\hline 5 & 10.6(Cill) & S.TIE+13 (1) & $1.26 E+06(\mathrm{CD})$ \\
\hline
\end{tabular}

"Ublowown in tank solids invertary aro assigaed by Tank leyer Model (T1M). 
WHC-SD-WM-ER350，Rev, 0.

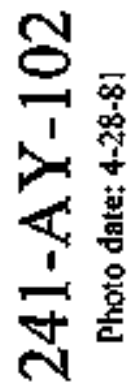

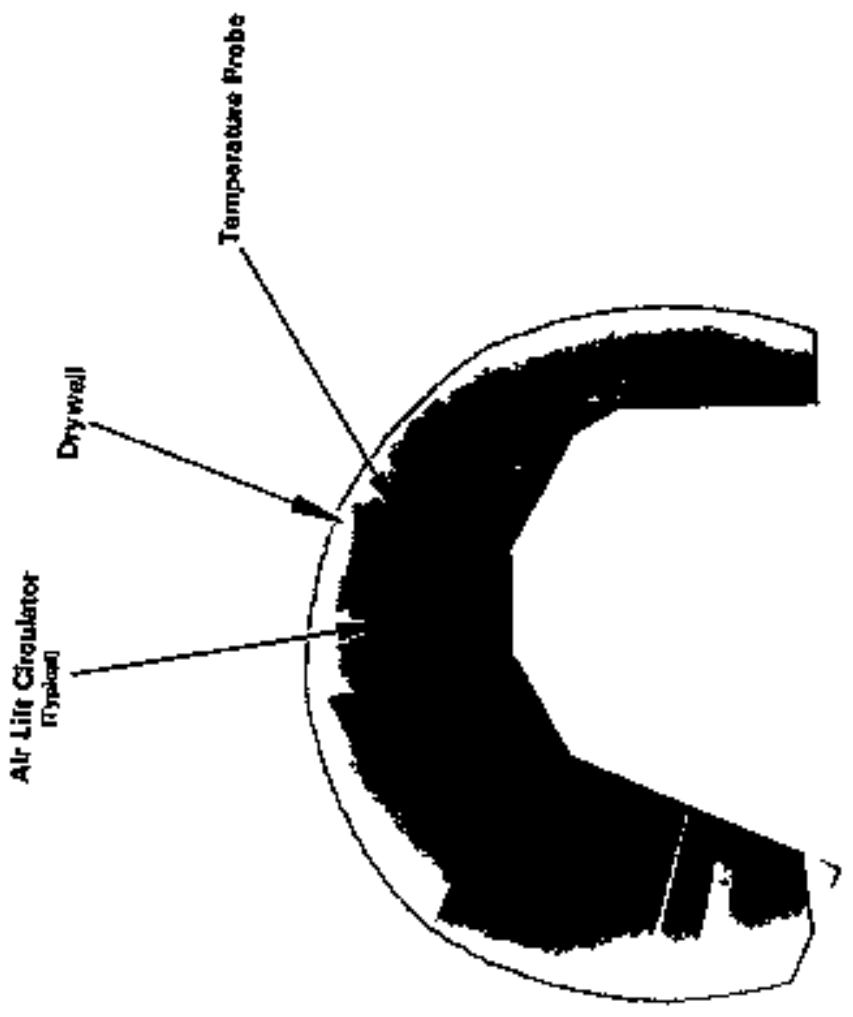

돈돌 


\subsubsection{AZ Tank Farm History}

The AZ Tank Farm is located east of Buffalo Avenue and west of Canton Avenue in the 200-East Area. The Az Tank Farm contains two, 100 series, 1,000,000 gallon, 75-foot diameter dotuble-shell tanks. The AZ Tank Farm is the latest tank design with a reinforced concrete shell and an insulating concrete base. A heat-treated, stress-relieved, primary steel liner and th non-stress-relieved, outer steel liner are inside the concrete shell. These tanks were made to hold aging waste from PUREX and B Plant. Maximum design temperatures in the tanks are: $350^{\circ} \mathrm{F}$ for sludge, $220^{\circ} \mathrm{F}$ for vapor, and $260^{\circ} \mathrm{F}$ for liguid. The tanks are at the same elevation and contain no cascade lines between tanks.

A color aerial photograph taken in 1993 of the Az Tank Farm shows the orientation of the 100 series tanks, leak detection pits, annulus ventilation equipment, instrument house, and the 241-AZ-152 Diversion (Sluice Transfer) Box. 


\section{AZ TANK FARM}

WHC-SD-WM-ER 350, Rev. 0 .

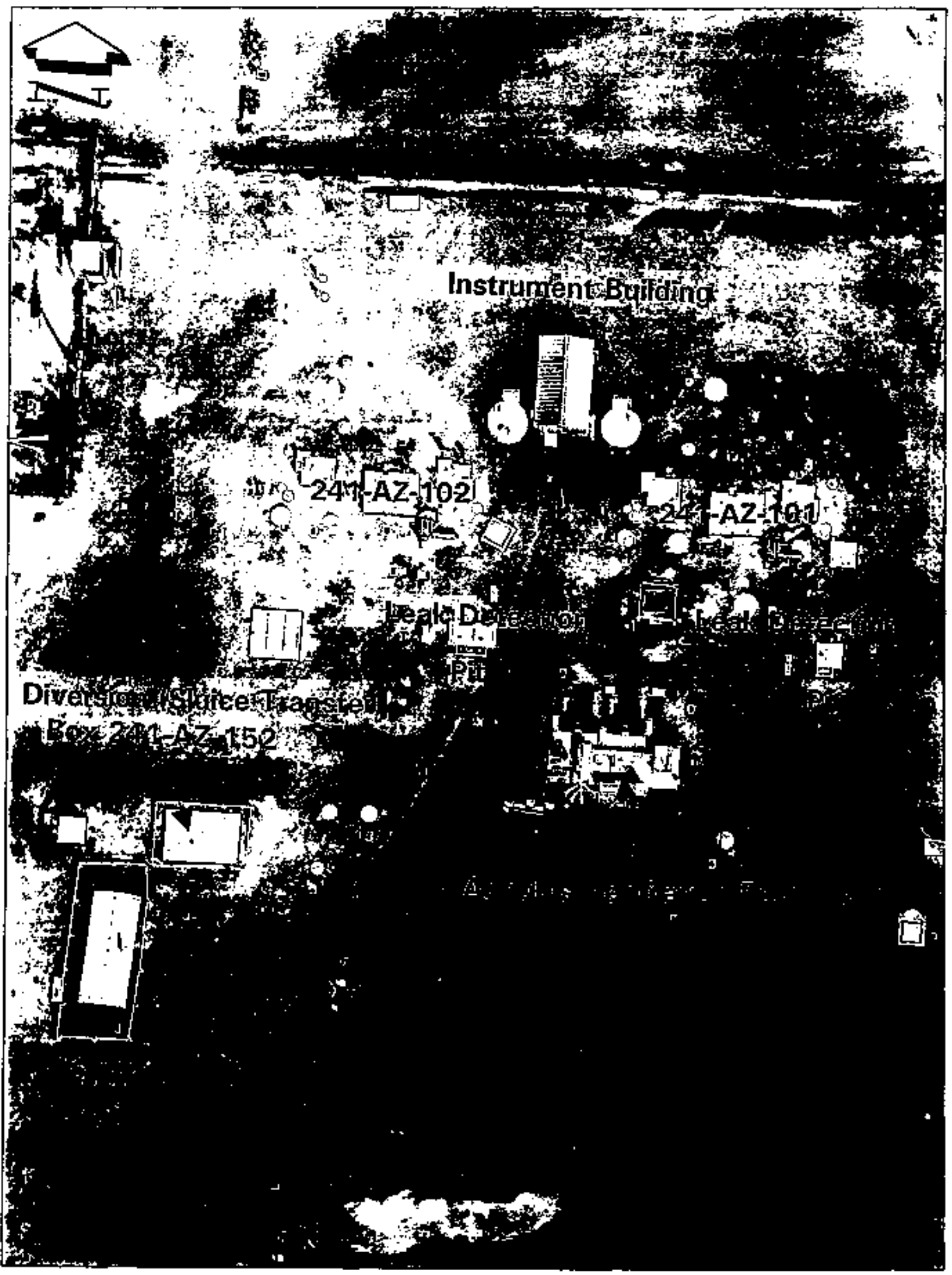


WHC-SD-WM-ER-350, Rev. O

\subsubsection{Az Tank Farm Waste History}

Both tanks in the Az Tank Farm are aging waste tanks and presently only recefve condensation from other aging waste tanks. Both tanks first received evapoxator waste in 1976 and conplexent concentrate waste in 1978 . Both tanks also received residual liquor, PUREx low-level waste, and noncomplexed waste while active. Tank 241-iz-101 received double-shell tank sluxry waste in 1978 .

\subsubsection{Az Tank Farm Temperature History}

The Az Tank Farm has thermocouples on the eir circulators and at various depths in the tank. Both tanks are recuired to have temperature readings recorded semiannumily and both are connected to the computer automated surveillance system. The computer automated surveillance system holds all the temperature data used to develop the statistical results for each tank.

\subsubsection{Az Tank Farm Occurrences}

Fifteen urusual events concerned A7 Tank Farm as a whole. Occurrence reports RL--HHC-Tank Farm-1993-0083 and RL--WHC-Tank Farm-1992-0012 concern equipment that was out of compliance with procedures. Occurrence report FL-WHC-Tank Farm-1993-0068 was written die to an unexpected waste transfer. Occurrence reports RL-WHC-Tank Farm-1993-0011, RL--WHC-Tank Farm-1991-1064, and RL--WHC-Tank Fanm-1991-0043; Off-Normal Reports 86-53, 86-22, 86-13, 86-10, and 85-39; and Unusual Occurrence Report 84-81 were written because falling equipment caused the tanks to pressurize. Dccurrence report RL-WHC-Tank Farm-I992-0016 concerns an electrical problem with the instrument panel. 才.0. Report 77-102 was written because radioactive material was found in the air sample filters of each tank annulus. For more information, refer to the supporting Document for the Southeast Quadrant HTCE for AZ Tank Farm (Brevick, 1995).

\subsubsection{A2 Tank Farm Ventilation}

Under the current syster, each tank is designed to have 2,000 CFM of atr travel through the anmulus. Air enters the tanks by infiltration because there is no supply fan. The tank air ducts are joined after leeving the tanks and the air is sent to the 702-A primary ventization system (the same system that AY rank Farm uses). In the arrulus system, ais enters a heating coil, two prefilters, and a HEPA tilter, before the duct is split so air can enter each tank's annulus. After traveling through each anmulus, the air enters two heaters and two HEPA Eilters before the ducts are joined for the 7,040 CFM exheust fan. The tank system shares the beckup system with the AY Tark Farm. For more information, refer to drawings H-2-92964, sheets 1 and 2 , and H-2-35749.

The psychrometric data are recorded in two parts, the tank data and the annulus data. For water and heat leaving the tank, the numbers are positive. Psychrometric data have been recorded for 14 years on the 


$$
\text { MHC-SD-MM-ER-350, Rev. } 0
$$

annuli. Two psychrometric data points were recorded almost one year apart for each of the tanks. Due to the small amount of data from within the tanks, no plots were made to display the data graphically. For more information, refer to the supporting Document for the Southeast ouadrant HTCE for AZ Tank Farm (Brevick, 1995).

\subsubsection{Current Status of Az Tank Farm}

Tanks 241-Az-101 and -102 in the AZ Tank Fezm are both indctive. Al1 tanks are actively ventilated and categorized as sound. The waste volume currently totals 1,911,000 gallons. The estimated volumes (Agnew, January 1994) depicted in each tank cross-section tota1 1,905,000 gallons of waste. At the tims of the estimats, there were 1,833,000 gallons of supernatant with 2,000 gallons of concentrated supernatant solids; 40,000 gallons of PUREX high-level waste (P3); 1,000 gallons of B Plant low-level waste (BL); 4,000 galions of PURBX low-level waste (PL2); 1,000 gallons of waste from z Plant; and 26,000 gallons of unknown waste (UNK) which could be waste that was sent to B plant for strontium recovery (SRR).

\subsection{Tank 241-AZ-101}

6.1.1 241-AZ-101 Tank History

6.1.1.1 Waste History of Tank 241-AZ-101

Tank 241-AZ-101 began service by receiving evaporator waste in the fourth quarter of 1976. The tank continued to receive evaporator waste until the fourth quarter of 1977. From the first guartex of 1978 until September 1980, the tank received complexed waste, double-shell slurry feed waste, non-complexed waste, water, evaporator waste, residual liquor, and complexant concentrate waste. The tank received non-complexed waste from october 1980 until January 1984. From the first guarter of 1981 until the first cuarter of 1986 , the tank received waste from PUREx. The tank has contained aging waste from February 1984 until the present. The tank is currently an inactive, concentrated waste holding tank that receives only condensate from other aging waste tanks.

\section{1 .1 .2 Temperature History of Tank 241-Az-101}

Temperature data for Tank 241-Az-101 are recorded by $15^{\text {thermocouples }}$ affixed at known elevations on seven thermocouple trees inside the tank. The thermocouple trees are located in risers $13 \mathrm{~A}, \mathrm{~B}, \mathrm{C}, \mathrm{B}$ and $16 \mathrm{~A}, \mathrm{~B}, \mathrm{C}$. There are between one and three thermocouples on each tree. Non-suspect temperature data for ell 15 thermocouples taken between July 1983 and uarch 1988 were available from the computer automated surveillance system. However, not all of the 15 thermocouples have data that encoupass the entire length of time. Non-suspect temperature data for all 15 of the thexmocouples were available from the data sheets recorded between November 1989 and April 1990. Within the time span of the computer automated surveillance system, there were several small breaks in the seculence of the temperature data. Within the time span of the manually recorded data, there were no significant breaks in the sequence of temperature data. The 
average temperature during these periods was $148^{\circ} \mathrm{F}$ with a minimum of $63^{\circ} \mathrm{F}$, a moximum of $263^{\circ} \mathrm{F}$, and a standard deviation of $40^{\circ} \mathrm{F}$. Linear regrestions were performed on each thermocouple over the life of the tank. The slopes from these regressions were averaged with a resulting average slope of 0.014. Refer to the supporting document for a more thorough review of the temperature date (Brevick, 1995).

\subsubsection{Occurrences of Tank 241-Az-101}

Five unusual events occurred at tank 241-Az-101, occurrence report RI--WHC-Tank Faxm-1992-0085 was witten due to procedural reguirements not being met. TFS \& 0-EFS-88-007 and off-Wormal Report 86-52 were written due to unexpected waste transfers. Off-Nozmal Report 86-16 concerns the tank pressurizing from an equipment failure. Unusual Occurrence Report 84-17 was written because of equipment filiure.

\section{1 .1 .4 Psychrometrics of Tank 241-Az-101}

The trend in the rates of heat exchange through the annular ventilation shows an increase from October 1900 to November 1994. This would suggest an increase in the rate of heat generation in Tank 241-A2-101, but no corroborating data from the tank ventilation exists.

\subsubsection{Current status of Tank 241-Az-101}

Tank 241-Az-101 entered service in November 1976 and currently stores 965, 000 gallons of waste. The following plan view and tank cross-section depict the approximate waste volune of 931,000 gallons and configuration of risers as of January 1994. At the time of the estimate, there were 902,000 gallons of superratant, 27,000 gallons of PUREx high-level waste (P3), 1,000 gallons of B Plant low-level waste (BL), and 1,000 gallons of PUREX low-level waste (PL2). The waste level in the tank is measured with the manual tape and has increased and decreased from January 1991 to January 1994. The increases and decreases were mostly flush water from miscelianeous sources between January 3991 and Januzry 1994 . The tank is actively ventilated and categorized as sound. Tank 241-Az-101 has 117 risers. Three 4-inch risers (no.SB, no.11A, and no.30A), ten 6-inch riser (no.15A, no.15B, no.15C, no.15D, no.15E, no.15G, no.15H, no.15I, no.15J, and no.15K), and one 42-inch riser (no.7B) are available for use.

\subsubsection{Inventory Estimate of Tank 241-Az-101}

The tank layer model (a volume based approximation) that follows was derived from the Los Alamos National Laboratory waste status and Transaction Recora summery (Agnew 1995) and Supernatant kixing Model (Agnew 1995). The estlmated inventories of total waste, solids, and supernatant in Tank 241-Az-101 are also presented.

\subsubsection{In-Tank Photograph of Tank 241-Az-101}

In April 1994, Tank 241-Az-101 contained 949,000 galions of high level or neutralized current acid waste from PUREx (Hanlon 1994) with a waste 


$$
\text { WHC-SD-WM-ER-350, Rev. } 0
$$

depth of about 29 feet. The most recent collage for this tank is 11 years old and was assembled from photographs taken in August 1983. At that time, the tank contained 650,000 gallons of non-complexed waste (McCann 1983). since the waste type and level have changed, the waste surface will not appear the same now as it did in 1983. These photographs do, however, provide an accurate picture of equipment inside the tank. This tank has more instruments and auxiliary equipment than other waste storage tanks because it is one of the four double-shell tanks containing aging waste. Monitoring instruments identified in this picture include three temperature probes, four level probes, and three drywells. The tank contains air lift circulators, heating coils, drains, risers, and ports.

6.1.3 Synopsis of Tank 241-Az-101

(To be completed.) 


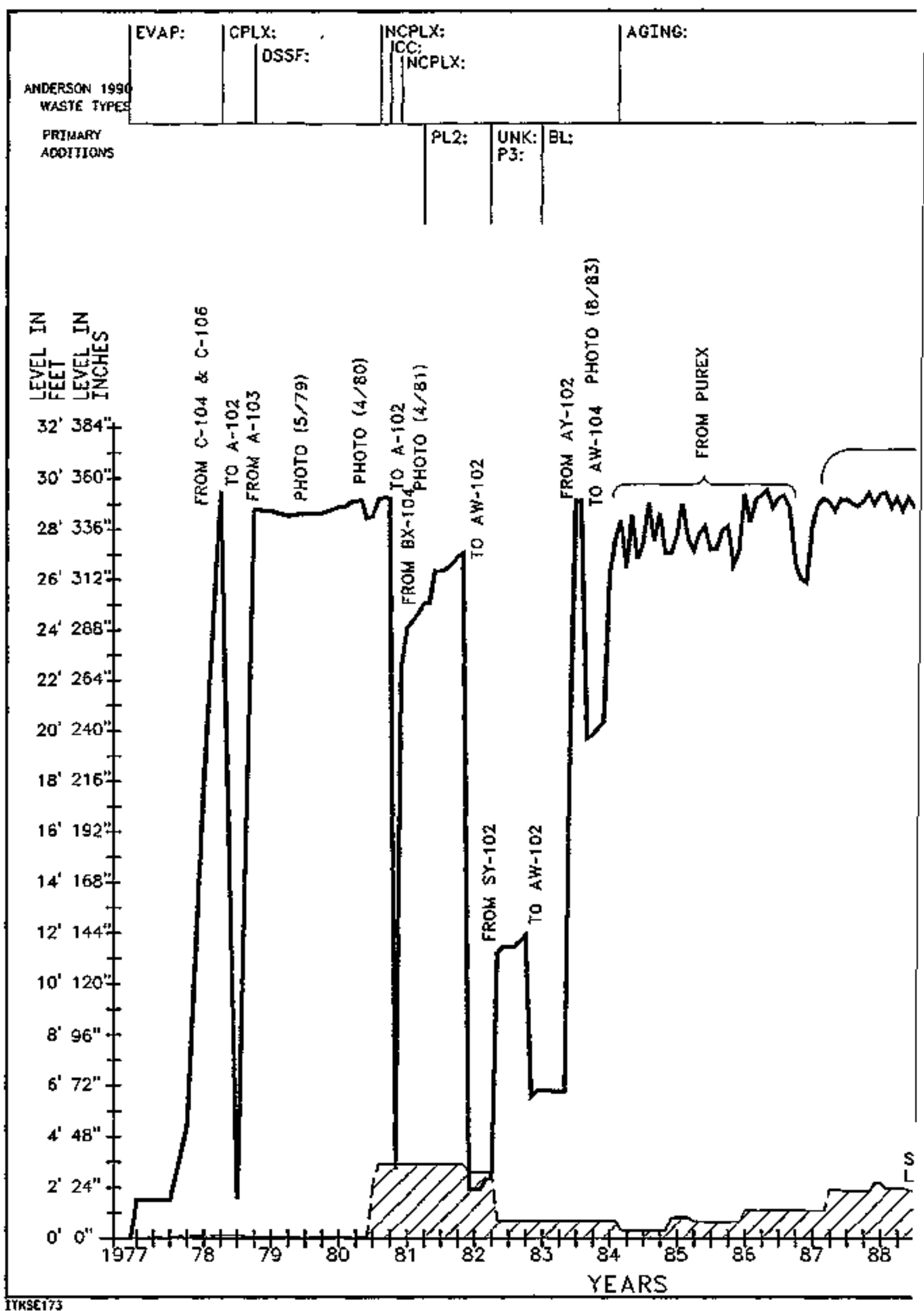


NOTES:

CONSTRUCT 1971-1977

NOMINAL CAPACITY: 1 OOD DO0 GAL

FLAT BOTTOM TANK, NO KNUCKLE.

75 FOOT DIAMETER DOUBLE-SHELL TANK SURFACE LEVEL READING: PHOTO

(LIOUIOS \& SOLIDS), FIC (SOLIOS)

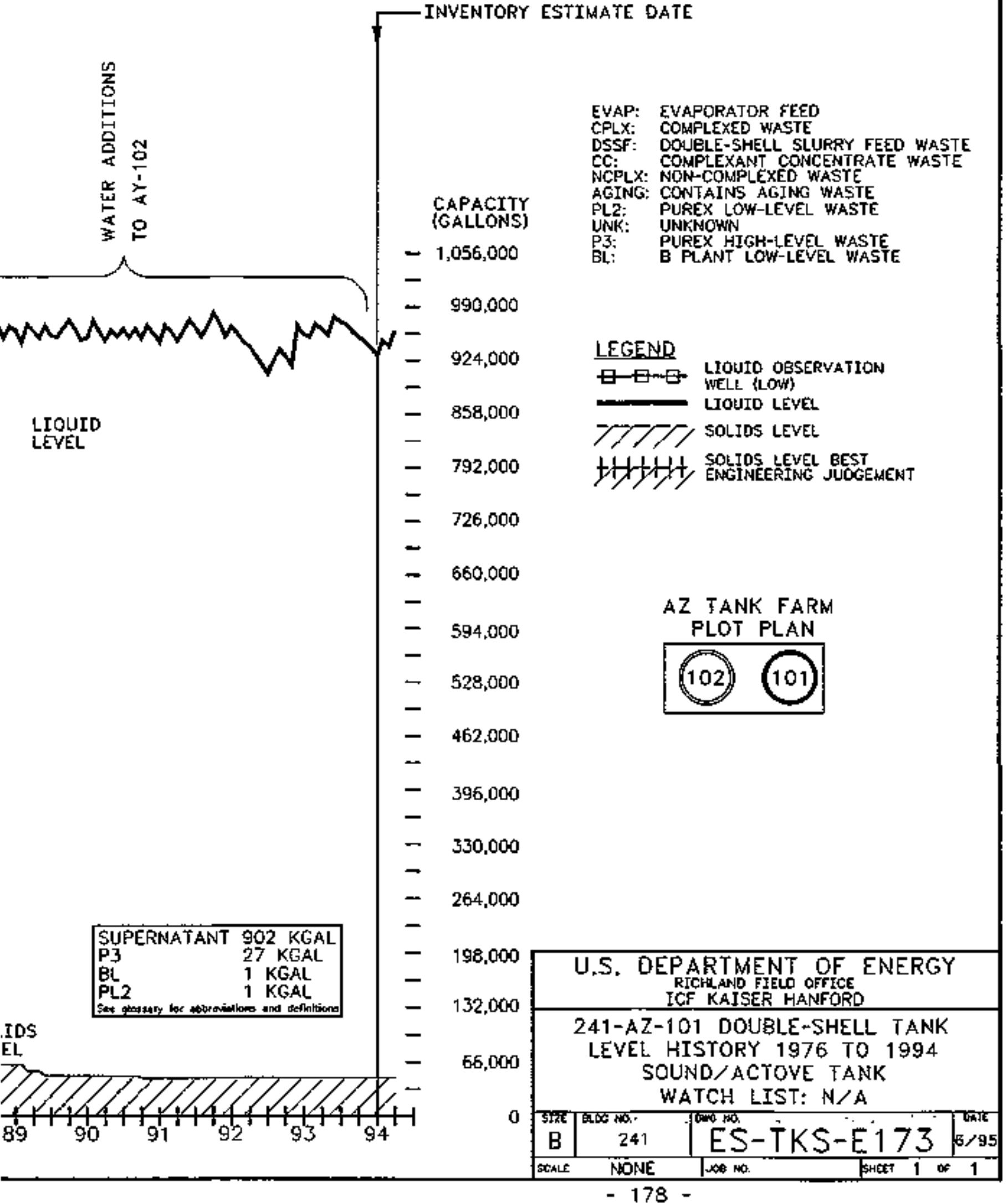


HHC-SD-HM-ER-350, ReV. 0

\begin{tabular}{|c|c|c|c|}
\hline \multicolumn{4}{|c|}{ Double-Shell Tank 241-AZ-10 1 } \\
\hline \multicolumn{4}{|c|}{ Tound hretoliay Bsilntate } \\
\hline \multicolumn{4}{|c|}{ 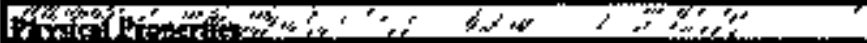 } \\
\hline Totol Warte & $4.03 \mathrm{~g}+06 \mathrm{~kg}$ & (931 kgl) & \\
\hline Her Laed. & \multicolumn{3}{|c|}{$115 \mathrm{~kW}$ (3.2948405_BTUAr) } \\
\hline Bulk Densitht & \multicolumn{3}{|c|}{$1.14(p / \infty)$} \\
\hline Water wht & \multicolumn{3}{|c|}{80.3} \\
\hline TOC wit\%C & \multicolumn{3}{|c|}{0.159} \\
\hline \multicolumn{4}{|c|}{ 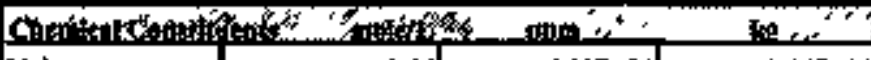 } \\
\hline $\mathrm{Na}^{+}$ & 3.04 & \multicolumn{2}{|l|}{ 6.11E+0.04 } \\
\hline$A E^{*}$ & 0.380 & \multirow{2}{*}{$\frac{2,078+103}{449 F+03}$} & 3.6SEHAd \\
\hline fe" (mal Fe) & $9.19 \mathrm{e}-02$ & & \multirow{2}{*}{$\frac{1.81 \mathrm{~B}+04}{448}$} \\
\hline Gestr & 2,4E-03] & IN] & \\
\hline Apt & 8.81E-0S] & $\mid 6,1]$ & 64.9 \\
\hline $1 \mathbf{2}^{2}$ & 6.92E-07 & 76:ege & 0.30 \\
\hline $\mathrm{Hg} \mathrm{s}^{*}$ & $5.415-07$ & 9.50000 & 0389 \\
\hline \multirow{2}{*}{ 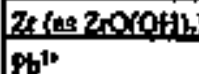 } & 5.1720 .5 & $4.0 \%$ & 164 \\
\hline & $7.69 \mathrm{E}-06$ & 139 & \multirow{2}{*}{$\frac{5.61}{2.1}$} \\
\hline $\mathrm{Ni}^{1+*}$ & $1,078-9 \mathrm{~F}$ & 5,9 & \\
\hline $\mathrm{s}^{5}$ & 6.68E-07] & 5.12E-02 & 0.206 \\
\hline Mhe & 7298204 & 3.4 & 155 \\
\hline Cي.' & $1,32 \mathrm{E}-12$ & 602 & $2,43 \mathrm{E}+103$ \\
\hline $\mathbf{K}^{+}$ & 1.9720 .5 & 67.4 & 272 \\
\hline OH- & 20) & $4.318+04$ & {$[.74 \mathrm{E}+0 \mathrm{~S}$} \\
\hline NO: & 0.563 & $3,058+404$ & {$[.735+408$} \\
\hline NO; & 0,471 & L90E+에 & 2,64E+64 \\
\hline $\boldsymbol{\alpha}^{2}$ & $8.66 \mathrm{E}=03$ & $4.55 \mathrm{E}+003$ & $1.83 \mathrm{E}+50 \mathrm{~A}$ \\
\hline $\mathrm{PO}^{2}$ & 1.36E-02 & L.13E+03 & 4.54E+03 \\
\hline $\mathrm{SO}^{3}$ & 0.121 & [A]IE+1)] & 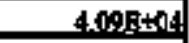 \\
\hline $86(x \leq 50,3)$ & 7.35E-02 & I.81E+03 & $7.30 \mathrm{E}+03$ \\
\hline$E$ & 2A6E- 09 & 409 & $1.65 \mathrm{E}+1 \mathrm{n}$ \\
\hline$a$ & 5.34E-02 & $1.66 \mathrm{E}+03$ & $6.67 \mathrm{E}+0.3$ \\
\hline ChHo2 & 4.01E-03 & 796 & $3,2\{18+0,3$ \\
\hline $\operatorname{seg} A^{4}$ & $1.43 \mathrm{E}-0 \mathrm{a}$ & 361] & L.ASB+03 \\
\hline HET $\mathrm{A}^{2}$ & $2.37<09$ & 569 & $2,29 \mathrm{E}+0 \mathrm{0}$ \\
\hline Plvealotes: & $3.97=-09$ & $2618+02$ & I.ASE:A4 \\
\hline $\cos 1015$ & $1.58 \mathrm{~B}-0 \mathrm{~g}$ & $t|a+7|$ & 329 \\
\hline gxallitet & 2.79g-06 & a.18건 & 0.740 \\
\hline Dep & $1 \mathrm{AGE}-0 \mathrm{OA}$ & 200 & 828 \\
\hline Intand & 1 A6E: 0 S & 99.51 & 381 \\
\hline $\mathrm{NH}$ & $1.5[a, 0]$ & 225 & 907 \\
\hline $\mathrm{PA}(\mathrm{CN})_{0}^{+}$ & $d$ & of & 0 \\
\hline 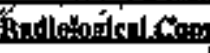 & 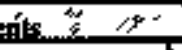 & $\because 6=6 i x$ & 纱 \\
\hline$P_{0}$ & & $0.156(\mu \mathrm{Ct} / \mathrm{s})$ & $10.4(\mathrm{~kg})$ \\
\hline II & $280 E-02(M)$ & $5.84 k+03(1, v d x)$ & $235 \mathrm{sin}+0.4 \mathrm{~kg}$ \\
\hline$\underline{Q}$ & 2.64:Cill & 2.31E+o3 (uCHs) & 9.3010+06(C) \\
\hline sr & 3.02 (Cil) & $264 \mathrm{~B}+03(\mu \mathrm{C} d \mathrm{~s} s)$ & $1,07 \mathrm{~B}+07(\mathrm{Ci})$ \\
\hline
\end{tabular}

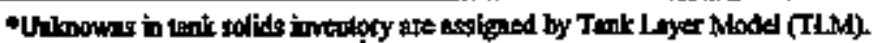

tVolume swenge for dertity, wases averaso Water we\% and TOC w\% C.

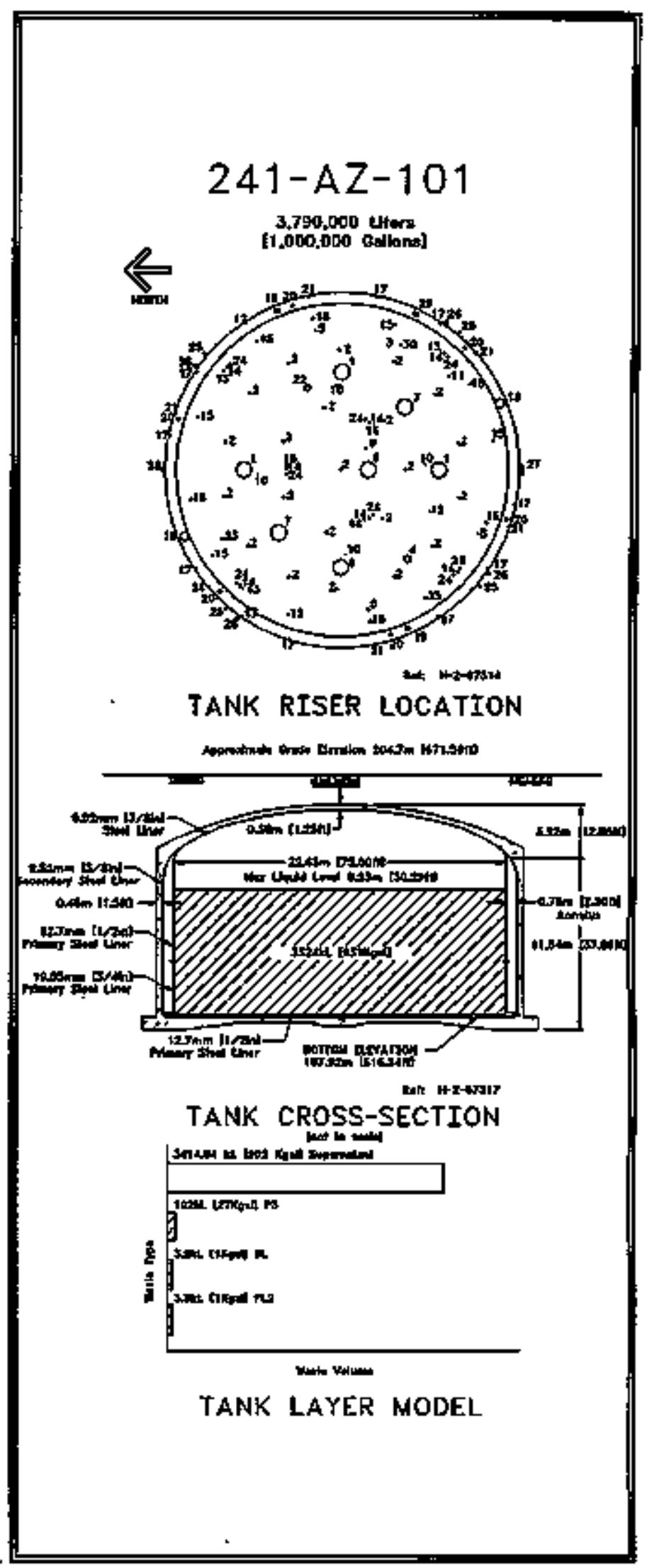


NHC-SD-WH-ER-350, Rev, 0

\begin{tabular}{|c|c|c|c|}
\hline \multicolumn{4}{|c|}{ Double-Shell Tank 24l-AZ-101 } \\
\hline \multicolumn{4}{|c|}{ 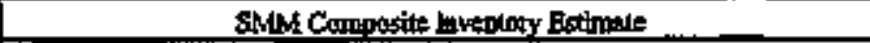 } \\
\hline 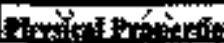 & $\because \because$ & 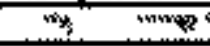 & $\operatorname{san} 5$ \\
\hline Total Superpinam & $3.84 \mathrm{E}+06 \mathrm{~kg}$ & (902 kgal) & \\
\hline Hathed & \multicolumn{3}{|c|}{$40.5 \mathrm{~kW}(1.38 \mathrm{P}+05 \mathrm{BTU} / \mathrm{hrd}$} \\
\hline Bulk:Densint: & \multicolumn{3}{|c|}{$1.12\{0 / 00)$} \\
\hline Watur wet & \multicolumn{3}{|c|}{81.7} \\
\hline$T O C, w \%(n+\infty)$ & \multicolumn{3}{|c|}{0.167} \\
\hline \multicolumn{4}{|c|}{ 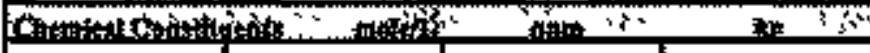 } \\
\hline $\mathbf{S a t}^{*}$ & 297 & $6.08 \mathrm{E}+04$ & $2.33 \mathrm{E}+0.5$ \\
\hline$A^{p+2}$ & 0.369 & B.4E+0? & $3,39 \mathrm{E}+\mathrm{ON}$ \\
\hline $\mathrm{Pe}^{*}$ (kgth $\left.\mathrm{F}_{0}\right)$ & $1.94 \mathrm{E}-03$ & 96.4 & 370 \\
\hline 온 & 2.51E-093 & 116 & 444 \\
\hline Bज" & $9.10 \mathrm{E}-0 \mathrm{~S}$ & 16.9 & 640 \\
\hline 1. & 6.52?E--07| & 8,$0 ; 0-10$ & a.ton \\
\hline $4=$ & $5.598-07$ & $9,97 \mathrm{E}-02$ & 0,389 \\
\hline 7. $7 \mathrm{as} \mathrm{OSOHL}$ & 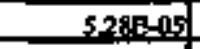 & 4.28: & 164 \\
\hline 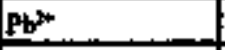 & $7.89 \mathrm{eng}$ & 1.4.5 & 5,58 \\
\hline$N^{20}$ & 6.148,nat & 25.1. & 129 \\
\hline$s$ & $6.890-07$ & $5.395-02$ & 0.206 \\
\hline $\mathrm{Mn}^{*+}$ & SUAEASA & 40,A & 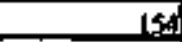 \\
\hline $\mathrm{Co}^{*}$ & 1.36E- -02 & 484 & $1.86 \mathrm{E}+03$ \\
\hline $\mathrm{x}^{*}$ & 203E-A3 & 70.5 & 271 \\
\hline O\&- & 2.43 & $3.68 \mathrm{E}+0.04$ & $1.41 \mathrm{E}+0 \mathrm{~S}$ \\
\hline No: & 0.575 & $3,196+(1)$ & 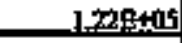 \\
\hline $\mathrm{NO}$ & 0.474 & $1.94 E+04$ & $7,45 E+04$ \\
\hline $\cos ^{2}$ & $2.498=02$ & $453 \mathrm{E}+03$ & $-1.74 \mathrm{E}+0 \mathrm{~A}$ \\
\hline Po: & L.39E-OQ & L+HER+05: & $4.51 \mathrm{~B}+05$ \\
\hline $\mathrm{se}^{2}$ & 0,121 & 1.04E +04 & $3.97 \mathrm{~g}+04$ \\
\hline $\mathrm{Si}\left(\mathrm{s} \mathrm{S} \mathrm{SO}^{2}\right)$ & 2.985-002 & 744 & $286 \mathrm{E}+03$ \\
\hline$F$ & $2478=00$ & 417 & $1.60 \mathrm{~g}+107$ \\
\hline ct & $5.38 \mathrm{E}-02$ & $1.70 \mathrm{E}+00$ & $6.51 E+05$ \\
\hline C.H. ${ }^{2}$ & $4,060-0.93$ & gat: & $3.20 \mathrm{~F}+1 \mathrm{~g}$ \\
\hline EDrA ${ }^{4}$ & $1.48 \mathrm{E}-09$ & 379 & $245 \mathrm{E}+09$ \\
\hline 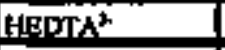 & $245 \mathrm{E}-09$ & 597 & $2,298+10$ \\
\hline 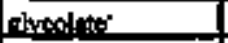 & AABRE-OS & $2726 \mathrm{E}+10 \mathrm{R}$ & $1,0.5 \mathrm{P}+04$ \\
\hline Erates' & $1.63 E-03$ & 85.7 & 329 \\
\hline$x+1 m \theta^{2}$ & $246 E-0.61$ & 0.193 & 0.740. \\
\hline DEP & $1.50 \mathrm{E}-03$ & 215 & 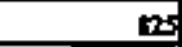 \\
\hline byat:al L & 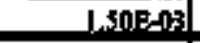 & 990 . & 380. \\
\hline $\mathrm{N} \mathrm{H}_{\mathrm{H}}$ & $1.518,0.2$ & 229 & 828 \\
\hline $\mathrm{F}=(\mathbf{O})_{0}{ }^{4}$ & of & of & 0 \\
\hline 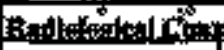 & latens - . & $\operatorname{mon} \backslash x$ & $\operatorname{man}$ \\
\hline $\mathrm{Pa}$ & 37.1 ( $\mu$ CNA) & & 2.11 (ks) \\
\hline u & 356 E-03 (M) & 753 (U⿴囗十丁) & $2.89 \mathrm{E}+0.30 \mathrm{sv}$ \\
\hline cs. & $257(\mathrm{C} / \mathrm{A})$ & $2.248+09$ (1 & $8.61 \mathrm{E}+06(\mathrm{C}) \mathrm{t})$ \\
\hline $\mathbf{S}$ & 6.58E-03 (Cir). & $3.85(\mu \mathrm{Cin} n)$ & $22 \leqslant E+04$ (C) \\
\hline
\end{tabular}

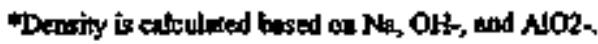

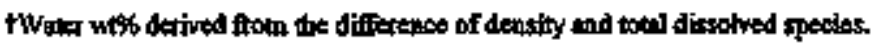

\begin{tabular}{|c|c|c|c|}
\hline \multicolumn{4}{|c|}{ Double-Shell Tank 241-AZ-101 } \\
\hline \multicolumn{4}{|c|}{ 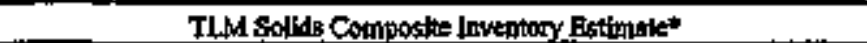 } \\
\hline \multicolumn{4}{|c|}{ 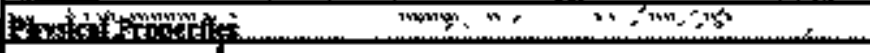 } \\
\hline Total Solid Weste & $1.89 \mathrm{E}+05 \mathrm{~kg}$ & $(29 \mathrm{~g}, \mathrm{~g} \mathrm{l})$ & \\
\hline Henlow & $74,8 \mathrm{~kW}$ & 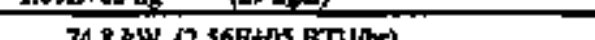 & \\
\hline 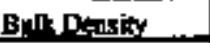 & \multicolumn{3}{|c|}{ 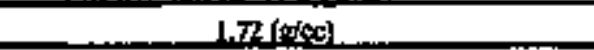 } \\
\hline Water wot & \multicolumn{3}{|c|}{52.1} \\
\hline TOC whts C (wet) & \multicolumn{3}{|c|}{ O.SEO } \\
\hline \multicolumn{4}{|c|}{ 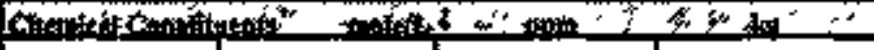 } \\
\hline $\mathbf{N r}^{*}$ & 5.02 & $6.70 \overline{\mathrm{E}+04}$ & $1278+04$ \\
\hline $\mathrm{All}^{\mathrm{l}^{4}+}$ & 0.875 & $\pm .32=04$ & $2.598+00$ \\
\hline$F^{2}$ (lotal Fo) & 289 & $9.32 \mathrm{E}+0 \mathrm{~d}$ & $1.77 \mathrm{E}+0 \mathrm{~d}$ \\
\hline 논 - & 2 FA에 04 & 76 & $\mathbf{1 . 4 5}$ \\
\hline \multicolumn{4}{|l|}{$\mathrm{Bi}^{*}$} \\
\hline \multicolumn{4}{|l|}{ mats } \\
\hline \multicolumn{4}{|l|}{ 岁? } \\
\hline \multicolumn{4}{|l|}{ 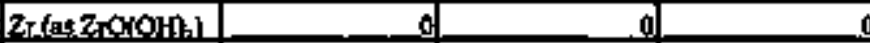 } \\
\hline $\mathrm{Pt}^{2 *}$ & 1.38E-06 & 0.166 & $3.13=-02$ \\
\hline $\mathrm{Ner}$ & L经E -02 & 5201 & 28.2 \\
\hline \multicolumn{4}{|l|}{$\mathrm{sr}^{\mathrm{a}}$} \\
\hline \multicolumn{4}{|c|}{ 1SOSESOL } \\
\hline $\mathrm{Ca}^{2 *}$ & 0.129 & 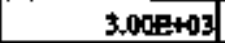 & 566 \\
\hline $\mathbf{K}^{+}$ & 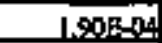 & 4.37 & 0.816 \\
\hline 아: & 17.4 & $1.20+0 s$ & $.24 E+04$ \\
\hline No: & 0.139 & 5,0000003 & 246 \\
\hline No: & 0,37 & $1.01 \mathrm{E}+0 \mathrm{at}$ & $1.9005+03$ \\
\hline $\mathrm{CO}^{2}$ & 0.139 & $485 \mathrm{~B}+03$ & 917 \\
\hline $\mathrm{PO}_{4}^{2}$ & 2.496.09 & 137 & 26.0 \\
\hline $\mathrm{SO}^{2}$ & $0.10 \times$ & $5.860 \mathrm{R}+10]$ & $\mathrm{L} .11 \mathrm{E}+103$ \\
\hline $\operatorname{Si}\left( \pm \mathbf{S i O}^{2}, \mathrm{y}\right.$ & 1.44 & $2.35 E+04$ & 4.45E+0: \\
\hline$E$ & 226509 & $25: 0$ & 473 \\
\hline c. & 4.01E-02 & 20: & 150 \\
\hline C.r. & $432 \mathrm{~F}-0 \mathrm{O}$ & 47.4 & 89 \\
\hline \multicolumn{4}{|l|}{ EOTA* } \\
\hline \multicolumn{4}{|l|}{ Hadotst } \\
\hline anolns: & $5.76 \mathrm{E} ! \mathrm{n}$ ? & 251 & $42 A$ \\
\hline \multicolumn{4}{|l|}{$\operatorname{scostan} \theta^{6}$} \\
\hline \multicolumn{4}{|l|}{ toxplm: $0^{2}$} \\
\hline DBP & 9.98E-05 & 15.4 & 2.90 \\
\hline brt:멍 & प9.98E-05 & 4,301 & 0.12 \\
\hline NH. & 1.500002 & 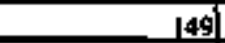 & 203 \\
\hline \multicolumn{4}{|l|}{$\mathrm{Fe}(\mathrm{CN})_{2}{ }^{-}$} \\
\hline \multicolumn{4}{|c|}{ 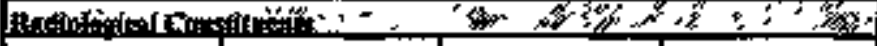 } \\
\hline Pu & & 2.65 (uCls) & $8.33(\mathbf{k g t})$ \\
\hline u & $0.7900 \mathrm{~m}$ & 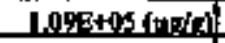 & 2.06E+04 $0 \mathrm{~kg}$. \\
\hline Cs & 6.39(C) & $3.68 \mathrm{R}+0.034 \mathrm{CC} / \mathrm{T}$ & E.9SE+0S(C) \\
\hline st & $96.8(\mathrm{CiL})$ & $\left.5.63 \mathrm{~g}+04(\mathrm{r} \text { 대 } 1)^{1}\right)$ & $1.06 \mathrm{E}+07(\mathrm{C})$. \\
\hline
\end{tabular}

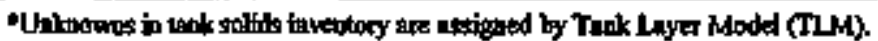





\subsubsection{1-AZ-102 Tank History}

\subsubsection{Waste History of Tank 241-AZ-102}

Tank 241-AZ-102 began service by receiving water in the second guarter of 1976 and was labeled as a spare. The tank received evaporator waste from the third quarter of 1976 until the second quarter of 1977. During the third and fourth guarters of 1977, the tank received residual liquor waste. The tank received complexant concentrate waste from the first cuarter of 1978 until November 1983. During December 1983 and January 1984, the tark received complexed waste. From February 1984 until February 1986, the tank received non-complexed waste. The tark received waste Erom PUREX from the first quarter of 1986 until the first guarter of 1990. From April 1996 until the present, the tank has contained aging waste. The tank is currently an inactive, dilute receiver tank that receives only condensate from other aging waste tanks.

\subsubsection{Temperature History of Tank 241-AZ-102}

Temperature data for Tank 241-AZ-102 are recorded by 15 thermocouples affixed at known elevations on seven thermocouple trees inside the tank. The thermocouple trees are located in risers 13A, B, C, D and $16 \mathrm{~A}, \mathrm{~B}, \mathrm{C}$. Between one and three thermocouples are on each tree. Non-suspect temperature data taken between July 1983 and February 1990 for all 15 thermocouples were aveilable from the computer automated surveillance system. However, not all of the 15 thernocouples have tata that encompass the entire length of tims. Non-suspect temperature data recorded between April 1990 and September 1990 for all 15 of the thermocouples were available from the data sheets. Within the time span of the computer automated surveillance systen, there were several small breaks in the sequence of the temperature data. Within the time span of the manually recorded data, there were no significant breaks in the sequence of temperature data. The average temperature during these periods was $116^{\circ} \mathrm{F}$ with a minimum of $54^{\circ} \mathrm{F}$, maximum of $249^{\circ} \mathrm{F}$, and a standard deviation of $48^{\circ} \mathrm{F}$. Lineor regressions were performed on each thermocouple over the life of the tank. The slopes from these regressions were averaged with a resulting average slope of 0.029 . Refer to the supporting docunent for a more thorough review of the temperature date (Brevick, 1995).

\subsubsection{Occurrences of Tank 241-AZ-102}

Four unusual events occurred at tank 241-Az-102, TFS \& 0-EFS-89-063 concerns a bent riser. TFS \& O-EFS-88-18 and Unusual Occurrence Report 76-143 were written due to equipment failures. Unusual Dccurrence Report 84-21 was written duse to an unexpected waste transfer.

6.2.1.4 Esychrometrics of Tank 241-Az-102

The trend in the rates of heat exchange through the annular ventilation shows an increase from October 1980 to November 1994. This 
WHC-SD-WM-ER-350, Rev. 0

would suggest an increase in the rate of heat generation in Tank 241-AZ -102, but no corroborating data from the tank ventilation exists.

\subsubsection{Current Status of Tank 241-Az-102}

Tank 241-AZ-102 entered service in November 1976 and currently stores 946,000 gellons of waste. The following plan view and tank cross-section depict the approximate waste volume of 974,000 gallons and configuration of risers as of January 1994. At the time of the estimate, there were 931,000 gelions of supernatant with 2,000 gallons of concentrated supernatant solids; 13,000 gallons of PUREx high-level waste (P3); 1,000 gallons of $\mathbf{z}$ Plant waste (Z); 3,000 gallons of FURkX low-level waste (PL2); and 26,000 gallons of unknown waste (UMK) which could be waste that was sent to $\mathrm{Blant}$ for strontium recovery (SRR). The waste level in the tank is measuzed with the manual tape and has increased and decreased from January 1991 to January 1994. The increases and decreases were mostly flush water from miscellaneous sources between January 1991 and January 1994. This tank is inactive and only receives condensate from aging waste tanks. The tank is actively ventilated and categorized as sound. Tank 241-Az-102 has 117 risers. Two 4-inch risers (no.5B and no.11A), twelve 6-inch risers (no.15A, no.15B, no.15C, no.15D, no.15E, no.15F, no.15G, no.15H, no.15I, no.15J, no.15K, and no.15L), and one 42-inch riser (no.7B) are available for use.

\subsubsection{Inventory Estimate of Tank 241-Az-102}

The tank layer model (a volume based approximation) that follows was derived from the Los Alamos National Laboratory Naste status and Transaction Record Summary (Agnew, 1995) and Supermatant Mixing Model (Agnew, 1995). The estimated inventories of total waste, solids, and supernatant in Tank 241-AZ-102 are also presented. Concentrated supernatant solids are considered as an integral part of the liquid for the purpose of estimating inventories, but are graphed as solids on the level histories. The actual substance, which was derived trom double-shell slurry, appears as a solid if undisturbed, but the particles are resuspended in solution if heated or disturbed.

\subsubsection{In-Tank Photograph of Tank 241-Az-102}

In April 1994, Tank 241-Az-102 contained 961,000 gallons of high-Ievel or neutralized current acid waste from PUREX (Fanlon, 1994) with a wate depth of about 29 feet. The most recent collage for this tank is 10 years old; it was assembled from photographs taken in october 1984. At that time, the tank contained 220,000 gallons of non-complexed waste (Mccann, 1984). Since the waste type and level have changed, the waste surface will not appear the same now as it did in 1984. These photographs do, however, provide an accurate picture of the equipment in the tank. This tank has more instruments and auxiliary equipment than other waste storage tanks because it is one of the four double-shell tarks containing aging waste. Monitaring instruments identified in this picture include five tenperature probes, four level probes, and five drywel.1s. The tank contains air lift circulators, heating coils, and some drains and nozzles. 
6.2.3 Synopsis of Tank 241-AZ-102

(To be completed.) 


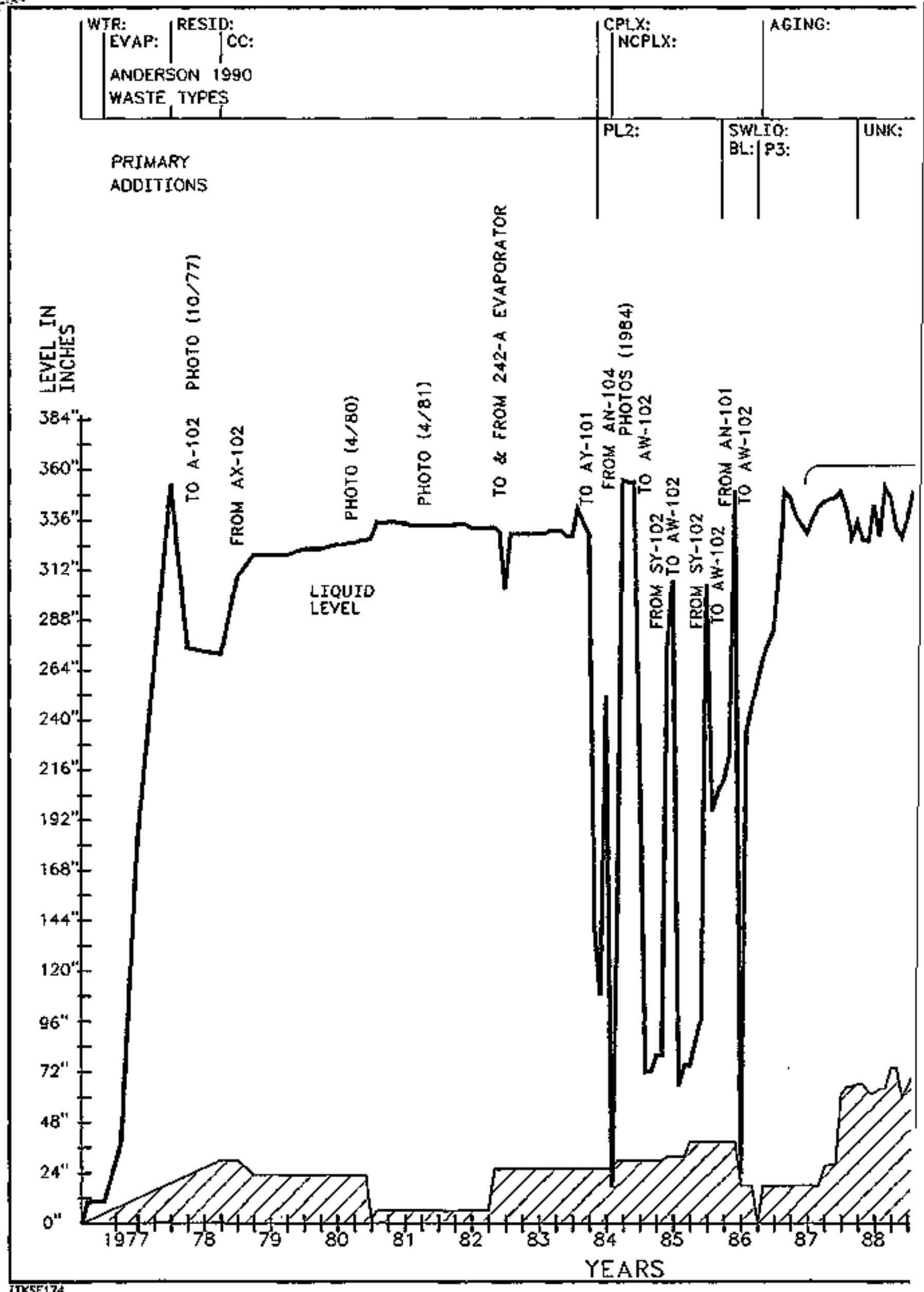


NOTES:

CONSTRUCT 1971-1977

NOWINAL CAPACITY: $1,000,000 \mathrm{GAL}$

FLAT BOTTOM TANK, NO KNUCKLE.

75 FOOI DIAMETER "DOUBLE-SHELI TANK

SURFACE LEVEL REAOING: PHOTO

(LIOUIOS \& SOLIOS). FIC (SOLIDS)

\section{INVENTORY E\$TIMATE DATE}

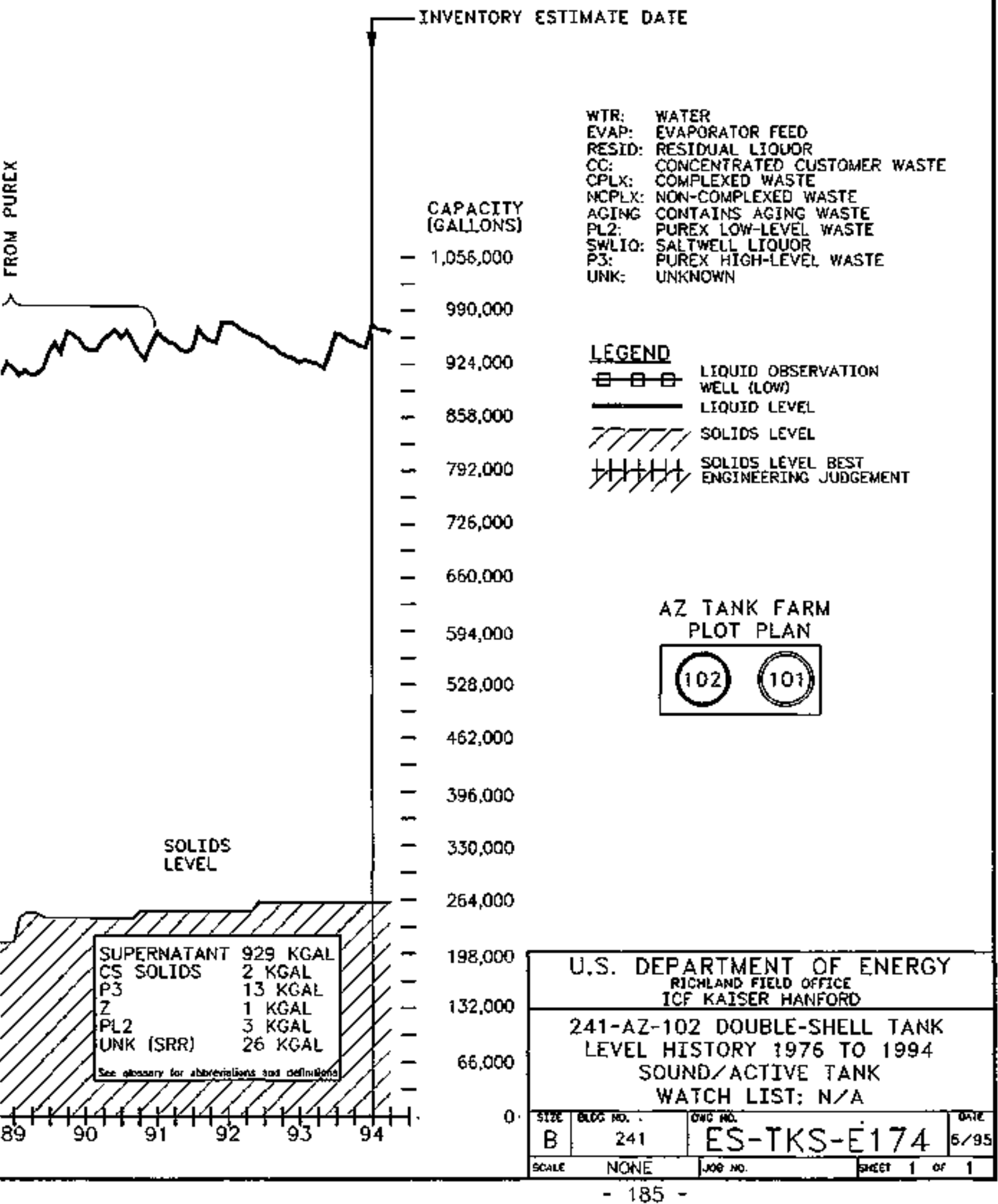


WHC-SD-WH-ER-350，Rev. 0

\begin{tabular}{|c|c|c|c|}
\hline \multicolumn{4}{|c|}{ Double-Shell Tank 241-AZ-102 } \\
\hline \multicolumn{4}{|c|}{ 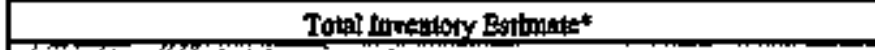 } \\
\hline \multicolumn{4}{|c|}{ 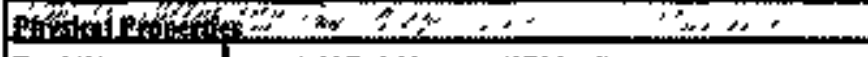 } \\
\hline & $3.39 \mathrm{get06 \textrm {Lg }}$ & (974 kat) & \\
\hline Hethoul & \multicolumn{3}{|c|}{$62,2 \mathrm{kw}(2,12 \mathrm{~g}+0 \mathrm{~S}$ (BTU/Ax) } \\
\hline 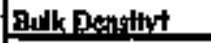 & \multicolumn{3}{|c|}{$1.05(0,0)$} \\
\hline Weer wrot & \multicolumn{3}{|c|}{92.5} \\
\hline TOC wac & \multicolumn{3}{|c|}{0.164} \\
\hline \multicolumn{4}{|c|}{ 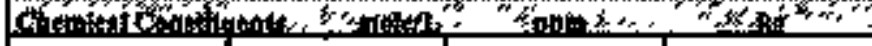 } \\
\hline $\mathrm{Sa*}^{*}$ & t.11 & $2.42 \mathrm{E}+0 \mathrm{~A}$ & $9.40 \mathrm{~B}+04$ \\
\hline$A A^{D+}$ & 0.1271 & $3.260+03$ & 1262404 \\
\hline$f=0$ & $6.862-02$ & $3.64 \mathrm{E}+03$ & $1.41 \mathrm{E}+04$ \\
\hline$\alpha^{*}$ & IPIE-01 & 5.97 & 23.2 \\
\hline$\theta+$ & $1.0 \mathrm{ge}-0.0$ & 0.215 & 0.036 \\
\hline 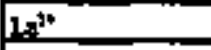 & $5 \Delta \pi R-19$ & 7.235E-04 & $2.80=-05$ \\
\hline $\mathrm{H}: \mathrm{s}^{*}$ & 7.13E-09 & 136E-03 & S.27E-AS \\
\hline $2,1 \times 2,05013,1$ & 6.89E-07] & 5.488002 & 0.232 \\
\hline$P t^{*}$ & $5,42 \mathrm{E}, 00$ & 0,100 & 0,414 \\
\hline Nitis & $4,66 \mathrm{E}-\mathrm{A}=1$ & 260 & 101 \\
\hline $\mathrm{si}^{*}$ & $5.7 \mathrm{BE}-09$ & $4,2,20,04$ & $1,87 \mathrm{E}-09$ \\
\hline $\min 4$ & 7npeos & 37 & 14.6 \\
\hline c: & $9.96 \mathrm{E}-09$ & 376 & $1.469+03$ \\
\hline $\mathbf{k}^{*}$ & g.13:-0.5 & 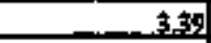 & | 13.2 \\
\hline OH: & 12A & $2.002+0.4$ & $7,75: 200$ \\
\hline : & 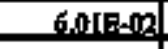 & 3.54:4t193 & $1,37 R_{t}+04$ \\
\hline Noi & 0.170 & $7,45 \mathrm{E}+0.03$ & $2.89 \mathrm{E}+0.04$ \\
\hline $\cos _{2}^{2}$ & 1.752002 & 1000 & $-3.898+02$ \\
\hline PO. ${ }^{2}$ & 8.9.anod & 80,4 & 3.2. \\
\hline $\operatorname{sos} 2$ & $4.80 \mathrm{e}-02$ & $4.39 \mathrm{~B}+0 \mathrm{~B}$ & $1.708+04$ \\
\hline sil $\left(\mathrm{u} S \mathrm{~s}, \mathrm{y}^{2}\right)$ & 5,6 BE:-02 & $1.52 \mathrm{E}+03^{3}$ & $5.888+09$ \\
\hline$F$ & $1.01 \mathrm{R}-0,9$ & 182 & 700 \\
\hline$\sigma$ & 1.83E-02 & 632 & $2.45 \mathrm{E}+03$ \\
\hline C.H. & 5.85E-AS & 10.5 & 40.8 \\
\hline EOTA & 3.71E-03 & 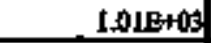 & $3.94 \mathrm{E}+0 \mathrm{z}$ \\
\hline HEDY: $A^{2}$ & $2,412-09$ & $-1.93 \mathrm{R}+0 \mathrm{0}$ & $2748+87$ \\
\hline olyeoltite" & 7.:48-0ㅇ & 559 & $2.17+ \pm 07$ \\
\hline meduro: & $1.90 \mathrm{~B}-0 \mathrm{~S}$ & 1.00 & 4,14 \\
\hline extlats- & 2.07ESOSP & $1,732,003$ & $6,700,003$ \\
\hline DBP & $5.20 \mathrm{E}-0 \mathrm{~A}$ & 8.99 & 34.6 \\
\hline huri!:shll & S20E-05 & 3.66. & 14.2 \\
\hline NH. & $6,71 \mathrm{E}_{-03}$ & 109 & 420 \\
\hline $\mathrm{Fe}(\mathrm{CN})_{3}^{4}$ & d & 0 & 0 \\
\hline 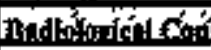 & 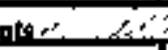 & 28.63 & Aُش \\
\hline Pu & & $0.154(\mathrm{p}$ & $9.99(\mathrm{~kg})$ \\
\hline$\underline{\mathrm{II}}$ & I.200.020 & 466 (4ted/T) & lofetod(ks) \\
\hline as & 138(C)L & $1.31 \mathrm{R}+03$ ( & 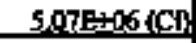 \\
\hline \$. & $1 . \$ \$(C) L)$ & $1.47 \mathrm{~B}+03(\mu \mathrm{C}) \mathrm{s})$ & $5.70 \mathrm{E}+96(\mathrm{CO})$ \\
\hline
\end{tabular}

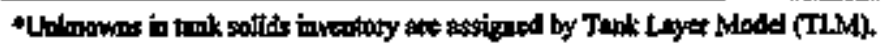

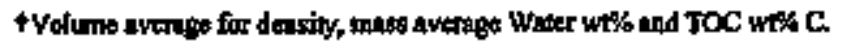

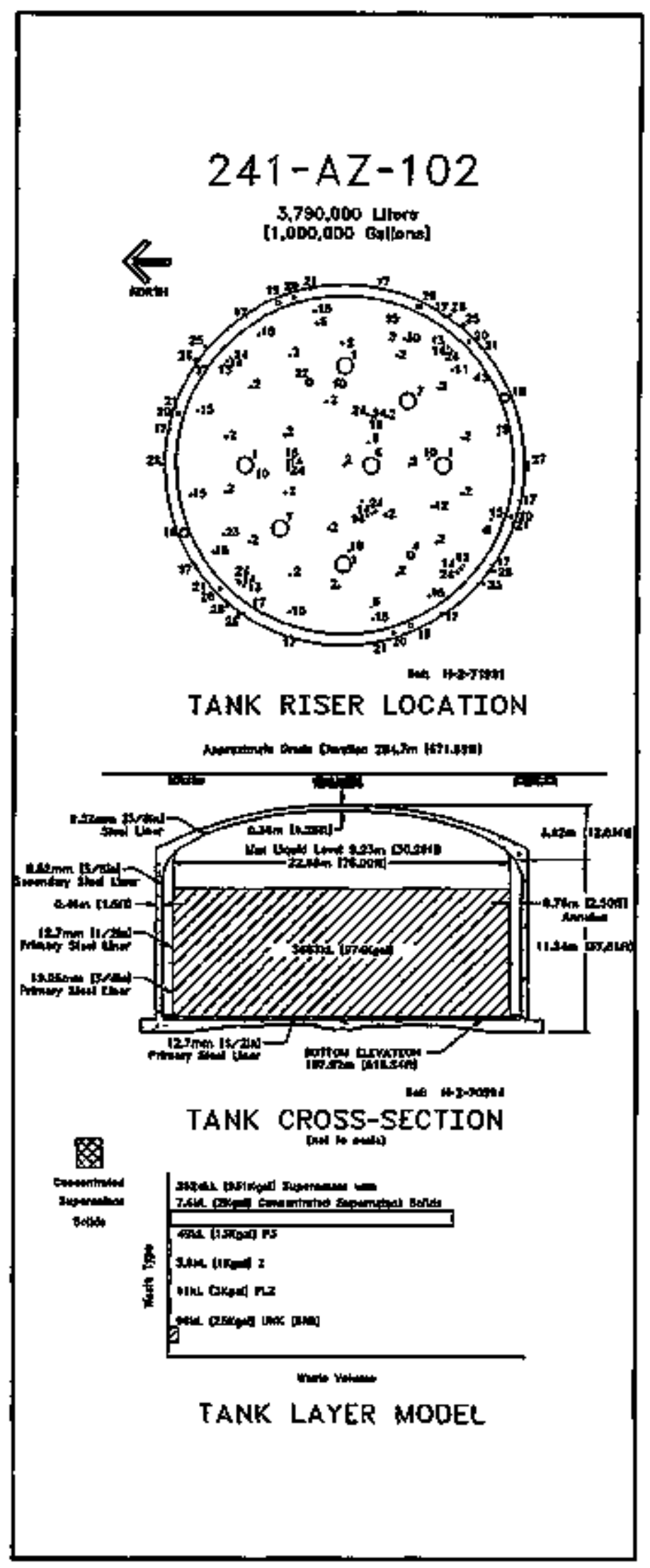


WHC-SD-FM-ER-350, Rev. 0

\begin{tabular}{|c|c|c|c|}
\hline \multicolumn{4}{|c|}{ Double-Shell Tank 241-AZ102 } \\
\hline \multicolumn{4}{|c|}{ 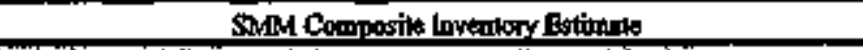 } \\
\hline \multicolumn{4}{|c|}{ 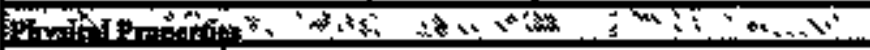 } \\
\hline Tomal Supenstant & \multicolumn{3}{|c|}{$3.65 \mathrm{E}+06 \mathrm{~kg} \quad(931 \mathrm{kgal})$} \\
\hline Henthost & \multicolumn{3}{|c|}{$22,2 \mathrm{~kW}(7,598 \mathrm{~F}+04 \mathrm{BT} ! \mathrm{hhr}$} \\
\hline Ban Donsity & \multicolumn{3}{|c|}{ 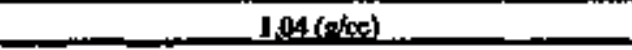 } \\
\hline Woder wat & \multicolumn{3}{|c|}{945} \\
\hline TOC wef C(wt) & \multicolumn{3}{|c|}{0.002} \\
\hline \multicolumn{4}{|c|}{ 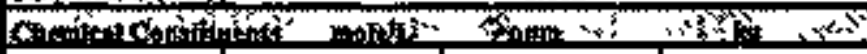 } \\
\hline $\mathrm{se}^{+}$ & 0.944 & $2.09 \mathrm{E}+\mathrm{Pa}$ & $7.65 \mathrm{E}+04$ \\
\hline$\Delta !^{3+}$ & $0.10 \%$ & $2.83 \mathrm{E}+103$ & $1048+64$ \\
\hline$\left.F_{0} \theta^{\prime \prime}\left(t_{0 t a}\right] \mathrm{Fe}\right)$ & 6.96E-04 & 37.5 & 197 \\
\hline $\mathrm{Cr}^{\mathrm{N}}$ & $9602-05$ & 4.83 & 13.7 \\
\hline Bir & $1.23 \mathrm{E}-0 \mathrm{0}$ & 0220 & 0.836 \\
\hline La. & $5.730-009$ & $2,68 \mathrm{k}, 0 \mathrm{a}$ & 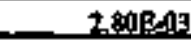 \\
\hline Hen & $7,460,09$ & $1.44 \mathrm{~B}, 03$ & $5.27 \mathrm{E}-03$ \\
\hline 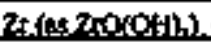 & 7.2J日-07 & 631SR-02 & 0.232 \\
\hline $\mathrm{ph}^{\mathrm{3}+}$ & $4,398-02$ & \$.73E-10 & 0.320 \\
\hline $\mathrm{NF}^{2+}$ & 221E-09 & 325 & 4.57 \\
\hline $\mathbf{s}^{3+}$ & 6.05E-09 & $5.12 \mathrm{E}-04$ & 1.87E-03 \\
\hline$M *$ & 5.778 .06 & $3,0.0$ & 112 \\
\hline $\mathrm{Ca}^{\mathbf{*}}$ & $4.87 \mathrm{E}-03$ & 185 & 687 \\
\hline $\mathbf{K}^{*}$ & 7.78E-065 & 29: & 10.7 \\
\hline atㅘ & 0917 & 1.51R+04 & $5.500+04$ \\
\hline NQ:- & 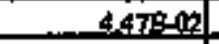 & $2.678+09$ & $9.768 \pm 0$ \\
\hline No: & 0.170 & $7.56 \mathrm{E}+0.3$ & $2,76 \mathrm{~B}+04$ \\
\hline $\mathrm{Con}^{2}$ & $6,50 E=03$ & 376 & $1,378+03$ \\
\hline Fo' & 725E-0A & 60.5 & 243 \\
\hline So: & $4,40 \mathrm{~g}_{2} \mathrm{n}$ & $4,26 \mathrm{~F}+0,3$ & J.66E+on \\
\hline Si $(\mathrm{L}$ S Sio,y & 1.15E-02 & 32 & $1.14 \mathrm{E}+0 \mathrm{~B}$ \\
\hline$F$ & L.07E-M & $187 \mathrm{Ti}$ & 684 \\
\hline$G$ & $1.74 E-02$ & 594 & 2.17E+0s \\
\hline CHO2 & 6. 6.7?:-19y & 112 & 40.8 \\
\hline EOTA* & $8.408,06$ & 2,45 & 899 \\
\hline HEDTA & 1.148-05 & 3.01 & 100 \\
\hline phoplats & $4.67+-04$ & 33.8 & 124 \\
\hline axetane & I99E-0S & L.19 & 4.14 \\
\hline oxtlater- & $2.16 \mathrm{R}-18$ & LYAE-03 & $670 \mathrm{E}-0.03$ \\
\hline DBP & $4,438-05$ & 6.88 & 25. \\
\hline bentantof & 449F-0.5 & 3.5 & $1 \mathrm{Lt}$ \\
\hline $\mathrm{NH}_{2}$ & $6795-03$ & 11 & 40. \\
\hline $\mathrm{F} \times\left(\mathrm{C} \mathrm{N}^{*}\right.$ & - & 0 & 0 \\
\hline 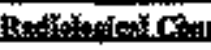 & & 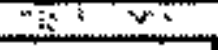 & 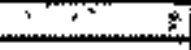 \\
\hline Pu & $15.8(\mu \operatorname{cin})$ & & 0.929:04) \\
\hline 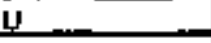 & $136 \mathrm{E}-03$ (a) & 312 - & 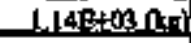 \\
\hline Cs & 1.34 (C) & $1.29 \mathrm{E}+03(\mathrm{~N} C \mathrm{C} / \mathrm{s})$ & $4.73 \mathrm{E}+06(\mathrm{Ci})$ \\
\hline S & $2, A 3 B-03(C) L)$ & $234(4 \mathrm{CS}-3)$ & $8.56 \mathrm{E}+03(\mathrm{C})$ \\
\hline
\end{tabular}

"Derisity is calculated based on $\mathrm{Na}, \mathrm{OH}-$ and Aloz2.

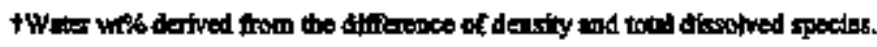

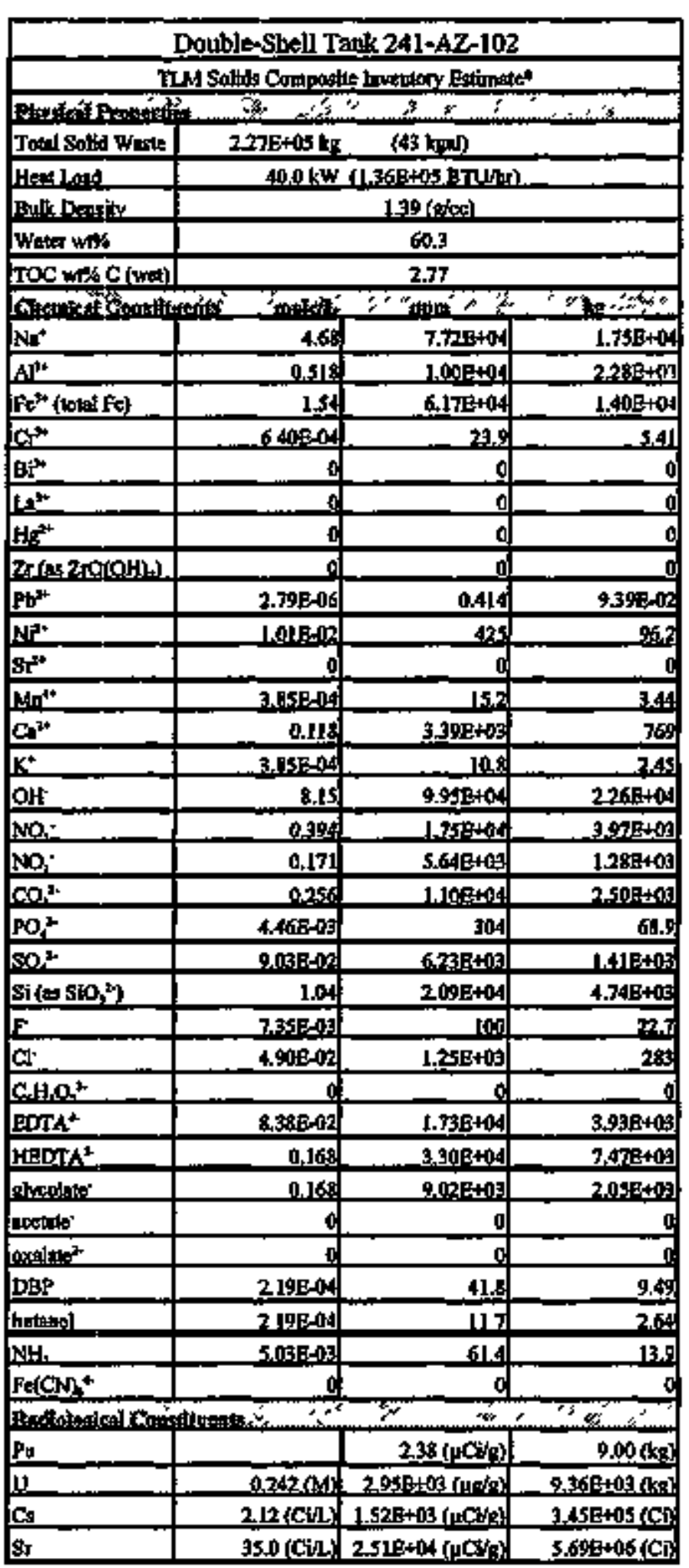

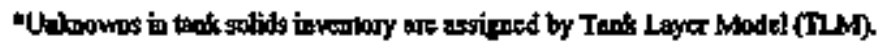


WHC-SD-WM-ER-350, ReV, O

PHOTO AZ-102 
1

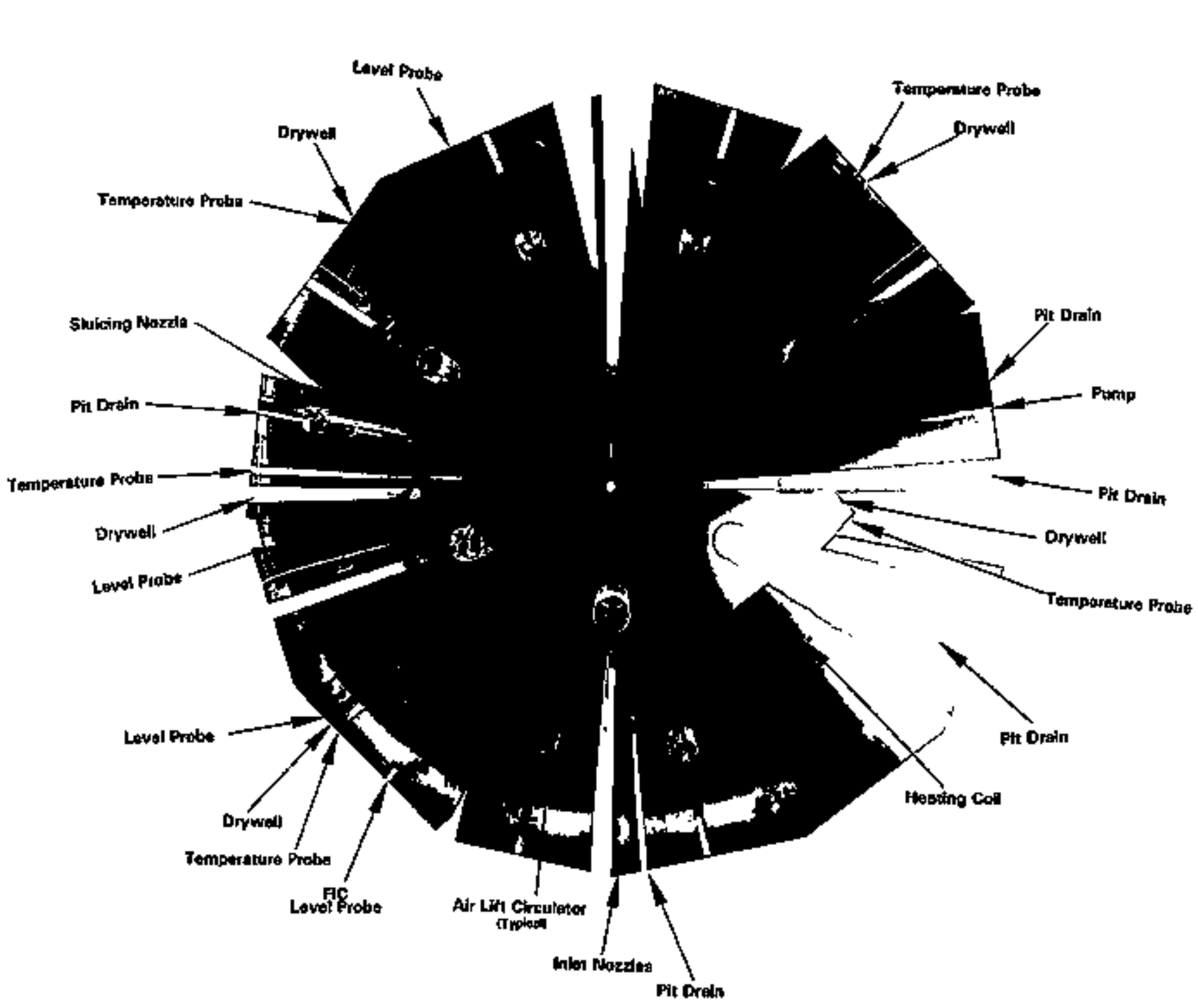

Phoco date: 10-24-84 
7.0.1 SY Tank Farm History

The SY Tank Farm is located east of Cooper Avenue and south of $16 \mathrm{th}$ street in the 200-West Area. The SY Tank Farm contains thres, 100 series, 1, 160,000 gallon, 75-foot diameter double-shell tanks. The SY Tank Farm is the latest tank design with a reinforced concrete shell and dome, and a insulating conerete base. A heat-treated, stress-relieved, primary steel liner and a non-stress-relieved, outer steel Iiner are inside the concrete shell. These tanks were made for the storage of concentrated supernatant. Maximum design temperature for liquid is $250^{\circ} \mathrm{F}$. The tanks are at the same elevation ana no cascade lines exist between tanks.

A color aerial photograph, taken in 1993, of the SY Tank Farm shows the orientation of the 100 series tanks, ventilation equipment, and instrument house. 


\section{SY TANK FARM}

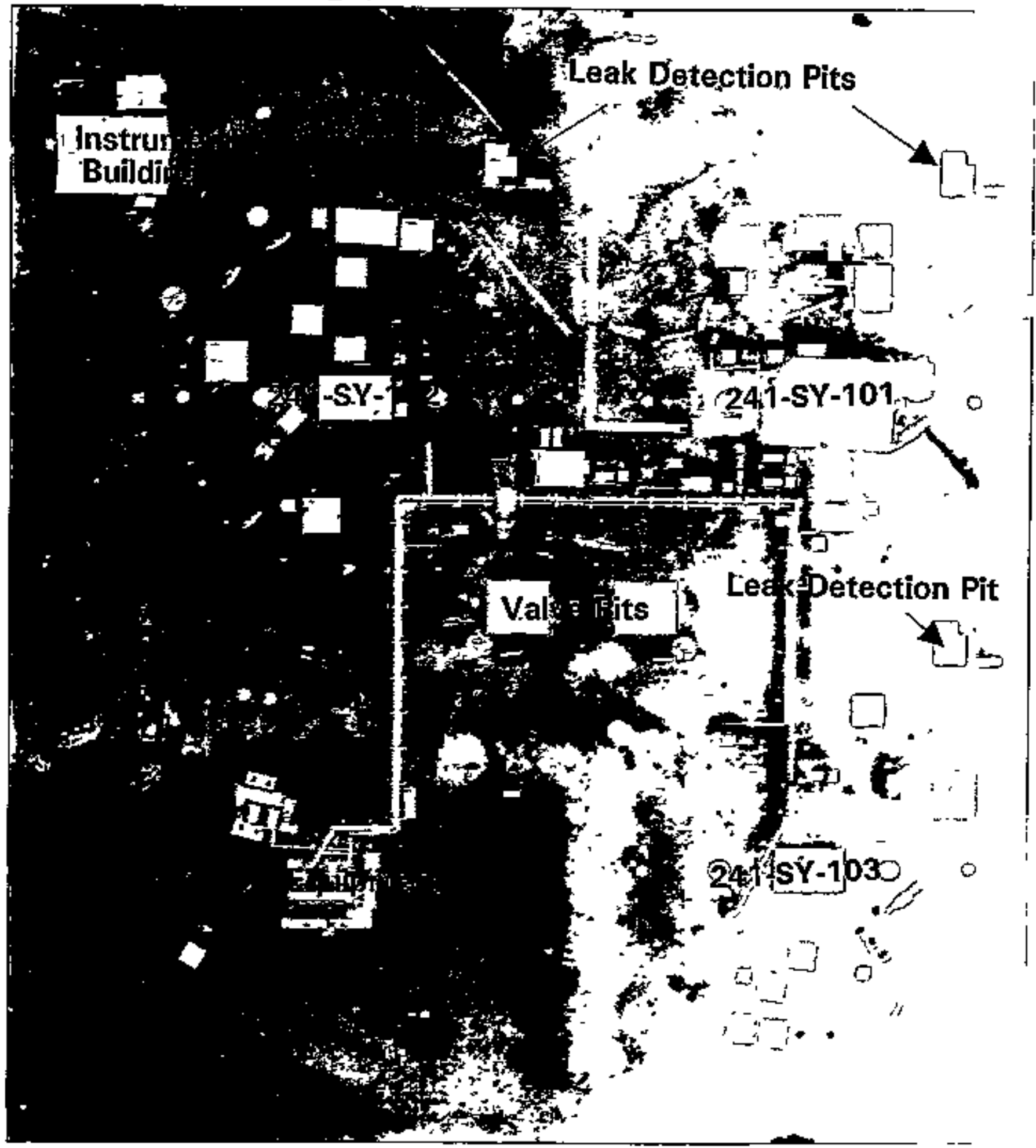


MHC-SD-MM-ER-350, ReV. 0

AERIAE SY 
WHC-SD-WM-ER-350, Rev, 0

7.0.1.1 SY Tank Farm Waste History

The SY Tank Fara began receiving waste in 1977, and only Tank 241-SY-102 renains active, receiving waste from PFP. Tank 241-SY-101 began receiving residual Iiquor from 242-S Evaporator in 1977. In 1978, Tank 241-SY-101 began receiving Hanford defense waste, double-shell tank slurry waste, comples concentrate waste, and partially neutralized feed waste. Tank 241-SY-102 also received partially neutralized feed waste and cormlex concentrate waste in 1978 along with non-complexed waste. Double-shell slurry waste was added in 1980 followed by dilute non-complexed waste from 200-East Area SSTs. The final tank in the SY Tank Farm (Tank 241-SY-103) begar receiving resichal liquor in 1977 and complexant concentrate in 1978. The final waste added to the SY Tank Farm was dilute non-complexed waste from 200-East Area SSTs.

\subsubsection{SY Tank Farm Temperature History}

Originally, the SY Tank Farm data were recorded from thermocouples on thermocouple trees. currently, temperatures are recorded with thermocouples that are attached to thermocouple trees and nultifunctional instrument trees (MITs). Tariks 241-SY-101 and 241-5Y-I03 are on the Hydrogen Watch iist. Tank 241-SY-101 temperature data are currently obtained during each shift with an increased number of readings taken before and after gas is vented. Tank 241-5Y-101 is monitoreô da1ly at a minimum, Tank 241-SY-103 is monitored weekly at a minimum, and Tank 242-5Y-102 is required to have temperatures recorded semiannually. All of the SY Tanks are monitored by the tank monitor and control system and reported on the surveillance analysis computer system. Historical data from the thermocouples have been stored on the computer automated surveillance system or surveillance analysis computer system. These two databases hold all the temperature data used in developing the statistical results for each tank.

\subsubsection{SY Tank Farm Occurrences}

Eight unusual events affected si Tank Farm as a whole. Occurrence reports RL--WHC-Tank Fara-1993-0100 and RL--WHC-Tank Farm-1992-0022 describe electrical equigment in the wrong configuration. Occurrence reports RI,-WHC-Tank Farm-1993-0062 and WAC-90-0319-TFarm were written because failing equipment caused the tanks to pressurize. Occurrence reports RL-WHC-Tank Farm-1992-0051 and RI--WHC-Tank Farm-1991-1063 concerin a loss of power causing the tanks to pressurize. Occurrence report RL--WhC-Tank Fazm-1991-1001 was written due to an equipment failure. Occurrence report RL--WHC-Tank Ferm-1990-0236 concerns equipusit that was out of compliasıce with procedures. For more informetion, refer to the Supporting Document for the southeast Quadrant HTCE for sY Tank Fam.

\subsubsection{SY Tank Farm Ventilation}

The ducts of all three tanks are joined so that the tank exhaust system and armulus exhaust system require one fan each. The tank system is designed to have a maximum flow from any one tank of 700 CFu. Air 


$$
\text { WHC-SD-WH-ER-350, ReV. } 0
$$

enters the tanks by infiltration because there is no supply fan. The tank system has a portable exhauster as a backup system. In the annulus system, 250 CFM of air enters a prefilter and a HEPA filter before entering the andulus. Ther the air from all three annuli enters a steam coil heater, a prefilter, and two nore HEPA filters before it is exhausted to the atmosphere. For more information, refer to drawing H-2-37744.

The psychrometric clata is recorded in two parts, the tank data and the annulus data. For water and heat leaving the tank, the numbers are positive. For more information, refer to the supporting Document for the Southeast quadrant HTCE Eor SX Tark Farin (Brevick, 1995).

\subsubsection{Current Status of SY Tank Farin}

Tanks 241-SY-101 and -103 were officially added to the Hydrogen watch Iist in January 1991. The two tanks have been identified as unzeviewed safety guestions due to concern that burning flammable gas could result in a radiologicel release. All tanks are actively ventilated and categorized as sound. Currently, the total waste volume is 2,608,000 gallons. The estimated volumes (Agnew, January 1994) depicted in each tank cross-section total 2,592,000 gallons of waste. At the time of the estimate, there were $2,521,000$ gallons of supernatant with 1,667,000 gallons of concentrated supernatant solids, 5,000 gallons of decontamination waste (DW), 25,000 gallons of $z$ plant waste $(z)$, and 41,000 gailons of salt sluryy waste (S2 SLTSLRY) generated from the 242-S Evaporator-crystallizer from 1977 until 1980 .

\subsection{Tank 241-5Y-101}

\subsubsection{1-SY-101 Tank History}

\subsubsection{Waste History of Tank 241-SY-101}

Tank 241-sY-101 began service by receiving residual liquor from the 242-5 Evaporator in the second quarter of 1977. The tank received residusl 1iguor until the fourth quarter of 1977. During the first quarter of 1978, the tank received Hanford defense residual liquor. From the second quarter of 1978 until September 1980, the tank received double-shell slurry waste, complexant concentrate waste, and partially neutralized feed waste. The tank has contained complexant concentrate waste from october I980 until the present. However, during March 1983 and May 1987, the tank waste was designated as double-shell slurry waste. The slight level changes are attributed to slurry growth as a result of gas generation. The tank has not received waste, other than waste water, since the fourth guarter of 1980. The tank is currently an inactive, concentrated waste holding tank.

\subsubsection{Temperature History of Tank 241-\$Y-101}

Temperature data from within Tark 241-SY-101 have been zecorded by two methods. The first method used a thermocouple tree located in riser 4 which had 18 thermocouples affixed at known elevations. Non-suspect temperature data recorded from seven themocouples on the thermocouple tres 
between July 1983 and March 1988 are availabie on the computer automated surveillance system. Non-suspect terrperature data recorded from all of the thermocouples on the tree between August 1990 and September 1992 are available on the surveillance analysis conputer syster. Within the time spans of each system, there were smali breaks in the secuence of temperature data. The average temperature for the thermocouple tree data during these periods was $123.5^{\circ} \mathrm{F}$ with a minimum of $51 \circ \mathrm{P}$, a maximum of $155^{\circ} \mathrm{F}$, and a standard deviation of $16.5^{\circ} \mathrm{F}$. Linear regressions were performed on each thermocouple on the thermocouple tree that had temperature data between January 1990 and January 1994. The slopes from these regressions were averaged with a resulting average slope of -0.015 .

The thermocouple tree was listed as out of service and replaced by a multi-functional instrument tree (WIT). The fIT is located in riser i7B. There are 22 thermocouples on the HIT at known elevations in the tank. Non-suspect temperature data from all of the thermocouples on the MIT recorded between September 1992 and August 1993 are dvailable on the surveillance analysis computer system. Within the time span of the surveillance analysis computer system, there were no significant breaks in the sequence of temperature data. The average temperature for the MIT data during this period was $115^{\circ} \mathrm{F}$ with a minimum of $82^{\circ} \mathrm{F}$, a maximum of $129^{\circ} \mathrm{F}$, and a standard deviation of $7.9^{\circ} \mathrm{F}$. Linear regressions were performed on each thermocouple on the MIT that had temperature data between September 1992 end August 1993. The slopes from these regressions were averaged with a resulting average slope of -0.0066 . Refer to the supporting doclunent for a more thorough review of the temperature data (Brevick, 1995).

\subsubsection{Occurrences of Tank 241-\$Y-101}

Thirty unusual events occurred at Tank 241-5Y-101. Occurrence reports RL--WHC-Tank Farm-1993-0105, RL--WHC-Tank Fexm-1993-0093, RI--WHC-Tank Farm-1993-0090, RJ--WHC-Tank Farn-1993-0079, RL--WHC-Tank Farm-1993-0058, RI--WfC-Tank Farm-1993-0016, RL--WHC-Tank Farm-1992-0063, RJ--WHC-Tank Farm-1992-0032, RL--WHC-Tank Farm-1991-1069, RL--WHC-Tank Farm-1991-1013, WHC-91-0141-TFarm, RL--WHC-Tank Farm-1990-0173, TFS \& 0-EFS-89-080, TFS \& O-EFS-89-059, and TF' \& 0-EPS-88-007; Off-Normal Reports 86-18 and 83-19; and Unusual occurrence Reports 78-16, 77-207, 77-175, and 77-92 account for each time the tank burped. Occurrence reports RU-WhC-Tenk Farm-1993-0077, RL=-hHC-Tank Farm-1993-0069, RL--WHC-Tank Farm-1993-0026, RI--WHC-Tank Farm-1992-0077, RL--WHC-Tank Farm-1991-1065, and RI--WHC-Tank Farm-1991-0200 concern equipment that was out of compliance with procedures. Occurrence reports RL--FHC-Tank Farm-1992-0076, RL--WHC-Tank Farm-1992-0003, and RL--WHC-Tark Farm-1991-0203 were written due to ecolipment failure.

\subsubsection{Psychrometrics of Tank 241-SY-101}

Psychrometric data have been recorded from this tank for 14 years and from the annulus for 17 years. The apparent trend of the evaporation rate from the tank has decreased from 143 gallons per week in May 1977 to 83.7 gallons per week in January 1995 (94.7 gallons per week in September 1991 ). over that same period, the trend in the rates of heat exchange through the 


$$
\text { HHC-SD-WM-ER-350, Rev. } 0
$$

primary tank and annular ventilation has apparently increased. A review of the psychrometric data in Tank 241-SY-101 would suggest an overall increase in the rate of heat generation by the waste.

\section{1 .2 Current Status of Tank 241-\$Y-101}

Tank 241-SY-101 entered service in April 1977 and currently stores 1,097,000 gallons of waste. The following plan view and tank cross-section depiat the approximate waste volume of 1,102,000 gallons and configuration of risers as of January 1994. At the time of the estimate, there were $1,102,000$ gallons of supernatent with $1,090,000$ gallons of concentrated supernatant solids. The waste level in the tank is measured with the PIC gauge and the manual tape. The waste level increased and decreased between January 1991 and January 1994. The increases were from slurry growth as a result of gas generation and the decreases were cuused by the venting of the gas between January 1991 and January 1994. This tank is on the Hydrogen watch List and, therefore, is prohibited from receiving waste. The tark is actively ventilated and categorized as sound. Tank 241-5Y-101 has 54 risers. Four 4-inch risers (no.11, no.14, no.16, and no.22) and two 12-inch risers (no.3 and no.7) are available for use.

\subsubsection{Inventory Estimate of Tank 241-SY-101}

The tank layer model (a volume based approximation) that follows was derived from the Los Alamos National Laboratory Waste status and Transaction Record Sumbry (Agnew, 1995) and Supernatant Mixing Model (Agnew, 1995). The estimated inventories of total waste, solias, and supwrnatant in Tank 241-SY-101 are also presented. Concentrated supernatant solids are considered as an integral part of the liguid for the purpose of estimating inventories, but are graphed as solids on the level histories. The actual substance, which was derived from double-shell slurry, appears as a solid if undisturbed, but the particles are resuspended in solution if hexted or disturbed.

\section{1 .2 .2 In-Tank Photograph of Tank 241-5Y-101}

In April, 1994, Tank 241-SY-101 contained 1,100,000 gallons of complexect concentrate (Hanlon, 1994) which is waste that has been processed through an evaporator. The 1989 collage for this tank shows an almost full tank of solid waste which was also complexed concentrate (Thurman, 1989) and is probably the same or similiar to the currant waste. The surface appears to have resulted from mixing several different materials togethex. Most of the waste appears to be grey, however, there is a large amount of off-white material. Tank walls are rusted. Equipment in the tank which has been identified includes two temperature probes, three level probes, a tank pressure port, and some risers. The waste height is about 33 feet.

7.1 .3 Symopsis of Tank 241-SY-101

(To be completect.) 


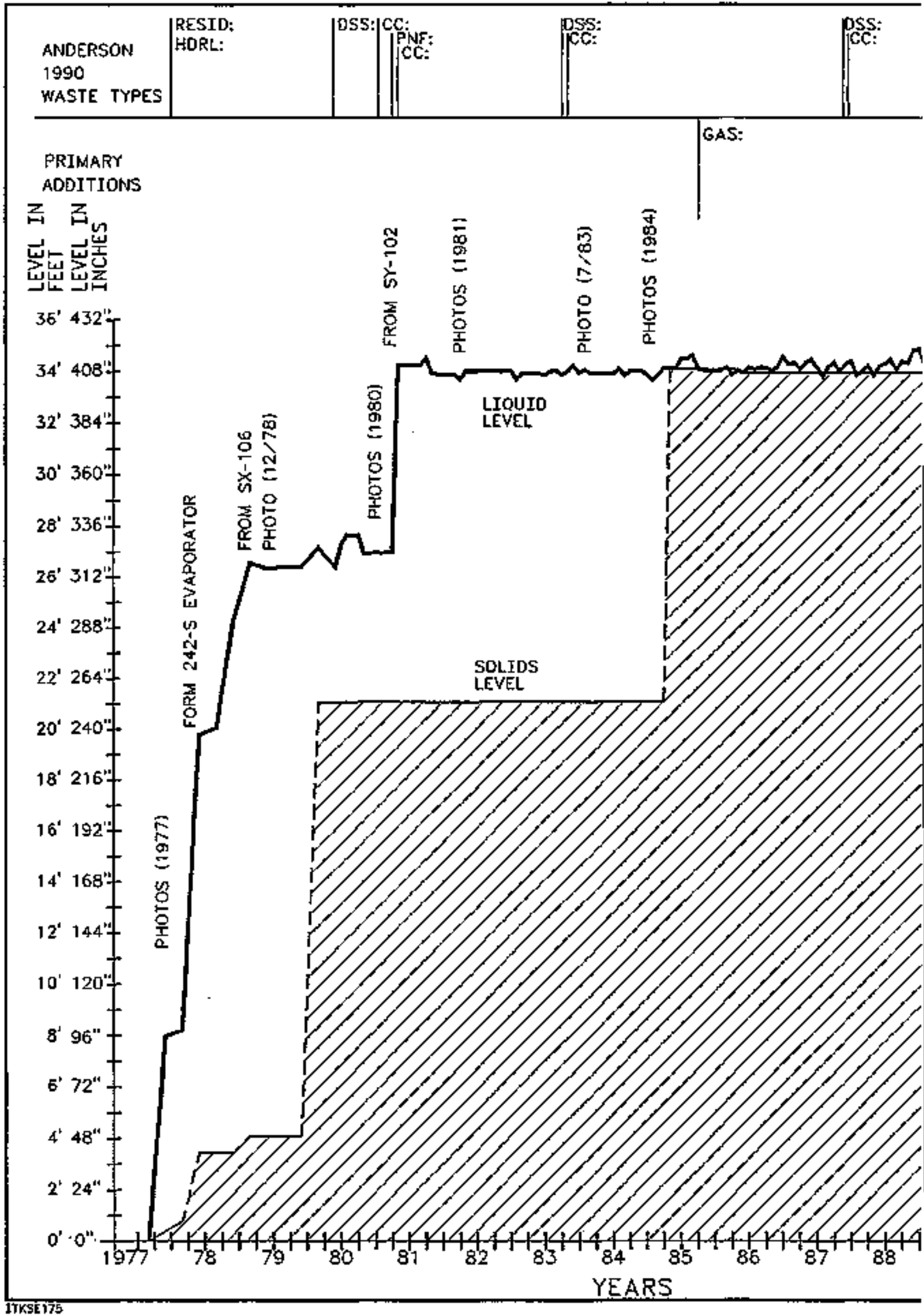


NQTES:

CONSTRLCT 1974-1976

NOWINAAL CAPACITY 1.160 .000 GAL

FS FOOT OA TAMER NOO KAUCKEE

SURFACE LEVE READING PHOTO

(LIOUIOS \& SOLIDS), FIC ISOLIOS)

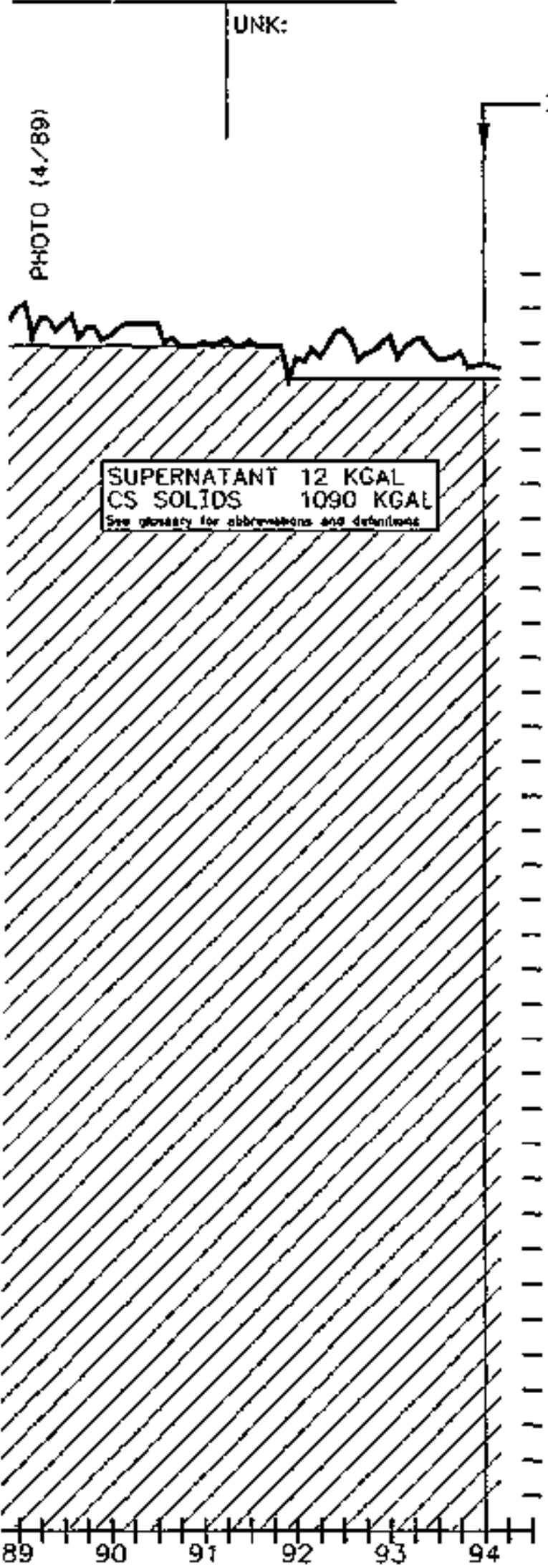

INVENTORY ESTIMATE DATE

CAPACITY

[GALLONS)

$-1,188,000$

-

$-1,122,000$

$-1,056,000$

990,000

924,000

858,000

792,000

726,000

660,000

594,000

528,000

462,000

396,000

330,000

264,000

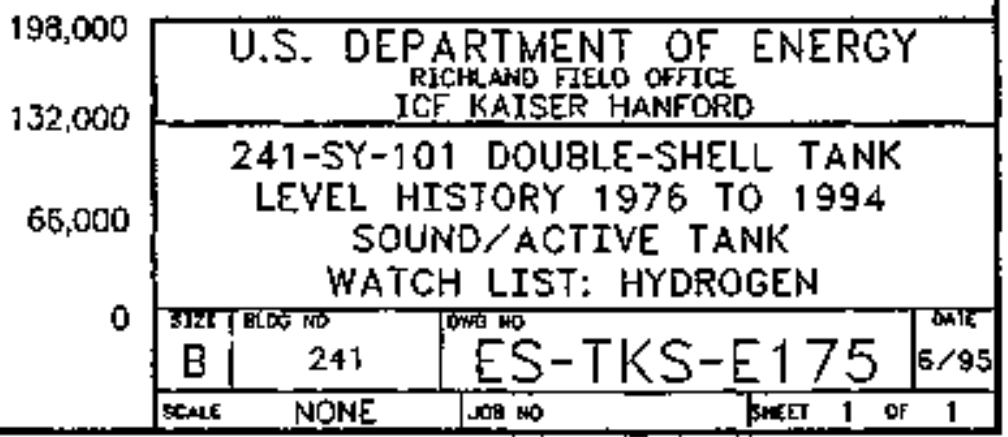

RESIO RESIDUAL LIQUOR

HORL HANFORD DEFENSE RESIDUAL LIOUOR

OSS DOUBLE-SHELL SLURRY

CC COMPLEXANT CONCENTRATE WASTE

PNF PARIIAE NEUTRALIZED FEED

UiNK
GAS LEYEL FLUXUATION DUE TO GAS BUILD-UP

\author{
LEGEND \\ E- 7 LIOUID OBSERVATION \\ WELL, (LOW") \\ LIOUIO LEVER \\ $77 / 7$ SOLIOS LEVEL

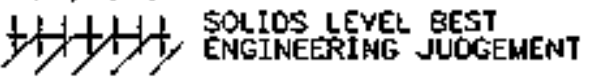

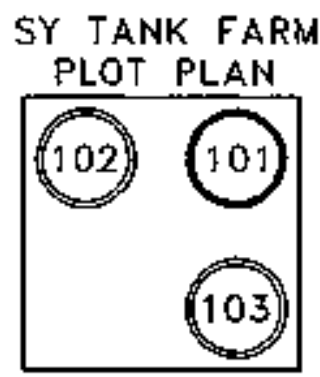


WHC-SD-WM-ER-350, Rev, O

\begin{tabular}{|c|c|c|c|}
\hline \multicolumn{4}{|c|}{ Double-Shell Tank 241-SY-101 } \\
\hline \multicolumn{4}{|c|}{ Ton huentory Estimate' } \\
\hline \multicolumn{4}{|c|}{ سمسئسm } \\
\hline Tonil Wato & \multicolumn{3}{|c|}{$6.43 \mathrm{E}+06 \mathrm{~kg},(1.10 \mathrm{E}+0 \mathrm{~s} \mathrm{~kg} g \mathrm{a})$} \\
\hline _ & \multicolumn{3}{|c|}{ 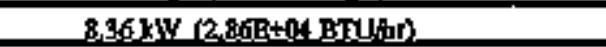 } \\
\hline Bulk Denstilut & \multicolumn{3}{|c|}{1.54 (15itool } \\
\hline Water witht & \multicolumn{3}{|c|}{40.5} \\
\hline Toc wex & \multicolumn{3}{|c|}{1.00} \\
\hline \multicolumn{4}{|c|}{ 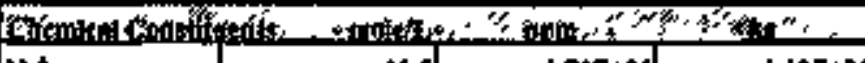 } \\
\hline $\mathrm{Na}^{2}$ & 11.5 & 1.7LE+15 & 1.10E $\div 016$ \\
\hline Al_ & t.61 & $2810+04$ & $1,81=0.05$ \\
\hline$F e^{1+}($ tode $F e)$ & 2.69g.03 & 97.4 & 626 \\
\hline G논 & $36 \pi=-12$ & $124 \mathrm{E}+03$ & 2.95E+03 \\
\hline gp? & 20se-03 & 278 & $1,79 \mathrm{E}+03$ \\
\hline ترام & $168 \mathrm{E}=0 \mathrm{~d}$ & |.49 & 9 9s \\
\hline 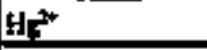 & L.1.0-0.5 & $1.5 \mathrm{~s}$ & 9.84 \\
\hline 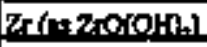 & I.2.:8_08! & 75.7 & 48 \\
\hline $\mathrm{Pb}^{\mathbf{2 +}}$ & 2.77E- & 3.72 & 25.9 \\
\hline$N=$ & $2,40 \mathrm{~B}=09$ & 963 & Sat7] \\
\hline$s^{*}$ & 1.75E-15) & 0,994 & 6.40 \\
\hline$M n^{*}$ & 9M1E-193 & 392 & 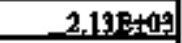 \\
\hline $\mathbf{C a}^{\mathbf{*}}$ & $1.08 \mathrm{E}-00$ & 409 & $3.15 \mathrm{E}+1.3$ \\
\hline $\mathbf{K}^{*}$ & 2.452402 & 639 & 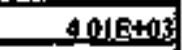 \\
\hline 아 & 6.93 & 7.658E+04 & 49IE+05 \\
\hline WO: & 3,400 & 1.37:-105 & 8.7. $9 \mathrm{E}+10 \mathrm{f}$ \\
\hline $\mathrm{NO}$ & 3.42 & $1.02 \mathrm{E}+05$ & $6,57 \mathrm{E}+0 \mathrm{~S}$ \\
\hline $60^{2}$ & 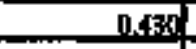 & $168 \mathrm{E} \pm 04$ & $1.08 \mathrm{E}+25$ \\
\hline $\mathrm{PO}_{1}^{2}$ & 0.162 & 9.99E+03: & $6.42 E+04$ \\
\hline $\mathrm{SO}_{2}^{2}$ & 0,334 & $2058+04$ & $1.307+0 \mathrm{~A}$ \\
\hline $33\left(\div 80^{2}\right)$ & $4250-02$ & 775 & $4.98 \mathrm{~B}+0 \mathrm{~g}$ \\
\hline $\mathrm{F}$ & - & 1ATE+nt & $2,478+t)$ \\
\hline Q & 0.199 & $4,58 E+103$ & 294E +20 \\
\hline C.H. & $3 A B E, 02$ & $4.27 \mathrm{E} \pm 03$ & $2.74 \mathrm{~B}+0 \mathrm{~A}$ \\
\hline EDTA $\mathbf{A}^{*}$ & $1.99 \mathrm{E}-0 \mathrm{O}$ & $3.72 \mathrm{E}+02$ & $2.39 \mathrm{E}+0 \mathrm{~N}$ \\
\hline HEDTA2 & 3.72R-D? & $6.62 \mathrm{~F}+02]$ & $4.26 \mathrm{~B}+0 \mathrm{~N}$ \\
\hline drealute & 0.1 .11 & $5.99 \mathrm{E}+\mathrm{n})]$ & $3,47 F+01$ \\
\hline " & $8.19 \mathrm{E}-03$ & 314 & $2.02 \mathrm{E}+0 \mathrm{~A}$ \\
\hline motate & 6.25E-15. & 3.54 & 220 \\
\hline DAP & 1.49E-02 & $1.36 \mathrm{~B}+03$ & $1.00 \mathrm{~B}+04$ \\
\hline butanol & 1.49르연 & 71त & A $61018+0: 3$ \\
\hline $\mathrm{NH}_{2}$ & $5,4090.02$ & 596 & $3,63: 2403$ \\
\hline $\mathrm{Fa}\left(\mathrm{CN}_{3}{ }^{4}\right.$ & 0 & 0 & \\
\hline 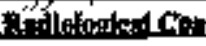 & istit: & 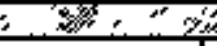 & 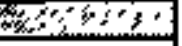 \\
\hline Pu & & $2,4 \mathrm{~B}_{\mathrm{B}} \mathrm{Oz}(\mu \mathrm{C}(\mathrm{I})$ & 260 (1) \\
\hline v & $6.01 \mathrm{E}-03(\mathrm{M})$ & $928\left(4 v_{18}\right)$ & $5.972+03(38)$ \\
\hline cs. & $0.415(\mathrm{C}) 2)$ & $269(\mu \mathrm{C} / \mathrm{g})$ & 1.73E+06(C) \\
\hline Sr & 8.94E-0 (C) (C) & $5.80(\mu \mathrm{Cl} / \mathrm{g})$ & 3.73E+04 (C) \\
\hline
\end{tabular}

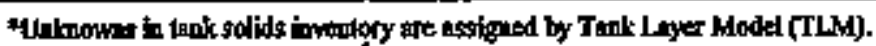

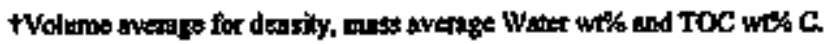

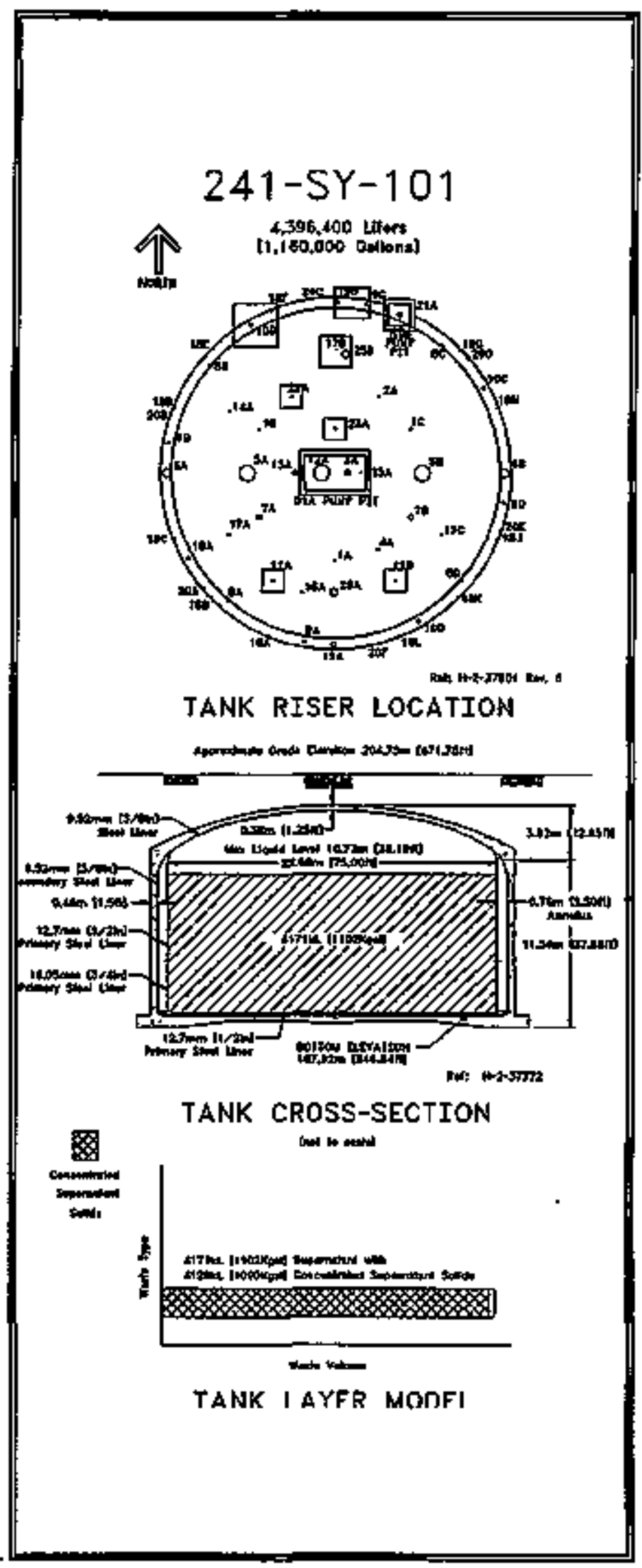




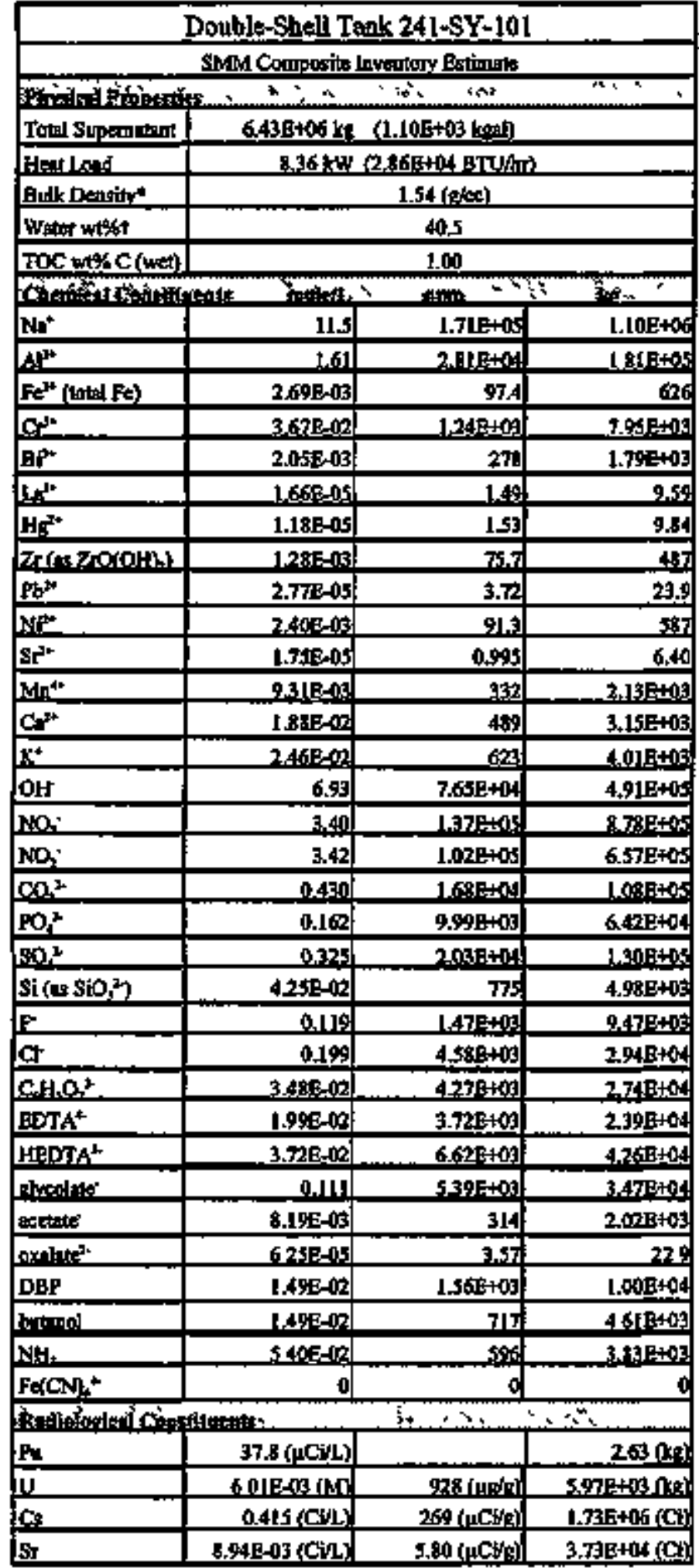

-Donsity is calculated based on Na, OH-, and AlOO2.

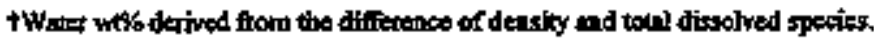

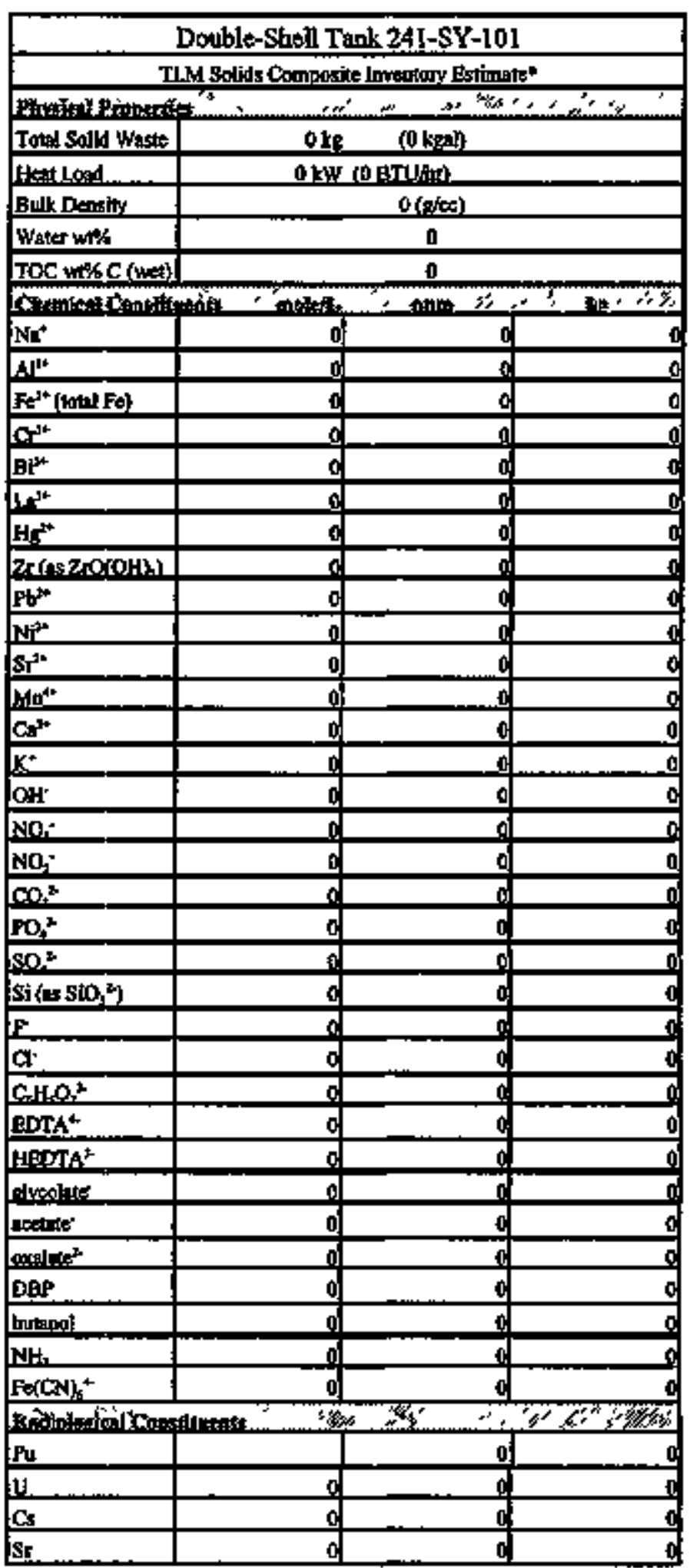

"Untoowns in tunk sollds inventocy are assfoged by Tank Leyer Moded (TLM). 


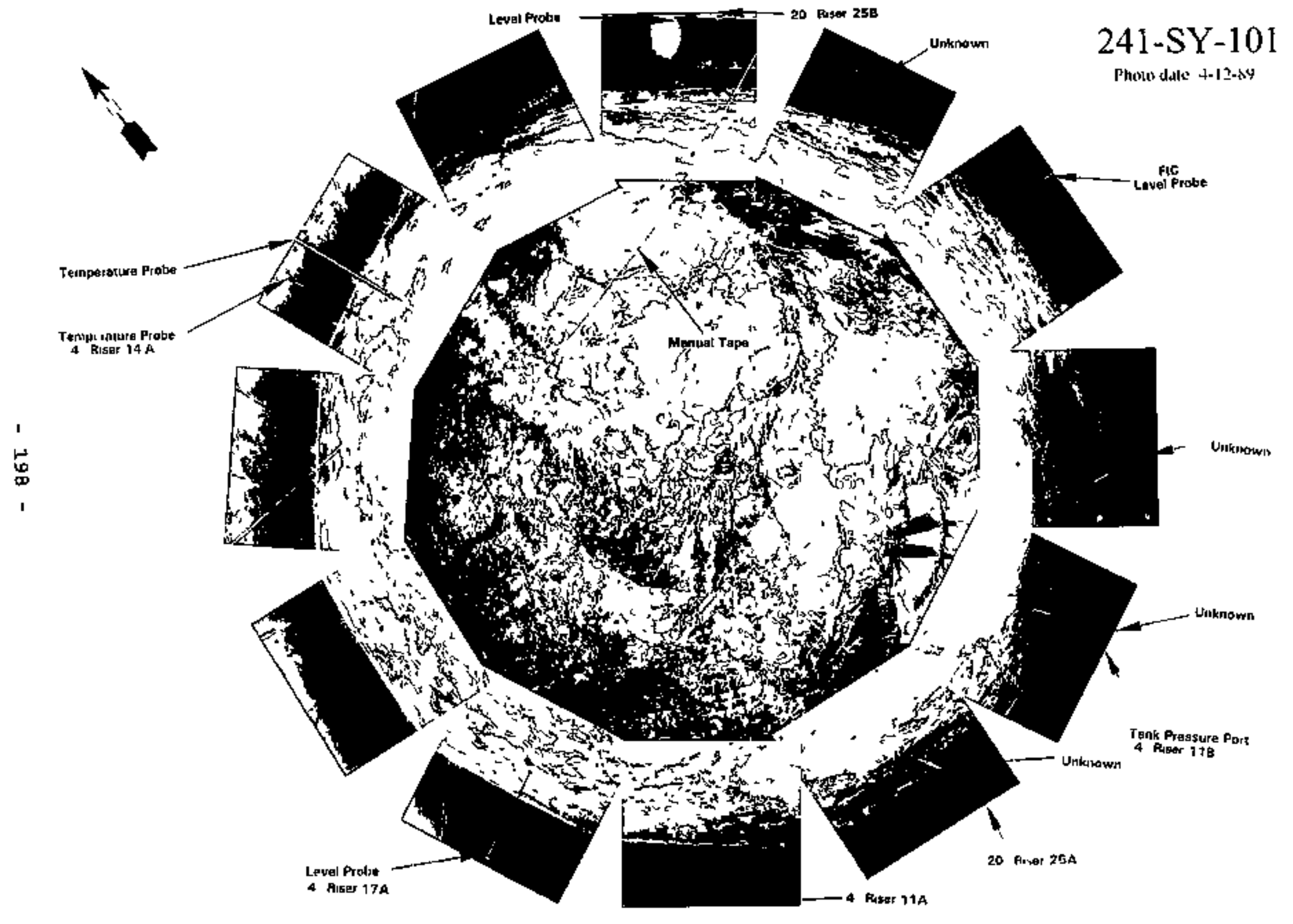




$$
\text { FHC-SD-TM-ER-350, Rev. } 0
$$

7.2 Tank 241-SY-102

7.2.1 241-SY-102 Tank History

7.2.1.1 Waste History of Tank 241-SY-102

Tank 241-SY-102 began service by receiving evaporator feed waste in the second quarter of 1977. The tank continued receiving evaporator feed waste watil the fourth quarter of 1977. From the first quarter of 1978 until september 1980, the tank received partially neutralized feed waste, non-complexed waste, and complexant concentrate waste. The tank received decontamination waste from the first quarter of 1980 until the first quarter of 1990. From October 1980 until october 1981, the tank received double-shell slurry feed waste. From the fourth quarter of 1981 until the second quarter of 1983 , the tank received dilute non-complexed waste from the 200-East area sSTs. The tank received non-complexed waste from November 1981 until My 1990. The tank has contained dilute non-complexed waste and PFP and TRU solids waste from June 1990 until the present. The tank is currently an active, dilute receiver tank that receives waste from PFF and non-complexed saltwell waste.

\subsubsection{Tentperature History of Tank 241-SY-102}

Tenperature data for Tank 241-5Y-102 are recorded by 18 thermocouples at known elevations on one thexmocouple tree inside the tank located in riser 4A. Only 13 of the 18 thermocouples have temperature dite. Nonsuspect temperature data taken between July 1983 and Nareh 1988 for oeven of the thermocouples were available from the computer automated surveillance system. Non-suspect temperature data recorded between January 1991 and December 1993 for seven of the thermocouples were available from the surveillance analysis computer system. Within the time spans of each system, there were small breaks in the sequence of temperature data. The average termperature during these periods was $76^{\circ} \mathrm{F}$ with a minimum of $52^{\circ} \mathrm{F}$, a maximum of $155^{\circ} \mathrm{F}$, and a standard deviation of $21^{\circ} \mathrm{F}$. Iinear regressions were performed on each thermocouple that had temperature data between January 1991 and January 1994. The slopes from these regressions were averaged with a resulting average slope of -0.0017 . Refer to the supporting aocument for a more thorough review of the temperature data (Brevick, 1995).

\section{2 .1 .3 Occurrences of Tank 241-SY-102}

Nine unustual events concerned Tank 241-SY-102. Occurrence reports RL--WHC-Tenk Farm-1993-0028 and RI--WHC-Tank Farm-1992-0082 and Unusual Occurrence Report 77-52 were written due to equipment failures. Occurrence report RL-WHC-Tank Farm-1991-1011 was written because failing equipment pressurized the tank. Occurrence report RL--hit-Tank Farm-1991-0192 and U.0. Report 77-64 were writter due to unexpected waste transfers. U.O. Reports 80-66,77-189, and 77-54 concerned radiation found on a sampling filter monitoring air in the andulus. 
HHC-SD-HH-ER-350, Rev. 0

7.2.1.4 Psychtometrics of Tank 241-SY-102

Fsychrometric data have been recorded for 17 yeaxs from this tank and annulus. The apparent trend of the evaporation rate from the tank has decxeased from 492.9 gallons per week in May 1977 to 30.8 gallons per week 1n January 1995. Over that same period, the trend in the rates of heat exchange through the primary tank and annular ventilation has apparently decreased. A review of the psychrometric data in Tank 241-5Y-102 would suggest an overall decrease in the rate of heat generation by the waste.

\section{2 .2 Current status of Tank 241-sY-102}

Tank 241-SY-102 entered service in April 1977 and currently stores 761,000 gellons of waste. The following plan view and tank exoss-section depict the approximate waste volume of 732,000 gallons and configuration of Iisers as of January 1994. At the time of the estimate, there were 661,000 gallons of superratant, 5,000 gallons of decontaminztion waste (DW), 25,000 gallons of $z$ Plant waste (Z), and 41,000 gallons of salt slurxy waste (S2SltStry) generated from the 242-S Evaporator-Crystallizer from 1977 until 1980. The waste level in the tank is messured with the FIC gauge and the manual tape and has increased from Jamuary 1991 to January 1.996. The increases were mostly flugh water from miscellaneous sources between January 1991 and January 1994. This tank is active and receives waste from PFP and non-conplexed saltwell waste. The tank is actively ventilated and cutegorized as sound. Tank 241-sY-102 has 54 risers. One 42-inch riser (no.5B) and one 12-inch riser (no.13A) are available for use.

\subsubsection{Inventory Estimate of Tank 241-SY-102}

The tank layer alodel (a volume based approximation) that follows was derived from the Los Alamos National Laboratory Waste status and Transaction Record Sumaty (Agnew 1995) and supernatant Mixing hodel (Agmew 1995). The estimeted inventories of total waste, solids, and supernatant in Tank 241-SY-102 are also presented.

\subsubsection{In-Tank Photograph of Tank 241-SY-102}

The 1981 collage for Tank 241-SY-102 shows a dark liquid waste surface with a swirl of white solids. The tank dome and walls appear slightly rusted. The photograph itself is adequate to see the instruments in the tank, but the Elash of the camera caused a bright reflection off the nearby equipment. The equipment within the tank has been identified and labeled for the reader. The tank contains 725,000 gallons of waste (Hanlon, 1994) which corresponds to a waste height of about 20 feet.

\section{2 .3 Bymopsis of Tank 241-\$Y-102}

(To be completed.) 


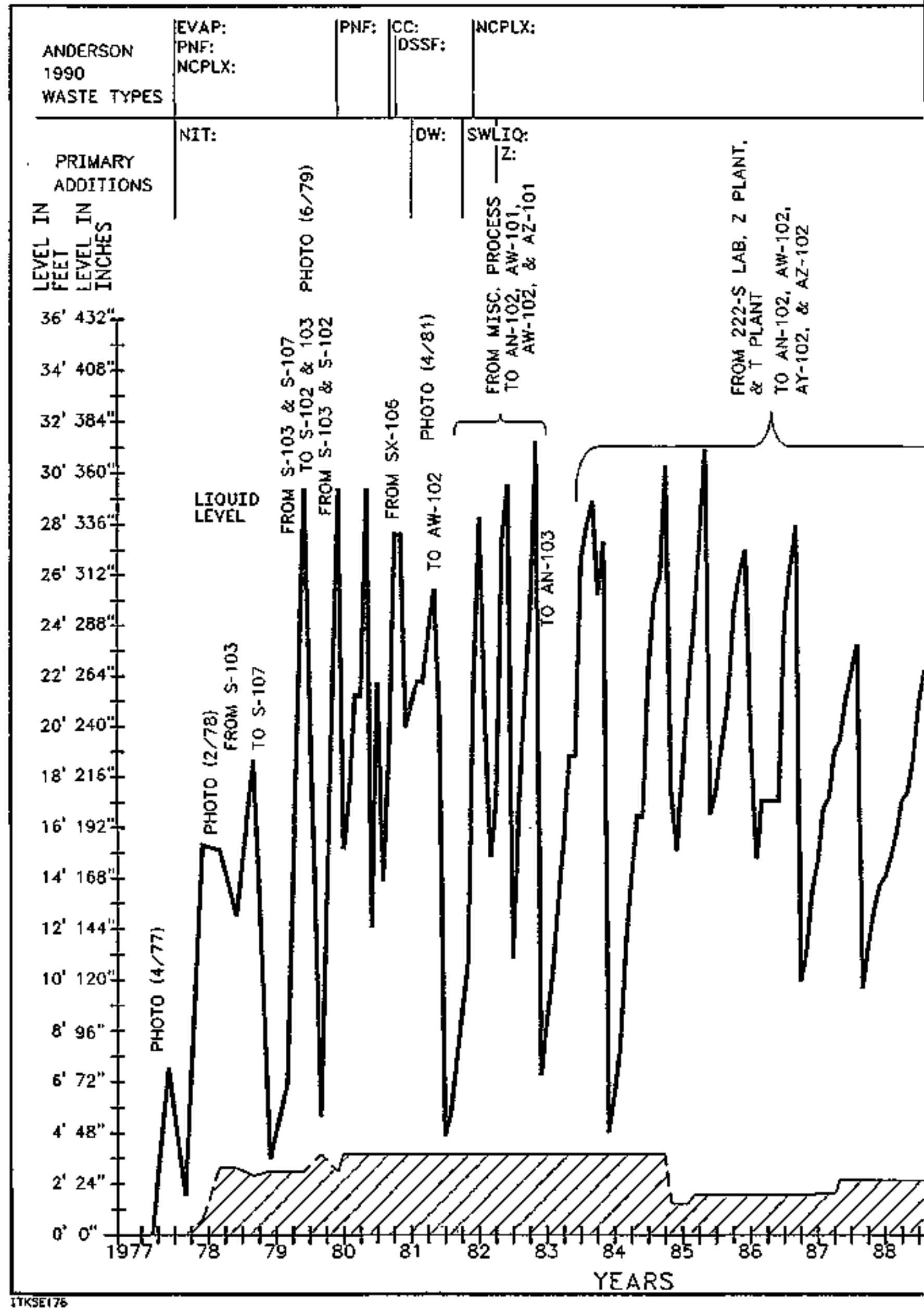




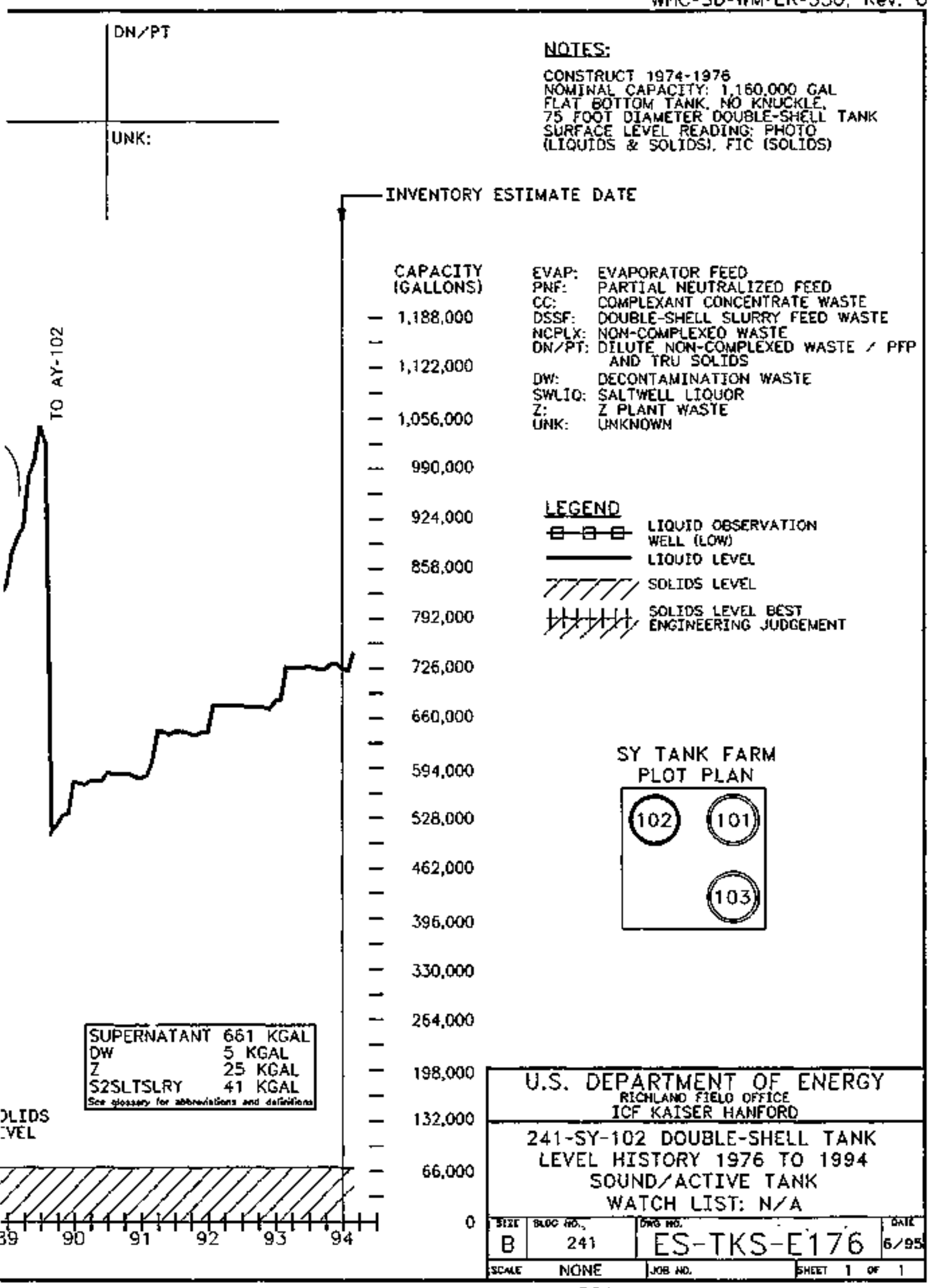


HHC-SD-WM-ER-350, Rev. 0

\begin{tabular}{|c|c|c|c|}
\hline \multicolumn{4}{|c|}{ Double-Shell Tank 241-SY-102 } \\
\hline \multicolumn{4}{|c|}{ Tolal brestoxy Estimarte" } \\
\hline 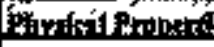 & $x_{0}=30$ & $\therefore$ mow & $\therefore$ \\
\hline Tolat Waste & $3.048+0.5 \mathrm{~kg}$ & (732 hogal) & \\
\hline Hentond & \multicolumn{3}{|c|}{ 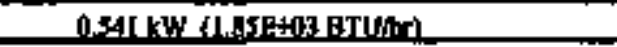 } \\
\hline Bulk Densitut & \multicolumn{3}{|c|}{$1.10(\mathrm{p} / \mathrm{k} \in \mathrm{x}$} \\
\hline Weter whtst & \multicolumn{3}{|c|}{86.4} \\
\hline $70 \mathrm{Cw} \% \mathrm{C}$ & \multicolumn{3}{|c|}{0.123} \\
\hline \multicolumn{4}{|c|}{ 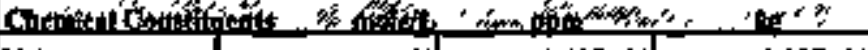 } \\
\hline $\mathrm{No}^{*}$ & 1,60 & $3.53 E+0$, & LOTE+09 \\
\hline $\mathrm{Al}^{\mathrm{B}}$ & $0.55 \times$ & J.75 & $4.4 F+04$ \\
\hline F:" (101t fo) & $8.638-02$ & $4392+03$ & 13:3+04 \\
\hline$C^{-14}$ & $1,35 \mathrm{SE}-02$ & $63:$ & J.4AE409 \\
\hline Bi $\mathbf{l}^{3+}$ & 3.17E-0.4 & 60,5 & 184 \\
\hline ts" & 1.40E-064 & 0.178 & 0.540 \\
\hline 点踏 & 1.47E-06 & 0269 & 0.817 \\
\hline $2(\mathrm{~s} 2 \mathrm{moOH})$ & 2.788-04 & 19.8 & 80.1 \\
\hline $\mathbf{p}^{\mathbf{3 n}}$ & 4.56E-0.5 & 0.86 : & 2.02 \\
\hline $\mathrm{Ni}^{2+}$ & 7.AOEE-0? & 300 & $1.198+693$ \\
\hline 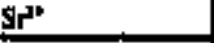 & $2.22 \mathrm{~B}-06$ & 0.293. & e.mog \\
\hline Lint & 9.200.84 & 46,1 & 100 \\
\hline $\mathrm{Cs}^{3 *}$ & L66-02 & 717 & $2.18 \mathrm{BE}+03$ \\
\hline $\mathrm{K}^{+}$ & 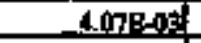 & {$[49$} & 440 \\
\hline $\mathrm{OH}^{\circ}$ & 2.22 & $3.44 \mathrm{E}+0.04$ & $1.05 E 405$ \\
\hline No: & 0.631 & $3,5, \mathrm{E} \pm \mathrm{QA}$ & $1008+405$ \\
\hline No: & 0,469 & $194 E+04$ & 5.918+04 \\
\hline $\cos 2$ & B,09E-02 & $4 A 36 \pm 09$ & $1.358+04$ \\
\hline $\mathrm{PO}^{2}$ & $2.07 \mathrm{~B} .02$ & $1.79 \mathrm{E}+103$ & $\$, 44 \mathrm{~B}+0\}$ \\
\hline $\mathrm{so}^{2}=$ & 3,66E-02 & 3.216:00 & 9.758 $\times 0$ : \\
\hline SFins sio,'] & $5.32 \mathrm{E}-0 \mathrm{3}$ & 136 & 414 \\
\hline $\mathbf{F}$ & $1.098=09$ & 189 & 575 \\
\hline $\mathbf{a}$ & 2.543002 & 827. & $2.50 \mathrm{E}+0.13$ \\
\hline C.Hon & 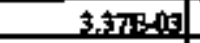 & 581 & 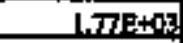 \\
\hline PDTA2 & $2,28-09$ & 503 & $1.53 B+03$ \\
\hline HEOTAS & $347 \mathrm{eng}$ & 806 & $2647+0 \mathrm{~F}$ \\
\hline aluenolute: & $1,138 \leq 025$ & 274 & $2,36 \pm 2+13$ \\
\hline axefate & 1.16E-0s] & 622 & 189 \\
\hline extates. & 5.30Re-96: & 0447 & 1.29 \\
\hline DEP & L.J5E-0Q⿻肀二 & 358 & 1.06et+03 \\
\hline harlno: & L.55E-0\}] & J俥 & 318 \\
\hline NH. & 1.2JEST: & 295 & 892 \\
\hline $\mathrm{Fe}\left(\mathrm{CN}_{4}\right)^{*}$ & of & 0 & 0 \\
\hline \multicolumn{4}{|c|}{ 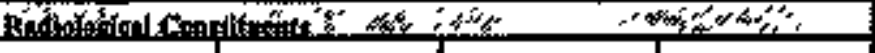 } \\
\hline$\rho_{0}$ & & $0.814(\mu \mathrm{Ci}(\mathrm{s})$ & 41.3 (kg) \\
\hline 1 & s.7120-04 (Mi) & |25: & 3810:al \\
\hline $\mathrm{Cg}_{9}$ & 4 (1) & 36.6 (x) & $1.11 \mathrm{E}+(\mathrm{S})\langle\mathrm{C}\rangle]$ \\
\hline SI & 1.01E-03(CiL)] & 0,919 (1) ciks) & $2.79 \mathrm{R}+09(\mathrm{C})]$ \\
\hline
\end{tabular}

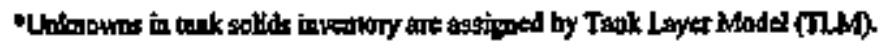

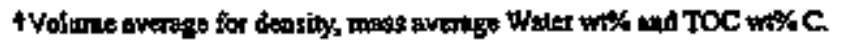

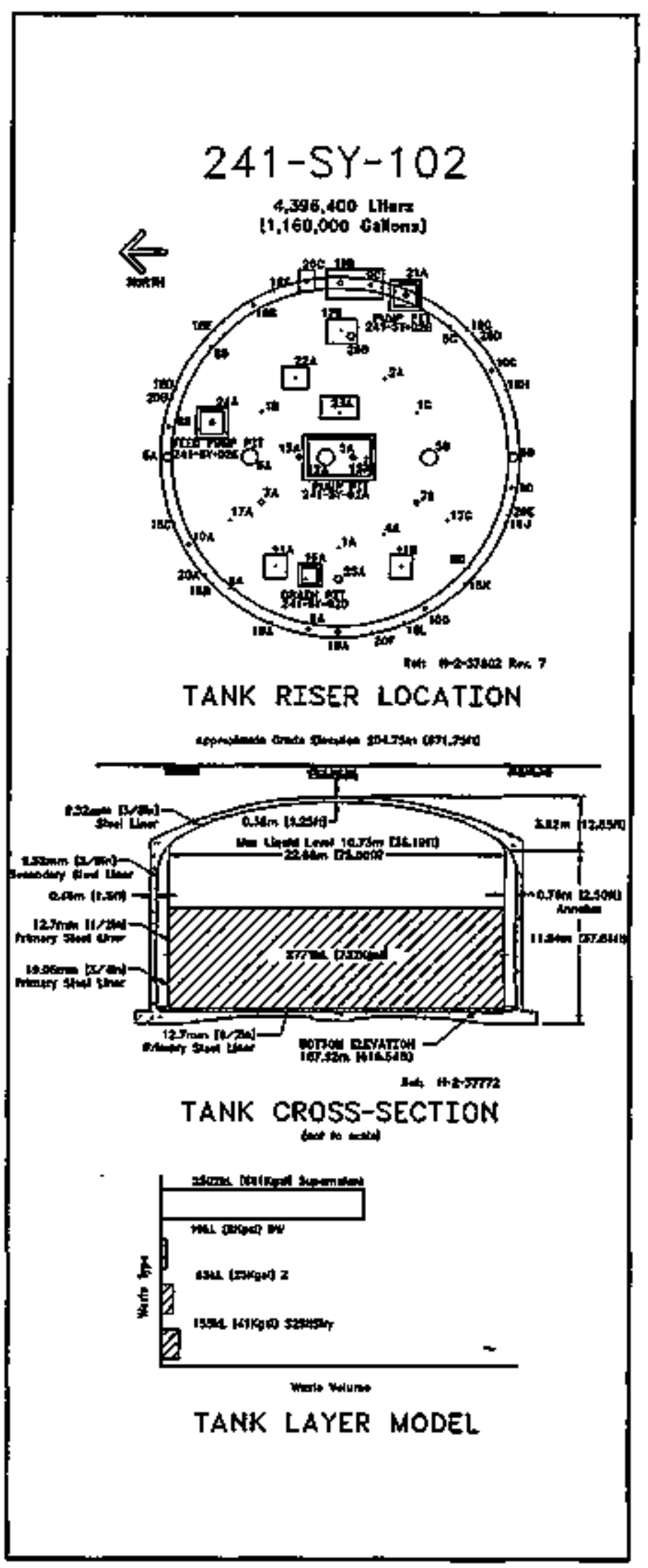


WHC-SD-KM-ER-350, Rev. 0

\begin{tabular}{|c|c|c|c|}
\hline \multicolumn{4}{|c|}{ Double-Shell Tank 241-\$Y-102 } \\
\hline \multicolumn{4}{|c|}{ 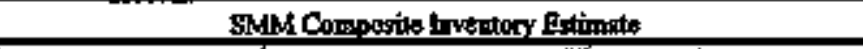 } \\
\hline 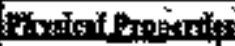 & שמוֹ' & (1) & $\because 4$ \\
\hline To蚔 Sypering & \multicolumn{3}{|c|}{$2.58 \mathrm{E}+06 \mathrm{~kg} \quad(66 \mathrm{t} \mathrm{kg}$} \\
\hline Hot loged & \multicolumn{3}{|c|}{ 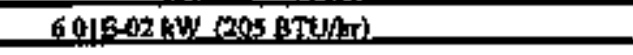 } \\
\hline Bubk Detrity & \multicolumn{3}{|c|}{$1.03(0.00)$} \\
\hline Wwer wtyt & \multicolumn{3}{|c|}{94.1} \\
\hline TOC w\%C (wt) & \multicolumn{3}{|c|}{0.018} \\
\hline \multicolumn{4}{|c|}{ 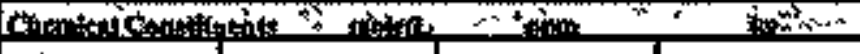 } \\
\hline $\mathbf{N a}^{+}$ & 0.744 & $1.66 \mathrm{~B}+04$ & 4.28E+04 \\
\hline $\mathrm{As}^{*}$ & 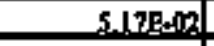 & 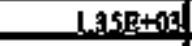 & $3.49 \mathrm{~F}+0 \mathrm{~s}$ \\
\hline$F_{0}+($ total Fe) & 122E-03 & 66.0 & 170 \\
\hline $\mathrm{C}^{+4}$ & $5,16 \mathrm{E} 203$ & 360 & 67] \\
\hline BP+ & $1.68 \mathrm{E}-0.5$ & $3.4 !$ & 8.80 \\
\hline L.8. & 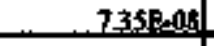 & gedest & $2,5,5-0 ?$ \\
\hline 부울 & $19 \mid 8-07$ & $3.71 \mathrm{E}-\mathrm{O}$ & 9.57E-02 \\
\hline $7.515790,1 \mathrm{~h}$ & $3,5,5 \mathrm{E}=0.5 \mathrm{~S}$ & 3.12 & 8.06 \\
\hline $\mathrm{Pb}^{\mathbf{2}}$ & 1.74E-06 & 0.350 & 0.902 \\
\hline $\mathrm{Nit}^{+*}$ & 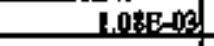 & 615 & 150 \\
\hline$s r^{2 *}$ & $7.7 \mathrm{ten}$ & $6.61 \mathrm{E}-03$ & 1.70B-M \\
\hline $\mathrm{Mn*}$ & 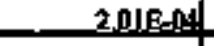 & 10.7 & 278 \\
\hline $\mathrm{Ca}^{3 *}$ & 853E-03 & 332 & 855 \\
\hline $\boldsymbol{X}^{*}$ & $2,39,5-0 \mathrm{~g}$ & 87.9 & 277 \\
\hline otr & $02 \pi$ & $4.57 \mathrm{E}+0 \mathrm{~s}$ & $1.18 \mathrm{E}+144$ \\
\hline $\mathrm{NO}$ & 0497 & 3998:104 & $770 \mathrm{P}+104$ \\
\hline $\mathrm{NO}$ & $4.00 \mathrm{E}-0 \mathrm{e}$ & $1.78 \mathrm{E}+0 \mathrm{~B}$ & $4.60 \mathrm{E}+0 \mathrm{E}$ \\
\hline$\omega_{1}^{2}$ & 3.788:09: & 2.2010R+0! & $5.68 F+n e$ \\
\hline $\mathrm{PO}_{4}{ }^{2}$ & $3.06 \mathrm{E}-0 \mathrm{3}$ & 282 & 7 \\
\hline $\mathrm{so}^{2}$ & S.58E_07 & 613 & J.58Et+of \\
\hline Si(us Sig.j) & $7.52 \mathrm{~B}-04$ & 205 & 52.9 \\
\hline$E$ & $3.11 F-07$ & 8.4. & 14 \\
\hline CT & $1.95 E-02$ & 663 & $\$ .71 \mathrm{E}+03$ \\
\hline $\mathrm{C}_{2} \mathrm{H}_{\mathrm{L}} \mathrm{S}^{2}$ & 5.45P-0A & 99.9 & 75 \\
\hline EDTA & $238 \mathrm{E}-04$ & 66.0 & 172 \\
\hline HEDTA & $3.88 \mathrm{E}=\mathrm{M}$ & 109 & 265 \\
\hline shesolfo: & $260=05$ & 189 & Af: \\
\hline metites & $2,82 \mathrm{E}-04$ & 16.2 & 41.7 \\
\hline sxaltats & $2785-17$ & $2,3 \pi=0$ & $6 \| \mathrm{ES}$ \\
\hline DEP & $2.925-04$ & 45.6 & 118 \\
\hline tytmal & $297 \leq 04$ & 2.A. & 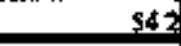 \\
\hline NH. & $2,195=03]$ & It: & \\
\hline FetCN) ${ }^{*}$ & 0] & of & 0 \\
\hline 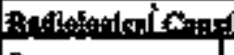 & $\tan a i^{n} \quad \alpha$ & 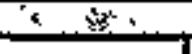 & 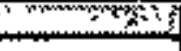 \\
\hline Pu & $4.91(\mu(5))$ & & $0.205(\mathbf{k})\}$ \\
\hline 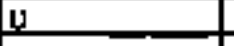 & L26E-AMA & 297 (nds) & $7 \leq 3$ AEI \\
\hline$C$ & 46:28 03 (C) & $\& 54(\mu \mathrm{C})(\mathrm{g})$ & L.I7E+04 (Ci) \\
\hline st & 3.145-04 (C) L) ] & $0.305(\mu C \mathrm{C} / \mathrm{s})$ & $786(\mathrm{Cl})$ \\
\hline
\end{tabular}

-Density is calculated based on $\mathrm{Nan}, \mathrm{OH}_{2}$, and AbOz.

tWater wt\% dertived flom the difterence of density and tonl dissedved spectes.

\begin{tabular}{|c|c|c|c|}
\hline \multicolumn{4}{|c|}{ Double-Shell Tank 241 SY-102 } \\
\hline \multicolumn{4}{|c|}{ 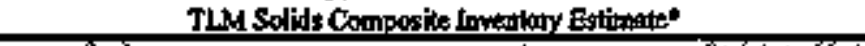 } \\
\hline 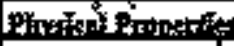 & (2) & 'm & 每"y \\
\hline Total Solid Whaste & 4.61E+16. kg & (7) kzal) & \\
\hline Heat Losd & $0.481 \mathrm{k} w$ & AEt03 BTU:Aht & \\
\hline Buink Density & & $1.71(\mathrm{e}(\mathrm{x} c)$ & \\
\hline Wata w\% & & 43.5 & \\
\hline TOC w:C C (weds & & 0.713 & \\
\hline \multicolumn{4}{|c|}{ 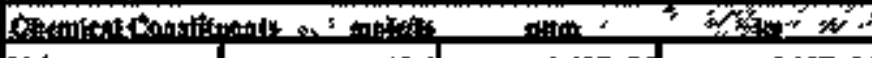 } \\
\hline $\mathrm{Ne}^{+}$ & 10.4 & $1.40 E+05$ & $6,45 E+04$ \\
\hline A! & s.t. & 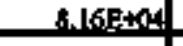 & $3.76 \mathrm{E}+14$ \\
\hline$F e^{7+}(t \operatorname{tat} 1 \mathrm{Fe})$ & 0.57 & 2.56E+04 & $1,32 E+04$ \\
\hline $\mathrm{Cr}^{5+}$ & 2.09E-A2 & $2.76 \mathrm{E}+10 \mathrm{~d}$ & L,27E+ald \\
\hline BP & 3.12E-AS & $\mathbf{3 8 0}$ & 175 \\
\hline $1 t^{3 *}$ & 13: & 1.17 & 0.515 \\
\hline$\underline{\mathrm{H}} \mathrm{g}^{* *}$ & $1.34 E-05$ & 1.57 & 0.72 \\
\hline 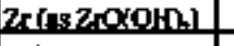 & 7.12E-0] & 113 & 570 \\
\hline $\mathrm{PQ}^{+*}$ & 3.09E-09 & 3.73 & 1.72 \\
\hline $\mathrm{NPB}^{\mathrm{B}}$ & 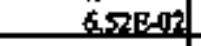 & $23 \mathrm{n}+03$ & 5.098R+03 \\
\hline Sra & 294E-0S & 1.501 & 0.692 \\
\hline $\mathrm{HI}^{+}$ & 7.610 .09 & 244 & 112 \\
\hline $\mathrm{Ce}^{2 *}$ & 0.23 & $2.87 \mathrm{E}+03$ & $1.32 \mathrm{~B}+03$ \\
\hline $\mathbf{K}^{*}$ & $2,025=019$ & $4 k$ & 214 \\
\hline OH: & $2+3$ & $2.02 E+05$ & $9.292+04$ \\
\hline NO: & 1.80. & 6.790 +0 & $3.13 x+104$ \\
\hline NO: & 4.40: & 1.15E+05 & $5.45 \mathrm{~B}+04$ \\
\hline $\cos ^{2}$ & $0.48,4$ & I. & $7.77 \mathrm{~B}+\mathrm{x}$ \\
\hline $\mathrm{PO}_{4}{ }^{2}$ & 0.185 & LO2E+04 & $4.71 E+O S$ \\
\hline $\mathrm{sos}^{3}$ & 0,318 & [.77E+口, & $8.177+10 \mathrm{~g}$ \\
\hline Si(a $\left.\mathrm{St}^{2} \mathrm{O}^{2}\right)$ & 4.79E-02 & 784 & 361 \\
\hline$F$ & $8,37 \mathrm{E}=0$ & 974 & $47 \pi$ \\
\hline Cr & 8.2:E-02 & L.71E+09 & $78:$ \\
\hline CHAOA. & 2978092 & 3.2.3.8.07 & 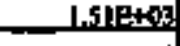 \\
\hline eñTA $A^{*}$ & 1.75E-02] & 295E+03 & $130 \mathrm{x}+0 \mathrm{~d}$ \\
\hline HEDTA & 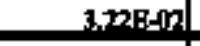 & $5.15 B+03$ & $2,37 \mathrm{~F}+0 \mathrm{~F}$ \\
\hline Plysed & 9.2550 .02 & $4058+03$ & $1898+03$ \\
\hline ecetids" & 9.29E-A3 & 320 & 147 \\
\hline 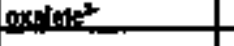 & 5.231E-0.5 & -2.67 & 1.23. \\
\hline DEP & 1.32E-02] & $206 \mathrm{E}+03$ & 947 \\
\hline botand & 1.32:_R! & $57 \mathrm{~A}$ & 26d \\
\hline $\mathbf{N H}$ & 0.Jan: & $1298=+103$ & 595 \\
\hline Fec(CN2* & & - & 0 \\
\hline 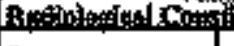 & tratist: & 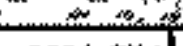 & $\theta_{n}$ \\
\hline Pu & & $5.35\left(\mu \mathrm{C} \mathrm{N}^{2}\right)$ & $41.1 \mathrm{~kg}$ \\
\hline $\mathbf{H}$ & Af78E-03 (un: & 664.(1) $\left.\mathrm{d}_{\mathrm{g}}\right)$ & $305(\mathrm{ks})$ \\
\hline $\mathrm{Cs}$ & 037L (CUL). & $216\left(\mathrm{ACH}_{\mathrm{s}}\right)$ & 9.97E404 (Cj) \\
\hline St & 7A75-49 (CiL) & 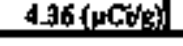 & 201E+(0) (Ci) \\
\hline
\end{tabular}

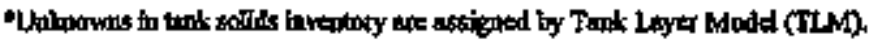




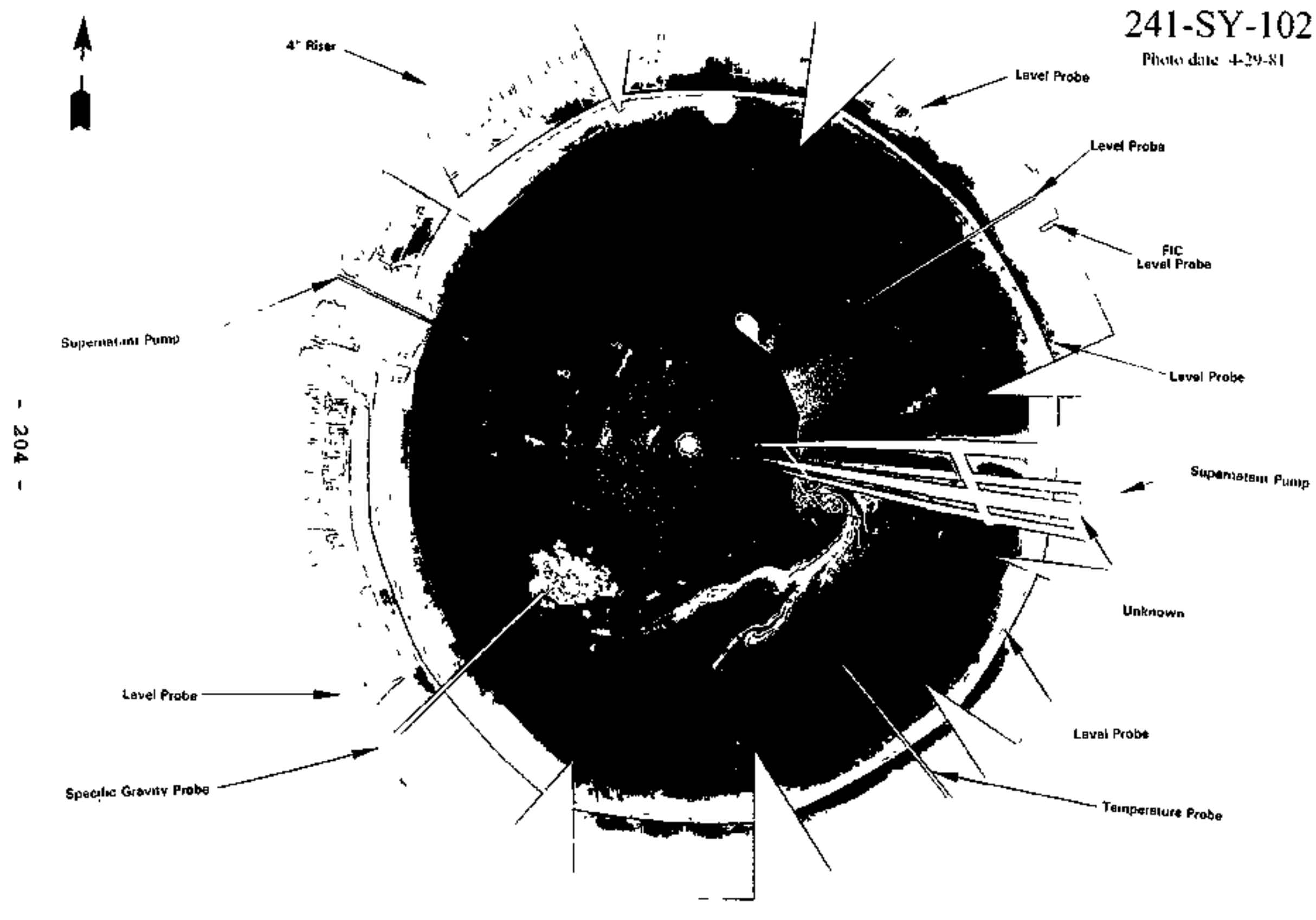


WHC-SD-WH-ER-350，Rev. 0

7.3 Tank 241-5Y-103

7.3.1 241-5Y-103 Tank History

7.3.1.1 Waste History of Tank 241-5Y-103

Tank 241-SY-103 began service by receiving residual liquor in the second quarter of 1977. The tark received residual liquor until the fourth quarter of 1977. From the first quarter of 1978 until August 1980, the tank received complexant concentrate waste. The tank contained doubleshell slurry waste from Oetober 1980 until May 1990. During March 1983 and May 1987, the waste was designated complexant concentrate waste. The tank received dilute non-complexed waste from the 200-East Area single-shell tanks from the second quarter of 1988 until the second quarter of 1989. From June 1990 until the present, the tank has contained complexant concentrate waste. The slight level changes are attributed to sluxry growth as a result of gas generation. The tank has not received waste since the second quarter of 1989. The tank is currently an inactive, concentrated waste holding tank.

\subsubsection{Temperature History of Tank 241-SY-103}

Tenperature data for Tank 241-5Y-103 are recorded by 18 thermocouplos at known elevations on on thermocouple tree inside the tank, located in riser $4 \mathrm{~A}$. Only 13 of the 18 thermocouples had temperature data. Nonsuspect temperature data taken between july 1983 and March 1988 for seven of the thermocouples were available from the conputer automated survejllance system. However, not all of the seven thermocouples have data that enconpass the entire Iength of time. Non-suspect tenmerature data recorded between January 1991 and September 1993 for seven of the thermocouples were available from the surveillance analysis computer system. However, not all of these thermocouples have data that encompass the entire length of time. Within the time spans of each system, there were small breaks in the sequence of temperature data. The average temperature during these periods was $109^{\circ} \mathrm{F}$ with a minimum of $67{ }^{\circ} \mathrm{F}$, a maximum of $135^{\circ} \mathrm{F}$, and a standard deviation of $15^{\circ} \mathrm{F}$. Linear regressions were performed on each thermocouple that had termerature data between January 1991 and January 1994. The slopes from these regressions were averaged with a resulting slope of -0.0090 . Refer to the supporting document for a more thorough review of the temperature data (Brevick, $1995\}$.

\section{3 .1 .3 Occurrences of Tank 241-SY-103}

Three unusual events occured at Tenk 241-5Y-103. Occurrence report RL-WHC-Tank Farm-1993-0101 was issued in November 1993 because a frozeri valve on the exhaust header partially blocked air flow. off-Normal Report 86-18 was written because Tenk 241-5Y-101 burped causing Tank 241-SY-103 to pressurize. Unusual occurrence Report 79-17 was issued in February 1979 because the liguid waste level decreased below established criteria. The decxase in Iicuid level was due to an unexpected waste transfer. 


$$
\text { WHC-SD-WH-ER-350, ReV. } 0
$$

\subsubsection{Psychrometrics of Tank 241-SY-103}

Psychrometric data have been recorded for 17 years from this tank and annulus. The apparent trend of the evaporation rate from the tank has increased from 112.8 gallons per week in May 1977 to 116.7 gallons per week in January 1995. over that same period, the trend in the rates of heat exchange through the primary tank ventilation has decreased. The rates of heat exchange through the annular ventilation show an increasing trend. The majority of the changes in the rate of heat exchange can be attributed to changes in the average ventilation rates. A review of the psychrometric data in Tank 24I-SY-103 would suggest an increase in the rate of heat generation by the waste.

\subsubsection{Current Status of Tank 241-SY-103}

Tank 241-sY-103 entered service in April 1977 and currently stores 750,000 gallons of waste. The following plan view and tank cross-section depict the approximate waste volume of 758,000 gallons and configuration of risers in January 1994. At the time of the estimate, there were 758,000 gallons of supernatant with 577,000 gallons of concentrated supernatant solids. The waste level in the tank is measured with the FIC gauge and the manual tape and has slightly increased and decreased from January 1991 to January 1994. The increases were slurry growth as a result of gas generation and the decreases were the venting of the gas between January 1991 and January 1994. This tank is on the Hydrogen Watch List and, therefore, is prohibited from receiving waste. The tank is actively ventilated and categorized as sound. Tank 241-5Y-103 has 54 risers as of Jamuary 1994. Four 4-inch risers (no.11, no.14, no.16, and no.22) and two 12-inch risers (no.3 and no.7) are available for use.

\subsubsection{Inventory Estimate of Tank 241-sY-103}

The tank layer model (a volume based approximation) that follows was derived from the Los Alamos National Laboratory Waste status and Transaction Record Summary (Agnew, 1995) and Supernatant Mixing Hodel (Agnew, 1995). The estimated inventories of total waste, solids, and supernatant in Tank 241-\$Y-103 are also presented. Concentrated supernatant solids tre considered as an integral part of the liguid for the purpose of estimating inventories, but are graphed as solids on the level. histories. The actual substance, which was derived fxom clouble-shell slurry, appears as a solid if undisturbed, but the particles are resuspended in solution if heated or disturbed.

\subsubsection{In-Tank Photograph of Tank 241-SY-103}

In April 1994, Tank 241-5Y-103 contained 744,000 gallons of couplexed concentrate (Hanton, 1994) which is waste that has been processed through an evaporator. The most recent collage for this tank was assembled it 1985 and at that time the tank contained 577,000 gallons of double shell $\$$ luriry. It appears the waste at that time was black liccuid. The tank walls appear to be in very good condition. The location of equipinent in the tank should be the same now as it was in 1985. Some level probes and a

$$
-206-\quad 6 / 95
$$


WHC-SD-WM-ER-350， Rev. 0

temperature probe axe visible. The waste height is about 23 feet.

7.3.3 Synopsis of Tank 241-SY-103

(To be completed.) 


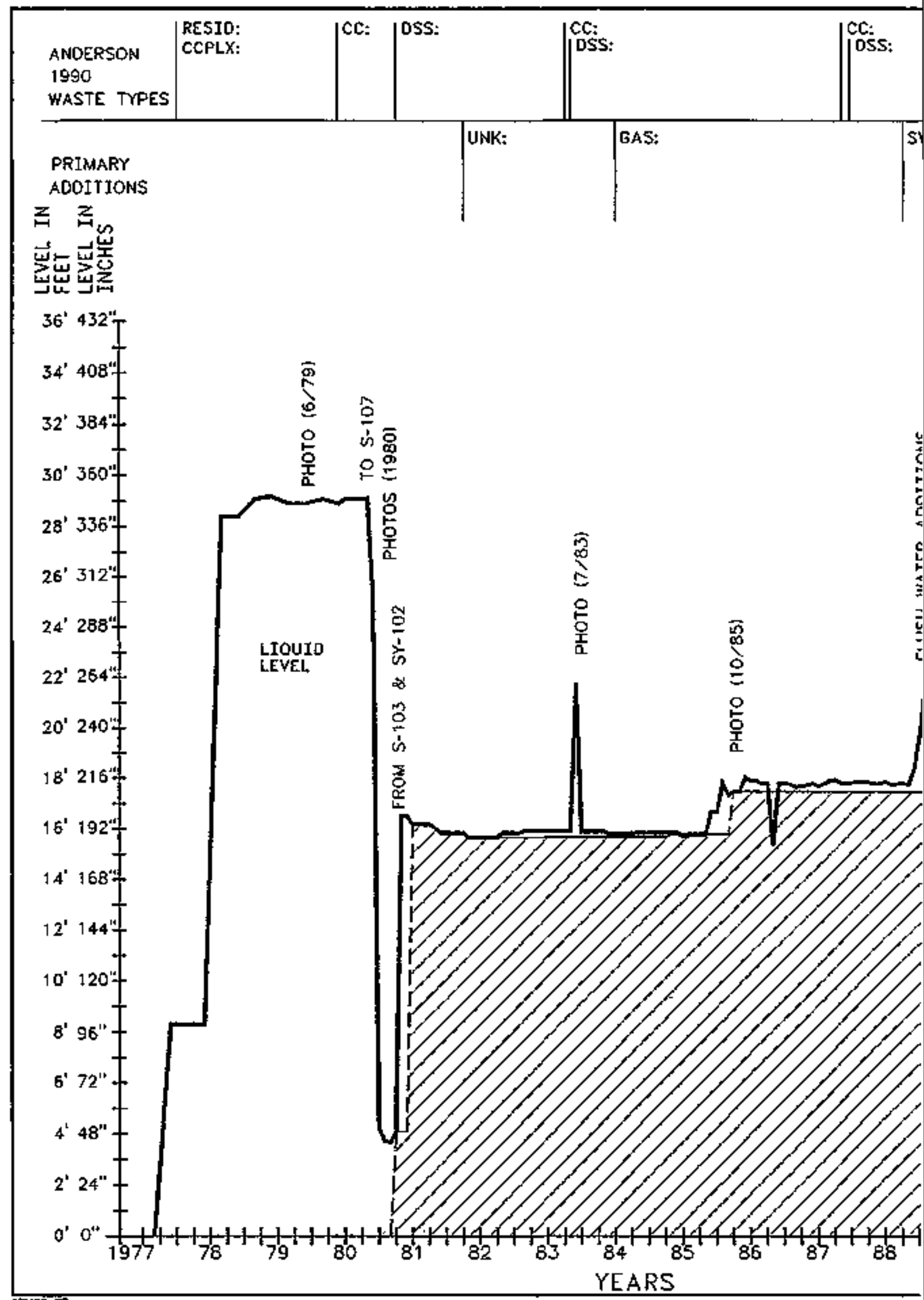


WHC-SD-TM-ER-350, Rev. 0

\begin{tabular}{|c|c|c|c|}
\hline \multicolumn{4}{|c|}{ Double-Shetl Tank 241-SY-103 } \\
\hline \multicolumn{4}{|c|}{ Thonl Irvepotary Esthosect" } \\
\hline \multicolumn{4}{|c|}{ 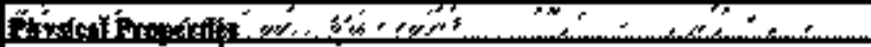 } \\
\hline Tol:] Wate & $4.21 \mathrm{E}+06 \mathrm{~kg}$ & (758 kgal) & \\
\hline Heallowd_. & \multicolumn{3}{|c|}{$536 \mathrm{~kW}(1838+04 \mathrm{BTH} / \mathrm{Mr})$} \\
\hline Bulk Denstut & \multicolumn{3}{|c|}{$1,47(g / \infty)$} \\
\hline Winer west & \multicolumn{3}{|c|}{45.7} \\
\hline Toc wath C & \multicolumn{3}{|c|}{$1.0 \mathrm{E}$} \\
\hline \multicolumn{4}{|c|}{ 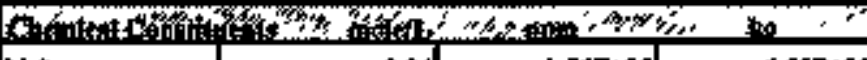 } \\
\hline $\mathrm{Na}^{*}$ & 9.94 & $1,56 \mathrm{E}+0.05$ & $6,56 \mathrm{~B}+0.5$ \\
\hline At? & $1,400]$ & $2,36 \mathrm{E}+04$ & $1,068+05$ \\
\hline 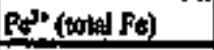 & 2.74E-03 & 104 & $\mathbf{4 4 0}$ \\
\hline$C^{*}$ & 3.2IE-AP| & $1.148+0.3$ & $4,798+03$ \\
\hline$\theta^{*}$ & L.6IE-OS: & 220 & 964 \\
\hline +4. & [ALERAS & 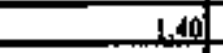 & 5,21 \\
\hline His & 9.81E-0 & 1.34 & 5.65 \\
\hline 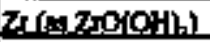 & 9.848 604 & GLW & 259 \\
\hline $\mathrm{Pb}^{2+}$ & $4.858-05$ & 6.64 & 21.8 \\
\hline $\mathrm{N}$ & 3.79p_-0] & 95.4 & 40 \\
\hline St" & 1.5720 .05 & 0.936 & 394 \\
\hline Lin" & 8.08E-03 & 302 & $1.278+0 ?$ \\
\hline Ct* & $1.92 E-02$ & 524 & $2,21 \mathrm{~B}+02$ \\
\hline $\mathbf{K}^{*}$ & $2,400-02$ & 639 & 2 269040? \\
\hline 아 & 6.00 & $7.01 \mathrm{E}+06$ & 2.95E+0.5 \\
\hline$N$ & $3,0,01$ & $1.7 \pi= \pm 0.5$ & $5,348+05$ \\
\hline No: & 2.4. & $800+00$ & $3.75 \mathrm{E}+05$ \\
\hline$\alpha_{2}{ }^{2}$ & $0,3 \times$. & $1.918+04$ & 6965010 \\
\hline $\mathrm{PO}_{1}^{2+}$ & $0.13 \times 4$ & $8.66 \mathrm{E}+03$ & $3,69 \mathrm{~F}+0 \mathrm{~d}$ \\
\hline 802 & 0281 & $1.80 \mathrm{atan}$ & 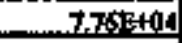 \\
\hline$S i\left(\operatorname{tas} s: 0^{2}\right)$ & $4.06 \mathrm{E}-02$ & 77 & $3,27 \mathrm{E}+0.3$ \\
\hline $\mathbf{F}$ & $9678-07$ & $125 \mathrm{se}+09$ & $\leq 271509$ \\
\hline a & 0.170 & $4.11 \mathrm{E}+0 \mathrm{03}$ & $1.73 E+04$ \\
\hline$C_{1}+H_{0}^{2}$ & $3,45 E=02$ & $4.45=403$ & $1.8 T 2+04$ \\
\hline EDTA* & $2.158-02$ & $4223+09$ & $1.73 E+04$ \\
\hline HAOTA. & 3.84E-19 | & $7.172+09$ & $3.028+04$ \\
\hline strenoles: & 0.104 & $5.31 \mathrm{E}+103$ & $2.24 \mathrm{E}+104$ \\
\hline methis" & $1.48 P-02$ & 595 & $2.51 E+05$ \\
\hline oxalutse & $5.600-0.5$ & 3.36 & 14.1 \\
\hline DBP & $1.64 \mathrm{E}-02$ & $+808+03$ & $2,57 \mathrm{E}+03$ \\
\hline Extmot & LAAP_DWI & 22 & $3.48 \mathrm{E}+0 \mathrm{a}$ \\
\hline $\mathrm{NH}$ & $469 \mathrm{E}=9$ & 513 & $2792+0$ \\
\hline FercN $4^{*}$ & & & \\
\hline \multicolumn{4}{|c|}{ 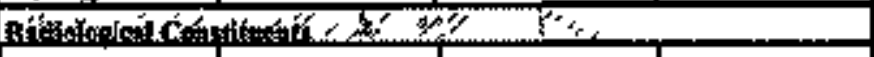 } \\
\hline $\mathrm{Pa}$ & & $252 \mathrm{~B}-12$ (p) $\mathrm{CV} / \mathrm{g})$ & 1.7 (kest) \\
\hline$\underline{y}$ & $5,20 \mathrm{E}-09 \mathrm{MS}$ & 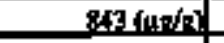 & 3.55E+15 (kP): \\
\hline Cs & 0.386 (CSL) & 263 (4, $\mathrm{CH}_{3} \mathrm{~B}^{3}$ & $1.11 \mathrm{E}+06(\mathrm{C})$ \\
\hline St & 8.76E-03 (ClL) & 5.97 (1xicin) & $2.51 E+O 4(C)$; \\
\hline
\end{tabular}

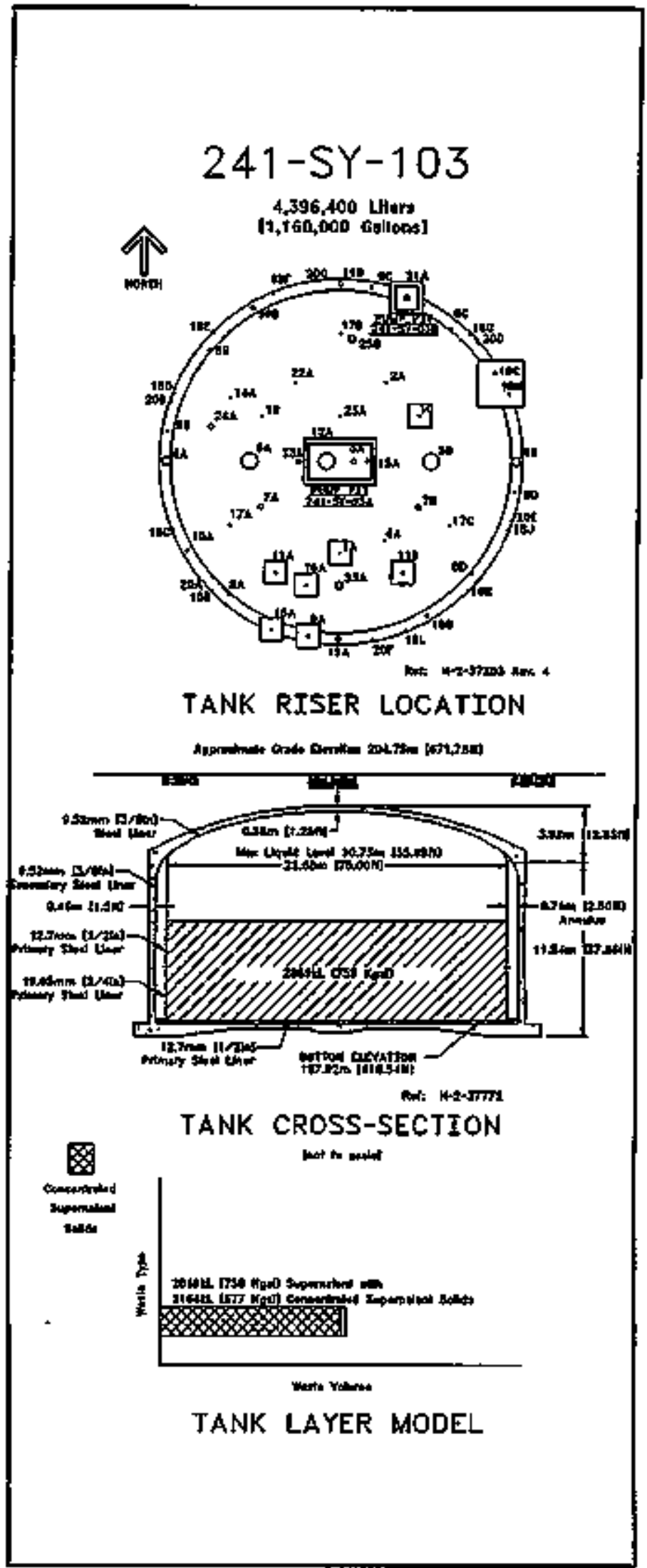




\begin{tabular}{|c|c|c|c|}
\hline \multicolumn{4}{|c|}{ Double-Shet| Tank 241-SY-103 } \\
\hline \multicolumn{4}{|c|}{ ShiM Cornposile time tory Estimnte } \\
\hline \multicolumn{4}{|c|}{ 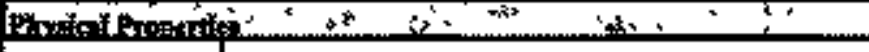 } \\
\hline Total Syermatigt & \multicolumn{3}{|l|}{$421 \mathrm{2}+06 \mathrm{~kg}$} \\
\hline lien load & \multicolumn{3}{|c|}{ s36kw a g36tod etworl } \\
\hline Balk Destits & \multicolumn{3}{|c|}{ 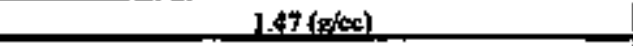 } \\
\hline Wate wot & \multicolumn{3}{|c|}{ 45.7 } \\
\hline TOC wto C (wat) & \multicolumn{3}{|c|}{1.08} \\
\hline \multicolumn{4}{|c|}{ 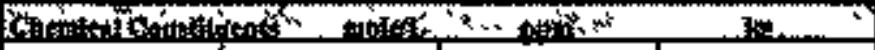 } \\
\hline $\mathbf{N a}^{+}$ & 9.94 & 1_S6E+4S & $6.56 \mathrm{~B}+0 \mathrm{05}$ \\
\hline$\Delta \mathbf{P}^{*}$ & $1,40]$ & 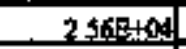 & $1088 \pm 05$ \\
\hline$F^{\prime *}$ (tote Fe) & $2.740-05$ & 104 & $\mathbf{4 4 0}$ \\
\hline $\mathbf{c}^{3+}$ & 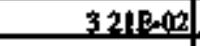 & $148+09$ & $479 \mathrm{~B}+0 \mathrm{P}$ \\
\hline Bst & $1.6+D_{-103}$ & 229 & 961 \\
\hline$L I^{1+}$ & $148 \mathrm{~B}_{-105}$ & LAd & 591 \\
\hline $\mathbf{H}_{\mathbf{3}} \mathbf{3}^{*}$ & 9.8LE-0. & 1,30 & S.6. \\
\hline $2 \pi(\div 70$ OOHA) & 9 영다에세 & 61.1. & $25:$ \\
\hline $\mathrm{Pz}^{2 *}$ & 4.85E-0s & 6.84 & 25.8 \\
\hline $\mathrm{Ni}^{2}$ & 239800 & 954 & 400 \\
\hline$s x^{*}$ & $157 \mathrm{E}-0 \mathrm{~s}$ & 0.936 & 3.94 \\
\hline $\operatorname{mgn} x^{12}$ & 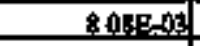 & 300 & 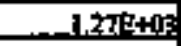 \\
\hline $\mathrm{Cs}^{2 *}$ & $1.920 \times 00$ & $\$ 24$ & $2,21 E+10$ \\
\hline$K^{+}$ & $240 \mathrm{E}-m$ & 639 & $260 \mathrm{E}+0 \mathrm{P}$ \\
\hline OH & 6.06 & 7.0타언 & $295 \mathrm{E}+4 \mathrm{~d}$ \\
\hline No: & $3.0,0$ & 1.27z+est & 534R+영 \\
\hline No: & 284 & 1.90E+04 & $3.75 \mathrm{E} \neq 0 \mathrm{0S}$ \\
\hline $\mathrm{CO}_{2}^{2}$ & (1.369] & 15istod & 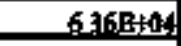 \\
\hline $\mathrm{FO}_{2}^{2}$ & 0.134 & LG6E+4a & $3.65 \mathrm{E}+0 \mathrm{~N}$ \\
\hline $\mathrm{BO}^{2}$ & 0.281 & L & $7.76 \mathrm{E}+5 ! \mathrm{a}$ \\
\hline Si(us Sig & 4.06E-00 & $7 \pi$ & $3.27 \mathrm{E}+0 \mathrm{~g}$ \\
\hline $\mathrm{F}$ & 967E-OP & 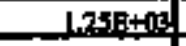 & 5.778ta? \\
\hline ct & 0.170 & $4.11 \mathrm{E}+0 \mathrm{3}$ & I. $7 \mathrm{BE}+0 \mathrm{~d}$ \\
\hline C.thos & $345 \mathrm{~F}-\mathrm{O}=2$ & $4459+09$ & $187 x+04$ \\
\hline BPTA ${ }^{*}$ & $2.15 \mathrm{~B}-0 \mathrm{2}$ & $422 \mathrm{x}+0 \mathrm{~g}$ & $1.72+04$ \\
\hline HEDTA & 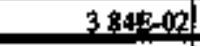 & $7 \mathrm{z}=\mathrm{A}+\mathrm{A}$ & $3004 \div 04$ \\
\hline phicoltrte: & 010]$. & $5318+0$, & $224 \mathrm{~B}+14$ \\
\hline actetate & $1.48 \mathrm{E}-0 \mathrm{O}$ & squ & $2 S L E+09$ \\
\hline soxnlatst & 5.6015-0.5 & 336 & 14 \\
\hline DBP & $1.64 \mathrm{E}-0 \mathrm{2}$ & $1.80 \mathrm{x}+0 \mathrm{O}$ & $7,57 \mathrm{E}+0 \mathrm{E}$ \\
\hline buthanal & 64E-02 & & 3.48E+os \\
\hline $\mathrm{N}_{\mathrm{H}}$ & $469 \mathrm{~F}=0$ & 셕 & 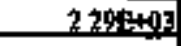 \\
\hline $\mathrm{Fe}\left(\mathrm{CN}_{\mathrm{S}}{ }^{*}\right.$ & in & 0 & \\
\hline 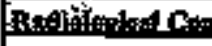 & 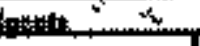 & س" & 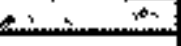 \\
\hline Pu & $36.9(\mu \mathrm{C})$ & & $1 . \pi \mathrm{f}(\mathrm{cos})$ \\
\hline 4 & $520 \mathrm{~F}-0 \mathrm{~A}$ AN) & $843(x)=d s$ & 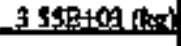 \\
\hline $\mathrm{Cs}$ & $0.3 \%\left(C_{2}\right)$ & 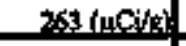 & L. $1 \mathrm{E}+06 \mathrm{C}(\mathrm{Ci})$ \\
\hline st & $8.76 \mathrm{E}-03(\mathrm{Cin})$ & $5.97(\mu c)-1)$ & $2,51 \mathrm{~B}+04(C)$ \\
\hline
\end{tabular}

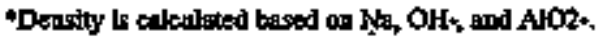

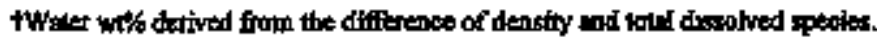

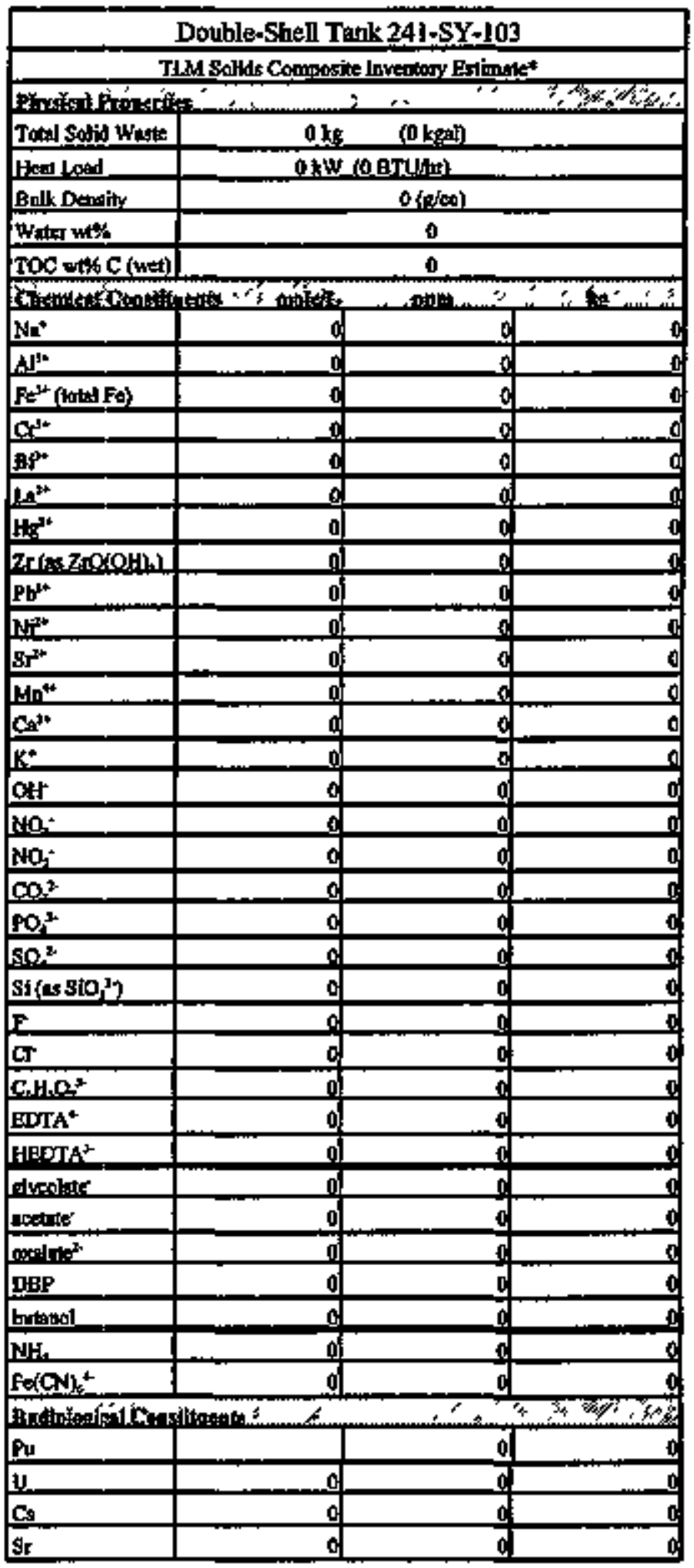

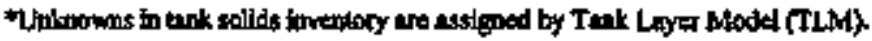




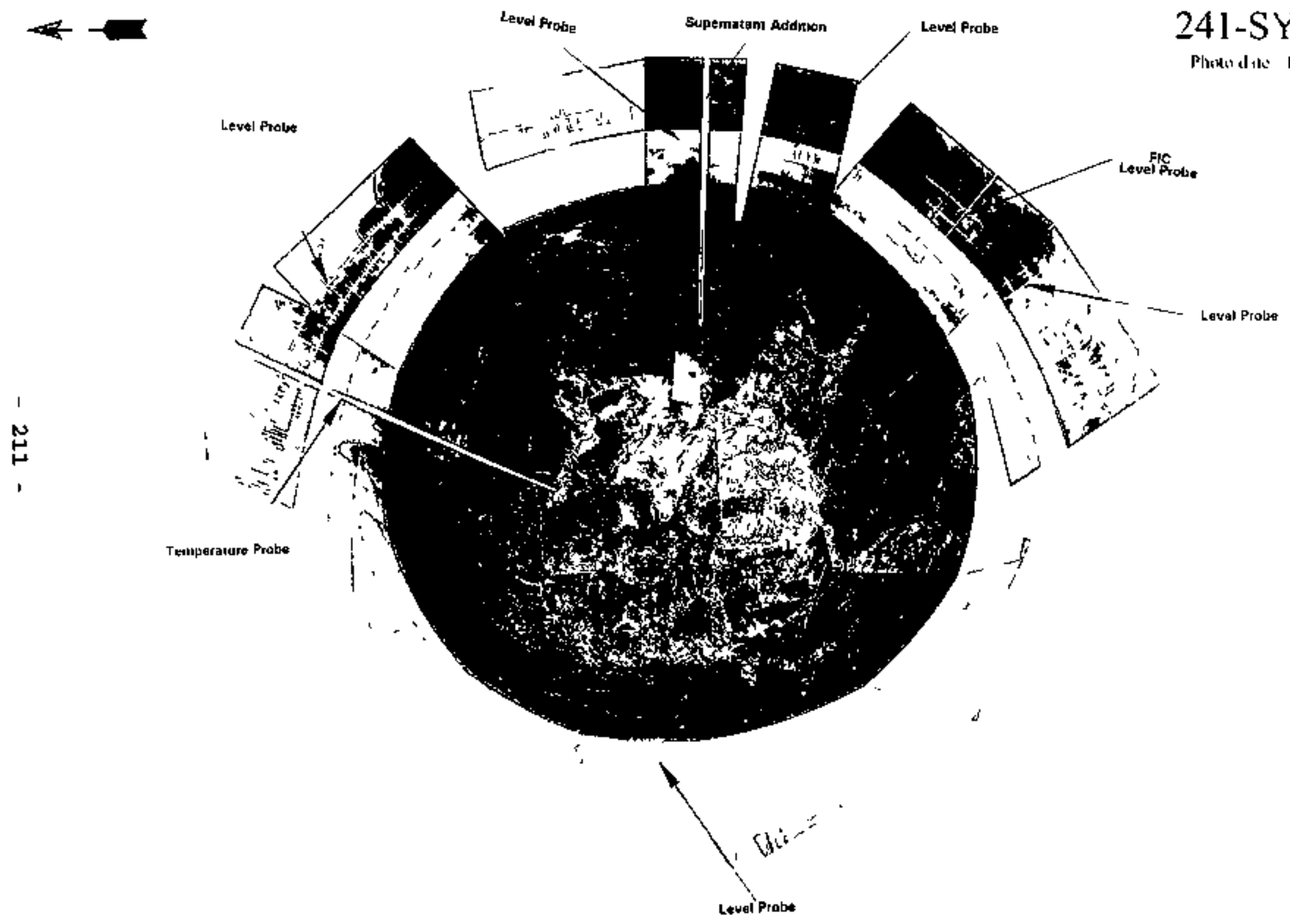


0.17

0.33

1

IAYIN

IAZIN

2c

1CEB

$1 \mathrm{cs}$

1st Generation Tank

222-B

$222-\mathrm{C}$

222-T

222-U

224

224-F

$231 \mathrm{z}$

242-A

242-B

242-5

242-T

2AYIN
Transaction flag key - monthly volumes dexived from semiannual reports.

Transaction flag key - monthly volumes derived fxom guarterly reports.

wonthly report

See Waste Abbreviations.

See Waste Abbreviations.

See Waste Aboreviations.

See Waste Abbreviations.

See Waste Abbreviations.

The original tark design found in Tank Farns $B, C$, $T$, $U$ (excluding the 200 series tanks), and BX. These tanks have an operating capacity of 530,000 gallons, a 75-foot diametsr, a 12-inch dish bottom, and a 4-foot knuckle. Also, see Type II tanks.

See Facilities.

See Facilities.

See Facilities.

See Facilities.

See Waste Abbreviations.

See Haste Abbreviations.

See Waste Abbreviations.

See Facilities.

See Facilities.

See Facilities.

See Facilities.

See Waste Abbreviations. 


$$
\text { WHC-SD-WH-ER-350, Rev. } 0
$$

2AZIN

$2 \mathrm{C}$

2nd Generztion Tank

2SYIN

3

3AWIN

3 rd Generation Tank

4th Generation Tank

5

$5-6 \#$

5AWIN

5th Generation Tank

6

6AWIN

A Plant (PUREX)

A1 SLTCK

A2 SLTSLRY

Active Tank

Active Drywell
See Waste Abbreviations.

See Waste Abbreviations.

Same as original tank design (1st generation or Type II) except the operating capacity was increased to 758,000 gallons. Also, see Type III tarks.

See Haste Abbreviations.

Quarterly report

See Waste Abbreviations.

The first generation of the Type IV tanks, contained only in the sx Tank Farm. These tanks have a 1,000,000 gallon operating capacity, a 75foot diameter, a 14.875-inch dish bottom, and no knuckle. Also, see Type IV tanks.

The second generation of the Type IV tanks, found only in the A Tank Farm. These tanks are the same as the 3ra generation except they have a flat bottom. Also, see Type IV tanks.

See Waste Abbreviations.

Cells 5 and 5 from B Plant

See Waste AJbreviations.

The third generation of the Type IV tanks, Eound only in the AX Tank Faxm. Thesse tanks are the same as the 4 th generation with the addition of grid drain slots beneath the steel liner bottom.

Semiannual report

See Faste Abbreviations.

See Facilities.

See LaㅗL Defined Waste List.

See LaNL Defined Waste List.

A tank that contains more than 33,000 gallons of waste and/or is still involved in waste management operations.

Drywell in which radiation readings of greater 
ADD

ADS

AGE, AGING

Aging Waste

Airlift circulator

Annulus

AR Vault

AR

Assumed Leaker

Assimed Re-leaker

Assumed Leaking Tank

\section{B SLTCK}

B

B Plant (222-B)

B860N

$$
\text { WHC-SD-MMLER-350, Rev. } 0
$$

than 50 counts/second are detected. To be considered active, the readings must be consistent as to depth and radiation level for repeated readings.

Ada primary waste from process.

Adjustment to waste amount - see CORR.

Waste abloreviation

High-leveI, first-cycle solvent extraction waste frorn the PUREX Plant (NCAW)

Airlift circulators are installed in tanks used to age wastes. The circulators promote mixing of the supernatant and prevent agglomeration of radionuclides. By maintaining motion within the body of liguid, the circulators minimize overheating and, consequently, minimize bumping.

A vessel space in the form of a ring; the space between concentric circular walls.

A structure containing tanks and chemical processing equipment that is used for waste processing or storage operations.

See LaNL Defined Waste List.

A waste storage tank for which surveillance data in the past has indicated a loss of liquid attributed to a breach of integrity.

A designation that exists after a tank has been declared an "assumed leaker" and then the surveillance data indicate a new loss of licuid attributed to a breach of integrity.

In 1984, the criteria designations of "suspect leaker", "questionable integrity", "confirmed leaker", "declared leaker", "borderline", and "dormant" were merged into one category now reported as "assumed leaker".

See IANE Defined Waste List.

See Waste Abbreviations.

See Facilities.

See Waste Abbreviations. 


$$
\text { WHC-SD-WM-ER-350, Rev, } 0
$$

Background Radiation

Baseline

BFSH

BL

BLEB

BLIX

BLIXB

BAw

BWW

BPDCC

BPDCS

BPDCV

BPFPS

BPLCS

BPLDC

BPLDW

Bumping, Tank Bump

BVCLN

BY SLTCK

C Plant (222-C)

C PLANT

Caisson
Radioactivity from naturally occurring sources; primarily radiation from cosmogenic and naturally occurring ractionuclides.

A reference; for example, a specified liquid level or radiation level against which new information is compared.

See Waste Abbreviations.

See Waste Abbreviations.

See Waste Abbreviations.

See Waste Abbreviations.

See Waste Abbreviations.

Battelle Northwest Laboratory

See Waste Abbreviations.

See Waste Abbreviations.

See Waste Abbreviations.

See Waste Abbreviations.

See Waste Abbreviations.

See Waste Abbreviations.

See Naste Abbrevietions.

Soe Waste Abbreviations.

A tank bump occurs when solids overheat in the lower portion of the tank. The hot solids rapidly transfer heat to the liquid, some of which quickly vaporizes. The sudden pressurization caused by vapor generation is called a "bump".

Ses Waste Abbreviations.

See LANL Defined Waste List.

See Facilities.

See SSW.

An underground structure used to store high-level waste; typical designs include corrugated metal or 
Calcine

CARB

CAs

Cascade

CASS

Cateh Tanks

CAN

$\mathrm{cc}$

CCGL

CCGR

CCPI

CCPLX

$\operatorname{cow}$

CDF

$\mathrm{CE}$

CELI 23

$$
\text { GHC-SD-WM-ER-350, Rev. } 0
$$

concrete cylinders, 55-gallon drums welded eno-toend, and verticel steel pipes below grade.

To heat a substance to a high temperature, but below its melting point, causing loss of volatile constituents such as moisture; refers also to the material produced by this process.

See Waste Abbreviations.

Cascade - see SET and END. This process filled three tanks with one purm using overflow siphoning. Normal use was with a secuence of tanks such as $101,102,103$, or 110, 111, 112.

Eleven of the single-shell tank farms (a.1 except the AX Tank Farm) were equipped with overflow lines between tanks. The tarks were connected in series and were placed at different elevations creating a downill gradient for liquids to flow from one tank to another.

Acronym for Computer Automated Surveillance System.

Small capacity single-shell tanks associated with diversion boxes and diverter gtations. The tanks are designed to receive any transfer line clean out, apilis or leakage from the boxes, or leakage from the adjacent pipe encasement.

Carrent acid waste; this is FUREX acid high-level waste.

Ses Waste Abbrevietions.

See Waste Abbreviations.

See Waste Abbreviations.

See Waste Abbreviations.

See faste Abbreviations.

Concentrated customer waste

composition data file or transaction flag key unit volume assumed to make stream active.

See Waste Abbreviations.

Waste from cell 23 at B Plant. Cell 23 contained 
CEM

CF

CON

COND

Condensate

Conductivity Exobe

Confirmed or

Declared Leaker

$\operatorname{COOL}$

CORR

CP

CPEX

CR vault

Crib

Crust

CSFD

CSR

css

$\operatorname{csT}$ an evaporator.

See Waste Abbreviations.

See Waste Abbreviations.

See Maste Abbreviations.

Condensate - see EVAP, EB.

Liquid formed from cooling vapors

A device that completes an electrical circuit when contacted by a conductive material.

The designation of any underground waste storage tank where the data are considered sufficient to support a conclusion with 95 percent confidence that the tank has leaked.

Change in waste volume due to cooling. See CORR.

Correction to waste amount - see ADJ, LEAK, COOL.

See Waste Abbreviations.

See Haste Abbreviations.

Facility located adjacent to C Fazm, used for scavenging campaign following uranium recovery. Ferrocyanide was added to tank supernatants in the CR vault and the slurry was returned to $C$ Farm.

A linear excavation approximately 15 feet in depth with a perforated pipe along the bottom. The ditch was backfilled with broken rock, gravel, or other loose material and then covered by soil and a membrane with very low permeablity. The pipe distributed intermediate level liquid wastes along the crib.

A hard surface layer that has formed on top of the liguid in many waste tanks that contain concentrated solutions.

See Raste Abbreviations.

See Waste Abbreviations.

See Waste Abbreviations.

See Waste Abbreviations. 
CSNLE

cswhw.

CTH

CW

$C W / Z R 2$

CWP

CHP/ZR

CWP2

CWR

$\operatorname{cx70}$

D

DBP

DC

DCS

DE

DE

Delfquescent

Desiccant

Diatomaceous Earth

DIL

DILFD

Ditch
See Haste Abbreviations.

See Waste Abbreviations.

Caustic waste for makeup

See Waste Abbreviations.

See Faste Abbreviations.

See Waste Abbreviations.

See Waste Abbreviations.

See LANL Defined Waste Ifist.

See Waste Abbreviations.

Ses Waste Abbreviations.

Transaction Flag Key - emount by difference

Dibutyl phosphate

See Waste Abbreviations,

Acronym for dilute caustic solutions

Acronym for diatomaceous earth that was added to Tanks 241-BX-102, -SX-113, -TX-106, and -0-104 from 1970 to 1972 .

See Land Defined Waste List.

Capable of absorbing moisture from the air and dissolving to become a 1 icuid.

A Arying agent such as diatomaceous earth.

Diatomite is a light Exiable siliceous material derived fxom diatom (algae) semains. It is added to selected underground wate storage tanks to absorb and, thereby, immobilize residual liquids (i.e. help stabilize the tank).

Dilution

Dllute feed

A linearly oriented excavation often used for the temporary aiversion or disposal of pxocess waste streams. 
WHC-SD WM-ER-350, Rev. 0

Diversion Box

DN/ PT

DN/ PD

DN

Double-she1l Tank

Double-Shell slurry

Double-she11 slurry Feed (DSSF)

Drywell

Drywe11 (in-tank)

DSS

DSSF

DUMM

DUMAY

DW

DWBIX

E
A below grade, concrete enclosure containing the remotely maintained jumpers and spare nozzles for the routing of waste solution to storage tank farms.

See Waste Albreviations.

See Waste Abbreviations.

See Waste Abbreviations.

The newer underground waste storage tanks consisting of a concrete shell and two concentric carbon steel liners with an ansulus between the liners.

Waste that exceeds the sodium aluminate saturation boundary in the evaporator without oxceeding receiver tank composition limits. For reporting purposes, DSs is considered s solid.

Waste concentrated just before reaching the sodium aluminate saturation boundary in the evaporator without exceeding receiver tank composition 1imits. This form is not as concentzated as DSS.

A steel casing, generally 6 inches in diameter, drilled into the ground to various depths and used to insert monitoring instruments for measuring the presence of radloactivity or moisture content.

A sealed cesing within thank that is attached to a riser. It is usea to insert experinental equipment, such as neutron or acoustical probes, to determine the level of drainable interstitial licruor.

See Waste Abbreviations.

See Waste Abbreviations.

See Waste Abbreviations.

See Waste Abbreviations.

See Waste Abbreviations.

See Waste Aboreviations.

Transaction flag key - waste transferred through evaporator. 
EB

EDTA

EF

EFD

END

Environs

EV

EVAP

EVAPF

Evaporator Feed

EVS

EVT

FD

FRCN

Ferrocyanide

FIC gauge
See Waste Abbreviations.

Ethylenediaminetetra-acetic acid

See Waste Abbreviations.

See Waste Abbreviations.

Disconnect cascaded tanks, see CAs, Set.

Surrounding area, vicinity

Evaporation

Ses Naste Abbreviations.

See Waste Abbreviations.

Any waste liguid that can be concentrated to form saltcake; 由.g., aged waste, low heat waste, dilute interstitial liquor, and other radioactive waste solutions.

Evaporator-Crystallizer

242-A and 242-S waste concentration facilities that oparate at a reduced pressure (vacuum) and are capable of producing a slurry containing about 30 volume percent solids at a specific gravity of greater than 1.6 .

Partial neutralization in the 242-S Evaporator.

HEDTA destruction in the 242-B or 242-T Evaporators.

See Waste Abbreviations.

Ferrocyanide wastes created during a scavenging campaign in 1953-57. See \$CAV, POO, TOO.

An ion composed of iron and cyanide with the chemical formula of $\mathrm{Fe}(\mathrm{CN}\}_{6}^{-1}$.

A Food Instrument Corporation automatic liguid level gauge based on a conductivity probe. At Hanfora, they are electrically connected to a computer for data transmission, analysis, and reporting. Iocal readings may also be obtained from a dial.

First- and Second-Cycle waste containing $10 \%$ of the original fission Decontamination Mastes product activity and 28 of the products. By-product cake solution was mixed with product 
FLSH

FP

FP

GA

Game Ray

GAS

Gar Instrument

GROJP

Gunite

$\mathrm{H}_{2} \mathrm{O}$

HDRL

HEAT

FEDTA

Heel

Hexone

High-Level Waste

$$
\text { WHC-SD-WH-ER-350, Rev, } 0
$$

waste and neutralized witb $50 \%$ caustic. The waste contained a mixture of suspended solids, iron, hydroxides, carbonate and phosphate, scavenger metals, chromiun, sodium, and silicofluoride.

See Waste Abbreviations.

Fission Product Waste. Waste produced at B Plant and Hot Seniworks in campaigns for $\mathrm{Cs}$ and $\mathrm{Sr}$ recovery during the I960s. Cs was removed from PUREX supernatant and $\mathrm{Sr}$ was removed from PUREX sludge; hoth were removed from acidic waste.

See Waste Abbreviations.

Gain to tank

Electronagnetic radiation emitted by the nuclei of some radioactive substances during decay, similar in rature to $\mathrm{X}$-rays.

Slurry growth as' a result of gas generation.

Instrument for detecting low-level beta and gamma radiation using a Geiger-Mueller tube.

A group of tanks where ITS was used to evaporate the supernatant phases. See ITS.

A building material, consisting of a mixture of cement, sand, and water, that is sprayed onto a mold.

Water

See Maste Abbreviations.

A tank correction, see CORR, COOL.

N-hydroxyethylenedianinetri-acetic acia

The amourt remaining in a vessel or containex after most of the contents have been removed.

Hethyl isobuty]. ketone, an organic solvent used in the REDOX solvent extraction process. Also jnown as Isobutyl methyl ketone, Hethyl isobutyl ketone, 4-Hethyl 2-pentanone, MIBK.

Waste from the fuel reprocessing operations in separations plants. 


$$
\text { WHC-SD-WM-ER-350, Rev. } 0
$$

Historical Information

FHO

HIIO

HIW

HOT-SEMI

HS

HS

HINP

I\&S

Inactive Tank

INST

Interim Isolation

Interim stabilization

Interstitial Liquor
All information obtained from published and unpublished sources. Unpublished sources include photographs and electronictlly retrieved data (i.e. liquid observation well data, temperatures, sampling results, and surface level data).

See Waste Abbreviations.

Hanford Laboratory Operations

See Waste Abbreviations.

See HS, SSW.

See Waste Abbreviations.

Hot Semi-Works (C Plant) - A pilot facility that served a variety of operations.

Dilute, non-complexed waste from the vitifification plant.

Tank isolated ana stabilized.

A tank that has been removed from liguidprocessing service, has been pumped to contain less than 33,000 gallons of waste, and is not yet or in the process of stabilization and interim isolation. This includes all tanks not in active or active-restricted categories. Also included are inactive spare tanks that would be used if an active tank failed.

Change in tank level due to change in instrumentation.

An administrative designation reflecting the completion of the physical effort required to minimize the addition of liquids into an inactive storage tank, process vault, surup, cátch tank, or diversion box. See Intrusion Prevention.

A tank which contains less than 50,000 gallons of drainable interstitial liquid and has less than 5,000 gallons of supernatant. If the tank was jet punped to achieve interin stabilization, then the jet pump flow must have been at or below 0.05 gallons per minute before interim stabilization is completed.

The 1inuid that fills the interstices (void space) within the solid material in a waste tank. 
Interstitial

Intrusion Mode

FIC Setting

Intrusion Prevention

ISO

ITS

IWW

IX

Jet Fump

Knuckle

L2225

L3A4A

LaF

Lateral

Leak Detection Pit

LFAK

LETF

Leve1 Adjustment
MHC-SD-MM-ER-350, REV. O

The volume within a solid matrix made up of the crevices, cracks, and other void space.

The FIC probe is positioned a short distance above the waste surface. If the surface level of the waste in the tank increases, thereby touching the probe tip, a positive indication is received.

An aministrative designation reflecting the completion of the physical effort required to minimize the addition of liguids into an inactive storage tank, process vault, catch tank, sump, or diversion box.

Tank is interimly isolated.

The In-Tank Solidification Progran was used to reduce waste volume directly by evaporating the wates from inside certain tanks in the BX and BY Farms. The process used both hot air (ITS-1) and an electric heatex (ITS-2).

Sse Waste Abbreviations.

See Waste Abbreviations.

A modified, commercially available, low capacity jet pump used as a saltwell puim.

Point where the side wa11 and the bottom curved surface of a tank meet.

See Waste Abbreviations.

See Waste Abbreviations.

See Maste Aloreviations.

Horizontal drywell under all tanks in A Farm and certain tanks in sx Farm.

Collection point for ary leakege fxom tanks in Ax Farm. The pits are equipped with radiation and Iiquid detection instruments.

Tank leak volume, see CORR.

Iicula effluent treatment facility from N Reactor.

Any update in the waste inventory (or tank level) in a tank. The adjustments usually result from surveillance observations or historical 
Level History

Liquid observation Well (LOW)

Liquid Level Best Engineering Judgement Line

LO

LINSC

LW

Metal Waste (MW)

Molarity

sole

19

3WF

N

NCAW irvestigations.

A diagram that shows the history of the waste level and waste level changes in a tank. The diagram also includes other related data.

Liquid observation wells are used to monitor the interstitial liquid level (III) in singleshell waste storage tanks. Three probes are used to monitor changes in the ILL: acoustic, gamuna, and neutron: Each method can indicate intrusions or leaks by increases or decreases in the ILL.

During the initial filling of certain singleshell tanks, only the liquid level was reported. To adjust for the big increase in level height, which occurred when solids were added to the record, a sloped line was used to reflect solids volume between the initial fill and the time the solids data were recorded.

Loss from tank.

See Waste Abbreviations.

See Waste Abbreviations.

Waste from extraction containing all the uranium, approximately $90 \%$ of the original fission product activity, and approximately 1t of the product. This waste was brought to the neutral point with $50 \%$ caustic and then treated with an excess of sodium carbonate. This procedure yielded almost completely soluble waste at a minimum total volune. The exact composition of the carbonate compounds was not known, but was assumed to be a uranium phosphate carbonate mixture.

Number of gram molecular weights (moles) per liter of solution.

The amount of a substance with weight equal to the molecular weight in gxams.

See Waste Abbreviations.

See Waste Abbreviations.

See Waste Abbreviations.

See Waste Abreviations. 
NCPL

NCPLEX

NCPIX

NCRW

Neutralized FUREX Acia Waste

Neutron Probe

NFAN

NHAW

NIT

Noise At The Bottom of Well - Drywell Probe

Non-Complexed (NCEEX)

NPH

NRAW

NRP82

NRPO4

NRSO4

NTA

Nuclear reactor
See Waste Abbreviations.

See Waste Abbreviations.

See Waste Abbreviations.

See Waste Abbreviations.

In 1956, the original plant neutralized all of the high-level waste and sent it to the A Tank Farm. As recovery of fission products began, a portion of the waste was trexted to recover strontium and then neutralized. As of 1967, all of the high-level waste left PUREX as an acid solution for treatment at B Plent.

Erobe equipped with a neutron source and detector. They are used in dry well monitoring to determine the moisture content of the soil as one way to detect leaks in underground waste storage tanks or pipelines.

See Waste Abbreviations.

See Waste Abbreviations.

$\mathrm{HNO}_{3} / \mathrm{KMNO}_{4}$ solution added turing evaporator operation.

Erroneous reading caused by probe coming into contact with foreign objects at the bottom of a we11.

General waste term applied to all Hanford site 1.juors not identified as complexed (containing organies\}.

Normal parafin hydrocaxbors

See Waste Abbreviations.

See Arste Abbreviations.

See Waste Abbreviations.

See Maste Abbreviations.

Nitrilotriacetic acid

A device for creating a controlled nuclear chain reaction using atomic fuel, as for the production of energy. 
Open Hole Saltwell

Organic Wash Waste (OWW) by washing with potassium permanganate and sodium carbonate, followed by dilute nitric acid and then a sodium carbonate wash.

Out-of-Service-Tank

Orw

$\mathbf{P}$

E1:

P2:

PADFG

BADWG

Partial Interim Isolation

PAS

PASF

PAY

PD

PDBNG

PDBSU

PDBTG

PDCSS

PDL 87

PDL89

A well in which a pump is inserted in solid waste. This type of well is frequently used to renove the liguid from tanks containing less than two feet of sludge.

A tank that does not meet the definition of an inservice tank. Before september 1988, these tanks were defined as inactive. (Note: All single-shell tanks are out of service.)

See Waste Abhreviations.

See Waste Abbxeviations.

See IARL Defined Waste List.

See IAML Defined Waste Iist.

See Waste Abbreviations.

See Waste Abbreviations.

The administrative designation for completion of the physical effort required for Interim Isolation, except for isolating the risers and piping that will bo reguired for jet pumping or for other methods af stabilization.

See Waste Abbreviations.

See Waste Abbreviations.

See Waste Abbreviations.

See Naste Abbreviations.

Ses Waste Abbreviations.

See Waste Abbreviations.

See Waste Abbreviations.

See Waste Abbreviations.

See Waste Abbreviations.

See waste Abbreviation. 


$$
\text { WHC-SD-WM-ER-350, Rev, } 0
$$

PDNSE

PDS87

PDS89

PDSLG

PDSUF

REECW

PFeON1:

PFeCN2:

PELIS

PFP \{Z Plant $\}$

PFF

PFPGR

PFPNT

PFPPT

PFPSI

pH

Pile

PL

PNI 89

PMS89

PN

PNF

POO-P\#\#

Portland cement

PRF
See Waste Abbreviations.

See Waste Abbreviations.

See Waste Abbreviations.

See Waste Abbreviations.

See Waste Abbreviations.

See Waste Abbroviations.

See LANL Defined Waste List.

See Lakl Defined Waste Iist.

See Haste Abbreviations.

See facilities.

Plutonium Finishing Plant waste (see $\mathrm{z}, 224$, PRF).

See Waste Abbreviations.

See Waste Abbreviations.

See Waste Abbreviations.

See Waste Abbreviations.

A measure of the hydrogen ion concentration in solution.

An early term used to deseribe a nuclear reactor. See Waste Abbreviations.

See Waste Abbreviations.

See Waste Abbreviations.

See Waste Abbreviations.

See Waste Abbreviations.

In-P1ent scaverging with FeCN - see SCAV, TOO-T\#\#.

A hydraulic cement made by finely pulverizing a mixtuxe of cley and Iimestone or similar materials.

Plutonium Reclamation Facility - Type of waste 
WHC-SD-AM-ER-350, Rev. 0

generated in $\mathrm{Z}$ Plant fox "finishirg wastes". Solvent based extraction process using $\mathrm{CCl} 1_{4} / \mathrm{TBP}$.

Primary Addition

Primary Stabilization

Probe

PSI.

PSS

PSSF

Psychrometry

FT

FUREX

PX865

PXPAW

PXESG

FXF'T

FXIOW

PXMEST

EXMSC

PXNAW

Questionable Integrity
An addition of waste fxom a specific plant or process vault. These additions come from the "Waste Status and Transaction Record Summry", WHC-SD-WM-TI-614\& -615, Rev, 0, DRAFT.

The condition of an inactive waste storege tank after all liouid above the solids, other than isolated surface pockets, has been removed. Isolated surface pockets of Iiquid are those not pumpable by conventional techniques.

A device used to obtain information about the enviromment. In this report, an instrument package designed to be inserted in drywells, risers, or ports to measure waste characteristics.

See Haste Abbreviztions.

See Waste Abbreviations.

See Waste Abbreviations.

Determination of humidity or dew point from wet and dry bulb temperatures with the difference in the two used as a measure of moisture in the atmosphere.

See Waste Abbreviatians.

See Facilities.

See Waste Abbreviations,

See Waste Abbreviations.

See Waste Abbreviations.

See Waste Ahbreviations.

See Waste Abbreviations.

See Waste Abbreviations.

See Waste Abbreviations.

See Waste Abbreviations.

Any tonk that has a small decrease in liquid level or a radiation incresse in an associated dry well, 


$$
\text { WHC-SD-AM-ER-350, Rev. } 0
$$

For which the remaining data for the tank are insufficient to support a conclusion with 950 confidence that the tank is sound.

$\mathbf{R}$

R SITCK:

R1:

R2:

Radiation zone

Radiation

Readily Available

Risers

REC

REDOX

Removed From Service (Tariks)

Rerun Drywell Data

RESD

RIX

RMC

RSN

RSS

RTX

5

S Flant (REDOX)

S1 SLTCK:
See Waste Abbreviations.

See IANL Defined Waste List.

See IANL Defined Waste Itist.

See LANL Defined Waste List.

An area containing radioactive materials in quantities significant enough to require controlling entry of personnel into the area.

Particles and electromagnetic energy enitted by nucleax transformations that are capable of producing lons when interacting with matter.

Risers located above grade which do not have apparatus attached to or contained in them.

Receive waste from another tank - see XFER,

See Facilities.

Any tank that is a confirmed leaker or is not intended for reuse.

Surveillance datt which supersedes "suspect data".

See Waste Abbreviations.

See Waste Abbreviations.

Remote Mechanical C-Iine - Process used in $z$ Plant.

See Waste Abbreviations.

See Waste Abbreviations.

See Waste Abbreviations.

Transaction Flag Key - Partial neutralization (PNF).

See Facilities.

See LANL Defined Woste List. 


$$
\text { WHC-SD-WH-ER-350, Rev. } 0
$$

S2 SLTSLRY :

Saltcake.

Saltwell

SCAV

Scavengea

scintillation Monitor

Self Concentrating

Self-Evaporation

SET

$\operatorname{sIX}$

SL

SL35Y

sludge

slugs

Sluicing, or sluiced

Slurry
See Land Defined Waste List.

Crystallized nitrate and other salts deposited in waste tanks, usually after measures are taken to remove moisture.

A hole frilled or sluiced into a saltcake and lined with a cylindrical screen to permit drainage and jet pumping of interstitial linuors.

Seavenging calmpign with FECW on TBP, 1952-57.

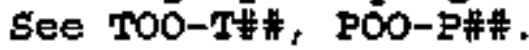

Waste which has been treated with ferrocyanide to remove cesium from the supernatant by precipitating it into the sludge.

A radiation detection instrument based on the principle that light pulses are produced in some materials when they are exposed to radiation.

Licuid, high-level radioactive waste whose decaying radionuclides sufficiently heat the solution to boil off the water, thus concentrating the waste.

a waste material in which moisture is boing lost as the Iiguid changes to a vapor and diffuses into the atmosphere.

Connect cascaded tanks together - see CAS and END.

See Waste Abbreviatcions.

See Waste Abbreviations.

See Waste Abbreviations.

Primarily insoluble metal hydroxides and oxides precipltated from neutralized waste.

in early term for uranium fuel elements which had been machined or extruded into short cylinders which were then clad or encased in corrosionresistant metals.

To wash with water. At Hanford, this has meant to dissolve or suspend in solution using a high pressure water stream.

Insoluble material suspended in water or aqueous solution. 
Sound Tank

SPRG

SRR

SRS

SRS

SSW

STAB

Stabilization

Static Tank

Strontium Semi-Works

su

Supernatant

Surveillance

Suspect Data

sv

SW RCR

SWLIQ
WHC-SD-FM-ER-350, Rev. 0

The classification of a waste storage tank for which surveillance data indicates there has been no loss of licuid attributed to a breach of integrity.

Sparge-transfer of water or volume

See Waste Abbreviations.

See Waste Abbreviations.

See Waste Abbreviations.

Ses Waste Abbreviations.

Tank stabilized by removal of 1iguid. Both floating suction and saltwell jet pumps are used to remove liquid.

The removal or immobilization, as cormleitely as possible, of the liquid contained in a radioactive waste storage tark by saltwell pumping, open hole saltwell purming, adaing älatomaceous earth, etc.

A tank with no significant change in liquid level or involvement in transfer operations during a stated period of time.

Called c Plant or Hot Semi-Works, was a pilot plant for both REDOX and FUREX, then reconfigured for strontiun recovery.

See Maste Abbreviations.

In waste storage tanks, the 1iquid quantity defined by the difference between the measured liquid level and the measured average solids level in a tank.

Regular or systematic watch kept over someone or something.

Surveillance data which does not fall within the expected range and is superseded by "reruns".

Transaction Flag Key - amount by difference in solids.

Saltwell receiver

See Waste Abbreviations. 
SWLQN

T Plant (222-T) .

T1 SLTCK:

T2 SLTCK:

Tank Farm

TBP

TBP

TCO

Terminal Liquor

TFECN

TH

Thermocouple

Thermocouple Tree

ThermoweIl

THL

Thorium
See Waste Abbreviation.

See Facilities.

See IANL Defined Waste Iist.

See IaNL Defined Waste Iist.

An area containing a number of aboveground or underground storage tanks for storing chemicals, petroleum products, or waste.

Tributyl phosphate, a solvent used in the PUREX solvert extraction process.

See Waste Abbreviations.

See Naste Abbreviations.

The liquid product from the evaporationcrystaliization process which, upon further concentration, forms a solid that is unacceptable for storage in single-shell tanks. Terminnl liguor is characterized by a caustic concentration of approximately $5.5 \mathrm{M}$ (the caustic molarity will be lower if the aluminum salt saturation is reached first).

See Waste Abbreviations.

See Waste Abbreviations.

A probe for measuring temperature, consisting of two dissimilar metal wires joined at one end (hot junction) with the free ends joined to a measuring instrument. Changes in electrical potential due to tempexature changes at the hot end are measured and calibrated to read out as temperature.

A group of thermocouples assembled in t pipe and irserted into a waste tank for measuring temperatures at regular vertical intervals.

A well in a waste tank which contains thermocouples.

See Waste Abbreviations.

A chomical elentent which is a fertile material. Fertile mearis that when it is subjected to radiation in a nuclear reactor, it will be coiverted, in this case, to ${ }^{233} \mathrm{U}$, a potential fuel. 
HHC-SD-FH-ER-350, Rev. 0

$T K$

TL

TOO-T\#\#

TPIAL

TPLAN

TEIAS

$T R$

Trench

trFlag

Tributyl Phosphate \{TBP\}

Type I Tank

Type II Tank

Type III Tank

Type IV Tank

Type V Tank

U Plant (222-U)

บ1บ2

UNEN
Tank. However, TK-17-2 was an early name for B Blant.

See Waste Abbreviations.

In-tank scavenging with FECh; see SCAV, P\#隹.

See Waste Abbreviations.

See Nagte Abbreviations.

See Waste Abbreviations.

Transfer from tank

A deep furrow in the ground. At Hanford, they are used for the disposal of solid waste.

Transaction Flag Keys - used by Werac - see CDF, D, E, S, SV, 1, 3, 6, 0.17, 0.33.

A chemical compound, an organic solvent, used in the PUREX solvent extraction process.

These are the 200 series tanks found in B, C, T, and $U$ Tank Farms. They have an operating capacity of 55,000 gallons, a 20-foot diameter, a six-inch deep dish bottom, and a three-foot kuuckle. Generation is not associated with Type I tanks.

These are the original (Ist generation) tank designs, which are found in B, C, T, to (excluding the 200 series tanks), and BX Tark Farms. Also, see 1st Gensration Tank.

These are the 2nd Generation tank designs, which are found in BY, $5, T X$, and TY Tank Farms, Also, see 2nd Generation Tank.

These are 3rd, 4th, and 5th generztion tank designs found in sx, $A$, and $A x$ Tank Farms, respectively. Also, see $3 \mathrm{rd}$ Generation Tank, 4th Generation Tank, and 5th Generation Tank.

These are the first double shell tank designs, which are found in AY, AZ, and SY Tank Farms.

See Facilities.

See Waste Abbreviations.

Unknown waste origin sink 
ULKGYWN:

UR

UR:

Watch List Tank

WATER

WTR

WVP

XFER

$\mathbf{z}$

z Plant

3 BLANT

ZAW

ZHIGH

ZLAB

ZLOW

ZPRFL

ZPRFS

ZRM

ZRUCL

2RuCs

Tab
See LANL Definea Waste List.

Uranium recovery operation in 222-U, 1952 - 57. Created TBP (primary waste) and FECN (scavenging wastes). See TFeCN, PFeCN, POO, TOO, FeCN.

See IAAN Defined Waste List.

An underground storage tank requiring special safety precautions because the tank could potentially release high-level radioactive waste if there are uncontrolled increases in tenperature or pressure. Special restrictions have been placed on these tanks by "Safety Measures for Waste Tanks at Hanford Nuclear Reservation", Section 3137 of the National Defense Authorization Act for Fiscal Year 1991, November 5, 1990, Fublic Law 101-501 (also known as the Wyden Amendment).

Flush watex from various sources

Water

Waste volume projections

Transfer of waste out of tank

See Waste Abbreviations.

See Facilities.

Plutonium Finishing Plant (PFP)

See Waste Abbreviations.

See Waste Abbreviations.

See Waste Abbreviations.

See Waste Abbreviations.

See Waste Abbreviations.

See Waste Abbreviations.

See Waste Abbreviations.

See Waste Abbreviations.

See Waste Abbreviations. 
8.1 Waste Abbreviations

1AYIN

LAZIN

$1 \mathrm{C}$

1 CEB

$1 \mathrm{CS}$

224

224-F

2312

2AYIN

2AZIN

$2 C$

2SYIN

3깨머

5-6

5AWIN

6AWIN

AGE, AGING

B

B860N

BFSH

BL

BLEB

BLIX

BLIXB
Concentrated complexed waste from 101AY inventory Ere 2-81 101Az inventory

Fixst oycle waste

1st cycle evaporator bottoms

1st eycle scavenging waste

224-U waste

224-U waste. LaF Pu finishing plant

Dilute, phosphate waste from 2312 laboratories

Pre 2-81 102AY inventory

Pre 2-81 concentrated complexed waste from $102 \mathrm{Az}$ inventory

Second cycle waste

Pre 2-81 1025Y inventory

Pre 2-81 103AW inventory

B Plant tank 5,6 waste

Pre 2-81 105AN inventory

Concentrated phosphate waste in 106Aw inventory Aging waste

B Elant high-level waste

Dilute, non-complexed waste from B Plant cell drainage

B Plant flush waste water

B Plant low-level waste

B Plant low-level evaporator bottoms

B Elant low level ion exchange?

B Plant low level ion exchange bottoms? 


$$
\text { HHC-SD-HM-ER-350, ReV. O }
$$

BNW

BPDCC

BPDCS

BPDCV

BPFPS

BPLCS

BPIDC

BPLDN

BVCLN

CARB

cC

CCGL

CCGR

CCPL

CCPLX

CE

CFFH

CF

$\cos$

CP

CPLX
Battelle Northwest Laboratory waste

Dilute, conplexed waste from B Plant cesium processing

Dilute, complexed waste from B Plant strontium processing

Dilute, comblexed waste from B Plant vessel clean-out

B Plant TRU solids from retrieved PFP solids

Dilute, non-complexed waste from B plant strontium processing

Dilute, complexed waste from B Plant cesium processing

Dilute, non-complexed waste from B Plant cesium processing

Dilute, non-complexed waste from $B$ Plant vessel clean-out

FUREx organic wash waste

Complexant concentrate waste

B Plant high TRU solids from retrieved complexed concentrate

Dilute, non-complexed waste from retrieved complexed concentrate

Complexant concentrate

Complexant concentrate - see CPLx

Evaporator concentrate

Concrete - see CON

Cesium Eesa

Concrete - see CEM.

Concentrated phosphate waste from N Reactor decontamination

Complexed waste 
WHC-SD-WM-ER-350, Rev. 0

CSFD

$\operatorname{CSR}$

Css

CST

CSWLE

CSWLW

$\mathrm{CW}$

CW/ZR2

CWP/ZR

CWP

CWR

$\operatorname{cx} 70$

DC

DE

DN/PD

DN

DN/ PT

DSS

DSSF

DUMAY, DUMAY

DW

DWBIX

EB

EF

EFD

EVAP
Cesium feed

Waste sent to B Plant for cesium recovery

Concentrated supexnatant solids

Caustic solution

Complexed waltwell liquid east area

complexed saltwell liquid west area

Coating waste

Coating waste (REDOX), Zirconium cladding

coating waste (PUREx), zirconium cladding

coating waste (PUREX)

Coating waste (REDOX)

Dilute, complexed mixture hot-semiworks TRD solids

Dilute complexed waste

Diatomaceous earth

DN with $\mathrm{P}$ TRU solids

Dilute non-complexed waste

DN with EFP TRt solids

Double-shell sluzry

Double-shell slurry feed

Dumrmy waste

Decontamination waste

Decontamination waste and B Plant ion exchange

Evaporator bottoms

Evaporator feed

Evaporator Eeed dilute

Evaporator feed (post 1976) 
EVAPF

FD

FLSH

FP

HDRL

HLO

FILW

HS

IhW

IX

L222S

I.3AAA

LaF

LENC

LW

LWA

MWE

N

NCAW

NCPL, NCPLEX, NCPLX

NCEW

NFAW

Natw

NRAN
Dilute, non-complexed waste from evaporator pad flush

Feed dilute

Flush water

Fission product waste

Hanford defense residual Iiquor

Hanford laboratory operations waste

High-level waste - generic for all Hanford tank wastes

Hot Semi-Works waste

PUREX \#1 acid concentrator waste

Ion exchange waste

222-s laboratory, dilute non-complexed waste

Dilute non-complexed labozatory wastes from 300 $\$ 400$ Areas

Ianthanum fluoride waste generated in PFP

Dilute, non-complexed waste from UNC fuels fabrication

Laboratory waste

Metal waste

Metal waste feed

N-Reactor waste

Neutralized current acid waste, primary HLW otream from PUREX process

Non-complexed waste

Neutralized cladding removal waste - same as CWP Aging waste from Pisex/PFH high level waste

Aging waste from PUREX/PFU processing of NPR fuel Aging waste from PUREX/PFM residue acid waste 


$$
\text { WHC-SD-WM-ER-350, REY. O }
$$

NRP82

NRPO4

NRSO4

OWW

$\mathbf{P}$

PADFG

PADWO

EAS

PASF

PAW

PD

PDBNG

PDBST

PDETG

PDCSS

PDL87

PDL89

PDNSG

PDS87

PDS89

PDSLC

PDSUP

Dilute, non-complexed waste Erom EY82 100-N Area waste transfer

Dilute, phosphate waste from 100-N Area

Dilute, non-complexed waste from 100-N Area

Organic wash waste

PUREX waste

PUREX ammonia destruction waste, from fuels grade fuel

PURE\& anmonia destruction waste, from weapons grade futl.

PUREX aciaified sluage

PUREX antmonia scrubber feed

PUREX acidified waste

PUREx decladding waste

Decladding sludge (non-Tru) from B plant processing

Dilute, non-complexed waste from B Plant decladaing waste

B Flant aging waste solids from PUREx decladding waste

Dilute non-complexed FUREX decladding waste, FY1986 only

PUREX decladding supernatant, 1987

PURRX decladding supernatant, non-TRU, spent metathesis removed

Non-TRU decladding sludge from PURRX

PUREX decladding sludge

PUREx decladding sludge after FY89

PUREX decladding sludge

Dilute, non-complexed waste, PURRX decladding waste 
NHC-SD-WM-ER-350, REv. 0

PFeCN

PFUMS

PFEGR

PFPNT

PFPET

PFPSL

PI

PLI.89

PuS89

EN

PNF

PSL

PSS

PSSF

PT

EX86s

EXsAN

EXPSG

PXFTF

PXILON

PXIAEY
Ferrocyanide sludge produced by in-plant scavenging of waste from uranium recovery

Dilute, non-complexed waste from shear/leach processing of NPR fuel

Dilute, non-complexed waste from retrieved PFP solids

Non-trV sludge from the PFP (z Plant)

Dilute, non-complexed wate from the PFP (with TRUEX)

TRO sludge from the PFP (2 PIant)

PUREx low-level waste

FuREX spent metathesis liquid after FY89

PoREX spent metathesis solids after FX89

PUREX neutralized cladding waste

Partially neutralized waste

PUREx sludge sluiced during recovery of strontium

PUREX sludge supernatant

PUREX sludge supernatant feed

TRU solids from 200 West

Dilute, non-complexed waste from EUREX miscellaneous streams (NPR fuel) FY86

B Plant aging waste supernatant from retrieved aging waste

B Plant aging waste solids from retrieved aging waste

Dilute, non-complexed waste from PUREX miscellaneous streams (FFTF)

PUREX low level waste

PUREX dilute, non-complexed declading: spent metathesis 
WHC-SD-ML-ER-350, Rev, O

EXMSC

PXINAW

R

RESD

RIX

RSN

RSS

RTX

SIX

St

SL3SY

SRR

SRS

SRS

SSW

SU

SWL.IQ

SWLQW

THP

TCO

TEECN

Т्म

THL

2T
Dilite, non-complexed waste from PUREX iniscellaneous streams (NPR fuel)

Aging waste from PUREX high level waste

REDOX waste

Residual evapozator liquor

REDOX ion exchange waste

REDOX supernatant

REDOX sluage superatiant

REDOX ion exchange

PUREX ion exchange waste

sludge

Double shell slurry from end of FY80, 1035Y inventory

Waste sent to B Plant for strontium recovery

Strontium sludge

strontium recovery supernatant

Strontium Semi-Works waste

Supernatant.

Dilute, non-conglexed waste from 200-East Area single shell tanks

Dilute, non-complexed waste from 200-West Area single shell tanks

Tri-butyl phosphate

Dilute non-complexed waste from terminal cleanout Ferrocyanide sludge produced by in-tank or infarm scavenging

Thoria HIW of cladding waste

Thoria low-level waste

Teximinal liquor 


$$
\text { WHC-SD-WM-ER-350, ReV. O }
$$

TPLAL, TPLAN

TPLAS

U1U2

$\mathbf{z}$

ZAW

ZHIGH

ZIABB

zLow

ZPRFL

ZPEFS

ZRMCL

ZRMCS
Dilute, non-complexed waste from T Plant

sludge from T plant operations

Dilute, non-complexed waste from $\mathrm{U1} / \mathrm{U} 2$ ground water purping

z plant waste

PUREX waste stream fxom zirconsum cladded fuel

Dilute, non-complexed waste from the PFP (without TRUEX)

Dilute, non-complexed waste from the EFP labordtories

Dilute, non-complexed waste from Pre-FY85 z plant operations

Dilute, non-complexed waste from PRF processing

PFP TRU aOlids from PRF processing

Dilute, non-complexed waste from PFP RMC processing

PFP TRU solids from PFP RHC processing 


$$
\text { HHC-SD-WH-ER-350, Rey, } 0
$$

8.2 LANL Defined wastes

$1 \mathrm{Cl}$

$1 \mathrm{c} 2$

$1 \mathrm{CFeCH}$

$2 \mathrm{Cl}$

$2 \mathrm{C} 2$

A1 SLTCK

A2 SLTSLRY

AR

B SLTCK

BY SLTCK

CWP2

CWR1

CWR2

DE

MW1

uW2

E1

22

PFECNI

First cycle decontamination waste from the $\mathrm{BiPO}_{4}$ process, 1944 to 1951.

First cycle decontamination waste from the $\mathrm{BiPO}_{4}$ process, 1952 to 1956.

??First cycle ferrocyanide scavenging waste?

Second cycle decontamination waste from the $\mathrm{BiFO}_{4}$ process, 1944 to 1951 .

Second cycle decontamination waste from the $\mathrm{BiPO}_{4}$ process, 1952 to 1956 .

Saltcake waste generated from the 242-A Evaporator-crystallizer from 1977 until 1980.

Salt slurry waste generated from the 242-A Evaporator-crystallizer from 1981 until 1994.

"Washed" PUREX sludge from the AR vault

Saltcake waste generated from the 242-B Evaporator from 1951 until 1955.

Saltcake waste generated from in-tank solidification units 1 and 2 between 1965 and 1974 .

Cladaing waste - PUREX 2???

REDOX cladding waste Erom 1.952 to 1960

REDOX cladding waste from 1961 to 1967

Diatomaceous earth

Metal waste from BiFO, 1944 to 1951

Metal waste from Bípo،, 1952 to 1956

PUREX high-level waste generated between 1955 and 1962 .

PUREX high-level waste generated between 1963 and 1967.

Ferrocyanide sludge generated from in-plant scavenging of waste from uranium recovery- 


$$
\text { HHC-SD-WH-ER-350, Rev. } 0
$$

$\mathrm{EF} \in \mathrm{CN} 2$

R SLTCK

R1

R2

s1 SLTCK

S2 SLTSLRY

T1 SLTCK

T2 SLTCR

UNRANOWN

UR
Same as PFecN1, except 0.0025 if ferrocyanide used.

Saltcake waste from the REDOX concentrator. REDOX waste generated between 1952 and 1957. REDOX waste generated between 1958 and 1966.

Saltcake waste generated from the 242-S Evaporator/crystaliizer from 1973 until 1976.

salt slurry waste generated from the 242-5 Evaporator-crystallizer from 1977 until 1980.

Saltcake waste generated from the 242-T Evaporator from 1951 until 1955.

Saltcake waste generated from the 242-T Evaporator from 1965 until 1955.

Unknown waste type

Uranium recovery waste (also known as tributyl phosphate (TBR) wastel. 


\subsection{Facilities}

A Plant (PUREX)

B Plant (222-B)

C Plant $(222-C)$

S Plant (REDOX)

T Plant (222-T)

U Plant (222-U)

PFP (Z Plant)

242-A

242-B

$242-5$

$242-\mathrm{T}$
The facility at Hanford which contains the latest solvent extraction process for recovery of both plutonium and uranium.

One of the three original bismuth-phosphate processing facilities, later converted to a waste fractionation plant.

Initially a pijot plant for REDOX, later a pilot plant for PUREX and $B$ Plant waste pertitioning.

The facility at Hanford which contains the original extraction process Eor recovery of both plutonium and uranium.

one of the three original bismuth-phosphate processing facilities, later converted to a decontamination facility.

One of the three original bismuth-phosphate processing Eacilities, Later converted to a uxanius recovery plant.

Plutonium Finishing Plant where the final operations occur for production of plutonium products.

A forced circulation vacuum evaporation system.

An evaporator that operates at atmospheric pressure. Also referred to as an open air type evaporator.

A forced circulation vacuum evaporation system.

An evaporator that operates at atmospheric pressurs. Also referred to as an open air type evaporator. 
MHC-SD-WH-ER-350, Rev, 0

Agnew, S.F., April 1995, Supernatant Mixing Model (ShM) Manual for Southeast Quadrant of Hanford Tank Farms, LA-UR-??-???, Los Alamos National Laboratory, Los Alamos, New Hexico.

Agnew, S.F., April 1995, Tank Inyer Model (TMM) Mantral for Southeast Quadrant of Hanford Tank Farms, LA-UR-??-???, Los Alamos National Laboratory, Los Alamos, New Mexico.

Agnew, S.F., April 1995, Waste Status and Transaction Record Sumpary for the Southeast Quadrant, WHC-SD-WH-TI-???, Rev. 1, Westinghouse Hanford Company, Richland, Washington.

Agnew, S.F., April 1995, Hanford Defined Wastes: Chemícal and Radionuclide Compositions, IA-UR-??-????, Los Alamos National Laboratory, Los Alanos, New Mexico.

Allen, G.K., Warch 1976, Estimated Inventory of Chemicals Added to Underground Waste Tanjes, 1944 through 1975, ARH-CD-610B, Atlantic Richfield Henford Company, Richland, Washington.

Alstad, A.T., September 19, 1991, Riser Configuration Document for singleSheII Waste Tanks, MHC-SD-RE-TI-053, Rev. 8, Westinghouse Hanford Company, Richland, Washington.

Anderson, J.D., January 1972 - December 1972, Waste Status Sumpary Chemical Processing Division, ARH-2456, Atlantic Richfield Henford Company, Richland, Washington.

Anderson, J.D., Jamuary 1973 - December 1973, Waste status Sumary Chemical Processing Division, ARH-2794, Atlantic Richfield Hanford Compeny, Richland, Washington.

Anderson, J.D., January 1974 - Decenber 1974, Waste Status Sumary operations Division, ARH-CD-133, Atlantic Richfield Hanford Contpany, Richland, washington.

Anderson, J.D., January 1974 - December 1974, Waste Status Summary Chemical Processing Division, AfH-CD-133, Atlantic Richfield Hanford Company, Richland, Washington.

Anderson, J.D., January 1975 - December 1975, Waste Status Sumary Production and Waste Management Division, ARH-CD-336, Atlantic Richfiela Henford Company, Richland, Mashington.

Anderson, J.D., January 1976 - September 1976, Waste Status Stumpary Production and Waste Management Division, ARH-C-702, Atlantic Richfiela Hanford Company, Richland, Washington.

Anderson, J.D., October 1976 - May 1977, Naste status Stumary - Production and Waste Maragement Division, AFH-CD-822, Atlantic Richfiela Hanford 
WHC-SD-FM-ER-350, Rev. 0

Company, Richland, Washington.

Anderson, J.D., June 1990, A History of the 200 Areas Tank Farms, WHC-MR-0132, Westinghouse Hanford Company, Richland, Washington.

ARCHO, October 1967, MonthIy Report, 200 Areas Operation, ARH-60 DEL, Atlantic Richfield Hanford Compary, Richland, Washington.

ARHCO, June 1969, SX Tagk Fazm Air Cooling Safety Analysis, ARH-1291, Atlantic Richfield Hanford Conpany, Richland, Washington.

ARHCO, July 1972 - December, Chemical Processing Division Waste Status Summary, Quarterly Reports, ARH-2456 C and D, Atlantic Riebfield Hanford Company, Rickland, Washington.

ARHCO, Januaxy 1973 - Decenber 1973, Chemical Processing Division waste Status Sumary, Quazterly Reports, ARH-2694 A, B, C, and D, Atlantic Richfield Hanford Company, Richland, Washington.

ARHCO, January 1973 - September 1975, Operations Division Weste Status Sumary, Quarterly Reports, ARH-CD-133 A, B, C, and D, Atlantic Richfield Hanford Company, Richland, Washington.

ARHCO, September 1976, Production and Waste Management Diviston Waste Status Sumary, Monthiy Reports, ARH-CD-702, Atlantic Richfield Hanford Company, Richland, Washington.

ARHCO, October 1976 - June 1977. Production and Waste Management Division waste status Summary, sonthly Report, ARH-CD-822, Atlantic Richtield Hanford Compary, Richland, Washington.

Batbad, H., D.M. Camaioni, M.A. Lilga, W.D. Samuels, and D.M. Strachan, February 1993, Tank Waste Chenistry - A New Understanding of Waste Aging, WHC-\$A-1694-FP, Westinghouse Hanford Company, Richland, Washington.

Boomer, R.D., June 1990, Functional Requizement Baseline for the closure of Single-She11 Tanks, WiC-EP-0338, Westinghouse Hanford Contany, Richland, Washington.

Borshein, G.L., and B.C. Simpson, October 1991, An Assessment of the Inventories of the Ferrocyanide Watchlist Tanks, WHC-SD-WH-BR-133, Rev. 0, Westinghouse Hanford Company, Richland, Washington.

Borsheim, G.I., August 2, 1989, Single-Shell Tark Isolation Safety Anelysis Report, SD-MM-SAR-006, Rev. 2, Westinghouse Hanford Company, Richlarid, Washington.

Borshiem, G.I. and N.W. Kirch, Wareh 1991, Summary of Single-She11 Tark Waste Stability, WHC-EP-0347, Westinghouse Hanford Company, Richland, weshington.

Boyles, V.C., Jume 1981, Safety Analysis Repott: Stabilization of 
THC-SD-FM-ER-350, ReV. 0

Boyles, V.C., June 1981, Safety Analysis Report: Stabilization of single-shell Waste Storage Tanks by Saltwell Jet Pumping, RHO-SD-WM-SAR-034, Rev. 0, Rockwell Hanford Operations, Richland, Washingtor.

Brevick, c.H., L.A. Gaddis, and W.W. Pickett, September 1995, Supporting Document for the Southeast Quadrant Historical Tank Content Dstimate Report for AN-Tank Farm, WHC-SD-WM-ER-314, Rev, 0, ICF Kaiser Hanfozd Coupany, Richland, Washington.

Brevick, C.H., I.A. Gaddis, and W.W. Eickett, September 1995, Supporting Document for the Southeast Quadrant HistoricaI Tani Content Estimate Report for AP-Tank Fard, WHC-SD-WM-ER-315, Rev, 0, ICF Kaiser Hanford Company, Richland, Mashington.

Brevick, C.F., I.A. Gaddis, and W.W. Pickett, September 1995, supporting Document for the Southeast Quadrant Historical Tenk Content Estimate Report for AW-Tani Fara, WAC-SD-WM-ER-316, Rev, 0, ICF Kaiser farford Company, Richland, Washington.

Brevick, C.H., I.A. Gaddis, and W.W. Pickett, September 1995, Sypporting Doctunent for the Southeast Quadrant Historical Trnk Content Estimite Report for AY-Tank Farm, WHC-SD-WM-ER-317, Rev. 0, ICF Kaiser Hanford Company. Richland, Washington.

Brevick, C.H., L.A. Gaddis, and W.W. Pickett, September 1995, Supporting Document for the Southeast Quadrant Historical Tank Content Estimate Report for AZ-Tank Farm, WHC-SD-hM-ER-338, Rev. O, ICF Kaiser Hanford company, Richland, Kashington.

Brevick, C.H., L.A. Gaddis, and W.W. Pickett, September 1995, Supporting Document for the Southeast Quadrant Historical Tenk Content Estinate Report for $S Y$-Tank Farm, WHC-SD-MM-ER-319, ReV, 0, ICF Kaiser Hanford Compary, Richland, washington.

Brown, W.G., April 26, 1993, Hazard Identification and Evaluation for NonStabilized Single ShelI Tanks, SD-WM-SAR-022, Rev. 0, Westinghouse Hanford Company, Richland, washington.

Bussell, J.H., Febzuary 3, 1992, fugineering Evaluation of Thermocouples in FeCW Watchlist Tanks, WHC-SD-WM-ER-134, Rev O-A, Westinghouse Hanford Company, Richland, washington.

Cain, R.J., 1977, Isolation and stabilizatian of spocial Tanks, Internal Letter to J.C. Womack, Rockwell. Hanford Company, Richland, Washington.

Carpenter, G.K., April 1953 - June 1953, Waste Status Summary - Separations Section, HW-28043 etc, General Electric Conpany, Richland, Washington.

Carpenter, G.K., september 1953 - May 1954, waste Status Sumary Separations Section, HW-29624 etc., Generel Electrie Company, Richland, washington. 
WHC-SD-WH-ER-350, Rev, 0

Carter, G.J., April 1986 - September 1986, Waste Status Sumbar, RHO-RE-SR-14, Rockwell Hanford Operations, Richland, Washington.

Cooley, C.R., and G.t. Richardson, July 17, 1963, Hot Semitworks Strontium-90 Recovery Program, Hi-72666, General Electric Company, Richland, Washington.

ERDA, December 1975, Waste Manegement Operations, ERDA-1538, Energy Research and Develogment Administration, Richland, Washington.

Escobar, G.A., Oetober 1986 - January 1987, Waste Status Sumary, RHO-RE-SR-14, Rockwe11 Hanford Operations, Richland, Washington.

Farley, W.G., May 20, 1992, Safety Assessment for Thermocouple Tree System Installation and Operation in Nonleaking Ferrocyanide Tenks, WHC-SD-WM-SAD-014, Rev. 1, Festinghouse Hanford Company, Riehland, Washington.

GE Co., July 10, 1951, REDOX Technical Manual, HN-18700 DEL, General Electric Conpany, Richland, Washington.

Gerber, M.S., April 1994, Pac-Wen of Hanford Site Await Decommissioning, WHC-SA-2454FP, Westinghouse Hanford Company, Richland, Washington

Gerber, M.S., September 1992, Iegend and Legacy: Fifty Years of Defense Production at the Hanfoxd site, WHC-MR-0293, Rev 2, Westinghouse Hanford Cormany, Richland, Washington

Gerber, M.S., November 1993, A Brief History of the PUREX and uo, Facilities, WHC-MR-0437, Westinghouse Hanford company, Richland, Washington.

Gerber, U.S., September 1993, Multiple Missions: The 300 area in Hanford Site History, WHC-MR-0440, Westinghouse Hanford Compeny, Richland, Washington.

Hanlon, B.M., Novenber 1989 - Decenber 1990, Tank Farm Surveillance and Waste status Summary Report, WHC-EP-0182, Nestinghouse Hanford Conpany. Richland, Washington.

Hanlon, B.M. January 1991 - December 1991, Tank Farm Surveillance and Waste Status Summary Report, WHC-EP-0182, Westinghouse Hanford Company, Richland, Washington.

Hanlon, B.M. January 1992 - December 1992, Tank Farm Surveillance and Waste status Summary Report, WiC-EP-0182, Westinghouse Hanford Company, Richland, Washtington.

Hanlon, B.M., July 1993, Tank Farm Surveiliance and Waste Status Stmmary Report for July 1993, WHC-EP-0182-64, Westinghouse Hanford Compary, Richland, washington. 


$$
\text { WHC-SD-WH-ER-350, Rev, } 0
$$

Hanlon, B.M., January 1993 - December, 1993, Tank Farm Surveillance and Waste Status Sumary Report, WHC-EP-0182, Westinghouse Franfoxd Conpany, Richland, Washington.

Hatch, P., December 18, 1969, Limitations for Use of Underground Waste Tanks, ARH-951, Atlantic Richfield Henford Company, Richland, Washington.

HEW, January 11, 1944, CVI, "Specifications for Construction of Composite Storage Tarks Bldg. No. 241," Froject 9536, CVI 73550, Hanford Engineer Works, Richland, Washington.

Jenkins, C., M. Danielson, B. Rarig, R. Campbell, T. Ambalam, C. Kenoyer, and I. Hall, February, 1993, Engineezing Evaluation of Alternatives Managing the Assumed Leak From SST 241-T-101, EEA-93-1, Kaiser Engineers Hanford, Richland, Washington.

Jungfleisch, F.M., March 1984, Prelininary Estination of the Waste Inventories in Hanford Tanks Through 1980, SD-WM-TI-057, Rev.0, Rockwe11 Hanford Operations, Richland, hastington.

KBH, February 1993, EEP Managing the Assumed treak Fram SST, KEEA-93-1, Kaiser Engineers Fanford, Richland, washington.

Kirkman, M.J., G.L. Ritter, and P.W. Smith, March 6, 1969, B Plant Production schedule and In-Tank solidification Alternatives, ARH-900, Atlantic Richfield Hanford Company, Richland, Washington.

Kreig, S.A., W.W. Jenkins, K.J. Leist, K.G. Squires, and J.F. Thompson, June 1990, Single-Shell Tank Waste Retrieval study, WHC-EP-0352, पC-721. Westinghouse Hanford Company, Richland, Washington.

Lentz, J.E., April 1959 - December 1959, Waste Status Stumaxy - Chemical Processing Department, HW-58579 etc., General Electric Conqany, Richland, Washington.

Lentz, J.E., January 1960 - December 1960, Waste Status Sumary - Chemical Processing Department, HW-63896 atc., General Electric Company, Richland, Washington.

Ijiveman, J.I., December 1975, Final Enviromental Statément, Waste Management Operations, Volume 1 and 2, BRDA-1538, Energy Research and Development Administration, Richland, Washington.

Lucas, G.Z., Jure 1989, Waste Types in Hanford SingIe-sheII Tanks, WHC-SD-ER-TI-00I, Rev. 0 , Westinghouse Hanford Congany, Richland, Washington.

HoBride, J.F., July 1953, Waste Status Stmmary - Separations Section, FN-29054, Beneral Electrid Company, Richland, Washtngton.

McCann, D.C., July 1981 - October 1981, Waste Status Summary, RHO-CD-14, Rockwell Hanford Operations, Richland, Washington. 
WHC-SD-WH-ER-350, Rev. 0

HcCann, D.C., October 1981 - December 1982, Waste Status Summary, RHO-RE-SR-14, Rockwell Hanford Operations, Richland, Washington.

UeCann, D.C., January 1983 - December 1983, Waste Status Sumaary, RHO-RE-SR-14, Rockwe11 Hanford Operations, Richlard, Washington.

MeCarin, D.C., Jamuary 1984 - February 1985, waste Status Sunmary, RHO-RE-SR-14, Rockwell Hanford Operations, Richland, Washington.

Minteer, D.J., November 1994, tncertitties In The Measured Net Mass Flow Rate of Water Leaving Waste Storage Tank 241-C-106 Via The Vent Systen, WHC-SD-MM-ER-3B3, Rev. DRAFT, Westinghouse Hanford Company, Richland, Washington.

Morganthaler, A.C., February 1952 - March 1953, Naste Status Summary Separations Section, HW-27897 etc., General Electric Company, Richland, Washington.

Mudd, O.C., January 1979 - December 1979, Waste Status Sumary, RHO-CD-14, Rockwell Hanford Operations, Richland, Washington.

Mudd, O.C., January 1980 - December 1980, Waste Status Sumary, RHO-CD-14, Rockwell Hanford Operations, Richland, Weshington.

Mudd, O.C., January 1981 - June 1981, waste status smmary, RHO-CD-14, Rockwell Hanford Operations, Richland, Washington.

Mulvey, C.A., June 1977 - December 1977, Waste Status Summary, RHO-CD-14, Rockwell Hanford Operations, Richland, Washington.

Mulvey, C.A., January 1978 - December 1979, Waste status Stumary, RHO-CD-14, Rockwell Hanford Operations, Richland, Washington.

Peterson, D.E., June 1954 - May 1955, Naste Status Sumary - Separations Section, HW-32389 etc., Generai Electric Company, Richlend, Washington.

Peterson, D.E., June 1955 - May 1956, Waste status Sumrary - Separations Section, HW-38000 etc., General Electric Company, Richland, Washington.

Peterson, D.E., September 1956 - December 1956, Waste Status Summary Chemical Processing Department, HW-45738 etc., General Electric Company, Richland, Washington.

Peterson, D.E., June 1956 - August 1956, Waste Status Sumary - Separations Section, HW-43895 etc., General Electric Company, Richland, Washington.

Pines, A.G., January 4, 1991, 244-AR Vatult Safety Analysis Report, SD-WM-SAR-0I8, Rev. O, Westinghouse Hanford Company, Richland, Wash坮gton. 
WHC-SD-FM-ER-350, Rev, 0

Prosk, W., and D.A. Smith, January 1986, Tank Isolation Safety Aralysis Report, SD-WM-SAR-006, .Rev. 1, Rockwell Hanford Operations, Richland, Washington .

RHO, June 1977 - October 1981, Waste status Sumary, Monthly Reports, RHO-CD-14, Rockwell Hanford Operations, Richland, Hashington.

RHO, November 1981 - June 1987, Waste status Summary, MonthIy Reports, RHO-RE-SR-014, Rockwell Hanford Operations, Richland, Washington.

Roberts, R.E., January 1957 - December 1957, Waste Status Summary Chemical Processing Department, HW-48144 etc., General Electric Company, Aichland, Washington.

Roberts, R.E., January 1958 - October 1958, Waste Status Summry - Chemical Processing Department, HW-54916 etc., General Electric Company, Richland, Washington.

Roberts, R.E., January 1961 - December 1961, Waste Status Summary Chemical Processing Department, HW-71610. etc., General Electric Company, Richland, hashington.

Roberts, R.E., January 1962 - December 1962, Waste statis Stumary Chemical Processing Department, HW-74647 etc., General Electric Company, Richland, Washington.

Roberts, R.E., January 1963 - December 1963, Waste Status Sumary ChemicaI Processing Department, HW-78279 etc., General Electric Company, Richland, washington.

Roberts, R.E., January 1964 - December 1964, Waste Status Surmary Chemical Processing Department, Hî-83308 etc., General Electric Company, Rìchland, Mashington.

Roberts, R.E., January 1965 - December 1965, Waste status Summary Chemfcal Processing Department, HW-83906 etc., General Electric Company, Richland, Washington.

Roberts, R.E., October 1966 - December 1966, Waste Status Summary Chentcal Processing Division, ISO-674, Isochem Inc., Richland, Hashington.

Roberts, R.E., January 1966 - September 1966, Waste Statis Stumary Chemical Processing Department, HW-83906 etc., General Electric Company, Richland, Washington.

Rodenhizer, D.G., September 30, 1987, Hanford Waste Tank Sluicing History, SD-WM-TI-302, Westinghouse Hanford Company, Richland, Washington. 
WHC-SD-WM-ER-350, Rev. 0

Rutherford, M.J., August 31, 1948, AdditionaI Waste Storage Facilities 200-East Area, Specification No. HW 3783, General Electric Company, Richland, Washington.

Scaief, C.C. III, October 19, 1993, TMACS I/o Termination Point Listing, WHC-SD-WM-TI-594, Rev, 0, Westinghouse Hanford Company, Richland, Washington.

Smith, D.A., August 1986, SAR, Hazard Identification and Evaluation for Nonstabilized Single-Shell Tanks, SD-FM-SAR-022, Rev. 0, Rockwell Hanford operations, Richland, Washington.

Stahl, S.H., Novembex 22, 1993, Hanford site Tank Farm Facilities Interim Safety Basis, VoIume 1 and 2, hHC-SD-WM-ISB-001, Hestinghouse Hanford Company, Richland, Hashington.

Stong, F.S., September 29, 1986, DrywelI Van In-Tank Liquid Observation Well Surveillance Data Interpretation, RHO-SD-WM-TI-237, Rockwell Hanford Operations, Richland, Vashington.

Thress, M.A., November 1958 - February 1959, Waste statis summary Chemical Processing Department, HW-58579 etc., General Electric Company, Richland, Hashington.

Thurnan, J.M., June 1987 - December 1987, Tank Farm Surveillance and Waste Status Sumary Report, Monthly Repoxts WHC-sp-0038, Westinghouse Hanford Company, Richiand, Washington.

Thurman, J.M., December 1987 - June 1993, Tank Farm Surveillance and Waste Status Summary Report, Monthly Reports, WHC-EP-0182-55, Hestinghouse Hanford Company, Richland, Nashington.

Thurman, J.M., February 1987 - June 1987, Waste status Summary, RHO-RE-SR-14, Rockweil Hanford Operations, Richland, Hashington.

Thurman, J.M., July 1987 - March 1988, Waste status summary, WHC-5E-0038, Westinghouse Hanford Company, Richland, Washington.

Thurman, J.M., April 1988 - December 1988, Tank Farm Surveillance and Waste Status Sumary Report, HHC-EP-0182, Westinghouse Hanfore Company, Richland, Washington.

Thurman, J.M., January 1989 - October 1989, Tank Farm surveillance and Waste Status Sumary Report, WHC-EP-01B2, Westinghouse Hanford Company, Richland, Washington.

Tran, T.T., April 27, 1993, Thermocouple status Single-shell and Double-Shell Waste Tanks, HHC-SD-WM-TI-553, Rev. 0, Hestinghouse Hanford 


$$
\text { WHC-SD-WM-ER-350, ReV. } 0
$$

Company, Richland, Washington.

U.S. DOE, December 1987, EIS, Disposal of Hanford Defense High Level, Transuranic, and Tank Wastes, DOE/EIS-0113 Volumes 1-5, Department of Energy, Richland, Washington.

Uebelacker, D.L., October 1968 - December 1968, waste status Summary Chemical Processing Division, ARH-1061, Atlantic Richtield Hanford Company, Richland, washington.

Uebelacker, D.I., January 1969 - December 1969, Waste Status Summary Chemical Frocessing Division, ARH-1200, Atlantic Richfield Hanford Conpany, Richland, Washington.

Uebelackex, D.I., Jamuary 1970 - December 1970, Waste status Stumary Chemical Processing Division, ARH-1666, Atlantic Richfield Hanford Company, Richland, Washington.

Vail, T.S., January 1985 - Harch 1986, Waste Status Sumary, RHO-RE-SR-14, Rockwell Hanford Operations, Richland, Washington.

Wagoner, J.D., March 18, 1993, Wyden Reguest, Document No. 9301156B R3, U.S. Department of Energy, Richland, Washington.

Waite, J.t., Apzil 1991, Tank Wastes Discharged Directly to the Soil at the hanford site, whC-MR-227, Westinghouse Hanford Conpany, Richland, Washington.

Welty, R.K., September 1988, Waste Storage Tank Status and Leak Detection Criteria, WHC-SD-WM-TI-356, westinghouse Hanford Company, vo1, 1 and 2, Richland, Washington.

Welty, R.K. and N.J. Vermeulen, September 12, 1989 with BCNs through November 8, 1993, Waste Starage Tank Status and Leak Dotection Criteria, WHC-SD-WM-TI-357, Rev. 1K, Westinghouse Hanford Company, Richland, Washington.

WHC, September, 1991, Faflure to Contintousiy Han Control Room During Transfer Per Procedure, occurrence Report RL-WHC-Tark Fam-1991-1019, Westinghouse Hanford Company, Richland, Washington.

WHC, July, 1991, High Radiation Readings in 241-BY DryweIls, Occurrence Report RL--WHC-Tank Farm-1991-1022, Westinghouse Hanford Compamy, Richland, Washington.

WHC, August 1993, Hanford Site Tank Farm Facilities Interim Safety Basis, WHC-SD-WM-ISB-001 Rev. 1, Volume 1 and Volume 2., Westinghouse Hanford Company,

WHC, March, 1993; Hanford Watchlist Mank Surveillance Trends, Letter to the Honorable Ron Wyden, Westinghouse Hanfoxd Compary, Richland, Washington. 
WHC-SD-WM-ER-350, ReV. 0.S?

WRC, July, 1993, Unauthorized Water Usage at 241-BY Tank Farm Results"in Exceecing Raw Water Operational Iinit, Occurrence Report RL--WHC-Tank Faxm-1993-0050, Westinghouse Hanford Company, Richland, Washington.

Winters, W.I., L. Jensen, L.M. Sasaki, R.L. Weiss, J.F. Keller, A.J. Schmidt, and M.G. Hoodruff, May 1989, Waste Characterization plan for the Hanford site single-shell Tanks, WHC-EP-0210, Westinghouse Hanford Company, Richland, Washington.

Wood, S.A., May 1993, Waste Tank Evaporation Water Ioss Computer Program, WAC-SD-WM-CSWD-055, Rev, 0., Westinghotse Hanford Company, Richland, Washington. 